\title{
MEDIDAS PROTECIONISTAS UTILIZADAS PELOS ESTADOS UNIDOS E UNIÃO EUROPÉIA PARA O AÇÚCAR: IMPACTO SOBRE A ECONOMIA DAS REGIÕES EXPORTADORAS DO BRASIL
}

\author{
Cinthia Cabral da Costa
}

\begin{abstract}
Tese apresentada à Escola Superior de Agricultura "Luiz de Queiroz", Universidade de São Paulo, para obtenção do título de Doutor em Ciências, Área de Concentração: Economia Aplicada.
\end{abstract}

P I R A C I C A B A

Estado de São Paulo - Brasil

Janeiro - 2004 


\title{
MEDIDAS PROTECIONISTAS UTILIZADAS PELOS ESTADOS UNIDOS E UNIÃO EUROPÉIA PARA O AÇÚCAR: IMPACTO SOBRE A ECONOMIA DAS REGIÕES EXPORTADORAS DO BRASIL
}

\author{
Cinthia Cabral da Costa \\ Engenheiro Agrônomo
}

Orientadora: Prof ${ }^{\mathrm{a}}$ Dr $^{\mathrm{a}}$ HeLOISA LEE BURNQUIST

\begin{abstract}
Tese apresentada à Escola Superior de Agricultura "Luiz de Queiroz", Universidade de São Paulo, para obtenção do título de Doutor em Ciências, Área de Concentração: Economia Aplicada.
\end{abstract}

P I R A C I C A B A

Estado de São Paulo - Brasil

Janeiro - 2004 


\title{
Dados Internacionais de Catalogação na Publicação (CIP) DIVISÃO DE BIBLIOTECA E DOCUMENTAÇÃO - ESALQ/USP
}

\author{
Costa, Cinthia Cabral da \\ M edidas protecionistas utilizadas pelos Estados U nidos e U nião Européia para o açúcar \\ : impacto sobre a economia das regiões exportadoras do Brasil / Cinthia Cabral da Costa. - \\ - Piracicaba, 2004. \\ 291 p. : il. \\ Tese (doutorado) - Escola Superior de A gricultura Luiz de Q ueiroz, 2004. \\ Bibliografia. \\ 1. A çúcar 2. Exportação 3. M ercado agrícola 4. Subsídio agrícola 5. Tarifa \\ alfandegária I. Título
}

CDD 338.476641

\section{"Permitida a cópia total ou parcial deste documento, desde que citada a fonte - O autor"}


“Imagine que o país de Isolândia ignore o parecer de seu grupo de economistas e decida não permitir o livre comércio de aço. O país permanece em equilíbrio sem o comércio internacional.

Então, um dia, um inventor de Isolândia descobre um novo método de produzir aço a custos muito baixos. Contudo, o método é bastante misterioso e o inventor insiste em mantê-lo secreto. O que é estranho é que o inventor não precisa de trabalhadores ou ferro para fabricar o aço. O único insumo de que necessita é de trigo.

O inventor é saudado como um gênio. Como o aço é usado para fabricar tantos produtos, a invenção reduz os preços de muitos bens e permite que os habitantes de Isolândia desfrutem de um padrão de vida mais alto. Os trabalhadores que antes trabalhavam na siderurgia sofrem quando as usinas fecham, mas acabam encontrando emprego em outras atividades. Alguns se tornam agricultores e cultivam o trigo que o inventor transforma em aço. Outros vão para novas indústrias que surgem em decorrência da maior prosperidade dos habitantes de Isolândia. Todos entendem que o deslocamento desses trabalhadores é parte inevitável do progresso.

Alguns anos depois, um repórter decide investigar esse misterioso processo de fabricação do aço. Entra sorrateiramente na fábrica do inventor e descobre que o inventor é um impostor. Ele não fabrica aço nenhum. Em vez disso embarcou ilegalmente trigo para vender no estrangeiro e importou aço de outros países. A única coisa que o inventor descobriu foram os ganhos do comércio internacional. .... Ele não era um inventor. Ele era apenas um economista."

Mankiw, 2001. p.199-200. 
Dedico ao meu pai, Geraldo.

À minha mãe, Andréa. À Gina.

Ao Frederico, ofereço. 


\section{AGRADECIMENTOS}

Aos bons Anjos que me protegem. Obrigada. À minha família e ao Frederico, de onde vem o incentivo que preciso.

À Escola Superior de Agricultura "Luiz de Queiroz" e ao Departamento de Economia, Administração e Sociologia, toda minha gratidão por ter me proporcionado o conhecimento necessário para a minha formação, e que foram, simbolicamente, representados neste trabalho. De maneira especial, agradeço a todos os meus professores. À eles, minha admiração e meu carinho.

À amiga e orientadora Heloisa Lee Burnquist, presente em toda minha pósgraduação, agradeço novamente por esta outra conquista.

À CAPES, pela bolsa concedida.

Este trabalho foi realizado ainda, com a colaboração de muitas outras pessoas, que acreditaram e apoiaram esta idéia. Neste sentido, agradeço aos professores: Silvia Miranda, Mirian Bacchi, Márcia Azanha, Marcos Jank, Rodolfo Roffman. Ao Prof. Joaquim Guilhoto, cabe um agradecimento especial pela confiança e por disponibilizar parte essencial dos dados que enriqueceram este trabalho. Ao André Nassar e ao Leonardo Bichara, pelas ajudas e informações. Ao Jefferson. À Marta Marjotta-Maistro. Aos especialistas do mercado de açúcar com os quais tive contato: César, da Crystalsev; ao Carlos Frederico, da Coinbra; e ao Stuart, da Coimex. Ao Prof. Orlando Silva, pela prontidão com que fui atendida. Aos colegas que sempre estiveram disponíveis quando precisei, em especial: ao amigo Rogério Freitas, pela constante ajuda e apoio; à Luciana Silveira; à Margarida, à Lana e ao Samuel, pela ajuda na fase final; Lucílio; Sérgio; Ari; 
Humberto; e a todos os demais colegas de convivência no LPD, muito obrigada pelas boas rizadas juntos.

Ao grupo de estudos em comércio internacional (GECINT), do qual tenho o prazer de participar desde o início, e que foi importante para realização deste trabalho. Espero de alguma forma estar sempre presente.

À Maielli pela amizade e atenção. À Ligiana e à Mariana pela revisão da tese. À todos os demais funcionários do departamento: Pedro, Elenice, Márcia, Helena, Cristiane, Maria Helena, Álvaro, Dona Maria e aos meninos da informática. E também aos funcionários do Cepea.

A Universidade Federal de Viçosa, meu eterno carinho e agradecimento, por tudo que me proporcionou.

Aos que não participaram diretamente da elaboração deste trabalho, mas foram importantes. Agradeço a companhia da turma da genética; à Dione, pela sua amizade; à Raquel Castro, pelas boas horas juntas; às demais amigas verdadeiras que conquistei e que me deram apoio e carinho mesmo distantes, ... eu sempre me lembrarei!

Agradeço, com muito carinho, à maestrina Cíntia Pinotti. Aos meus amigos e companheiros de flauta: Cléa, Álvaro, Kathia, Raquel Lima e Carol.

À todos que me ensinaram algo... espero ter crescido também em sabedoria, e não apenas em conhecimento. 


\section{SUMÁRIO}

Página

LISTA DE FIGURAS .......................................................................

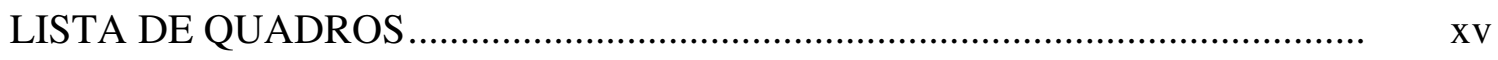

LISTA DE TABELAS .........................................................................

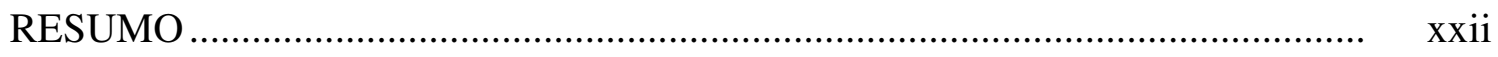

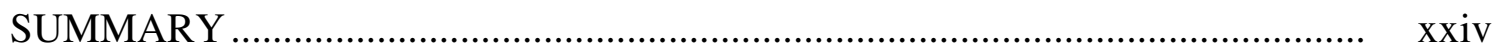

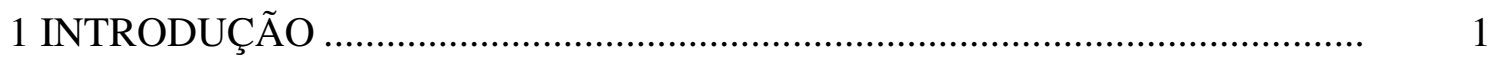

$1.1 \mathrm{O}$ problema e sua importância.................................................................... 1

1.1.1 Importância e características da produção de açúcar no Brasil ............................ 4

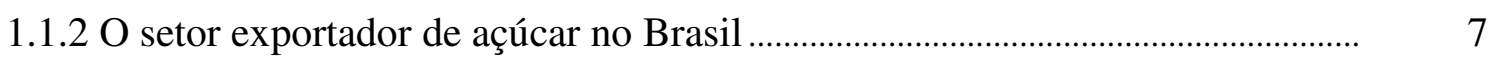

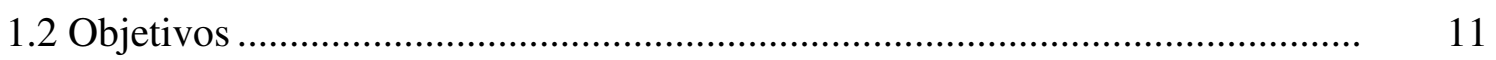

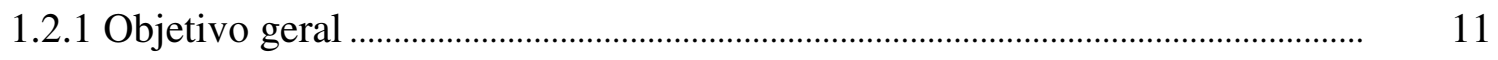

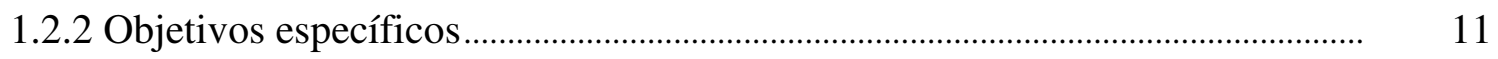

2 REVISÃO DE LITERATURA ….............................................................. 12

2.1 Panorama mundial do mercado de açúcar...................................................... 12

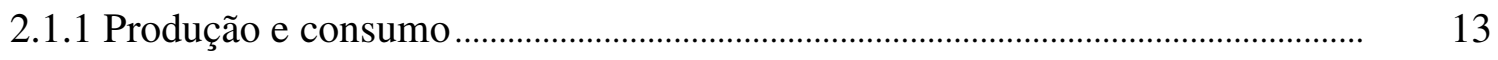

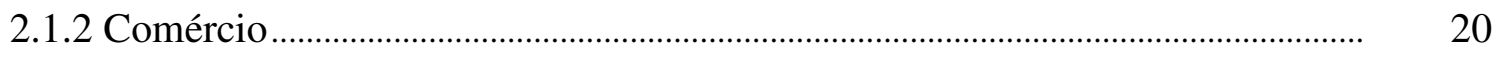

2.1.3 Políticas para o açúcar no mundo ................................................................................ 32

2.1.3.1 Políticas e o mercado de adoçantes nos Estados Unidos...................................... 33

2.1.3.1.1 Características gerais do mercado de adoçantes nos Estados Unidos....... 33

2.1.3.1.2 Principais políticas protecionistas ........................................................ 36

2.1.3.1.2.1 A taxa de empréstimo.................................................................. 36

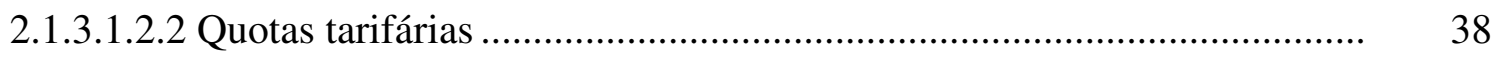


2.1.3.2 Políticas e o mercado de adoçantes na União Européia (UE) ................................. 40

2.1.3.2.1 Características gerais do mercado .......................................................... 41

2.1.3.2.2 Principais políticas protecionistas ..................................................... 42

2.1.3.3 Políticas e o mercado de adoçantes no Japão................................................................. 48

2.1.3.3.1 Características gerais do mercado .......................................................... 48

2.1.3.3.2 Principais políticas protecionistas ....................................................... 49

2.1.3.4 Análise gráfica dos preços de importação nos Estados Unidos, União Européia e Japão ............................................................................................ 50

2.1.4 Acordos comerciais no mercado internacional de açúcar........................................ 53

2.1.5 Dependência e efeitos de políticas comerciais de outros países ............................ 56

2.2 Efeitos mundiais da liberalização comercial do mercado de açúcar.................. 61

2.3 Modelos de equilíbrio parcial utilizados para estudar o comércio internacional de commodities ..................................................................... $\quad 65$

2.3.1 Pressuposições alternativas adotadas na estimação de equações de exportação e de importação........................................................................................ 66

2.3.2 Estudos sobre as exportações brasileiras de açúcar .............................................. 68

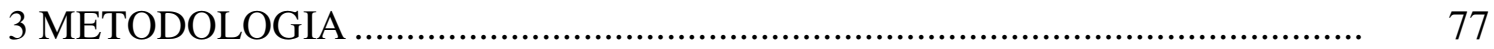

3.1 Impactos dos instrumentos de política protecionista dos países desenvolvidos sobre as exportações brasileiras de açúcar ............................ $\quad 77$

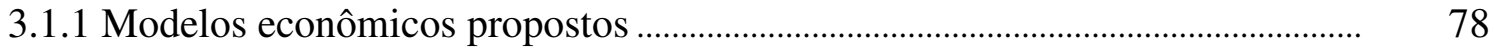

3.1.1.1 Modelo econômico proposto para avaliar efeitos de redução em quotas tarifárias e suporte interno de preço para países importadores .

3.1.1.2 Modelo econômico proposto para avaliar efeitos de redução em subsídios para exportação.

3.1.1.3 Modelo de demanda de Armington (1969)

3.1.1.4 Modelo de oferta de exportação para o açúcar.............................................................. 90

3.1.1.4.1 Modelo de oferta das exportações brasileiras de açúcar bruto ........................ 90

3.1.1.4.2 Modelo de oferta das exportações de açúcar da União Européia ................... 94

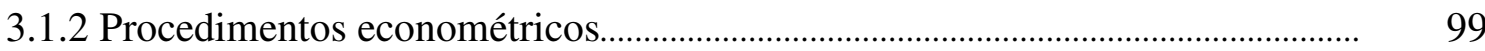




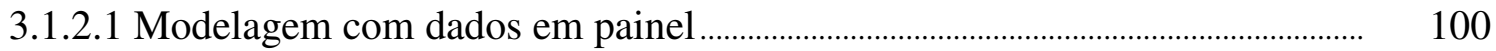

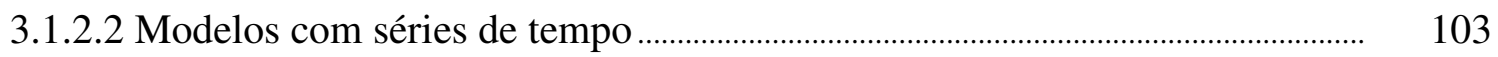

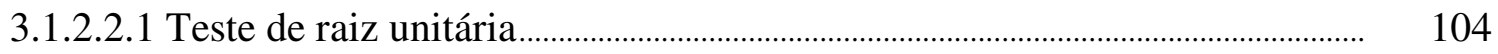

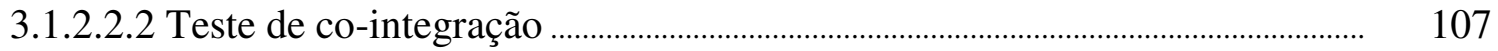

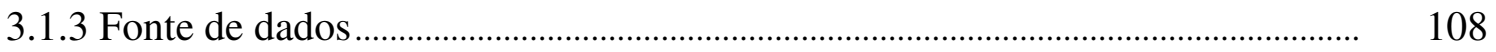

3.2 Efeitos dos impactos das exportações brasileiras de açúcar sobre a economia brasileira ............................................................................. 115

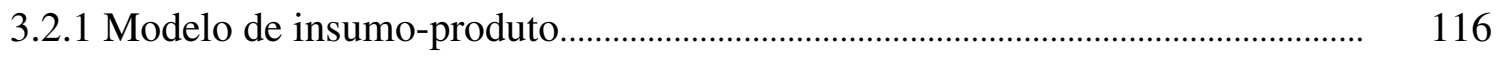

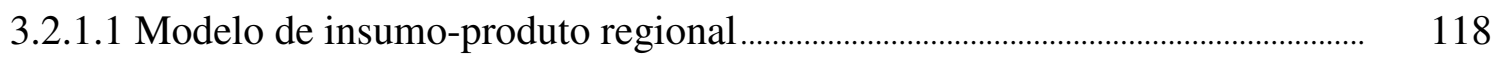

3.2.2 Índices de ligações de Rasmussen-Hirschman...................................................... 120

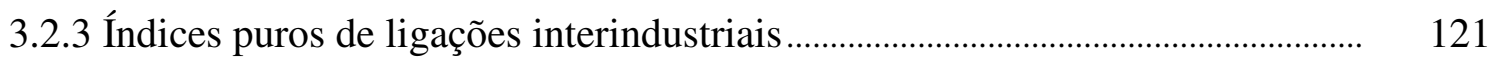

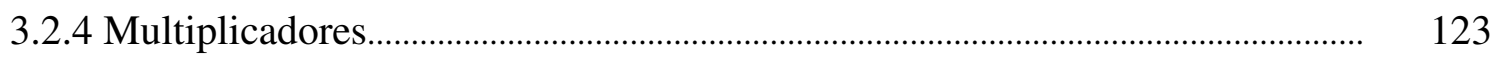

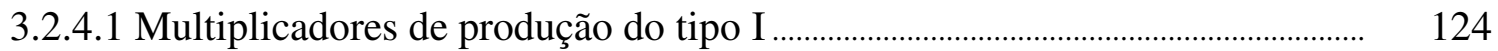

3.2.4.2 Multiplicadores de produção do tipo II..................................................................... 124

3.2.4.3 Impactos na produção.................................................................................................. 125

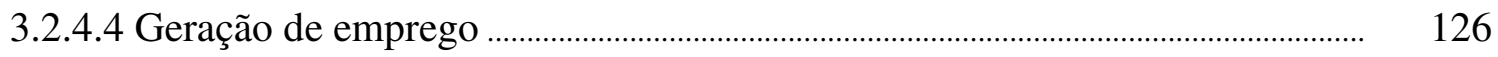

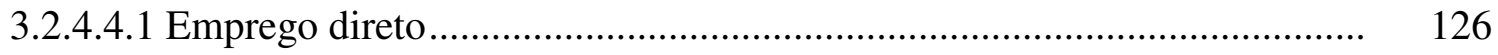

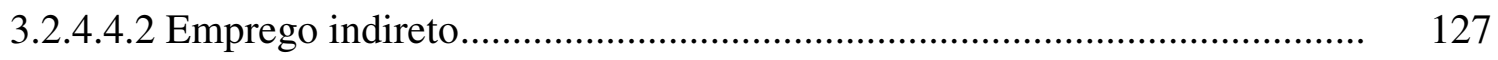

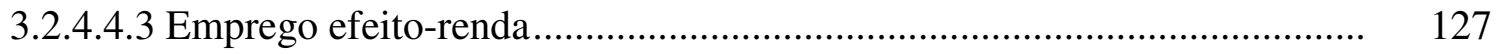

3.2.5 Matriz de insumo-produto utilizada ....................................................................... 128

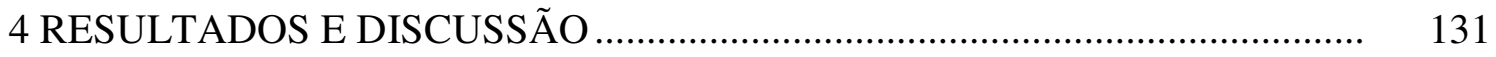

4.1 Funções de exportações brasileiras de açúcar.................................................. 132

4.1.1 Função de exportação de açúcar bruto na região Centro-Sul................................. 132

4.1.2 Função de exportação de açúcar na região Norte-Nordeste .................................. 136

4.2 Impactos da redução de políticas protecionistas no mercado de açúcar dos

EUA sobre as exportações de açúcar bruto do Brasil para os EUA ................. 139

4.2.1 Demanda de importação de açúcar bruto dos Estados Unidos ............................. 140

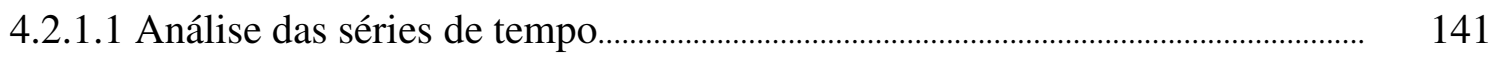

4.2.1.2 Modelos para estimação da demanda com termo de correção de erro 
4.2.1.3 Função de demanda por importação de açúcar bruto brasileiro pelos EUA.

4.2.2 Impacto sobre as exportações brasileiras de açúcar bruto para os Estados

Unidos

4.3 Impactos da redução de políticas protecionistas no mercado de açúcar da União Européia sobre as exportações brasileiras de açúcar bruto e refinado ...

4.3.1 Funções de demanda de importação de açúcar bruto e de oferta de exportação de açúcar refinado da União Européia

4.3.2 Impacto sobre as exportações brasileiras de açúcar bruto para a União Européia

4.3.3 Impacto sobre as exportações brasileiras de açúcar refinado

4.3.3.1 Funções de demanda pela importação de açúcar refinado da União

Européia - países selecionados.

4.3.3.2 Impacto da redução do subsídio da União Européia sobre as exportações de açúcar refinado do bloco europeu e do Brasil.

4.4 Impactos do aumento das exportações de açúcar sobre a economia brasileira.

4.4.1 Análise dos índices de ligações na economia

4.4.1.1 Índices de ligações de Rasmussen-Hirschman

4.4.1.2 Índices puro de ligação

4.4.2 Multiplicadores de produção tipo I e tipo II

4.4.3 Análise de sensibilidade das exportações de açúcar nas regiões Centro-Sul e Norte-Nordeste do Brasil.

4.4.4 Impactos das alterações estimadas nas exportações brasileiras de açúcar, sobre a economia das regiões exportadoras do Brasil

5 CONCLUSÕES

ANEXOS

REFERÊNCIAS BIBLIOGRÁFICAS 


\section{LISTA DE FIGURAS}

Página

1 Evolução da produção de açúcar nas regiões Centro-Sul e NorteNordeste do Brasil, nas safras de 1990/91 a 2001/02 ................................. 6

2 Evolução das exportações brasileiras dos dois principais tipos de açúcar exportados e participação (\%) do capítulo de açúcar nas exportações totais do Brasil, no período de 1990 a 2001.............................................. 8

3 Média das exportações de açúcar total das regiões Norte-Nordeste e Centro-Sul do Brasil nos sub-períodos de 1990/1995 e 1996/2001_............ 9

4 Taxa geométrica de crescimento da produção de açúcar total de 1994 a 2002, para o mundo e principais países e blocos produtores........................

5 Taxa geométrica de crescimento do consumo de açúcar total de 1994 a 2002, para o mundo e principais países e blocos consumidores.

6 Participação (\%) das exportações na produção mundial total de açúcar;

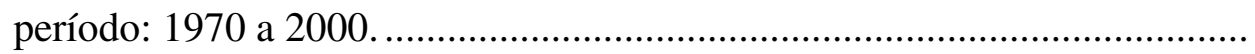

7 Razão da parcela da produção doméstica exportada (açúcar total, em equivalente bruto) por alguns dos maiores exportadores mundiais, para os anos de 1994 e 2000

8 Evolução da produção de açúcar de cana, açúcar de beterrada e HFCS nos Estados Unidos; período: 1992 a 2001.

9 Preço do açúcar bruto no mercado dos EUA e no mercado mundial e preço do HFCS no mercado norte-americano; período: 1994 a 2000. ..........

10 Preços de importação e de exportação de açúcar bruto e refinado na União Européia, em US\$/kg; período: 1994 a 2000. 
11 Posição dos países que compõem a União Européia com respeito à oferta de açúcar................................................................................ 46

12 Produção, preço de exportação de açúcar no mercado mundial e subsídio, da União Européia; período: 1989 a 2001.

13 Preço médio de importação de açúcar bruto em mercados selecionados, em US\$ 1000/toneladas; período de 1994 a 2000.

14 Preço médio de importação de açúcar refinado em mercados selecionados, em US\$ 1000/toneladas; período: 1994 a 2000.

15 Países que possuem participação das exportações de açúcar nas exportações agrícolas totais maior do que $20 \%$. Média das participações no período de 1994 a 2000.

16 Preço médio de exportação de açúcar bruto de países selecionados, em US\$/kg; período: 1994 a 2000.

17 Efeitos de remoção de quota tarifária e do programa de suporte de preço sobre preço e quantidade de açúcar comercializado com o Brasil.

Efeitos de redução de subsídio às exportações de açúcar da União

18 Européia sobre preço e quantidade de açúcar exportado pelo bloco............ 86

19 Fluxograma de destino do açúcar bruto produzido no mercado brasileiro. .

20 Fluxograma dos modelos que foram estimados para avaliar os impactos dos equivalentes tarifários incidentes sobre exportações brasileiras, pelos EUA e UE, sobre as exportações brasileiras de açúcar bruto.

21 Fluxograma dos modelos que foram estimados para avaliar os impactos dos equivalentes subsídios incidentes nas exportações da UE, sobre as exportações brasileiras de açúcar refinado.

22 Procedimento seqüencial para testar a estacionariedade de uma série de tempo.

23 Participação das exportações da região Centro-Sul, Norte-Nordeste e do Brasil, no valor da importação de açúcar bruto dos Estados Unidos; período: 1996 a 2001.

24 Países utilizados para compor as variáveis cross section na estimação 
das equações de demanda por importação de açúcar bruto e de oferta pela exportação de açúcar refinado da União Européia.

25 Participação das exportações da região Centro-Sul, e Norte-Nordeste, no valor da importação de açúcar bruto dos dois grupos de países da União Européia; período: 1996 a 2001.

26 Índices de Rasmussen-Hirschman para frente (FL) e para trás (BL) dos setores do Centro-Sul (CS) e do Norte-Nordeste (NN)

27 Índices puros de ligação para frente (PFL) e para trás (PBL) dos setores do Centro-Sul (CS) e do Norte-Nordeste (NN).

28 Multiplicadores de produção tipo I (MS1) e tipo II (MS2), sobre a economia brasileira, em relação ao aumento de demanda final nos setores do Centro-Sul (CS) e do Norte-Nordeste (NN).

29 Impactos na produção anual da economia das regiões Centro-Sul e Norte-Nordeste do Brasil, em relação ao aumento de demanda final de açúcar de R \$ 1 milhão nas regiões Centro-Sul e Norte-Nordeste.

30 Impactos no número de empregos/ano da economia das regiões CentroSul e Norte-Nordeste do Brasil, em relação ao aumento de demanda final de açúcar de R \$ 1 milhão nas regiões Centro-Sul e Norte-Nordeste... Impactos na produção da economia das regiões Centro-Sul e Norte-

31 Nordeste do Brasil, em relação ao aumento de demanda final de açúcar estimado anteriormente.

32 Impactos no número de empregos da economia das regiões Centro-Sul e Norte-Nordeste do Brasil, em relação ao aumento de demanda final de açúcar estimado anteriormente.

33 Volume total, em tonelada, e preço médio, em US $\$ / \mathrm{kg}$, da exportação de açúcar bruto na Região Centro-Sul; período: 1994 a 2002.

34 Preço mundial de açúcar bruto comercializado na Bolsa de Nova Iorque (Cents/lb peso) - contrato $\mathrm{n}^{\mathrm{o} .} 11$; período: 1982 a 2002.

35 Volume, em tonelada, e preço médio, em US\$/kg, de exportação de açúcar bruto na região Norte-Nordeste; período: 1994 a 2002. 
36 Volume, em tonelada, e preço médio, em US\$/kg, de exportação de açúcar refinado na região Centro-Sul; período de 1994 a 2002 ................. 246

37 Volume, em tonelada, e preço médio, em US\$/kg, de exportação de açúcar refinado na região Norte-Nordeste; período: 1994 a 2002 .............. 247

38 Preço de açúcar bruto comercializado na Bolsa de Londres - LIFFE Contrato $\mathrm{n}^{\text {o. }} 5$ (Cents/lb peso); período: 1982 a 2002 ............................... 248

39 Índice da taxa de câmbio efetiva real (IPA-OG - exportações, média 1995 = 100); período: 1995 a 2002. 


\section{LISTA DE QUADROS}

Página

1 Resumo dos instrumentos de políticas protecionistas para o açúcar, utilizados pela União Européia, Estados Unidos e Japão.

2 Definição das variáveis utilizadas nos modelos econométricos, as quais foram descritas nos modelos econômicos, e fonte dos dados.

3 Definição dos setores que compõem a matriz insumo-produto utilizada neste trabalho

4 Valores estimados das elasticidades-preço de oferta das exportações e, ou, preço de demanda por importações, de açúcar bruto ou refinado, nos países (regiões) estudados. 


\section{LISTA DE TABELAS}

Página

1 Custo médio de produção de açúcar nas regiões produtoras do Brasil, no mundo e nos maiores países exportadores................................................. 5

2 Maiores produtores mundiais de açúcar, em 1000 toneladas, para as safras

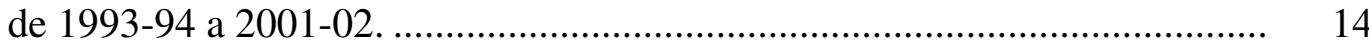

3 Relação entre produção/consumo para os maiores produtores mundiais de açúcar; período: 1994 a 2002 .................................................................. 15

4 Maiores consumidores mundiais de açúcar, em 1000 toneladas, para o período de 1994 a 2002 ........................................................................... 18

5 Consumo per capita dos maiores consumidores mundiais de açúcar, em kg de açúcar/ano; período: 1994 a 2001.

6 Maiores importadores mundiais de açúcar bruto, em 1000 toneladas; período: 1994 a 2000.

7 Maiores importadores mundiais de açúcar bruto, em 1000 dólares; período: 1994 a 2000 .

8 Maiores importadores mundiais de açúcar refinado, em 1000 toneladas métricas; período: 1994 a 2000.

9 Maiores importadores mundiais de açúcar refinado, em 1000 dólares; período: 1994 a 2000.

10 Maiores exportadores mundiais de açúcar bruto, em toneladas; período: 1994 a 2000.

11 Maiores exportadores mundiais de açúcar bruto, em 1000 dólares; 
período: 1994 a 2000.

12 Maiores exportadores mundiais de açúcar refinado, em 1000 toneladas; período: 1994 a 2000.

13 Maiores exportadores mundiais de açúcar refinado, em 1000 dólares; período: 1994 a 2000.

14 Média das taxas de empréstimo dos EUA, em US\$/kg; período: 1994 a 1998.

15 Limites das quotas tarifárias “in” para os países com os maiores acessos no mercado norte-americano, em toneladas; período: 1995/96 a 2001/02.....

16 Resultados estimados por Borrell \& Pearce (1999), CIE (2002) e Sheales et al. (1999), de algumas mudanças ocorridas no mercado mundial de açúcar frente a efeitos de menores intervenções nesse mercado.

17 Efeito de algumas reduções em intervenções governamentais sobre os preços mundiais de açúcar bruto.

18 Elasticidades de oferta e demanda para as exportações brasileiras de açúcar encontrados em trabalhos enfocando os períodos de 1961-1984 e 1961-1994.

19 Estimativas das elasticidades de oferta de exportação de açúcar bruto na região Centro-Sul do Brasil.

20 Estimativas das elasticidades de oferta de exportação de açúcar bruto na região Norte-Nordeste do Brasil.

21 Teste de raiz unitária, estatísticas $\tau_{\tau}, \tau_{\mu}$ e $\tau$.

22 Teste de co-integração de Johansen.

23 Estimativas das elasticidades de substituição e de demanda da importação de açúcar bruto nos Estados Unidos - modelo com correção de erro; período de 1982 a 2001.

24 Estimativas das elasticidades-preço direta da demanda pela exportação de açúcar bruto das regiões Centro-Sul e Norte-Nordeste do Brasil, nos Estados Unidos; período: 1982 a 2001. 
25 Estimativas das mudanças percentuais em volume e preço das exportações brasileiras de açúcar bruto em razão de mudanças nos níveis tarifários das importações dos EUA.

26 Estimativas de equivalentes tarifários do preço doméstico dos Estados Unidos em relação aos preços de exportação de açúcar bruto das regiões Centro-Sul e Norte-Nordeste do Brasil.

27 Estimativas das elasticidades de substituição e de demanda da importação extra-bloco de açúcar bruto para o primeiro grupo de países da União Européia.

28 Estimativas das elasticidades de substituição e de demanda da importação extra-bloco de açúcar bruto para o segundo grupo de países da União Européia.

29 Estimativas das elasticidades-preço direta da demanda pela exportação das regiões Centro-Sul e Norte-Nordeste do Brasil, para os dois grupos de países importadores na União Européia.

30 Estimativas das elasticidades de oferta das exportações de açúcar refinado da União Européia; período de 1989 a 1999.

31 Estimativas das mudanças percentuais em volume e preço das exportações brasileiras de açúcar bruto em razão de mudanças nos níveis tarifários das importações dos dois grupos de países da União Européia.

32 Estimativas de equivalentes tarifários do preço de comércio intra-bloco da União Européia em relação aos preços de exportação de açúcar bruto das regiões Centro-Sul e Norte-Nordeste do Brasil.

33 Participação do valor das exportações da UE em relação à importação total de açúcar refinado nos países selecionados $\left(\mathrm{S}_{\mathrm{ij}}\right)$, no período de 1996 a 1999 e participação geral no período de 1989 a 1999.

34 Estimativas das elasticidades-preço de substituição e de demanda da importação de açúcar refinado para países selecionados, importadores da União Européia e do Brasil; período de 1989 a 1999. 
35 Estimativas das elasticidades-preço direta $\left(\eta_{i j}\right)$ e preço cruzada $\left(\eta_{i j k}\right)$ da demanda pela importação de açúcar refinado da União Européia para cada um dos países selecionados.

36 Estimativas das mudanças percentuais em volume e preço das exportações européias de açúcar refinado em razão de mudanças nos níveis de subsídios concedidos

37 Impactos estimados sobre a demanda pelas exportações de açúcar refinado nas duas regiões brasileiras, em função de redução de $1 \%$ no nível de subsídio cruzado as exportações de açúcar refinado na União Européia.

38 Impactos estimados sobre a demanda pelas exportações de açúcar refinado nas duas regiões brasileiras, em função de redução total nos atuais níveis de subsídio cruzado as exportações de açúcar refinado na União Européia.

39 Choques estimados sobre as exportações brasileiras de açúcar, pela eliminação das políticas protecionistas nos Estados Unidos e na União Européia.

40 Impactos na produção e no emprego da região Norte-Nordeste em razão de aumento nas exportações brasileiras de açúcar estimadas pela eliminação das políticas protecionistas nos Estados Unidos e na União Européia.

41 Impactos na produção e no emprego da região Centro-Sul em razão de aumento nas exportações brasileiras de açúcar estimadas pela eliminação das políticas protecionistas nos Estados Unidos e na União Européia.

42 Índices de ligações de Rasmussen-Hirschman, para frente (FL) e para trás (BL), das matrizes inter-regionais do Centro-Sul e do Norte-Nordeste, e seus respectivos ordenamentos em relação ao impacto na economia brasileira, considerando apenas os setores da região analisada.

43 Índices puros normalizados, para frente (PFL), para trás $(\mathrm{PBL})$ e total 
(PTL), nas matrizes inter-regionais do Centro-Sul e Norte-Nordeste, e seus respectivos ordenamentos em relação ao impacto na economia brasileira, considerando apenas os setores da região analisada.

44 Multiplicadores de Leontief tipos I (MS1) e II (MS2) nas matrizes interregionais do Centro-Sul e Norte-Nordeste, e seus respectivos ordenamentos.

45 Variações nos níveis de produção dos setores da economia brasileira, resultantes de aumento na demanda final de açúcar de $\mathrm{R}$ \$ 1 milhão nas regiões Centro-Sul e Norte-Nordeste.

46 Variações no número de empregos gerados nos setores da economia brasileira, resultantes de aumento na demanda final de açúcar de $\mathrm{R} \$ 1$ milhão nas regiões Centro-Sul e Norte-Nordeste.

47 Variações nos níveis de produção dos setores da economia brasileira, resultantes de alterações nas exportações de açúcar do Centro-Sul e do Norte-Nordeste do Brasil, em R\$ 1.000, estimadas em função dos choques nas políticas protecionistas para o açúcar nos Estados Unidos e na União Européia.

48 Variações no número de empregos dos setores da economia brasileira, resultantes de alterações nas exportações de açúcar do Centro-Sul e do Norte-Nordeste do Brasil, estimadas em função dos choques nas políticas protecionistas para o açúcar nos Estados Unidos e na União Européia..........

49 Volumes (em Toneladas) e Preço (em US\$/kg) de exportação de açúcar bruto da região Centro-sul, para os países considerados na estimação da equação de oferta, de 1996 a 2002

50 Variáveis utilizadas para estimar a equação de oferta da exportação de açúcar bruto da região Centro-Sul.

51 Variáveis utilizadas para estimar a equação de oferta da exportação de açúcar bruto da região Norte-Nordeste.

52 Variáveis utilizadas para estimar a equação de demanda da importação de açúcar bruto dos EUA. 
53 Variáveis utilizadas para estimar a equação de demanda da importação extra-bloco de açúcar bruto da União Européia, países do primeiro grupo.... 254

54 Variáveis utilizadas para estimar a equação de demanda da importação extra-bloco de açúcar bruto e oferta de exportação extra-bloco de açúcar refinado da União Européia, países do segundo grupo................................

55 Variáveis utilizadas para estimar a equação de demanda pela importação de açúcar refinado originado da União Européia..........................................

56 Matriz insumo-produto inter-regional do Brasil, ano de 1999, valores

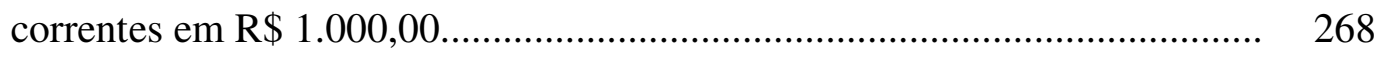




\title{
MEDIDAS PROTECIONISTAS UTILIZADAS PELOS ESTADOS UNIDOS E UNIÃO EUROPÉIA PARA O AÇÚCAR: IMPACTO SOBRE A ECONOMIA DAS REGIÕES EXPORTADORAS DO BRASIL
}

\author{
Autora: CINTHIA CABRAL DA COSTA \\ Orientadora: $\operatorname{Prof}^{\mathrm{a}} \mathrm{Dr}^{\mathrm{a}}$ HELOISA LEE BURNQUIST
}

\section{RESUMO}

As exportações brasileiras de açúcar, especialmente as originadas da região Centro-Sul, são altamente competitivas no mercado mundial. Contudo, sofrem efeitos de políticas protecionistas no âmbito do comércio internacional, alterando a movimentação da produção em resposta à determinação de oferta e demanda de mercado. O objetivo deste estudo foi identificar e quantificar os efeitos que as medidas protecionistas para o açúcar nos Estados Unidos e na União Européia, tiveram sobre a exportação brasileira de açúcar, e sua repercussão na economia brasileira como um todo, tomando como base o impacto nas principais regiões produtoras do país. Utilizando o modelo descrito por Gardner (1987), verificou-se que a eliminação do equivalente tarifário, referente as quotas tarifárias de importação e programas de preço mínimo, nos Estados Unidos, aumentaria a participação brasileira no mercado de açúcar bruto em cerca de $18 \%$, considerando as exportações médias que ocorreram para o mercado norte-americano no período de 1996 a 2002. Na União Européia, a redução de quotas de importação e a política de sustentação de preços provocariam um aumento de 55\%, em média, nas exportações brasileiras, entre 1996 e 2002. Esse valor é obtido pressupondo-se que os outros potenciais exportadores não expandam suas participações no mercado 
internacional. Em termos de volume e valor exportado, os cálculos considerando a extinção de medidas protecionistas para o açúcar nos mercados da UE e dos EUA, produziram resultados semelhantes, com impactos estimados para a economia brasileira de incremento no valor da produção de, aproximadamente, R\$ 166 milhões/ano e de geração de 6.547 empregos/ano, considerando os impactos diretos, indiretos e de efeito do aumento da renda, dos dois efeitos agindo simultaneamente, e nas duas regiões exportadoras do Brasil. Os resultados obtidos quando se considera a eliminação do valor calculado como equivalente subsídio do mercado europeu, para suas exportações de açúcar refinado, no entanto, sinalizam impactos mais expressivos que a eliminação do equivalente tarifário sustentado pelo bloco e pelos Estados Unidos. Esse impacto foi também mais expressivo para a região Centro-Sul comparado à da região NorteNordeste do Brasil. Os resultados sugerem que, neste contexto, o volume das exportações brasileiras de açúcar refinado aumentaria três vezes mais que o volume das exportações de açúcar bruto, se ambos os equivalentes tarifários, para os Estados Unidos e União Européia, fossem eliminados conjuntamente. Uma simulação do impacto dessa mudança na economia brasileira, indica a possibilidade de que incrementos na produção e emprego ocorram nessa mesma proporção: aumento de cerca de R \$ 263 milhões/ano em produção (sendo R 211 milhões na região Centro-Sul e R\$ 52 milhões na região Norte-Nordeste) e 8.480 empregos/ano gerados, considerando os efeitos diretos, indiretos e os impactos induzidos pelo efeito renda das famílias (sendo 5.256 na região Centro-Sul e 3.223 na região Norte-Nordeste). O valor total da produção estimulada pelos três impactos foi maior no Centro-Sul do Brasil. Já em relação à porcentagem do aumento da produção existente na economia, foi mais significativo o impacto na região Norte-Nordeste. Essas informações são úteis para a formulação de políticas econômicas e para a previsão de reações dos mercados frente a mudanças em variáveis internacionais, que são polêmicas na comunidade internacional. 


\title{
PROTECTIONIST MEASURES USED BY THE UNITED STATES AND EUROPEAN UNION FOR SUGAR: IMPACTS UPON THE ECONOMY OF BRAZILIAN EXPOTABLE REGIONS
}

\author{
Author: CINTHIA CABRAL DA COSTA \\ Adviser: $\operatorname{Prof}^{\mathrm{a}} \operatorname{Dr}^{\mathrm{a}}$ HELOISA LEE BURNQUIST
}

\section{SUMMARY}

Brazilian sugar exports, particularly those produced in the Center-South region, are highly competitive in the international market, but bear the effects of protectionist policies in international trade, as production changes compared to what would be obtained in response to supply and demand market signs. The objective of this study was to identify and measure the effects that protectionist measures for sugar, of the United States and European Union, had upon Brazilian sugar exports, together with its impact upon the overall economy, considering the results upon the main sugar producing regions of the country. A model described by Gardner (1987), was used to verify that the elimination of the tariff equivalent, relative to the import tariff quotas, together with the phase out of the minimum price program in the United States, would have increased the Brazilian participation in the raw sugar market by about 18 percent of its average exports to the US market through the 1996 to 2002 period. In the European Union, the reduction of import quotas and of the price support policy, showed and increase of 55 percent, on average, upon Brazilian exports, considering the same period of 1996 to 2002. This value is obtained under the assumption that other potential exporters will not expand their share in the international sugar market. In terms of export volume and 
value, calculations considering the extinction of protectionist measures for sugar in the EU and United States markets, produced results very similar, with estimated impacts of an increase in the production value upon the Brazilian economy by approximately $\mathrm{R} \$$ 166 million per year, together with the generation of 6.547 employments per year. These results were obtained considering the direct and indirect impacts of an income increase, besides the effects of these two effects acting simultaneously, and in the two major exportable regions in Brazil. The results obtained as one considers the elimination of the calculated value, as a subsidy equivalent of the European market for refined sugar exports, however, indicated more expressive effects compared to the elimination of equivalent tariff sustained by that trade bloc and by the United States. This impact was also more expressive for the Center-South region compared to the North-Northeastern Brazil. The results suggest that in this context, the export volume of refined sugar would increase three times more than the expansion in the raw sugar exports, if both are equivalent tariffs for the United States and the European Union were simultaneously eliminated. The simulation of the impact of this change in the Brazilian economy indicates the possibility that increases the increments in production and employment occur in this same proportion: production increased by $\mathrm{R} \$ 263$ million per year (being R \$ 211 million in the Center South region and R\$ 52 million in the North-Northeastern region) and 8.480 employments per year were created, considering direct, indirect and the impacts induced by the effects of family income (such that 5.256 in the Center-South region and 3.223 in the North-Northeast). The total production value stimulated by the three impacts was greater in the Center-South Brazil. However, the percentage increase in the actual level of production was more significant in the North Northeast. This is useful information to formulate economic policies and to forecast the market reaction in face of changes in the international variable what is still a controversial matter within the international community. 


\section{INTRODUÇÃO}

O objetivo deste estudo foi identificar e quantificar o impacto que liberalizações comerciais e reformas na política agrícola, que podem vir a ocorrer, tanto nos Estados Unidos, como na União Européia ${ }^{1}$, podem ter sobre as exportações brasileiras de açúcar, desagregadas por grande região produtora de cana (regiões Centro-Sul e Norte-Nordeste do Brasil), e sua repercussão na economia como um todo daquelas regiões.

\subsection{O problema e sua importância}

O açúcar é tido como uma fonte energética de consumo básico em todos os países. Com essa justificativa, diversos países, sejam esses grandes produtores, exportadores ou importadores de açúcar intervêm no comércio, afetando os preços internacionais do produto. $\mathrm{O}$ açúcar é conhecido como o produto agrícola mais protegido do mundo (Braz, 2003; Centre for International Economics - CIE, 2003; Elbehri et al., 2000; Pinazza \& Alimandro, 2003; União da Agroindústria Canavieira de São Paulo UNICA, 2003a). Carvalho (2003) indicou que o mercado livre internacional é menor do que 30\% do consumo mundial de açúcar. Segundo Ramos (2001), as políticas açucareiras estão entre as mais antigas políticas setoriais implementadas pelas nações desenvolvidas. $\mathrm{O}$ autor considera que isto se deve à importância do açúcar para o consumo humano e por ser um dos produtos que possuem um complexo de atividades urbanas e rurais.

${ }^{1}$ Os dados referentes à União Européia incluem os 15 países que, atualmente, a integram: Bélgica, Alemanha, França, Itália, Luxemburgo, Países Baixos, Dinamarca, Irlanda, Reino Unido, Grécia, Espanha, Portugal, Áustria, Finlândia e Suécia. 
As regras do Acordo Geral sobre Tarifas e Comércio $\left(\right.$ GATT) ${ }^{2}$ têm tido impacto pouco expressivo sobre o comércio internacional agrícola. Por exemplo, na Rodada Uruguai, enquanto para a maioria dos produtos manufaturados os subsídios à exportação foram proibidos, para produtos agrícolas esses são permitidos, conquanto não sejam utilizados para alcançar mais do que uma justa participação no mercado mundial daquele produto (Tanner, 1996).

O mercado de açúcar foi o maior exemplo de negociações de reformas comerciais no GATT durante a Rodada Uruguai (Larson \& Borrell, 2001). No entanto, segundo esses mesmos autores, a União Européia, o Japão, e os EUA preservaram suas políticas protecionistas entre provisões de anexos especiais para o Acordo Geral (GATT).

Entre os países desenvolvidos que adotam medidas protecionistas no mercado do açúcar, este estudo procurou identificar os impactos das medidas adotadas pelos EUA e pela União Européia sobre a economia das duas regiões exportadoras de açúcar do Brasil, que são as regiões Centro-Sul e Norte-Nordeste. As exportações brasileiras participaram com cerca de $11 \%$ e $3,5 \%$ do volume das importações totais de açúcar bruto, respectivamente, nos Estados Unidos e na União Européia. Esta participação apresenta-se bem inferior à participação do Brasil no mercado mundial, que foi acima de $20 \%$ nos últimos anos, provavelmente em função das medidas protecionistas adotadas nestes mercados.

Apesar das barreiras tarifárias impostas pelo Japão sobre as exportações brasileiras de açúcar refinado, e também por causa delas, a participação das exportações brasileiras na importação total daquele país tem sido marginal (foi estimada em 0,06\%, considerando o período de 1996 a 2001). O Japão importa, predominantemente, açúcar bruto proveniente da Austrália e Tailândia, em função da proximidade com aqueles países, e sem imposição tarifária. Assim, em função da ausência de dados passados, não

\footnotetext{
${ }^{2}$ O GATT foi estabelecido em 1947 e sofreram mudanças em oito rodadas de negociações multilaterais posteriores. Foi incorporado ao acordo final da Rodada Uruguai, incorporando o Acordo Agrícola.
} 
foram estimados os impactos de eliminação de equivalentes tarifários do Japão sobre as exportações brasileiras de açúcar refinado.

Segundo Gardner (1987), se um país quer aumentar o preço e a receita dos produtores, uma alternativa é isolar o mercado doméstico de potenciais competidores internacionais. Instrumentos políticos para isso incluem as tarifas de importação, as quotas tarifárias e os subsídios à exportação.

O regime de quota tarifária é composto de uma tarifa cobrada até certo volume de importação (denominada tarifa $i n$ ), e uma tarifa mais alta (tarifa out), cobrada sobre o volume que supera o limite imposto pela quota. No mercado internacional de açúcar, as tarifas out cobradas pelos EUA e pela União Européia tornam proibitivas as importações acima da quota.

Os subsídios fornecidos aos produtores na União Européia, por exemplo, resultam de políticas agrícolas do bloco, que mantêm altos preços domésticos para esses produtos, particularmente para o açúcar, através de políticas de sustentação de preços. Como conseqüência, a maioria dos países que compõem a União Européia passou de importador líquido na década de 1970 para exportador líquido de açúcar no período corrente. O mesmo se aplica para o bloco como um todo ${ }^{3}$. Os altos preços subsidiados favoreceram a produção de excedentes exportáveis, e com condições de competir em termos de preço no mercado mundial, em função dos altos ganhos assegurados no mercado doméstico, por uma política complexa de sustentação de preços. Este efeito foi denominado por Frandsen et al. (2001) de subsídio cruzado para as exportações de açúcar.

Conforme descrito em Pinazza \& Alimandro (2003), em 2000, a Aliança Global para a Reforma e Liberalização do Comércio de Açúcar (Global Alliance for Sugar Trade Reform and Liberalization) reuniu os maiores grupos de produtores mundiais e emitiu um documento no qual exigia: a eliminação gradativa dos subsídios às exportações de açúcar e das políticas de apoio doméstico que distorcem as regras do

\footnotetext{
${ }^{3}$ A história e explicação da política agrícola adotada pela UE pode ser melhor entendida em Marques (1993).
} 
comércio; o efetivo acesso de todos ao mercado, com a eliminação das barreiras não tarifárias e, com o tempo, a redução consensual e coordenada de todas as tarifas. Em uma dimensão maior, a reunião da Organização Mundial do Comércio $(\mathrm{OMC})^{4}$, em 2003, apresentou como principal medida para o setor a inclusão do mercado agrícola na pauta de negociações entre 2002 e 2005.

O Comitê sobre Acesso a Mercados, vinculado à $\mathrm{OMC}$, tem por função coordenar as atividades ligadas ao tema, incluindo temas tarifários e não tarifários, com o objetivo de liberalizar o comércio internacional. Assim, a agenda futura para este tema inclui negociações tarifárias e de redução de subsídios, principalmente destinados às exportações para produtos agrícolas (Thorstensen, 1999). Tais negociações podem alterar as exportações brasileiras de açúcar bruto e refinado, modificando os níveis de importância desses produtos para a economia brasileira. Tais informações são úteis na formulação de políticas para o setor sucroalcooleiro e na previsão de reações dos mercados frente a mudanças em variáveis nacionais e internacionais.

\subsubsection{Importância e características da produção de açúcar no Brasil}

A capacidade de absorção de mão-de-obra é uma das características mais notáveis relacionadas ao setor sucroalcooleiro (produção de açúcar e álcool). Segundo a UNICA (2003b), o agronegócio da cana-de-açúcar investe, em média, US\$ 10 mil por emprego. Em comparação com outras atividades industriais, são investidos: US\$ 200 mil na petroquímica, US\$ 145 mil na metalurgia, US\$ 98 mil na indústria de bens de capital, US\$ 91 mil no setor automobilístico, US\$ 70 mil na área de bens intermediários e US\$ 44 mil em bens de consumo.

A atividade canavieira do Brasil responde por cerca de um milhão de empregos diretos, 511 mil apenas na produção de cana-de-açúcar, e o restante distribuído na

\footnotetext{
${ }^{4}$ A OMC é uma organização estabelecida na Rodada Uruguai e tem como objetivo fiscalizar e orientar as políticas mundiais em relação ao GATT 1994 (que incorpora o Acordo Agrícola) e outros acordos de comércio estabelecidos nessa Rodada. Segundo Pinazza \& Alimandro (2003), a Organização Internacional do Açúcar (OIA), perdeu espaço à medida que a OMC se tornou o fórum das negociações comerciais para o setor. Segundo estes autores, a OIA reconhece o protecionismo praticado pelos EUA e UE.
} 
agroindústria de açúcar e álcool (UNICA, 2003c). Na média, tem-se que 55\% da cana brasileira é utilizada para produção de álcool e 45\%, açúcar (UNICA, 2003d).

O agronegócio da cana-de-açúcar reúne 6\% dos empregos agroindustriais, que, por sua vez, geram 14\% dos empregos totais do país (UNICA, 2003c).

A produção brasileira esteve, historicamente, concentrada em duas grandes regiões produtoras de açúcar: o Nordeste (denominado Norte-Nordeste por alguns autores) e o Centro-Sul. A região Norte-Nordeste é caracterizada, geralmente, por baixa produção e custos maiores. Entretanto, os valores apresentados por Carvalho (2001) e descritos na Tabela 1, sugerem que ambas as regiões produtoras são competitivas no mercado mundial.

Tabela 1. Custo médio de produção de açúcar nas regiões produtoras do Brasil, no mundo e nos maiores países exportadores.

\begin{tabular}{|c|c|}
\hline Origem da produção & US\$/ton. \\
\hline \multicolumn{2}{|l|}{ Brasil } \\
\hline Estado de São Paulo & 165 \\
\hline Região Centro-Sul & 180 \\
\hline Região Norte-Nordeste & 210 \\
\hline \multicolumn{2}{|l|}{ Mundo (média) } \\
\hline De cana-de-açúcar & $320 / 364$ \\
\hline De beterraba & $612 / 737$ \\
\hline \multicolumn{2}{|l|}{ Maiores exportadores } \\
\hline Cana-de-açúcar (incluindo Brasil) & $268 / 334$ \\
\hline Beterraba & $565 / 713$ \\
\hline HFCS (adoçante originado do milho) & 309 \\
\hline
\end{tabular}

Fonte: UNICA / LMC Internacional, citado por Carvalho (2001)

Nota: a região Centro-Sul é definida agregando-se os estados: Minas Gerais, São Paulo, Rio de Janeiro, Espírito Santo, Paraná, Santa Catarina, Rio Grande do Sul, Mato Grosso, Mato Grosso do Sul e Goiás. A região Norte-Nordeste compreende os estados: Alagoas, Pernambuco, Sergipe, Paraíba, Maranhão, Piauí, Bahia, Tocantins, Rio Grande do Norte, Pará, Amapá, Rondônia, Roraima e Amazonas. 
A Tabela 1 também compara a competitividade da produção de açúcar originada da cana-de-açúcar e da beterraba, assim como do adoçante originado do milho (HFCS), que são os produtos substitutos ao açúcar de cana mais utilizados no mundo.

A diferença na produção regional no Brasil pode ser observada na Figura 1, onde se tem que a produção de açúcar na região Nordeste foi bem inferior quando comparada à região Centro-Sul. Na safra de 2001/02, o volume de açúcar produzido pela região Nordeste representou $13,4 \%$ do total brasileiro, contra $38 \%$ na safra 1990/91. Este declínio é esperado que continue, por causa do processo de desregulamentação do setor ${ }^{5}$.

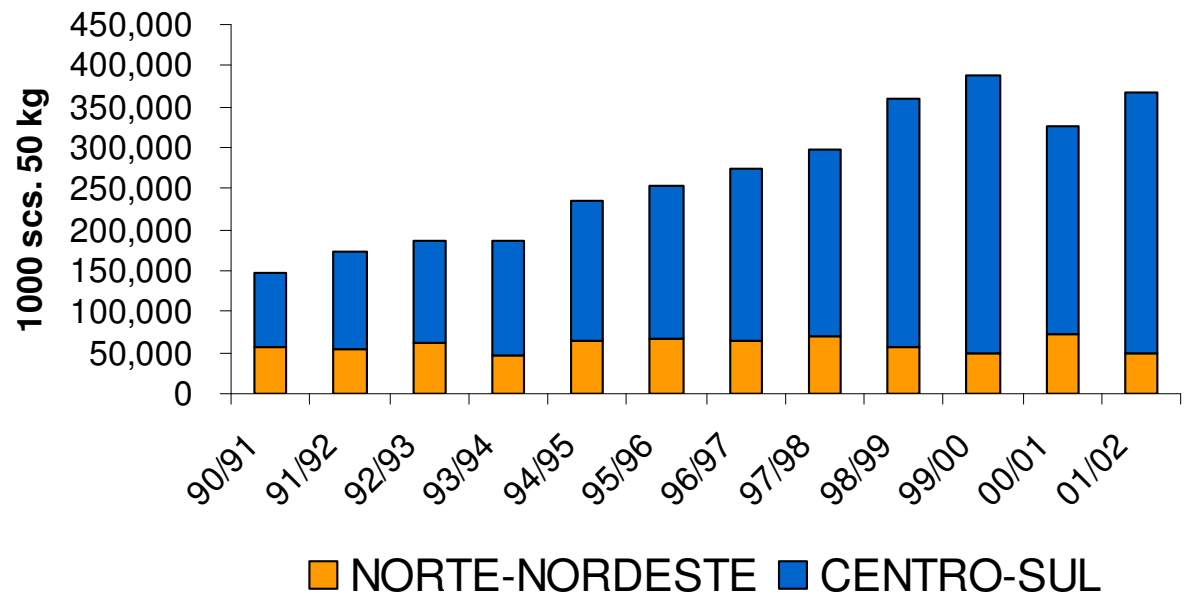

Figura 1 - Evolução da produção de açúcar nas regiões Centro-Sul e Norte-Nordeste do Brasil, nas safras de 1990/91 a 2001/02.

Fonte: UNICA (2003e)

Em contraste com a região Nordeste, a região Centro-Sul é caracterizada por alta produtividade e um excelente desenvolvimento ambiental, sendo considerada uma das áreas com menores custos de crescimento da área de cana-de-açúcar no mundo, e com significativo potencial de expansão.

\footnotetext{
${ }^{5}$ A indústria do açúcar no Brasil foi caracterizada por considerável intervenção governamental no mercado, incluindo quotas a produtores, subsídios a produção, regulação de preços em vários pontos da cadeia de mercado, controle de exportação, e administração dos terminais de exportação. No início dos anos 1990 se estabeleceu o processo de abertura comercial aos mercados externos, e houve o esgotamento do modelo de intervenção estatal. O sistema de quotas tarifárias, que vinha sendo mantido para as exportações de açúcar, foi suspenso em julho de 1994, se refletindo no aumento das exportações desse produto na safra de 1995/1996 (Burnquist et. al., 2002).
} 
Carvalho (2000) estimou uma distribuição de 61,5\% do volume de açúcar consumido no país sendo de uso direto e que, deste total, $34 \%$ do consumo seria de açúcar refinado e $66 \%$, de açúcar do tipo cristal. Portanto, do total de açúcar produzido no país, estima-se que a produção de açúcar refinado seja igual ao volume exportado acrescido de $21 \%$ (34\% de 61,5\%) da produção destinada ao consumo interno. A produção de açúcar bruto é estimada como a soma do volume exportado com $79 \%{ }^{6}$ da produção destinada ao consumo interno.

\subsubsection{O setor exportador de açúcar no Brasil}

Com a liberação das exportações brasileiras a partir da safra 1994/95, por causa do processo de desregulamentação do setor sucroalcooleiro, houve uma tendência de aumento, tanto da produção quanto das exportações de açúcar. A Figura 2 ilustra o aumento das exportações brasileiras de açúcar bruto (correspondente ao código NCM 1701.11.00) e refinado (principal tipo de açúcar exportado, código NCM 1701.99.00 no Brasil $)^{7}$ na década de $1990^{8}$.

Deve-se ressaltar, ainda, que o aumento do valor da taxa de câmbio em 1999 também contribuiu para o aumento das exportações brasileiras de açúcar naquele ano. Por outro lado, a quebra de safra em 2000, na região Centro-Sul, foi responsável pela redução no volume exportado total naquele ano.

\footnotetext{
${ }^{6} 79 \%=(100 \%-61,5 \%)+61,5 \% * 66 \%$; onde o primeiro termo corresponde ao uso indireto do açúcar, uso industrial, que ocorre geralmente na forma de açúcar bruto.

7 Esta distinção entre açúcar bruto e refinado nos códigos descritos foi também utilizada em Brasil (2003a).

${ }^{8}$ No período de 1990 a 1995, as exportações brasileiras foram descritas pelo código NBM. Assim, para associar os mesmos produtos no código NCM tem-se que, para açúcar bruto, NCM 1701.11.00, os NBM correspondentes são: 1701.11.0100, 1701.11.0200, 1701.11.0300 e 1701.11.9900. Para açúcar refinado, NCM 1701.99.00, os NBM correspondentes são: 1701.99.0100, 1701.99.0200 e 1701.99.9900.
} 


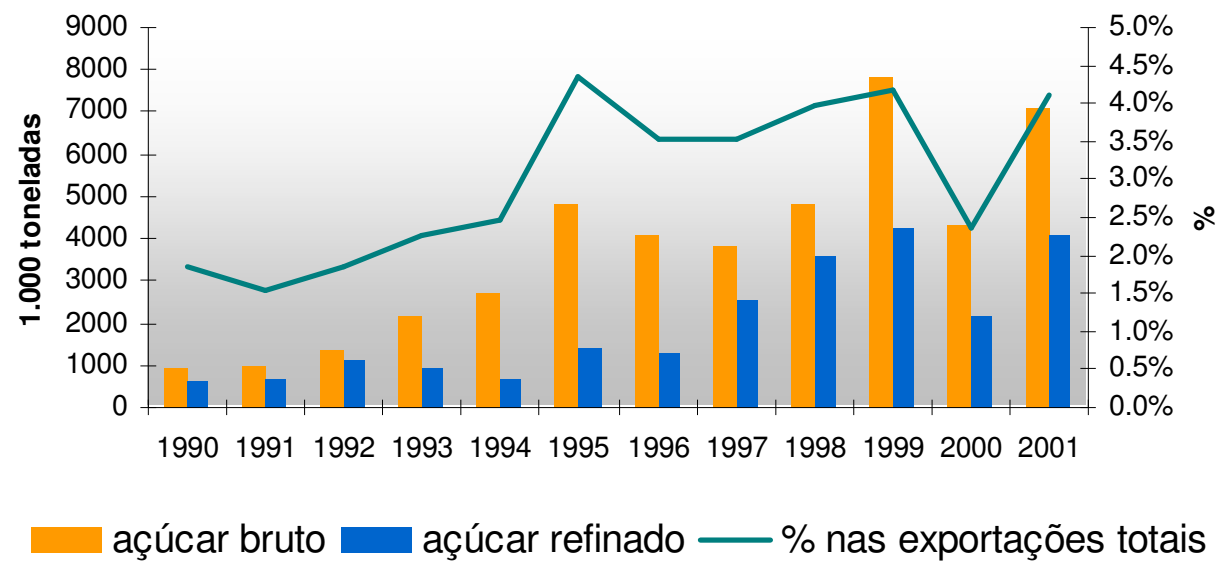

Figura 2 - Evolução das exportações brasileiras dos dois principais tipos de açúcar exportados e participação (\%) do capítulo de açúcar nas exportações totais do Brasil, no período de 1990 a 2001.

Fonte: Brasil (2003b)

Já as exportações da região Nordeste, por causa da redução dos subsídios a essa região, tiveram sua participação diminuída no total das exportações do Brasil (Figura 3). A crescente participação das exportações originadas no Estado de São Paulo, decorrentes do processo de desregulamentação, foi a principal razão interna para o aumento das exportações brasileiras. Isso foi verificado no trabalho de Costa \& Burnquist (2003), onde as autoras verificaram que o efeito da competitividade, dado pela desregulamentação do setor sucroalcooleiro, sobre o aumento das exportações brasileiras de açúcar na segunda metade da década de 1990, ocorreu de maneira significativa na região Centro-Sul (explicando $89 \%$ do aumento das exportações). Na região NorteNordeste, o aumento das exportações de açúcar foi explicado apenas pelo crescimento do tamanho do mercado mundial de açúcar e pelo incremento das importações dos países que importaram dessa região. 


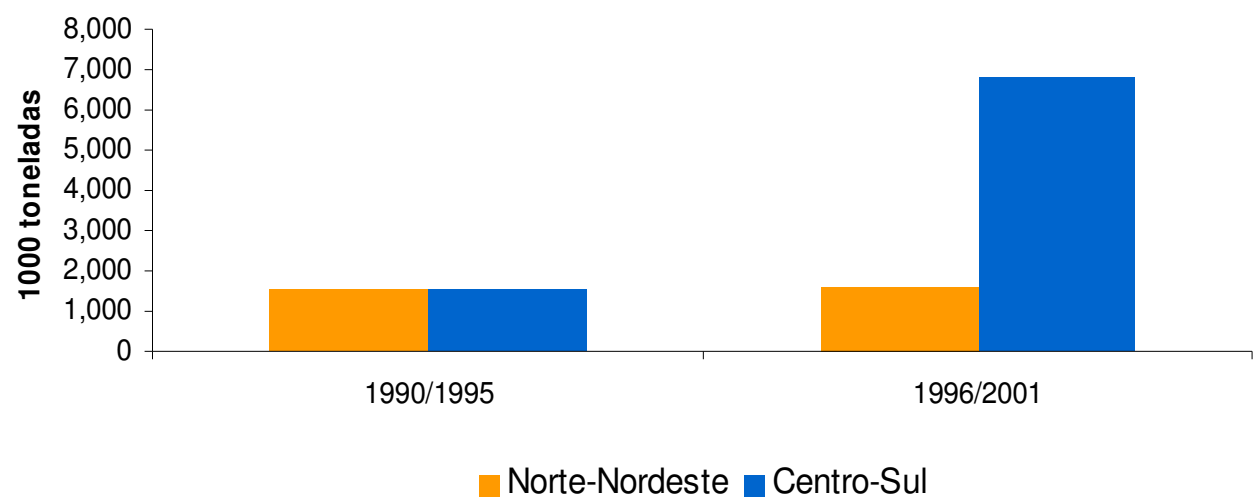

Figura 3 - Média das exportações de açúcar total das regiões Norte-Nordeste e CentroSul do Brasil nos sub-períodos de 1990/1995 e 1996/2001.

Fonte: Brasil (2003b)

Segundo dados de Brasil (2003b), do total das exportações do capítulo 17 do Sistema Harmonizado (que corresponde a açúcares e outros produtos de confeitaria), no período de 1996 a 2001: na região Centro-Sul, 58,8\% foi de açúcar bruto (correspondente ao código NCM 1701.11.00) e 40,2\% foi de açúcar refinado (principal tipo de açúcar exportado, código NCM 1701.99.00 no Brasil). Por outro lado, as exportações de açúcar da região Norte-Nordeste, nesse mesmo período, foram de 81,9\% de açúcar bruto e 16,4\% de açúcar refinado. As exportações brasileiras de outros produtos, dentro do capítulo 17, corresponderam a cerca de $1 \%$ das exportações no período de 1996 a 2001.

A diferenciação das exportações das duas regiões se reflete também em relação aos seus importadores. Das exportações originadas da região Centro-Sul, a Rússia foi o país que mais aumentou suas importações no segundo período (acima de 1 milhão de toneladas). Outros países que aumentaram as importações de açúcar dessa região foram: Emirados Árabes, Nigéria, Egito, Marrocos, Iêmen, Canadá, Arábia Saudita, Indonésia, Romênia, Irã, Malásia, Jordânia e Somália. A Rússia também foi o maior responsável pelo aumento das exportações da região Norte-Nordeste no período de 1996 a 2001, apresentando um incremento médio superior a 600 mil toneladas. Por outro lado, Egito e 
Marrocos reduziram, individualmente, suas importações de açúcar da região NorteNordeste em mais de 100 mil toneladas no segundo período 9 .

É importante considerar que os produtores de açúcar no Brasil utilizam, em sua maioria, usinas que possuem destilaria anexa ${ }^{10}$. Assim, podem alterar o mix de produção entre açúcar e álcool, apresentando um grande potencial de desviar mais cana para a produção de açúcar em detrimento ao álcool.

Devido ao grande crescimento da cana-de-açúcar utilizado como matéria-prima em ambas as indústrias (açúcar e álcool) no Brasil, o país demonstra potencial de expansão de exportação de açúcar mais rápido do que em qualquer outro dos maiores exportadores.

Num panorama geral do mercado, tem-se que: o mercado exportador de açúcar no Brasil deixou de ser regulamentado pelo governo; o açúcar brasileiro é um dos mais competitivos no mercado mundial; e o mercado desse produto é um dos mais regulamentados a nível mundial, havendo uma tendência de maior liberalização em futuras negociações da OMC. Assim, há uma clara possibilidade de aumento futuro das exportações brasileiras de açúcar. Esse trabalho procurou analisar o aumento das exportações brasileiras de açúcar decorrentes da eliminação de medidas protecionistas nos EUA e na União Européia para este produto. Os resultados das variações nas exportações de açúcar foram utilizados como aumento na demanda final do setor correspondente na matriz insumo-produto referente à região exportadora do Brasil que sofreu o impacto. Essas informações têm como objetivo subsidiar futuras negociações contra os entraves estabelecidos no mercado internacional de açúcar.

\footnotetext{
${ }^{9}$ Informações verificadas a partir de dados de Brasil, 2003b.

${ }^{10}$ Segundo dados apresentados no Seminário açúcar e álcool: o Brasil no cenário global - Piracicaba (2002), 85,5\% da produção de açúcar e 79,8\% da produção de álcool, na região centro-sul, em setembro de 2002, são produzidos por usinas com destilarias anexas.
} 


\subsection{Objetivos}

\subsubsection{Objetivo geral}

Analisar o impacto de medidas protecionistas que prevalecem para o mercado interno de açúcar nos Estados Unidos e na União Européia no setor de indústria de açúcar e na economia das duas regiões produtoras e exportadoras de açúcar do Brasil: Centro-Sul e Norte-Nordeste.

\subsubsection{Objetivos específicos}

(a) Identificar as principais barreiras protecionistas impostas ao comércio mundial de açúcar;

(b) Especificar e estimar um modelo econômico que identifique os efeitos de mudança tarifária incidentes sobre o volume e o preço recebido pelas exportações brasileiras;

(c) Especificar e estimar um modelo econômico para identificar o impacto da redução de subsídios que favorecem a exportação de açúcar em um mercado exportador, sobre o volume das exportações brasileiras nos importadores comuns entre Brasil e o mercado subsidiado;

(d) Simular efeitos da eliminação dos equivalentes tarifários e de subsídios do açúcar nos Estados Unidos e na União Européia, e quantificar os efeitos nas exportações brasileiras deste produto. Utilizar os resultados encontrados como choques de demanda final para analisar os efeitos sobre os níveis de produção e emprego na economia brasileira. 


\section{REVISÃO DE LITERATURA}

Esse capítulo tem como objetivos: (i) descrever o panorama do mercado mundial de açúcar, identificando os principais países produtores, consumidores, importadores e exportadores, e as políticas internacionais que restringem a comercialização de açúcar no mundo; (ii) relatar estudos sobre os efeitos de reduções de barreiras comerciais no mercado internacional de açúcar; e (iii) revisar modelos de equilíbrio parciais utilizados para estudar o comércio internacional de commodities, e o estágio atual das pesquisas sobre as exportações brasileiras de açúcar. Este conhecimento é essencial para subsidiar a justificativa do trabalho, assim como para construir modelos econômicos requeridos para a análise, e para interpretar os resultados encontrados.

\subsection{Panorama mundial do mercado de açúcar}

Com a finalidade de obter um panorama do comércio mundial de açúcar, são descritos, a seguir, os principais países produtores, consumidores, importadores e exportadores de açúcar. Os importadores e exportadores de açúcar foram subdivididos em importadores e exportadores de açúcar nas formas bruto e refinado. Essa distinção entre os tipos de açúcar é importante para a compreensão do mercado internacional desse produto. De maneira geral, os países desenvolvidos são grandes importadores de açúcar bruto e os países menos desenvolvidos importam, na sua maioria, açúcar refinado.

O mercado mundial de açúcar é caracterizado por intervenções governamentais que distorcem a produção, o consumo e o mercado de açúcar (Sheales et al., 1999). Tais 
distorções são onerosas, tanto para consumidores, como para produtores, em muitos países. Esses autores descrevem como principais objetivos das políticas que afetam o mercado de açúcar: (i) promoção para melhoria da renda para produtores domésticos; (ii) aumento da eficiência técnica; e (iii) estabilidade no mercado em termos de oferta para consumidores e preços para consumidores e produtores. Indiretamente, as políticas protecionistas também afetam a atratividade do açúcar comparado com outros adoçantes usados em bebidas e setores de alimentos processados (Sheales et al., 1999).

\subsubsection{Produção e consumo}

Segundo estimativas da United States Department of Agriculture - USDA (2002a), a produção mundial de açúcar é prevista em cerca de 138 milhões de toneladas na safra 2002/03, aproximadamente 19\% acima dos 116 milhões de toneladas produzidos na safra 1993/94. O Brasil é um dos maiores produtores mundiais de açúcar, situando-se, na segunda metade da década de 1990, em primeiro lugar no ranking dos maiores produtores em alguns anos, sendo eventualmente ultrapassado pela União Européia (UE) ou pela Índia. Os maiores produtores de açúcar no período considerado, como descrito na Tabela 2, foram: Brasil, União Européia, Índia, China, Estados Unidos (EUA), Tailândia, Austrália e México.

O açúcar produzido mundialmente pode ser originado de duas culturas: a cana e a beterraba. Entretanto, em razão de menores custos de produção, a produção de açúcar a partir da cana compreende mais de $80 \%$ do total mundial. Os países da União Européia são basicamente produtores de açúcar de beterraba e os países em desenvolvimento destacam-se na produção do açúcar a partir da cana-de-açúcar.

O Brasil foi também o país que apresentou o maior dinamismo no desenvolvimento da produção de açúcar, com a maior taxa de crescimento da produção no período descrito, entre os países selecionados (Figura 4). A produção brasileira, que representou cerca de $10 \%$ da produção mundial em 1993/94, passou a 15\% e $16 \%$ nas últimas duas safras (Tabela 2). Na Tabela 3 também se visualiza, para os maiores 
produtores mundiais de açúcar, a relação da produção total com seu consumo doméstico. Essa relação demonstra que há excesso de produção do país quando ela é maior do que 1, e excesso de demanda quando for menor do que 1. Assim, entre os países selecionados, o Brasil obteve a maior evolução desse índice no período considerado.

Tabela 2. Maiores produtores mundiais de açúcar, em 1000 toneladas, para as safras de 1993-94 a 2001-02.

\begin{tabular}{lrrrrrrrrr}
\hline & $1993-94$ & $1994-95$ & $1995-96$ & $1996-97$ & $1997-98$ & $1998-99$ & $1999-00$ & $2000-01$ & $2001-02$ \\
\hline Mundo & 116.032 & 122.220 & 123.009 & 124.899 & 130.709 & 136.420 & 129.978 & 133.205 & 138.313 \\
Brasil & 12.500 & 13.700 & 14.650 & 15.700 & 18.300 & 20.100 & 17.100 & 20.350 & 22.950 \\
UE & 16.761 & 17.234 & 18.221 & 19.305 & 17.818 & 19.498 & 18.520 & 16.238 & 17.589 \\
Índia & 16.410 & 18.225 & 14.616 & 14.592 & 17.436 & 20.219 & 20.480 & 19.380 & 18.550 \\
China & 6.299 & 6.686 & 7.789 & 8.631 & 8.969 & 7.525 & 6.849 & 8.760 & 8.970 \\
EUA & 7.191 & 6.686 & 6.536 & 7.276 & 7.597 & 8.203 & 7.869 & 7.261 & 7.938 \\
Tailândia & 5.448 & 6.223 & 6.013 & 4.245 & 5.386 & 5.721 & 5.107 & 6.355 & 6.000 \\
Austrália & 5.196 & 5.049 & 5.659 & 5.567 & 4.997 & 5.448 & 4.162 & 4.610 & 5.301 \\
México & 4.556 & 4.660 & 4.835 & 5.490 & 4.985 & 4.977 & 5.223 & 5.393 & 5.305 \\
Cuba & 3.300 & 4.450 & 4.200 & 3.200 & 3.760 & 4.060 & 3.500 & 3.600 & 3.600 \\
Paquistão & 3.212 & 2.643 & 2.560 & 3.805 & 3.791 & 2.595 & 2.648 & 3.006 & 3.210 \\
Colômbia & 2.071 & 2.002 & 2.132 & 2.154 & 2.199 & 2.330 & 2.225 & 2.300 & 2.305 \\
África do Sul & 1.770 & 1.769 & 2.408 & 2.413 & 2.646 & 2.685 & 2.895 & 2.542 & 2.725 \\
Turquia & 1.678 & 1.375 & 2.025 & 2.372 & 2.947 & 2.348 & 2.756 & 1.796 & 2.336 \\
Guatemala & 1.333 & 1.334 & 1.566 & 1.720 & 1.561 & 1.617 & 1.632 & 1.910 & 1.789 \\
Argentina & 1.180 & 1.590 & 1.380 & 1.750 & 1.830 & 1.670 & 1.540 & 1.600 & 1.550 \\
Rússia & 1.655 & 2.060 & 1.710 & 1.350 & 1.300 & 1.500 & 1.550 & 1.630 & 1.700 \\
Ucrânia & 3.600 & 3.800 & 2.935 & 2.032 & 2.000 & 1.720 & 1.687 & 1.790 & 1.900 \\
Egito & 1.088 & 1.092 & 1.156 & 1.170 & 1.180 & 1.390 & 1.400 & 1.450 & 470 \\
Indonésia & 2.450 & 2.090 & 2.094 & 2.190 & 1.492 & 1.690 & 1.800 & 1.700 & 1.800 \\
Filipinas & 1.647 & 1.791 & 1.829 & 1.802 & 1.682 & 1.620 & 1.805 & 1.920 & 1.900 \\
\hline Fon & & & & & & & & &
\end{tabular}

Fonte: USDA (2002a)

A Tabela 3 mostra, ainda, que apenas nove dos vinte países considerados na relação dos maiores produtores registraram excesso de produção durante todo o período analisado. 
Tabela 3. Relação entre produção/consumo para os maiores produtores mundiais de açúcar; período: 1994 a 2002.

\begin{tabular}{lccccccccc}
\hline & 1994 & 1995 & 1996 & 1997 & 1998 & 1999 & 2000 & 2001 & 2002 \\
\hline Austrália & 6,11 & 5,87 & 5,83 & 5,62 & 5,02 & 5,48 & 4,18 & 4,52 & 5,05 \\
Cuba & 7,02 & 6,85 & 6,00 & 4,57 & 5,70 & 5,72 & 4,86 & 5,00 & 5,00 \\
Guatemala & 3,37 & 3,25 & 3,63 & 3,85 & 3,46 & 3,59 & 3,49 & 3,82 & 3,58 \\
Tailândia & 3,63 & 3,99 & 3,76 & 2,50 & 2,99 & 3,47 & 2,92 & 3,44 & 3,24 \\
Brasil & 1,56 & 1,69 & 1,72 & 1,78 & 2,01 & 2,21 & 1,85 & 2,15 & 2,38 \\
Colômbia & 1,54 & 1,44 & 1,58 & 1,63 & 1,78 & 1,67 & 1,70 & 1,75 & 1,76 \\
África do Sul & 1,35 & 1,27 & 1,71 & 1,77 & 2,18 & 1,84 & 1,75 & 1,55 & 1,64 \\
UE & 1,14 & 1,22 & 1,27 & 1,35 & 1,25 & 1,34 & 1,28 & 1,12 & 1,21 \\
México & 1,06 & 1,13 & 1,14 & 1,29 & 1,13 & 1,11 & 1,15 & 1,17 & 1,15 \\
Turquia & 0,92 & 0,72 & 1,03 & 1,17 & 1,42 & 1,15 & 1,41 & 0,92 & 1,09 \\
Argentina & 0,90 & 1,18 & 1,02 & 1,21 & 1,20 & 1,09 & 1,05 & 1,10 & 1,07 \\
China & 0,79 & 0,83 & 0,94 & 0,96 & 1,01 & 0,89 & 0,79 & 0,99 & 1,00 \\
Índia & 1,19 & 1,23 & 0,93 & 0,87 & 1,03 & 1,17 & 1,15 & 1,05 & 0,98 \\
Filipinas & 0,89 & 0,91 & 0,96 & 0,95 & 0,89 & 0,84 & 0,93 & 0,98 & 0,97 \\
Ucrânia & 1,57 & 1,69 & 1,37 & 1,07 & 0,98 & 0,89 & 0,80 & 0,87 & 0,95 \\
Paquistão & 1,11 & 0,86 & 0,84 & 1,24 & 1,18 & 0,79 & 0,77 & 0,87 & 0,93 \\
EUA & 0,85 & 0,77 & 0,74 & 0,82 & 0,84 & 0,91 & 0,86 & 0,80 & 0,87 \\
Indonésia & 0,88 & 0,72 & 0,68 & 0,70 & 0,53 & 0,53 & 0,55 & 0,50 & 0,51 \\
Rússia & 0,34 & 0,41 & 0,34 & 0,29 & 0,26 & 0,24 & 0,23 & 0,23 & 0,24 \\
Egito & 0,67 & 0,66 & 0,61 & 0,61 & 0,61 & 0,72 & 0,69 & 0,71 & 0,23 \\
\hline
\end{tabular}

Fonte: elaborado a partir de dados da USDA (2002a)

Os países que apresentaram volume produzido superior a três vezes o consumo doméstico foram Austrália, Cuba, Guatemala e Tailândia. Observa-se também uma tendência geral à redução na relação produção/consumo em importantes países produtores de açúcar. Essa relação caiu de 6,11 para 5,05 para a Austrália, e de 7,02 para 5,00 no caso de Cuba. Conforme pode ser visualizado na Figura 4, a baixa taxa de 
crescimento ${ }^{11}$ de produção, particularmente nesses dois países, forma bem menores do que as suas respectivas taxas de crescimento para o consumo de açúcar. Isso, provavelmente, poderia explicar o declínio das relações observadas na Tabela 3.

As informações descritas na Tabela 3 fornecem também uma indicação dos países que são potenciais importadores e daqueles que são potenciais exportadores no mercado internacional. No momento apropriado essas considerações são discutidas.

Em relação às taxas de crescimento da produção, os países que apresentam valores acima do desvio-padrão (linha pontilhada na Figura 4), além do Brasil, são: África do Sul, China e Turquia. E com a taxa de crescimento da produção de açúcar negativa, e menor do que o desvio-padrão tem-se: Ucrânia, Egito e Indonésia.

Assim, esses valores podem indicar um aumento da concorrência de exportação do açúcar brasileiro com aquele proveniente, principalmente, da África do Sul, pois esse país apresentou, também, excesso de oferta no mesmo período (Tabela 3). Indicam também um aumento potencial de exportação para os mercados da Ucrânia, Egito e Indonésia.

A demanda mundial de açúcar, por sua vez, cresceu cerca de $17 \%$ no período de 1994 a 2001, percentual que se situa acima do crescimento populacional estimado pela The Food and Agricultural Organization - FAO (2002) para o mesmo período, que foi de aproximadamente $10 \%$. Os maiores consumidores mundiais de açúcar, conforme visualizado na Tabela 4, foram Índia, União Européia, Brasil, China, Estados Unidos, Rússia e México. Desses países, apenas a Rússia não se incluiu, também, entre os maiores produtores. $\mathrm{O}$ fato de ser grande consumidora per capita justifica o excesso de demanda russo, expresso pelo baixo índice da relação produção/consumo (Tabela 3).

\footnotetext{
${ }^{11}$ A taxa geométrica de crescimento corresponde à letra " $r$ " na expressão: $X_{t}=X_{0}(1+r)^{t}$, em que $X_{t}$ é a quantidade exportada no período $t$ e $X_{0}$ é a quantidade exportada no período inicial; $t$ é o número de anos considerados.

Aplicando logaritmo na expressão anterior tem-se: $\log X_{t}=\log X_{0}+t \log (1+r)$.

Calcula-se $\log (1+r)=z$ por operação algébrica simples na expressão anterior e, então, encontra-se o valor de $r$ por: $r=e^{z}-1$.
} 


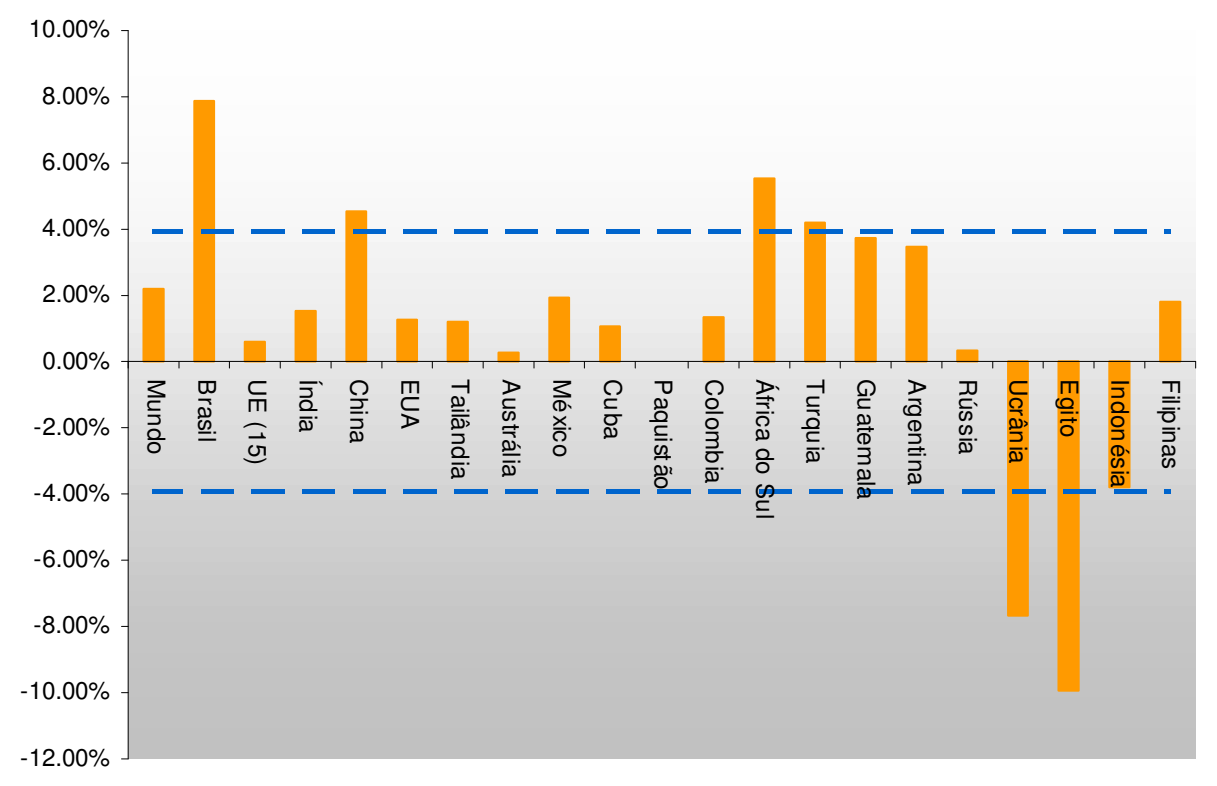

Figura 4 - Taxa geométrica de crescimento da produção de açúcar total de 1994 a 2002, para o mundo e principais países e blocos produtores.

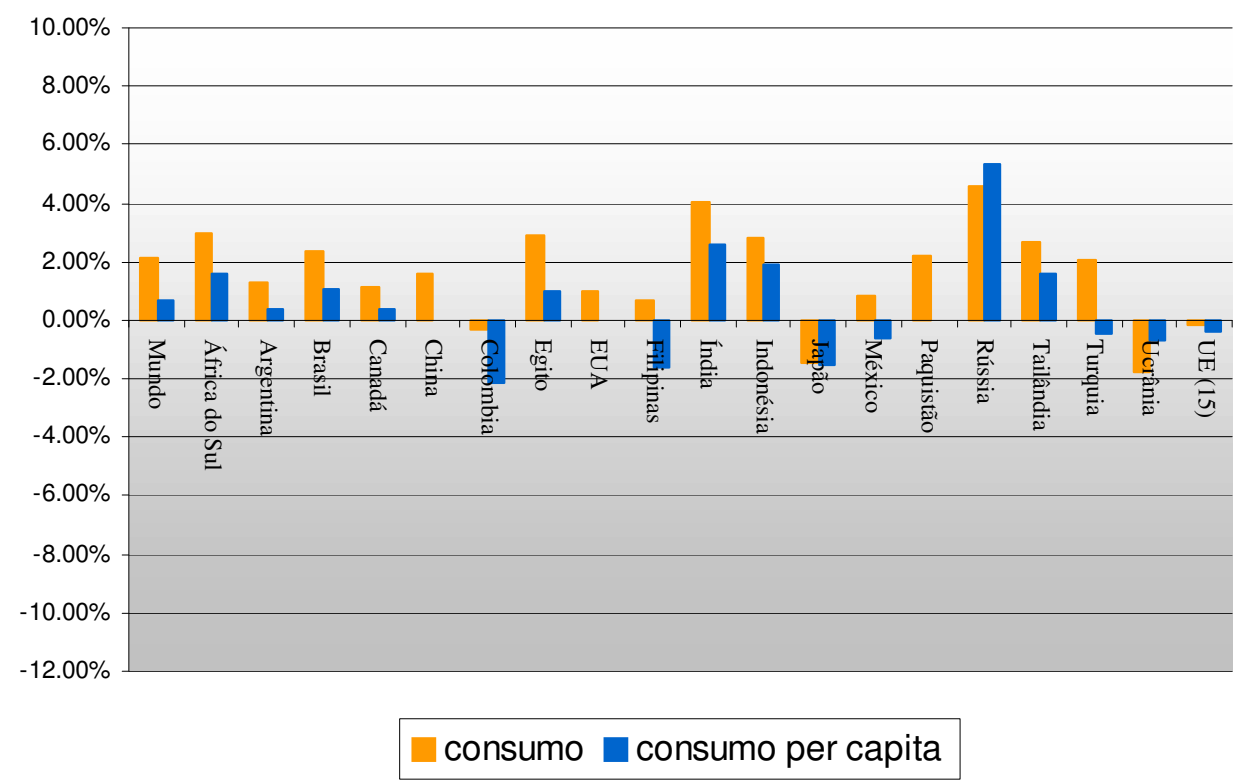

Figura 5 - Taxa geométrica de crescimento do consumo de açúcar total de 1994 a 2002, para o mundo e principais países e blocos consumidores. 
Tabela 4. Maiores consumidores mundiais de açúcar, em 1000 toneladas, para o período de 1994 a 2002.

\begin{tabular}{lrrrrrrrrr}
\hline & 1994 & 1995 & 1996 & 1997 & 1998 & 1999 & 2000 & 2001 & 2002 \\
\hline Mundo & 112.793 & 118.329 & 123.023 & 123.677 & 124.384 & 127.079 & 129.699 & 131.766 & 133.449 \\
Índia & 13.841 & 14.820 & 15.697 & 16.700 & 16.977 & 17.296 & 17.845 & 18.400 & 19.000 \\
UE & 14.659 & 14.146 & 14.332 & 14.307 & 14.250 & 14.523 & 14.420 & 14.451 & 14.500 \\
Brasil & 8.000 & 8.100 & 8.500 & 8.800 & 9.100 & 9.100 & 9.250 & 9.450 & 9.650 \\
China & 7.948 & 8.040 & 8.268 & 9.012 & 8.907 & 8.476 & 8.650 & 8.880 & 9.000 \\
EUA & 8.470 & 8.667 & 8.866 & 8.903 & 9.079 & 9.049 & 9.192 & 9.058 & 9.149 \\
Rússia & 4.900 & 5.000 & 5.100 & 4.580 & 4.995 & 6.130 & 6.840 & 6.940 & 7.005 \\
México & 4.310 & 4.140 & 4.240 & 4.240 & 4.400 & 4.482 & 4.543 & 4.615 & 4.615 \\
Indonésia & 2.800 & 2.900 & 3.100 & 3.150 & 2.800 & 3.200 & 3.300 & 3.400 & 3.500 \\
Paquistão & 2.900 & 3.090 & 3.050 & 3.080 & 3.210 & 3.300 & 3.450 & 3.450 & 3.450 \\
Japão & 2.520 & 2.520 & 2.385 & 2.323 & 2.313 & 2.142 & 2.293 & 2.317 & 2.243 \\
Turquia & 1.830 & 1.900 & 1.960 & 2.020 & 2.080 & 2.050 & 1.950 & 1.950 & 2.150 \\
Ucrânia & 2.300 & 2.250 & 2.150 & 1.900 & 2.039 & 1.937 & 2.100 & 2.050 & 2.000 \\
Egito & 1.620 & 1.647 & 1.890 & 1.920 & 1.950 & 1.940 & 2.030 & 2.035 & 2.040 \\
Filipinas & 1.849 & 1.970 & 1.900 & 1.900 & 1.890 & 1.930 & 1.940 & 1.950 & 1.950 \\
Canadá & 1.139 & 1.209 & 1.220 & 1.240 & 1.240 & 1.240 & 1.243 & 1.255 & 1.250 \\
Tailândia & 1.500 & 1.560 & 1.600 & 1.698 & 1.800 & 1.650 & 1.750 & 1.850 & 1.850 \\
Colômbia & 1.344 & 1.390 & 1.350 & 1.325 & 1.238 & 1.393 & 1.305 & 1.315 & 1.310 \\
África do Sul & 1.315 & 1.393 & 1.405 & 1.367 & 1.213 & 1.460 & 1.650 & 1.635 & 1.660 \\
Argentina & 1.310 & 1.350 & 1.350 & 1.451 & 1.520 & 1.530 & 1.470 & 1.450 & 1.450 \\
\hline Fonte. & & & & & & & & &
\end{tabular}

Fonte: USDA (2002a)

No que se refere ao consumo, para se obter uma medida mais realista, deve-se dividir os volumes consumidos pela população total do país, obtendo-se o consumo per capita. Assim, a Tabela 5 indica o consumo per capita de açúcar para os principais países consumidores descritos na Tabela 4 . 
Tabela 5. Consumo per capita dos maiores consumidores mundiais de açúcar, em kg de açúcar/ano; período: 1994 a 2001.

\begin{tabular}{|c|c|c|c|c|c|c|c|c|}
\hline & 1994 & 1995 & 1996 & 1997 & 1998 & 1999 & 2000 & 2001 \\
\hline Mundo & 20 & 21 & 21 & 21 & 21 & 21 & 21 & 21 \\
\hline Brasil & 51 & 51 & 53 & 54 & 55 & 54 & 54 & 55 \\
\hline Rússia & 33 & 34 & 35 & 31 & 34 & 42 & 47 & 48 \\
\hline México & 48 & 45 & 46 & 45 & 46 & 46 & 46 & 46 \\
\hline Ucrânia & 44 & 44 & 42 & 37 & 40 & 39 & 42 & 42 \\
\hline Canadá & 39 & 41 & 41 & 41 & 41 & 41 & 40 & 40 \\
\hline Argentina & 38 & 39 & 38 & 41 & 42 & 42 & 40 & 39 \\
\hline UE & 39 & 38 & 38 & 38 & 38 & 39 & 38 & 38 \\
\hline África do Sul & 33 & 35 & 34 & 33 & 29 & 34 & 38 & 37 \\
\hline EUA & 32 & 32 & 33 & 32 & 33 & 32 & 32 & 32 \\
\hline Colômbia & 36 & 36 & 34 & 33 & 30 & 34 & 31 & 31 \\
\hline Turquia & 30 & 31 & 31 & 32 & 32 & 31 & 29 & 29 \\
\hline Egito & 27 & 27 & 30 & 30 & 30 & 29 & 30 & 29 \\
\hline Tailândia & 26 & 27 & 27 & 28 & 29 & 27 & 28 & 29 \\
\hline Filipinas & 28 & 29 & 27 & 27 & 26 & 26 & 26 & 25 \\
\hline Paquistão & 24 & 25 & 24 & 24 & 24 & 24 & 24 & 24 \\
\hline Japão & 20 & 20 & 19 & 18 & 18 & 17 & 18 & 18 \\
\hline Índia & 15 & 16 & 17 & 17 & 17 & 17 & 18 & 18 \\
\hline Indonésia & 14 & 15 & 15 & 15 & 14 & 15 & 16 & 16 \\
\hline China & 7 & 7 & 7 & 7 & 7 & 7 & 7 & 7 \\
\hline
\end{tabular}

Fonte: elaborado a partir de dados da FAO (2002) e USDA (2002a)

Observa-se que o ranking descrito na Tabela 4 para os maiores consumidores de açúcar, em volume absoluto, é diferente daquele descrito para os maiores consumidores per capita, justificando a importância deste último. A média mundial de consumo per capita de açúcar foi da ordem de $20 \mathrm{~kg} / \mathrm{ano}$. Em 2001, o Brasil teve o maior consumo per capita entre os países considerados, acima de 50 kg/ano. A Rússia veio em segundo lugar, apresentando, a despeito da tendência de declínio do consumo 
observado para vários países, as maiores taxas de crescimento de consumo em valor absoluto e consumo per capita dos países selecionados (Figura 5). O consumo de açúcar no país passou de 33 kg/hab./ano em 1994 para 48 kg/hab./ano em 2001. Para os demais países, o consumo per capita sofreu pouca ou nenhuma variação.

A China, identificada como o quarto maior consumidor mundial do produto, foi o menor consumidor de açúcar per capita entre os 19 maiores consumidores mundiais. Deve-se ressaltar, no entanto, que isto não expressa o consumo per capita de adoçantes nestes países. Os Estados Unidos, por exemplo, a despeito do baixo consumo per capita de açúcar, têm um alto consumo de xarope de milho, denominado HFCS (high fructose corn syrup), substituto do açúcar no uso industrial. Assim, segundo estimativas da FAO (2002) e USDA (2002a), quando considerado o consumo de açúcar e HFCS em conjunto, o consumo per capita desses adoçantes nos EUA (incluindo Porto Rico) esteve na média de 60 kg/hab./ano para o período entre 1994 e 2001.

Deve-se ressaltar ainda, conforme observado na Figura 5, que a taxa de crescimento do consumo per capita foi negativa ou estagnada no período descrito, para vários países. Esses dados corroboram o fato de que políticas protecionistas em muitos desses países acabam por incentivar o consumo de adoçantes alternativos ao açúcar, reduzindo, conseqüentemente, o consumo per capita de açúcar.

\subsubsection{Comércio}

O açúcar é comercializado mundialmente nas formas bruto e refinado. Segundo a FAO (2003a), em 2001, 130 países produziram açúcar. Dados dessa mesma instituição indicam haver uma tendência à auto-suficiência pelos países. Até início da década de 1980, mais de $20 \%$ da produção mundial estava sendo anualmente comercializada. Essa participação passou a ser próxima de 15\% na década de 1990 (Figura 6). 


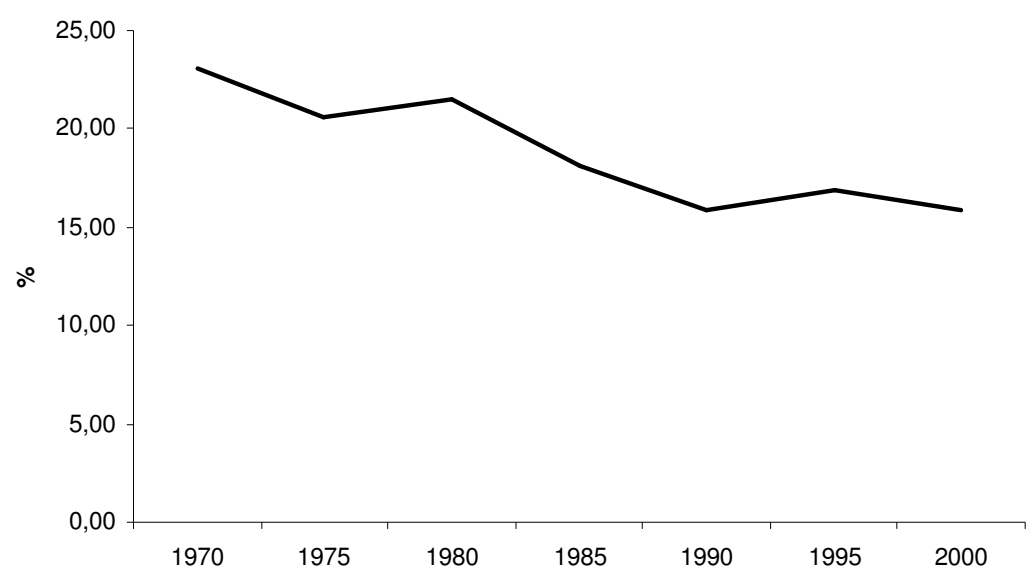

Figura 6 - Participação (\%) das exportações na produção mundial total de açúcar; período: 1970 a 2000.

Fonte: elaborado a partir de dados da FAO (2003b)

Os países que se destacaram na importação de açúcar bruto e de açúcar refinado são descritos nas Tabelas 6, 7, 8 e 9, com seus respectivos volumes e valores importados de 1994 a 2000. Nas Tabelas que contêm os volumes de importação, são também descritas suas respectivas taxas geométricas de crescimento para o período considerado.

Observa-se que o açúcar foi importado predominantemente na forma bruta no período descrito. Entretanto, o consumo é, de maneira geral, realizado na forma de açúcar refinado. Segundo Sheales et al. (1999), a maior influência sobre a escolha de açúcar na forma bruto ou refinado para importação dos países é sua capacidade relativa interna para a produção/refino do açúcar doméstico. Assim, os países importam açúcar bruto se há uma capacidade de refino em excesso para atender o requerimento de produção doméstica.

A Tabela 3, visualizada no tópico anterior, indicou excesso de demanda em países que têm menor relação, e abaixo de 1, entre produção e consumo. Os países que apresentaram excesso de demanda na maior parte do período descrito nessa tabela foram: Rússia, Egito, Indonésia, EUA, Paquistão, Ucrânia, Filipinas e China. Assim, seria de se esperar uma grande importação de açúcar nesses países. Verifica-se que, 
entre os países descritos na razão produção/consumo (Tabela 3) como países com excesso de demanda, a maioria foi relacionada entre os maiores importadores.

Tabela 6. Maiores importadores mundiais de açúcar bruto, em 1000 toneladas; período: 1994 a 2000.

\begin{tabular}{lrrrrrrrr}
\hline & 1994 & 1995 & 1996 & 1997 & 1998 & 1999 & 2000 & \multicolumn{1}{c}{$\mathrm{r}$} \\
\hline Mundo & 15.794 & 18.134 & 20.71 & 20.768 & 20.523 & 22.877 & 20.228 & $4,21 \%$ \\
Rússia & 1.181 & 1.252 & 1.692 & 2.519 & 3.673 & 5.774 & 4.546 & $25,18 \%$ \\
UE (15) & 2.018 & 1.914 & 1.993 & 1.815 & 1.897 & 1.868 & 1.783 & $-2,04 \%$ \\
Japão & 1.654 & 1.743 & 1.662 & 1.71 & 1.561 & 1.519 & 1.562 & $-0,95 \%$ \\
Coréia & 1.274 & 1.306 & 1.400 & 1.437 & 1.378 & 1.375 & 1.462 & $2,31 \%$ \\
EUA & 1.486 & 1.602 & 2.721 & 2.878 & 1.96 & 1.614 & 1.336 & $-1,76 \%$ \\
China & 1.544 & 2.665 & 1.329 & 890 & 607 & 547 & 887 & $-8,83 \%$ \\
Irã & 0 & 33 & 113 & 420 & 872 & 1.249 & 1.099 & - \\
Canadá & 1.002 & 920 & 1.228 & 1.052 & 977 & 813 & 814 & $-3,42 \%$ \\
Egito & 381 & 392 & 646 & 800 & 375 & 445 & 536 & $5,83 \%$ \\
Indonésia & 103 & 334 & 693 & 589 & 116 & 614 & 435 & $27,04 \%$ \\
Malásia & 959 & 1.033 & 1.252 & 1.166 & 1.039 & 1.158 & 1.187 & $3,61 \%$ \\
Nigéria & 20 & 8 & 100 & 49 & 49 & 51 & 105 & $31,83 \%$ \\
\hline
\end{tabular}

Fonte: FAO (2003b)

$\mathrm{r}$ - representa a taxa geométrica de crescimento dos valores importados pelos respectivos países, no período considerado na tabela.

A União Européia, a Rússia, os Estados Unidos, o Japão, a Coréia e a China foram, nessa ordem, os principais importadores de açúcar bruto, respondendo conjuntamente por $57 \%$ das importações mundiais em 2000, sendo 22,47\% das importações mundiais apenas da Rússia. Esse país apresentou também, entre os países selecionados, uma das maiores taxas de crescimento das importações no período. Refletindo as políticas protecionistas adotadas na UE e nos EUA, as taxas de crescimento das importações desses países foram negativas. A taxa negativa calculada 
para a China, por sua vez, pode estar associada ao aumento de sua produção doméstica (Tabela 2).

Tabela 7. Maiores importadores mundiais de açúcar bruto, em 1000 dólares; período: 1994 a 2000.

\begin{tabular}{lrrrrrrr}
\hline & 1994 & 1995 & 1996 & 1997 & 1998 & 1999 & 2000 \\
\hline Mundo & 5.329 .710 & 7.049 .108 & 7.522 .661 & 7.015 .264 & 6.467 .020 & 5.774 .248 & 4.945 .933 \\
UE (15) & 1.152 .313 & 1.266 .415 & 1.359 .848 & 1.113 .686 & 1.135 .884 & 1.035 .182 & 851.821 \\
Rússia & 344.934 & 481.551 & 535.656 & 805.811 & 1.082 .688 & 1.131 .790 & 690.244 \\
EUA & 611.301 & 745.458 & 1.089 .144 & 1.034 .497 & 758.339 & 596.859 & 510.025 \\
Japão & 492.718 & 618.197 & 535.067 & 510.966 & 410.079 & 276.342 & 302.195 \\
Coréia & 366.996 & 440.416 & 443.074 & 419.971 & 374.955 & 280.821 & 292.345 \\
Irã & 0 & 11.500 & 27.000 & 80.000 & 225.896 & 257.595 & 235.507 \\
Canadá & 257.876 & 258.437 & 319.367 & 276.875 & 231.732 & 182.270 & 191.680 \\
Egito & 109.352 & 143.926 & 208.625 & 263.195 & 80.500 & 63.500 & 184.900 \\
China & 402.423 & 810.129 & 411.947 & 251.431 & 163.328 & 102.023 & 160.109 \\
Indonésia & 37.468 & 150.573 & 292.975 & 236.538 & 35.140 & 137.342 & 86.237 \\
Malásia & 253.203 & 307.745 & 310.432 & 354 & 268.140 & 255.846 & 253.629 \\
Nigéria & 6.000 & 3.315 & 38.000 & 14.000 & 16.000 & 10.303 & 17.739 \\
\hline
\end{tabular}

Fonte: FAO (2003b)

Comparando as Tabelas 6 e 7, o que se verifica de mais significativo é a mudança de posição relativa da China. Esse país superava o Canadá e o Egito em volume importado, mas em valor importado situava-se abaixo desses mesmos países. Isso sugere que a China importou açúcar a um preço unitário relativo menor do que o Canadá e o Egito. Da mesma maneira, UE e EUA situaram-se em posição superior no ranking do valor importado de açúcar bruto pelos principais países importadores relativamente ao ranking do volume de açúcar importado, sugerindo preços de importação de açúcar bruto relativamente maiores nesses países. 
As Tabelas 8 e 9 mostram, respectivamente, o volume e o valor importado de açúcar refinado pelos maiores países importadores desse produto. A União Européia, Indonésia, Argélia, Nigéria, Israel, Iraque, Rússia e Alemanha foram, nesta ordem, os principais importadores de açúcar refinado, e responderam por $41 \%$ das importações mundiais em 2000. Verifica-se que a importação de açúcar refinado foi menor, e que os países importadores foram mais diversificados nesse mercado do que no mercado de açúcar bruto ${ }^{12}$.

Tabela 8. Maiores importadores mundiais de açúcar refinado, em 1000 toneladas métricas; período: 1994 a 2000.

\begin{tabular}{lrrrrrrrr}
\hline & 1994 & 1995 & 1996 & 1997 & 1998 & 1999 & 2000 & \multicolumn{1}{c}{$\mathrm{r}$} \\
\hline Mundo & 12.577 & 13.419 & 12.678 & 13.24 & 14.222 & 15.446 & 13.769 & $1,52 \%$ \\
\hline UE (15) & 1.132 & 1.539 & 1.507 & 2.079 & 2.162 & 2.243 & 1.949 & $9,49 \%$ \\
Indonésia & 15 & 220 & 414 & 599 & 857 & 1.573 & 1.121 & $104,66 \%$ \\
Argélia & 415 & 472 & 404 & 514 & 708 & 775 & 782 & $11,14 \%$ \\
Nigéria & 406 & 719 & 468 & 554 & 896 & 626 & 616 & $7,19 \%$ \\
Israel & 366 & 340 & 408 & 429 & 434 & 438 & 410 & $1,92 \%$ \\
Iraque & 246 & 211 & 230 & 330 & 319 & 378 & 275 & $1,88 \%$ \\
Rússia & 1.003 & 1.811 & 1.469 & 956 & 387 & 128 & 271 & $-19,58 \%$ \\
Alemanha & 192 & 184 & 198 & 178 & 198 & 186 & 241 & $3,78 \%$ \\
Chile & 71 & 129 & 164 & 275 & 201 & 226 & 208 & $19,55 \%$ \\
China & 68 & 382 & 50 & 99 & 119 & 123 & 122 & $10,42 \%$ \\
\hline
\end{tabular}

Fonte: FAO (2003b)

$\mathrm{r}$ - representa a taxa geométrica de crescimento dos valores importados pelos respectivos países, no período considerado na tabela.

Entre os países e o bloco econômico descritos na Tabela 8, apenas a Rússia apresentou taxa de crescimento negativa no período considerado. Isso poderia ser

\footnotetext{
${ }^{12}$ Enquanto seis países foram responsáveis por $57 \%$ das importações mundiais de açúcar bruto, de 1994 a 2000 , tem-se que oito países responderam por cerca de $41 \%$ das importações mundiais de açúcar refinado, no mesmo período.
} 
reflexo de um possível aumento da capacidade instalada de refino naquele país, uma vez que as importações de açúcar bruto aumentaram significativamente no mesmo período. A Indonésia se destacou com significativa taxa de crescimento de suas importações de açúcar bruto e, principalmente, de açúcar refinado nesse período, o que pode ser reflexo da queda de sua produção doméstica no período (Tabela 2).

Tabela 9. Maiores importadores mundiais de açúcar refinado, em 1000 dólares; período: 1994 a 2000.

\begin{tabular}{lrrrrrrr}
\hline & 1994 & 1995 & 1996 & 1997 & 1998 & 1999 & 2000 \\
\hline Mundo & 5.190 .945 & 6.572 .645 & 6.242 .869 & 5.771 .176 & 5.577 .390 & 5.089 .867 & 4.464 .133 \\
UE (15) & 898.877 & 1.392 .701 & 1.351 .436 & 1.555 .452 & 1.584 .111 & 1.574 .227 & 1.183 .578 \\
Argélia & 192.500 & 219.033 & 184.913 & 190.799 & 250.788 & 207.738 & 207.216 \\
Indonésia & 5.894 & 99.915 & 175.390 & 194.846 & 314.330 & 391.316 & 196.872 \\
Alemanha & 166.671 & 176.215 & 184.763 & 145.669 & 162.574 & 144.020 & 162.193 \\
Israel & 126.945 & 162.483 & 162.780 & 155.844 & 143.163 & 120.702 & 111.384 \\
Iraque & 98.500 & 93.000 & 111.000 & 150.000 & 122.000 & 145.000 & 122.600 \\
Nigéria & 142.000 & 222.918 & 185.000 & 197.000 & 227.000 & 138.500 & 90.606 \\
Rússia & 327.045 & 827.012 & 683.963 & 338.592 & 127.485 & 36.871 & 74.597 \\
Chile & 24.896 & 53.012 & 65.047 & 97.298 & 63.092 & 57.093 & 52.714 \\
China & 22.640 & 119.658 & 18.876 & 36.292 & 37.171 & 32.049 & 36.752 \\
\hline
\end{tabular}

Fonte: FAO (2003b)

Comparando as Tabelas 8 e 9, verifica-se a mudança na posição relativa entre a Alemanha e a Nigéria. A Alemanha importou, em praticamente todo o período analisado, um volume de açúcar refinado menor do que Israel, Iraque e Nigéria. Entretanto, o valor importado de açúcar refinado da Alemanha foi maior do que o valor importado desses três países, em quase todo o período, indicando um preço de importação maior na Alemanha. Isso ocorre por causa de medidas protecionistas adotadas nos países da União Européia, reflexo da Política Agrícola Comum (PAC) adotada nesses países, que elevam o preço do açúcar dentro do bloco europeu, refletindo no preço de suas importações. 
Com a Nigéria ocorre o inverso do descrito para a Alemanha. Esse país importou um volume de açúcar refinado maior do que Israel, Iraque e Alemanha; mas o valor importado situou-se abaixo desses países, nos anos de 1999 e 2000.

De maneira geral, nota-se que as participações da União Européia e da Rússia foram significativas tanto na importação de açúcar bruto quanto na de açúcar refinado. No caso da Rússia, isso se explica possivelmente pela sua grande demanda do produto (relação produção/consumo abaixo de 0,3 desde 1997), além da população extensa e do consumo per capita alto e ascendente.

O destaque da União Européia na importação de açúcar não teria a mesma explicação, uma vez que o bloco foi o segundo maior produtor e apresenta relação produção/consumo maior do que 1. Neste caso, isso se deve à intensa importação de açúcar refinado entre os 15 países que compõem, atualmente, a União Européia. Segundo dados da FAO (2003b), a importação de açúcar refinado com países fora do bloco foi de menos de $10 \%$ da importação intra-bloco de açúcar refinado.

Os países que se destacam na exportação de açúcar bruto e de açúcar refinado são descritos nas Tabelas 10,11, 12 e 13, com seus respectivos volumes e valores exportados, de 1994 a 2000.

A Figura 7 ilustra, para alguns dos maiores exportadores mundiais de açúcar, a razão da produção doméstica que foi exportada (açúcar total exportado em equivalente bruto) nos anos de 1994 e 2000. Brasil, Colômbia, Guatemala, México e África do Sul foram, entre os países selecionados, os que mais aumentaram suas participações para o mercado internacional em relação às suas produções totais de açúcar. A África do Sul, em particular, aumentou significativamente a participação de suas exportações na produção total durante a segunda metade da década de 1990. 


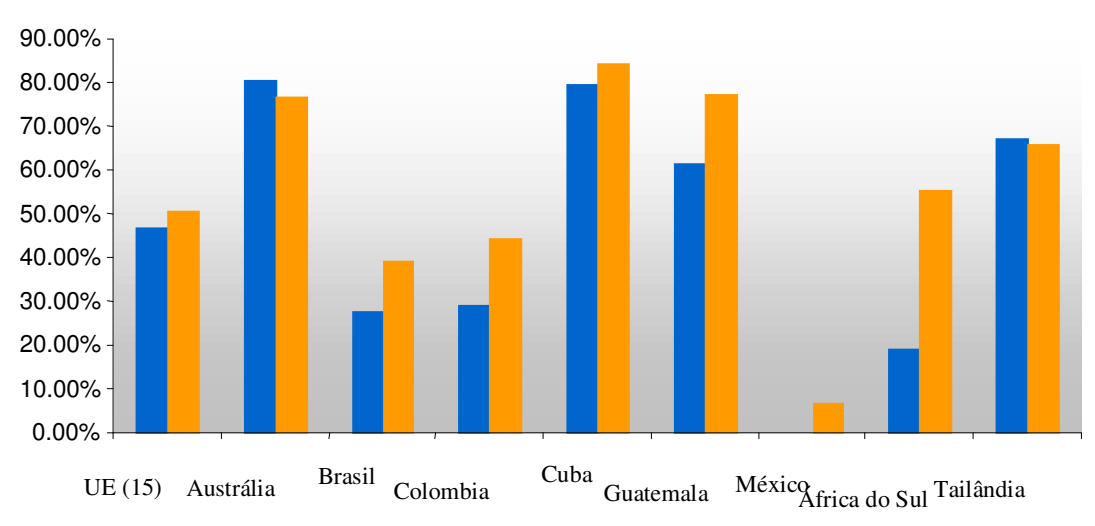

$1994-2000$

Figura 7 - Razão da parcela da produção doméstica exportada (açúcar total, em equivalente bruto) por alguns dos maiores exportadores mundiais, para os anos de 1994 e 2000.

Fonte: FAO (2003b) e USDA (2002a)

Observa-se que o Brasil e a Austrália foram os maiores exportadores de açúcar bruto, seguidos de Cuba, Tailândia, Guatemala e África do Sul, que juntos responderam por 77,5\% das exportações mundiais em 2000.

Em termos de volume exportado de açúcar bruto, destaca-se na Tabela 10 a participação do Brasil. Em 1994, o Brasil deteve 16,8\% das exportações mundiais e, em 2000, apresentou uma participação de 20,9\% das exportações do mundo, nível comparável ao da Austrália e Cuba. Entretanto, o Brasil registrou uma taxa de crescimento de suas exportações, no período, superior à daqueles dois países: $8,14 \%$ de crescimento ao ano para o Brasil contra 2,64\% da Austrália e 1,17\% de Cuba. Destacase a alta taxa de crescimento das exportações da União Européia, Colômbia e, principalmente, do México, no período. Essas taxas podem ser, respectivamente, um reflexo da política de subsídios às exportações adotadas na União Européia; da redução no consumo per capita na Colômbia, originando um excesso ainda maior de produção nesse país, como pode ser observado na Tabela 3; e do aumento das exportações do México para os países do NAFTA no período. 
Tabela 10. Maiores exportadores mundiais de açúcar bruto, em toneladas; período: 1994 a 2000.

\begin{tabular}{lrrrrrrrr}
\hline & 1994 & 1995 & 1996 & 1997 & 1998 & 1999 & 2000 & $\mathrm{R}$ \\
\hline Mundo & 16.203 & 19.926 & 21.498 & 21.197 & 20.139 & 23.032 & 20.796 & $4,25 \%$ \\
Brasil & 2.717 & 4.800 & 4.090 & 3.844 & 4.789 & 7.827 & 4.346 & $8,14 \%$ \\
Austrália & 3.446 & 3.951 & 3.828 & 4.074 & 4.448 & 4.076 & 4.028 & $2,64 \%$ \\
Cuba & 3.188 & 2.600 & 3.827 & 3.571 & 2.566 & 3.135 & 3.418 & $1,17 \%$ \\
Tailândia & 1.902 & 2.801 & 2.967 & 2.450 & 1.359 & 1.998 & 2.321 & $3,38 \%$ \\
Guatemala & 693 & 867 & 796 & 1.033 & 1.342 & 1.145 & 1.260 & $10,49 \%$ \\
África do Sul & 250 & 295 & 632 & 789 & 892 & 707 & 738 & $19,79 \%$ \\
Colômbia & 199 & 264 & 460 & 447 & 662 & 553 & 699 & $23,29 \%$ \\
Mauricio & 519 & 524 & 772 & 575 & 602 & 534 & 424 & $-3,30 \%$ \\
UE (15) & 25 & 92 & 36 & 72 & 65 & 96 & 125 & $30,87 \%$ \\
México & 0.1 & 475 & 605 & 536 & 278 & 156 & 90 & $207,98 \%$ \\
\hline
\end{tabular}

Fonte: FAO (2003b)

$\mathrm{r}$ - representa a taxa geométrica de crescimento dos valores importados pelos respectivos países, no período considerado na tabela.

Comparando as Tabelas 10 e 11, observa-se uma mudança de posição relativa quanto ao volume ou valor exportado de Mauricio. Em 2000, Mauricio possuía volume exportado menor do que Guatemala, África do Sul e Colômbia, entretanto, ultrapassou esses países em valor exportado. Assim, o preço de exportação do açúcar bruto originado de Mauricio, em 2000, foi maior do que os preços na Guatemala, África do Sul e Colômbia. Uma vez que esse país possui a maior quota de acesso especial para o mercado protegido da União Européia, justifica-se esse maior preço pago pelas suas exportações. Esta política da UE foi explorada no próximo item. 
Tabela 11. Maiores exportadores mundiais de açúcar bruto, em 1000 dólares; período: 1994 a 2000.

\begin{tabular}{lrrrrrrr}
\hline & 1994 & 1995 & 1996 & 1997 & 1998 & 1999 & 2000 \\
\hline Mundo & 4.869 .542 & 6.617 .367 & 6.853 .540 & 6.317 .872 & 6.002 .053 & 4.877 .101 & 4.944 .003 \\
Austrália & 848.888 & 1.180 .350 & 1.083 .727 & 1.125 .542 & 1.360 .000 & 996.000 & 1.544 .000 \\
Brasil & 787.861 & 1.450 .653 & 1.190 .736 & 1.045 .395 & 1.094 .687 & 1.162 .307 & 761.792 \\
Cuba & 748.007 & 704.405 & 957.457 & 844.596 & 593.694 & 458.210 & 447.677 \\
Tailândia & 487.697 & 832.500 & 784.479 & 578.697 & 346.485 & 299.932 & 334.251 \\
Mauricio & 321.502 & 366.887 & 449.403 & 357.463 & 371.337 & 320.358 & 211.150 \\
Guatemala & 161.469 & 238.171 & 202.035 & 255.344 & 316.620 & 195.158 & 190.782 \\
África do Sul & 54.000 & 65.000 & 88.600 & 176.898 & 245.000 & 137.696 & 151.763 \\
Colômbia & 52.505 & 85.444 & 132.864 & 123.459 & 182.994 & 103.253 & 122.195 \\
UE (15) & 22.077 & 56.260 & 47.165 & 65.916 & 59.675 & 77.865 & 73.138 \\
México & 34.000 & 80.030 & 205.485 & 117.915 & 70.538 & 33.176 & 14.348 \\
\hline
\end{tabular}

Fonte: FAO (2003b)

As Tabelas 12 e 13 a seguir descrevem, respectivamente, os volumes e valores exportados de açúcar refinado pelos maiores exportadores desse produto. A União Européia lidera, de longe, a exportação dessa categoria. Os países descritos na Tabela 12 foram responsáveis por cerca de $80,7 \%$ das exportações mundiais de açúcar refinado em 2000.

Dentre os principais exportadores de açúcar refinado selecionados, apenas Brasil, Tailândia e Colômbia exportam ambos os tipos de açúcar. No caso do Brasil e da Tailândia, destaca-se também que houve uma taxa de crescimento ao ano para as exportações de açúcar refinado maior do que de açúcar bruto. Para a Colômbia observase o inverso, a taxa de crescimento das exportações de açúcar bruto foi de $23,29 \%$ ao ano, enquanto a de açúcar refinado foi negativa, de - $0,16 \%$ ao ano. Mais uma vez, temse um alto valor da taxa de crescimento das exportações do México, provavelmente pelo mesmo motivo descrito anteriormente (inserção no NAFTA). A Austrália, apesar de não 
ser um exportador expressivo de açúcar refinado, vem aumentando rapidamente sua participação no mercado mundial desse produto.

A exportação de açúcar refinado da União Européia foi da ordem de 8 milhões de toneladas no período descrito, situando-se em torno de $50 \%$ das exportações mundiais no período analisado. A participação da União Européia no mercado mundial de açúcar pode ser melhor avaliada a partir de dados da FAO (2003b), que mostraram que cerca de $70 \%$ do volume de açúcar refinado exportado da UE é destinado à comercialização extra-bloco, porém, em termos de valor, esse percentual cai para aproximadamente $50 \%$, no período de 1994 a 2000. A política de subsídios às exportações adotada pela UE poderia explicar esse diferencial entre volume e valor exportado, cabendo às exportações intra-bloco um preço mais elevado do produto. Dado que a UE foi o maior importador mundial de açúcar bruto no mesmo período, verifica-se que os países desse bloco econômico compram açúcar bruto para refinar e reexportá-lo.

Os exportadores de açúcar refinado derivado de açúcar bruto têm flexibilidade para deslocar entre o mercado de açúcar bruto e refinado. Aqueles exportadores são classificados em duas categorias.

A primeira categoria é de exportadores de açúcar refinado e importadores de açúcar bruto, os quais pagam uma "taxa de refino". Países engajados nesta atividade são a China e a Coréia (quarto maior importador de açúcar bruto e sexto maior exportador de açúcar refinado entre os países selecionados nas Tabelas 6 e 12), além da União Européia. Refinadores desses países operam no processamento do mercado doméstico. Entretanto, como exportadores, eles são expostos aos preços mundiais. Como resultado, sua demanda de importação de açúcar bruto e sua oferta de açúcar refinado no mercado exportador podem ser sensivelmente alteradas, dependendo do premium na relação de preços do açúcar bruto e refinado. 
Tabela 12. Maiores exportadores mundiais de açúcar refinado, em 1000 toneladas; período: 1994 a 2000.

\begin{tabular}{lrrrrrrrr}
\hline & 1994 & 1995 & 1996 & 1997 & 1998 & 1999 & 2000 & \multicolumn{1}{c}{ r } \\
\hline Mundo & 13.263 & 14.416 & 13.874 & 15.76 & 17.845 & 18.062 & 16.736 & $3,95 \%$ \\
UE & 6.961 & 7.109 & 5.985 & 7.196 & 8.111 & 7.086 & 8.047 & $2,44 \%$ \\
Brasil & 690 & 1.439 & 1.288 & 2.528 & 3.575 & 4.273 & 2.158 & $20,94 \%$ \\
Tailândia & 709 & 959 & 1.486 & 1.582 & 927 & 1.272 & 1.765 & $16,43 \%$ \\
Turquia & 457 & 4 & 4 & 169 & 258 & 485 & 561 & $3,47 \%$ \\
Colômbia & 339 & 245 & 259 & 370 & 359 & 369 & 336 & $-0,16 \%$ \\
Coréia & 274 & 227 & 276 & 264 & 340 & 297 & 303 & $1,73 \%$ \\
México & 0.3 & 7 & 47 & 335 & 673 & 336 & 198 & $191,42 \%$ \\
Austrália & 10 & 69 & 214 & 151 & 46 & 105 & 132 & $52,55 \%$ \\
\hline
\end{tabular}

Fonte: FAO (2003b)

$\mathrm{r}$ - representa a taxa geométrica de crescimento dos valores importados pelos respectivos países, no período considerado na tabela.

Tabela 13. Maiores exportadores mundiais de açúcar refinado, em 1000 dólares; período: 1994 a 2000.

\begin{tabular}{lrrrrrrr}
\hline & 1994 & 1995 & 1996 & 1997 & 1998 & 1999 & 2000 \\
\hline Mundo & 5.302 .494 & 6.555 .126 & 6.098 .013 & 6.178 .355 & 6.142 .973 & 5.130 .186 & 4.613 .028 \\
UE & 3.149 .052 & 3.830 .981 & 3.230 .972 & 3.373 .271 & 3.364 .964 & 2.721 .418 & 2.649 .038 \\
Brasil & 204.344 & 468.806 & 420.759 & 725.929 & 846.194 & 748.419 & 437.633 \\
Tailândia & 196.346 & 322.243 & 478.361 & 465.116 & 296.050 & 252.465 & 309.637 \\
Turquia & 162.438 & 1.718 & 2.718 & 61.085 & 74.685 & 105.491 & 129.116 \\
Colômbia & 99.697 & 88.609 & 83.873 & 112.514 & 108.635 & 76.841 & 71.860 \\
Coréia & 96.474 & 95.347 & 106.271 & 97.087 & 108.566 & 73.232 & 71.672 \\
México & 284 & 3.632 & 14.603 & 90.605 & 183.975 & 76.105 & 36.480 \\
Austrália & 4.195 & 30.000 & 82.904 & 53.028 & 17.451 & 26.734 & 35.532 \\
\hline
\end{tabular}

Fonte: FAO (2003b) 
A segunda categoria de exportadores de açúcar refinado é composta por produtores de açúcar de cana que podem mudar a proporção de açúcar bruto e açúcar refinado em seu mix de exportação, de acordo com o premium da relação de preços entre esses produtos. Os maiores exportadores que se alternam na exportação de açúcar bruto e refinado, atualmente, são o Brasil, a Tailândia, o México e a África do Sul.

Portanto, verificou-se que o panorama geral do comércio mundial de açúcar encontra-se concentrado nas mãos de poucos mercados, e como foi descrito posteriormente, distorcido por várias políticas protecionistas de alguns desses mercados. Dessa maneira, verifica-se a importância de se conhecer as principais políticas adotadas em relação à comercialização de açúcar no mundo e as possíveis conseqüências de alterações nas mesmas. São esses conhecimentos que irão fornecer alguns fundamentos para as análises a serem realizadas neste trabalho.

\subsubsection{Políticas para o açúcar no mundo}

A motivação e os objetivos das políticas de açúcar em países em desenvolvimento são diversos e, às vezes, contraditórios. Alguns países, como Zimbábue, têm conservado baixos preços aos consumidores, enquanto até recentemente

o Brasil usou restrições às exportações para favorecer a indústria doméstica de etanol. Geralmente, muitos governantes de países em desenvolvimento, procurando a autosuficiência, protegem as indústrias domésticas, algumas das quais do próprio Estado. Freqüentemente, esse protecionismo resulta em altos preços para os consumidores.

Neste item foi realizada uma revisão das principais políticas protecionistas e acordos especiais vigentes no mercado mundial de açúcar. O entendimento da mistura de mercados livres e protegidos para o açúcar é importante para lideranças políticas durante o processo de reforma do mercado doméstico (Larson \& Borrell, 2001). Tais políticas são aplicadas por países desenvolvidos, sendo que os países que se caracterizam por provocar as maiores distorções no mercado de açúcar são os Estados Unidos, a União Européia e o Japão. 
Uma análise realizada por Ramos (2001) para o mercado mundial de açúcar no período de 1930 a 1960 indicou que as políticas açucareiras dos países desenvolvidos sempre foram políticas de defesa de seus mercados e dos capitais investidos na produção de açúcar, atuando dentro ou fora de seus territórios. Por isso, os acordos mundiais fracassaram em seus objetivos de estabilizar os preços ou de evitar a formação e expansão dos excedentes de produção.

Uma outra conseqüência do protecionismo no mercado de açúcar em muitos países é que tanto o açúcar de cana quanto o de beterraba vêm sofrendo com a competição de adoçantes substitutos, que competem em termos de preço e de características calóricas com o açúcar. Esses produtos alternativos são os adoçantes derivados do amido de milho, particularmente a isoglucose ou HFCS (high fructose corn syruy) e os edulcorantes sintéticos, como o aspartame e o acesulfame-k.

\subsubsection{Políticas e o mercado de adoçantes nos Estados Unidos}

$\mathrm{Na}$ tentativa de controlar a produção, consumo e importação de açúcar nos EUA, o governo desse país sustenta os preços domésticos do açúcar e utiliza sistemas de quotas tarifárias de importação para administrar a oferta total. Enquanto procura proteger produtores domésticos de açúcar, aquelas políticas têm dado incentivos substanciais para o desenvolvimento e a produção de adoçantes alternativos, como o HFCS.

\subsection{Características gerais do mercado de adoçantes nos Estados Unidos}

Conforme verificado em itens anteriores, os Estados Unidos têm se mantido, nos últimos anos, como o quinto maior produtor e também o quinto maior consumidor mundial de açúcar (Tabelas 2 e 4). Entretanto, observa-se na Tabela 3 que esse país apresentou excesso de demanda (relação produção/consumo menor do que 1) em todo o período descrito. Assim, os Estados Unidos se apresentaram também como grandes importadores de açúcar. Deve-se destacar, porém, que essa importação foi significativa 
para o produto bruto (Tabela 10), indicando grande capacidade excedente de refino dentro desse país.

Por outro lado, os Estados Unidos investiram substancialmente em novos equipamentos de processamento, na adaptação de novas tecnologias, na melhoria nas variedades de produção e na expansão da área plantada, visando aumentar a produção doméstica de açúcar. Esse aumento na produção de açúcar, unido com as restrições às importações, resultou em aumento na participação do mercado doméstico dos EUA.

Outra característica do mercado norte-americano é que, conforme pode ser observado na Figura 8, a produção de açúcar de beterraba foi maior do que a de açúcar de cana, e a produção de HFCS (um xarope derivado do milho) foi quase igual à soma da produção de açúcar daqueles dois tipos. O alto preço doméstico do açúcar nos EUA é o principal fator que tem encorajado o desenvolvimento e o amplo uso de substitutos. $\mathrm{O}$ HFCS é um bom substituto para o açúcar na produção de bebidas leves, por exemplo. Como resultado, um grande crescimento do consumo desse adoçante ocorreu nas indústrias de bebidas. Ganhos substanciais podem ser obtidos com uma redução nos custos de produção desse produto, uma vez que o seu preço é menor do que o do açúcar no mercado doméstico dos EUA (Sheales et al., 1999), em função da proteção dada ao açúcar. Assim, os produtores de HFCS ganharam com os altos preços domésticos de açúcar (Figura 9), originado do protecionismo existente no mercado do açúcar.

Por causa do menor preço do HFCS é que, nos EUA, a isoglucose e os demais adoçantes derivados do amido de milho já conquistaram a maior parcela do mercado consumidor, alcançando em conjunto uma taxa de participação de $40 \%$ do total, contra $36 \%$ do açúcar e $24 \%$ dos edulcorantes sintéticos.

A importação de açúcar nos EUA está sujeita a quotas tarifárias e a um acesso mínimo acometido sobre o Acordo Agrícola da Organização Mundial de Comércio (OMC). A quota tarifária para açúcar de cana bruto é alocada sobre uma base país por país, enquanto para açúcar refinado é sobre o primeiro a chegar, primeiro a servir. 


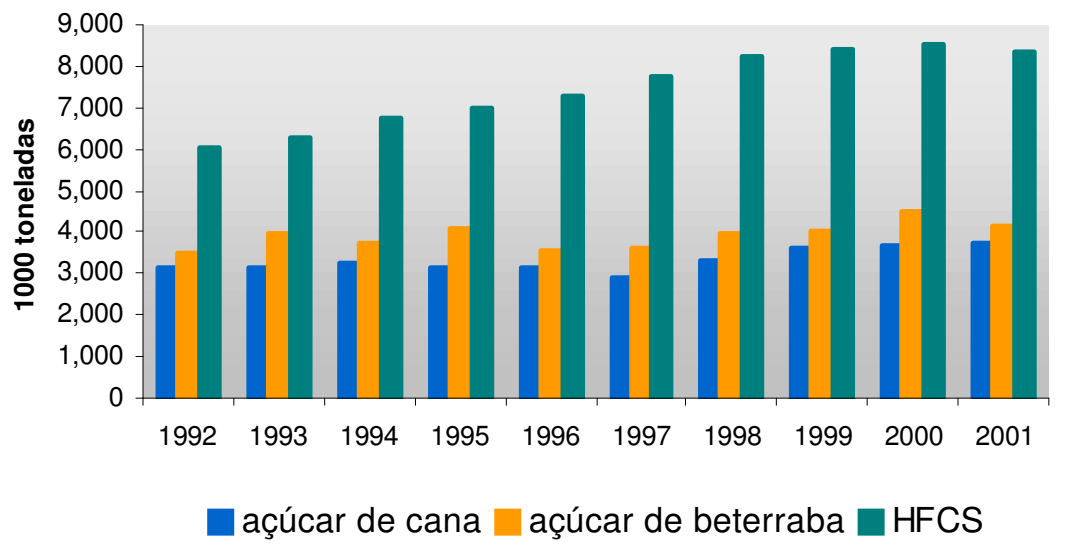

Figura 8 - Evolução da produção de açúcar de cana, açúcar de beterrada e HFCS nos Estados Unidos; período: 1992 a 2001.

Fonte: USDA (2002b)

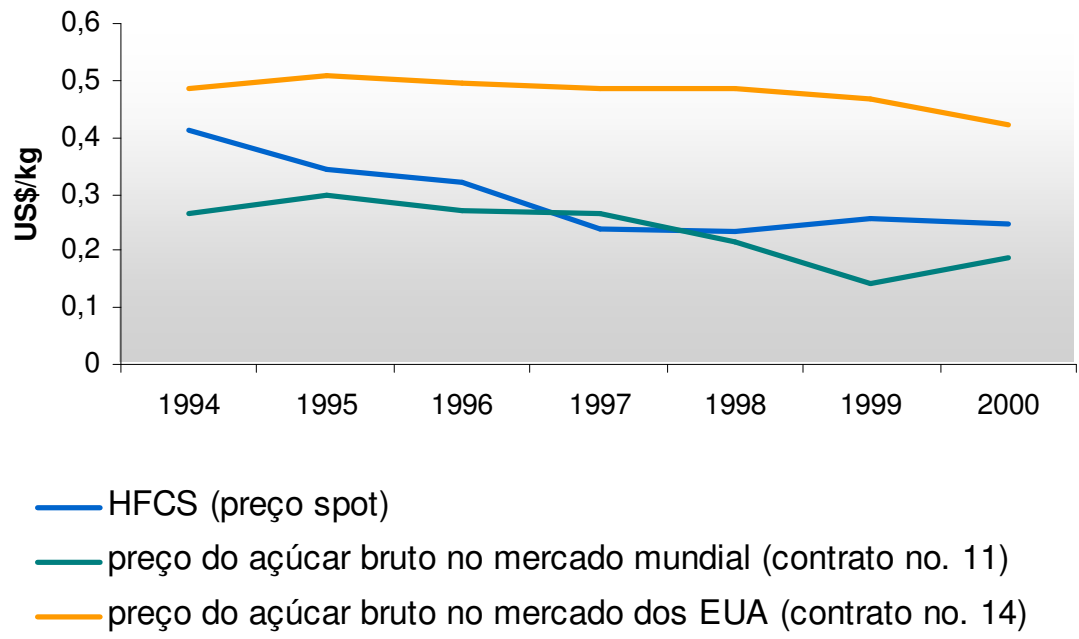

Figura 9 - Preço do açúcar bruto no mercado dos EUA e no mercado mundial e preço do HFCS no mercado norte-americano; período: 1994 a 2000.

Fonte: USDA (2002b)

Nota: preço em Cents per Pound, previamente transformado em US $\$ / \mathrm{kg}$ pelo fator de conversão de 0,022046 . 
Um adicional relativamente pequeno sobre o açúcar bruto é também importado fora da quota, sem taxa aduaneira, sob três programas: o programa do açúcar refinado re-exportado; programa "Sugar-Containing Products Re-Export"; e o programa de álcool "Polyhydric". Os dois primeiros programas promovem acesso, a preços mundiais, com o propósito de exportar açúcar refinado ou o produto manufaturado. O programa de álcool aprova acesso, a preços mundiais, de açúcar para o uso em manufaturados de álcool "polyhydric", para propósitos da indústria não-alimentícia.

Com o aumento da produção doméstica de açúcar, do uso de HFCS e os altos preços de açúcar doméstico, a importação de açúcar bruto dos EUA tem sido relativamente estática, situando-se em cerca de 2 milhões de toneladas ao ano durante a década de 1990.

\subsection{Principais políticas protecionistas}

Com o objetivo de sustentar retornos para os produtores dos Estados Unidos, o governo tem políticas próprias para o açúcar. A indústria norte-americana do produto é descrita como a mais forte sustentação da atividade agrícola desse país.

Há dois elementos principais das políticas de açúcar: a provisão de preços básicos sustentados para os produtores de açúcar (a taxa de empréstimo) e o sistema de quotas tarifárias para importação. Não há, por sua vez, suporte governamental direto para produtores de HFCS e outros adoçantes e substitutos do açúcar (Sheales et al., 1999).

\subsection{A taxa de empréstimo}

A taxa de empréstimo ("loan rate") é o preço do açúcar considerado como base pelo governo dos EUA para realizar empréstimos para usineiros e processadores de açúcar com o objetivo de manter estoques de açúcar. Aqueles empréstimos são obtidos da Commodity Credit Corporation (CCC) e tem um período de restituição de nove meses. $\mathrm{O}$ açúcar de cana bruto e o açúcar de beterraba refinado são usados por usineiros 
e processadores como garantia para os empréstimos (Sheales et al., 1999 e USDA, 1999).

Nesse programa, quando o açúcar é vendido, os usineiros e processadores restituem o empréstimo para o CCC. Antes da ação de 1996 do Federal Agriculture Improvement and Reform (FAIR), aqueles empréstimos poderiam ser pagos com entrega de seus estoques de açúcar, caso os preços de mercado estivessem abaixo ou idênticos ao valor equivalente ao empréstimo. Como resultado, a taxa de empréstimo tendia a colocar um teto sobre os preços domésticos. Tendo sido garantido um preço mínimo no mercado doméstico para seu açúcar, usineiros e processadores deveriam pagar aos produtores um preço mínimo fixado para a cana e a beterraba. A Tabela 14 mostra valores de empréstimo para açúcar de cana e de beterraba, de 1994 a 1998.

Tabela 14. Média das taxas de empréstimo dos EUA, em US\$/kg; período: 1994 a 1998.

\begin{tabular}{lccccc}
\hline & 1994 & 1995 & 1996 & 1997 & 1998 \\
\hline Açúcar de cana bruto & 0,397 & 0,397 & 0,397 & 0,397 & 0,397 \\
Açúcar de beterraba refinado & 0,517 & 0,505 & 0,505 & 0,505 & 0,505 \\
\hline
\end{tabular}

Fonte: USDA (1999)

Com o FAIR em 1996, os empréstimos só poderiam ser pagos com o produto se a quota tarifária de importação em qualquer ano excedesse 1,36 milhões de toneladas. Nesse caso, haveria uma penalidade de US\$22,0463/t sobre qualquer estoque que fosse transferido aos setores do governo para desonerar o empréstimo. Isso poderia reduzir o preço doméstico a um nível inferior ao da taxa de empréstimo. Entretanto, se quotas de importação caíssem abaixo de 1,36 milhões de toneladas, o estoque do produto não poderia ser utilizado como pagamento do empréstimo. Nesse caso, o empréstimo deveria ser compensado com pagamento à vista, e a obrigação pela manutenção dos estoques decairia sobre os processadores.

Em 2002, o Congresso norte-americano encaminhou o Farm Security and Rural Investment Act (FSRIA), substituindo o FAIR, um ano antes do final do programa. No 
FSRIA de 2002, os produtores domésticos obtiveram sucesso em prolongar as políticas de suporte do açúcar. A taxa de empréstimo foi conservada para os níveis de 1996. A multa foi eliminada, a taxação adotada previamente para suprir uma pequena receita ao governo foi finalizada, e a taxa sobre os empréstimos do CCC foi reduzida, fazendo o programa do açúcar mais lucrativo para os produtores (Orden, 2002).

Conforme pode ser observado na Figura 9, o preço doméstico para o açúcar bruto (indicado pelo preço estabelecido no contrato $\mathrm{n}^{0} 14$ da Bolsa de Nova Iorque) esteve sempre acima do preço estabelecido pela taxa de empréstimo. Isto ocorre por causa da combinação dos efeitos da taxa de empréstimo e da quota tarifária, limitando a oferta de açúcar nos EUA e elevando, conseqüentemente, seu preço.

\subsection{Quotas tarifárias}

A quota tarifária sobre importação é o principal instrumento de proteção para a indústria de açúcar dos EUA. As quotas tarifárias são usadas para limitar a oferta de açúcar no mercado doméstico, com o objetivo essencial de impedir que os preços domésticos de açúcar caiam abaixo da taxa de empréstimo. A quota tarifária é estabelecida anualmente pela Secretaria de Agricultura dos EUA, em acordo com o acesso de mercado estabelecido pela OMC. A Tabela 15 ilustra as maiores quotas estabelecidas pelos EUA de 1995/96 a 2001/02.

O comitê da OMC sobre acesso ao mercado provém a quota tarifária de importação do açúcar para os EUA para um mínimo de 1,139 milhão de toneladas ao ano, sendo os 1,117 milhão de tonelada de açúcar bruto e 22 mil toneladas de açúcar refinado. A alocação das quotas tarifárias para os países ofertantes tem sido baseadas sobre a proporção de suas participações médias de importação de açúcar bruto dos EUA durante os anos 1975-1981, excluindo anos de alta e de baixa. Neste período as importações dos EUA de açúcar foram relativamente irrestritas. 
Tabela 15. Limites das quotas tarifárias "in” para os países com os maiores acessos no mercado norte-americano, em toneladas; período: 1995/96 a 2001/02.

\begin{tabular}{lcccccccc}
\hline & $1995 / 96$ & $1996 / 97$ & $1997 / 98$ & $1998 / 99$ & $1999 / 00$ & $2000 / 01$ & $2001 / 02$ \\
\hline Austrália & 185.044 & 168.386 & 126.552 & 89.912 & 87.408 & 87.408 & 87.402 \\
Brasil & 323.271 & 294.169 & 221.084 & 157.076 & 152.700 & 152.700 & 152.691 \\
Rep. Dominicana & 350.940 & 357.060 & 268.350 & 190.657 & 185.346 & 185.346 & 185.335 \\
Guatemala & 107.014 & 97.380 & 73.186 & 51.997 & 50.549 & 50.549 & 50.546 \\
Filipinas & 237.422 & 273.881 & 205.837 & 146.243 & 142.169 & 142.169 & 142.160 \\
& & & & & & & \\
$\begin{array}{l}\text { Subtotal - açúcar } \\
\text { de cana bruto }\end{array}$ & 2.167 .160 & 2.100 .001 & 1.600 .000 & 1.164 .937 & 1.135 .000 & 1.117 .195 & 1.117 .195 \\
& & & & & & & \\
Total para açúcar & 2.189 .160 & 2.122 .001 & 1.625 .000 & 1.189 .937 & 1.170 .000 & 1.260 .983 & 1.288 .983 \\
\hline
\end{tabular}

Fonte: USDA (2002b)

Entretanto, o mercado mundial de açúcar tem mudado significativamente desde que as proporções das quotas tarifárias foram determinadas. Conseqüentemente, alguns países, como o Haiti, Barbados e Gabão, não têm ofertado qualquer de suas quotas nos últimos anos. Outros exportadores, como Austrália, Brasil e Tailândia, são capazes de ofertar suas quotas correntes alocadas e muito mais. Isto sugere que variações na tarifa extra-quota para o Brasil são importantes para provocar variações na quantidade de açúcar comercializada entre esses países. Com a introdução do sistema de quotas em 1982, as exportações de açúcar brasileiro para os EUA recuaram 60\% (Brasil, 2003c).

Segundo Brasil (2003c), as exportações de açúcar bruto sujeitam-se a uma tarifa específica intra-quota de US\$14,60/t, cujo equivalente ad valorem estimado é de até 10,1\%. Os países da América Central e os Andinos estão isentos de tarifas; entretanto, por considerar que o Brasil possui vantagens comparativas nesse produto, ele é o único 
país latino-americano não beneficiado pelo Sistema Geral de Preferências (SGP) ${ }^{13}$. As tarifas extra quota estão sujeitas a US\$ 338,70/t, que para preços entre US\$ 200,00/t e US\$ 250,00/t significam tarifas ad valorem de $140 \%$ a $170 \%$. O México paga tarifa extra quota de US\$282,47/t, devendo ter livre acesso em 2008, em função de sua inserção no NAFTA.

Segundo Sheales et al. (1999), em adição às tarifas dentro e fora da quota, os EUA podem também aplicar uma terceira camada tarifária (a qual não é aplicada para o México e Canadá) como uma proteção a mais para a importação de açúcar. Esta proteção é particularmente relevante quando os preços mundiais estão baixos, como uma ação para não haver importação de açúcar fora da quota.

Com a proteção imposta, os preços mundiais devem ser extremamente baixos perante o açúcar importado para poder ser competitivo com o açúcar produzido domesticamente. Estudo realizado por Boyd et. al. (1996) revelou que os benefícios trazidos por uma remoção na política de quotas de açúcar nos EUA, que é o maior componente do programa de açúcar, excederiam em peso as perdas para a economia como um todo daquele país.

\subsubsection{Políticas e o mercado de adoçantes na União Européia (UE)}

O sistema de suporte de preços de açúcar na UE acarreta distorções substanciais ao mercado mundial. Isso ocorre por meio de controle da produção doméstica e do comércio com outros países, criando estoques de oferta. Aqueles estoques são mantidos no mercado mundial com a assistência de subsídios de exportação, deprimindo os preços mundiais de açúcar.

\footnotetext{
${ }^{13}$ O SGP é concedido unilateralmente pelo país importador, no caso, os EUA, e representa um sistema em que um conjunto de países menos desenvolvidos, estabelecidos por esse importador, é beneficiado por tarifas menores do que as tarifas aplicadas de maneira geral.
} 


\subsection{Características gerais do mercado}

A União Européia foi o segundo maior produtor (depois do Brasil) e o segundo maior consumidor (depois da Índia) de açúcar, no período de 1990 a 2000. A maioria da produção da UE é de açúcar de beterraba. Pouco açúcar de cana é também produzido em Portugal e na Espanha, sendo menos de 0,1\% da produção total de açúcar, segundo a FAO (2003a). Os maiores países produtores de açúcar na União Européia são a França e a Alemanha, que juntas produziram cerca de 50\% do açúcar total na União Européia na segunda metade da década de 1990.

Tanto o consumo total quanto o consumo per capita da União Européia se mantiveram constantes no período descrito, e o consumo de adoçantes alternativos tem sido encorajado por políticas de açúcar que mantêm os preços domésticos do açúcar significativamente acima daqueles prevalecentes no mercado mundial (Sheales et al., 1999). Entretanto, conforme relatado por Cooper et. al. (1995), o mercado de isoglucose, principal concorrente do açúcar, também estava sendo regulamentado na UE. Segundo esses autores, a produção de isoglucose é limitada em cerca de $2 \%$ da quota de açúcar. Cooper et. al. (1995) estimaram o impacto da desregulamentação do mercado da isoglucose sobre o mercado de adoçantes na União Européia, concluindo que poderia ocorrer uma troca de aproximadamente $25 \%$ no uso industrial de açúcar pelo adoçante alternativo. Os autores descrevem, contudo, que essa taxa de substituição é menor do que a observada nos EUA.

Conforme já mencionado em itens anteriores, o mercado de importação e exportação de açúcar da União Européia é bastante singular em relação ao de outros países do mundo. Apesar de sua auto-suficiência em relação ao produto, até recentemente, a União Européia foi o segundo maior importador de açúcar bruto em volume, sendo o primeiro em valor importado desse produto, e o primeiro maior importador de açúcar refinado, em volume e em valor. Entretanto, aproximadamente 90\% da importação de açúcar refinado da UE foi feita intra-bloco. Por outro lado, mais de $70 \%$ do volume exportado de açúcar refinado pela UE foi extra-bloco (analisado no período de 1994 a 2001). 
A maior parte da importação de açúcar bruto da União Européia, por sua vez, compreende os mercados preferenciais e garantidos do Protocolo do Açúcar do Acordo de Lomé entre a União Européia e as suas ex-colônias da África, Caribe e Pacífico $(\mathrm{ACP})^{14}$. Os mais importantes exportadores de açúcar para a União Européia dentro deste grupo são: Mauricio, Fiji, Guiana, Jamaica e Suazilândia. Segundo dados da European Commission (1998, 2000), no período de 1989 a 1999, Mauricio exportou uma média de 29,83\% do valor e 28,26\% do volume importado total da União Européia, sendo o maior ofertante de açúcar bruto para o bloco.

Dessa maneira, podem-se caracterizar dois mercados na UE: (i) um mercado importador de açúcar bruto, com suporte interno de preço e quotas de importação; e (ii) um mercado exportador de açúcar refinado, com subsídio dado a estas exportações. Acredita-se que as maiores distorções causadas ao mercado mundial de açúcar são originadas deste segundo efeito.

\subsection{Principais políticas protecionistas}

A UE tem um sistema de mercado altamente regulamentado para açúcar que é designado para prover sustentação de preços para os produtores domésticos. Esse suporte interno de preços é conservado para níveis que são geralmente bem acima dos preços mundiais.

Sob o regime de açúcar da UE, o volume de produção que recebe preços sustentados é, entretanto, limitado por um sistema de quotas. Sob esse sistema, uma quantidade de açúcar que cobre basicamente o consumo doméstico, chamada de quota A, recebe sustentação de preços mais elevados. Uma quantidade adicional, chamada de quota B, cobre a exportação de açúcar excedente, como uma “compensação" por não ter sido vendida ao preço doméstico. Uma produção acima da combinação das quotas A e $\mathrm{B}$, chamada de açúcar $\mathrm{C}$, não recebe suporte de preços.

\footnotetext{
${ }^{14}$ Fazem parte dos países da ACP: Barbados, Belize, Congo, Fiji, Guiana, Costa do Marfim, Jamaica, Quênia, Madagascar, Malawi, Mauricio, Suriname, St. Chiristopher \& Nevis, Suazilândia, Tanzânia, Trinidad \& Tobago, Uganda, Zâmbia e Zimbábue (Pinazza \& Alimandro, 2003).
} 
A quota A é, de longe, a maior das duas quotas de produção da UE. Ela tem sido fixada em 11,98 milhões de toneladas equivalente de açúcar branco desde 1995/96 para o grupo de 15 países contidos na UE. A quota B é muito menor, estabelecida em 2,61 milhões de toneladas. A produção de açúcar C, o qual é exportado sem suporte, não é limitada.

O Acordo Agrícola definido na Rodada Uruguai e fiscalizado pela OMC a partir da sua data de implementação (1995) fez algumas modificações nas políticas européias para o açúcar. Com esse acordo, a importação de açúcar pela UE foi limitada por uma quota tarifária. Neste acordo, importações abaixo de 1,3902 milhão de toneladas ao ano seriam capazes de entrar com tarifas baixas ou zero. Desse volume, entretanto, cerca de 1,305 milhão de toneladas foi garantida para completo acesso para países específicos da ACP cobertos pela convenção de Lomé e para a Índia. Esse açúcar recebe a mesma sustentação de preços do açúcar produzido internamente na UE e entra nos países do bloco com tarifa zero. Adicionalmente, como resultado da ampliação do mercado europeu de doze para quinze países em 1995, a UE aumentou a quantidade de compromisso de importação com a OMC e novos membros. Entretanto, o acesso para a UE além daquelas quantidades foi restrito por altas tarifas.

Segundo Brasil (2003c), as exportações de açúcar do Brasil para a União Européia estiveram sujeitas a quota tarifária cujo correspondente ad valorem é 66,39\%.

Outro resultado do Acordo Agrícola para o açúcar da UE foi a redução dos subsídios de exportação de 1,612 milhões de toneladas ao ano para 1,274 milhões de toneladas até o ano de 2000. Entretanto, esta redução excluía as exportações subsidiadas equivalentes a aproximadamente 1,3 milhões de toneladas do açúcar importado a cada ano dos países da ACP e da Índia.

Efetivamente, nada foi feito para reduzir as políticas européias de indução da produção, consumo e distorção do mercado relacionadas ao mercado de açúcar (Sheales et al., 1999). 
A Figura 10 ilustra a distorção dos preços provocada pelas políticas de açúcar da Política Agrícola Comum (PAC) do bloco.

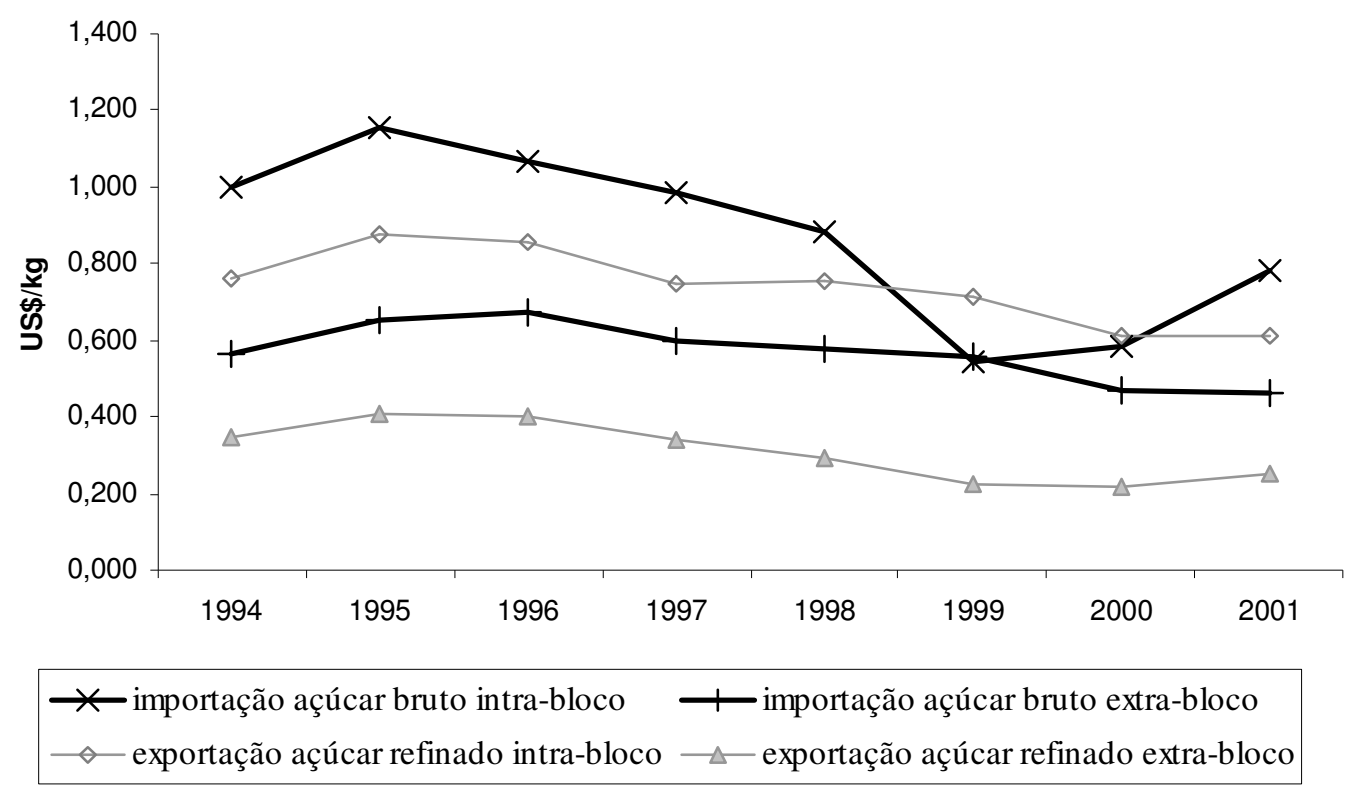

Figura 10 - Preços de importação e de exportação de açúcar bruto e refinado na União Européia, em US\$/kg; período: 1994 a 2000.

Fonte: FAO (2003b)

Segundo dados da FAO (2003b) apresentados na Figura 10, no período de 1994 a 2000, os preços se comportaram da seguinte maneira: altos preços de exportação intrabloco de açúcar refinado e de importação intra-bloco de açúcar bruto, como resultado do suporte de preço interno, subsidiando a produção de açúcar no bloco; alto preço de importação extra-bloco de açúcar bruto, que pode ser explicado pelo preço elevado pago à importação dos países da ACP; menor preço de exportação extra-bloco de açúcar refinado, refletindo o subsídio da UE para que o açúcar refinado seja competitivo no mercado mundial.

Conforme mostrado na Tabela 12, o volume de açúcar refinado exportado pela UE está entre 7 e 8 milhões de toneladas. Isto sugere que há um volume significativo de exportação de açúcar acima da quota B estabelecida pela UE. A viabilidade do grande 
volume de açúcar exportado pela quota $\mathrm{C}$ na $\mathrm{UE}$, entretanto, não pode ser um reflexo da competitividade dos países desse bloco na produção de açúcar. Os altos preços do produto no mercado doméstico não competem com os preços mundiais estabelecidos. Com isto, fica a questão de como os produtores da UE conseguem suportar a exportação de um grande volume de açúcar, a preços mundiais, e sem receber subsídios diretos.

Para responder a esta questão, Frandsen et al. (2001) procuraram modelar a política de açúcar da UE. Esses autores mostraram que a oferta de açúcar para exportação é muito diferenciada entre os países membros da União Européia. Enquanto alguns países produzem grandes quantidades da quota $\mathrm{C}$ de açúcar ano após ano, outros nunca administraram a sua quota subsidiada. Os autores indicaram as diferentes funções de custo marginal dos países membros, supondo que os produtores são obrigados, contratualmente, a entregar uma certa quantidade fixa de açúcar de beterraba para refinarias a cada ano, independentemente da variação na produção. Estes resultados podem ser visualizados, graficamente, na Figura 11.

Como o fracasso dos produtores em preencher o contrato pode penalizar suas altas quotas, a produção observada de açúcar $\mathrm{C}$ pode refletir o fato que os produtores, deliberadamente, superestimam suas quotas como método para preenchê-las no contrato em anos de baixa produção. Desta maneira, os autores encontraram que: França, Alemanha, Áustria e Reino Unido são capazes de produzir açúcar para o mercado mundial (quota $\mathrm{C}$ ), pois possui custo marginal menor do que o preço mundial $\left(\mathrm{P}_{\mathrm{w}}\right)$; Dinamarca, Bélgica e Espanha podem abastecer as quotas nacionais, pois possui custo marginal menor do que o preço definido pela quota $\mathrm{B}\left(\mathrm{P}_{\mathrm{B}}\right)$; que o custo de produção na Suécia, Holanda e Irlanda podem impedi-los de utilizar a quota B (custo marginal acima de $P_{B}$ ); e que Itália e Finlândia e, principalmente, Portugal e Grécia poderiam ter dificuldades em produzir a quota $\mathrm{A}$ (custo marginal acima de $\mathrm{P}_{\mathrm{A}}$ ). 


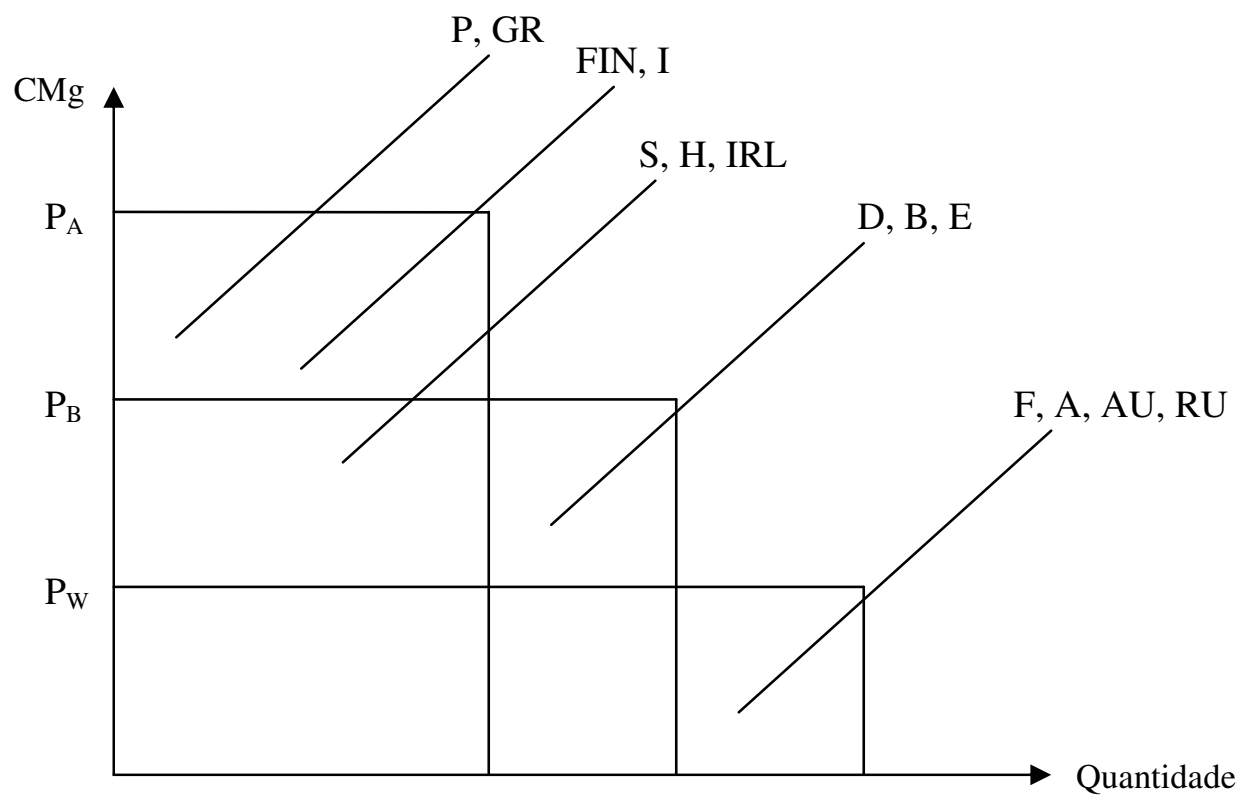

Figura 11 - Posição dos países que compõem a União Européia com respeito à oferta de açúcar.

Fonte: Frandesen et al. (2001)

A: Alemanha; AU: Áustria; B: Bélgica; D: Dinamarca; E: Espanha; GR: Grécia; F:

França; FIN: Finlândia; H: Holanda; I: Itália; IRL: Irlanda; P: Portugal; RU: Reino Unido; S: Suécia.

Os autores consideraram esse efeito como sendo um subsídio cruzado às exportações de açúcar. A concessão de subsídio cruzado para essas exportações é uma política que encoraja a produção além da demanda doméstica. Isso prejudica países em desenvolvimento, que encontram dificuldades para competir no mercado internacional com os subsídios de exportação de açúcar da UE. De outro lado, a política é baseada em um nível muito alto de proteção, fazendo com que seja virtualmente impossível exportar açúcar para a UE, a não ser que seja um exportador com acordo comercial específico com o bloco. 
A UE está sob pressão internacional, notavelmente de outros membros da OMC, para reformar sua política do açúcar. O objetivo desta reforma seria, primeiramente, eliminar o subsídio cruzado das exportações de açúcar para o mercado mundial. Como descrito por Colsera (2002), a prática de subsídios gera um ciclo perverso com conseqüências negativas sobre o mercado. $\mathrm{O}$ autor explica que, com a concessão de subsídios aumentando a produção e, conseqüentemente, levando a um excesso de oferta doméstica, os preços caem. Desta maneira, a existência de políticas protecionistas leva a subsídios adicionais, gerando um ciclo vicioso. A Figura 12 procura ilustrar este efeito.

Na Figura 12 observa-se que, enquanto o preço que a UE vende ao mercado mundial reduziu cerca de $30 \%$, os $\operatorname{subsídios}^{15}$ aumentaram neste período em $42 \%$. Assim, de modo exploratório, pode-se inferir que a estabilidade da produção observada na UE foi determinada pelos crescentes subsídios concedidos aos produtores domésticos.

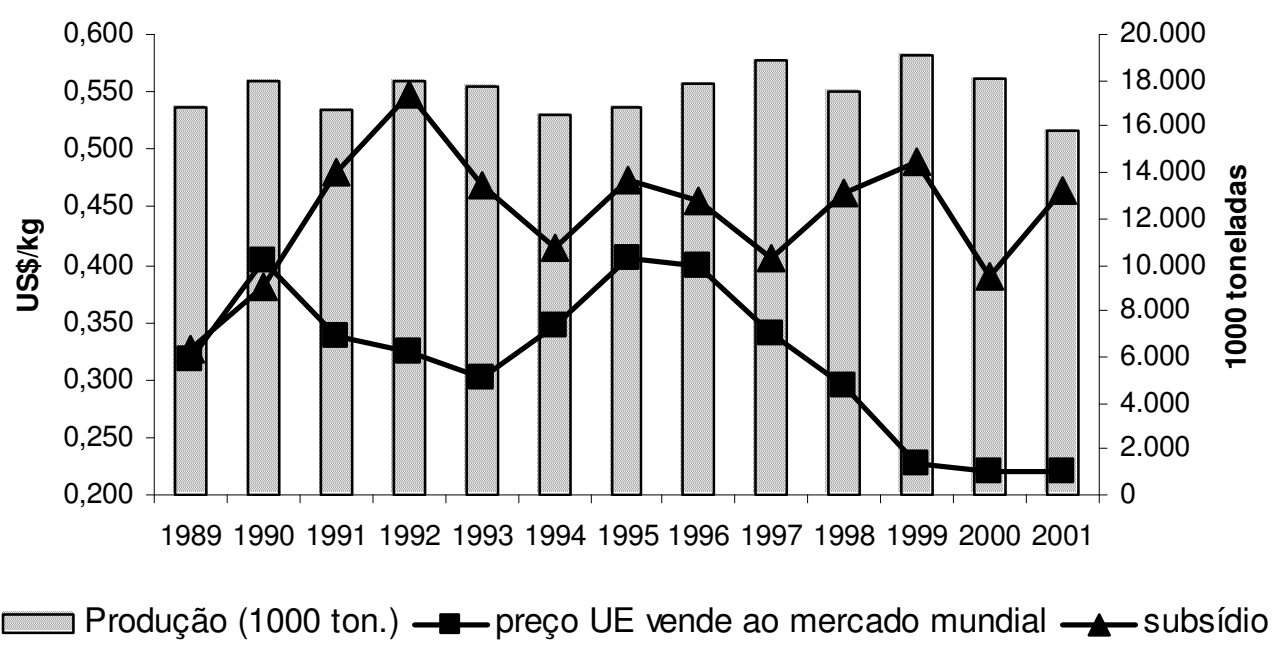

Figura 12 - Produção, preço de exportação de açúcar no mercado mundial e subsídio, da União Européia; período: 1989 a 2001.

Fonte: FAO (2003b)

\footnotetext{
${ }^{15}$ Os subsídios foram estimados pela diferença entre o preço de importação intra-bloco e o preço de exportação extra-bloco, na União Européia.
} 
Segundo Pinazza \& Alimandro (2003), a administração da política açucareira da UE é paliativa e altamente custosa. Esses autores alertam que há uma tendência de se tornar ainda mais complexa e embaraçosa, à medida que a incorporação de países do Centro e do Leste do continente aumente o excedente do produto.

\subsubsection{Políticas e o mercado de adoçantes no Japão}

O Japão tem uma das maiores e mais diversas indústrias de açúcar e adoçantes do mundo. A indústria é sujeita a expressivas intervenções governamentais na forma de suporte de preços aos produtores, taxação e tarifas sobre importação. A produção de açúcar do Japão (de beterraba e de cana) abastece somente um terço do consumo anual de açúcar. O balanço é altamente importador de açúcar na forma bruta para processamento pela ampla indústria de refino de açúcar de cana existente no país.

\subsection{Características gerais do mercado}

Durante a segunda metade da década de 1990, a produção de açúcar no Japão se manteve em cerca de 800 mil toneladas ao ano, contribuindo com cerca de $35 \%$ do consumo daquele país. A maior parte da produção foi de açúcar de beterraba (segundo dados da FAO, 2003a).

O consumo per capita do país é próximo ao da média mundial, entretanto, tem tido uma tendência declinante nos últimos anos. O Japão também tornou-se um dos maiores produtores e consumidores de isoglucose do mundo, vindo dessa forma a reduzir consideravelmente suas importações de açúcar. O HFCS é o adoçante alternativo dominante nesse mercado, com consumo estimado em 1996/1997 de 737 mil toneladas (Mitsui, $1999^{16}$ citado por Sheales et al., 1999). Segundo esse mesmo autor, o preço ao atacado de HFCS tem sido de cerca de $60 \%$ do preço do açúcar, oferecendo um claro incentivo para a substituição onde o uso deste produto for tecnicamente possível.

\footnotetext{
${ }^{16}$ MITSUI \& CO Ltd. Japan sugar starch ethanol yearbook. Tokyo, 1999.
} 
Conforme já verificado anteriormente, na segunda metade da década de 1990, o Japão foi o terceiro maior importador, em volume, de açúcar na forma bruta (a Rússia e a União Européia foram os dois primeiros). As importações japonesas foram realizadas predominantemente na forma bruta, pois o país possui uma grande capacidade instalada de refino. Segundo Sheales et al. (1999), cerca de $80 \%$ do total das importações provêm da Austrália e da Tailândia.

Já as importações de açúcar refinado não foram significativas em termos do comércio internacional nesse país.

\subsection{Principais políticas protecionistas}

A administração dos preços de açúcar, concedida sob uma lei de estabilização desses preços, é o principal elemento da política do açúcar no Japão. Os principais objetivos dessa lei são estabilizar os preços domésticos de açúcar, proteger o mercado doméstico de importadores competitivos e prover suporte de renda para agricultores domésticos. Os altos preços sustentados são reforçados ainda por substancial proteção às importações e forte regulamentação do setor.

Sob o Acordo Agrícola do GATT de 1994, o Japão deveria reduzir em 15\% o total de tarifas e taxas de importação. Entretanto, a redução dos preços domésticos foi mitigada por mudanças em outras sobretaxas e taxas sobre importação de açúcar.

Segundo Brasil (2003c), o Japão apresenta uma escalada tarifária para o açúcar, oferecendo uma estrutura tarifária progressiva à medida que os produtos adquirem maior valor agregado. As alíquotas para o açúcar vão desde 35,3 ienes/kg até 103,1 ienes/kg, significando uma tarifa ad valorem que varia entre $118,03 \%$ e $344,72 \%$.

Assim, as políticas de açúcar do Japão têm reduzido significativamente a demanda por importação de açúcar naquele país, encorajando diretamente o aumento da produção doméstica de açúcar e deprimindo o consumo, bem como estimulando a substituição por HFCS. Isso, por sua vez, como ocorre com as políticas adotadas nos 
EUA e na UE, tem também contribuído para diminuir os preços mundiais do açúcar e reduzir a renda dos produtores de açúcar nos países exportadores.

Vale ressaltar, entretanto, que como o Japão impõe uma política de "escalada tarifária", apenas o preço de importação de açúcar refinado está acima da média mundial. O preço de importação de açúcar bruto, em geral, não se mostrou tão elevado, como será descrito no item a seguir.

\subsubsection{Análise gráfica dos preços de importação nos Estados Unidos, União Européia e Japão}

A análise realizada neste item procurou comparar os preços de importação de açúcar bruto e refinado entre os principais países ou bloco que conduzem políticas protecionistas (EUA, UE e Japão), com outros grandes importadores do produto e a média mundial desses preços. Essa análise mostra as distorções de preços que algumas políticas protecionistas provocam, à medida que os preços de importação de um determinado país se distanciam muito da média mundial. Os preços foram obtidos pelo produto do valor com o volume importado pelos países analisados.

As Figuras 13 e 14 mostram, em dólares por tonelada, o efeito das medidas protecionistas que são aplicadas nos Estados Unidos, na União Européia e no Japão. Como descrito nos itens anteriores, esses países aplicam medidas protecionistas no mercado de açúcar, para proteger o mercado doméstico ou para beneficiar alguns países em função de acordos bilaterais. 


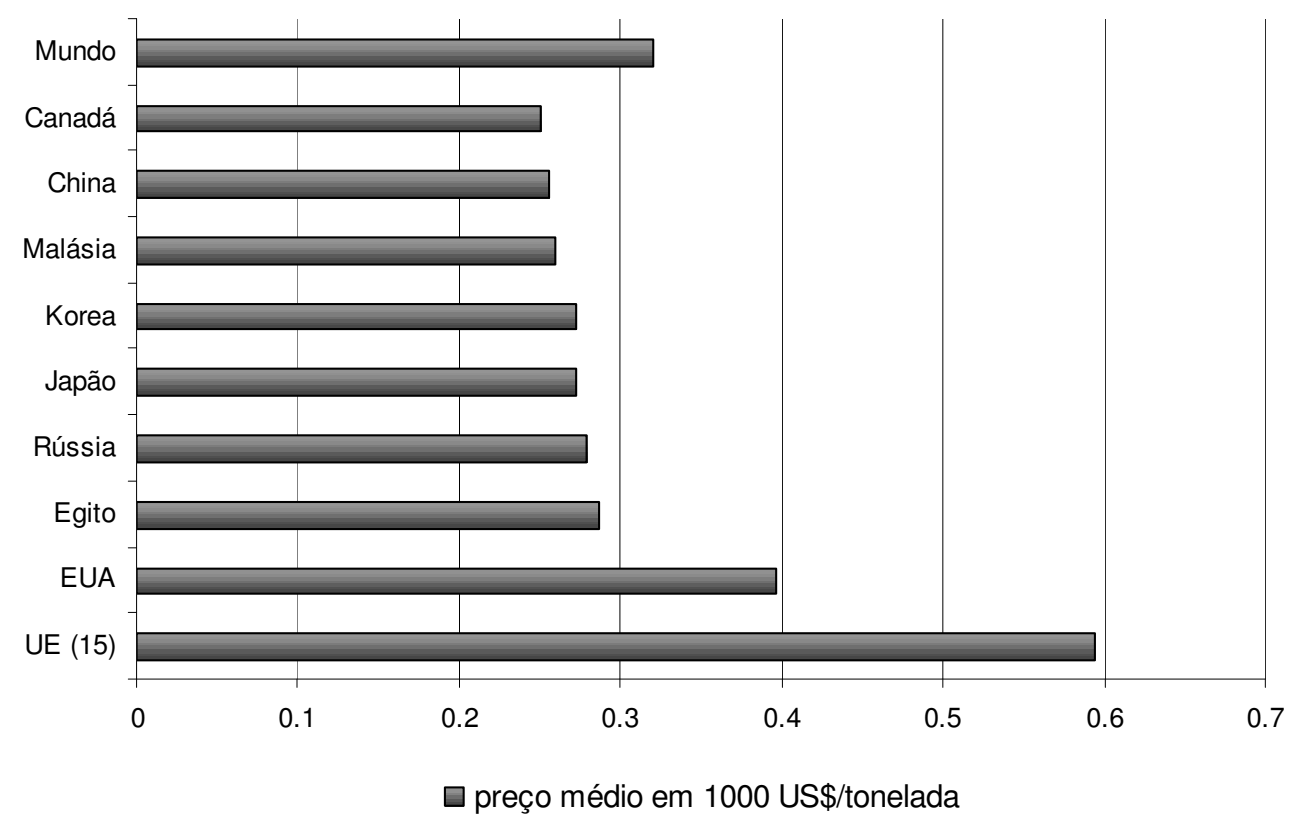

Figura 13 - Preço médio de importação de açúcar bruto em mercados selecionados, em US\$ 1000/toneladas; período de 1994 a 2000.

Fonte: FAO (2003b)

As políticas protecionistas aplicadas nesses países podem ser identificadas pela diferenciação no preço médio de suas importações em relação ao preço médio de importação de outros países que têm o mercado de açúcar isento dessas barreiras e a média de preço mundial. Isto pode ocorrer porque, os importadores dos países que adotam as políticas protecionistas, além de pagarem a tarifa correspondente à importação de açúcar bruto (intra ou extra-quota), e os pagamentos de todas as despesas referentes àquela importação, recebem um preço mais elevado no mercado interno. Quando a importação é realizada dentro do limite estabelecido com a tarifa intra-quota, o preço pago ao exportador é, geralmente, maior do que o preço no mercado mundial, uma vez que a tarifa mais baixa (em relação a tarifa extra-quota) possibilita ao importador conceder um preço mais elevado ao exportador do produto. Isto é o que acontece, por exemplo, em relação às quotas de importação dos EUA, onde os 
exportadores recebem um preço mais elevado por estas exportações, apesar da tarifa existente no mercado importador.

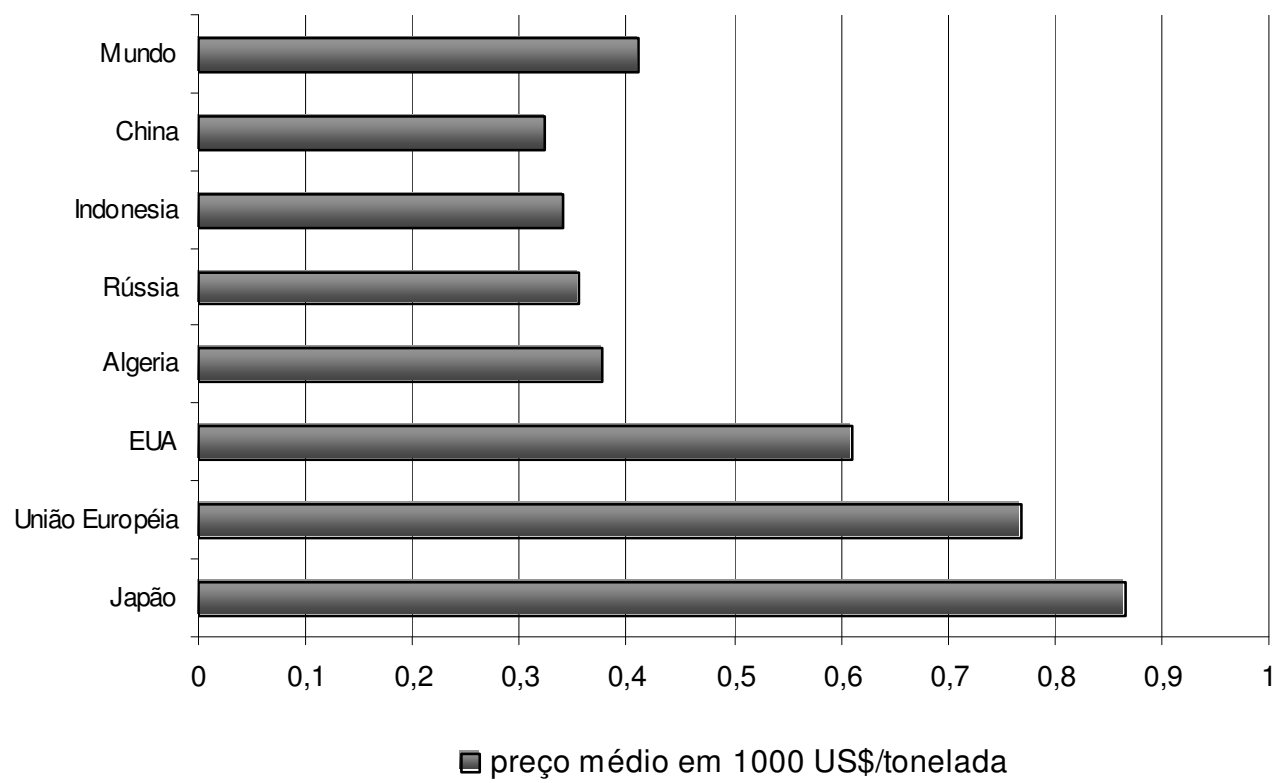

Figura 14 - Preço médio de importação de açúcar refinado em mercados selecionados, em US\$ 1000/toneladas; período: 1994 a 2000.

Fonte: FAO (2003b)

Na Figura 13, os EUA e, principalmente, a UE tiveram preços de importação bem acima da média mundial. O Japão, por sua vez, não apresentou preços mais elevados para o açúcar bruto, entretanto, como pode ser observado na Figura 14, esse país apresentou o mais elevado preço de importação para açúcar do tipo refinado. Isso é justificado pela política tarifária adotada no Japão (“escalada tarifária”), que consiste em aumento gradual de tarifa a medida que aumenta o grau de elaboração do produto. Em relação aos preços de importação do açúcar refinado na UE, estes foram mais elevados porque a importação deste açúcar é na sua maior parte intra-bloco, e o preço mais elevado reflete o valor pago pelos consumidores do bloco para promover a política de subsídio se refletiu na média estimada na Figura 14. 
No Quadro 1 tem-se um resumo das medidas protecionistas descritas nos itens anteriores no mercado de açúcar, para os EUA, UE e o Japão.

\begin{tabular}{|c|c|c|c|c|}
\hline & Quotas tarifárias & $\begin{array}{c}\text { Escalada } \\
\text { tarifária }\end{array}$ & $\begin{array}{l}\text { Subsídios à } \\
\text { exportação }\end{array}$ & $\begin{array}{c}\text { Suporte doméstico dos } \\
\text { preços }\end{array}$ \\
\hline $\begin{array}{l}\text { União } \\
\text { Européia }\end{array}$ & $\begin{array}{l}\text { Quota "in" de } \\
\text { importação de } 1,39 \\
\text { milhão de tonelada/ano. } \\
\text { Entretanto, 1,305 milhão } \\
\text { de tonelada é garantida } \\
\text { para os países da ACP. } \\
\text { Quota "extra" proibitiva. }\end{array}$ & Não. & $\begin{array}{l}\text { Sim. Estima-se } \\
\text { também um } \\
\text { subsídio cruzado } \\
\text { à exportação de } \\
\text { açúcar. }\end{array}$ & $\begin{array}{l}\text { Sistema de quotas de } \\
\text { produção (quotas A, B e } \\
\text { C), onde as quotas A e B } \\
\text { recebem preços } \\
\text { sustentados, muito } \\
\text { superiores aos preços do } \\
\text { mercado internacional. }\end{array}$ \\
\hline $\begin{array}{l}\text { Estados } \\
\text { Unidos }\end{array}$ & $\begin{array}{l}\text { Quota "in" de } \\
\text { importação de } 1,117 \\
\text { milhão de tonelada/ano } \\
\text { de açúcar de cana bruto. } \\
\text { Quota "extra" proibitiva. }\end{array}$ & Não. & Não. & $\begin{array}{l}\text { Taxa de empréstimo, } \\
\text { com: US } \$ 0,397 / \mathrm{kg} \text { para } \\
\text { açúcar de cana bruto e, } \\
\text { US } \$ 0,505 / \mathrm{kg} \text { para } \\
\text { açúcar de beterraba } \\
\text { refinado. }\end{array}$ \\
\hline Japão & Não. & $\begin{array}{l}\text { Sim. } \\
\text { Onerando as } \\
\text { importações } \\
\text { de açúcar } \\
\text { refinado. }\end{array}$ & Não. & $\begin{array}{l}\text { Lei de estabilização dos } \\
\text { preços de açúcar } \\
\text { refinado. }\end{array}$ \\
\hline
\end{tabular}

Quadro 1 - Resumo dos instrumentos de políticas protecionistas para o açúcar, utilizados pela União Européia, Estados Unidos e Japão.

Nota: os valores numéricos descritos no quadro são relativos ao ano de 2000.

\subsubsection{Acordos comerciais no mercado internacional de açúcar}

O Artigo XXIV do Acordo Geral, criado no GATT durante a Rodada Uruguai (1994) estabeleceu regras para a formação de acordos preferenciais de comércio e criou o Comitê sobre Acordos Regionais. De acordo com o Artigo XXIV, as partes contratantes do Acordo Geral reconhecem a vantagem da maior liberdade de comércio, mas reconhecem, também, que o objetivo de uniões aduaneiras ou áreas de livre comércio deve ser o de facilitar o comércio entre as partes do acordo e não levantar barreiras ao comércio de outras partes contratantes (Thorstensen, 1999). Os acordos 
comerciais têm o intuito de buscar, numa fase mais avançada, a globalização dos mercados.

Entretanto, paralelamente às políticas para o mercado de açúcar e seus principais efeitos na comercialização mundial desse produto, tem-se também os acordos que vem sendo realizados entre países. Na contramão do estabelecido pelo Artigo XXIV do Acordo Geral, esses acordos podem afetar a comercialização de açúcar, quando algum país incluído possui política protecionista neste mercado.

Foram inicialmente descritos os efeitos do Acordo de Livre Comércio da América do Norte (NAFTA), da Política Comum Européia e a União Européia, e a seguir, o possível efeito da implementação do acordo da The Asia Pacific Economic Cooperation - APEC, sobre a comercialização do açúcar.

O comércio de adoçante entre EUA e México, incorporados ao NAFTA, ilustra bem como acordos regionais podem propagar políticas protecionistas. Logo após assinar o acordo, o México prontamente moveu suas tarifas para níveis próximos aos dos EUA (Larson \& Borrell, 2001). Segundo esses mesmos autores, geralmente, esses acordos tendem a propagar as políticas nacionais protecionistas para fora do país. Isso pode ser benéfico por reduzir suporte às indústrias domésticas e restrições ao mercado. Entretanto, acordos entre grupos regionais de países para coordenar o mercado e políticas domésticas podem ter efeitos adversos para países não membros daqueles acordos (Sheales et al., 1999).

Como demonstrado no tópico 2.1.2, o México apresentou a maior taxa de crescimento de exportações de açúcar, entre os maiores exportadores mundiais, na segunda metade da década de 1990 (Tabelas 8 e 10), indicando o benefício desfrutado por esse país em função do NAFTA.

O exemplo do NAFTA também ilustra como novas intervenções políticas podem gerar conseqüências inesperadas e induzir políticas baseadas em investimentos irreversíveis. O acordo México-EUA afetou tarifas para açúcar e outros adoçantes, mais notavelmente o HFCS. O auxílio das tarifas provocou um crescimento da indústria de 
açúcar mexicana, e novos investimentos em açúcar aumentaram. Mas o protecionismo também criou oportunidades para manufaturados e adoçantes alternativos, desde que taxas tarifárias para o HFCS caíram mais rapidamente do que tarifas para o açúcar. A partir de 1996, a importação de adoçantes começou a competir com o açúcar doméstico do México e firmas dos EUA introduziram novos investimentos no México. Isso foi em parte por causa da vantagem temporária que o NAFTA proporcionou aos adoçantes frente ao açúcar, acarretando uma oportunidade para a indústria de HFCS cobrir os altos custos fixos associados com sistemas de transporte e moagem úmida de plantas de milho (Larson \& Borrell, 2001).

Outro exemplo de acordos regionais que tem efeitos econômicos adversos é a União Européia e a Política Comum Agrícola. Esta política da UE tem resultado em altos preços internos para produtores e consumidores. Ao mesmo tempo, ela tem contribuído para reduzir os preços mundiais, por causa das exportações subsidiadas da UE, utilizadas para administrar ou reduzir a oferta interna dessa commodity (Sheales et al., 1999). Já o efeito da expansão do acesso do açúcar mexicano nos EUA sobre os preços mundiais pode ser mínimo, mas a oferta de quotas tarifárias para os EUA pode ser reduzida em aproximadamente US\$ 24 milhões, segundo estimativa de Sheales et al. (1999), por causa de leve redução dos preços no mercado norte-americano.

Um acordo regional que está em vias de implementação é o grupo APEC. A APEC foi estabelecida em 1989 e conta atualmente com 21 economias, incluindo: Austrália, Brunei, Canadá, Chile, China, Hong Kong, Indonésia, Japão, Coréia, Malásia, México, Nova Zelândia, Nova Guiné, Peru, Filipinas, Rússia, Singapura, Taipei Chinesa, Tailândia, EUA e Vietnam (APEC, 2003). A APEC tem uma meta de liberação e abertura comercial em 2010 para economias industrializadas e em 2020 para membros de economia em desenvolvimento (Sheales et al., 1999). Uma liberalização substancial no mercado de açúcar para as economias-chaves da APEC poderia resultar, segundo Sheales et al. (1999), em preços mundiais de açúcar estimados em 25\% maiores em 2005 do que na ausência dessas mudanças políticas. Esse aumento seria proveniente do crescimento das importações de açúcar dos EUA e Japão. 
De maneira geral, verifica-se que os objetivos não atingidos para o mercado mundial de açúcar na Rodada Uruguai foram ou seriam implementados nos acordos regionais de comércio, entre os países membros. Entretanto, os países não membros continuariam sendo negativamente afetados por esses acordos regionais, porque a continuação do uso de políticas protecionistas dentro desses países acordados origina efeitos negativos no comércio com outros países.

\subsubsection{Dependência e efeitos de políticas comerciais de outros países}

Anteriormente foram descritas as principais políticas que afetam o mercado internacional do açúcar. Tais políticas são aplicadas por países desenvolvidos, mas afetam a comercialização mundial do produto. Assim, os efeitos dessas políticas, de forma particular em alguns países menos desenvolvidos (na forma de dependência), e no mercado mundial em geral, são informações relevantes.

Segundo Larson \& Borrell (2001), as políticas de países que dominam o mercado de açúcar influenciam aqueles menos importantes em dois caminhos significativos. Primeiro, a intervenção difundida de grandes países encoraja outros para instituir políticas protecionistas. A influência pode ser indireta ou mais explicita, especialmente durante a negociação de acordos comerciais regionais. Segundo, acordos de acesso especial freqüentemente resultam em indústrias domésticas de açúcar que são dependentes externamente de determinadas políticas e influenciam políticas domésticas designadas para alocar espaços de acesso do acordo. Exemplos incluem políticas de açúcar em Fiji, Cuba, Filipinas e Zimbabue (Larson \& Borrell, 2001).

Acordos de acessos especiais são componentes importantes do mercado internacional de açúcar. Dois programas significativos - programas dos EUA e da UE são especialmente antigos. Como mencionado anteriormente, o Acordo de Lomé oferece quotas baseadas em acessos preferenciais para o mercado de açúcar protegido pela UE,

que inclui países na África, Ásia e Caribe, antigas colônias da Europa. Os EUA provêm acesso preferencial para países em desenvolvimento. 
Entretanto, conforme relatado por Larson \& Borrell (2001), os acordos de acesso especial podem ter, também, impactos negativos sobre o desenvolvimento dos países beneficiados. Os programas dos EUA e da UE mantêm uma maior participação de quotas de acesso especial para poucos países. Entretanto, mesmo quando a participação da quota total é relativamente pequena, o efeito sobre pequenas indústrias de açúcar em pequenos países pode ser alto, uma vez que essas indústrias podem ser significativamente dependentes dos acordos especiais de comércio.

De acordo com dados da FAO (2003b), entre 1994 e 2000, 13 países (descritos na Figura 15) dependiam da exportação de açúcar, que correspondia a mais de $20 \%$ de suas exportações agrícolas totais no período considerado (Figura 15).

Excetuando Cuba, os demais países dependem das políticas protecionistas dos países da União Européia e dos Estados Unidos. Assim, acordos especiais de comércio com o açúcar podem ser lucrativos enquanto estes prevalecem. No entanto, por serem dependentes de políticas estrangeiras, os riscos para o mercado, como aqueles decorrentes de mudanças políticas, tendem a ser abrupto e de difícil controle.

A história turbulenta da indústria cubana de açúcar ilustra esse ponto. A indústria de açúcar em Cuba cresceu entre 1904 e 1925, chegando a 5 milhões de toneladas, as quais constituíram $23 \%$ da produção mundial. Grande parte desse açúcar era absorvida pelo mercado protegido dos EUA, sob acordos especiais de comércio. Em 1929, as exportações de Cuba (cerca de $77 \%$ da produção de açúcar da ilha) satisfaziam metade do consumo de açúcar dos EUA. O sustento de aproximadamente dois terços da população de Cuba dependia direta ou indiretamente do açúcar (Braga, 1997 ${ }^{17}$, citado por Larson \& Borrell, 2001).

\footnotetext{
${ }^{17}$ BRAGA, M. To relieve the misery: sugar mill workers and the 1933 Cuban revolution. In: BROWN, J. (Ed.). Workers' control in Latin América, 1930-1979. Chapel Hill: University of North Carolina Press, 1997.
} 


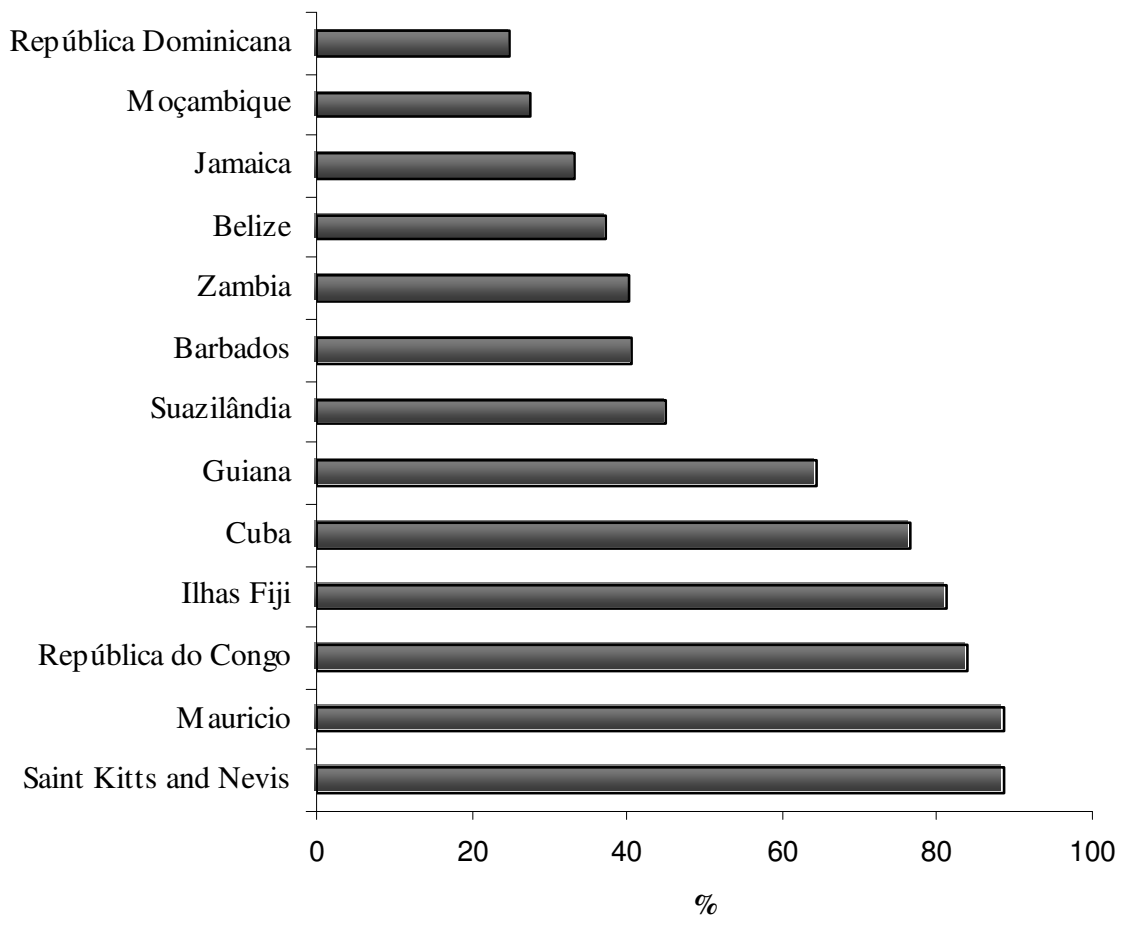

Figura 15 - Países que possuem participação das exportações de açúcar nas exportações agrícolas totais maior do que $20 \%$. Média das participações no período de 1994 a 2000.

Fonte: elaborado a partir de dados da FAO (2003b)

Em 1930, entretanto, com a depressão dos EUA e a redução na demanda doméstica, o governo daquele país passou a proteger os produtores nacionais e a produção no Hawai, Porto Rico e Filipinas. Por volta de 1932, a produção de açúcar de Cuba teve queda de cerca de 2,5 milhões de toneladas e foi negociada por um valor muito inferior aos preços mundiais. A renda dos trabalhadores caiu significativamente (Larson \& Borrell, 2001).

A produção de açúcar de Cuba recuperou-se durante a Segunda Guerra Mundial, alcançando 6 milhões de toneladas em 1947. Cerca de metade do açúcar de Cuba foi para o mercado protegido dos EUA, enquanto o restante foi direcionado para o 
mercado mundial. No entanto, a Revolução Cubana de 1959 e o embargo dos EUA de 1960 causaram uma mudança estrutural na economia de Cuba e na indústria do açúcar.

Durante as três décadas seguintes, Cuba foi dependente de países do bloco soviético. Quando houve o colapso do bloco soviético, ocorreu a segunda crise cubana. De 1990 a 2001, a produção de açúcar caiu a uma taxa geométrica de crescimento de 7,21\% ao ano (segundo dados da FAO, 2003a). Entretanto, conforme descrito na Figura 15, até 2000 as exportações agrícolas totais de Cuba continuavam dependentes do açúcar.

Mauricio é um exemplo de que a dependência de acessos especiais pode gerar barreiras legislativas para a diversificação. A cultura da cana-de-açúcar ocupa $90 \%$ da área cultivada nesse país (Central Intelligence Agency - CIA, 2002). Condições especiais para trabalhadores naquele país, regulação especial do mercado de terra e outras regulações específicas para a indústria do açúcar restringiram recursos para que Mauricio pudesse produzir o suficiente para ir de encontro com a quota dos EUA, além de ter acesso preferencial também no mercado protegido da UE. Todos esses incentivos são consequiências dos altos preços (em virtude das quotas tarifárias) e de acessos especiais oferecidos por esses demandantes, principalmente pela UE. Para a média dos preços de exportação de açúcar bruto no período de 1994 a 2000, Mauricio se destacou como o maior beneficiário dessas políticas (Figura 16). Como resultado, oportunidades para aumentar a diversificação foram limitadas e mais terras foram alocadas para produção de açúcar.

Como pode ser verificado na Figura 16, o preço médio das exportações de açúcar bruto por alguns países da ACP foram significativamente maiores do que o de outros grandes exportadores. Isso realça a dependência das exportações dos países da ACP para os mercados protecionistas dos EUA e da UE. 


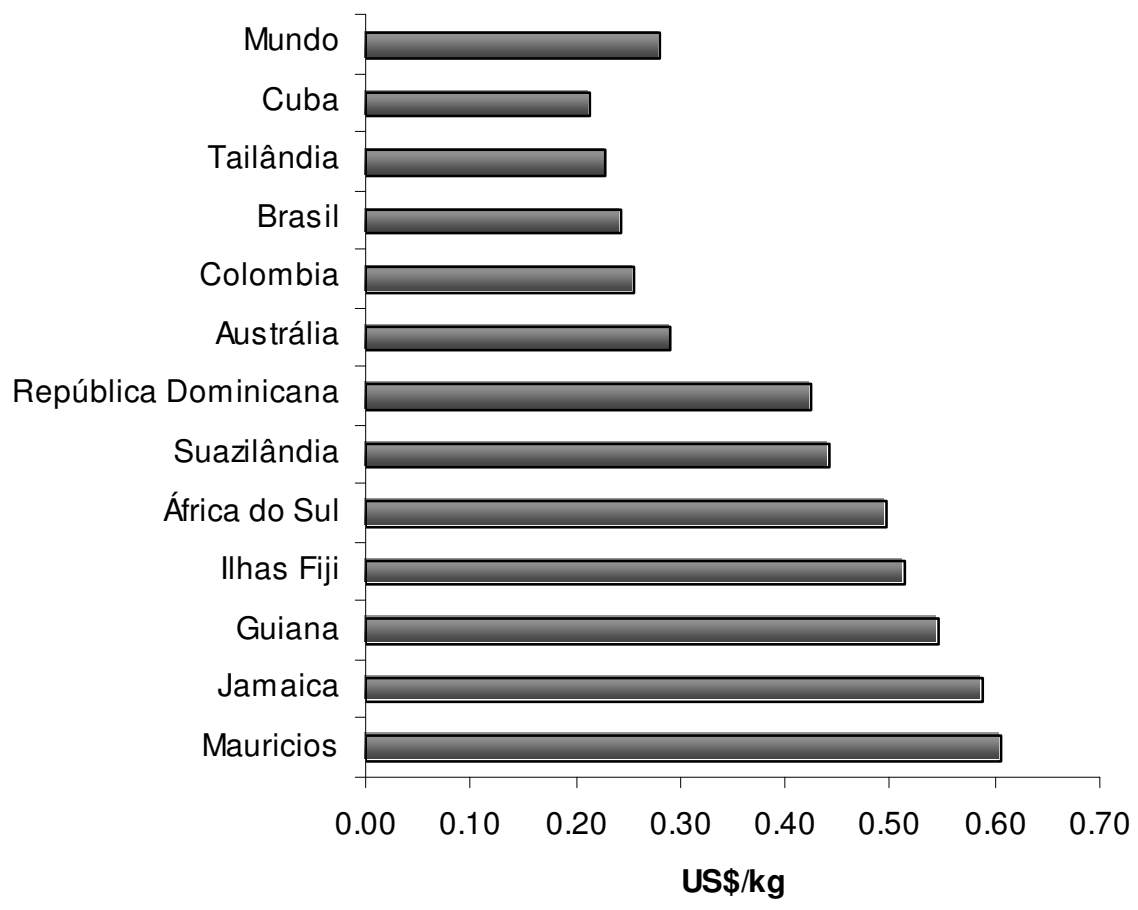

Figura 16 - Preço médio de exportação de açúcar bruto de países selecionados, em US\$/kg; período: 1994 a 2000.

Fonte: FAO (2003b)

Já na economia internacional como um todo, a redução dos preços mundiais, ocasionada por distorções de mercado criadas por políticas para o açúcar, resultam em custos de bem-estar para países exportadores competitivos nesse mercado. Assim, o efeito das políticas protecionistas individualmente sobre os exportadores mundiais de açúcar depende de seu acesso aos mercados dos EUA e da UE (Sheales et al., 1999).

Os exportadores com quotas para os mercados protecionistas se beneficiam dos altos preços que aplicam para a proporção de suas vendas cobertas pela quota daqueles países (como mostra a Figura 16). Entretanto, eles devem negociar o restante de suas exportações em outros mercados do mundo, a preços que são substancialmente deprimidos pelos programas daqueles mesmos países (Sheales et al., 1999). 
De outro lado, países que importam açúcar bruto isento de tarifas, incluindo alguns países de alta renda, como Japão e Canadá (o que pode ser observado na Figura 13), são beneficiados pelos menores preços mundiais pagos aos países exportadores, que são, em muitos casos, países em desenvolvimento (Sheales et al., 1999).

Independentemente do efeito sobre os níveis de preços ao todo, políticas protecionistas existentes para o açúcar têm também contribuído para aumentar a instabilidade nos preços mundiais. Por usar quotas de importação para estabilizar preços domésticos para produtores e consumidores, muitos ajustamentos na oferta e demanda nos EUA são forçados sobre os próprios produtores e consumidores. Isso tem o efeito de aumentar a variação de preço de produtores e consumidores no mercado internacional (Sheales et al., 1999).

\subsection{Efeitos mundiais da liberalização comercial do mercado de açúcar}

Nos itens anteriores, verificou-se que os principais efeitos das medidas protecionistas adotadas no mercado de açúcar são: (i) para os países beneficiados pelo alto valor das tarifas, ocorre uma artificialização de sua competitividade, podendo levar a conseqüências críticas para a economia desses países no caso de eliminação dessas políticas; (ii) para os países não beneficiados, e que são competitivos na produção de açúcar, há uma perda de receita em suas exportações, uma vez que tais políticas deprimem o preço mundial do produto pelo alto volume ofertado. A mensuração desses efeitos, por sua vez, torna-se de fundamental importância para a análise de tal mercado e para possíveis previsões. A seguir, são descritos alguns estudos que mensuraram os impactos da redução dos atuais níveis de intervenção no mercado de açúcar sobre os principais países que participam deste mercado.

Procurando estudar os possíveis efeitos da diminuição na proteção a que se encontra submetido o mercado de açúcar, Borrell \& Pearce (1999), CIE (2002) e Sheales et al. (1999) obtiveram resultados coincidentes em termos de tendência, mas com magnitudes de efeitos diferentes na maioria das vezes. Isso pode ser explicado pelo fato 
desses estudos enfocarem previsões para períodos distintos ou utilizarem modelos distintos na análise.

Nesses trabalhos há um caminho coincidente, indicando que, uma vez eliminadas as barreiras ao comércio de açúcar (suporte de preços, subsídios e altas tarifas de importação) nos principais mercados que possuem essas políticas, os quais, em geral, são países desenvolvidos, haveria uma redução nos preços domésticos de açúcar daqueles países. Isso provocaria, por sua vez: aumento do consumo, redução na produção e, conseqüentemente, aumento de suas importações. Em contrapartida, para atender a essa demanda crescente, os países que possuem menores custos na produção de açúcar, os quais são, na sua maioria, países em desenvolvimento, aumentariam suas exportações, sendo que o aumento da demanda poderia elevar os preços mundiais do produto.

Para mensurar esses efeitos, Sheales et al. (1999) utilizaram o modelo denominado ABARE's, prevendo as mudanças para o ano de 2005. Borrell \& Pearce (1999) utilizaram um modelo do mercado mundial de adoçantes (GSM - Global Sweetener Market), desenvolvido pela Sugar Division of CSR Australia Ltda, com a hipótese de remoção conjunta de todas as proteções comerciais em todos os países consideradas no ano 2000 e seus efeitos, tendo sido feito todos os ajustamentos necessários no novo mercado, em 2008. Utilizando esse mesmo modelo (GSM), CIE (2002) estudou os efeitos de reduções protecionistas no mercado de açúcar para o ano de 2012.

A Tabela 16 sintetizou algumas das mudanças previstas para o mercado mundial de açúcar frente à eliminação das principais barreiras protecionistas desse mercado, descritas nos trabalhos mencionados.

Como no trabalho de Borrell \& Pearce (1999) os resultados foram previstos para 2008, é coerente que as diferenças encontradas por esses autores devido à maior liberalização do mercado mundial de açúcar sejam maiores do que aquelas encontradas por Sheales et al. (1999), que previu seus resultados para 2005. Isso ocorre porque é natural um período de ajuste do mercado frente a mudanças políticas drásticas, como as 
previstas nesses trabalhos. Da mesma maneira, pode-se explicar as diferenças em relação aos resultados de CIE (2002).

Tabela 16. Resultados estimados por Borrell \& Pearce (1999), CIE (2002) e Sheales et al. (1999), de algumas mudanças ocorridas no mercado mundial de açúcar frente a efeitos de menores intervenções nesse mercado.

\begin{tabular}{|c|c|c|c|}
\hline & $\begin{array}{c}\text { Borrell \& Pearce } \\
\text { (1999) } \\
\text { Previsão para } 2008\end{array}$ & $\begin{array}{c}\text { CIE (2002) } \\
\text { Previsão para } 2012\end{array}$ & $\begin{array}{l}\text { Sheales et al. (1999) } \\
\text { Previsão para } 2005\end{array}$ \\
\hline $\begin{array}{l}\text { Preço mundial do } \\
\text { açúcar bruto }\end{array}$ & Aumento de $38 \%$ & Aumento de $63 \%$ & Aumento de $41 \%$ \\
\hline $\begin{array}{l}\text { Produção de açúcar no } \\
\text { Brasil }\end{array}$ & Aumento de $15 \%$ & $\begin{array}{c}\text { Aumento de } \\
27,5 \% *\end{array}$ & Aumento de $11 \%$ \\
\hline $\begin{array}{l}\text { Produção de açúcar na } \\
\text { Austrália }\end{array}$ & Aumento de $25 \%$ & Aumento de $41 \% *$ & Aumento de $16 \%$ \\
\hline $\begin{array}{l}\text { Produção de açúcar na } \\
\text { Tailândia }\end{array}$ & Aumento de $25 \%$ & Aumento de $42 \% *$ & Aumento de $16 \%$ \\
\hline $\begin{array}{l}\text { Produção de açúcar no } \\
\text { Japão }\end{array}$ & Redução de $44 \%$ & Redução de 59\%* & Redução de $22 \%$ \\
\hline $\begin{array}{l}\text { Produção de açúcar nos } \\
\text { Estados Unidos }\end{array}$ & Redução de $32 \%$ & Redução de $41 \% *$ & Redução de $13 \%$ \\
\hline $\begin{array}{l}\text { Exportação de açúcar } \\
\text { no Brasil }\end{array}$ & $\begin{array}{l}\text { Aumenta em mais } \\
\text { de } 50 \% *\end{array}$ & - & Aumento de $22 \% *$ \\
\hline $\begin{array}{l}\text { Exportação de açúcar } \\
\text { na Austrália }\end{array}$ & $\begin{array}{l}\text { Aumenta em mais } \\
\text { de } 50 \% *\end{array}$ & - & Aumento de $20 \% *$ \\
\hline $\begin{array}{c}\text { Exportação de açúcar } \\
\text { na Tailândia }\end{array}$ & $\begin{array}{l}\text { Aumenta em mais } \\
\text { de } 100 \% *\end{array}$ & - & Aumento de $28,5 \% *$ \\
\hline
\end{tabular}

Fonte: Borrell \& Pearce (1999); CIE (2002) e Sheales et al. (1999)

Nota: representa o aumento ou redução dos itens considerados que o mercado estaria exposto com a redução das intervenções existentes, em relação ao que seria esperado ocorrer sem tais mudanças, na mesma época, estimados pelos próprios autores.

* Os impactos foram dados, originalmente, em volumes e foram estimados em variação percentual pela autora, com base nos volumes exportados de anos anteriores ao do estudo. 
Outros resultados encontrados por Borrell \& Pearce (1999) indicam a redução nos preços domésticos de açúcar naqueles países em que as barreiras comerciais foram eliminadas. São eles: Japão, com redução de $65 \%$ dos preços; Estados Unidos, México, Indonésia e leste europeu, reduzindo $25 \%$ dos respectivos preços; e China, Ucrânia e Filipinas, com queda de $10 \%$ nos seus preços domésticos de açúcar.

Sheales et al. (1999), por sua vez, também estudaram os efeitos de mudanças políticas em alguns mercados. A Tabela 17 sumariza os resultados encontrados.

Tabela 17. Efeito de algumas reduções em intervenções governamentais sobre os preços mundiais de açúcar bruto.

\begin{tabular}{lr}
\hline & $\begin{array}{r}\text { Mudanças estimadas no } \\
\text { preço mundial de } \\
\text { açúcar bruto (\%) }\end{array}$ \\
\hline Redução de 50\% da tarifa ad valorem nos Estados Unidos & 5 \\
Corte da taxa de empréstimo nos Estados Unidos & 9 \\
Liberalização completa do mercado dos Estados Unidos & 17 \\
Eliminação da intervenção de preços na União Européia & 19 \\
$\begin{array}{l}\text { Redução das quotas de produção A e B para aproximadamente 1,2 } \\
\text { milhões de toneladas na União Européia }\end{array}$ & 4 \\
$\begin{array}{l}\text { Remoção da tarifas aduaneiras de importação no Japão } \\
\text { Redução das barreiras tarifárias na APEC, mas mantendo a política } \\
\text { da UE }\end{array}$ & 5 \\
\hline
\end{tabular}

Fonte: Sheales et al. (1999)

Nota: representa o aumento dos preços mundiais que o mercado estaria exposto em cada uma das mudanças políticas consideradas.

Apesar das projeções realizadas em tais trabalhos, a relevância do presente estudo consiste em realizar uma análise que, sendo de equilíbrio parcial, realize previsões mais precisas em relação aos efeitos sobre as exportações, enfocando, distintamente, graus diferenciados de processamento do açúcar exportado. A análise diferenciada do açúcar bruto e refinado é importante, uma vez que têm sido crescentes as 
exportações brasileiras de açúcar refinado e esses produtos encontram diferenças em relação às políticas protecionistas no mercado mundial.

A análise e estimação de elasticidades-preço de oferta e de demanda por exportação são de interesse para pesquisadores e políticos, uma vez que descrevem como as exportações respondem a mudanças nas atividades econômicas (elasticidaderenda) e nos preços domésticos, relativamente aos preços estrangeiros (elasticidadepreço). As elasticidades de fluxos de comércio em resposta a mudanças na taxa de câmbio é outra informação importante e que tem merecido destaque nos estudos de comércio internacional.

Segundo Sawyer \& Sprinkle (1999), aquelas elasticidades-preço são especialmente importantes para mensurar efeitos de políticas para a redução de tarifas multilaterais negociadas no âmbito do GATT/OMC, assim como efeitos de reduções de tarifas bilaterais negociadas sobre vários acordos regionais para áreas de livre comércio. São também importantes para estimar efeitos de redução de tarifas preferenciais, como no Sistema Geral de Preferências (SGP) ${ }^{18}$. Assim, a efetividade de políticas de comércio internacional é dependente do tamanho dos efeitos de preço, de renda e mesmo de outras variáveis relevantes sobre o fluxo de comércio. Em função da importância dessas informações para a condução de políticas de comércio internacional, a modelagem de equações de oferta e demanda tem uma longa história na literatura econômica e econométrica desde a década de 1950.

\subsection{Modelos de equilíbrio parcial utilizados para estudar o comércio internacional de commodities}

Nesse item foram revisados estudos relacionados às funções de exportação e de importação de maneira geral, de modo a fornecer um arcabouço teórico para justificar os modelos a serem utilizados no presente estudo. A seguir, foi realizada uma revisão para

\footnotetext{
${ }^{18}$ Tarifas SGP são tarifas menores do que as tarifas aplicadas, concedidas pelos países desenvolvidos aos países menos desenvolvidos. Assim, ela é concedida unilateralmente e pode ser aplicada seletivamente.
} 
o setor exportador brasileiro de açúcar, onde se procurou situar a contribuição do presente trabalho nas literaturas relativas ao estudo deste tema.

\subsubsection{Pressuposições alternativas adotadas na estimação de equações de exportação e de importação}

Conforme descrito por Braga \& Markwald (1983) e Zini (1988), para a especificação das equações de comércio exterior, existem duas formulações teóricas distintas que devem ser escolhidas em função do tamanho do país em relação ao(s) produto(s) analisado(s) no contexto do comércio internacional.

Tem-se uma formulação teórica, que procura descrever uma economia pequena, onde o volume de comércio de um país depende de suas condições internas. Zini (1988) descreve que investigações empíricas das funções de comércio costumavam levantar a hipótese de oferta de exportação infinitamente preço-elástica, e a análise ficava confinada à função de demanda por exportação, o que, segundo esse mesmo autor, é uma hipótese questionável, pois requer tecnologia de produção com retorno constante de escala ou com excesso considerável de capacidade instalada. Analogamente, Braga \& Markwald (1983) expõem que estudos econométricos sobre as exportações de manufaturados no Brasil têm se concentrado na estimação de funções de oferta, sem revelarem interesse especial pelo lado da demanda, que é suposta infinitamente elástica, com base na hipótese de "país pequeno". Esta hipótese também é criticada, pois, segundo Zini (1988), a existência de restrições ao comércio e a dependência para com supridores habituais limita o acesso externo aos mercados domésticos.

A segunda formulação teórica para a especificação do comércio internacional indica que a oferta e a demanda por exportação não são funções infinitamente elásticas do preço, e sua estimação requer a resolução do problema da identificação causada pela determinação simultânea de preço e quantidade. Essa formulação pressupõe um modelo competitivo para as exportações em análise. 
Assumindo a consideração de economia competitiva, várias especificações de modelos de oferta e demanda por exportações foram descritas na literatura, com algumas diferenças em relação às variáveis incluídas e métodos de especificação desses modelos. Sawyer \& Sprinkle (1999) descrevem, também, que a modelagem para os fluxo de comércio pode ser desagregada em função da natureza dos bens comercializados (commodities homogêneas versus bens diferenciados); do uso final da commodity (para consumo final versus bens intermediários); e da distribuição geográfica do comércio.

Nesse sentido, entre os trabalhos realizados para as exportações brasileiras, destacam-se os de Braga e Markwald (1983), que estimaram funções de oferta e de demanda das exportações de manufaturados no Brasil, e Zini (1988), que estimou estas mesmas funções para grupos de bens: produtos industrializados, produtos minerais, produtos agrícolas e exportações totais.

Além da formulação teórica dos modelos, uma preocupação constante desses autores diz respeito à forma de estimação dos mesmos.

Segundo Zini (1988), funções de demanda e de oferta de exportação podem ser especificadas assumindo que os produtos importados não são substitutos perfeitos para os bens domésticos. Essa condição é importante de ser considerada, pois em um modelo competitivo com custos marginais constantes se supõe que os bens são substitutos perfeitos, e dever-se-ia observar uma dominação plena de cada mercado ou por bens importados ou por bens exportados, ou seja, a elasticidade-preço seria infinita. Não é isto, no entanto, que se observa nos mercados internacionais, justificando-se a hipótese de substituição imperfeita. Assim, o autor descreve que, como conseqüência, é possível estimar elasticidades-preço finitas tanto para a oferta quanto para a demanda de produtos de exportação e de importação. O modelo de substitutos perfeitos aplica-se ao comércio com bens homogêneos, como as commodities.

Partindo dessa mesma idéia, duas outras pressuposições podem ser descritas em modelos de comércio internacional: (i) os produtos importados do país A são substitutos perfeitos para os mesmos produtos importados do país B, implicando numa elasticidade 
de substituição infinita e razão de preços constantes; e (ii) os produtos importados são diferenciados por fatores outros que não os preços.

Conforme demonstrado em estudos empíricos conduzidos para outros países (Babula, 1987; Bredahl et. al., 1979; Duffy et. al., 1990; Fontes et. al., 1989; Johnson et. al., 1979; Penson \& Babula, 1988; Sarris, 1983; entre outros), e para estudos aplicados para o Brasil (Ferreira, 1998; Oliveira et. al., 1996; Rocha, 2002; Silva, 1992;), as elasticidades das funções de importação podem variar de acordo com os mercados. Estes resultados corroboram com a hipótese (ii) descrita anteriormente.

Estudos nesse sentido têm enfocado o comportamento da demanda, sugerindo um comportamento diferenciado do país conforme a origem de suas importações. A teoria da demanda por produtos distinguidos por país de origem foi desenvolvida por Armington (1969), e segundo Sarris (1981) ${ }^{19}$, citado por Babula (1987), o modelo de Armington (1969) é considerado teoricamente poderoso, com substancial conteúdo econômico, sendo uma promissora técnica para modelar o comércio agrícola nos EUA.

Em relação ao comportamento da oferta das exportações brasileiras de açúcar, muitos estudos já foram realizados. A seguir são descritos alguns destes estudos.

\subsubsection{Estudos sobre as exportações brasileiras de açúcar}

A finalidade deste tópico é destacar a originalidade e a relevância do presente estudo como complementar às atuais pesquisas realizadas que analisaram e, ou, deram alguma contribuição na direção de avaliar fatores condicionantes das exportações brasileiras de açúcar.

Nesse sentido, os estudos abrangendo o mercado internacional de açúcar que têm sido realizados no Brasil relacionam-se a mensurações: do grau de competitividade

\footnotetext{
${ }^{19}$ SARRIS, A.H. Empirical models of International Trade in Agricultural Commodities. In: MCCALLA, A.F.; JOSLING, T.E. Imperfect markets in international trade. Montclair: Allenheld, Osmun and Co., 1981.
} 
do açúcar brasileiro em relação aos seus competidores, de elasticidades de substituição entre exportadores e de funções de oferta e demanda por exportação desse produto.

Burnquist \& Miranda (1999), Stalder (1997) e Veiga Filho (2000) analisaram as mudanças ocorridas nas exportações brasileiras de açúcar na década de 1990.

Segundo Veiga Filho (2000), há várias razões explicativas para o crescimento sustentado das exportações do açúcar brasileiro na década de 1990, que podem ser de origem externa e interna. Segundo esse autor, a principal razão externa pode ser o fim do acordo bilateral URSS-Cuba, que possibilitou ao Brasil ocupar o lugar de Cuba no comércio de açúcar com os países da antiga União Soviética (URSS). A crescente participação das exportações originadas no Estado de São Paulo, ocasionadas a partir do processo de desregulamentação, seria a principal razão interna para o aumento das exportações brasileiras. Assim, procurando comprovar essas hipóteses, Veiga Filho (2000) separou a década de 1990 em dois subperíodos, o primeiro abrangendo os anos de 1992 a 1995 e o segundo, de 1996 a 1999. O autor encontrou que o aumento das exportações brasileiras no segundo subperíodo, em relação ao primeiro, foi explicado em $14,13 \%$ pelo efeito tamanho de mercado, que mede o impacto da alteração no volume do comércio mundial em um determinado país exportador. A maior competitividade do país explicou $88,74 \%$ do aumento das exportações brasileiras na segunda metade da década de 1990. O autor conclui, conforme estabelecido a priori, que essa maior competitividade é fortemente derivada dos menores custos de produção, cuja média é de US\$ 190/t em São Paulo.

Resultado semelhante foi obtido por Burnquist \& Miranda (1999), que avaliaram as mudanças nas exportações brasileiras de açúcar do subperíodo de 1991/1994 para 1995/1997, utilizando um modelo de market-share constante. As autoras concluíram que: o efeito competitividade, interpretado como um indicador da habilidade apresentada pelo país em competir de forma efetiva com outras fontes de oferta, explicou uma porção expressiva das mudanças nas exportações entre os dois subperíodos; o crescimento do mercado global de açúcar, denominado como efeito tamanho de mercado, explicou $17 \%$ do aumento das exportações. 
Stalder (1997), analisando o market-share para o Brasil no período de 1979 a 1994, mostrou que o país vem crescendo em participação no mercado de açúcar, especificamente desde 1990, não só devido ao crescimento do mercado mundial, mas também ao incremento na sua competitividade. A autora verificou também que o perfil do mercado que importa do Brasil modificou-se ao longo do período analisado, indicando uma maior diversificação dos países de destino do açúcar. Entre os anos de 1990 e 1994, o Brasil perdeu participação no total importado pelo mercado sulamericano, com exceção dos países que constituem o Mercosul. Verificou-se uma tendência de redução na demanda de açúcar de países importadores tradicionais, ao mesmo tempo que a demanda nos mercados no Sudeste Asiático, Oriente Médio e África cresce.

Nesse trabalho, a autora encontrou indicações de que o Brasil não tem se apropriado da parcela que Cuba vem perdendo no mercado internacional. Os dados de market-share sugeriram que os países agrupados como "Resto do Mundo" são os prováveis beneficiários dessa perda, sobretudo a Austrália e a Tailândia, que apresentaram expansão nas exportações de açúcar nesse mesmo período.

A autora estimou também coeficientes de elasticidade de substituição entre o Brasil e outros exportadores mundiais. Encontrou-se que o açúcar exportado pelo Brasil apresentou certo grau de substituição pelo açúcar originado de outros países exportadores, em relação ao mercado importador mundial como um todo. É o caso, por exemplo, de Brasil e África do Sul, sugerindo um comportamento de competição via preços nesses mercados. Entretanto, em alguns casos houve indicações da existência de diferenciação do açúcar conforme a origem das exportações. As elasticidades de substituição estimadas para Brasil/Austrália e Brasil/Tailândia, no caso do açúcar refinado, sugerem a existência dessa diferenciação do mercado importador diante dos produtos exportados pelos dois países. A autora atribuiu essa diferenciação a fatores como: preferência do mercado importador, localização geográfica, relacionamentos históricos, acordos preferenciais, fatores institucionais ou facilidade de crédito, entre outros. 
Vários autores analisaram ainda equações de oferta e, ou, demanda por exportações brasileiras de açúcar (Bacchi et. al., 2002; Barros et. al., 2002; Carvalho, 1986; Reis \& Crespo, 1998), com o objetivo de obter elasticidades de demanda e de oferta do açúcar no mercado internacional.

Carvalho (1986) procurou estimar os coeficientes estruturais de oferta e demanda de exportação de açúcar, compreendendo o período de 1961 a 1984. O autor levou em consideração a simultaneidade existente entre quantidades exportadas e preços de exportação, bem como a possibilidade da ocorrência de desequilíbrio nesse mercado. No modelo de equilíbrio do mercado descrito pelas eq. (1) e (2), o logaritmo da quantidade demandada pelas exportações brasileira de açúcar ( $Q X D)$ foi descrito como função dos logaritmos: da razão dos preços de exportação do açúcar brasileiro pelo preço de exportação de produto competitivo $(P X / P W)$; da renda mundial $(R M)$ e da quantidade ofertada pelos outros países exportadores $(Q M)$. Do lado da oferta, o logaritmo do preço de exportação do açúcar brasileiro $(P X)$ foi descrito como função dos logaritmos: da quantidade ofertada $(Q X S)$; da razão da taxa de câmbio pelo índice de preços ao atacado $(T C / I P)$; da disponibilidade interna líquida de açúcar $(Q I)$ e da renda interna do Brasil $(R I)$.

$$
\begin{aligned}
& \ln Q X D=a_{0}+a_{1} \ln (P X / P W)+a_{2} \ln R M+a_{3} \ln Q M \\
& \ln P X=b_{0}+b_{1} \ln Q X S+b_{2} \ln (T C / I P)+b_{3} \ln Q I+b_{4} \ln R I
\end{aligned}
$$

Entretanto, o autor argumenta que o mercado de açúcar apresenta um moderado grau de incerteza, o que implicaria em rigidez no ajustamento de preços e quantidades, gerando possíveis desequilíbrios. Assim, novas equações de oferta e demanda por exportação foram construídas. À equação de demanda, acrescentou-se um termo que representa a quantidade de exportações defasada de um ano. Por sua vez, o preço de exportação ajusta-se ao excesso de oferta. Portanto, à equação de oferta, acrescentou-se um termo que representa o preço das exportações defasado de um ano. Nas equações representando o modelo de desequilíbrio pode-se também fazer distinção entre curto e longo prazos. 
Segundo o autor, os resultados obtidos com o modelo de desequilíbrio foram melhores, indicando que a demanda de exportação de açúcar a longo prazo é preçoinelástica, com valor igual a -0,153 (essa elasticidade era unitária no modelo de equilíbrio), e renda elástica de 2,883. A variável que mede a quantidade ofertada pelos outros países exportadores $(Q M)$ não foi incluída na estimação do modelo. Do lado da oferta, o autor encontrou que a mesma é preço-inelástica, com valor de 0,260 no longoprazo, e apresentou elasticidade unitária de longo-prazo em face das variações na disponibilidade interna de açúcar para exportação $(1,003)$. As variáveis razão da taxa de câmbio pelo índice de preços ao atacado $(T C / I P)$ e da renda interna do Brasil (RI) também não foram incluídas na estimação do modelo.

A partir dos valores de elasticidades-preço de demanda e de oferta, o autor procurou ainda avaliar o impacto de um programa de estabilização de preços sobre a estabilidade da receita cambial. Encontrou-se que ambos choques na oferta ou na demanda não afetam substancialmente o nível médio da receita de exportação e sua respectiva variância.

Reis \& Crespo (1998) utilizaram, de maneira semelhante, um modelo de equilíbrio simultâneo entre oferta e demanda de exportações para procurar explicar a dinâmica das exportações brasileiras de açúcar, compreendendo o período 1961 a 1994, incluindo assim dez anos a mais em relação à análise realizada por Carvalho (1986). O modelo teórico proposto pelos autores foi baseado num dos modelos empregados pelo Fundo Monetário Internacional (FMI) em estudos sobre demanda e oferta de exportações de commodities dos países em desenvolvimento, adaptado para o caso do açúcar brasileiro, conforme descrito nas eq. (3) e (4). Assim, os autores utilizaram como variáveis explicativas para a demanda: preço do açúcar brasileiro exportado $\left(P_{t}^{x}\right)$; preço do açúcar exportado pelo mundo, excluindo o Brasil $\left(P_{t}^{i}\right)$; somatório do produto interno bruto dos principais países importadores de açúcar brasileiro ( $\left.P I B_{t}^{a}\right)$; quantidade de açúcar exportada pelo continente americano, excluindo o Brasil e Cuba $\left(Q_{t}^{a}\right)$; preço das exportações mundiais de produtos substitutos do açúcar $\left(P_{t}^{0}\right)$. Para a equação de oferta, 
utilizaram as seguintes variáveis explicativas: preço do açúcar brasileiro exportado, contemporâneo e com uma defasagem $\left(P_{t}^{x}, P_{t-1}^{x}\right)$; preço interno de varejo do açúcar no Brasil, contemporâneo e com uma defasagem $\left(P_{t}^{b}, P_{t-1}^{b}\right)$; consumo aparente de açúcar no Brasil $\left(C A_{t}^{b}\right)$; taxa de câmbio real do Brasil ( $\left.T C R_{t}^{b}\right)$; estoque inicial de açúcar no mundo $\left(E_{t}\right)$.

$$
\begin{aligned}
& Q_{t}^{d}=f\left(P_{t}^{x} / P_{t}^{i}, P I B_{t}^{a}, Q_{t}^{a}, P_{t}^{0}\right) \\
& Q_{t}^{s}=f\left(P_{t}^{x} / P_{t}^{b}, P_{t-1}^{x} / P_{t-1}^{b}, C A_{t}^{b}, T C R_{t}^{b}, E_{t}\right)
\end{aligned}
$$

A Tabela 18 mostra os valores das elasticidades encontradas por esses autores, fazendo uma comparação com o trabalho anterior quando as variáveis são coincidentes.

Tabela 18. Elasticidades de oferta e demanda para as exportações brasileiras de açúcar encontrados em trabalhos enfocando os períodos de 1961-1984 e 1961-1994.

\begin{tabular}{lcc}
\hline & Carvalho (1986) & Reis \& Crespo (1998) \\
& $1961-1984$ & $1961-1994$ \\
\hline Demanda & $-0,153$ & $-0,322$ \\
Preço $\left(P X / P W\right.$ e $\left.P_{t}^{x} / P_{t}^{i}\right)$ & 2,883 & 1,457 \\
Renda mundial $\left(R M\right.$ e $\left.P I B_{t}^{a}\right)$ & - & 1,204 \\
Exportação de outros países $\left(Q_{t}^{a}\right)$ & - & $-0,065$ \\
$\quad$ Preço de substitutos do açúcar $\left(P_{t}^{0}\right)$ & & \\
Oferta & 0,260 & $0,221(t)$ e \\
Preço de exportação $(\mathrm{PX}$ e & & $0,196(t-1)$ \\
$\left.\quad P_{t}^{x} / P_{t}^{b}, P_{t-1}^{x} / P_{t-1}^{b}\right)$ & 1,003 & 0,921 \\
Disponibilidade interna ou Consumo & & -392 \\
aparente $\left(\mathrm{QI}\right.$ e $\left.C A_{t}^{b}\right)$ & - & 1,378 \\
Taxa de câmbio real $\left(T C R_{t}^{b}\right)$ & - & \\
Estoque mundial $\left(E_{t}\right)$ &
\end{tabular}

Fonte: Carvalho (1986); Reis \& Crespo (1998)

Entretanto, esses autores encontraram resultados não coerentes com o previsto. Do lado da demanda, o grau de substituição entre o açúcar do Brasil e o açúcar dos 
concorrentes $\left(Q_{t}^{a}\right)$ apresentou sinal contrário ao esperado. Os autores argumentaram que, no período estudado, o Brasil aproveitou-se de um mercado próprio, no qual não existiam fortes ameaças da concorrência, possivelmente em razão da importância e poder do país dentro do comércio mundial do produto.

Resultados não esperados do lado da oferta referem-se ao valor negativo da taxa de câmbio $\left(T C R_{t}^{b}\right)$ e ao valor positivo para estoque mundial $\left(E_{t}\right)$. Em relação à taxa de câmbio os autores argumentaram que:

"a relação inversa entre a taxa de câmbio real e as exportações de açúcar pode ser explicada porque o câmbio foi supervalorizado em épocas de melhores cotações internacionais do açúcar. Nesses anos, o efeito positivo dos melhores preços externos sobre as exportações foi superior ao efeito negativo do câmbio supervalorizado. Em épocas de baixas cotações internacionais, a situação foi inversa” (Reis \& Crespo, 1998, p.29).

E em relação ao valor não previsto da elasticidade da oferta para o estoque mundial, segundo os autores, essa relação pode se apresentar de duas formas:

"tradicionalmente os estoques iniciais em cada ano açucareiro afetam negativamente os preços internacionais, pois são um reflexo do excesso de oferta nos países produtores. Pode ser verificado que, desde 1961, para cada ciclo de preços existe um ciclo inverso de estoques mundiais relativos (estoque/produção) mundiais. Por outra parte, grandes volumes estocados sem uso imediato podem induzir um país produtor a aumentar a oferta exportável, ainda que em anos de preços baixos, caso o custo de armazenagem seja superior ao custo incorrido por exportar a preços baixos em relação a um nível inicial" (Reis \& Crespo, 1998, p.30).

Assim, os autores concluem que esta última relação foi predominante no Brasil para o período estudado. 
As diferenças nos resultados encontrados pelos dois autores, apesar de ambos utilizarem uma grande parte do período coincidente, podem ser atribuídas a diferenças nos modelos utilizados e no cálculo de algumas das variáveis utilizadas. Carvalho utilizou menor número de variáveis explicativas em ambas as equações de demanda e oferta, em comparação aos modelos de Reis \& Crespo, mas, por outro lado, este autor incluiu a variável dependente defasada naquelas equações, o que não foi feito por aqueles autores.

De maneira geral, uma restrição a estes dois estudos refere-se aos períodos de tempo considerados, de 1961 a 1984 ou a 1994, uma vez que, nestes períodos, tanto preços, como produção e comercialização dos produtos do setor sucroalcooleiro se encontravam regulamentados pelo governo e, portanto, não poderiam refletir plenamente as condições lógicas que se encontrariam em livre mercado.

Utilizando então um período após a desregulamentação do setor sucroalcooleiro e das exportações brasileiras de açúcar (de janeiro de 1995 a dezembro de 2000), Barros et. al. (2002) desenvolveram um modelo teórico ajustado para os diferentes produtos, no qual a equação de oferta de exportação é derivada das funções de oferta e demanda internas. No modelo elaborado (eq. 5), a quantidade exportada $(Q X)$ foi função: do preço interno do produto $(P D)$; do nível de renda do Brasil $(Y)$; da taxa de câmbio efetiva $(T C)$ e do preço recebido pelas exportações $(P E)$.

$$
Q X=h(P E, T C, P D, W, Y)
$$

onde $W$ representa deslocadores da oferta doméstica.

Entre os produtos analisados pelos autores, o açúcar e a soja foram os produtos mais influenciados pela taxa de câmbio (elasticidade igual a 2,8 para o açúcar) e pelo preço externo (elasticidade igual a 2,5 para o açúcar). Por outro lado, um aumento de $1 \%$ no preço doméstico do açúcar reduz as exportações do produto em 2,9\%, ceteris paribus. Os autores concluíram que os preços domésticos tendem a refletir o desempenho da produção brasileira em face da demanda interna, e que as exportações de açúcar são as mais sensíveis ao comportamento do mercado interno. 
Bacchi et. al. (2002), utilizando a mesma função descrita por Barros et. al. (2002), estimaram uma função de oferta de exportação brasileira de açúcar utilizando a metodologia de Auto-Regressão Vetorial (VAR). Assim, o modelo da função de exportação foi definido considerando-se que o quantum exportado do produto depende dos excedentes do mercado doméstico (eq. 5). Os autores concluíram que a função de exportação dada pela diferença da oferta e demanda doméstica apresentou-se adequada para a análise, mostrando que nossas exportações podem ser consideradas como o excedente do volume requerido no mercado interno. Os resultados mostram que o aumento do preço de exportação e a desvalorização da moeda nacional causam significativo aumento das exportações; e que um aumento do preço doméstico ou da renda interna tem reflexo negativo sobre o quantum exportado. Os autores descrevem, também, que seria importante a introdução do preço do álcool no modelo ajustado para a análise das exportações de açúcar, o que não foi feito em função da indisponibilidade desses dados para a maior parte do período de abrangência do estudo, pois os preços foram tabelados até janeiro de 1999 para álcool hidratado.

Portanto, os resultados de Bacchi et. al. (2002) foram consistentes com os obtidos por Barros et. al. (2002), realizados para períodos aproximadamente coincidentes. Entretanto, em ambos os estudos, não foi considerada a influência da demanda internacional do produto brasileiro sobre o preço e a quantidade exportada. 


\section{METODOLOGIA}

O procedimento utilizado neste estudo consistiu na separação de duas etapas metodológicas. Primeiro, identificaram-se modelos econômicos para descrever: (i) o efeito da quota tarifária e do suporte interno de preços, em um dado país importador, sobre o volume e preço das exportações (brasileiras) para este país; (ii) o impacto do subsídio sobre exportações que concorrem com as exportações (brasileiras) no mercado mundial, sobre o volume das exportações (brasileiras) para os mercados importadores comuns. Esses instrumentos políticos foram identificados como as principais medidas adotadas nos EUA e na UE, como forma de isolar o mercado doméstico desses países. Conforme descrito no Quadro 1, tanto EUA quanto UE utilizam as medidas protecionistas descritas em (i). Mas, apenas a UE possui exportações subsidiadas, como descrito no instrumento (ii). Posteriormente, foram descritos os procedimentos econométricos e fonte de dados utilizados para estimação dos modelos necessários para a análise. A segunda etapa consistiu na demonstração dos modelos utilizados para analisar o nível de importância do setor de indústria de açúcar em relação à economia das duas regiões exportadoras (Centro-Sul e Norte-Nordeste) e os impactos que poderiam ser causados na economia brasileira em decorrência dos resultados obtidos na primeira etapa.

\subsection{Impactos dos instrumentos de política protecionista dos países desenvolvidos sobre as exportações brasileiras de açúcar}

Neste item, inicialmente demonstraram-se, de forma algébrica, os modelos adotados para a análise. Os procedimentos econométricos e os dados a serem utilizados foram descritos a seguir. 


\subsubsection{Modelos econômicos propostos}

Gardner (1987) descreveu modelos econômicos utilizados para a estimação de efeitos de mudanças em políticas econômicas sobre a comercialização de commodities. Segundo este autor, as intervenções políticas que visam aumentar a renda dos produtores, geralmente, são efetivadas por aumento de receitas ou redução de custos. $\mathrm{O}$ autor utilizou modelos teóricos para mostrar os efeitos de diferentes políticas aplicadas a mercado de commodities com esses objetivos. No contexto do comércio internacional de commodities, Gardner (1987) elaborou modelos matemáticos contemplando os efeitos de instrumentos de política comercial, tais como subsídios aos produtores, aos consumidores e tarifas de importação.

Neste item, apresenta-se uma adequação dos modelos de Gardner (1987) para estimar os impactos de mudanças em políticas do açúcar nos países que exercem efeitos protecionistas neste mercado.

A identificação de modelos de demanda e de oferta dos mercados considerados neste trabalho é necessária, a princípio, para a composição dos parâmetros definidos nos modelos descritos por Gardner (1987). Estes modelos são apresentados no presente trabalho, posteriormente aos modelos de Gardner (1987).

\subsubsection{Modelo econômico proposto para avaliar efeitos de redução em quotas tarifárias e suporte interno de preço para países importadores}

Para analisar os efeitos de reduções nos níveis tarifários de países importadores

relevantes no comércio internacional, Gardner (1987) parte de pressupostos básicos de oferta e de demanda, tais como:

$$
\begin{aligned}
& Q_{S}=S\left(P_{S}\right), S^{\prime}>0 \\
& Q_{d}=D\left(P_{d}\right), D^{\prime}<0
\end{aligned}
$$


onde $Q_{S}$ é a quantidade ofertada pelo país exportador, $Q_{d}$ é a quantidade demandada do país importador, e $P$ é o nível de preço, demandado ou ofertado, conforme o subscrito $d$ ou $s$, respectivamente.

Considerando que o preço interno prevalecente em um país $i$ qualquer, é determinado aplicando-se uma tarifa sobre o preço de oferta do mercado (ou país) exportador, pode-se escrever as equações anteriores da seguinte maneira:

$$
\begin{aligned}
& P_{S}=B Q_{S}^{1 / \theta} \\
& P_{S}+T=A Q_{d}^{1 / \eta_{i}}
\end{aligned}
$$

onde os consumidores do país $i$ pagam o preço de mercado internacional mais uma taxa tarifária, $T$. As variáveis $A$ e $B$ são as constantes do modelo; e $Q_{S}^{1 / \theta}$ e $Q_{d}^{1 / \eta_{i}}$ são as funções inversas de oferta e de demanda respectivamente, em que $\theta$ representa a elasticidade-preço de oferta, comum para todos os países demandantes; e $\eta_{i}$ é a elasticidade-preço de demanda para o país $i$. Espera-se que a quantidade ofertada seja positivamente relacionada com o preço $(\theta>0)$, e a elasticidade-preço de demanda tenha sinal negativo $\left(\eta_{i}<0\right)$. Ou seja, espera-se uma relação inversa entre a variação no nível de preço e no volume importado pelo país $i^{20}$.

Aplicando logaritmo e diferenciando todos os termos das eq. (8) e (9), tem-se que:

$$
\begin{aligned}
& d \ln P=\frac{1}{\theta} d \ln Q \\
& d \ln P=\frac{1}{\eta_{i}} d \ln Q-d \ln T
\end{aligned}
$$

Igualando as eq. (10) e (11), obtém-se:

\footnotetext{
${ }^{20}$ Considerando-se, portanto, que o país é grande importador, segundo o conceito utilizado pela economia internacional.
} 


$$
\begin{aligned}
& \frac{1}{\theta} d \ln Q=\frac{1}{\eta_{i}} d \ln Q-d \ln T \\
& {\left[\frac{1}{\theta}-\frac{1}{\eta_{i}}\right] \frac{d \ln Q}{d \ln T}=-1} \\
& \frac{d \ln Q}{d \ln T}=\frac{-1}{1 / \theta-1 / \eta_{i}}
\end{aligned}
$$

A eq. (12) descreve o efeito final sobre o volume total exportado para o país $i$ quando ocorre um choque no nível tarifário (ad valorem) desse país. Partindo das hipóteses previamente estabelecidas para as elasticidades-preço de oferta e de demanda $\left(\theta>0\right.$ e $\left.\eta_{i}<0\right)$, espera-se que a elasticidade definida pela eq. (12) apresente sinal negativo. Neste caso, uma redução no nível tarifário do país $i$ provoca um aumento da quantidade importada por este país.

Para mensurar o grau de proteção da tarifa, deve-se identificá-la como porcentagem do preço que prevaleceria com livre comércio. Esta quantificação pode ser feita de forma direta estimando a tarifa ad valorem.

Para identificar o efeito sobre o preço de oferta $\left(P_{S}\right)$, divide-se a eq. (10), ou a eq. (11), por $d \ln T$ e substitui na eq. (12), da seguinte maneira:

$$
\begin{aligned}
& \frac{d \ln P}{d \ln T} \theta=\frac{d \ln Q}{d \ln T} \\
& \frac{d \ln P}{d \ln T} \theta=\frac{-1}{1 / \theta-1 / \eta_{i}} \\
& \frac{d \ln P}{d \ln T}=\frac{-1 / \theta}{1 / \theta-1 / \eta_{i}}
\end{aligned}
$$

Multiplicando (13) por $\theta / \theta$, tem-se:

$$
\frac{d \ln P}{d \ln T}=\frac{-1}{1-\theta / \eta_{i}}
$$


Onde a eq. (14) expressa o efeito da uma variação no nível de tarifa do país $i$ sobre o preço de oferta da commodity considerada para aquele país. Esse efeito será negativo considerando a hipótese de que $\theta>0$ e $\eta_{i}<0$. Isto implica que uma redução no nível tarifário aumenta o preço de exportação do país. Verifica-se também que, quanto maior o valor absoluto da elasticidade-preço da oferta em relação à elasticidade-preço da demanda $\left(|\theta|>\left|\eta_{i}\right|\right)$, tanto menor será o efeito da redução tarifária sobre o preço de importação. Isto significa que o país exportador tenderá a aumentar sua oferta para o país $i$, de maneira a assegurar que o efeito sobre o preço seja desprezível.

A análise do efeito de uma tarifa quantificada na forma ad valorem pode ser estendida para a análise de outras políticas protecionistas do mercado que têm como efeito final o aumento do preço de importação. Desta maneira, essa análise pode ser aplicada também para o caso de remoção simultânea das quotas tarifárias de importação de açúcar e da política de suporte de preço doméstico de açúcar nos países desenvolvidos. A Figura 17 mostra o efeito da remoção simultânea desses dois instrumentos de política comercial quando aplicados ao mercado doméstico de açúcar do país importador.

Tem-se o mercado importador no Gráfico 1 da Figura 17, e o mercado exportador, representando especificamente o caso brasileiro (para isto, foi utilizada a elasticidade de demanda de Armington (1969), que diferencia o mercado importador considerado), no Gráfico 2.

O Gráfico 2 da Figura 17 pode ser interpretado como o efeito de uma redução tarifária, onde o importador pagou $\mathrm{P}_{1}$, e o exportador recebeu $\mathrm{P}_{\mathrm{W}}$, obedecendo assim às pressuposições adotadas por Gardner (1987). Entretanto, as políticas comumente adotadas para o mercado de açúcar nos países desenvolvidos são uma combinação de altos preços domésticos, sustentados por uma política que garante um preço mínimo aos produtores $\left(\mathrm{P}_{\mathrm{S}}\right)$, e a presença de quotas tarifárias impostas à importação $\left(\mathrm{Q}_{\mathrm{TRQ}}\right)$. Essas duas políticas combinadas resultam em um efeito semelhante àquele descrito quanto à presença de tarifa. A tarificação ad valorem do efeito de suporte de preço, combinada 
com a eliminação da quota tarifária, foi estimada visando a quantificação de uma redução dessas políticas sobre as exportações brasileiras para os mercados considerados.

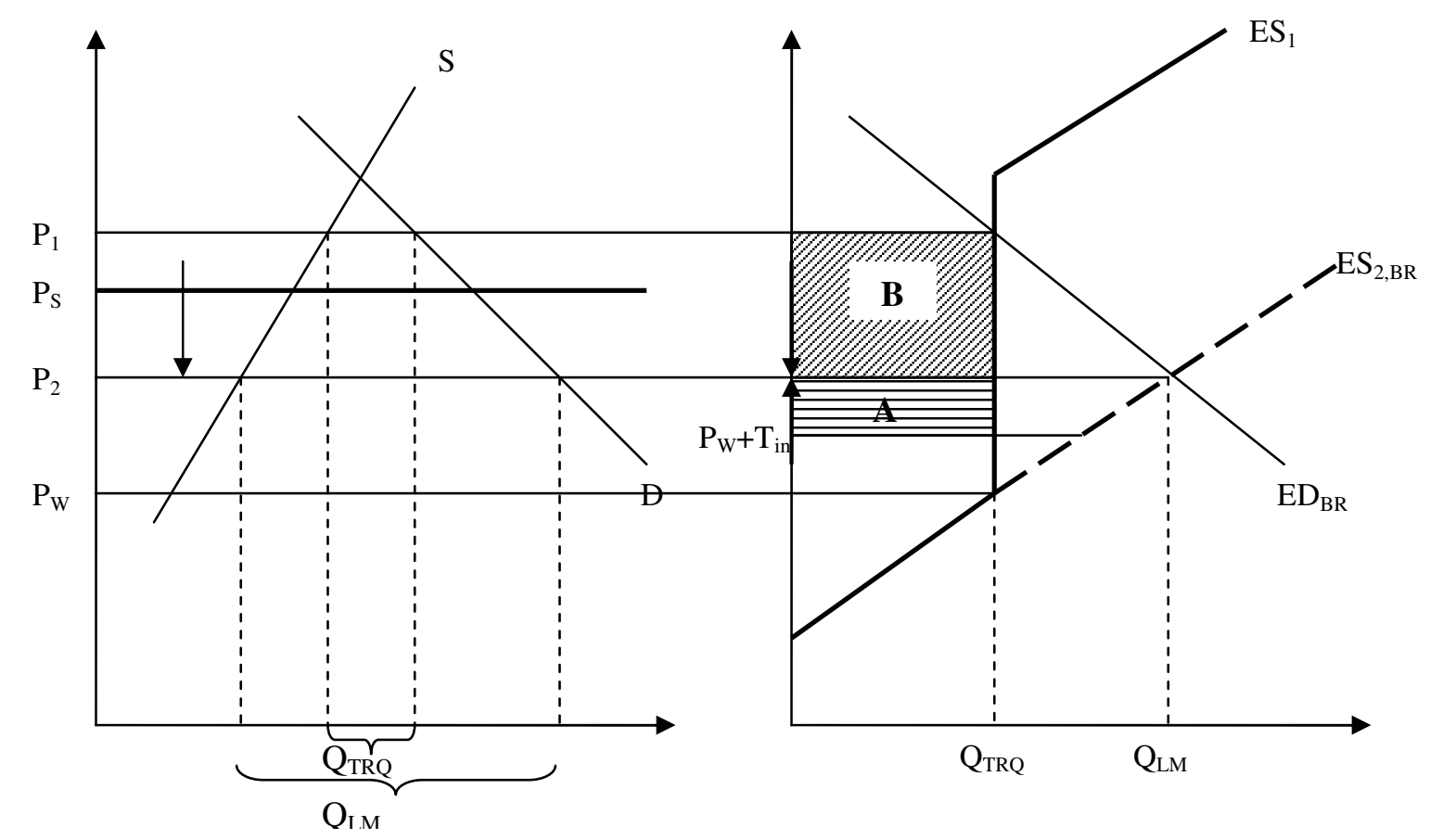

(Gráfico 1) Mercado doméstico de açúcar do importador.

(Gráfico 2) Mercado exportador de açúcar do Brasil.

Figura 17 - Efeitos de remoção de quota tarifária e do programa de suporte de preço sobre preço e quantidade de açúcar comercializado com o Brasil.

Fonte: Beghin et. al. (2003)

Como pode ser verificado no Gráfico 2 da Figura 17, nos mercados importadores que adotam as políticas protecionistas mencionadas, apesar dos importadores pagarem uma tarifa dentro da quota de importação estabelecida, o preço recebido no mercado doméstico pelo mesmo produto é maior, proporcionando um ganho em relação àquela importação. Este ganho é definido como o rent do importador.

O objetivo das eq. (12) e (14) descritas anteriormente é estimar os efeitos de uma mudança no nível das tarifas de países importadores sobre preço e volume 
exportado. Para o presente trabalho, as equações serão aplicadas para captar o efeito de mudanças no nível de tarifa dos EUA e da UE sobre o preço e volume exportado pelo Brasil.

\subsubsection{Modelo econômico proposto para avaliar efeitos de redução em subsídios para exportação}

Gardner (1987) descreveu um modelo cujos princípios básicos são semelhantes àqueles descritos para o modelo de estimação de redução tarifária, porém enfocando o caso de um preço mais elevado recebido pelo lado da oferta. Neste caso, os produtores são estimulados a aumentar sua produção e, conseqüentemente, podem aumentar também o excedente exportável, caso exista.

Como no caso da análise do equivalente tarifário (ad valorem) que afeta as importações do país, o subsídio às exportações pode ser calculado como um equivalente ad valorem em relação ao preço das exportações do país que subsidia.

Para analisar os efeitos de reduções no nível de subsídio sobre as exportações de um país relevante no comércio internacional, Gardner (1987) partiu dos mesmos pressupostos básicos de oferta e de demanda, descritos pelas eq. (6) e (7). Entretanto, considera que o preço de oferta do país exportador se altera, como resultado de um nível de subsídio aplicado sobre o preço demandado pelos importadores. Para representar esse contexto analítico, definem-se as seguintes equações de oferta e de demanda:

$$
\begin{aligned}
& P_{D}+S=B Q_{S}^{1 / \theta} \\
& P_{D}=A Q_{D}^{1 / \eta_{i}}
\end{aligned}
$$

onde os consumidores do país $i$ pagam o preço de mercado, e os produtores esperam receber o preço de mercado mais um subsídio, $S$. As variáveis $A$ e $B$ são as constantes do modelo; e $Q_{S}^{1 / \theta}$ e $Q_{d}^{1 / \eta_{i}}$ são as funções inversas de oferta e de demanda, respectivamente, em que $\theta$ representa a elasticidade-preço de oferta, comum para todos os países 
demandantes; e $\eta_{i}$ é a elasticidade-preço de demanda para o país $i$. Espera-se que a quantidade ofertada seja positivamente relacionada com o preço $(\theta>0)$, e a elasticidadepreço de demanda tenha sinal negativo $\left(\eta_{i}<0\right)$, ou seja, espera-se uma relação inversa entre a variação no nível de preço de demanda e o volume importado pelo país $i$.

Aplicando logaritmo e diferenciando todos os termos das eq. (15) e (16), tem-se que:

$$
\begin{aligned}
& d \ln P=\frac{1}{\theta} d \ln Q-d \ln S \\
& d \ln P=\frac{1}{\eta_{i}} d \ln Q
\end{aligned}
$$

Igualando as eq. (17) e (18):

$$
\begin{aligned}
& \frac{1}{\eta_{i}} d \ln Q=\frac{1}{\theta} d \ln Q-d \ln S \\
& {\left[\frac{1}{\eta_{i}}-\frac{1}{\theta}\right] \frac{d \ln Q}{d \ln S}=-1} \\
& \frac{d \ln Q}{d \ln S}=\frac{-1}{1 / \eta_{i}-1 / \theta}
\end{aligned}
$$

Onde a eq. (19) descreve o efeito final sobre o volume exportado para o país $i$ quando ocorre uma variação no nível do subsídio (ad valorem) no país exportador. Partindo das hipóteses previamente estabelecidas para as elasticidades-preço de oferta e de demanda ( $\theta>0$ e $\left.\eta_{i}<0\right)$, espera-se que a elasticidade definida pela eq. (19) apresente sinal positivo. Neste caso, uma redução no nível de subsídio do país exportador provoca uma redução da quantidade comercializada com o país importador.

Para identificar o efeito sobre o preço de demanda $\left(P_{D}\right)$, divide-se a eq. (17), ou a eq. (18), por $d \ln S$ e substitui na eq. (19), da seguinte maneira: 


$$
\begin{aligned}
& \frac{d \ln P}{d \ln S} \eta_{i}=\frac{d \ln Q}{d \ln S} \\
& \frac{d \ln P}{d \ln S} \eta_{i}=\frac{-1}{1 / \eta_{i}-1 / \theta} \\
& \frac{d \ln P}{d \ln S}=\frac{-1 / \eta_{i}}{1 / \eta_{i}-1 / \theta}
\end{aligned}
$$

Multiplicando (20) por $\eta_{i} / \eta_{i}$ :

$$
\frac{d \ln P}{d \ln S}=\frac{-1}{1-\eta_{i} / \theta}
$$

Onde a eq. (21) expressa o efeito da uma variação no nível de subsídio do país exportador sobre o preço de oferta da commodity considerada naquele país. Esse efeito será negativo considerando a hipótese de que $\theta>0$ e $\eta_{i}<0$. Isto implica que uma redução no subsídio aumenta o preço de exportação. Se o valor absoluto da elasticidade-preço da oferta for maior do que o da elasticidade-preço da demanda $\left(|\theta|>\left|\eta_{i}\right|\right)$, maior será o efeito da redução do subsídio sobre o preço.

O Gráfico 1 da Figura 18 representa o mercado doméstico do país exportador; e o Gráfico 2 desta figura representa o mercado das exportações de açúcar da UE. A UE pratica, internamente, o nível de preço $\mathrm{P}_{\mathrm{d}}$ descrito na Figura 18. Entretanto, o excedente da produção doméstica é exportado, extra-bloco, no nível do preço mundial $\left(\mathrm{P}_{\mathrm{W}}\right)$. Os altos preços domésticos suportados para os produtores foram considerados como subsídio cruzado para as exportações do açúcar extra-bloco.

A Figura 18 ilustra como o efeito de redução no subsídio cruzado à exportação da União Européia pode afetar o preço e a quantidade exportada do bloco, em função da demanda dos importadores deste mercado.

Conforme mostrado na Figura 18, a adoção de políticas que concedem subsídios aos produtores cria distorções na produção. A principal consequiência é que o produtor toma a sua decisão de produzir a partir dos subsídios oferecidos pelas quotas A 
e B. Com isso, o volume de produção não corresponderá aos níveis de demanda, gerando um excedente que provoca distorções no funcionamento do mercado, afetando também o mercado internacional. $\mathrm{O}$ excedente de oferta de açúcar no mercado europeu é ofertado no mercado mundial, ao nível de preço $\mathrm{P}_{\mathrm{W}}$, suportados pelo subsídio cruzado oferecido pelas quotas A e B.

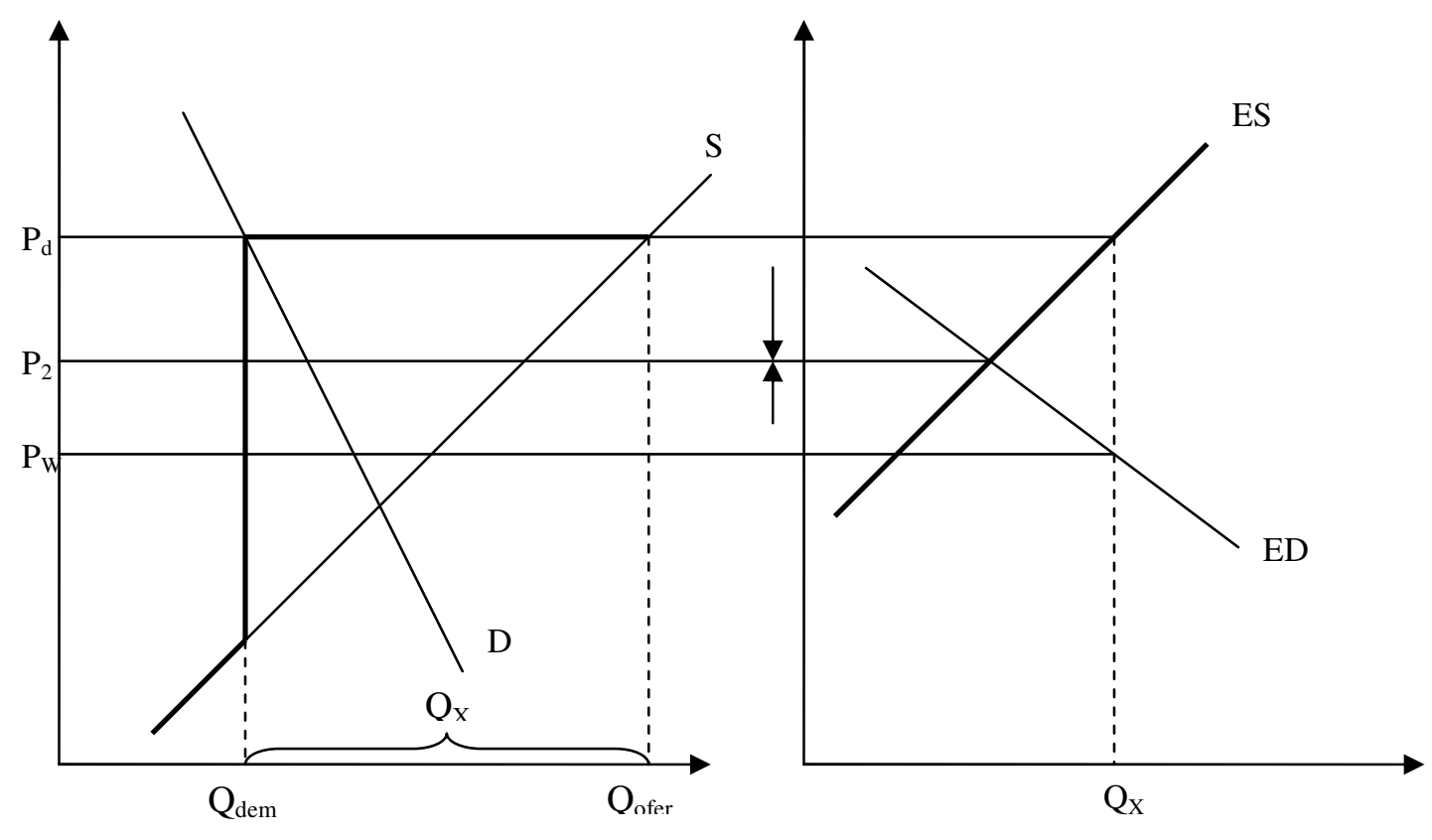

(Gráfico 1) Mercado doméstico da União Européia.

(Gráfico 2) Mercado exportador de açúcar da UE.

Figura 18 - Efeitos de redução de subsídio às exportações de açúcar da União Européia sobre preço e quantidade de açúcar exportado pelo bloco.

Neste estudo, o interesse foi estimar o efeito de redução no subsídio sobre o preço de exportação do país que subsidia, ou seja, o valor da elasticidade descrita na eq. (21). Isto se justifica porque o aumento das exportações brasileiras, em função de redução no subsídio de outros países exportadores, é estimado via efeito preço cruzado da demanda dos importadores. 
O modelo utilizado para estimar as elasticidades-preço de demanda foi o modelo de Armington (1969). Para estimar a elasticidade-preço de oferta do Brasil e dos países que subsidiam, foi utilizado um modelo com base nas características dos mercados exportadores considerados. Partiu-se de um modelo que considera o excedente de consumo doméstico para explicar as exportações de açúcar do Brasil e da União Européia.

\subsubsection{Modelo de demanda de Armington (1969)}

Para estimar os modelos descritos anteriormente (itens 3.1.1.1 e 3.1.1.2), foi necessário estimar elasticidades de oferta e de demanda para alguns mercados de interesse neste estudo. Neste item foi especificado o modelo utilizado para estimar as elasticidades-preço e preço cruzado da demanda de um país importador.

O modelo de demanda de Armington (1969) parte da hipótese de que os bens são diferenciáveis. Neste caso, os bens são chamados heterogêneos (ou substitutos imperfeitos), o que significa que seus compradores estão dispostos a pagar diferentes preços para obter a mesma quantidade de bens, originados de diferentes vendedores. Assim, são possíveis movimentos de preços independentes entre ofertantes. Outra implicação da heterogeneidade é que cada ator no mercado pode ser tanto comprador como vendedor ao mesmo tempo. As barreiras comerciais adotadas em alguns países, e incidentes de maneira diferenciada entre os países ofertantes, podem ser interpretadas como um instrumento para diferenciar os bens.

Assim, baseado na pressuposição de que os consumidores internacionais vêem os mesmos bens originados em países diferentes como diferentes tipos de produtos, Armington (1969) desenvolveu os fundamentos da chamada "teoria da demanda por produtos distinguidos por país de origem", que será utilizada no presente trabalho.

O modelo proposto por Armington (1969) tem as seguintes pressuposições:

- Existe separabilidade fraca entre os bens; 
- As elasticidades de substituição de importação para pares de produtos são constantes;

- A elasticidade de substituição é a mesma para cada par de produtos dentro de um mercado particular.

A demonstração algébrica deste modelo se encontra no Anexo deste trabalho. Armington (1969) demonstra que, para estimar as elasticidades-preço de demanda para um dado país (i) em relação a seus ofertantes, é necessário, inicialmente, a estimação de dois valores de elasticidades: a elasticidade-preço de substituição para o produto demandado e a elasticidade-preço da demanda total pelo produto no país considerado.

A elasticidade de substituição para o produto demandado pode ser estimada da seguinte maneira:

$$
\frac{M_{i j}}{M_{i}}=b_{i j}{ }_{i}\left(\frac{P_{i j}}{P_{i}}\right)^{-\sigma_{i}}
$$

onde $\sigma_{i}$ é a elasticidade de substituição de importação do país $i ; M_{i j}$ e $P_{i j}$ são, respectivamente, o volume e o preço de importação originada de um país $j$ qualquer para o país $i$, do produto considerado; e $M_{i}$ e $P_{i}$ são, respectivamente, o volume e o preço de importação total do produto pelo país i.

Aplicando logaritmo na eq. (22) tem-se o valor da elasticidade de substituição obtido diretamente pelo coeficiente da razão dos preços $P_{i j} / P_{i}$.

A elasticidade-preço de demanda total do país $i$ pode ser estimada como:

$$
\frac{d M_{i}}{M_{i}}=\varepsilon_{i} \frac{d D}{D}-\omega_{i} \frac{d P_{i}}{P_{i}}
$$

em que $\varepsilon_{i}=\frac{\partial X_{i}}{\partial D} \frac{D}{X_{i}}$ e $\omega_{i}=\frac{\partial X_{i}}{\partial P_{i}} \frac{P_{i}}{X_{i}}$ correspondem, respectivamente, às elasticidadesrenda e preço da demanda. 
Deve-se levar também em conta que todos os preços são representados em moeda estrangeira. Assim, a demanda de cada país depende também da sua taxa de câmbio, a qual deve ser incluída na eq. (23) descrita anteriormente. Dessa maneira, a equação a ser estimada será:

$$
\frac{d M_{i}}{M_{i}}=\varepsilon_{i} \frac{d D}{D}-\omega_{i} \frac{d P_{i}}{P_{i}}+\phi \frac{d t c_{i}}{t c_{i}}
$$

em que $\phi$ indica quanto as importações do país $i$ são influenciadas pela sua própria taxa de câmbio.

Utilizando os valores de elasticidades de substituição $\left(\sigma_{i}\right)$ e de preço $\left(\omega_{i}\right)$ estimados nas eq. (22) e (24), respectivamente, juntamente com a participação do valor importado do país $j$ em relação ao valor das importações totais do país demandante $(i)$, para um dado produto, $\left(S_{i j}\right)$, a teoria de Armington (1969) mostra que a elasticidadepreço direta da demanda pela importação originada do país $j$, no país $i\left(\eta_{i j}\right)$, pode ser obtida da seguinte maneira:

$$
\eta_{i j}=-\left\lfloor\left(1-S_{i j}\right) \sigma_{i}+\omega_{i} S_{i j}\right\rfloor
$$

E a elasticidade-preço cruzada da demanda pela importação originada do país $j$, em relação ao preço do produto do país $k$, no país $i$, é descrita como:

$$
\eta_{i k}=\sum_{k \neq j}\left[S_{i k} \sigma_{i}-S_{i k} \omega_{i}\right]
$$

em que $k$ é outro país ofertante do produto considerado para o país $i$.

A elasticidade-preço direta da demanda para alguns dos principais países importadores do açúcar brasileiro é a variável de interesse para estimar as eq. (12) e (14) no modelo descrito no item 3.1.1.1, e as eq. (19) e (21) no modelo descrito no item 3.1.1.2.

A elasticidade-preço cruzada da demanda foi utilizada numa etapa posterior à estimação do modelo descrito em 3.1.1.2, para estimar o aumento das exportações 
brasileiras resultante do efeito de aumento do preço do exportador, considerando-se que este reduziu o nível de subsídio. O efeito de redução de subsídios que promovem exportações competitivas no mercado mundial, sobre o preço dessas exportações, foi inicialmente estimado no item 3.1.1.2. Para estimar o impacto sobre as exportações brasileiras, foram tomados os valores estimados para as elasticidades-preço cruzada das importações brasileiras em relação ao preço do país que subsidia. Além disso, consideraram-se os países que importam tanto do mercado que subsidia, quanto do mercado brasileiro.

\subsubsection{Modelo de oferta de exportação para o açúcar}

A estimação dos modelos descritos nos itens 3.1.1.1 e 3.1.1.2 requer o conhecimento de duas elasticidades-preços de oferta para conduzir a análise proposta neste trabalho:

(i) uma referente ao mercado brasileiro, onde a oferta de exportação é definida fundamentalmente para o açúcar bruto; e

(ii) para o mercado da União Européia, pressupondo-se que este subsidia suas exportações.

Esses dois mercados diferem em diversos aspectos, porém a distinção entre a forma como é estruturada a produção e a geração de excedentes exportáveis é de fundamental importância na presente análise. Em função das características diferenciadas desses dois mercados exportadores, são identificados, a seguir, modelos de oferta das exportações, também diferenciados para os mercados considerados.

\subsection{Modelo de oferta das exportações brasileiras de açúcar bruto}

O modelo descrito para a oferta das exportações brasileiras de açúcar descrito em Bacchi et. al. (2002) e Barros et. al. (2002) consideraram o quantum exportado como sendo o excedente de consumo doméstico. Entretanto, como a função de exportação 
deste trabalho foi descrita para as exportações de açúcar bruto, que não é consumido diretamente pela população, a função de exportação foi elaborada considerando as variáveis deslocadoras dessa exportação, e não o excedente de consumo doméstico.

O modelo foi elaborado especificamente para as exportações de açúcar bruto, considerando os fatores deslocadores destas exportações. A Figura 19 apresenta como os possíveis deslocadores dessa exportação. O açúcar bruto pode ser exportado diretamente, na proporção de $(1-z)$ do total de açúcar bruto produzido internamente, ou pode ser refinado (proporção $z$, onde $1>z>0$ ), seja para uso no mercado doméstico (onde do total refinado, $t$, onde $1>t>0$, será consumido domesticamente) ou para a exportação (1- $t$, do total de açúcar refinado). Os fatores que influenciam a oferta doméstica de açúcar bruto também podem ser considerados como deslocadores desta exportação, uma vez que, quanto mais açúcar for produzido domesticamente, mais açúcar bruto poderá ser exportado.

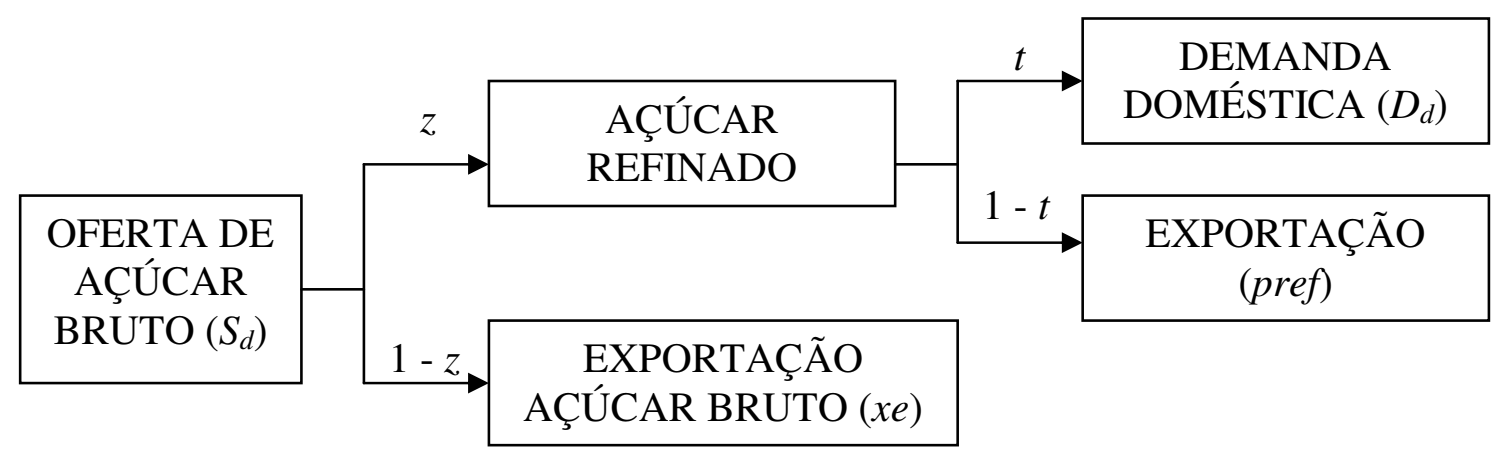

Figura 19 - Fluxograma de destino do açúcar bruto produzido no mercado brasileiro.

Nota: $z$ representa a proporção do açúcar bruto produzido domesticamente que é refinado, sendo $1>z>0$; e $t$ é a proporção do açúcar refinado que é demandado no mercado doméstico, onde $1>t>0$.

É importante considerar que, apesar do Brasil estar assumindo, progressivamente, a posição de grande país exportador de açúcar no mercado internacional, o país encontrou-se em um período de transição no período tomada para as análises. Desta maneira, não foi considerada uma demanda internacional negativamente inclinada pelo produto brasileiro, como definido para uma função de 
exportação característica de um país grande no comércio internacional. Mais especificamente, considerou-se que o volume exportado pelo país, durante o período considerado, não foi suficientemente elevado para alterar os preços no mercado internacional, quando altera suas vendas.

Pressupõe-se que a demanda pelo açúcar refinado no mercado doméstico pode deslocar a oferta de exportação de açúcar bruto. Sendo $\ln D_{d}$ o logaritmo da demanda doméstica de açúcar refinado, a função de demanda doméstica pode ser definida, representando-se as variáveis transformadas em seu valor logaritmo, como:

$$
\ln D_{d}=\alpha_{1}-\alpha_{2} \ln p d+\alpha_{3} \ln Y
$$

em que $p d$ é o preço doméstico do açúcar refinado; e $Y$ um deslocador da demanda, considerado, por exemplo, como a renda doméstica. Espera-se que o aumento no preço doméstico reduza a demanda pelo produto, e vice-versa; e que um aumento da renda aumente a demanda.

Para indicar a influência da oferta de açúcar refinado para exportação como deslocadora da oferta de exportação de açúcar bruto, pressupõe-se que a arbitragem entre os preços internacionais de açúcar bruto e de açúcar refinado determina quando o produto é exportado na sua forma bruta (quando preço de exportação do açúcar bruto $p x>$ preço de exportação de açúcar refinado - pref), ou quando é ofertado no mercado internacional na forma de refinado (quando $p x<$ pref).

Por último, afetando de maneira positiva a exportação de açúcar bruto, tem-se os fatores formadores da oferta do açúcar bruto, no mercado doméstico. A função que descreve a oferta de açúcar bruto no mercado doméstico $\left(S_{d}\right)$ é descrita na eq. (28):

$$
\ln S_{d}=\varphi_{0}+\varphi_{1} \ln p d+\varphi_{2} \ln p x-\varphi_{3} \ln W
$$

em que $p d$ é o preço doméstico do açúcar refinado. Foi utilizado o preço doméstico do açúcar refinado e não do açúcar bruto, porque não há dados disponíveis em relação a este último. A exportação de açúcar bruto, por ser outro caminho para o açúcar bruto produzido domesticamente, também influencia na sua produção. Assim, o preço de 
exportação de açúcar bruto ( $p x)$ é outra variável que influencia positivamente a produção de açúcar bruto. $W$ é um deslocador da oferta, sendo que dentre os principais deslocadores da produção de açúcar, tem-se a produção de álcool combustível.

Voltando as relações descritas na Figura 19, tem-se uma relação negativa entre o volume de açúcar bruto exportado ( $x e$ ) com a demanda doméstica de açúcar refinado $\left(D_{d}\right)$ e com o preço de exportação de açúcar refinado (pref). Essa relação é positiva, no entanto, com a oferta doméstica de açúcar bruto $\left(S_{d}\right)$ :

$$
(1-z) \ln x e=-\left(z t \ln D_{d}+(z(1-t)) \alpha_{4} \ln \text { pref }\right)+S_{d}
$$

Substituindo as eq. (27) e (28) na eq. (29), tem-se que a quantidade ofertada para exportação é uma função de:

$$
\begin{aligned}
& \ln x e=-\frac{z t}{1-z}\left(\alpha_{1}-\alpha_{2} \ln p d+\alpha_{3} \ln Y\right)-\frac{z(1-t) \alpha_{4}}{1-z} \ln p r e f+\frac{1}{1-z}\left(\varphi_{0}+\varphi_{1} \ln p d+\varphi_{2} \ln p x-\varphi_{3} \ln W\right) \\
& \ln x e=\frac{\varphi_{0}-z t \alpha_{1}}{1-z}+\frac{\varphi_{2}}{1-z} \ln p x+\frac{z t \alpha_{2}+\varphi_{1}}{1-z} \ln p d-\frac{z t \alpha_{3}}{1-z} \ln Y-\frac{z(1-t) \alpha_{4}}{1-z} \ln p r e f-\frac{\varphi_{3}}{1-z} \ln W
\end{aligned}
$$

Verifica-se que um aumento na proporção do açúcar total ofertado que é refinado $(z)$, aumenta, em módulo, o valor das elasticidades das variáveis que deslocam o açúcar para o refino (preço doméstico de açúcar refinado, renda doméstica e preço de exportação). Havendo um aumento na proporção $z$, conseqüentemente, reduz-se a proporção (1-z) do açúcar destinado para exportação, o que reduz, em módulo, o valor da elasticidade-preço de exportação de açúcar bruto $(p x)$ e do deslocar da oferta $(W)$. Da mesma maneira, um aumento na proporção do açúcar refinado para exportação (1- $t$ ) aumenta o valor da elasticidade-preço de exportação de açúcar refinado (pref) e reduz o valor das elasticidades do preço doméstico de açúcar refinado $(p d)$ e da renda doméstica $(Y)$, uma vez que reduz o valor de $t$.

Como $p x$ é o preço das exportações brasileiras de açúcar bruto em moeda doméstica, esta variável pode ser decomposta no preço das exportações ( $p e$ ) em moeda estrangeira multiplicada pela taxa de câmbio ( $t c$ ), sendo ambas positivamente 
relacionadas ao volume exportado de açúcar bruto. Assim, a eq. (30) pode ser escrita da seguinte maneira:

$$
\ln x e=f(\ln p e, \ln t c, \ln p d, \ln Y, \ln \text { pref }, \ln W)
$$

Espera-se uma relação positiva da quantidade exportada de açúcar bruto com as variáveis: preço de exportação de açúcar bruto, taxa de câmbio e preço doméstico de açúcar refinado; e uma relação negativa com a renda doméstica, com o preço de exportação de açúcar refinado e com o deslocador de oferta de açúcar $(W)$.

O coeficiente estimado para a variável lnpe fornece, diretamente, o valor da elasticidade-preço de oferta da exportação de açúcar bruto (descrito como $\theta$ nas eq. 12 e 14), que será estimado para as exportações das regiões Centro-Sul e Norte-Nordeste do Brasil. O valor dessa elasticidade será utilizado nas eq. (12) e (14), para que, juntamente com a estimativa da elasticidade da demanda, se obtenham, pela eq. (12), estimativas do efeito final sobre o volume exportado para o país $i$, quando ocorre um choque no nível tarifário (ad valorem) desse país. A eq. (14) expressa o efeito de uma variação no nível de tarifa sobre o preço de exportação para o país $i$.

É importante destacar que, como são diferenciadas as características de produção de açúcar das regiões Centro-Sul e Norte-Nordeste do Brasil, as exportações de açúcar bruto nestas regiões também se comportam de maneira distintas. Por exemplo, tem-se que o Norte-Nordeste não apresenta exportações significativas de açúcar refinado, ao contrário do vem acontecendo em relação às exportações da região CentroSul. Desta maneira, a variável do preço de exportação de açúcar refinado (pref) pode não ser significativa quando incluída na oferta de exportação de açúcar bruto da região Norte-Nordeste.

\subsection{Modelo de oferta das exportações de açúcar da União Européia}

Como demonstrado na Figura 18, o quantum exportado foi definido como sendo o excedente de consumo doméstico do bloco, em que o alto valor do preço do produto é o subsídio recebido pelo produtor para exportar o produto ao nível do preço 
mundial. Desta maneira, como descrito em Bacchi et. al. (2002) e Barros et. al. (2002) para o mercado brasileiro, no logaritmo tem-se:

$$
\ln x e=\ln S_{d}-\ln D_{d}
$$

onde lnxe é o logaritmo do volume ofertado de açúcar pela União Européia; $\ln S_{d}$ é o logaritmo da oferta total de açúcar e $\ln D_{d}$ é o logaritmo da demanda doméstica da UE. As funções de oferta e de demanda doméstica, por sua vez, são definidas na forma logarítmica, como:

$$
\begin{aligned}
& \ln S_{d}=\alpha_{0}+\alpha_{1} \ln p d+\alpha_{2} \ln W \\
& \ln D_{d}=\alpha_{3}+\alpha_{4} \ln p d+\alpha_{5} \ln Y
\end{aligned}
$$

em que $p d$ é o preço doméstico do açúcar da UE. Este preço incorpora o valor do subsídio pago ao produtor, fazendo com que o alto preço recebido no mercado da UE possibilite que este açúcar possa ser exportado ao nível de preço internacional. $W$ é um deslocador da oferta, considerado como o volume importado de açúcar bruto pela UE, uma vez que este açúcar é refinado, podendo ser exportado, em função do excedente doméstico; e $Y$ é um deslocador da demanda, considerado como a renda doméstica.

Substituindo as eq. (33) e (34) na eq. (32):

$$
\begin{aligned}
& \ln x e=\alpha_{0}+\alpha_{1} \ln p d+\alpha_{2} \ln W-\left(\alpha_{3}+\alpha_{4} \ln p d+\alpha_{5} \ln Y\right) \\
& \ln x e=\left(\alpha_{0}-\alpha_{3}\right)+\left(\alpha_{1}-\alpha_{4}\right) \ln p d+\alpha_{2} \ln W-\alpha_{5} \ln Y
\end{aligned}
$$

Portanto, a quantidade ofertada para exportação é uma função de:

$$
\ln x e=f(\ln p d, \ln W, \ln Y)
$$

Sendo $p d$ descrito em moeda estrangeira, espera-se também o efeito da taxa de câmbio sobre as exportações. Assim, tem-se o seguinte modelo que procurou descrever o excedente exportável de açúcar refinado da União Européia:

$$
\ln x e=f(\ln p d, \ln t c, \ln W, \ln Y)
$$


Do modelo descrito em (37), espera-se uma relação positiva da quantidade exportada com seu preço $(p d)$; com o volume importado de açúcar bruto $(W)$; e com a taxa de câmbio (tc). Para a variável renda espera-se um efeito negativo, por aumentar a demanda interna reduzindo o excedente exportável. Entretanto, a taxa de câmbio e a renda são variáveis que afetam, também, o volume importado de açúcar bruto. Esperase, porém, sinais contrários aos descritos para as exportações de açúcar refinado. Desta maneira, aqueles coeficientes foram avaliados, considerando sua significância no modelo, para definir a inclusão ou não na estimação do modelo.

O coeficiente estimado para a variável lnpd fornece, diretamente, o valor da elasticidade de oferta da exportação de açúcar refinado da União Européia (descrito como $\theta$ nas eq. 19 e 21). O valor dessa elasticidade será utilizado nas eq. (19) e (21), de maneira que, juntamente com a estimativa da elasticidade da demanda, se obtenham: pela eq. (19), estimativas do efeito final sobre o volume exportado para o país $i$, quando ocorre um choque no nível de subsídio (ad valorem) da UE; e pela eq. (21), o efeito final sobre o preço de exportação da UE quando ocorre uma variação no nível de subsídio.

Os modelos utilizados para estimar o aumento das exportações brasileiras de açúcar foram apresentados de maneira sintética nas Figuras 20 e 21. 
Impactos dos equivalentes tarifários incidentes sobre exportações brasileiras, pelos EUA e UE, sobre as exportações brasileiras de açúcar bruto

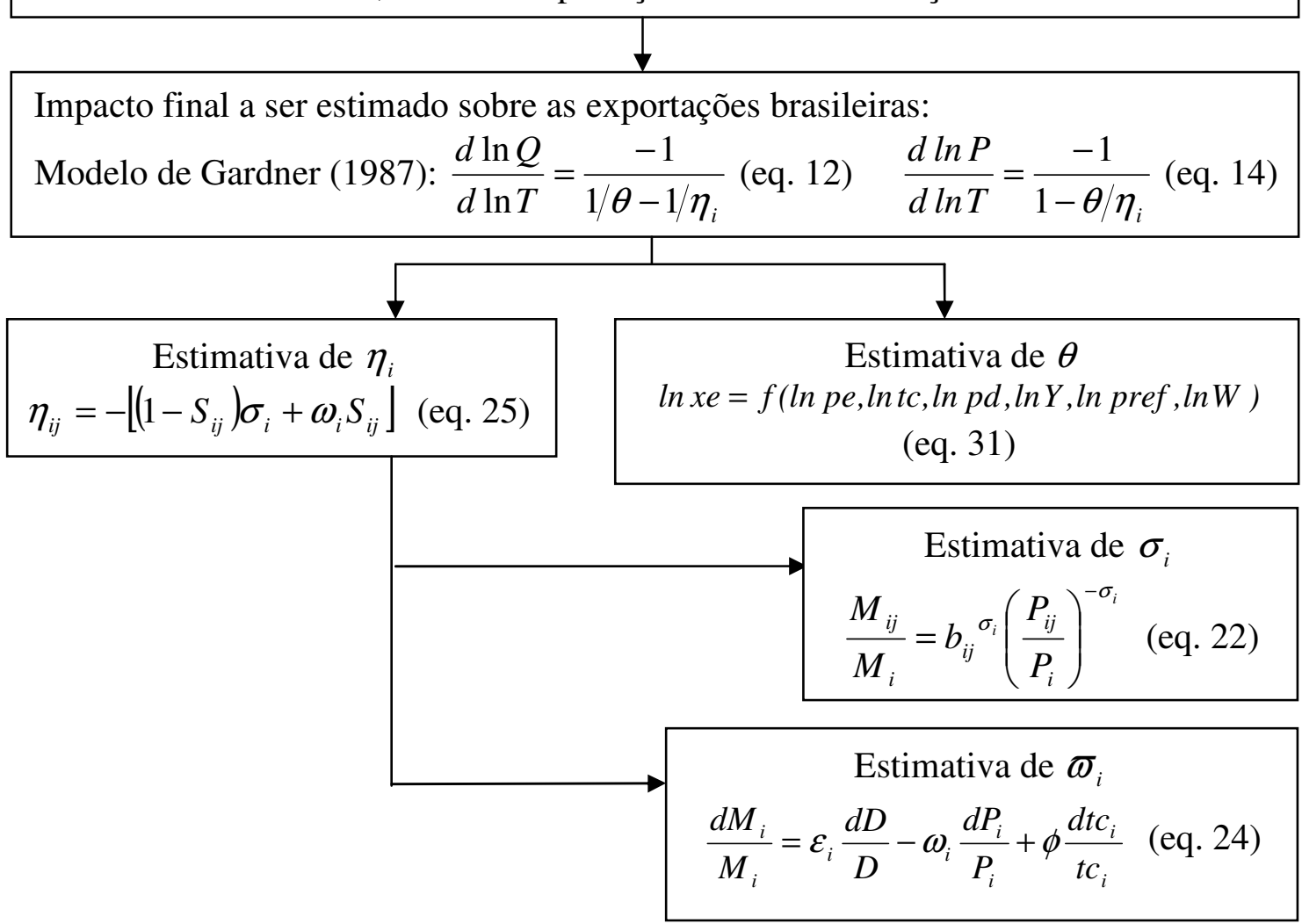

Figura 20 - Fluxograma dos modelos que foram estimados para avaliar os impactos dos equivalentes tarifários incidentes sobre exportações brasileiras, pelos EUA e UE, sobre as exportações brasileiras de açúcar bruto.

Nota: $d \ln Q / d \ln T$ é a variação da quantidade importada em função de uma variação no equivalente tarifário; $d \ln P / d \ln T$ é a variação do preço de importação em função de uma variação no equivalente tarifário; $\eta_{i}$ é a elasticidade-preço de demanda por importação diferenciada por país de origem, em que $i$ representa os mercados dos EUA e da UE; $\sigma_{i}$ é a elasticidade de substituição; e $\varpi_{i}$ é a elasticidade-preço total de importação; $\theta$ é a elasticidade-preço de oferta de exportação, estimada para as regiões Centro-Sul e Norte-Nordeste do Brasil. 
Impactos do equivalente subsídio incidentes nas exportações da UE sobre as exportações brasileiras de açúcar refinado

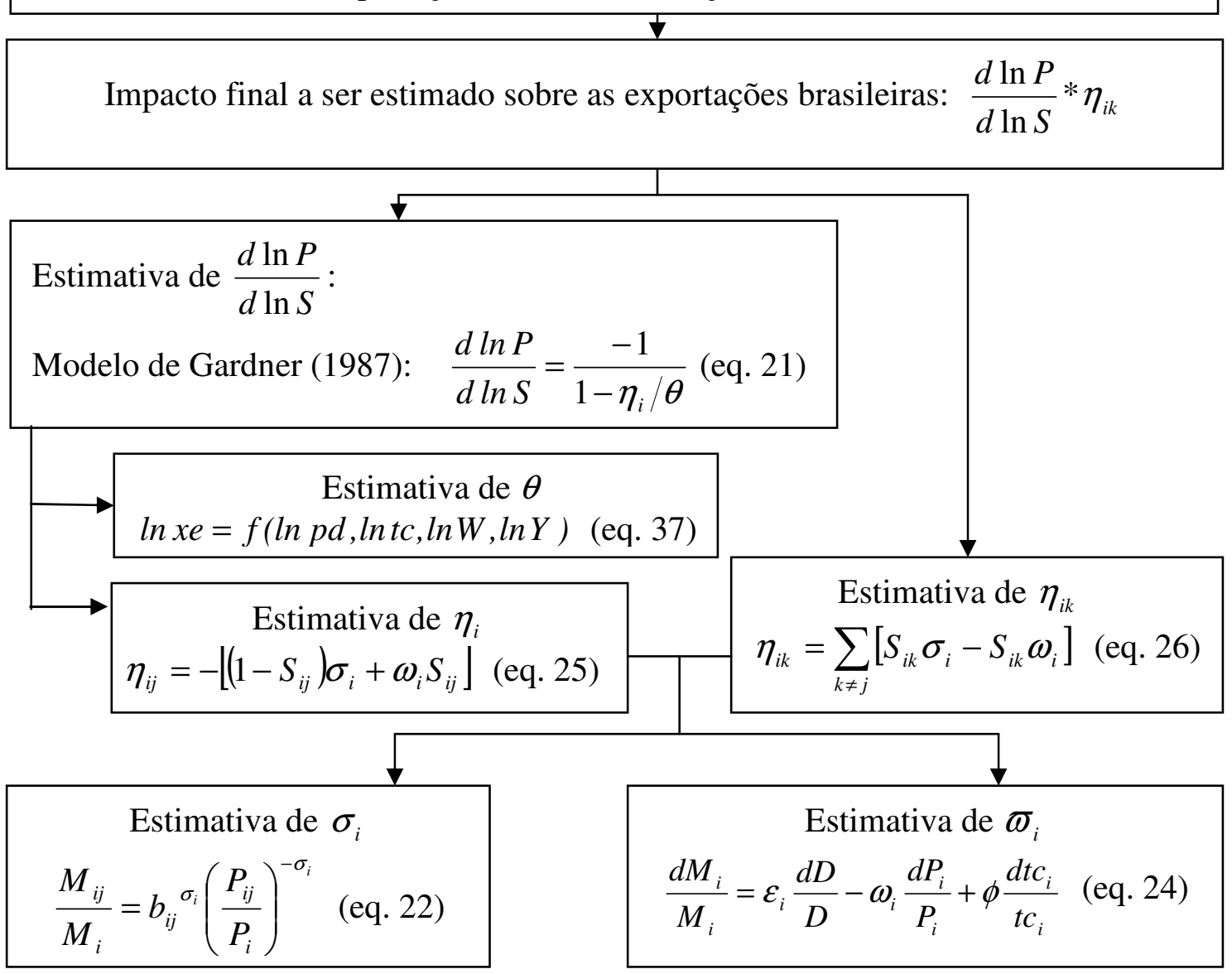

Figura 21 - Fluxograma dos modelos que foram estimados para avaliar os impactos dos equivalentes subsídios incidentes nas exportações da UE, sobre as exportações brasileiras de açúcar refinado.

Nota: $d \ln P / d \ln S$ é a variação do preço de exportação da UE em função de uma variação no equivalente subsídio; $\eta_{i k}$ é a elasticidade-preço cruzada de demanda por importação diferenciada por país de origem, em que $i$ foram países selecionados que importam açúcar refinado da UE e do Brasil e $k$ representa a UE; $\eta_{i}$ é a elasticidade-preço de demanda diferenciada por país de origem; $\sigma_{i}$ é a elasticidade de substituição; e $\varpi_{i}$ é a elasticidade-preço total de importação; $\theta$ é a elasticidadepreço de oferta de exportação européia. 


\subsubsection{Procedimentos econométricos}

Os modelos mostrados anteriormente procuraram descrever o comportamento de demandas e de ofertas de exportação de interesse para identificação dos efeitos de redução em instrumentos políticos que protegem o mercado doméstico de açúcar em países desenvolvidos, sobre as exportações brasileiras deste produto.

Neste item foram descritos os procedimentos econométricos para proceder à estimação empírica dos modelos necessários à análise. Foram utilizados dados anuais para todas as equações estimadas, com o objetivo de compatibilizar os resultados obtidos nesta primeira etapa, com os dados da matriz insumo-produto que foi utilizada na segunda etapa. Uma das dificuldades encontradas foi a limitação do número de observações para análise.

A estimação de equações utilizando dados cross section juntamente com dados de séries de tempo (denominados dados em painel ou em pooling) procura suprir esta deficiência. Desta maneira, quando possível, este procedimento foi adotado para estimar as equações definidas pelos modelos econômicos.

Para estimar a equação de oferta de exportação do Brasil foram utilizadas as exportações para alguns dos maiores importadores de açúcar bruto do Brasil como variáveis cross section e o período após a desregulamentação das exportações brasileiras como os dados para compor a série temporal. Para estimação das equações referentes ao mercado de açúcar da União Européia foram utilizados, como dados cross section, os países do bloco. A série temporal foi composta de acordo com os dados disponíveis. Estimativas de elasticidades de demanda por importação de açúcar refinado, utilizadas com o propósito de verificar o efeito de redução de subsídios na exportação de açúcar refinado da UE sobre as exportações brasileiras deste produto, foram realizadas também com dados em painel, considerando os países como unidades cross section.

Apenas a equação de demanda por importação de açúcar bruto dos EUA foi estimada utilizando somente dados de séries de tempo. Desta maneira, foi requerido uma série mais extensa de dados, composta de 1982 a 2001. Para proceder a estimação 
econométrica das equações necessárias para calcular o valor da elasticidade-preço de importação de açúcar bruto, foi previamente realizada uma análise das séries de tempo utilizadas no modelo.

A seguir são descritos os procedimentos econométricos utilizados para estimação correta das equações. Primeiro foi descrito o procedimento econométrico para estimar dados em painel. A seguir foram descritos os procedimentos econométricos utilizados para analisar os dados de séries de tempo e proceder a modelagem (testes de raiz unitária, co-integração e modelo com correção de erro) utilizada na estimação da equação de demanda por importação dos EUA.

\subsubsection{Modelagem com dados em painel}

A estimação de equações utilizando dados em painel foi necessária neste estudo para obter um número de observações satisfatório. Como os dados para composição da série temporal foram poucos, por serem dados anuais recentes, a combinação desses dados com uma série cross section fornece um conteúdo de informações mais rico para a análise.

O método de Mínimos Quadrados Ordinários é restritivo quanto ao comportamento de perturbações estocásticas de regressão, como homocedasticidade e não-autocorrelação. Desta maneira, a estimação de equações onde se combinam observações cross section com séries temporais requer o desenvolvimento de processos de estimação mais adequados. Isto ocorre porque o comportamento das observações cross section é, provavelmente, diferente do comportamento da série temporal. Procedimentos de estimação utilizando o modelo de regressão linear generalizado procuram eliminar os problemas que podem surgir ao se utilizar observações em painel.

A formulação do modelo econométrico com dados em painel é a seguinte:

$$
y_{i t}=\sum_{k=1}^{p} X_{i t k} \beta_{k}+\mu_{i t}
$$


$i=1, \ldots, N$

$t=1, \ldots, T$

em que $N$ é o número de unidades cross section; $T$ é o número de observações de cada cross section; $k$ é o número de variáveis exógenas do modelo; $y$ é a variável endógena considerada; $\beta$ é o parâmetro das variáveis exógenas consideradas na equação e $\mu$ é o termo de erro.

Portanto, o processo de estimação dos coeficientes do modelo $\left(\hat{\beta}_{k}\right)$ é o de Mínimos Quadrados Generalizados (MQG), onde:

$$
\hat{\beta}_{k}=\left(X^{\prime} \hat{V}^{-1} X\right)^{-1} X^{\prime} \hat{V}^{-1} Y
$$

sendo $\hat{V}$ a matriz de covariância.

Desta maneira, a estimação da matriz $V$ é o foco principal da estimação dos modelos utilizando dados em painel. Dependendo da forma apresentada pela estrutura do termo de erro da regressão, há diferentes maneiras de se proceder a estimação da matriz $V$ e, conseqüentemente, dos coeficientes da equação.

Os dois principais métodos de estimação de dados em painel, método de FullerBattese e método de Parks, consideram que as estruturas do termo de erro assumem, respectivamente, três componentes do termo de erro ou que o modelo assuma um processo autoregressivo com correlação contemporânea entre as unidades cross section. Um terceiro método de estimação descrito em SAS (1993) como método Da Silva, considera que o modelo apresenta componentes de variância com médias móveis. Entretanto, este método não foi explorado aqui, uma vez que não foram verificadas presenças de médias móveis nos dados analisados e, portanto, o método não se apresentou adequado em nenhuma das regressões realizadas.

No método de Fuller-Battese, os erros da regressão têm a seguinte composição:

$$
\mu_{i t}=v_{i}+e_{t}+\varepsilon_{i t}
$$


onde $v_{i}, e_{t}$ e $\varepsilon_{i t}$ são independentemente distribuídos com média zero e variância positiva $\sigma_{v}^{2}, \sigma_{e}^{2}$ e $\sigma_{\varepsilon}^{2}$.

Portanto, neste método, a matriz de covariância para o vetor de erro é expressa da seguinte maneira:

$$
V=\mathrm{E}\left(\mu \mu^{\prime}\right)=\sigma_{\varepsilon}^{2} \mathrm{I}_{N T}+\sigma_{v}^{2} \mathrm{~A}+\sigma_{e}^{2} \mathrm{~B}
$$

sendo:

$\mathrm{A}=\mathrm{I}_{N} \otimes \mathrm{J}_{T}$

$\mathrm{B}=\mathrm{J}_{N} \otimes \mathrm{I}_{T}$

onde, $\mathrm{I}_{N T}, \mathrm{I}_{N}$ e $\mathrm{I}_{T}$ são matrizes identidade de o $\operatorname{rdem} N T, N$ e $T ; \mathrm{J}_{N}$ e $\mathrm{J}_{T}$ são matrizes $N$ x $N$ e $T$ x $T$ com todos os elementos iguais a 1; e $\otimes$ representa o produto de Kronecker.

O método de Fuller e Battese oferecem condições suficientes para que o estimador, $\hat{\beta}_{k}$, seja não viesado e normalmente e assintoticamente distribuído.

O método de Parks, de outra maneira, considera o modelo autoregressivo de primeira ordem com o termo de erro aleatório $\mu_{i t}, i=1,2, \ldots, N, t=1,2, \ldots, T$, tem a seguinte estrutura

$\mathrm{E}\left(\mu_{i t}^{2}\right)=\sigma_{i i}$, ou seja, apresenta heterocedasticia;

$\mathrm{E}\left(\mu_{i t} \mu_{j t}\right)=\sigma_{i j}$, é contemporaneamente correlacionado;

$\mu_{i t}=\rho_{i} \mu_{i, t-1}+\varepsilon_{i t}$, possui estrutura autoregressiva;

onde $\mathrm{E}\left(\varepsilon_{i t}\right)=0 ; \mathrm{E}\left(\mu_{i, t-1} \varepsilon_{j t}\right)=0 ; \mathrm{E}\left(\varepsilon_{i t} \varepsilon_{j t}\right)=\phi_{i j} ; \mathrm{E}\left(\varepsilon_{i t} \varepsilon_{j s}\right)=0, \operatorname{com} s \neq t ; \mathrm{E}\left(\mu_{i 0}\right)=0$; $\mathrm{E}\left(\mu_{i 0} \mu_{j 0}\right)=\sigma_{i j}=\phi_{i j} /\left(1-\rho_{i} \rho_{j}\right)$.

Neste modelo, a matriz de covariância para o vetor de erro é expressa da seguinte maneira: 


$$
V=\mathrm{E}\left(\mu \mu^{\prime}\right)=\left[\begin{array}{cccccc}
\sigma_{11} P_{11} & \sigma_{12} P_{12} & . & . & . & \sigma_{1 N} P_{1 N} \\
\sigma_{21} P_{21} & \sigma_{22} P_{22} & . & . & . & \sigma_{2 N} P_{2 N} \\
\cdot & \cdot & \cdot & & & \cdot \\
\cdot & \cdot & & \cdot & & \cdot \\
\cdot & \cdot & & & . & \cdot \\
\sigma_{N 1} P_{N 1} & \sigma_{N 2} P_{N 2} & . & . & . & \sigma_{N N} P_{N N}
\end{array}\right]
$$

sendo:

$$
P_{i j}=\left[\begin{array}{cccccc}
1 & \rho_{j} & \rho_{j}^{2} & \cdot & \cdot & \rho_{j}^{T-1} \\
\rho_{i} & 1 & \rho_{j} & \cdot & \cdot & \rho_{j}^{T-2} \\
\rho_{i}^{2} & \rho_{i} & 1 & \cdot & \cdot & \rho_{j}^{T-3} \\
\cdot & \cdot & \cdot & \cdot & & \cdot \\
\cdot & \cdot & \cdot & & \cdot & \cdot \\
\rho_{i}^{T-1} & \rho_{i}^{T-2} & \rho_{i}^{T-3} & \cdot & \cdot & 1
\end{array}\right]
$$

Assim, Parks demonstra que seu estimador é consistente e assintoticamente, normalmente distribuído com

$$
\operatorname{Var}\left(\hat{\beta}_{k}\right)=\left(X^{\prime} V^{-1} X\right)^{-1}
$$

Portanto, a estimação da matriz $V$ do método de Mínimos Quadrados Generalizados consiste no principal desafio para estimação dos modelos utilizando dados em painel.

\subsubsection{Modelos com séries de tempo}

Como descrito anteriormente para modelos com dados em painel, o uso do método de Mínimos Quadrados Ordinários também pode ser restritivo com dados de séries temporais, quando estas variáveis não são estacionárias. A ausência de estacionariedade nos dados é uma característica comum nas séries de tempo econômicas (Greene, 1993).

A seguir são descritos os modelos para aplicação dos testes nas séries de tempo: teste de raiz unitária e de co-integração. O teste de raiz unitária consiste em averiguar a 
estacionariedade das séries temporais, e o teste de co-integração verifica a existência de relação estável de longo prazo entre as variáveis integradas de mesma ordem.

\subsection{Teste de raiz unitária}

Conforme definido em Greene (1993), uma série $\left(x_{t}\right)$ é considerada estacionária se satisfaz as seguintes condições:

1. $E\left[x_{t}\right]$ é independente de $t$;

2. $\operatorname{Var}\left[x_{t}\right]$ é uma constante, independente de $t$;

3. $\operatorname{Cov}\left[x_{t}, x_{s}\right]$ é uma função de $t-s$, mas não de $t$ ou $s$.

Testes que detectam esta característica das séries de tempo foram descritos por Dickey \& Fuller (1981) e são conhecidos como testes de raiz unitária de Dickey-Fuller.

Os testes de raiz unitária consistem na estimação das seguintes equações:

(a) $\Delta x_{t}=\alpha+\theta T+\gamma_{1} x_{t-1}+\sum_{j=1}^{n} \gamma_{j} \Delta x_{t-j}+e_{t}$

(b) $\Delta x_{t}=\alpha+\gamma_{1} x_{t-1}+\sum_{j=1}^{n} \gamma_{j} \Delta x_{t-j}+e_{t}$

(c) $\Delta x_{t}=\gamma_{1} x_{t-1}+\sum_{j=1}^{n} \gamma_{j} \Delta x_{t-j}+e_{t}$

(d) $\Delta \Delta x_{t}=\gamma_{1} \Delta x_{t-1}+\sum_{j=1}^{n} \gamma_{j} \Delta \Delta x_{t-j}+e_{t}$

Sendo:

$x$ = uma variável considerada no modelo proposto;

$\gamma_{1}=\sum_{j=1}^{n} \gamma_{i}-1$

$T=$ tendência determinística do modelo. 
O valor de $n$ deve ser tal que torne a série dos resíduos $\left(e_{t}\right)$ uma série "ruído branco" (série estacionária). Um procedimento que tem sido muito utilizado para determinação do valor de $n$ é o critério de Akaike (AIC) e Schwarz (SC) ${ }^{21}$.

Uma série é estacionária se $\sum_{\mathrm{j}=1}^{\mathrm{n}} \gamma_{\mathrm{i}}-1<0$ e $\gamma \in(-1,1)$. Se $\gamma-1=0$ tem-se que a série tem uma tendência explosiva, sendo caracterizada como não-estacionária. Para corrigir este problema, as variáveis devem ser diferenciadas e, então, constatada a estacionariedade da série nas diferenças.

O procedimento para identificação de raiz unitária na série é o seguinte: na eq. (a) a hipótese nula conjunta testada é dada por $\mathrm{H}_{0}: \alpha=\theta=\gamma=0$, enquanto para a eq. (b) a hipótese nula conjunta testada é dada por $\mathrm{H}_{0}: \alpha=\gamma=0$ e na eq. (c) testa-se a hipótese $\mathrm{H}_{0}: \gamma=0$. As estatísticas $\tau_{\tau}, \tau_{\mu}$ e $\tau$ foram utilizadas, respectivamente, para testar $\mathrm{o}$ coeficiente $\gamma=0$ nas eq. (a), (b) e (c). Os coeficientes dos termos constante $(\alpha)$ e tendência $(\theta)$, nos modelos descritos nas eq. (a) e (b), foram testados como definido pelo fluxograma da Figura 22. As estatísticas a serem utilizadas para testar a significância dos parâmetros foram descritas do lado esquerdo desta figura.

Caso a série seja não estacionária segundo os procedimentos descritos no fluxograma da Figura 22, aplica-se mais uma diferença na eq. (c), descrita pela eq. (d), e testa-se novamente a hipótese $\mathrm{H}_{0}: \gamma=0$. Sendo a série estacionária na primeira diferença, ela é representada como sendo I(1), ou seja, integrada de ordem 1. Este fato caracteriza a série com raiz unitária.

${ }^{21}$ Os critérios de AIC e SC consistem no seguinte:

$A I C=\ln \sigma^{2}+\frac{2}{N}$ (número de parâmetros) $\quad$ e $S C=\ln \sigma^{2}+\frac{\ln N}{N}$ (número de parâmetros), sendo $\sigma^{2}$ a soma dos quadrados dos resíduos estimados do processo auto-regressivo de ordem $n$ dividida pelo número de observações $(\boldsymbol{N})$. O modelo mais adequado é aquele que apresentar o menor valor para os critérios AIC e SC. Maiores detalhes podem ser encontrados em Lütkepohl (1993). 


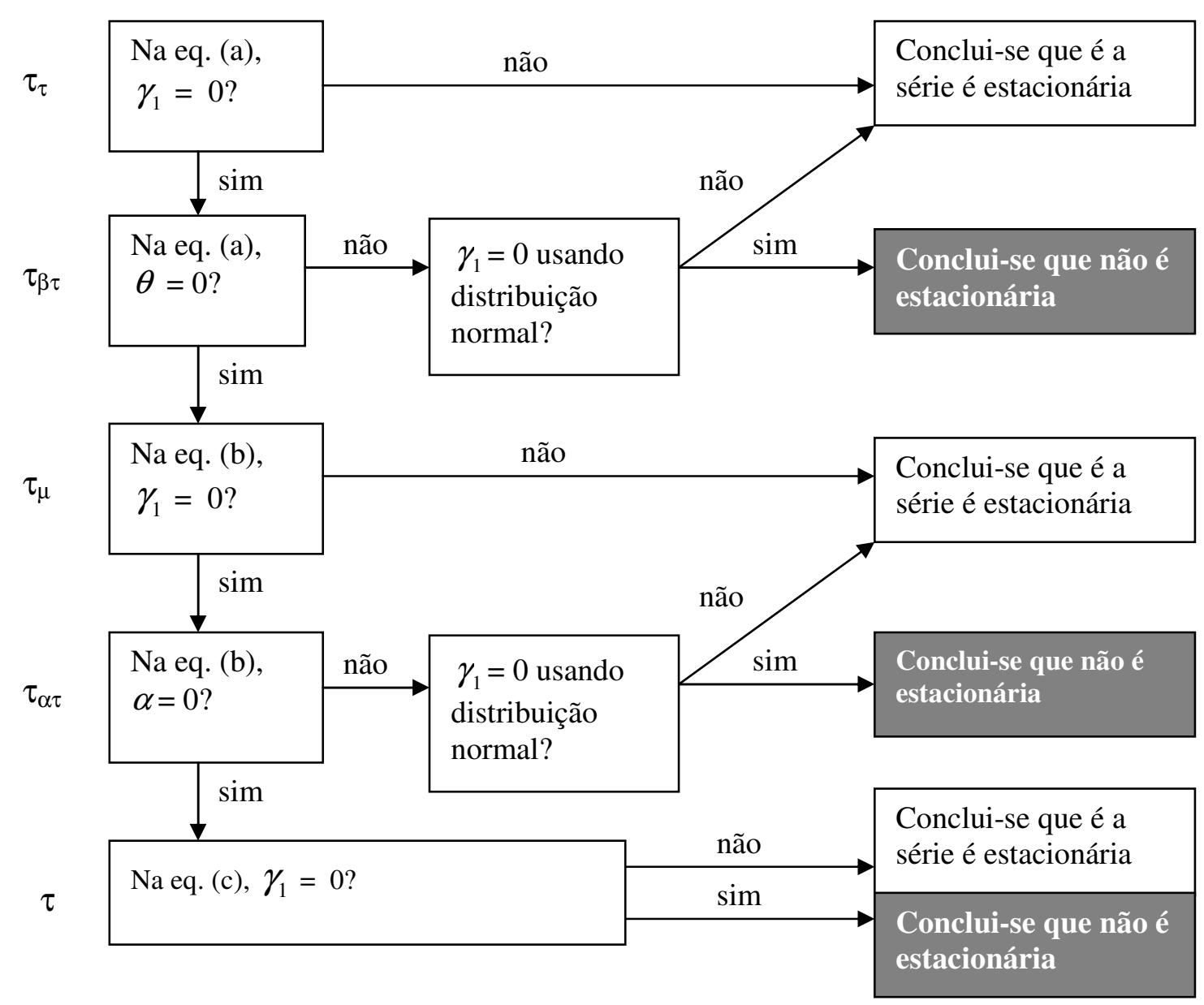

Figura 22 - Procedimento seqüencial para testar a estacionariedade de uma série de tempo.

Fonte: Enders (1995, p.257)

A diferenciação dos dados apenas não resolve o problema de especificação do modelo a ser estimado. Isto ocorre porque informações de longo prazo são perdidas no processo de diferenciação. O conceito de co-integração descrito a seguir pode ser empregado para solucionar esse problema. Uma vez que duas ou mais variáveis são cointegradas, o termo de correção de erro estimado neste teste recupera as informações de longo prazo entre as variáveis. 


\subsection{Teste de co-integração}

Sendo as variáveis integradas de mesma ordem, torna-se importante capturar as informações de longo prazo perdidas no processo de diferenciação destas variáveis. Este processo é definido como co-integração. Segundo Lütkepohl (1993), dado um processo $k$-dimensional $y_{t}$ integrado de ordem $\mathrm{d}, y_{t} \sim \mathrm{I}(\mathrm{d})$. O processo $y_{t} \mathrm{I}(\mathrm{d})$ é chamado cointegrado se há uma combinação linear $c^{\prime} y_{t}$ a qual é integrada de ordem menor do que d. A identificação do vetor $c$ é importante para correção do modelo estimado com as variáveis nas diferenças. Desta maneira, o modelo estimado possui informações de curto e longo prazos do relacionamento entre as variáveis selecionadas.

Para identificar a presença de co-integração e estimar o(s) vetor(es) de correção de erro (c), foi utilizado o procedimento descrito por Johansen (1988), definido como modelo de Johansen. Este modelo procura determinar o ranking de co-integração no seguinte modelo auto regressivo vetorial (VAR), utilizando um modelo com constante (Johansen, 1996):

$$
\Delta y_{t}=\sum_{i=1}^{p-1} \Gamma_{i} \Delta y_{t-i}+\Pi y_{t-1}+\mu+\varepsilon_{t}
$$

onde $y_{t}$ é um vetor com $k$ variáveis, $\varepsilon_{t} \sim N(0, \Sigma)$ e $E\left(\varepsilon_{t} \varepsilon_{t}^{\prime}\right)=0$ para qualquer $t$ diferente de $s$. Os critérios AIC e SC foram utilizados para a determinação do valor de $p$.

A matriz de coeficientes de $y_{t-1}$, matriz $\Pi$, contém as informações de longo prazo entre as variáveis. Considerando que $r$ seja o posto da matriz $\Pi$, a análise da eq. (42) para determinação da presença de co-integração e definição do vetor de correção de erro ocorre da seguinte maneira: se $r=k$, então $y_{t}$ é estacionário; se $r=0$, então $\Pi$ é uma matriz nula e $y_{t}$ é integrado de primeira ordem; finalmente, se $0<r<k$, existem matrizes $\alpha$ e $\beta$ de dimensão $k \times r$ tais que $\Pi=\alpha \beta^{\prime}$ e o vetor $\beta^{\prime} y_{t}$ é estacionário, havendo, portanto, $r$ vetores de co-integração (as $r$ colunas de $\beta$ ).

A identificação da presença e do número de vetores de co-integração é realizada pela análise dos testes do traço e do teste do máximo autovalor, cujas distribuições não 
seguem a distribuição qui-quadrada padrão, portanto, os valores críticos foram apresentados por Johansen \& Juselius (1990).

\subsubsection{Fonte de dados}

Neste item foram descritas todas as fontes utilizadas para compor os dados das variáveis descritas nos modelos econômicos descritos anteriormente. Como foram estimadas várias equações de oferta de exportação e de demanda por importação, os nomes das variáveis se repetem em várias delas. Assim, foi definido no Quadro 2, para cada uma das equações estimadas, as variáveis utilizadas e a fonte para obtenção dos dados. Para estimar as equações de demanda estimaram-se as eq. (22) e (24) para cada equação de demanda considerada. Os modelos econômicos das equações de oferta estimados foram descritos nas eq. (38) e (44).

De maneira geral, as variáveis utilizadas foram: volume e valor importado de açúcar bruto ou refinado; volume e valor exportado de açúcar bruto ou refinado; os preços de exportação e de importação, obtidos dividindo o valor exportado e importado pelo respectivo volume; taxa de câmbio do país, sendo utilizada, sempre que possível, a taxa de câmbio efetiva real; preço doméstico de açúcar refinado; e renda. Para a renda, foi utilizado como proxy o índice do PIB ou o valor total das importações realizadas no período. Segundo Richardson $(1973)^{22}$, citado por Silva (1992), o valor das importações totais pode ser uma variável de escala mais apropriada para a renda, uma vez que para muitos produtos, como bens intermediários e de capital, a renda seria menos indicada do que a produção, e o total das importações representaria ambos.

${ }^{22}$ RICHARDSON, J.D. On improving the estimate of the export elasticity of substitution. Canadian Journal of Economics, v.5, n.3, p.349-357, 1972. 


\begin{tabular}{|c|c|}
\hline Variáveis & Definição das variáveis e fonte dos dados \\
\hline \multicolumn{2}{|c|}{ Modelo de oferta de exportação de açúcar bruto do Centro-Sul } \\
\hline$x e$ & $\begin{array}{l}\text { Volume exportado de açúcar bruto. Dados obtidos no Sistema AliceWeb } \\
\text { do Ministério do Desenvolvimento, Indústria e Comércio Exterior, } \\
\text { correspondentes à linha tarifária } 1701.11 .00 \text { para os estados das regiões } \\
\text { Sudeste, Sul e Centro-Oeste do Brasil (Brasil, 2003b); }\end{array}$ \\
\hline pe & $\begin{array}{l}\text { Preço de exportação de açúcar bruto. Dados obtidos no Sistema } \\
\text { AliceWeb do Ministério do Desenvolvimento, Indústria e Comércio } \\
\text { Exterior, dividindo-se o valor pelo volume exportado correspondente à } \\
\text { linha tarifária } 1701.11 .00 \text { para os estados das regiões Sudeste, Sul e } \\
\text { Centro-Oeste do Brasil (Brasil, 2003b); }\end{array}$ \\
\hline$t c$ & $\begin{array}{l}\text { Taxa de câmbio. Os índices da taxa de câmbio foram obtidos do Instituto } \\
\text { de Pesquisas Econômicas Aplicadas - IPEA, fazendo a média simples } \\
\text { anual para os valores mensais da "Taxa de câmbio - efetiva real - INPC - } \\
\text { exportações - índice (média } 1995=100 \text { )" (IPEA, 2003a); }\end{array}$ \\
\hline pref & $\begin{array}{l}\text { Preço de exportação de açúcar refinado, utilizado como proxy da variável } \\
\text { que considera o deslocador de oferta das exportações. Dados obtidos no } \\
\text { Sistema AliceWeb do Ministério do Desenvolvimento, Indústria e } \\
\text { Comércio Exterior, dividindo-se o valor pelo volume exportado } \\
\text { correspondente à linha tarifária } 1701.99 .00 \text { para os estados das regiões } \\
\text { Sudeste, Sul e Centro-Oeste do Brasil (Brasil, 2003b); }\end{array}$ \\
\hline
\end{tabular}

Quadro 2 - Definição das variáveis utilizadas nos modelos econométricos, as quais foram descritas nos modelos econômicos, e fonte dos dados. 


\begin{tabular}{|c|c|}
\hline Variáveis & Definição das variáveis e fonte dos dados \\
\hline ren & $\begin{array}{l}\text { Preço doméstico recebido pelo açúcar refinado no Centro-Sul. Foram } \\
\text { utilizados os valores mensais de preço de açúcar cristal recebido pelo } \\
\text { produtor no Estado de São Paulo, divulgados pelo Centro de Estudos } \\
\text { Avançados em Economia Aplicada - CEPEA (2003), e deflacionados } \\
\text { pelo índice geral de preços (IGP-DI) da Fundação Getúlio Vargas. Foi } \\
\text { calculada a média simples anual dos preços deflacionados; } \\
\text { Renda doméstica. Foi utilizado o valor do PIB do Brasil como proxy da } \\
\text { renda. Dados obtidos junto ao Instituto de Pesquisas Econômicas } \\
\text { Aplicadas - "PIB (preços 2002) R\$ valor real”" (IPEA, 2003b); }\end{array}$ \\
\hline \multicolumn{2}{|c|}{ Modelo de oferta de exportação de açúcar bruto do Norte-Nordeste } \\
\hline$x e$ & $\begin{array}{l}\text { Volume exportado de açúcar bruto. Dados obtidos no Sistema AliceWeb } \\
\text { do Ministério do Desenvolvimento, Indústria e Comércio Exterior, } \\
\text { correspondentes à linha tarifária } 1701.11 .00 \text { para os estados das regiões } \\
\text { Norte e Nordeste do Brasil (Brasil, 2003b); }\end{array}$ \\
\hline pe & $\begin{array}{l}\text { Preço de exportação de açúcar bruto. Dados obtidos no Sistema } \\
\text { AliceWeb do Ministério do Desenvolvimento, Indústria e Comércio } \\
\text { Exterior, dividindo-se o valor pelo volume exportado correspondente à } \\
\text { linha tarifária } 1701.11 .00 \text { para os estados das regiões Norte e Nordeste do } \\
\text { Brasil (Brasil, 2003b); }\end{array}$ \\
\hline$t c$ & $\begin{array}{l}\text { Taxa de câmbio. Os índices da taxa de câmbio foram obtidos junto ao } \\
\text { Instituto de Pesquisas Econômicas Aplicadas, fazendo a média simples } \\
\text { anual para os valores mensais da "Taxa de câmbio - efetiva real - INPC - } \\
\text { exportações - índice (média } 1995=100 \text { )" (IPEA, 2003a); }\end{array}$ \\
\hline
\end{tabular}

Quadro 2 - Definição das variáveis utilizadas nos modelos econométricos, as quais foram descritas nos modelos econômicos, e fonte dos dados. 


\begin{tabular}{|c|c|}
\hline Variáveis & Definição das variáveis e fonte dos dados \\
\hline$p d$ & $\begin{array}{l}\text { Preço doméstico recebido pelo açúcar refinado no Norte-Nordeste. } \\
\text { Foram utilizados os valores mensais de preço de açúcar cristal recebido } \\
\text { pelo produtor no Estado de Alagoas, divulgados pelo CEPEA (2003), e } \\
\text { deflacionados pelo índice geral de preços (IGP-DI) da Fundação Getúlio } \\
\text { Vargas. Entretanto, estes dados começaram a ser coletados a partir de } \\
\text { dez/1999. Foram também deflacionados pelo índice geral de preços (IGP- } \\
\text { DI) da Fundação Getúlio Vargas os preços de açúcar para Recife, obtidos } \\
\text { da Pesquisa Nacional da Cesta Básica, boletim do Departamento } \\
\text { Intersindical de Estatística e Estudos Sócio-Econômico - DIEESE (2003), } \\
\text { para o período estudado. Foi calculada a margem entre os dois preços } \\
\text { para o período de dez/1999 a dez/2002 e calculada a média. Este valor } \\
\text { médio da margem foi subtraído das médias anuais deflacionadas dos } \\
\text { preços de 1996 a } 1999 \text { obtidos no DIEESE (2003). A média anual } \\
\text { deflacionada do preço recebido pelo produtor de Alagoas (dados de } \\
\text { CEPEA, 2003) foi utilizada para compor os dados de } 2000 \text { a 2002; }\end{array}$ \\
\hline ren & $\begin{array}{l}\text { Renda da região Norte-Nordeste. Foram utilizados os valores de } \\
\text { dezembro de cada ano do índice acumulado do ano da produção física } \\
\text { industrial do Nordeste (Gêneros da indústria de transformação = produtos } \\
\text { alimentares). Estes dados foram obtidos no IBGE (2003a); }\end{array}$ \\
\hline \multicolumn{2}{|c|}{ Modelo de demanda de importação de açúcar bruto dos EUA } \\
\hline$M i$ & $\begin{array}{l}\text { Volume importado de açúcar bruto pelos EUA. Dados obtidos junto a } \\
\text { FAO (2003b); }\end{array}$ \\
\hline
\end{tabular}

Quadro 2 - Definição das variáveis utilizadas nos modelos econométricos, as quais foram descritas nos modelos econômicos, e fonte dos dados. 


\begin{tabular}{|c|c|}
\hline Variáveis & Definição das variáveis e fonte dos dados \\
\hline$P i$ & $\begin{array}{l}\text { Preço importado de açúcar bruto pelos EUA, calculado dividindo-se o } \\
\text { valor pelo volume importado do açúcar bruto dos EUA, dados da FAO } \\
(2003 \mathrm{~b}) \text {; }\end{array}$ \\
\hline$M_{i j}$ & $\begin{array}{l}\text { Volume de açúcar bruto importado pelos EUA em relação a um dado } \\
\text { país, no caso, o Brasil. Dados obtidos no Sistema AliceWeb do } \\
\text { Ministério do Desenvolvimento, Indústria e Comércio Exterior, } \\
\text { correspondente às exportações brasileiras para os EUA da linha tarifária } \\
\text { 1701.11.00 (Brasil, 2003b); }\end{array}$ \\
\hline$P_{i j}$ & $\begin{array}{l}\text { Preço de açúcar bruto importado pelos EUA em relação a um dado país, } \\
\text { no caso, o Brasil. Dados obtidos no Sistema AliceWeb do Ministério do } \\
\text { Desenvolvimento, Indústria e Comércio Exterior, dividindo-se o valor } \\
\text { pelo volume exportado correspondente das exportações brasileiras para } \\
\text { os EUA, pertencentes à linha tarifária } 1701.11 .00 \text { (Brasil, 2003b); }\end{array}$ \\
\hline$p d$ & $\begin{array}{l}\text { Preço do açúcar bruto pago aos importadores de açúcar dos EUA. Foi } \\
\text { utilizado o preço vigente no contrato no. } 14 \text { do açúcar bruto na Bolsa de } \\
\text { Nova Iorque (USDA, 2001); }\end{array}$ \\
\hline$t c$ & $\begin{array}{l}\text { Taxa de câmbio dos EUA. Foi utilizada a "Taxa de câmbio - efetiva real - } \\
\text { índice (média } 1995=100) \text { - dólar norte-americano" obtida no IPEA } \\
(2003 c) \text {; }\end{array}$ \\
\hline ren & $\begin{array}{l}\text { PIB dos EUA, utilizado como proxy para a renda. Foi utilizado o índice } \\
\text { (média } 1995=100) \text { do PIB para os Estados Unidos, obtido no IPEA } \\
(2003 \mathrm{c}) \text {; }\end{array}$ \\
\hline
\end{tabular}

Quadro 2 - Definição das variáveis utilizadas nos modelos econométricos, as quais foram descritas nos modelos econômicos, e fonte dos dados. 


\begin{tabular}{|c|c|}
\hline Variáveis & Definição das variáveis e fonte dos dados \\
\hline \multicolumn{2}{|c|}{$\begin{array}{l}\text { Modelo de demanda de importação de açúcar bruto e oferta de exportação de açúcar } \\
\text { refinado da União Européia }\end{array}$} \\
\hline$M i$ & $\begin{array}{l}\text { Volume importado extra-bloco de açúcar bruto pelos países da UE. } \\
\text { Dados obtidos da European Commission }(1998,2000) \text {, na linha tarifária } \\
\text { 1701.11; }\end{array}$ \\
\hline$P i$ & $\begin{array}{l}\text { Preço de importação extra-bloco de açúcar bruto dos países da UE. } \\
\text { Calculado dividindo o valor pelo volume importado, dados obtidos na } \\
\text { European Commission }(1998,2000) \text {, na linha tarifária 1701.11. Os } \\
\text { valores, em euros, foram previamente transformados em dólares; }\end{array}$ \\
\hline$M_{i j}$ & $\begin{array}{l}\text { Volume de açúcar bruto importado pelos países da UE em relação a um } \\
\text { dado país, no caso, Mauricio. Dados obtidos na European Commission } \\
(1998,2000) \text {, correspondente à linha tarifária } 1701.11 \text {; }\end{array}$ \\
\hline$P_{i j}$ & $\begin{array}{l}\text { Preço de açúcar bruto importado pela UE em relação a um dado país, no } \\
\text { caso, Mauricio. Calculado dividindo o valor pelo volume importado de } \\
\text { Mauricio, segundo dados obtidos na European Commission }(1998,2000) \text {, } \\
\text { na linha tarifária 1701.11. Os valores, em euros, foram previamente } \\
\text { transformados em dólares; }\end{array}$ \\
\hline$p d$ & $\begin{array}{l}\text { Preço recebido pelos importadores de açúcar bruto da UE. Foi utilizado o } \\
\text { preço de importação intra-bloco de açúcar bruto dos países da UE, } \\
\text { calculado dividindo o valor pelo volume importado intra-bloco, segundo } \\
\text { dados obtidos na European Commission }(1998,2000) \text {, na linha tarifária } \\
\text { 1701.11. Os valores, em euros, foram previamente transformados em } \\
\text { dólares; }\end{array}$ \\
\hline
\end{tabular}

Quadro 2 - Definição das variáveis utilizadas nos modelos econométricos, as quais foram descritas nos modelos econômicos, e fonte dos dados. 


\begin{tabular}{|c|c|}
\hline Variáveis & Definição das variáveis e fonte dos dados \\
\hline$t c$ & $\begin{array}{l}\text { Taxa de câmbio dos países da UE. Foi utilizada a "Taxa de câmbio - } \\
\text { efetiva real - índice (média } 1995=100) \text { " obtida no International } \\
\text { Monetary Fund - IMF }(2000) \text {; }\end{array}$ \\
\hline ren & $\begin{array}{l}\text { Renda da UE, sendo utilizado o valor total das importações como proxy } \\
\text { para a renda. Os dados foram obtidos no IMF (2000); }\end{array}$ \\
\hline xe & $\begin{array}{l}\text { Volume exportado extra-bloco de açúcar refinado pelos países da UE. } \\
\text { Dados obtidos da European Commission }(1998,2000) \text {, na linha tarifária } \\
\text { 1701.99; }\end{array}$ \\
\hline$p d r$ & $\begin{array}{l}\text { Preço recebido pelos exportadores de açúcar refinado da UE. Foi } \\
\text { utilizado o preço de exportação intra-bloco de açúcar refinado dos países } \\
\text { da UE. Calculado dividindo o valor pelo volume exportado, dados da } \\
\text { European Commission (1998, 2000), na linha tarifária 1701.99. Os } \\
\text { valores, em euros, foram previamente transformados em dólares; }\end{array}$ \\
\hline \multicolumn{2}{|c|}{ Modelo de demanda por importação de açúcar refinado para os países selecionados } \\
\hline$M i$ & $\begin{array}{l}\text { Volume importado de açúcar refinado pelos países selecionados. Dados } \\
\text { obtidos na FAO (2003b) e United Nations (2003); }\end{array}$ \\
\hline$P i$ & $\begin{array}{l}\text { Preço de importação de açúcar refinado dos países selecionados. } \\
\text { Calculado dividindo o valor pelo volume importado, segundo dados } \\
\text { obtidos na FAO (2003b) e United Nations ( } 2003) \text {; }\end{array}$ \\
\hline$M_{i j}$ & $\begin{array}{l}\text { Volume de açúcar refinado importado pelos países selecionados em } \\
\text { relação a um dado país, no caso, a União Européia. Dados obtidos na } \\
\text { European Commission }(1998,2000) \text {, correspondentes às exportações } \\
\text { européias para aqueles países, na linha tarifária 1701.99; }\end{array}$ \\
\hline
\end{tabular}

Quadro 2 - Definição das variáveis utilizadas nos modelos econométricos, as quais foram descritas nos modelos econômicos, e fonte dos dados. 


\begin{tabular}{|cl|}
\hline Variáveis & Definição das variáveis e fonte dos dados \\
\hline$P_{i j}$ & Preço de açúcar refinado importado pelos países selecionados em relação \\
& a um dado país, no caso, a União Européia. Dados obtidos na European \\
& Commission $(1998,2000)$, dividindo-se o valor pelo volume \\
& correspondente às exportações européias para aqueles países, na linha \\
& tarifária 1701.99 . Os valores, em euros, foram previamente \\
& transformados para dólares; \\
& Taxa de câmbio. Foi utilizada a "Taxa de câmbio - efetiva real - índice \\
& (média 1995 = 100)" obtida no IMF (2000). Para os países que não \\
& dispunham deste dado, foram utilizados os valores da taxa de câmbio \\
& nominal, sendo transformada em índice e deflacionados pelo índice de \\
& preços ao consumidor daqueles países. Estes dados também foram \\
& obtidos do IMF (2000); \\
& Renda. Foi utilizado o valor total das importações como proxy para a \\
& renda. Os dados foram obtidos no IMF (2000);
\end{tabular}

Quadro 2 - Definição das variáveis utilizadas nos modelos econométricos, as quais foram descritas nos modelos econômicos, e fonte dos dados.

Deve-se ressaltar que as variáveis foram utilizadas no logaritmo, de modo a se obter diretamente os valores das elasticidades desejados. Assim, todas as variáveis descritas no Quadro 2 receberam um prefixo $l n$, indicando esta transformação.

\subsection{Efeitos dos impactos das exportações brasileiras de açúcar sobre a economia brasileira}

A análise de insumo-produto permite vislumbrar a estrutura produtiva de um país ou região, sendo um instrumento adequado quando se deseja estudar as interrelações econômicas existentes entre os setores econômicos, quantificar efeitos sobre 
setores produtivos, contas do governo, regiões, nível de emprego, renda das famílias e meio-ambiente, em relação a mudanças que impactam a economia. Trata-se, portanto, de uma técnica adequada à realização de simulações e tomada de decisões referentes a políticas tributária e fiscais, política comercial, alocação de recursos públicos, distribuição de renda, desenvolvimento tecnológico, política de preços e desenhos regulatórios.

Neste estudo foram identificadas as alterações sobre a economia brasileira, diante de mudanças em políticas protecionistas no mercado internacional de açúcar. Com esta finalidade, foi utilizada a análise da matriz de insumo-produto, verificando o impacto derivado de alterações na demanda final das exportações de açúcar.

Inicialmente, foi feita uma análise comparativa do setor de indústria de açúcar em relação aos demais setores da economia nas duas regiões consideradas, Centro-Sul e Norte-Nordeste do Brasil. Para isso, foram calculados os índices de ligação para frente e para trás de Rasmussen-Hirschman e índices puros de ligação para todos os setores da economia. Esses índices avaliam a importância do setor analisado em relação aos demais, e os setores que se apresentam mais relacionados com este.

Para verificar o efeito de reduções nas políticas protecionistas do mercado internacional de açúcar sobre a economia das duas regiões brasileiras consideradas, simulou-se um cenário de eliminação dessas políticas e as respectivas alterações nas exportações brasileiras de açúcar bruto e de açúcar refinado, para cada uma das duas regiões exportadoras, Centro-Sul e Norte-Nordeste. Foi determinado como essas alterações poderão afetar os níveis de produção e emprego, tanto no setor analisado, como na economia brasileira.

\subsubsection{Modelo de insumo-produto}

Nas relações fundamentais do modelo de insumo-produto, a economia deve ser composta por $n$ setores, conforme a eq. (43): 


$$
\sum_{j=1}^{n} z_{i j}+c_{i}+g_{i}+i_{i}+e_{i}=x_{i}
$$

onde:

$z_{i j}=$ produção do setor $i$ que é comprada pelo setor $j$;

$c_{i}=$ produção do setor $i$ que é comprada pelas famílias;

$g_{i}=$ produção do setor $i$ que é comprada pelo governo;

$i_{i}=$ produção do setor $i$ que é destinada ao investimento;

$e_{i}=$ produção do setor $i$ que é destinada a exportação;

$x_{i}=$ produção doméstica total do setor $i$, composta da demanda final e insumos intermediários.

A demanda final da produção do setor $i$, representada por $y_{i}$, é composta pelas variáveis: $c_{i}, g_{i}, i_{i}$ e $e_{i}$. O coeficiente técnico $a_{i j}$, que mostra a quantidade de insumo do setor $i$ necessária para a produção de uma unidade de produto total do setor $j$, é representado da seguinte maneira:

$$
a_{i j}=z_{i j} / x_{j}
$$

Matricialmente, as variáveis $a_{i j}, x_{j}$ e $y_{j}$ formam, respectivamente, a matriz $A$ de dimensão $(n \times n)$, e os vetores $X$ e $Y$ de ordem $(n \times 1)$.

O sistema aberto de Leontief, que considera a proporção dos insumos por unidade do produto final fixo, será:

$$
A X+Y=X
$$

De acordo com Miller \& Blair (1985), as variações na demanda final, $Y$, são determinadas exogenamente e a produção total, $X$, pode ser obtida da seguinte forma:

$$
X=(I-A)^{-1} Y
$$


onde $(I-A)^{-1}$ é a matriz de coeficientes técnicos de insumo diretos e indiretos, conhecida como a matriz inversa de Leontief.

Os pressupostos principais que norteiam a teoria de insumo-produto são:

- equilíbrio geral na economia a um dado nível de preços;

- inexistência de ilusão monetária por parte dos agentes econômicos;

- retornos constantes à escala;

- preços constantes.

Por considerar preços constantes, os resultados descritos nas análises da matriz insumo-produto são considerados como análises de curto prazo.

\subsubsection{Modelo de insumo-produto regional}

Segundo Miller e Blair (1985), os estudos com matrizes regionais podem ser realizados de duas maneiras: (i) com modelos regionais, cujos objetivos são quantificar os impactos de uma variação na demanda final em um setor da região sobre todos os seus setores produtivos; e (ii) com modelos inter-regionais, que além de estudarem os fluxos de produto dentro de cada região, permitem também estudar os fluxos entre as diferentes regiões.

Neste trabalho foi utilizado um estudo inter-regional de duas regiões. As análises inter-regionais são desenvolvidas por meio de coeficientes de insumos intraregionais (dentro de uma região específica) e inter-regionais (entre uma determinada região e as demais). Desta maneira, os fluxos inter-regionais de comércio foram incorporados na análise de cada região, obtendo-se uma análise mais realista dos fluxos existentes na economia brasileira.

Os coeficientes técnicos estimados para o modelo inter-regional, diferentemente do descrito na eq. (44), são obtidos da seguinte maneira:

$$
a_{i j}^{L L}=z_{i j}^{L L} / x_{j}^{L}
$$




$$
\begin{aligned}
& a_{i j}^{M M}=z_{i j}^{M M} / x_{j}^{M} \\
& a_{i j}^{L M}=z_{i j}^{L M} / x_{j}^{M} \\
& a_{i j}^{M L}=z_{i j}^{M L} / x_{j}^{L}
\end{aligned}
$$

Em que $a_{i j}^{L L}$ e $a_{i j}^{M M}$ são os coeficientes intra-regionais; $a_{i j}^{L M}$ e $a_{i j}^{M L}$, os coeficientes interregionais; $z_{i j}^{L L}$ é o fluxo monetário do setor $i$ para o setor $j$ dentro da região $L ; z_{i j}^{M M}$ é o fluxo monetário do setor $i$ para o setor $j$ dentro da região $M ; z_{i j}^{L M}$ e $z_{i j}^{M L}$ são os fluxos monetários do setor $i$ para o setor $j$, respectivamente, da região $L$ para a região $M$ e da região $M$ para a região $L ; x_{j}^{L}$ e $x_{j}^{M}$ são os níveis da produção total do setor $j$, respectivamente, dentro das regiões $L$ e $M$.

Considerando os $n$ setores da economia brasileira, a matriz de coeficientes técnicos $A^{L L}$ pode então ser construída da seguinte maneira:

$$
A^{L L}=\left[\begin{array}{cccccc}
a_{11}^{L L} & a_{12}^{L L} & \cdot & \cdot & \cdot & a_{1 n}^{L L} \\
a_{21}^{L L} & a_{21}^{L L} & \cdot & \cdot & \cdot & a_{2 n}^{L L} \\
\cdot & \cdot & \cdot & & & \cdot \\
\cdot & \cdot & & \cdot & & \cdot \\
\cdot & \cdot & & & \cdot & \cdot \\
a_{n 1}^{L L} & a_{n 2}^{L L} & . & . & \cdot & a_{n n}^{L L}
\end{array}\right]
$$

De maneira semelhante são construídas as matrizes $A^{L M}, A^{M L}$ e $A^{M M}$. As matrizes $A, X$ e $Y$, descritas na eq. (46), que estima a matriz inversa de Leontief, são estimadas da seguinte maneira:

$$
\begin{aligned}
A & =\left[\begin{array}{ccc}
A^{L L} & \vdots & A^{L M} \\
\cdots & \cdots & \cdots \\
A^{M L} & \vdots & A^{M M}
\end{array}\right] \\
X & =\left[\begin{array}{c}
x^{L} \\
\cdots \\
x^{M}
\end{array}\right]
\end{aligned}
$$




$$
Y=\left[\begin{array}{c}
Y^{L} \\
\cdots \\
Y^{M}
\end{array}\right]
$$

O sistema de Leontief é escrito assim:

$$
\left\{\left[\begin{array}{ccc}
I & \vdots & 0 \\
\cdots & \cdots & \cdots \\
0 & \vdots & I
\end{array}\right]-\left[\begin{array}{ccc}
A^{L L} & \vdots & A^{L M} \\
\cdots & \cdots & \cdots \\
A^{M L} & \vdots & A^{M M}
\end{array}\right]\right\}\left[\begin{array}{c}
x^{L} \\
\cdots \\
x^{M}
\end{array}\right]=\left[\begin{array}{c}
Y^{L} \\
\cdots \\
Y^{M}
\end{array}\right]
$$

em que $Y^{L}=\left(I-A^{L L}\right) x^{L}-A^{L M} x^{M}$ e $Y^{M}=-A^{M L} x^{M}+\left(I-A^{M M}\right) x^{M}$.

A estimação da matriz inversa de Leontief a partir da eq. (52) é a principal diferença quando se utiliza uma matriz inter-regional.

\subsection{2 Índices de ligações de Rasmussen-Hirschman}

Rasmussen (1956) e Hirschman (1958) definiram índices de ligações entre os setores da economia, definindo como chaves aqueles altamente dependente de outros setores, seja como demandante (ligação para trás) ou ofertante (ligação para frente) de insumos. Os setores chaves apresentam, segundo esses autores, índice maior do que 1.

Os índices se baseiam na equação $B=(I-A)^{-1}$, que expressa a matriz inversa de Leontief. A matriz I é uma matriz identidade de ordem igual a da matriz $A$, e $A$ foi definida na eq. (51). Pode-se definir $b_{i j}$ como um elemento da matriz $B$ e obter $B^{*}$ como a média de todos os elementos de $B . B_{\bullet j}$ e $B_{i \bullet}$ são, respectivamente, as somas dos elementos de uma coluna e de uma linha de B. Algebricamente, tem-se:

$$
\begin{aligned}
& B_{\bullet j}=\sum_{i=1}^{n} b_{i j} \\
& B_{i \bullet}=\sum_{j=1}^{n} b_{i j}
\end{aligned}
$$


sendo $i, j=1,2, \ldots, \mathrm{n}$.

Assim, obtêm-se os índices de ligações para trás $H_{j}$, poder de dispersão, e os índices de ligações para frente $H_{i}$, sensibilidade da dispersão, respectivamente, como:

$$
\begin{aligned}
& H_{j}=\left[B_{\bullet j} / n\right] / B^{*} \\
& H_{i}=\left[B_{i \bullet} / n\right] / B^{*}
\end{aligned}
$$

Dessa forma, o índice será maior do que 1, se o setor demandar ou ofertar para os demais setores numa proporção maior do que a média apresentada pela economia como um todo.

\subsection{3 Índices puros de ligações interindustriais}

Alternativamente aos índices apresentados no item anterior, os impactos de um setor sobre os demais setores podem ser calculados levando em consideração o tamanho relativo da produção dos setores envolvidos. Assim, tem-se um indicador mais realista da importância do setor analisado em relação aos demais.

A idéia básica é isolar cada setor da economia, de forma a identificar a diferença da produção total da economia com e sem cada um daqueles setores. Matricialmente, esse índice é demonstrado a seguir, conforme descrito em Guilhoto et al. (1996). Os cálculos dos índices puros de ligação iniciam-se pela matriz $A$, matriz de coeficientes de insumos diretos na qual estão representados o setor analisado $j$ e o resto da economia:

$$
A=\left(\begin{array}{ll}
A_{j j} & A_{j r} \\
A_{r j} & A_{r r}
\end{array}\right)
$$

onde $A_{j j}$ e $A_{r r}$ são, respectivamente, matrizes que representam insumos diretos do setor $j$ e do resto da economia; $A_{r j}$ e $A_{j r}$ representam matrizes dos insumos diretos 
comprados pelo setor $j$ do resto da economia e os insumos diretos comprados pelo resto da economia do setor $j$.

A matriz inversa de Leontief, utilizando-se a matriz acima, é dada por:

$$
L=(I-A)^{-1}=\left[\begin{array}{cc}
L_{j j} & L_{j r} \\
L_{r j} & L_{r r}
\end{array}\right]=\left[\begin{array}{cc}
\Delta_{j j} & 0 \\
0 & \Delta_{r r}
\end{array}\right]\left[\begin{array}{cc}
\Delta_{j} & 0 \\
0 & \Delta_{r}
\end{array}\right]\left[\begin{array}{cc}
I & A_{j r} \Delta_{r} \\
A_{r j} & I
\end{array}\right]
$$

e seus elementos são:

$$
\begin{aligned}
& \Delta_{j}=\left(I-A_{j j}\right)^{-1} \\
& \Delta_{r}=\left(I-A_{r r}\right)^{-1} \\
& \Delta_{j j}=\left(I-\Delta_{j} A_{j r} \Delta_{r} A_{r j}\right)^{-1} \\
& \Delta_{r r}=\left(I-\Delta_{r} A_{r j} \Delta_{j} A_{j r}\right)^{-1}
\end{aligned}
$$

Utilizando-se a matriz inversa de Leontief calculada a partir da matriz $A$, que possui o setor $j$ isolado do resto da economia, pode-se calcular:

$$
X=(I-A)^{-1} \cdot Y
$$

e derivar um conjunto de índices que podem ser usados para ordenar os setores tanto em termos de sua importância no valor da produção gerado quanto para verificar como ocorre o processo de produção na economia. Das eq. (58) a (63), tem-se que:

$$
\left(\begin{array}{c}
X_{j} \\
X_{i}
\end{array}\right)=\left(\begin{array}{cc}
\Delta_{j j} & 0 \\
0 & \Delta_{r r}
\end{array}\right)\left(\begin{array}{cc}
\Delta_{j} & 0 \\
0 & \Delta_{r}
\end{array}\right)\left(\begin{array}{cc}
I & A_{j r} \Delta_{r} \\
A_{r j} \Delta_{j} & I
\end{array}\right)\left(\begin{array}{l}
Y_{j} \\
Y_{r}
\end{array}\right)
$$

Continuando a multiplicação do lado esquerdo da equação:

$$
\left(\begin{array}{l}
X_{j} \\
X_{r}
\end{array}\right)=\left(\begin{array}{cc}
\Delta_{j j} & 0 \\
0 & \Delta_{r r}
\end{array}\right)\left(\begin{array}{l}
\Delta_{j} Y_{j}+\Delta_{j} A_{j r} \Delta_{r} Y_{r} \\
\Delta_{r} A_{r j} \Delta_{j} Y_{j}+\Delta_{r} Y_{r}
\end{array}\right)
$$

Os valores de índice puro de ligação para trás $(P B L)$ e índice puro de ligação para frente $(P F L)$ são obtidos como: 


$$
\begin{aligned}
& P B L=\Delta_{r} A_{r j} Y_{j} \\
& P F L=\Delta_{j} A_{j r} \Delta_{r} Y_{r}
\end{aligned}
$$

O índice puro de ligação para trás representa o impacto do valor da produção total do setor $j$ sobre o resto da economia, livre da demanda de insumos próprios e dos retornos do resto da economia para o setor.

O índice puro de ligação para frente representa o impacto do valor da produção total do resto da economia sobre o setor $j$. O índice puro do total das ligações é a soma dos dois índices, que são expressos em valores correntes:

$$
P T L=P B L+P F L
$$

Neste trabalho, como se utilizou matrizes inter-regionais, os índices de ligação (puro e de Rasmussen-Hirschman) foram obtidos de maneira interdependentes, cujos valores trazem os efeitos das interações regionais. Algebricamente, os índices foram calculados utilizando a matriz $A$ descrita na eq. (51).

\subsubsection{Multiplicadores}

Os multiplicadores avaliam o impacto de uma variação na demanda final sobre a variável econômica de interesse (produção, renda, emprego, etc). Neste trabalho foram calculados os multiplicadores de produção na versão tipo I e na versão tipo II. Os impactos na produção e os geradores de emprego direto, indireto e o induzido pelo consumo das famílias foram obtidos a partir dos multiplicadores calculados.

O impacto na produção obtido a partir do multiplicador de produção do tipo I determina o quanto a economia ou o setor em análise terá de produzir para satisfazer uma unidade adicional de demanda final. Este multiplicador toma o consumo das famílias como exógeno.

Já o impacto na produção obtido a partir do multiplicador do tipo II leva em consideração a endogeneização do consumo das famílias, o que operacionalmente 
significa trabalhar com uma matriz $Z$ (transações intersetoriais) com a dimensão $(n+1) \times(n+1)$. Como resultado, os multiplicadores do tipo II embutem efeitos diretos (sobre o próprio setor), indiretos (sobre os demais setores) e induzidos (via consumo endogeneizado da família).

Em relação aos impactos sobre o emprego, a metodologia empregada neste trabalho foi utilizada por Najberg \& Ikeda (1999), que consideraram três tipos de empregos gerados na economia: emprego direto, emprego indireto e o emprego efeitorenda, assim denominado por esses autores.

\subsubsection{Multiplicadores de produção do tipo I}

Fazendo $B=(I-A)^{-1}$ a partir da eq. (51), o multiplicador de produção do setor $j$ na matriz inter-regional será:

$$
M S_{j}=\sum_{i=1}^{n} b_{i j}, \quad j=1, \ldots, n
$$

onde $M S_{j}$ é o multiplicador de produção do tipo I; e $b_{i j}$ é um elemento da matriz inversa de Leontief.

\subsubsection{Multiplicadores de produção do tipo II}

Os multiplicadores de produção calculados apoiam-se sobre uma participação das famílias no consumo final, a qual depende do que é produzido em cada setor. No caso dos multiplicadores do tipo II, o consumo do setor família é transferido da demanda final para a matriz $Z$ de transações intersetoriais e, no caso deste trabalho, interregionais, de onde resultam uma linha e uma coluna adicionais. Esse raciocínio significa tornar o modelo fechado em relação às famílias.

Neste caso, a matriz inversa de Leontief $B$ é obtida a partir de uma matriz $\bar{A}$ de coeficientes técnicos, onde se considera a endogeneização no consumo das famílias, de 
modo que o multiplicador setorial é definido a partir da matriz $\bar{B}=(I-\bar{A})^{-1}$. O multiplicador de produção do tipo II é definido como:

$$
M \bar{S}_{j}=\sum_{i=1}^{n} \bar{b}_{i j}, \quad j=1, \ldots, n
$$

onde $M \bar{S}_{j}$ é o multiplicador de produção do tipo II e $\bar{b}_{i j}$ é um elemento qualquer da matriz inversa de Leontief com o consumo das famílias endogeneizado.

\subsubsection{Impactos na produção}

Para estimar o impacto da variação nas exportações de açúcar das regiões Centro-Sul e Norte-Nordeste do Brasil nas economias daquelas regiões, a matriz com os impactos estimados foi multiplicada pela matriz dos multiplicadores descritos anteriormente.

O valor calculado representa o valor total de produção de toda a economia que é acionada, direta e indiretamente, para atender a variação na demanda final do setor $j$. Matricialmente, essa alteração na produção é descrita como:

$$
\Delta X=B^{*} \Delta Y
$$

As alterações no vetor $Y(\Delta Y)$, decorrem das alterações nas exportações brasileiras de açúcar.

Analogamente, o valor total de produção da economia que é acionado para atender a variação na demanda final do setor $j$, de maneira direta, indireta e pelo efeito renda, é calculado como:

$$
\Delta X=\bar{B} * \Delta Y
$$




\subsubsection{Geração de emprego}

A metodologia empregada para o modelo de geração de emprego foi utilizada por Najberg \& Ikeda (1999). Estes autores consideram três tipos de empregos gerados na economia: emprego direto, emprego indireto e o emprego efeito-renda. A metodologia consiste em associar os multiplicadores de produção aos coeficientes de emprego dos setores da economia, os quais, multiplicados pelos multiplicadores de produção do tipo I, fornecem o número de empregos gerados direta e indiretamente para uma variação na demanda final (também denominados de multiplicador de emprego do tipo I). Os multiplicadores de emprego tipo II, por sua vez, fornecem o número de empregos gerados direta, indiretamente e pela indução, a partir de um incremento na demanda final das famílias, que será denominado de emprego efeito-renda.

\subsection{Emprego direto}

O emprego direto corresponde à mão-de-obra requerida pelo setor em que se observa o aumento da demanda final. Neste caso, a variação na produção ocorre na mesma magnitude da variação na demanda, no setor considerado:

$$
\Delta X_{i}=\Delta Y_{i}
$$

Dado um aumento no nível da demanda final, o aumento correspondente no número de emprego direto gerado $\left(L_{i}\right)$ é dado como:

$$
\Delta L_{i}=\left(\frac{L_{i}}{X_{i}}\right) \Delta X_{i}
$$

em que $L_{i} / X_{i}$ é o coeficiente de emprego do setor $i$. 


\subsection{Emprego indireto}

$\mathrm{O}$ emprego indireto corresponde à mão-de-obra requerida pelos demais setores que fornecem bens intermediários para o setor considerado (i). Para seu cálculo, parte-se do multiplicador de produção do tipo I, que considera a produção gerada direta e indiretamente para uma variação na demanda final do setor $i$. Neste caso, a variação na produção ocorre em uma magnitude maior do que a variação na demanda, no setor $i$ :

$$
\Delta X_{i}=B * \Delta Y_{i}
$$

Assim, dado um aumento no nível da demanda final, o aumento correspondente no número de empregos gerados ( $L^{\text {ind }+d i r}$ ) é dado como:

$$
\Delta L^{i n d+d i r}=\lambda * B * \Delta Y_{i}
$$

em que $\lambda$ é o vetor $1 \times n$ dos coeficientes de emprego para os $n$ setores da economia.

O número de empregos gerados na eq. (76) corresponde aos empregos diretos e indiretos. Assim, o número de empregos indiretos $\left(\Delta L^{\text {ind }}\right)$ gerados na economia são obtidos por diferença:

$$
\Delta L^{i n d}=\Delta L^{i n d+d i r}-\Delta L_{i}
$$

\subsection{Emprego efeito-renda}

Como descrito no item 3.2.4.2, incorporando o consumo das famílias na matriz de transações intersetoriais, pode-se verificar o aumento do emprego, ocasionado por um aumento de renda. Segundo Najberg \& Ikeda (1999), isso se justifica pelo fato de o consumo privado representar mais de $60 \%$ da renda. $\mathrm{O}$ raciocínio de funcionamento desse sistema é o seguinte: parte da receita das empresas obtida com a venda do produto que aumentou sua demanda se transforma em renda dos trabalhadores ou dos empresários, por meio do pagamento de salários ou do recebimento de dividendos. 
Ambos gastarão parcela de sua renda consumindo bens e serviços de outros setores e realimentando o processo de geração de emprego na economia.

Para estimar a quantidade de emprego efeito-renda na economia, parte-se da matriz inversa de Leontief $\bar{B}=(I-\bar{A})^{-1}$ definida anteriormente. Em relação aos empregos gerados em decorrência da elevação de uma unidade monetária de demanda final pelo produto de um setor $i$, tem-se que a mudança no número de empregos será dada por:

$$
\Delta L^{E R+i n d+d i r}=\lambda * \bar{B} * \Delta Y
$$

onde $(\lambda * \bar{B})$ é o multiplicador de emprego do tipo II.

Como no multiplicador de emprego tipo I, os valores resultantes sinalizam postos gerados a partir de uma certa variação na demanda final do setor $j$.

O número de empregos gerados na eq. (78) corresponde aos empregos diretos, indiretos e de efeito-renda. Assim, o número de empregos efeito-renda é obtido pela diferença entre $\Delta L^{E R+i n d+d i r}$ e o número de empregos diretos e indiretos $\left(\Delta L^{i n d+d i r}\right)$ gerados na economia:

$$
\Delta L^{E R}=\Delta L^{E R+i n d+d i r}-\Delta L^{i n d+d i r}
$$

em que $\Delta L^{E R}$ é o número de postos de empregos gerados pelo efeito-renda.

Como foram analisadas matrizes inter-regionais, os multiplicadores de produção e de emprego estimados correspondem aos níveis de produção e emprego gerados na região em que foi dado o choque, assim como nas demais regiões consideradas.

\subsubsection{Matriz de insumo-produto utilizada}

A definição da matriz insumo-produto utilizada é importante para a obtenção dos resultados a serem investigados no presente trabalho. Foi utilizada uma matriz de insumo-produto inter-regional do Brasil, para o ano de 1999. As regiões consideradas 
foram: Centro-Sul e Norte-Nordeste. A estimação da matriz de 1999 e sua desagregação nas duas regiões analisadas e nos setores estudados foi obtida por Guilhoto ${ }^{23}$. Na região Centro-Sul, considerou-se os estados: Distrito Federal, Goiás, Mato Grosso, Mato Grosso do Sul, Espírito Santo, Minas Gerais, Rio de Janeiro, São Paulo, Paraná, Santa Catarina e Rio Grande do Sul. E para compor a região Norte-Nordeste, foram considerados todos os estados da região Norte e Nordeste.

Em relação aos setores descritos nessa matriz, a fim de se ter uma maior riqueza de informações, foram desagregados alguns setores de maior interesse para o estudo, enquanto outros setores, os quais possuem menores relações com o objetivo deste trabalho, foram agregados. Em relação à matriz insumo-produto formada por 42 setores, divulgada pelo IBGE, foram desagregados os setores cana-de-açúcar do setor agropecuária e álcool do setor de elementos químicos. A matriz utilizada foi composta por 20 setores, os quais estão descritos no Quadro 3, juntamente com os setores correspondentes da matriz divulgada pelo IBGE que foram agregados para construir a matriz utilizada.

\begin{tabular}{|c|c|c|}
\hline \begin{tabular}{|l|}
$\begin{array}{l}\mathrm{N}^{0} \text { do } \\
\text { setor }\end{array}$ \\
\end{tabular} & $\begin{array}{l}\text { Nome do setor da matriz } \\
\text { utilizada }\end{array}$ & $\begin{array}{l}\text { Setores agregados em relação a matriz } \\
\text { divulgada pelo IBGE }\end{array}$ \\
\hline 1 & Cana-de-açúcar & \\
\hline 2 & Resto agropecuária & Agropecuaria \\
\hline \multirow[t]{2}{*}{3} & Extrativa & Extrativa mineral \\
\hline & & Extração de petróleo e gás \\
\hline \multirow[t]{3}{*}{4} & Metalurgia & Siderurgia \\
\hline & & Metalurgia não-ferrosos \\
\hline & & Outros metalúrgicos \\
\hline 5 & Máquinas e tratores & \\
\hline \multirow[t]{2}{*}{6} & Material elétrico e eletrônico & Material elétrico \\
\hline & & Equipamentos eletrônicos \\
\hline \multirow[t]{2}{*}{7} & Material de transporte & Automóveis, caminhões e ônibus \\
\hline & & Outros veículos e peças \\
\hline
\end{tabular}

Quadro 3 - Definição dos setores que compõem a matriz insumo-produto utilizada neste trabalho.

${ }^{23}$ GUILHOTO, J.J.M. (USP. FEA. Departamento de Economia, São Paulo). Comunicação pessoal, 2003. 


\begin{tabular}{|c|c|c|}
\hline $\begin{array}{l}\mathrm{N}^{\mathrm{o}} \text { do } \\
\text { setor }\end{array}$ & $\begin{array}{l}\text { Nome do setor da matriz } \\
\text { utilizada }\end{array}$ & $\begin{array}{l}\text { Setores agregados em relação a matriz } \\
\text { divulgada pelo IBGE }\end{array}$ \\
\hline \multirow[t]{2}{*}{8} & \multirow{2}{*}{$\begin{array}{l}\text { Madeira, mobiliário, celulose, } \\
\text { papel e gráfica }\end{array}$} & Madeira e mobiliário \\
\hline & & Papel e gráfica \\
\hline 9 & Álcool & \multirow[b]{2}{*}{ Elementos químicos } \\
\hline 10 & $\begin{array}{c}\text { Outros elementos químicos } \\
\text { não petroquímicos }\end{array}$ & \\
\hline 11 & Refino do petróleo & \\
\hline \multirow[t]{3}{*}{12} & \multirow[t]{3}{*}{ Produtos do refino do petróleo } & Químicos diversos \\
\hline & & Farmacêutica e de perfumaria \\
\hline & & Artigos de plástico \\
\hline \multirow[t]{3}{*}{13} & \multirow[t]{3}{*}{ Têxtil, vestuário e calçados } & Indústria têxtil \\
\hline & & Artigos do vestuário \\
\hline & & Fabricação de calçados \\
\hline 14 & Fabricação de açúcar & \\
\hline \multirow[t]{6}{*}{15} & \multirow[t]{6}{*}{ Outros produtos alimentares } & Indústria do café \\
\hline & & Benef. prod. vegetais \\
\hline & & Abate de animais \\
\hline & & Indústria de laticínios \\
\hline & & Fab. óleos vegetais \\
\hline & & Outros prod. alimentares \\
\hline \multirow[t]{3}{*}{16} & \multirow[t]{3}{*}{ Indústrias diversas } & Minerais não metálicos \\
\hline & & Indústria da borracha \\
\hline & & Indústria diversas \\
\hline 17 & \multicolumn{2}{|c|}{ Serviços industriais de utilidade pública } \\
\hline 18 & \multicolumn{2}{|l|}{ Construção civil } \\
\hline 19 & Serviços prestados às famílias & \\
\hline \multirow[t]{8}{*}{20} & \multirow[t]{8}{*}{ Outros serviços } & Comércio \\
\hline & & Transportes \\
\hline & & Comunicações \\
\hline & & Instituiçōes financeiras \\
\hline & & Serviços prestados às empresas \\
\hline & & Aluguel de imóveis \\
\hline & & Administração pública \\
\hline & & Serviços privados não mercantis \\
\hline
\end{tabular}

Quadro 3 - Definição dos setores que compõem a matriz insumo-produto utilizada neste trabalho. 


\section{RESULTADOS E DISCUSSÃO}

Neste capítulo, a apresentação dos resultados foi dividida em duas etapas: uma primeira em que se apresentam os resultados do impacto das medidas protecionistas analisadas sobre as exportações brasileiras de açúcar bruto e de açúcar refinado, acompanhado de sua discussão; e uma segunda, em que se apresentam as alterações nas economias das regiões Centro-Sul e Norte-Nordeste do Brasil, resultantes da ausência de políticas protecionistas consideradas no estudo, também acompanhados de sua discussão.

A primeira etapa, por sua vez, foi sub-dividida em quatro partes. Na primeira parte foram apresentados os resultados dos modelos da oferta de exportação de açúcar das regiões Centro-Sul e Norte-Nordeste do Brasil estimados, seguidos de sua análise. Na segunda parte, apresentou-se uma estimativa do impacto de uma redução de medidas políticas protecionistas no mercado de açúcar dos EUA, sobre as exportações brasileira de açúcar para os Estados Unidos.

As terceira e quarta partes também apresentam os resultados de uma estimativa do impacto sobre as exportações brasileiras, resultantes de uma redução da proteção ao mercado de açúcar da União Européia, proporcionada pela Política Agrícola Comum (PAC), acompanhadas de uma avaliação dos resultados. Neste âmbito, avaliaram-se dois efeitos: (i) o impacto sobre as exportações brasileiras de açúcar bruto para a UE; e (ii) o impacto sobre as exportações brasileiras de açúcar refinado para alguns dos principais importadores da commodity, comuns ao Brasil e à União Européia. 


\subsection{Funções de exportações brasileiras de açúcar}

Conforme apresentado na parte introdutória deste trabalho e no Apêndice 1, são bastante distintas as características das regiões exportadoras de açúcar no Brasil (região Centro-Sul e Norte-Nordeste). Estas diferenças referem-se ao tipo e ao volume de açúcar produzido e exportado pelas duas regiões.

Os resultados de estimativas das funções de oferta das exportações brasileiras de açúcar bruto das regiões Centro-Sul e do Norte-Nordeste são apresentados e discutidos neste item.

\subsubsection{Função de exportação de açúcar bruto na região Centro-Sul}

Neste item foram apresentados e discutidos os resultados da função de exportação de açúcar bruto na região Centro-Sul do Brasil. A estimação do modelo econômico, elaborado no item 3.1.1.2, foi realizada utilizando uma análise em painel, considerando alguns dos principais países importadores.

Procurando estabelecer um padrão de comportamento das exportações do Centro-Sul do Brasil, onde a mudança estrutural causada pelo processo de desregulamentação não influenciasse as elasticidades do modelo, foram consideradas, para a estimativa da as exportações para os principais países importadores, e que importaram de maneira constante, a partir de 1996.

Dentre os países descritos como maiores importadores de açúcar bruto da região Centro-Sul ${ }^{24}$, não foram consideradas as exportações para Arábia Saudita e Malásia, que importaram somente a partir de 1998, e Indonésia, que não importou nos anos de 1996 e 2000. Portanto, a estimação da função de oferta das exportações de açúcar bruto da região Centro-Sul considerou as exportações para Rússia, Emirados Árabes Unidos, Egito, Irã, Costa do Marfim, Canadá, Marrocos, Romênia, Nigéria,

\footnotetext{
${ }^{24}$ Para identificar os principais países importadores, estes foram ordenados de maneira decrescente em volume importado, onde se considerou a média destas importações de 1996 a 2002.
} 
Argélia, Bulgária e Ucrânia, que agregam cerca de $76 \%$ das exportações consideradas para fins desta análise no período de 1996 a 2002. A Tabela 49 do Apêndice 2 descreve o volume e o preço (valor dividido pelo volume de exportação) de exportação dos países considerados, assim como a estimação desses valores onde a exportação da região foi zero.

Para eliminar problemas econométricos observados ao se utilizar todos os países descritos na Tabela 49, foi necessário agrupar os países, considerando: África (Argélia, Costa do Marfim, Marrocos e Nigéria); Europa (Bulgária, Romênia e Ucrânia); Países Árabes e Egito (Emirados Árabes, Irã e Egito); Rússia e Canadá. O Egito foi agrupado com os países Árabes e não com outros países africanos, em razão da similaridade, em termos de volume, das exportações para esse país com as verificadas para os Emirados e Irã. A Tabela 50 no Apêndice 2 descreve todas as variáveis utilizadas na estimação da função de exportação de açúcar bruto da região Centro-Sul.

Como descrito anteriormente, o uso do preço médio de exportação de açúcar refinado na região justifica-se pelo fato de o Brasil pertencer à categoria dos países exportadores que podem mudar a proporção de açúcar bruto e açúcar refinado em seu mix de exportação, de acordo com o premium da relação de preços entre esses produtos. Assim, com o excedente doméstico de açúcar bruto utilizado para exportação, os usineiros podem ser estimulados a exportar o açúcar no estado bruto, ou refiná-lo, dependendo das condições de preços oferecidos por cada um dos produtos no mercado internacional.

Em relação à variável representativa do deslocamento de oferta doméstica de açúcar bruto, não foram significativas no modelo tanto a variável representativa do preço quanto da quantidade produzida de álcool combustível, seja de anidro ou de hidratado. O fato do álcool não ser uma variável significativa no deslocamento da produção de açúcar pode ser explicado pelo fato de que, como o açúcar possui um mercado internacional, os preços e, conseqüentemente, a produção caminha no sentido do açúcar para o álcool, e não o inverso. A ausência de relação causal do preço de álcool anidro para o preço de 
açúcar cristal foi constatado por Costa (2000) e Alves (2002), para o Estado de São Paulo.

Selecionadas as variáveis do modelo, foram realizadas, inicialmente, análises econométricas, constatando-se problemas de heterocedasticia e correlação entre as unidades cross-section; além de autocorrelação e estrutura auto-regressiva em cada unidade cross-section. Foi identificado um processo auto-regressivo de ordem 1 para Canadá, Europa e Rússia. Em função do pequeno número de observações na série temporal, os resultados de heterocedasticia e autocorrelação de resíduos não foram conclusivos. O resultado mais expressivo foi a ocorrência de altos valores de correlação serial em grande parte dos países.

Os resultados sugerem que o método Parks para estimação do modelo econométrico foi o mais indicado. Além disso, este método mostrou-se mais eficiente, com altos níveis de significância dos coeficientes estimados, o que não ocorreu quando utilizado o método de Fuller. Entretanto, a estimação pelo método de Fuller não apresentou coeficientes estimados com sinais contraditórios em relação ao método escolhido.

Os valores dos coeficientes estimados são descritos na Tabela 19. Os valores entre parênteses, abaixo dos coeficientes, indicam os níveis de significância dos testes ' $\mathrm{t}$ ' correspondentes.

Os sinais de todas as variáveis (lnpe, lntc, lnpd, lnpref e lnren) foram coerentes com o esperado pelo modelo econômico elaborado anteriormente. Os coeficientes estimados descrevem que a variação de $1 \%$ no preço de exportação de açúcar bruto da região Centro-Sul provoca uma variação, no mesmo sentido, de 1,28\% no volume exportado. Já a variação de $1 \%$ na taxa de câmbio do país altera, no mesmo sentido, as exportações em $1,18 \%$. Outra elasticidade interessante de ser analisada em termos do comércio internacional é a elasticidade-preço de oferta cruzada para açúcar refinado. Segundo as estimativas obtidas, tem-se que uma alteração de $1 \%$ no preço de açúcar refinado para exportação causa uma variação de sentido oposto na exportação de açúcar bruto de 3,9\%. Esta elasticidade evidencia a proposição de que o Brasil, e 
especificamente a região Centro-Sul, altera seu mix de exportação de açúcar bruto e refinado, conforme o comportamento dos preços de exportação destes produtos.

Tabela 19. Estimativas das elasticidades de oferta de exportação de açúcar bruto na região Centro-Sul do Brasil.

\begin{tabular}{ccccccc}
\hline & Intercepto & lnpe & lntc & lnpd & lnpref & lnren \\
\hline Volume & 209,029 & 1,284 & 1,185 & 1,527 & $-3,909$ & $-9,781$ \\
exportado (lnxe) & & & & & & \\
& $(0,00)$ & $(0,00)$ & $(0,00)$ & $(0,00)$ & $(0,00)$ & $(0,00)$ \\
& & & & & & \\
$\mathrm{R}^{2}=95 \%$ & & & & & & \\
\hline
\end{tabular}

Fonte: resultados de pesquisa.

Nota: $\ln x e=\operatorname{logaritmo}$ da quantidade exportada; lnpe $=$ Logaritmo do preço de exportação, em US $\$ / \mathrm{kg}$; lntc = logaritmo do índice taxa de câmbio efetiva real; $\operatorname{lnp} d=$ logaritmo do preço doméstico de açúcar da região Centro-Sul, em $\mathrm{R} \$ / \mathrm{kg}$; lnpref = logaritmo do preço de exportação de açúcar refinado, em US $\$ / \mathrm{kg}$; lnren = logaritmo da variável PIB, utilizada como proxy para estimar o efeito renda.

Os valores das elasticidades estimadas para as variáveis que deslocam a exportação de açúcar bruto pelo aumento de demanda doméstica de açúcar refinado (lnpd e lnren), também foram significativas. Espera-se que, o aumento de $1 \%$ no preço doméstico de açúcar refinado do Centro-Sul reduziria a sua demanda doméstica, aumentando a exportação de açúcar bruto em 1,5\%. Em relação a renda doméstica, espera-se que o aumento de $1 \%$ na renda reduza, aproximadamente, em 9,8\% as exportações de açúcar bruto do Centro-Sul do Brasil. 


\subsubsection{Função de exportação de açúcar na região Norte-Nordeste}

A estimação da função de oferta elaborada no item 3.1.1.2 foi realizada utilizando dados em painel, considerando exportações para: Rússia, Bulgária, Egito e a soma das exportações para os demais países, exceto Estados Unidos. As exportações para os Estados Unidos não foram consideradas na estimação da oferta das exportações da região Norte-Nordeste, uma vez que foram limitadas pelas quotas impostas por aquele país. Dessa maneira, considerou-se cerca de $86 \%$ do volume e $75 \%$ do valor exportado pela região Norte-Nordeste, no período de 1996 a 2002.

Conforme descrito anteriormente, as exportações de açúcar da região NorteNordeste no período estudado foram, predominantemente, de açúcar bruto. As exportações de açúcar refinado ocorreram apenas marginalmente. Assim, ao contrário do que se observa na região Centro-Sul, não houve um efeito de substituição entre as exportações de açúcar bruto e de açúcar refinado ${ }^{25}$.

Da mesma maneira que no Centro-Sul, em relação à variável representativa do deslocamento de oferta doméstica de açúcar bruto, tanto a variável representativa do preço quanto da quantidade produzida de álcool combustível não foram significativas no modelo estimado.

Estima-se também que, com base em dados de produção e exportação (UNICA, 2002; Brasil, 2003b), a participação da produção da região Norte-Nordeste destinada ao consumo doméstico foi cerca de 18\% do consumo do Brasil no período de 1996 a 2002, enquanto esta mesma participação foi de $82 \%$ para a região Centro-Sul. Assim, acreditase que a produção do Norte-Nordeste é consumida basicamente na própria região, havendo uma "fronteira móvel" até onde o açúcar é economicamente viável importar do Centro-Sul, devido ao frete, considerando-se que este irá competir com o açúcar produzido naquela região. Como proxy para a renda, que afeta o excedente exportável de açúcar na região Norte-Nordeste, foi utilizada uma variável que representa apenas o

${ }^{25}$ Isto pode ser explicado pela baixa qualidade de cana produzida naquela região, dificultando a obtenção de um açúcar de melhor qualidade e desestimulando, assim, investimentos para melhorar o produto exportado. 
nível de renda regional. Considerou-se, então, o índice que mede a produção de alimentos da região Norte-Nordeste, fornecido pelo IBGE, como proxy para a renda da região Norte-Nordeste. A Tabela 51 do Apêndice 2 descreve as variáveis utilizadas na estimação do modelo.

Analisando os dados que compõem o modelo para estimação econométrica apropriada, identificou-se que, em função do número de observações limitado que compõe a série temporal, os resultados de heterocedasticia e autocorrelação de resíduos não foram conclusivos. No entanto, de forma similar ao observado na estimação do modelo anterior, observaram-se altos valores de correlação serial em grande parte dos países. Assim, o método de Parks mostrou-se mais eficiente que o método de Fuller, embora este último não tenha apresentado resultados contraditórios em relação aos obtidos com o método de Parks. A Tabela 20 apresenta os valores dos coeficientes estimados e, entre parênteses, os valores dos níveis de significância dos testes ' $t$ ' correspondentes.

Tabela 20. Estimativas das elasticidades de oferta de exportação de açúcar bruto na região Norte-Nordeste do Brasil.

\begin{tabular}{cccccc}
\hline & Intercepto & lnpe & lntc & lnpd & lnren \\
\hline $\begin{array}{c}\text { Volume exportado } \\
(\text { lnxe })\end{array}$ & $-4,82$ & 0,71 & 4,03 & 0,82 & $-0,11$ \\
& $(0,60)$ & $(0,42)$ & $(0,01)$ & $(0,24)$ & $(0,93)$ \\
$\mathrm{R}^{2}=28 \%$ & & & & & \\
\hline
\end{tabular}

Fonte: resultados de pesquisa.

Nota: $\ln x e=$ logaritmo da quantidade exportada; Inpe $=$ Logaritmo do preço de exportação, em US\$/kg; lntc = logaritmo do índice taxa de câmbio efetiva real; lnpd = logaritmo do preço doméstico de açúcar da região, em $\mathrm{R} \$ / \mathrm{kg}$; lnren = logaritmo da variável PIB, utilizada como proxy para estimar o efeito renda da região analisada. 
Os sinais das variáveis lnpe, lntc, lnpd e lnren foram coerentes com o esperado pelo modelo econômico. Verifica-se que os coeficientes estimados indicam que a variação de $1 \%$ no preço de exportação do açúcar bruto da região Centro-Sul provoca uma variação no mesmo sentido de $0,7 \%$ no volume exportado. Já a variação de $1 \%$ na taxa de câmbio do país altera, no mesmo sentido, as exportações em 4\%. Considerando as variáveis deslocadoras da exportação pelo lado da demanda doméstica de açúcar refinado, estimou-se que o aumento de $1 \%$ no preço doméstico de açúcar refinado, reduziria a demanda naquela região, aumentando as exportações de açúcar bruto em $0,8 \%$. E o aumento de $1 \%$ da renda na região Norte-Nordeste, reduziria em $0,11 \%$ o volume de açúcar bruto exportado pela região. Os resultados levam a concluir, ainda, que o modelo não foi bem especificado face à baixa capacidade de explicação das variáveis especificadas no modelo. Um fator que pode explicar essa deficiência são os sérios problemas climáticos enfrentados na região. Ao contrário da ampla possibilidade de expansão da produção de cana-de-açúcar e exportação de açúcar do Centro-Sul, a produção no Norte-Nordeste apresenta-se estagnada e, portanto, não responde de maneira expressiva aos fatores incluídos na função de exportação.

Com relação à função de exportação da região Centro-Sul, observa-se que aquela região apresentou os maiores e mais significativos coeficientes (exceto para a variável taxa de câmbio), ao contrário dos estimados para as exportações do NorteNordeste. Isso pode ser justificado pelos menores custos de produção no Centro-Sul, fazendo com que esta região se apresente mais sensível a variações, principalmente aos preços das exportações.

A seguir são estimados os impactos da redução das políticas protecionistas dos Estados Unidos e da União Européia, incidentes no mercado de açúcar, sobre as exportações brasileiras.

Como verificado na revisão sobre o mercado internacional de açúcar, os países desenvolvidos importam, predominantemente, açúcar do tipo bruto para refinar dentro do país. Esta é uma tendência geral desses países, uma vez que o refino é um processo industrial, e a competitividade pode ser idêntica, ou mesmo superior, à verificada na 
indústria brasileira. Portanto, os impactos das barreiras impostas sobre a importação de açúcar por parte dos países desenvolvidos foram analisados enfocando as exportações brasileiras de açúcar do tipo bruto ${ }^{26}$.

Por outro lado, os subsídios incidentes nos países da União Européia promoveram a exportação de açúcar refinado desse bloco para o mercado mundial, dado que países menos desenvolvidos importam, predominantemente, açúcar do tipo refinado $^{27}$. Verificou-se o impacto da redução de subsídios no mercado de açúcar da União Européia sobre as exportações brasileiras de açúcar do tipo refinado.

\subsection{Impactos da redução de políticas protecionistas no mercado de açúcar dos EUA sobre as exportações de açúcar bruto do Brasil para os EUA}

As exportações brasileiras de açúcar bruto sofrem dois tipos de restrições de demanda no mercado norte-americano: apoio interno com preço doméstico mais elevado do que no mercado internacional e quota tarifária. Desta maneira, preços mais elevados reduziriam a demanda de importação dos EUA, assim como a presença das quotas tarifárias, uma vez que a tarifa extra-quota torna proibitiva as importações norteamericanas acima do volume estabelecido.

Para se estimar as alterações das exportações brasileiras de açúcar ocasionadas por mudanças nos mecanismos de apoio interno e quota tarifária, utilizou-se o modelo descrito por Gardner (1987) no item 3.1.1.1. Para isso, as políticas existentes foram previamente transformadas em equivalente tarifário.

\footnotetext{
${ }^{26}$ Cerca de $96 \%$ das importações de açúcar dos EUA e da UE, no período de 1989 a 2001, foram de açúcar do tipo bruto. Neste mesmo período, as exportações brasileiras de açúcar bruto para os EUA responderam por cerca de $10 \%$ do valor das exportações nacionais deste tipo de açúcar, sendo 9,75\% exportados pela região Norte-Nordeste. Já as exportações de açúcar bruto para o mercado da UE foram cerca de $0,57 \%$ do valor das exportações de açúcar bruto da região Centro-Sul e 1,73\% destas exportações na região Norte-Nordeste.

27 Segundo dados da FAO (2003), as importações de açúcar refinado dos países de baixa renda correspondem a mais de $70 \%$ das importações de açúcar dos tipos bruto e refinado nos últimos anos. $\mathrm{E}$ considerando as importações mundiais, exceto os países desenvolvidos, esta participação tem sido acima de $50 \%$ desde 1998.
} 
O modelo de Gardner (1987) se baseia em dois componentes importantes: elasticidade-preço de oferta da exportação e elasticidade-preço de demanda da importação. $\mathrm{O}$ valor da elasticidade-preço de exportação estimada anteriormente para o Brasil indicou o comportamento da oferta das exportações brasileiras em conseqüência de uma alteração neste preço. Em seguida, foi estimada a função de demanda dos EUA. A elasticidade-preço de demanda dos EUA, pelas exportações de açúcar bruto da região Centro-Sul e da região Norte-Nordeste, foi relacionada, especificamente, às exportações brasileiras daquelas duas regiões, uma vez que se considerou que as elasticidades de demanda são diferenciadas em relação ao país exportador, e que são diferentes para os mercados importadores considerados. A Figura 20 descreve os modelos de oferta e demanda a serem estimados para compor o modelo de Gardner (1987).

\subsubsection{Demanda de importação de açúcar bruto dos Estados Unidos}

Para estimar a elasticidade-preço da demanda de importação de um país, para um produto originado de um dado país exportador, inicialmente foram estimadas as eq. (22) e (24) descritas no item 3.1.1.3. Essas equações estimam, respectivamente, a elasticidade-preço de substituição do açúcar brasileiro em relação ao originado de outros países que exportam para este mercado, e de demanda do país importador considerado.

O estudo foi realizado a partir de 1982, porque a partir deste ano foram impostas as quotas de importação de açúcar nos EUA, estabelecendo um padrão de comportamento uniforme em relação às medidas protecionistas adotadas no país desde então.

Considerando o comportamento das importações anuais de açúcar bruto dos EUA, estimaram-se as elasticidades-preço e de substituição. Os valores das variáveis utilizadas para estimação desses coeficientes são descritos na Tabela 52 do Apêndice 3.

É importante lembrar que a estimativa da elasticidade-preço de demanda pela importação de açúcar bruto foi realizada utilizando o valor do preço doméstico dos EUA para o açúcar (valores apresentados pelo contrato $n^{\circ} 14$ da Bolsa de Nova Iorque). Isto 
foi feito porque, como apresentado na Figura 17 e descrito no capítulo metodológico, a curva de demanda por importação passa pelo preço doméstico, que é o preço resultante dos programas de empréstimo dos EUA e de quota tarifária. Como o propósito foi estimar a redução do equivalente tarifário referente àquelas políticas protecionistas, o impacto se daria no preço doméstico, refletindo então nas suas importações. De outra maneira, para estimar a elasticidade-preço de substituição, foi considerada a relação do preço de importação do produto brasileiro com o preço de importação geral do açúcar bruto nos EUA, e não com o preço doméstico. Isto se justifica porque, neste caso, estima-se a substituição do açúcar brasileiro em relação ao originado em outros países exportadores para o mercado norte-americano, e não em relação ao preço do produto no mercado doméstico dos EUA.

Inicialmente, foi realizada uma análise nas séries das variáveis utilizadas em relação à presença de raiz unitária e de co-integração. Os modelos de elasticidade de substituição e de demanda por importação de açúcar bruto dos EUA foram estimados a seguir, utilizando os resultados da análise temporal das variáveis.

\subsubsection{Análise das séries de tempo}

$\mathrm{Na}$ Tabela 21, são apresentados os resultados referentes à análise de raiz unitária das variáveis utilizadas na estimação das equações propostas por Armington (1969) para calcular as elasticidades-preço de demanda por importação diferenciada por local de origem.

Os resultados indicam a presença de raiz unitária ao nível de significância de $1 \%$, na maioria das variáveis consideradas no estudo, uma vez que foram aceitas as hipóteses de estacionariedade nos modelos na primeira diferença destas variáveis. Para todas as variáveis analisadas foram encontrados altos níveis de significância da estatística "Q" do teste de Box-Pierce, rejeitando a hipótese de nulidade deste teste, que considera a existência de autocorrelação entre os resíduos. 
Tabela 21. Teste de raiz unitária, estatísticas $\tau_{\tau}, \tau_{\mu}$ e $\tau$.

\begin{tabular}{lccccc}
\hline Variáveis & $\begin{array}{c}\text { Defasagens } \\
(\mathrm{n})\end{array}$ & $\begin{array}{c}\text { Modelo (a) } \\
\mathrm{H}_{0}: \gamma=0\end{array}$ & $\begin{array}{c}\text { Modelo (b) } \\
\mathrm{H}_{0}: \gamma=0\end{array}$ & $\begin{array}{c}\text { Modelo (c) } \\
\mathrm{H}_{0}: \gamma=0\end{array}$ & $\begin{array}{c}\text { Modelo (d), } \\
\mathrm{H}_{0}: \gamma=0\end{array}$ \\
\hline $\ln M_{i}$ & 2 & -2.86 & -3.03 & -0.95 & $-3.81^{*}$ \\
$\ln p d$ & 2 & -1.61 & -1.94 & -0.02 & $-4.67^{*}$ \\
$\ln t c$ & 2 & -0.02 & -2.36 & -0.73 & $-2.38^{* *}$ \\
$\ln r e n$ & 1 & -3.15 & -1.25 & 1.9 & $-1.83^{\mathrm{ns}}$ \\
$\ln \left(M_{i j} / M_{i}\right)$ & 1 & -3.67 & -3.53 & -0.5 & $-6.03^{*}$ \\
$\ln \left(P_{i j} / P_{i}\right)$ & 1 & -2.54 & -3.10 & $-3.09 *$ & $-4.21^{*}$ \\
\hline
\end{tabular}

Fonte: resultados de pesquisa.

Nota: $\ln M_{i}=$ Logaritmo do volume total importado de açúcar; $\ln p d=$ logaritmo do preço doméstico de açúcar bruto; lntc = logaritmo do índice taxa de câmbio efetiva real; lnren = logaritmo da variável PIB utilizada como proxy para estimar o efeito renda; $e_{\mathrm{t}-1}$ é o termo de correção de erro dos modelos estimados; $\ln \left(M_{i j} / M_{i}\right)=$ Logaritmo da participação das importações originadas do país $j$ nas importações totais do país $i ; \ln \left(P_{i j} / P_{i}\right)=$ Logaritmo da relação entre o preço de importação do país $j$ no preço geral da importação do país $i$.

* Significativo ao nível de significância de 1.

** Significativo ao nível de significância de 5\%. Valores críticos segundo Dickey \& Fuller (1981) e Fuller (1976)

Apenas a variável lnren não foi estacionária na primeira diferença. Entretanto, apresenta um valor próximo do nível de significância, tanto em nível quanto nas diferenças. Assim, ao nível de $10 \%$ de significância, a variável lnren pode ser considerada estacionária na primeira diferença, ou seja, I(1).

Em seguida, foram realizados os testes de co-integração entre as variáveis utilizadas em cada uma das duas equações estimadas, de elasticidade de substituição e de demanda geral de importação de açúcar bruto dos EUA. Para estimação da cointegração, foi utilizado o modelo de Johansen, conforme descrito na parte 
metodológica. Os resultados da estimação da presença de co-integração entre aquelas equações são apresentados na Tabela 22.

Tabela 22. Teste de co-integração de Johansen.

\begin{tabular}{ccccc}
\hline Equação & Hipótese Nula & $\begin{array}{c}\text { Hipótese } \\
\text { Alternativa }\end{array}$ & $\lambda_{\max }$ & $\lambda_{\text {trace }}$ \\
\hline Demanda geral & $\mathrm{r} \leq 3$ & $\mathrm{r}=4$ & 8.22 & 8.22 \\
de importação - & $\mathrm{r} \leq 2$ & $\mathrm{r}=3$ & 15.24 & 23.46 \\
eq. (24) & $\mathrm{r} \leq 1$ & $\mathrm{r}=2$ & 19.83 & $43.29^{*}$ \\
& $\mathrm{r} \leq 0$ & $\mathrm{r}=1$ & $107.17^{*}$ & $150.47^{*}$ \\
Elasticidade de & $\mathrm{r} \leq 1$ & $\mathrm{r}=2$ & 8.92 & 8.92 \\
$\begin{array}{c}\text { substituição }- \\
\text { eq. }(22)\end{array}$ & $\mathrm{r} \leq 0$ & $\mathrm{r}=1$ & 10.39 & 19.32 \\
\hline
\end{tabular}

Fonte: resultados de pesquisa.

* Significativo a 1\% de significância. Valores críticos em Osterwald-Lenum (1992).

Modelo com constante restrito ajustado com três defasagens.

Os resultados apresentados indicaram que os testes do máximo autovalor $\left(\lambda_{\max }\right)$ e do traço $\left(\lambda_{\text {trace }}\right)$ foram significativos para a hipótese nula de que há pelo menos um vetor de co-integração, apenas para o modelo de demanda por importação. Portanto, os resultados mostraram que há relação de equilíbrio de longo prazo entre as variáveis deste modelo. Entretanto, os testes de máximo autovalor e do traço foram conflitantes na indicação de um segundo vetor de correção de erro. Desta maneira, foram estimadas equações utilizando um e dois vetores, e o nível de significância deste segundo vetor foi utilizado para estabelecer a sua inclusão no modelo.

Em relação à equação de elasticidade de substituição, não foi identificado nenhum vetor de co-integração ao nível de $1 \%$ de significância. Entretanto, considerando o nível de $10 \%$ de significância, há um vetor de co-integração entre as variáveis $\ln \left(M_{i j} / M_{i}\right)$ e $\ln \left(P_{i j} / P_{i}\right)$. Como descrito anteriormente, foram estimadas equações com um vetor de correção de erro e sem este vetor, sendo o seu nível de significância utilizado para estabelecer o modelo a ser aplicado. 
Identificada a presença de raiz unitária e a presença de co-integração nas variáveis utilizadas nos modelos, para correta estimação dos mesmos, as variáveis foram diferenciadas e foi incorporado o termo de correção de erro. O termo de correção de erro é o vetor identificado no teste de co-integração.

\subsubsection{Modelos para estimação da demanda com termo de correção de erro}

Os modelos desenvolvidos nas eq. (22) e (24) descrevem as variáveis para estimação do modelo de demanda de interesse, as quais foram analisadas no item anterior. Tais modelos foram descritos para as variáveis em nível. Entretanto, uma vez que as séries possuem raiz unitária e se apresentam co-integradas, foram utilizadas na primeira diferença, e incluído o termo de correção de erro nos modelos, recuperando, assim, as informações de longo prazo perdidas nas diferenças das variáveis.

Como não houve consenso no teste de co-integração em relação ao número de vetores a se incluir no modelo descrito para as eq. (22) e (24), inicialmente foram realizadas estimações para verificar o nível de significância dos vetores incertos, com critério de decisão sobre a sua inclusão nos modelos. Na equação de demanda geral de importação, o segundo vetor de correção de erro não foi significativo no modelo, sendo, portanto, excluído daquela estimação. Na equação que procurou estimar o grau de elasticidade de substituição das importações de açúcar bruto nos EUA, conforme definido na eq. (22), a inclusão do vetor de correção de erro foi significativa, melhorando, inclusive, o nível de significância do coeficiente que estima a elasticidade de substituição. Portanto, foi incluído um vetor de correção de erro neste modelo.

Os resultados dos modelos finais estimados são descritos na Tabela 23, com seus respectivos níveis de significância do teste "t", descritos entre parênteses abaixo dos coeficientes. 
Tabela 23. Estimativas das elasticidades de substituição e de demanda da importação de açúcar bruto nos Estados Unidos - modelo com correção de erro; período de 1982 a 2001.

\begin{tabular}{cccccccc}
\hline & Intercepto & $\Delta \ln \left(P_{i j} / P_{i}\right)$ & $\Delta \operatorname{lnpd}$ & $\Delta \operatorname{lntc}$ & $\Delta \ln r e n$ & $e_{\mathrm{t}-1}$ & $\mathrm{R}^{2}$ \\
\hline$\Delta \ln \left(M_{i j} / M_{i}\right)$ & $-1,26$ & $-4,70$ & - & - & - & $-0,48$ & $57 \%$ \\
& $(0,00)$ & $(0,00)$ & - & - & - & $(0,00)$ & \\
& & & & & & & \\
Volume importado & 1,04 & - & 0,72 & 0,87 & $-1,48$ & 0,14 & $15 \%$ \\
$\left(\Delta \ln M_{i}\right)$ & $(0,40)$ & - & $(0,53)$ & $(0,27)$ & $(0,69)$ & $(0,39)$ & \\
& & & & & & &
\end{tabular}

Fonte: resultados de pesquisa.

Nota: $\ln \left(M_{i j} / M_{i}\right)=$ Logaritmo da participação das importações originadas do país $j$ nas importações totais do país $i ; \ln \left(P_{i j} / P_{i}\right)=$ Logaritmo da relação entre o preço de importação do país $j$ no preço geral da importação do país $i ; \ln M_{i}=$ Logaritmo do volume total importado de açúcar; lnpd = logaritmo do preço doméstico de açúcar bruto; lntc = logaritmo do índice taxa de câmbio efetiva real; lnren = logaritmo da variável PIB utilizada como proxy para estimar o efeito renda; $e_{\mathrm{t}-1}$ é o termo de correção de erro dos modelos estimados. $\mathrm{O}$ símbolo $\Delta$ na frente das variáveis indica a diferenciação das séries.

Verificou-se que a elasticidade-preço de demanda foi positiva, provavelmente porque foi utilizado o preço doméstico na sua estimação. Assim, a redução neste preço diminui também os ganhos obtidos pelo importador. A explicação é que quanto menor o preço doméstico, menor o diferencial em relação ao preço internacional, conferindo um menor lucro (rent) ao importador. Entretanto, o sinal desta variável não compromete a análise, uma vez que o sinal negativo da elasticidade-preço de substituição foi de acordo com o previsto e compensa o resultado positivo da elasticidade-preço de demanda. $\mathrm{O}$ resultado da elasticidade de substituição estima que a redução de $1 \%$ do preço de importação do produto brasileiro em relação aos preços dos demais países aumentaria 
em 4,7\% a participação do produto brasileiro em relação aos demais (Tabela 23). Observa-se também que as variáveis descritas no modelo de demanda geral de importação $\left(\Delta \ln M_{i}\right)$ não foram significativas, ao contrário do coeficiente de elasticidade de substituição identificado na equação $\Delta \ln \left(M_{i j} / M_{i}\right)$.

\subsubsection{Função de demanda por importação de açúcar bruto brasileiro pelos EUA}

O passo seguinte foi estimar as elasticidades-preço de demanda, especificamente para as exportações brasileiras de açúcar, uma vez que se considerou que as elasticidades de demanda são diferenciadas em relação ao país exportador, e que são diferentes para os mercados importadores considerados.

No caso brasileiro, considerou-se não apenas uma elasticidade-preço da demanda diferenciada em relação à de outros países, como também essa elasticidade diferenciada entre as grandes regiões produtoras do país. A qualidade diferenciada do produto obtido nas regiões Centro-Sul e Norte-Nordeste é um fator que justifica tal consideração, ou seja, que também a demanda pelo açúcar das regiões Centro-Sul e Norte-Nordeste são diferenciadas. Enquanto o Centro-Sul exporta predominantemente açúcar VHP, o Norte-Nordeste exporta açúcar com menor grau de polarização, que é o açúcar demerara. Além disso, deve-se considerar que os períodos de safra das duas regiões são diferentes. O período de safra da região Centro-Sul é de abril/maio a novembro/dezembro, enquanto no Norte-Nordeste a safra vai de setembro a março. Portanto, foram consideradas também diferenciadas as demandas pelo açúcar bruto das duas regiões exportadoras do Brasil, foram também consideradas diferenciadas.

A Figura 23 ilustra o comportamento diferenciado em relação às exportações das regiões Centro-Sul e Norte-Nordeste nas importações de açúcar bruto dos EUA. Verifica-se que, em média, a região Norte-Nordeste exportou quase o valor total das exportações de açúcar bruto do Brasil para os EUA, sendo no período de 1996 a 2001, equivalente a mais de $10 \%$ das importações do produto nos EUA. Isso se explica pela forma como as quotas de exportação são alocadas no país. Essas quotas são distribuídas 
apenas para os produtores da região Nordeste, tendo como justificativa a importância da atividade na região e a diferença em termos de capacidade de desenvolvimento regional que tem prevalecido entre os estados produtores de cana da região Centro-Sul com relação aos estados do Norte-Nordeste.

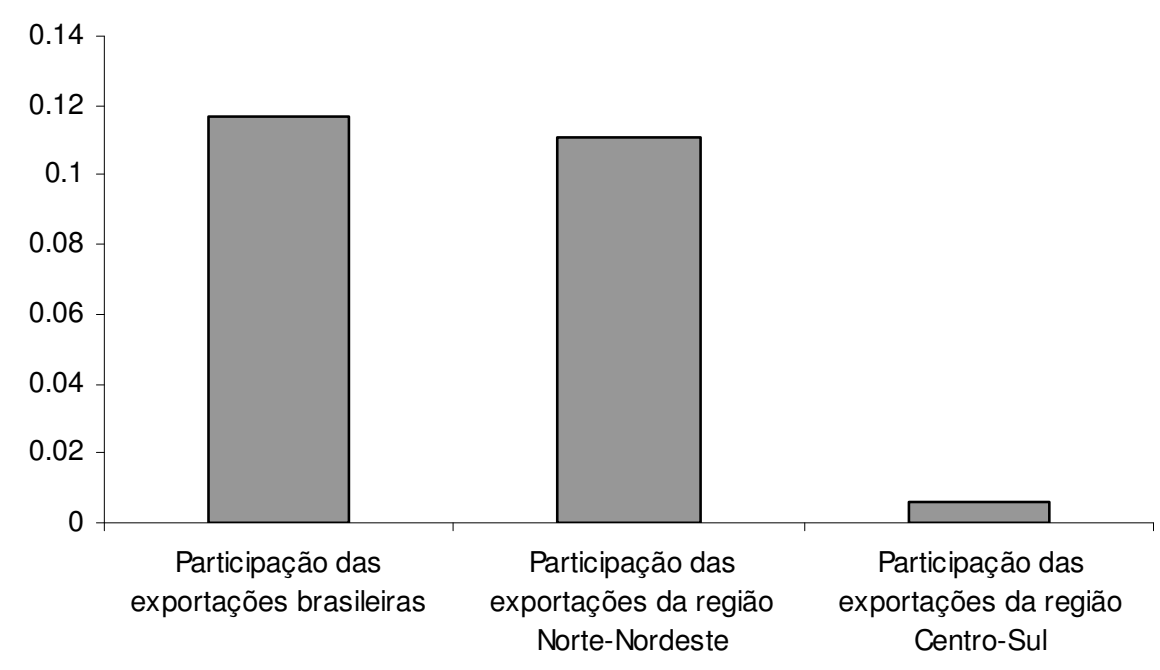

Figura 23 - Participação das exportações da região Centro-Sul, Norte-Nordeste e do Brasil, no valor da importação de açúcar bruto dos Estados Unidos; período: 1996 a 2001.

Fonte: Brasil (2003b); FAO (2003b)

Diante do comportamento das importações de açúcar bruto nos EUA e das exportações brasileiras para este país, foram estimadas as elasticidades-preço direta da demanda pela exportação da região Centro-Sul e da região Norte-Nordeste, nos EUA. Os valores dessas elasticidades foram apresentados na Tabela 24 e estimados conforme descrito na eq. (25) do item 3.1.1.3.

Portanto, a elasticidade-preço direta da demanda pela exportação da região Centro-Sul apresentou-se mais elástica do que a elasticidade-preço da demanda pela exportação da região Norte-Nordeste, no mercado dos EUA. Isso ocorreu porque, em função da menor exportação do Centro-Sul para o mercado norte-americano, esta região possui um potencial maior para aumentar suas exportações. 
Tabela 24. Estimativas das elasticidades-preço direta da demanda pela exportação de açúcar bruto das regiões Centro-Sul e Norte-Nordeste do Brasil, nos Estados Unidos; período: 1982 a 2001.

\begin{tabular}{cccccc}
\hline & $S_{i j}$ & $\left(1-S_{i j}\right)$ & $\sigma_{i}$ & $\varpi_{i}$ & $\eta_{i j}$ \\
\hline Centro-Sul & 0,00586 & 0,99414 & $-4,7$ & 0,72 & $-4,668$ \\
Norte-Nordeste & 0,11095 & 0,88905 & $-4,7$ & 0,72 & $-4,098$ \\
\hline
\end{tabular}

Fonte: resultados de pesquisa.

Nota: $S_{i j}=$ participação do valor importado de cada região (Centro-Sul e Norte-Nordeste) em relação ao valor das importações totais dos Estados Unidos; $\sigma_{i}=$ elasticidade de substituição estimada na Tabela $23 ; \varpi_{i}=$ elasticidade-preço de importação estimada na Tabela 23; $\eta_{i j}=$ elasticidade-preço direta da demanda pela importação originada do país $j$, no país $i$.

Assim, a redução de $1 \%$ no preço de importação de açúcar dessas regiões aumentaria em 4,67\% as importações originadas da região Centro-Sul, e em 4,10\% as importações originadas da região Norte-Nordeste do Brasil, ao ano, considerando os dados referentes ao período estudado. Entretanto, é importante lembrar que isto não significa que o volume exportado pela região Centro-Sul para os EUA seja superior ao exportado pela região Norte-Nordeste. As estimativas do aumento das exportações são obtidas com base nos volumes efetivamente realizados ao longo dos últimos anos, e conforme foi apresentado na Figura 23, o Norte-Nordeste exportou, em média, um volume significativamente maior de açúcar bruto para os EUA, em relação à região Centro-Sul. Isso parece sugerir que o impacto de uma redução no nível tarifário pelos EUA poderá ser maior na região Nordeste do que no Centro-Sul do Brasil. De fato, existe alguma vantagem para o Norte-Nordeste em termos logísticos. No entanto, se as exportações ocorrerem sob condições competitivas, possivelmente a região Centro-Sul deve expandir suas exportações para os EUA em proporção muito maior que o NorteNordeste. 


\subsubsection{Impacto sobre as exportações brasileiras de açúcar bruto para os Estados Unidos}

A estimação dos efeitos marginais da redução nos níveis tarifários dos EUA sobre volume e preço das exportações brasileiras é o objetivo final deste tópico. Calculados os valores das elasticidades-preços de oferta e de demanda anteriormente, foram estimados os efeitos finais sobre o volume e o preço de exportação, conforme descritas nas eq. (12) e (14) do item 3.1.1.1. Na Tabela 25 constam os resultados das variações marginais em volume e preço de açúcar bruto comercializado entre Brasil e EUA.

Tabela 25. Estimativas das mudanças percentuais em volume e preço das exportações brasileiras de açúcar bruto em razão de mudanças nos níveis tarifários das importações dos EUA.

\begin{tabular}{lcccc}
\hline & $\begin{array}{c}\text { Elasticidade- } \\
\text { preço de oferta }\end{array}$ & $\begin{array}{c}\text { Elasticidade-preço } \\
\text { de demanda }\end{array}$ & $d Q / d T$ & $d P / d T$ \\
\hline Centro-Sul & 1,284 & $-4,67$ & $-1,01$ & $-0,78$ \\
Norte-Nordeste & 0,710 & $-4,10$ & $-0,61$ & $-0,85$ \\
\hline
\end{tabular}

Fonte: resultados de pesquisa.

Nota: $d Q / d T=$ variação da quantidade importada em função de uma variação no equivalente tarifário; $d P / d T$ = variação do preço de importação em função de uma variação no equivalente tarifário.

Observa-se uma mudança maior em relação ao volume comercializado nas exportações do Centro-Sul, e em relação ao preço nas exportações do Norte-Nordeste. Considerando o volume exportado do Brasil para os EUA, tem-se, no período de 1996 a 2002, os volumes exportados do Centro-Sul e do Norte-Nordeste para os EUA foram, respectivamente, de 146.016 e 1.307 .997 toneladas. Isto equivale a cerca de 20.859 e 186.856 toneladas/ano, respectivamente. Neste mesmo período, o preço médio das 
exportações para os EUA foi de $\mathrm{R} \$ 0,21 / \mathrm{kg}$ e $\mathrm{R} \$ 0,41 / \mathrm{kg}$, respectivamente, para as regiões Centro-Sul e Norte-Nordeste.

Assim, dada uma redução de $1 \%$ no nível tarifário imposto pelos EUA para as exportações brasileiras de açúcar bruto, as exportações do Centro-Sul poderiam aumentar em 1,01\%, o que significaria, pela média do período de 1996 a 2002, um aumento de aproximadamente 210 toneladas/ano. Por outro lado, esta mesma redução tarifária aumentaria em $0,61 \%$ as exportações da região Norte-Nordeste, equivalendo a 1.140 toneladas/ano.

Extrapolando esta análise marginal, e considerando um equivalente tarifário $a d$ valorem referente às políticas protecionistas no mercado norte-americano, que elevam o preço doméstico do produto, em relação às exportações brasileiras, este efeito se torna bem mais significativo. Inicialmente foi estimado o equivalente tarifário do preço doméstico, resultante dos efeitos de suporte de preço doméstico e quota tarifária, em relação ao preço de exportação do Brasil. Esta estimativa está descrita na Tabela 26, sendo diferenciada para as exportações das duas regiões. Essa diferenciação em relação às duas regiões é importante, uma vez que as exportações do Norte-Nordeste recebem um preço bem maior do que o recebido pelas exportações do Centro-Sul do país.

Tabela 26. Estimativas de equivalentes tarifários do preço doméstico dos Estados Unidos em relação aos preços de exportação de açúcar bruto das regiões Centro-Sul e Norte-Nordeste do Brasil.

\begin{tabular}{ccc}
\hline & Centro-Sul & Norte-Nordeste \\
\hline Equivalente tarifário & $99 \%$ & $15 \%$ \\
\hline
\end{tabular}

Fonte: Resultados de pesquisa.

Observa-se que o preço das exportações do Centro-Sul apresentou um equivalente tarifário bem superior ao do Norte-Nordeste. Portanto, enquanto o CentroSul teria o potencial de aumentar cerca de $99 \%$ de suas exportações para os EUA $(d Q / d T$ 
* equivalente tarifário), o Norte-Nordeste poderia aumentar em, no máximo, 9,15\% $(d Q / d T *$ equivalente tarifário) suas exportações para este mercado. Isto significa, em volume exportado, 20.650 toneladas/ano para o Centro-Sul, e 17.097 toneladas/ano para o Norte-Nordeste. E os preços, com elasticidades de 0,78 e 0,85 , poderiam aumentar em até $77 \%$ e $12 \%$, respectivamente, para o Centro-Sul e o Norte-Nordeste. Isto significaria um nível de preço de US\$ $0,37 / \mathrm{kg}$ e US\$ $0,46 / \mathrm{kg}$ de açúcar bruto, respectivamente, para essas regiões.

Em termos de valor total exportado pelo Brasil, calculou-se um aumento equivalente a US\$ 7.640 mil para as exportações do Centro-Sul, e US\$ 7.865 mil para as exportações do Norte-Nordeste, em função de uma redução total do equivalente tarifário sobre as exportações brasileiras. Vale ressaltar que essas estimativas foram realizadas tendo-se como base as exportações médias, no período recente, do Brasil para aquele mercado.

\subsection{Impactos da redução de políticas protecionistas no mercado de açúcar da União Européia sobre as exportações brasileiras de açúcar bruto e refinado}

Neste item foram analisados dois efeitos em relação a mudanças na política agrícola da UE. Primeiramente, foi analisado o impacto sobre as exportações brasileiras de açúcar bruto, diante da redução no suporte interno de preço e de quota tarifária do mercado europeu sobre as exportações brasileiras. Em seguida, foi verificado o impacto sobre as exportações brasileiras de açúcar refinado para alguns dos principais importadores deste produto comuns entre o Brasil e a União Européia, diante da redução no subsídio ao produtor doméstico da UE.

Inicialmente foram descritos o mercado importador de açúcar bruto e exportador de açúcar refinado dos países que compõem o bloco europeu, com o objetivo de se conhecer esses mercados. As funções de demanda pelas importações e de oferta de exportação da União Européia foram então estimadas, obtendo-se assim as elasticidadespreço de demanda pelas importações de açúcar bruto e de oferta das exportações de 
açúcar refinado. Estes coeficientes foram posteriormente utilizados para compor o modelo de Gardner (1987), o qual procurou analisar os efeitos nas mudanças de políticas agrícolas da UE.

\subsubsection{Funções de demanda de importação de açúcar bruto e de oferta de exportação de açúcar refinado da União Européia}

Como comentado na revisão bibliográfica, Frandsen et. al. (2001) encontraram que: França, Alemanha, Áustria e Reino Unido são capazes de produzir açúcar para o mercado mundial (quota C); Dinamarca, Bélgica e Espanha podem abastecer as quotas nacionais; o custo de produção na Suécia, Holanda e Irlanda podem impedi-los de utilizar a quota B; e que Itália, Finlândia e, notavelmente, Portugal e Grécia poderiam ter dificuldades em produzir a quota A. Esses resultados foram obtidos com base nos custos de produção destes países.

Diante dessas informações, que indicaram a diferenciação entre os países da UE, foi realizado um estudo preliminar com o objetivo de identificar os fatores determinantes do comércio de açúcar nestes países. Observou-se a presença de dois tipos de países, em relação ao mercado de açúcar. Num primeiro grupo de países, a importação de açúcar bruto mostrou-se relacionada à produção doméstica, ou seja, os países importaram mais quando a produção doméstica reduziu. Esses países não foram exportadores de açúcar refinado. Desta maneira, a importação de açúcar teve o objetivo de complementar a produção para o consumo doméstico. Os países que apresentaram este comportamento foram: Portugal, Grécia, Itália, Finlândia, Irlanda e Suécia. A correlação entre importação de açúcar bruto e a produção doméstica de açúcar bruto foi

de $-38 \%$ para esses países. O segundo grupo compreendeu exportadores mundiais de açúcar refinado, que importaram açúcar bruto extra-bloco em função de condições favoráveis àquelas importações de açúcar bruto, para reexportá-lo como refinado. Pertencem a este grupo de países: França, Alemanha, Reino Unido, Áustria, Dinamarca, Bélgica-Luxemburgo, Espanha e Holanda. Estes resultados corroboram com os encontrados por Frandsen et al. (2001), uma vez que os países descritos por estes autores 
como incapazes de produzir as quotas B e mesmo a quota A correspondem ao primeiro grupo de países. Da mesma forma, os países do segundo grupo foram aqueles descritos pelos autores como capazes de produzir para o mercado mundial ou de abastecer as quotas nacionais. Entre os países descritos por Frandsen et al. (2001) como podendo ser incapazes de produzir a quota $\mathrm{B}$, apenas Holanda apresentou-se como exportadora de açúcar refinado, sendo incluída no segundo grupo dos países da UE.

Naqueles países exportadores de açúcar refinado, não foi observada uma relação negativa entre produção doméstica e importação de açúcar bruto (o valor da correlação foi de 0,08). Entretanto, observou-se correlação de $77 \%$ entre as exportações de açúcar refinado com a produção doméstica, para o período de 1989 a 1999.

Foram então estimadas duas funções de importação de açúcar bruto para a União Européia. Uma considerando as importações para os países que não apresentaram excedente de oferta, e outra para os países que possuem excedente de oferta e, ainda assim, importaram açúcar bruto. A função de oferta de exportação de açúcar refinado foi estimada para este segundo grupo de países.

Entretanto, houve alguns problemas em relação a alguns dados: as estatísticas para Áustria, Suécia e Finlândia, consideradas como integrantes da UE, apenas estão disponíveis a partir de 1995; e Dinamarca e Irlanda não apresentaram importação extrabloco em vários dos anos considerados. Desta maneira, estes países foram excluídos da estimação econométrica das funções anteriormente descritas.

As equações de oferta de exportação de açúcar refinado e de demanda por importação de açúcar bruto foram estimadas utilizando dados em painel, estando os países utilizados como variáveis cross section descritos na Figura 24. A série de tempo considerada foi de 1989 a 1999, em função da disponibilidade de dados para este período. As estimativas daquelas equações foram descritas nas Tabelas 27, 28 e 30.

Em relação às importações extra-bloco de açúcar bruto na União Européia, estas são, na sua maior parte, originadas dos países da ACP (África, Caribe e Pacífico), ex-colônias de países europeus. Entre estes países, Mauricio foi o de maior 
representatividade nas importações européias totais (participação média no período de 1989 a 1999 de $29,83 \%$ em valor e 28,26\% em volume). Por este motivo, para estimar as elasticidades de substituição pelas importações de açúcar bruto dos países da UE, foram utilizados os volumes e preços das importações de Mauricio ${ }^{28}$.

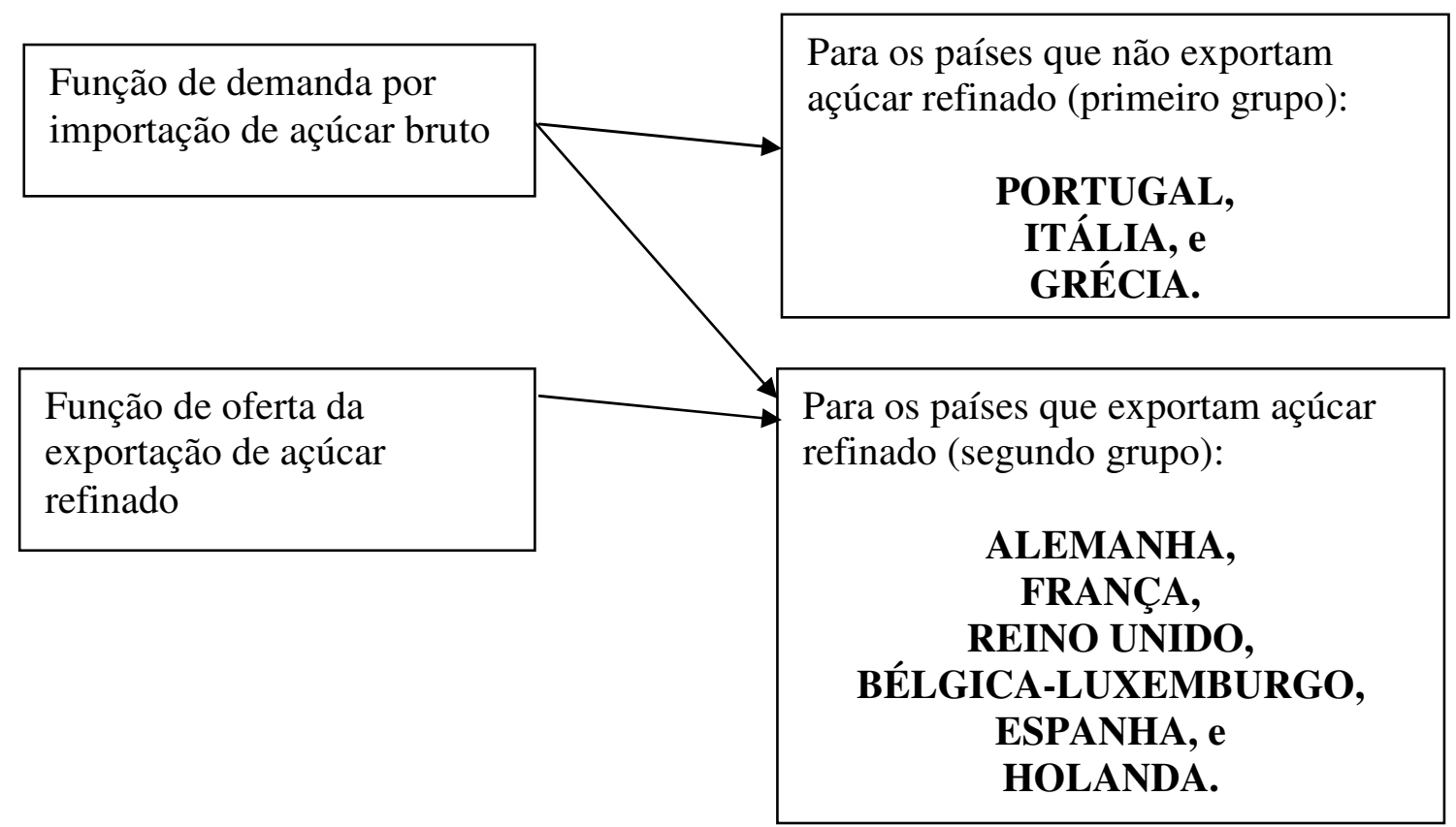

Figura 24 - Países utilizados para compor as variáveis cross section na estimação das equações de demanda por importação de açúcar bruto e de oferta pela exportação de açúcar refinado da União Européia.

Nas Tabelas 27 e 28 têm-se as equações estimadas utilizadas para compor o modelo de demanda de Armington (1969). Na Tabela 27 foram descritas as estimativas das eq. (22) e (24) para a demanda por açúcar bruto pelos países do primeiro grupo (países que não exportam açúcar refinado).

\footnotetext{
${ }^{28}$ As importações originadas de Mauricio foram utilizadas a fim de se ter o maior volume de dados referentes à importação de um país, para cada um dos países da UE.
} 
Tabela 27. Estimativas das elasticidades de substituição e de demanda da importação extra-bloco de açúcar bruto para o primeiro grupo de países da União Européia.

\begin{tabular}{ccccccc}
\hline & Intercepto & $\ln \left(P_{i j} / P_{i}\right)$ & lnpd & lntc & Inren & $\mathrm{R}^{2}$ \\
\hline $\ln \left(M_{i j} / M_{i}\right)$ & $-0,92$ & $-1,81$ & - & - & - & $73 \%$ \\
& $(0,00)$ & $(0,00)$ & - & - & - & \\
Volume & 32,52 & - & $-0,25$ & $-4,87$ & $-0,09$ & $15 \%$ \\
importado $\left(\ln M_{i}\right)$ & & - & $(0,49)$ & $(0,14)$ & $(0,86)$ & \\
& $(0,02)$ & - & & & & \\
\hline
\end{tabular}

Fonte: resultados de pesquisa.

Nota: no primeiro grupo de países da União Européia inclui: Portugal, Grécia, Itália, Finlândia, Irlanda e Suécia. Variáveis do modelo: $\ln \left(M_{i j} / M_{i}\right)=$ Logaritmo da participação das importações originadas do país $j$ nas importações totais do país $i ; \ln \left(P_{i j} / P_{i}\right)=$ Logaritmo da relação entre o preço de importação do país $j$ no preço geral da importação do país $i$; $\ln M_{i}=$ Logaritmo do volume total importado de açúcar; lnpd = logaritmo do preço doméstico de açúcar bruto; lntc = logaritmo do índice taxa de câmbio efetiva real; lnren = logaritmo da variável valor total das importações, utilizada como proxy para estimar o efeito renda.

$\mathrm{Na}$ Tabela 28 têm-se estas mesmas estimativas para os países do segundo grupo, ou seja, as elasticidades de demanda por importação de açúcar bruto para os países da UE que importam açúcar bruto e exportam açúcar refinado. As variáveis utilizadas estão descritas nas Tabelas 53 e 54 do Apêndice 4.

Foram realizadas análises para definição do melhor ajustamento econométrico a ser utilizado. Constataram-se problemas de autocorrelação e correlação entre as unidades cross section. Não foi observado componente de médias móveis. O método de Parks foi o mais indicado para as estimações realizadas, não havendo contradições dos resultados quando utilizado o método de Fuller-Battese. 
Tabela 28. Estimativas das elasticidades de substituição e de demanda da importação extra-bloco de açúcar bruto para o segundo grupo de países da União Européia.

\begin{tabular}{ccccccc}
\hline & Intercepto & $\ln \left(P_{i j} / P_{i}\right)$ & $\operatorname{lnpd}$ & lntc & lnren & $\mathrm{R}^{2}$ \\
\hline $\ln \left(M_{i j} / M_{i}\right)$ & $-1,03$ & $-1,41$ & - & - & - & $63 \%$ \\
& $(0,00)$ & $(0,00)$ & - & - & - & \\
Volume & $-8,27$ & - & 0,50 & 1,46 & 2,12 & $73 \%$ \\
importado $\left(\ln M_{i}\right)$ & & - & $(0,00)$ & $(0,11)$ & $(0,00)$ & \\
& $(0,02)$ & & & & \\
\hline
\end{tabular}

Fonte: resultados de pesquisa.

Nota: no segundo grupo de países da UE se encontram: França, Alemanha, Reino Unido, Áustria, Dinamarca, Bélgica-Luxemburgo, Espanha e Holanda. Variáveis do modelo: $\ln \left(M_{i j} / M_{i}\right)=$ Logaritmo da participação das importações originadas do país $j$ nas importações totais do país $i ; \ln \left(P_{i j} / P_{i}\right)=$ Logaritmo da relação entre o preço de importação do país $j$ no preço geral da importação do país $i$; $\ln M_{i}=$ Logaritmo do volume total importado de açúcar; lnpd = logaritmo do preço doméstico de açúcar bruto; lntc = logaritmo do índice taxa de câmbio efetiva real; lnren = logaritmo da variável valor total das importações, utilizada como proxy para estimar o efeito renda.

Diante dos resultados das estimativas das equações de importação, identificaram-se as diferenças existentes entre os dois grupos de países da UE. Ambos apresentaram altos coeficientes de elasticidade de substituição em relação ao preço de importação de açúcar bruto, entretanto, no primeiro grupo a elasticidade de câmbio foi negativa, conforme o esperado pelo modelo econômico, o que não aconteceu em relação aos países exportadores de açúcar. Isto ocorreu, provavelmente, pela característica ambígua desta variável nos países que são importadores de açúcar bruto e exportadores de açúcar refinado. Corroborando com esta situação em relação à taxa de câmbio apresentada pelos países exportadores de açúcar da UE, tem-se que, quando estimados 
pelo método de Fuller, o coeficiente referente à taxa de câmbio apresentou-se contrário ao obtido pelo método de Parks e descrito na Tabela 28.

As elasticidades-preço e renda também apresentaram sinais contrários comparando as duas equações, sendo não significativas nos países do primeiro grupo. Como o preço considerado foi o preço interno, descrito como o preço de comércio intrabloco, tem-se que nos países do primeiro grupo, a possibilidade de ganho do importador (rent) não foi fator determinante para aumento das importações. $O$ sinal da renda foi coerente ao esperado pelo modelo econômico considerando os países exportadores de açúcar.

No segundo grupo de países (exportadores de açúcar refinado), a elasticidaderenda foi maior do que a encontrada para o primeiro grupo e significativa no nível de $1 \%$. O alto valor desta elasticidade $(2,12 \%)$ pode ser explicado pelo fato de que a importação deste açúcar foi motivada principalmente pela exportação de açúcar refinado subsidiado, sendo que os subsídios sobre estas exportações ocorrem, principalmente, por parte dos consumidores europeus. A elasticidade-preço foi positiva, indicando que o rent adquirido pelos importadores foi outro fator importante para determinar as importações, e a taxa de câmbio apresentou sinal contrário ao esperado e também significativo.

O sinal positivo para a taxa de câmbio pode ser explicado pelo fato de que estes países, em condições favoráveis às exportações, importam o produto bruto para fazer o refino e reexportar este açúcar.

Comparando os resultados encontrados nas Tabelas 27 e 28 com os obtidos para os EUA (Tabela 23), verifica-se uma menor elasticidade de substituição das importações do bloco europeu. Enquanto a elasticidade de substituição das importações dos EUA foi da ordem de 4,7\%, a UE apresentou valores de 1,8\% e 1,4\% para a importação nos dois grupos de países. Essa menor resposta da substituição das importações ao preço pode ser explicada, provavelmente, pelo motivo político das importações de açúcar bruto do bloco em relação aos seus maiores exportadores, os países da ACP. Com a dependência das exportações de açúcar desses países em relação às importações do bloco, a UE consegue o domínio político nos países da ACP. 
Além disto, os países da ACP recebem preços elevados pelas suas exportações de açúcar. Os altos preços dessas importações são explicados pelo fato de que as importações desses países são isentas de quaisquer barreiras e, como ocorre nos EUA, o preço interno do produto na UE é muito elevado. Por outro lado, as exportações brasileiras para o mercado europeu são limitadas por quotas tarifárias. A participação das exportações brasileiras nas importações extra-bloco de açúcar bruto dos dois grupos de países importadores da UE é ilustrada na Figura 25.

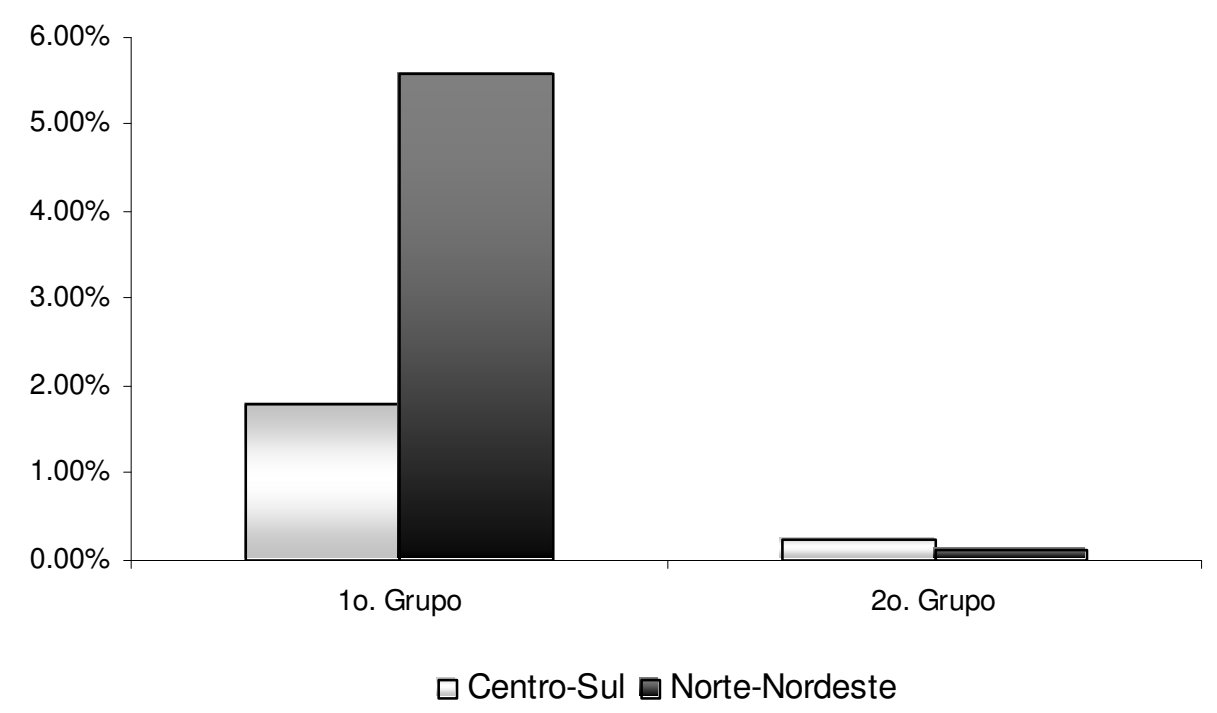

Figura 25 - Participação das exportações da região Centro-Sul, e Norte-Nordeste, no valor da importação de açúcar bruto dos dois grupos de países da União Européia; período: 1996 a 2001.

Fonte: Brasil (2003b); FAO (2003b)

Observa-se que, predominantemente, o Brasil exportou açúcar bruto para os países da UE que não exportaram açúcar refinado (países do primeiro grupo). Portanto, a redução de políticas protecionistas da UE, incluindo a redução de suas exportações de açúcar refinado, não prejudicariam as exportações de açúcar bruto do Brasil para aquele mercado. Isto ocorre porque a maior parte das importações européias originadas do Brasil é destinada para o consumo doméstico destes importadores. 
A partir dos valores calculados para as elasticidades-preço e substituição, e das participações das exportações das regiões Centro-Sul e Norte-Nordeste nas importações de açúcar bruto dos dois grupos de países da UE, foram calculadas as elasticidadespreço diretas específicas para as duas regiões exportadoras. As participações das exportações brasileiras (regiões Centro-Sul e Norte-Nordeste) foram calculadas apenas a partir de 1996, porque até meados da década de 1990, regulamentações internas restringiam o poder competitivo do Brasil no mercado internacional de açúcar. As elasticidades-preço de demanda das importações européias pelas exportações brasileiras estão descritas na Tabela 29.

Tabela 29. Estimativas das elasticidades-preço direta da demanda pela exportação das regiões Centro-Sul e Norte-Nordeste do Brasil, para os dois grupos de países importadores na União Européia.

\begin{tabular}{ccccccc}
\hline & & $S_{i j}$ & $\left(1-S_{i j}\right)$ & $\sigma_{i}$ & $\varpi_{i}$ & $\eta_{i j}$ \\
\hline \multirow{2}{*}{ Primeiro grupo } & Centro-Sul & 0,018 & 0,982 & $-1,81$ & $-0,25$ & $-1,78$ \\
& Norte-Nordeste & 0,056 & 0,944 & $-1,81$ & $-0,25$ & $-1,72$ \\
& & & & & & \\
\multirow{2}{*}{ Segundo grupo } & Centro-Sul & 0,002 & 0,998 & $-1,41$ & 0,5 & $-1,41$ \\
& Norte-Nordeste & 0,001 & 0,999 & $-1,41$ & 0,5 & $-1,41$ \\
\hline
\end{tabular}

Fonte: resultados de pesquisa.

Nota: $S_{i j}=$ participação do valor importado de cada região (Centro-Sul e Norte-Nordeste) em relação ao valor das importações totais dos Estados Unidos; $\sigma_{i}=$ elasticidades de substituição estimadas nas Tabelas 27 e 28; $\varpi_{i}=$ elasticidades-preço de importação estimadas nas Tabela 27 e $28 \eta_{i j}=$ elasticidade-preço direta da demanda pela importação originada do país $j$, no país $i$. No primeiro grupo de países da União Européia inclui: Portugal, Grécia, Itália, Finlândia, Irlanda e Suécia. No segundo grupo se encontram: França, Alemanha, Reino Unido, Áustria, Dinamarca, Bélgica-Luxemburgo, Espanha e Holanda. 
Em comparação com os resultados da elasticidade de demanda encontrados para os EUA (Tabela 24), observa-se que os valores descritos na Tabela 29 são menores, também por causa do menor valor da elasticidade de substituição dos países da UE, como descrito anteriormente.

Observou-se também uma resposta semelhante da demanda da UE pelas duas regiões exportadoras de açúcar do Brasil, entretanto, os dois grupos de países importadores responderam de maneira um pouco diferenciada. Essa diferença ocorreu, principalmente, pelo menor valor da elasticidade de substituição das importações do segundo grupo da UE. Foi encontrada uma elasticidade-preço de demanda das importações brasileiras de aproximadamente $-1,75$ para os países do primeiro grupo (1,78 para as importações do Centro-Sul e -1,72 para as importações do Norte-Nordeste); e de -1,41 para os países do segundo grupo. Ou seja, a redução de $1 \%$ no preço de importação de açúcar dessas regiões aumentaria em 1,78\% as importações originadas da região Centro-Sul, e em 1,72\% as importações da região Norte-Nordeste do Brasil, ao ano, para os países do primeiro grupo da UE.

Associadas às importações de açúcar bruto do segundo grupo de países, têm-se também as exportações de açúcar refinado. Assim, em relação à função de oferta da exportação de açúcar refinado, como uma aproximação do preço recebido pelo produtor da UE pelas exportações extra-bloco, foi utilizado o preço das exportações intra-bloco do produto. O preço de exportação de açúcar refinado intra-bloco foi utilizado porque os produtores exportam tanto intra quanto extra-bloco. Entretanto, em função dos maiores preços intra-bloco recebidos (quota $\mathrm{A}$ ), é que o produtor terá estímulo para aumentar sua produção e, conseqüentemente, seu excedente exportável para o mercado externo. A Tabela 30 descreve os coeficientes obtidos na estimação da equação de oferta das exportações de açúcar refinado da UE. Os coeficientes foram estimados pelo método de Parks, não obtendo valores contraditórios aos verificados pelo método Fuller-Battese. 
Tabela 30. Estimativas das elasticidades de oferta das exportações de açúcar refinado da União Européia; período de 1989 a 1999.

\begin{tabular}{ccccc}
\hline & Intercepto & lnpdr & Intc & InMi \\
\hline $\begin{array}{cccc}\text { Volume exportado } \\
(\text { Inxe) }\end{array}$ & 17,09 & 0,26 & $-1,11$ & 0,15 \\
& $(0,00)$ & $(0,00)$ & $(0,02)$ & $(0,00)$ \\
$\mathrm{R}^{2}=47 \%$ & & & & \\
\hline
\end{tabular}

Fonte: resultados de pesquisa.

Nota: em que lnxe é o logaritmo do volume exportado extra-bloco de açúcar refinado; $\operatorname{lnpdr}$ é o logaritmo do preço de exportação intra-bloco de açúcar refinado da União Européia; lntc é o logaritmo do índice da taxa de câmbio (efetiva real) dos países; e lnMi é o logaritmo do volume importado extra-bloco de açúcar bruto.

As análises realizadas anteriormente foram muito importantes para a compreensão dos resultados descritos na Tabela 30. Como demonstrado, as exportações de açúcar refinado estiveram relacionadas com as importações de açúcar bruto. Este fato pode estar influenciando para o sinal negativo do coeficiente da taxa de câmbio no modelo de oferta. Isto ocorre porque a redução da taxa de câmbio favorece as importações de açúcar, que pode então ser reexportado. O sinal desta variável apresentou-se contraditório em relação às estimativas de demanda por importação de açúcar bruto (Tabela 28) e oferta de exportação de açúcar refinado (Tabela 30) pelos países do segundo grupo, justamente pela característica ambígua que ela representa para o mercado de açúcar nestes países. Da mesma maneira que a taxa de câmbio, a variável renda também influencia de maneira contrária à importação e à exportação de açúcar. A inclusão do volume importado de açúcar bruto, portanto, foi importante para a estimação correta deste modelo.

Foram importantes e estatisticamente significativos para explicar a oferta de exportação de açúcar refinado da UE: (i) o estímulo do preço recebido pelo produtor no 
mercado interno do bloco, com elasticidade estimada de $0,26 \%$ e (ii) o estímulo para a importação do açúcar bruto, cuja elasticidade foi estimada em $0,15 \%$.

\subsubsection{Impacto sobre as exportações brasileiras de açúcar bruto para a União Européia}

Considerando a média do período de 1996 a 2002, o volume de açúcar bruto exportado pelo Centro-Sul foi de 12.607 toneladas/ano ao preço de US\$ 0,259/kg para os países do primeiro grupo e de 6.776 toneladas/ano, com preço médio de US\$ 0,262/kg para os países do segundo grupo. Já as exportações de açúcar bruto do NorteNordeste corresponderam a 26.174 toneladas/ano, a US\$ 0,342/kg para os países do primeiro grupo da UE e 1.743 toneladas/ano, custando US\$ 0,458/kg para os países do segundo grupo.

Para estimar os efeitos de redução em tarifas sobre o volume e o preço de comércio do bem transacionado, conforme o modelo proposto por Gardner (1987), foram utilizadas as elasticidades de oferta das exportações brasileiras e de demanda pela importação de açúcar do Brasil nas eq. (12) e (14). Os modelos de oferta e demanda a serem estimados estão apresentados no fluxograma da Figura 20, no capítulo metodológico. Os resultados obtidos destas equações foram descritos na Tabela 31.

Observa-se que os efeitos finais estimados sobre o volume e preço de comercialização de açúcar entre as regiões ofertantes do Brasil (Centro-Sul e NorteNordeste) com os países demandantes da UE (primeiro e segundo grupos) apresentaram diferenças mais significativas considerando a região exportadora. Enquanto a região Centro-Sul apresentou maior resposta da redução tarifária em relação ao volume comercializado do que em relação ao preço, a região Norte-Nordeste apresentou resposta inversa (uma redução tarifária da UE afetaria, em termos percentuais, mais o preço do que o volume comercializado). 
Tabela 31. Estimativas das mudanças percentuais em volume e preço das exportações brasileiras de açúcar bruto em razão de mudanças nos níveis tarifários das importações dos dois grupos de países da União Européia.

\begin{tabular}{|c|c|c|c|c|c|}
\hline & & $\begin{array}{c}\text { Elasticidade- } \\
\text { preço de } \\
\text { oferta }\end{array}$ & $\begin{array}{c}\text { Elasticidade- } \\
\text { preço de } \\
\text { demanda }\end{array}$ & $d Q / d T$ & $d P / d T$ \\
\hline \multirow{2}{*}{ Primeiro grupo } & Centro-Sul & 1,284 & $-1,78215$ & $-0,746$ & $-0,5812$ \\
\hline & Norte-Nordeste & 0,71 & $-1,7229$ & $-0,502$ & $-0,7081$ \\
\hline \multirow{2}{*}{ Segundo grupo } & Centro-Sul & 1,284 & $-1,40898$ & $-0,671$ & $-0,5232$ \\
\hline & Norte-Nordeste & 0,71 & $-1,40948$ & $-0,4721$ & $-0,6650$ \\
\hline
\end{tabular}

Fonte: resultados de pesquisa.

Nota: no primeiro grupo de países da União Européia inclui: Portugal, Grécia, Itália, Finlândia, Irlanda e Suécia. No segundo grupo se encontram: França, Alemanha, Reino Unido, Áustria, Dinamarca, Bélgica-Luxemburgo, Espanha e Holanda. $d Q / d T=$ variação da quantidade importada em função de uma variação no equivalente tarifário; $d P / d T$ = variação do preço de importação em função de uma variação no equivalente tarifário.

Conforme os resultados descritos na Tabela 31, uma redução de $1 \%$ no nível tarifário imposto pelos países do primeiro grupo do bloco às exportações de açúcar bruto do Brasil aumentaria o volume exportado do Centro-Sul em 0,75\%, e em 0,50\% o volume exportado do Norte-Nordeste. Considerando o volume médio exportado dessas duas regiões para o mercado da UE no período de 1996 a 2002, este efeito significaria um aumento em 94,55 toneladas/ano nas exportações do Centro-Sul e 130,87 toneladas/ano nas exportações do Norte-Nordeste. Para o segundo grupo de países da UE este efeito seria menos significativo, em função do menor volume exportado do Brasil para estes países. 
Extrapolando esta análise marginal, e considerando a proteção do mercado europeu em equivalente tarifário sobre as exportações brasileiras deste tipo de açúcar, esse efeito se torna bem mais significativo. O equivalente tarifário do preço doméstico, resultante dos efeitos de suporte de preço doméstico e quota tarifária, em relação ao preço de exportação das regiões Centro-Sul e Norte-Nordeste do Brasil, foi estimado e descrito na Tabela 32.

Tabela 32. Estimativas de equivalentes tarifários do preço de comércio intra-bloco da União Européia em relação aos preços de exportação de açúcar bruto das regiões Centro-Sul e Norte-Nordeste do Brasil.

\begin{tabular}{lcccc}
\hline & \multicolumn{2}{c}{ Primeiro grupo } & \multicolumn{2}{c}{ Segundo grupo } \\
& Centro-Sul & Norte-Nordeste & Centro-Sul & Norte-Nordeste \\
\hline Equivalente tarifário & $152 \%$ & $91 \%$ & $149 \%$ & $42 \%$ \\
\hline
\end{tabular}

Fonte: resultados de pesquisa.

Nota: no primeiro grupo de países da União Européia inclui: Portugal, Grécia, Itália, Finlândia, Irlanda e Suécia. No segundo grupo se encontram: França, Alemanha, Reino Unido, Áustria, Dinamarca, Bélgica-Luxemburgo, Espanha e Holanda.

Observa-se que o preço das exportações do Centro-Sul apresentou um equivalente tarifário bem superior ao do Norte-Nordeste. Portanto, enquanto o CentroSul teria o potencial de aumentar $114 \%$ suas exportações para os países do primeiro grupo da UE, o Norte-Nordeste poderia aumentar em, no máximo, 45,4\% suas exportações para este mesmo grupo de países. Isto significa, em volume exportado, 14.372 toneladas/ano para o Centro-Sul, e 11.883 toneladas/ano para o Norte-Nordeste. E os preços, com elasticidades de 0,58 e 0,71 , poderiam aumentar em até $88 \%$ e $65 \%$, respectivamente, para o Centro-Sul e o Norte-Nordeste. Isto significaria um nível de preço de US\$ $0,48 / \mathrm{kg}$ e US\$ $0,56 / \mathrm{kg}$ de açúcar bruto, respectivamente, para essas regiões. 
Em termos de valor total exportado do Brasil para o primeiro grupo de países da UE, calculou-se um aumento equivalente a US\$ 6.898,56 mil para as exportações do Centro-Sul, e de US\$ 6.654,48 mil para as exportações do Norte-Nordeste, em função de uma redução total do equivalente tarifário sobre as exportações brasileiras. Vale ressaltar que estas estimativas foram realizadas tendo-se como base as exportações médias, no período recente, verificadas do Brasil para aquele mercado. Como estas exportações foram pequenas, em função das restrições impostas neste mercado, o efeito estimado também obteve uma magnitude de igual proporção.

O impacto sobre as exportações brasileiras para o segundo grupo de países da UE não foi analisado. Isto porque, como descrito anteriormente, as importações de açúcar bruto deste grupo de países responderam de maneira positiva à exportação de açúcar refinado (ver Tabela 30), sendo esta exportação outro efeito da política protecionista da UE. Como o objetivo deste estudo foi o de identificar o efeito da redução destas políticas, não haveria sentido em estimar o aumento da exportação de açúcar bruto para os países do segundo grupo. No item a seguir foi estimado o impacto da redução nos subsídios concedidos aos produtores domésticos da UE que favorecem a exportação de açúcar refinado.

\subsubsection{Impacto sobre as exportações brasileiras de açúcar refinado}

A política protecionista mantida para o mercado de açúcar na UE afeta não apenas as exportações brasileiras de açúcar bruto para o bloco europeu, como identificado na análise anterior, mas também prejudica as exportações brasileiras de açúcar refinado. Isto acontece porque, ao preço doméstico recebido pelos produtores de

açúcar da UE, estes são capazes de ofertar excedentes do produto, sendo este excedente de açúcar ofertado do tipo refinado. Os subsídios recebidos pelos produtores de açúcar permitem que os países exportadores de açúcar refinado da UE coloquem seu produto no mercado internacional ao nível de preço deste mercado. Este efeito é conhecido como subsídio cruzado às exportações, e vem recebendo críticas e pressões para sua extinção na OMC. O Brasil, por sua vez, vem expandindo as exportações de açúcar refinado nos 
últimos anos, mas encontra, nas exportações da UE, um forte concorrente no mercado internacional do produto.

Neste item, considerou-se o impacto das exportações de açúcar refinado pela UE sobre as exportações brasileiras. Torna-se claro que o mercado europeu, neste contexto, foi restrito aos países do segundo grupo ${ }^{29}$ identificados anteriormente.

Inicialmente, foram estimadas as equações de demanda de alguns dos países importadores de açúcar refinado, comuns ao Brasil e à UE. A demanda foi estimada em relação às importações da UE, uma vez que se necessita da elasticidade-preço direta $\left(\eta_{i j}\right)$ para compor o modelo de Gardner (1987), e da elasticidade-preço cruzada $\left(\eta_{i j k}\right)$ em relação a estas importações. O modelo de Gardner (1987) procurou estimar o impacto de uma redução nos subsídios sobre o volume e o preço de exportação da UE. Já a elasticidade-preço cruzada estimou o aumento das exportações brasileiras resultantes do aumento no preço das exportações européias. O fluxograma apresentado na Figura 21, no capítulo metodológico, descreve os modelos a serem estimados e as equações calculadas para identificar o impacto sobre as exportações de açúcar refinado no Brasil.

\subsubsection{Funções de demanda pela importação de açúcar refinado da União Européia - países selecionados}

Este item apresenta os países selecionados para a estimação das elasticidadespreço direta e preço cruzada de demanda pelas importações de açúcar refinado originadas da UE. Desta maneira, o primeiro desafio foi selecionar um número de países que têm uma participação significativa nas exportações de açúcar refinado da UE, e que sejam, ao mesmo tempo, importadores de açúcar brasileiro. A Tabela 33 apresenta os países selecionados, e as respectivas participações nas importações da UE em relação à importação total de açúcar refinado realizadas por esses países (valor do $S_{i j}$, utilizado

${ }^{29}$ No segundo grupo se encontram: França, Alemanha, Reino Unido, Áustria, Dinamarca, BélgicaLuxemburgo, Espanha e Holanda. 
para estimar as elasticidades-preço direta e cruzada das importações destes países). Os países listados na Tabela 33 foram responsáveis por um total médio de $42 \%$ do valor das exportações extra-bloco da UE, realizadas no período de 1989 a 1999.

Tabela 33. Participação do valor das exportações da UE em relação à importação total de açúcar refinado nos países selecionados $\left(S_{i j}\right)$, no período de 1996 a 1999 e participação geral no período de 1989 a 1999.

\begin{tabular}{lclc}
\hline País importador & $S_{i j}$ & País importador & $S_{i j}$ \\
\hline Argélia & 0.51 & Israel & 0.83 \\
Arábia Saudita & 0.18 & Jordânia & 0.29 \\
Costa do Marfim & 0.54 & Nigéria & 0.08 \\
Egito & 0.24 & Serra Leoa & 0.66 \\
Emirados Árabes & 0.74 & Síria & 0.73 \\
Gâmbia & 0.15 & Sri Lanka & 0.09 \\
Gana & 0.26 & Tunísia & 0.73 \\
Índia & 0.23 & Turquia & 0.65 \\
Indonésia & 0.05 & Iêmen & 0.08 \\
Irã & 0.42 & & \\
Participação do valor importado originado da & & \\
UE na importação total dos países & & 0.37 \\
\hline
\end{tabular}

Fonte: European Commission (1998, 2000); FAO (2003b)

Em seguida, foram estimadas as equações de elasticidade de substituição e de elasticidade de demanda total pelas importações de açúcar refinado para os países selecionados. Os dados utilizados foram descritos na Tabela 55, que se encontra no Apêndice 5. Estimou-se um único valor de elasticidade de substituição e de elasticidade de demanda para todos os países considerados. O mesmo se aplica à elasticidade-preço direta em relação à demanda pelas importações européias. Foi estimado um único valor destas elasticidades porque elas foram utilizadas para estimar o efeito da redução do 
subsídio na UE sobre o nível de preço do açúcar comercializado com este bloco, e, provavelmente, este efeito ocorrerá considerando o conjunto de países que demandam o produto da UE. Para estimar a elasticidade-preço direta da demanda utilizou-se como valor do $S_{i j}$ a participação geral das importações européias em todos os países considerados, descrita na última linha da Tabela 33.

É importante ressaltar, ainda, que foram realizadas análises para definição do melhor ajustamento econométrico a ser utilizado entre os métodos de estimação considerados. Constatou-se problema de singularidade na matriz de correção do modelo de Parks (matriz V). Portanto, sem problemas econométricos, as equações foram estimadas pelo método de Fuller \& Battese, cujos coeficientes estão descritos na Tabela 34. As estimativas de ambos os métodos não apresentaram diferenças significativas dos coeficientes.

Os sinais dos coeficientes obtidos e descritos na Tabela 34 apresentaram-se de acordo com o esperado pelo modelo econômico. A elasticidade-preço de substituição dos países importadores de açúcar refinado foi elástica (elasticidade maior do que 1), e a elasticidade-preço da importação geral de açúcar refinado apresentou-se inelástica. Isso indica que os países importadores reduzem a importação de açúcar em proporção menor do que um aumento do preço. No entanto, existe uma relativa facilidade em substituir a origem do açúcar importado, indicando mercado relativamente competitivo. É interessante notar que esta característica foi observada em todas as equações de demanda estimadas neste trabalho.

Os coeficientes estimados indicam que um aumento de $1 \%$ no preço de importação de açúcar refinado reduziria o volume demandado do produto em $0,63 \%$. Para a taxa de câmbio, a elasticidade resultou em torno de 0,3\%. Entretanto, não foi significativa. A renda foi outro fator importante na determinação da importação de açúcar refinado pelos países considerados para a análise (descritos na Tabela 33). Provavelmente, isso ocorreu porque a maioria desses países é classificada como países menos desenvolvidos, nos quais o fator renda é determinante para o consumo, mesmo de alimentos considerados básicos. 
Tabela 34. Estimativas das elasticidades-preço de substituição e de demanda da importação de açúcar refinado para países selecionados, importadores da União Européia e do Brasil; período de 1989 a 1999.

\begin{tabular}{ccccccc}
\hline & Intercepto & $\ln \left(P_{i j} / P_{i}\right)$ & $\ln P i$ & $\operatorname{lntc}$ & $\ln r e n$ & $\mathrm{R}^{2}$ \\
\hline $\ln \left(M_{i j} / M_{i}\right)$ & $-1,35$ & $-1,06$ & - & - & - & $4 \%$ \\
& $(0,00)$ & $(0,00)$ & - & - & - & \\
Volume & 11,70 & - & $-0,63$ & $-0,30$ & 0,53 & $11 \%$ \\
importado $\left(\ln M_{i}\right)$ & $(0,00)$ & - & $(0,04)$ & $(0,33)$ & $(0,00)$ & \\
& & & & & & \\
\hline
\end{tabular}

Fonte: resultados de pesquisa.

Nota: $\ln \left(M_{i j} / M_{i}\right)=$ Logaritmo da participação das importações originadas do país $j$ nas importações totais do país $i ; \ln \left(P_{i j} / P_{i}\right)=$ Logaritmo da relação entre o preço de importação do país $j$ no preço geral da importação do país $i ; \ln M_{i}=$ Logaritmo do volume total importado de açúcar; $\ln P i=$ logaritmo do preço de importação de açúcar refinado; lntc = logaritmo do índice taxa de câmbio efetiva real; lnren = logaritmo da variável valor da importação total, utilizada como proxy para estimar o efeito renda.

Os valores do coeficiente de determinação $\left(\mathrm{R}^{2}\right)$, descritos na Tabela 34, não são comparáveis aos observados nas equações estimadas anteriormente. De maneira geral, observou-se que a metodologia de Fuller \& Battese calculou um valor de $\mathrm{R}^{2}$ menor do que quando utilizado o método de Parks. Enquanto o método de Fuller utiliza a matriz $V$ descrita na eq. (40) como matriz de ponderação para estimar os coeficientes por Mínimos Quadrados Generalizados, Parks calcula esta mesma matriz $V$ de maneira diferente, como descrito na eq. (41). A utilização de métodos diferentes de estimação requer que o cálculo do coeficiente de determinação seja também diferente, não sendo comparáveis entre si.

Os valores das elasticidades de substituição e de preço descritos na Tabela 34 foram utilizados para estimar os valores das elasticidades-preço direta e cruzada do 
açúcar importado. A elasticidade-preço cruzada da demanda foi estimada, de outra maneira, considerando um valor por país importador de açúcar refinado da UE. Isto porque é o valor desta elasticidade que interfere no volume de açúcar exportado pelo Brasil, e em função dos diferentes valores destas elasticidades, tem-se também, de maneira distinta, o impacto sobre as exportações brasileiras, para cada um dos países selecionados. Nesta etapa, foi importante determinar a participação das exportações brasileiras para os países selecionados, porque o impacto sobre as mesmas foi estimado tendo-se como base as exportações verificadas para aqueles mercados.

Por causa da desregulamentação das exportações brasileiras de açúcar, o período tomado como base para estimar o aumento destas exportações em função de redução nas barreiras protecionistas foi de 1996 a 2002. Entretanto, como neste item foram consideradas também as exportações da UE, e os dados disponíveis neste caso são até 1999, foi padronizado um período base para estimar o impacto nas exportações brasileiras e européias, sendo de 1996 a 1999. Considerando o período base estabelecido, as exportações para os países selecionados totalizaram 44\% do valor das exportações européias extra-bloco e $74 \%$ do valor das exportações brasileiras totais de açúcar refinado (sendo $63 \%$ originárias do Centro-Sul e $11 \%$ do Norte-Nordeste). Os valores da elasticidade-preço direta e das elasticidades-preço cruzadas, utilizadas para as estimações do próximo item, estão descritos na Tabela 35.

Verifica-se na Tabela 35 que a elasticidade de demanda pela importação de açúcar refinado da UE foi de 0,9 . Ou seja, um aumento de $1 \%$ no preço de oferta da UE, ocasionado por redução dos subsídios ao produtor doméstico, reduziria a quantidade demandada pelo açúcar europeu em $0,9 \%$.

Em relação à elasticidade-preço cruzada, os valores devem ser interpretados da seguinte maneira: um aumento de $1 \%$ do preço de oferta de açúcar refinado da UE aumenta a demanda de um outro país ofertante em $\eta_{i j k}(\%)$ no país importador considerado. No caso desta análise, foi verificado o quanto aumentaria a demanda pela importação de açúcar refinado do Brasil. 
Tabela 35. Estimativas das elasticidades-preço direta $\left(\eta_{i j}\right)$ e preço cruzada $\left(\eta_{i j k}\right)$ da demanda pela importação de açúcar refinado da União Européia para cada um dos países selecionados.

\begin{tabular}{|c|c|c|c|c|c|c|}
\hline & $S_{i j}$ & $\left(1-S_{i j}\right)$ & $\sigma_{i}$ & $\varpi_{i}$ & $\eta_{i j}$ & $\eta_{i j k}$ \\
\hline Argélia & 0,51 & 0,49 & $-1,06$ & $-0,63$ & - & 0,87 \\
\hline Arábia Saudita & 0,18 & 0,82 & $-1,06$ & $-0,63$ & - & 0,30 \\
\hline Costa do Marfim & 0,54 & 0,46 & $-1,06$ & $-0,63$ & - & 0,92 \\
\hline Egito & 0,24 & 0,76 & $-1,06$ & $-0,63$ & - & 0,41 \\
\hline Emirados Árabes & 0,74 & 0,26 & $-1,06$ & $-0,63$ & - & 1,26 \\
\hline Gâmbia & 0,15 & 0,85 & $-1,06$ & $-0,63$ & - & 0,25 \\
\hline Gana & 0,26 & 0,74 & $-1,06$ & $-0,63$ & - & 0,44 \\
\hline Índia & 0,23 & 0,77 & $-1,06$ & $-0,63$ & - & 0,38 \\
\hline Indonésia & 0,05 & 0,95 & $-1,06$ & $-0,63$ & - & 0,09 \\
\hline Irã & 0,42 & 0,58 & $-1,06$ & $-0,63$ & - & 0,71 \\
\hline Israel & 0,83 & 0,17 & $-1,06$ & $-0,63$ & - & 1,40 \\
\hline Jordânia & 0,29 & 0,71 & $-1,06$ & $-0,63$ & - & 0,50 \\
\hline Nigéria & 0,08 & 0,92 & $-1,06$ & $-0,63$ & - & 0,13 \\
\hline Serra Leoa & 0,66 & 0,34 & $-1,06$ & $-0,63$ & - & 1,12 \\
\hline Síria & 0,73 & 0,27 & $-1,06$ & $-0,63$ & - & 1,23 \\
\hline Sri Lanka & 0,09 & 0,91 & $-1,06$ & $-0,63$ & - & 0,16 \\
\hline Tunísia & 0,73 & 0,27 & $-1,06$ & $-0,63$ & - & 1,23 \\
\hline Turquia & 0,65 & 0,35 & $-1,06$ & $-0,63$ & - & 1,11 \\
\hline Iêmen & 0,08 & 0,92 & $-1,06$ & $-0,63$ & - & 0,13 \\
\hline Participação total & 0,37 & 0,63 & $-1,06$ & $-0,63$ & $-0,90$ & - \\
\hline
\end{tabular}

Fonte: resultados de pesquisa.

Nota: $S_{i j}=$ participação do valor das exportações da UE em relação a importação total de açúcar refinado nos países selecionados; $\sigma_{i}=$ elasticidade de substituição estimada na Tabela 34; $\varpi_{i}=$ elasticidade-preço de importação estimada na Tabela 34. 
Dos países selecionados, os que aumentariam a importação de outros países de maneira mais do que proporcional ao aumento de preço do açúcar europeu foram: Emirados Árabes, Israel, Serra Leoa, Síria, Tunísia e Turquia. Isto ocorreu porque, nestes países, mais de $60 \%$ do valor importado de açúcar refinado foi originário da UE e, no caso de aumento de preço deste ofertante, o deslocamento da importação seria, conseqüentemente, maior.

Os resultados das elasticidades descritas na Tabela 35 foram utilizados no próximo item, quando foram estimados os impactos da redução dos subsídios na UE.

\subsubsection{Impacto da redução do subsídio da União Européia sobre as exportações de açúcar refinado do bloco europeu e do Brasil}

Neste tópico, a análise foi conduzida da seguinte maneira: (i) foi estimado o modelo descrito por Gardner (1987) para verificar o efeito de redução no subsídio concedido aos produtores da UE sobre volume e preço de suas exportações; (ii) com base nos resultados obtidos no item (i) em relação ao efeito sobre o nível de preço, e na estimativa da elasticidade-preço cruzada das exportações da UE obtidas no item anterior, obteve-se o efeito estimado sobre o volume das exportações brasileiras (desagregadas em Centro-Sul e Norte-Nordeste).

As elasticidades de oferta das exportações de açúcar refinado da UE e de demanda por alguns países selecionados foram estimadas nos itens 4.3.1 e 4.3.3.1, respectivamente. Com base nesses dados, o modelo de Gardner (1987) identificou os possíveis efeitos da redução nos subsídios (considerado aqui como subsídio cruzado) da UE sobre o comércio de açúcar refinado com os países demandantes considerados. Os resultados obtidos da aplicação das eq. (19) e (21) do modelo utilizado está descrito na Tabela 36. 
Tabela 36. Estimativas das mudanças percentuais em volume e preço das exportações européias de açúcar refinado em razão de mudanças nos níveis de subsídios concedidos.

\begin{tabular}{lcccc}
\hline & $\begin{array}{c}\text { Elasticidade- } \\
\text { preço de oferta }\end{array}$ & $\begin{array}{c}\text { Elasticidade-preço } \\
\text { de demanda }\end{array}$ & $d Q / d S$ & $d P / d S$ \\
\hline $\begin{array}{l}\text { Exportação da } \\
\text { União Européia }\end{array}$ & 0,26 & $-0,90$ & 0,20 & $-0,22$ \\
\hline
\end{tabular}

Fonte: resultados de pesquisa.

Nota: $d Q / d S$ = variação da quantidade exportada em função de uma variação no equivalente subsídio; $d P / d S$ = variação do preço de exportação em função de uma variação no equivalente subsídio.

Os resultados do modelo de Gardner (1987), estimados para verificar o efeito sobre volume e preço comercializado da UE com os países demandantes selecionados, indicaram que a redução de $1 \%$ no nível do subsídio da UE $(d S)$ diminuiria em $0,20 \%$ a quantidade demandada de açúcar refinado, e aumentaria o preço de exportação do açúcar europeu em $0,22 \%$.

Esses resultados mostraram-se pouco expressivos se comparados com os resultados obtidos em relação à redução dos equivalentes tarifários sobre as exportações brasileiras de açúcar bruto para a UE e os EUA. Nestes casos, a redução de 1\% dos equivalentes tarifários incidentes nas exportações brasileiras gerou impactos estimados, de maneira geral, acima de $0,5 \%$ sobre volume e preço comercializado com o Brasil. Esta diferença pode ser atribuída aos menores valores das elasticidades-preço de oferta e de demanda estimadas em relação ao comércio com o açúcar refinado da UE. O baixo valor da elasticidade-preço de oferta pode ser explicado pelo fato de que o nível de subsídio da UE apresenta-se tão elevado que uma redução marginal não seria capaz de provocar reduções expressivas na oferta do produto. Do lado da demanda, como mencionado anteriormente, a demanda inelástica em relação à importação de açúcar 
refinado da UE pode ter sido influenciada por fatores políticos utilizados para pressionar a preferência em relação à importação do produto originado do bloco europeu.

A Tabela 36 apresentou os resultados obtidos para identificar o impacto desta redução de subsídio na UE sobre as próprias exportações européias. Na Tabela 37 estão descritos os impactos estimados da redução de $1 \%$ de subsídio na UE sobre o aumento das exportações brasileiras. Para isto foi utilizado apenas o impacto sobre o nível de preço $(d P / d S)$. Isto ocorre porque o valor da elasticidade-preço cruzada da demanda é a ligação existente entre o efeito da redução do subsídio na UE com as exportações brasileiras de açúcar refinado. A segunda coluna da Tabela 37, que descreve o aumento percentual da demanda nos países selecionados, foi estimada multiplicando a elasticidade de variação do preço de exportação em função de uma variação no equivalente subsídio $(d P / d S=-0,22)$, descrita na Tabela 36 , pela elasticidade-preço cruzada da demanda de outros países em relação ao preço da UE, descrita na Tabela 35.

A diferença do impacto em relação às regiões Centro-Sul e Norte-Nordeste, neste caso, decorre apenas da média de suas exportações para os mercados de destino selecionados, uma vez que a elasticidade é a mesma.

Os países que aumentariam a demanda pelas importações de açúcar refinado do Centro-Sul do Brasil em um volume superior a 100 toneladas seriam Egito, Jordânia, Nigéria, Argélia e Índia. A demanda pelas importações do Norte-Nordeste, mais tímida, seria mais significativa para Argélia, Nigéria, Tunísia, Gana e Irã.

Da mesma maneira como foi considerado para a análise da redução do equivalente tarifário sobre as exportações brasileiras de açúcar bruto, foi também estimado o nível total de subsídio do mercado europeu. Calculou-se então um equivalente subsídio, em termos percentuais, em relação ao preço que a UE exporta extra-bloco. Para isto, foram considerados os preços médios de exportação praticados intra e extra-bloco, no período de 1989 a 2001, segundo dados da FAO (2003b). A diferença entre esses preços foi da ordem de $139 \%$ do preço extra-bloco, que é o preço concorrente com o do mercado mundial do produto. Desta maneira, havendo uma 
redução total no nível de subsídio ao preço doméstico do mercado europeu para o açúcar refinado, a demanda pelo açúcar do Brasil, nos países selecionados, seria significativamente maior, conforme mostrado na Tabela 38 .

Tabela 37. Impactos estimados sobre a demanda pelas exportações de açúcar refinado nas duas regiões brasileiras, em função de redução de $1 \%$ no nível de subsídio cruzado as exportações de açúcar refinado na União Européia.

\begin{tabular}{|c|c|c|c|c|c|}
\hline & \multirow{2}{*}{$\begin{array}{c}\% \text { do } \\
\text { aumento da } \\
\text { demanda }\end{array}$} & \multicolumn{2}{|c|}{$\begin{array}{c}\text { Média das exportações no } \\
\text { período de } 1996 \text { a } 1999 \\
\text { (ton./ano) }\end{array}$} & \multicolumn{2}{|c|}{$\begin{array}{l}\text { Aumento de demanda } \\
\text { (ton./ano) }\end{array}$} \\
\hline & & Centro-Sul & Norte-Nordeste & Centro-Sul & Norte-Nordeste \\
\hline Argélia & $0,19 \%$ & 59413 & 22500 & 113,66 & 43,04 \\
\hline Arábia Saudita & $0,07 \%$ & 6250 & 500 & 4,08 & 0,33 \\
\hline Costa do Marfim & $0,20 \%$ & 22400 & 1500 & 45,35 & 3,04 \\
\hline Egito & $0,09 \%$ & 285859 & 13800 & 255,04 & 12,31 \\
\hline Emirados Árabes & $0,28 \%$ & 7569 & 0 & 20,95 & 0,00 \\
\hline Gâmbia & $0,05 \%$ & 24787 & 2115 & 13,48 & 1,15 \\
\hline Gana & $0,10 \%$ & 98606 & 28822 & 96,44 & 28,19 \\
\hline Índia & $0,08 \%$ & 134456 & 3500 & 112,50 & 2,93 \\
\hline Indonésia & $0,02 \%$ & 86977 & 0 & 17,61 & 0,00 \\
\hline Irã & $0,16 \%$ & 54723 & 17675 & 85,04 & 27,47 \\
\hline Israel & $0,31 \%$ & 3281 & 0 & 10,14 & 0,00 \\
\hline Jordânia & $0,11 \%$ & 203719 & 0 & 222,51 & 0,00 \\
\hline Nigéria & $0,03 \%$ & 467436 & 122897 & 136,68 & 35,94 \\
\hline Serra Leoa & $0,25 \%$ & 16 & 750 & 0,04 & 1,85 \\
\hline Síria & $0,27 \%$ & 14325 & 3500 & 38,75 & 9,47 \\
\hline Sri Lanka & $0,03 \%$ & 148638 & 150 & 51,10 & 0,05 \\
\hline Tunísia & $0,27 \%$ & 11650 & 11223 & 31,50 & 30,35 \\
\hline Turquia & $0,24 \%$ & 2500 & 3500 & 6,08 & 8,52 \\
\hline Iêmen & $0,03 \%$ & 170144 & 0 & 48,12 & 0,00 \\
\hline \multicolumn{4}{|c|}{ Aumento total das exportações brasileiras de açúcar refinado } & 1309 & 205 \\
\hline
\end{tabular}

Fonte: resultados de pesquisa. 
Verifica-se, na Tabela 38, que se o Brasil suprir todo o aumento de demanda estimado, as exportações brasileiras deste produto aumentariam em cerca de 211 mil toneladas. Em relação ao atual nível da exportação existente (considerando a média do período de 1996 a 1999), o aumento estimado, apenas para os 19 países selecionados, representa 7,7\% das exportações brasileiras (6,6\% das exportações do Centro-Sul e $1 \%$ do Norte-Nordeste). Considerando apenas as exportações daquelas regiões, este aumento correspondeu a 9,5\% das exportações do Norte-Nordeste no período, e 7,4\% das exportações do Centro-Sul. Vale ressaltar que esses resultados foram estimados considerando os países selecionados anteriormente, e as exportações do Brasil para aqueles países. Portanto, um aumento maior no nível das exportações brasileiras poderia ser alcançado, pois contemplaria outros países não incluídos na presente análise.

Comparando os resultados obtidos na Tabela 38 com aqueles verificados em relação à redução total dos equivalentes tarifários dos EUA e da UE para o açúcar bruto importado do Brasil, constata-se que a eliminação dos subsídios que favorecem as exportações de açúcar da UE resultam em um efeito bem mais significativo. Enquanto a redução total do equivalente tarifário dos EUA e da UE impostos sobre as exportações brasileiras produziu um aumento de demanda pelo açúcar bruto do Brasil em cerca de 37.750 toneladas/ano e 26.260 toneladas/ano, respectivamente, a redução dos subsídios cruzados sobre as exportações de açúcar refinado da UE aumentaria a demanda pelo açúcar refinado do Brasil em cerca de 211.000 toneladas/ano. Ou seja, um volume exportado quase quatro vezes maior de açúcar refinado do que de açúcar bruto, sendo que este volume poderia ser ainda superior em função da interferência comercial da UE nas exportações brasileiras em um número maior de países.

O maior impacto que a redução dos subsídios ocasiona, em relação à redução do equivalente tarifário, ocorre porque, no caso dos subsídios da UE, as exportações brasileiras são prejudicadas frente a um grande número de países importadores, enquanto a redução tarifária afeta as exportações apenas para os EUA e para a UE. Além disto, o açúcar refinado, por ser um produto mais elaborado, possui um preço maior do que o comercializado para o açúcar bruto. 
Tabela 38. Impactos estimados sobre a demanda pelas exportações de açúcar refinado nas duas regiões brasileiras, em função de redução total nos atuais níveis de subsídio cruzado as exportações de açúcar refinado na União Européia.

\begin{tabular}{|c|c|c|c|c|c|}
\hline & & \multicolumn{2}{|c|}{$\begin{array}{c}\text { Média das exportações no } \\
\text { período de } 1996 \text { a } 1999 \\
\text { (ton./ano) }\end{array}$} & \multicolumn{2}{|c|}{$\begin{array}{c}\text { Aumento da demanda } \\
\text { (ton./ano) }\end{array}$} \\
\hline & & Centro-Sul & $\begin{array}{l}\text { Norte- } \\
\text { Nordeste }\end{array}$ & Centro-Sul & $\begin{array}{l}\text { Norte- } \\
\text { Nordeste }\end{array}$ \\
\hline Argélia & $26,41 \%$ & 59413 & 22500 & 15691 & 5942 \\
\hline Arábia Saudita & $9,73 \%$ & 6250 & 500 & 608 & 49 \\
\hline Costa do Marfim & $27,80 \%$ & 22400 & 1500 & 6227 & 417 \\
\hline Egito & $12,51 \%$ & 285859 & 13800 & 35761 & 1726 \\
\hline Emirados Árabes & $38,92 \%$ & 7569 & 0 & 2946 & 0 \\
\hline Gâmbia & $6,95 \%$ & 24787 & 2115 & 1723 & 147 \\
\hline Gana & $13,90 \%$ & 98606 & 28822 & 13706 & 4006 \\
\hline Índia & $11,12 \%$ & 134456 & 3500 & 14952 & 389 \\
\hline Indonésia & $2,78 \%$ & 86977 & 0 & 2418 & 0 \\
\hline Irã & $22,24 \%$ & 54723 & 17675 & 12170 & 3931 \\
\hline Israel & $43,09 \%$ & 3281 & 0 & 1414 & 0 \\
\hline Jordânia & $15,29 \%$ & 203719 & 0 & 31149 & 0 \\
\hline Nigéria & $4,17 \%$ & 467436 & 122897 & 19492 & 5125 \\
\hline Serra Leoa & $34,75 \%$ & 16 & 750 & 6 & 261 \\
\hline Síria & $37,53 \%$ & 14325 & 3500 & 5376 & 1314 \\
\hline Sri Lanka & $4,17 \%$ & 148638 & 150 & 6198 & 6 \\
\hline Tunísia & $37,53 \%$ & 11650 & 11223 & 4372 & 4212 \\
\hline Turquia & $33,36 \%$ & 2500 & 3500 & 834 & 1168 \\
\hline Iêmen & $4,17 \%$ & 170144 & 0 & 7095 & 0 \\
\hline \multicolumn{4}{|c|}{ Aumento total da demanda pelas exportações } & 182138 & 28692 \\
\hline
\end{tabular}

Fonte: Resultado de pesquisa. 
Considerando os preços médios de exportação de açúcar refinado (do período de 1996 a 1999) do Centro-Sul e do Norte-Nordeste, estes foram cerca de US\$ 0,23/kg e US\$ 0,29/kg, respectivamente. Assim, o valor do aumento da demanda pelas exportações brasileiras poderia ser estimado em US\$ 41,891 milhões para as exportações do Centro-Sul e em US\$ 8,320 milhões para as exportações do NorteNordeste.

Finalizando a primeira etapa deste capítulo, em que foram estimadas as elasticidades relativas ao aumento da demanda pelas exportações brasileiras em função da eliminação nas barreiras protecionistas dos mercados norte-americano e europeu e calculados os aumentos de demanda em função da redução total naqueles níveis de proteção, é importante mencionar as principais limitações desta etapa. Como já mencionado, as elasticidades estimam os efeitos marginais. Portanto, o efeito relativo da redução total nos níveis de proteção deve ser analisado com cautela. Acredita-se que esses efeitos foram subestimados, pois, à medida que as políticas protecionistas diminuíssem, os valores das elasticidades tenderiam a aumentar. Como não houve reduções nas políticas protecionistas significativas no período, e para os mercados estudados, as elasticidades calculadas tendem a ser menos elásticas do que seriam caso aqueles efeitos estivessem presentes.

Neste item estimaram-se várias elasticidades de oferta e de demanda, as quais foram utilizadas para compor os modelos de Gardner (1987). Sendo as estimativas dessas elasticidades, por si só, uma contribuição a mais deste trabalho, elas foram sintetizadas no Quadro 4. Neste quadro têm-se os resultados de todas as elasticidadespreço de oferta das exportações e, ou, as elasticidades de substituição e preço de demanda por importação de açúcar bruto ou refinado, conforme o interesse em relação ao país (ou região) considerado.

As elasticidades de substituição e preço de demanda por importação foram utilizadas para calcular as elasticidades-preço direta e preço cruzada de demanda pelas importações originadas de um país ou região específicos. Os diferentes valores das elasticidades-preço direta e cruzada encontrados para cada país (ou região) foram 
calculados considerando a participação do valor importado da origem do produto em relação ao valor das importações totais daquele país (ou região).

\begin{tabular}{|l|c|c|c|c|c|c|}
\hline & \multicolumn{2}{|c|}{$\begin{array}{c}\text { Elasticidade-preço de } \\
\text { oferta de exportação }\end{array}$} & \multicolumn{2}{|c|}{\begin{tabular}{c}
\multicolumn{2}{c|}{ Elasticidade substituição da } \\
demanda por importação
\end{tabular}} & \multicolumn{2}{c|}{$\begin{array}{c}\text { Elasticidade-preço de } \\
\text { demanda por importação }\end{array}$} \\
\hline & bruto & refinado & bruto & refinado & bruto & refinado \\
\hline Centro-Sul do Brasil & 1,284 & - & - & - & - & - \\
\hline $\begin{array}{l}\text { Norte-Nordeste do } \\
\text { Brasil }\end{array}$ & 0,71 & - & - & - & - & - \\
\hline Estados Unidos & - & - & $-4,7$ & - & 0,72 & - \\
\hline $\begin{array}{l}\text { União Européia - } \\
\text { primeiro grupo }\end{array}$ & - & - & $-1,81$ & - & $-0,25$ & - \\
\hline $\begin{array}{l}\text { União Européia - } \\
\text { segundo grupo }\end{array}$ & - & 0,26 & $-1,41$ & - & 0,50 & - \\
\hline Países selecionados & & & & $-1,06$ & - & $-0,63$ \\
\hline
\end{tabular}

Quadro 4 - Valores estimados das elasticidades-preço de oferta das exportações e, ou, preço de demanda por importações, de açúcar bruto ou refinado, nos países (regiões) estudados.

Nota: no primeiro grupo de países da União Européia inclui: Portugal, Grécia, Itália, Finlândia, Irlanda e Suécia. No segundo grupo se encontram: França, Alemanha, Reino Unido, Áustria, Dinamarca, Bélgica-Luxemburgo, Espanha e Holanda. Os países selecionados foram: Argélia, Arábia Saudita, Costa do Marfim, Egito, Emirados Árabes, Gâmbia, Gana, Índia, Indonésia, Irã, Israel, Jordânia, Nigéria, Serra Leoa, Síria, Sri Lanka, Tunísia, Turquia e Iêmen.

Em seguida, os resultados obtidos nesta primeira etapa foram utilizados como aumento de demanda final pelas exportações brasileiras do setor de fabricação de açúcar, na matriz de insumo-produto. Considerando as inter-relações desta matriz, estimou-se o 
impacto deste aumento de demanda, diferenciado em relação à economia das regiões Centro-Sul e Norte-Nordeste do Brasil.

\subsection{Impactos do aumento das exportações de açúcar sobre a economia brasileira}

Como descrito anteriormente, o impacto sobre a economia brasileira resultante das alterações nas exportações brasileiras de açúcar, mensuradas nos itens anteriores foi verificado utilizando uma matriz de insumo-produto do Brasil empregando dados de 1999. Esta matriz foi estimada e desagregada para as regiões Centro-Sul e NorteNordeste do Brasil por Guilhoto ${ }^{30}$. Alguns setores descritos nessa matriz, de maior interesse para o presente estudo, foram desagregados, a fim de ter uma maior riqueza de informações. Outros setores, menos relevantes, dado o objetivo deste trabalho foram agregados. A estimação dos setores trabalhados está descrita no Quadro 3 do capítulo metodológico, e foi obtida por Guilhoto ${ }^{30}$. A matriz utilizada está descrita na Tabela 56 do Apêndice 6.

O setor que sofreu o impacto da redução nas políticas protecionistas internacionais para o mercado de açúcar descrito neste trabalho foi o de fabricação de açúcar (identificado como setor número 14 na matriz insumo-produto). Esse setor inclui os produtos exportados enfocados pela análise (açúcar bruto e açúcar refinado). Entretanto, o setor fabricação de açúcar está diretamente relacionado ao setor de produção de álcool e com a produção de cana-de-açúcar, os quais são, respectivamente, substituto e insumo da produção de açúcar. Dessa forma, esses setores foram também desagregados e analisados de maneira mais detalhada.

Algumas características importantes da matriz inter-regional analisada devem ser descritas, a fim de justificar alguns tratamentos dados posteriormente neste trabalho. Verificaram-se valores transacionados (compras e vendas) bem superiores na região Centro-Sul do que na região Norte-Nordeste. Como vários setores foram agregados, os

\footnotetext{
${ }^{30}$ GUILHOTO, J.J.M. (USP. FEA. Departamento de Economia, São Paulo). Comunicação pessoal, 2003.
} 
setores desagregados (açúcar, álcool e cana-de-açúcar) foram penalizados em termos de valores de compra e venda, enquanto, por exemplo, o setor 20 (outros serviços) que foi extremamente agregado em relação aos demais, apresentou valores muito superiores aos dos demais setores.

Este item tem por objetivo verificar as inter-relações dos setores enfocados pela análise com os demais da economia, a fim de investigar as estimativas dos valores de ganhos e perdas nos níveis de produção e de emprego, resultantes dos impactos de mudanças em políticas protecionistas, descritas no item anterior. Os resultados dessa segunda etapa deste capítulo foram descritos em quatro partes.

$\mathrm{Na}$ primeira parte foram apresentados alguns índices que mostram o relacionamento entre os setores da economia. Foram calculados os índices de Rasmussen-Hirschman, que mensuram o grau de ligação dos setores, com base na demanda por insumos de outros setores (índice para trás), e como ofertantes de insumos para outros setores da economia (índice para frente). Mensurando essas mesmas relações, mas levando em consideração o nível de produção existente na economia, foram calculados os índices puros de ligação. Esses índices foram obtidos de maneira integrada, considerando as compras e vendas dos setores de cada região para toda a economia brasileira, e não apenas dentro da região analisada. Entretanto, o NorteNordeste apresenta valores de compras e vendas realizadas pelos setores bem menores do que aquela observada no Centro-Sul. Assim, de maneira a não subestimar a importância dos setores do Norte-Nordeste na economia brasileira, os índices foram ponderados pelos valores do nível de produção dos setores da própria região. Os multiplicadores dos tipos I e II da matriz inter-regional foram descritos na segunda parte.

$\mathrm{Na}$ terceira parte, estimou-se o impacto de um aumento de $\mathrm{R} \$ 1$ milhão nas exportações de açúcar para cada uma das regiões analisadas, com a finalidade de identificar a sensibilidade das exportações de cada região para a economia brasileira. A quarta parte estimou o impacto de um aumento das exportações de açúcar, em função da eliminação de medidas protecionistas no mercado de açúcar dos EUA e da EU, sobre o 
nível total de produção e emprego na economia das regiões Centro-Sul e Norte-Nordeste do Brasil.

\subsubsection{Análise dos índices de ligações na economia}

O cálculo dos índices de ligação, para frente e para trás, teve como objetivo mostrar um panorama da economia das regiões Centro-Sul e Norte-Nordeste do Brasil, indicando os setores mais importantes como demandantes ou como ofertantes de insumos na economia. Os índices de Rasmussen-Hirschman, por um lado, estimam a importância dos setores sem considerar o nível de produção em cada um deles. Por outro lado, os índices puros levam em consideração o valor da produção de cada setor, sendo uma indicação mais realista do grau de importância dos setores dentro da economia. Foram estimados os dois índices, procedendo a uma comparação entre eles.

\subsubsection{1 Índices de ligações de Rasmussen-Hirschman}

Os índices de Rasmussen-Hirschman calculados para todos os setores analisados na matriz inter-regional do Brasil (definida pelas regiões Centro-Sul e NorteNordeste) são apresentados na Tabela 42 do Anexo B. Os índices para frente mensuram o inter-relacionamento de cada setor como ofertante de insumo para os demais setores da economia nacional. Os índices de ligação para trás relacionam os setores da matriz interregional que são demandantes da produção de outros setores da economia nacional.

A Figura 26 ilustra os valores obtidos para os índices de ligação para frente e para trás nos setores das duas regiões, Centro-Sul e Norte-Nordeste, considerando as inter-relações entre elas.

Os maiores valores de índices para frente, dentre os setores da região CentroSul, em ordem descrescente, foram: 20 - outros serviços $\left[\mathrm{FL}^{31}=2,83\right]$; 4 - metalurgia

\footnotetext{
${ }^{31}$ Valor calculado para o índice de ligação de Rasmussen-Hirschman para frente.
} 
$[\mathrm{FL}=1,567] ; 11$ - refino de petróleo $[\mathrm{FL}=1,343] ; 17$ - Serviço de Utilidade Pública $[\mathrm{FL}=1,22]$; e 2 - resto da agropecuária $[\mathrm{FL}=1,195]$.

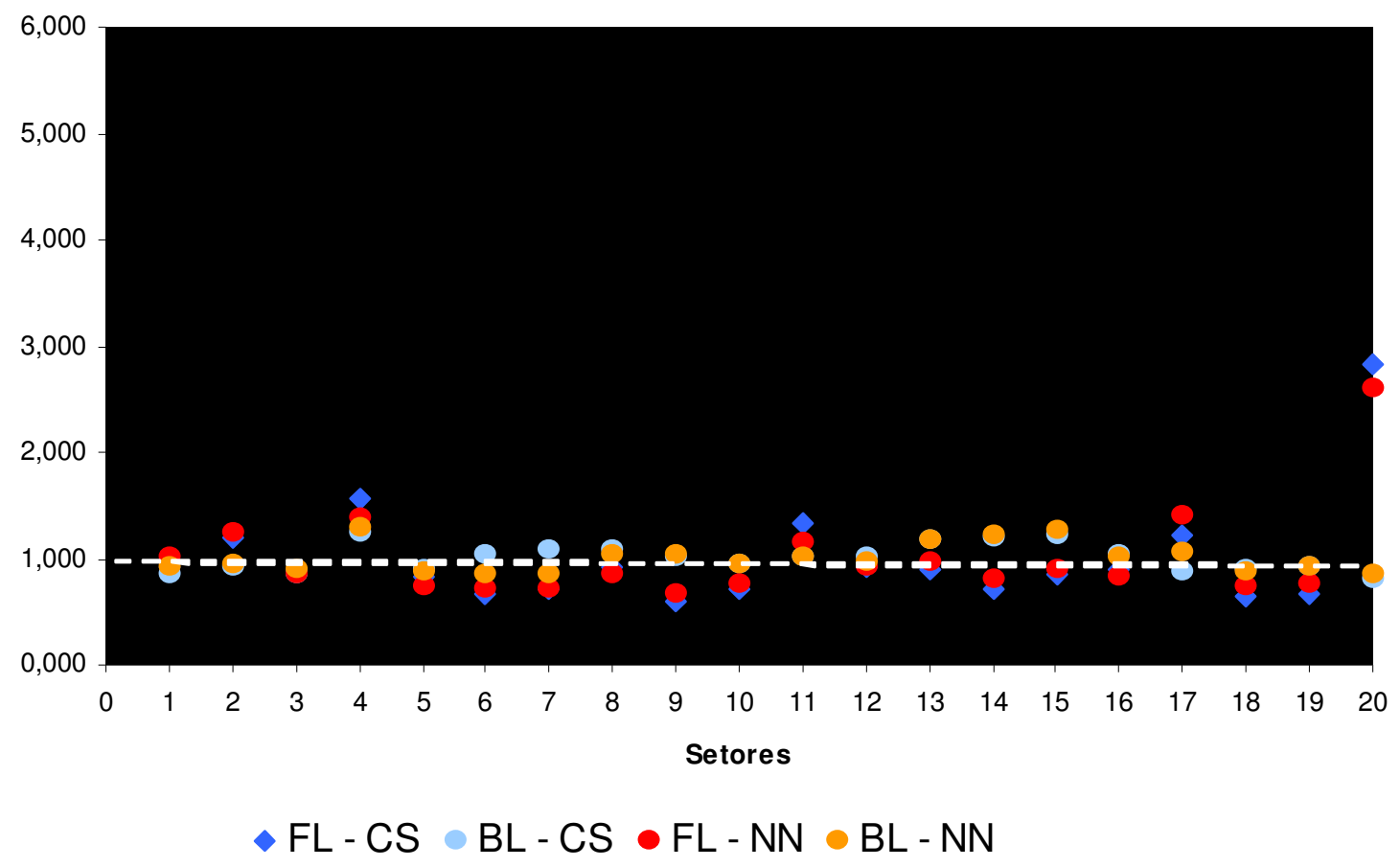

Figura 26 - Índices de Rasmussen-Hirschman para frente (FL) e para trás (BL) dos setores do Centro-Sul (CS) e do Norte-Nordeste (NN).

Fonte: resultados de pesquisa.

Nota: setor 1 - Cana-de-açúcar; setor 2 - Resto agropecuária; setor 3 - Extrativa; setor 4 - Metalurgia; setor 5 - Máquinas e tratores; setor 6 - Material elétrico e eletrônico; setor 7 - Material de transporte; setor 8 - Madeira, mobiliário, celulose, papel e gráfica; setor 9 - Álcool; setor 10 - Outros elementos químicos não petroquímicos; setor 11 - Refino de petróleo; setor 12 - Produtos do refino do petróleo; setor 13 - Têxtil, vestuário e calçados; setor 14 - Fabricação de açúcar; setor 15 - Outros produtos alimentares; setor 16 - Indústrias diversas; setor 17 Serviços industriais de utilidade pública; setor 18 - Construção civil; setor 19 Serviços prestados às famílias; setor 20 - Outros serviços. 
De maneira semelhante, estes mesmos setores apresentaram também os maiores índices no Norte-Nordeste, mas em diferente ordem decrescente de importância: 20 outros serviços $[\mathrm{FL}=2,6] ; 17$ - Serviço de Utilidade Pública $[\mathrm{FL}=1,39] ; 4$ - metalurgia $[\mathrm{FL}=1,377] ; 2$ - resto da agropecuária $[\mathrm{FL}=1,25]$; e 11 - refino do petróleo $[\mathrm{FL}=$ $1,14]$.

Os resultados referentes aos maiores índices para trás, indicam que ambas as regiões (Centro-Sul, denominada como CS, e Norte-Nordeste, descrita como NN) seguiram uma mesma ordem decrescente de importância para um único conjunto de setores, identificados como: 4 -metalurgia $\left[\mathrm{BL}^{32}-\mathrm{CS}=1,24\right.$; $\left.\mathrm{BL}-\mathrm{NN}=1,28\right] ; 15$ - outros produtos alimentares [BL-CS = 1,215; BL-NN = 1,256]; 14 - fabricação de açúcar [BL$\mathrm{CS}=1,206 ; \mathrm{BL}-\mathrm{NN}=1,256]$; e 13 - têxtil, vestuário e calçados [BL-CS = 1,16; BL-NN $=1,18]$.

Tem-se uma indicação, portanto, que dentre os quatro setores que determinam a maior demanda por insumos de outros setores da economia, encontra-se o setor de fabricação de açúcar. Já se tem, portanto, uma dimensão da importância do crescimento desse setor, seja pelas vendas ao mercado interno ou ao mercado internacional para alavancar o crescimento em outros setores da economia.

Os setores podem, ainda, ser analisados utilizando o critério de que os setores chaves da economia são aqueles com índices maiores do que 1, ou seja, índices maiores do que a média obtida pelos demais setores da região. Na Figura 26, as linhas pontilhadas indicam o valor unitário para estes índices. Verifica-se que, em ambas regiões, os setores de fabricação de açúcar (14) e de álcool (9) foram setores chaves para trás na economia. Ou seja, são setores que demandam mais da economia brasileira do que a média demandada pelos demais setores daquelas regiões.

É interessante notar, entretanto, que o setor de cana-de-açúcar no Centro-Sul não foi um setor chave em relação ao índice de ligação para frente, ao contrário do verificado para o setor do Norte-Nordeste. Isto indica que no Centro-Sul, a média dos

\footnotetext{
${ }^{32}$ Valor calculado para o índice de ligação de Rasmussen-Hirschman para trás.
} 
setores ofertantes de produtos para a economia brasileira foi maior do que a oferta de cana-de-açúcar.

Comparando-se as regiões verifica-se que os setores que apresentaram os valores dos índices mais diferenciados foram: 6 - material elétrico e eletrônico e 7 material de transporte. Esses foram setores chaves como demandantes de insumos da economia brasileira no Centro-Sul, e pouco importantes no Norte-Nordeste. O setor 17 Serviço de Utilidade Pública (SIUP), que foi setor chave no Norte-Nordeste, apresentando o quinto maior índice para trás, teve índice de impacto na demanda de insumos na economia de 1,063. Entretanto, este setor posicionou-se em décimo sétimo lugar em importância no Centro-Sul, com índice de impacto na economia daquela região de 0,88 .

Observa-se que, em ambas as regiões, o setor de cana-de-açúcar (setor 1) foi um importante ofertante de insumo na economia brasileira, apresentando-se como o sexto maior ofertante, conforme ordenamento em relação aos valores do índice para frente dos setores da economia, e assumindo valor de 0,927 do índice de ligação para frente no Centro-Sul e de 1,007 no Norte-Nordeste, para a agregação dos setores realizada nesta análise. Da mesma maneira, os setores de álcool (9) e de fabricação de açúcar (14) tiveram maiores índices de ligação para trás, sendo o setor 14 o terceiro maior setor em relação a este índice nas duas regiões [BL-CS $=1,206$; BL-NN = 1,211] e o setor 9 foi o nono maior em relação ao índice para trás da região Centro-Sul [BL-CS $=1,022]$ e o sétimo maior da região Norte-Nordeste [BL-NN = 1,039]. Esta comparação entre os setores de fabricação de açúcar e álcool pode sugerir que há um maior ganho na economia brasileira quando a cana-de-açúcar é utilizada para o processamento do açúcar em detrimento ao álcool.

\subsubsection{2 Índices puro de ligação}

Índices alternativos aos descritos anteriormente foram propostos por Guilhoto et al. (1996). Nestes índices, os impactos de um setor sobre os demais são calculados 
levando em consideração o tamanho relativo da produção dos setores. Por serem estimados a partir de uma matriz inter-regional, os índices puros de ligação calculados para um determinado setor, por exemplo, do Centro-Sul, mostram o impacto puro da produção deste setor sobre a produção dos demais setores desta região e do resto do Brasil. Entretanto, utilizou-se como numerário para este índice, uma medida adimensional, obtida pela normalização em relação ao valor da produção. A ponderação pelo valor da produção utilizou o valor da região analisada. Isto foi feito para que, como descrito anteriormente, seja estimada a importância dos setores do Norte-Nordeste para aquela região, não sendo comparados com os setores do Centro-Sul, que possuem um nível de produção muito superior.

A Tabela 43 no Anexo B, apresenta os valores calculados dos índices puros de ligação para frente, para trás e total, e suas respectivas ordenações. Esses mesmos valores são ilustrados na Figura 27. Estes resultados permitem destacar as diferenças existentes entre as duas regiões do país, como demandantes e ofertantes de insumos na economia.

Os resultados descritos na Tabela 43 (no Anexo B) indicam que os setores que apresentaram os maiores valores para os índices puros de ligações para frente (setores chaves como ofertantes de insumos na economia) foram os mesmos descritos para os índices de Rasmussen-Hirschman, nas duas regiões. Isto permite concluir que não houve divergências entre as duas metodologias utilizadas.

Em ordem decrescente, os setores que apresentaram os maiores índices para frente, e cujos valores são apresentados entre colchetes, nas duas regiões, foram: 20 outros serviços [PFL-CS = 4,474; PFL-NN = 5,447]; 2 - resto da agropecuária [PFL-CS $=2,544 ;$ PFL-NN = 3,46]; e 11 - refino de petróleo [PFL-CS = 2,45; PFL-NN = 1,7]; o setor 4 - metalurgia foi o quarto maior no Centro-Sul [PFL-CS $=1,847$ ] e o quinto na economia do Norte-Nordeste [PFL-NN = 1,476]; o setor 17 - SIUP, de outra maneira, foi o quarto maior ofertante (pelo índice puro) na economia do Norte-Nordeste [PFL-NN $=1,5]$ e o quinto na economia do Centro-Sul [PFL-CS = 1,159]. De maneira geral, os 
índices encontrados nestes setores foram maiores do que aqueles descritos para o índice de Rasmussen-Hirschman.

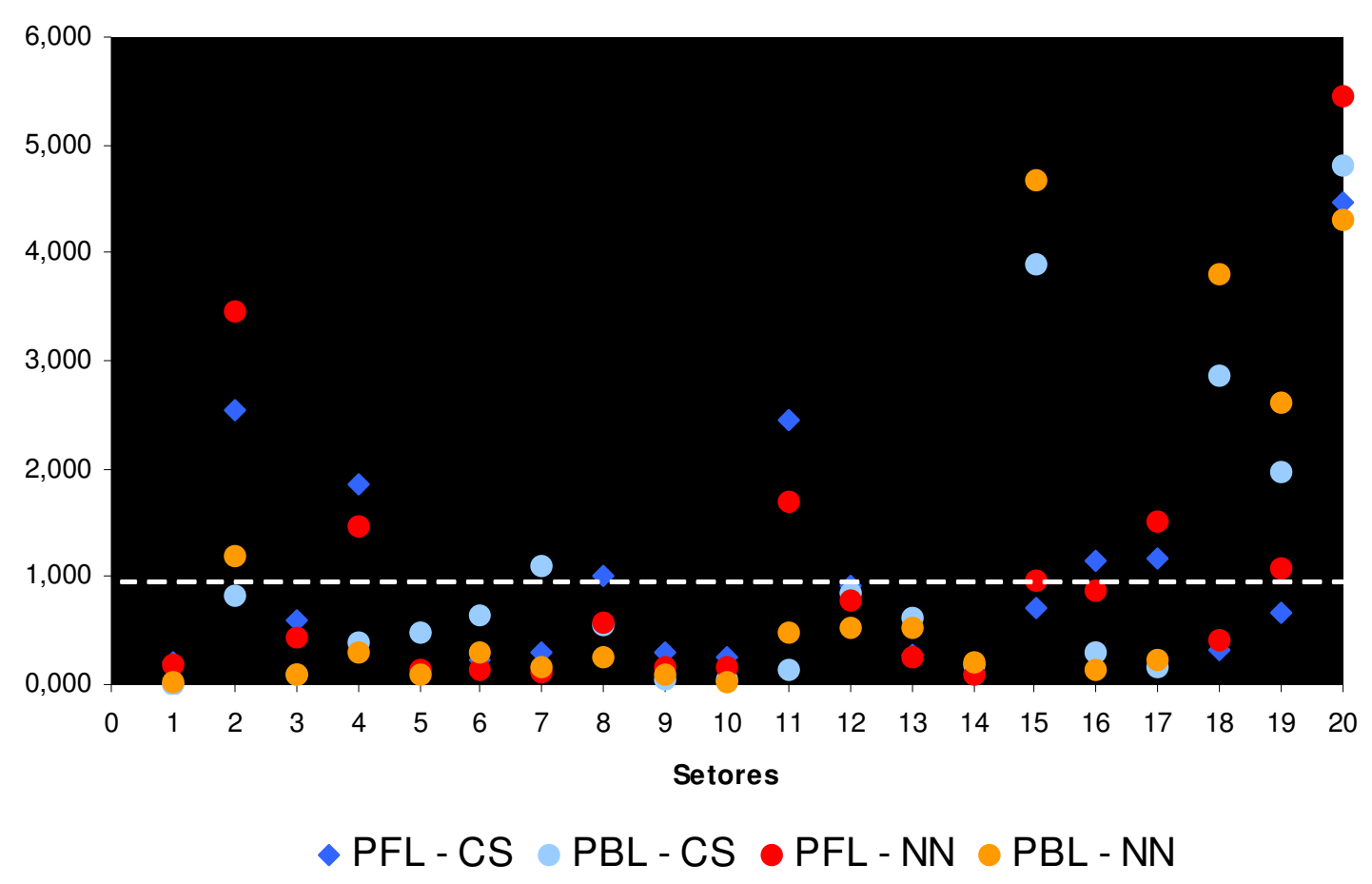

Figura 27 - Índices puros de ligação para frente (PFL) e para trás (PBL) dos setores do Centro-Sul (CS) e do Norte-Nordeste (NN).

Fonte: resultados de pesquisa.

Nota: setor 1 - Cana-de-açúcar; setor 2 - Resto agropecuária; setor 3 - Extrativa; setor 4 - Metalurgia; setor 5 - Máquinas e tratores; setor 6 - Material elétrico e eletrônico; setor 7 - Material de transporte; setor 8 - Madeira, mobiliário, celulose, papel e gráfica; setor 9 - Álcool; setor 10 - Outros elementos químicos não petroquímicos; setor 11 - Refino de petróleo; setor 12 - Produtos do refino do petróleo; setor 13 - Têxtil, vestuário e calçados; setor 14 - Fabricação de açúcar; setor 15 - Outros produtos alimentares; setor 16 - Indústrias diversas; setor 17 Serviços industriais de utilidade pública; setor 18 - Construção civil; setor 19 Serviços prestados às famílias; setor 20 - Outros serviços. 
Por outro lado, comparando o índice puro para trás com o de RasmussenHirschman, apenas o setor 15 - outros produtos alimentares ficou entre os setores chaves demandantes de insumos na economia daquelas regiões. Os setores da região Centro-Sul que apresentaram índices puros para trás maiores do que 1 foram: 20 - outros serviços $[\mathrm{PBL}=4,81] ; 15$ - outros produtos alimentares $[\mathrm{PBL}=3,88] ; 18$ - construção civil $[\mathrm{PBL}=2,869] ; 19$ - serviços prestados às famílias $[\mathrm{PBL}=1,979]$; e 7 - material de transporte $[\mathrm{PBL}=1,109]$. Para o Norte-Nordeste, os setores chaves como demandantes de insumos foram: 15 - outros produtos alimentares $[\mathrm{PBL}=4,66] ; 20$ - outros serviços $[\mathrm{PBL}=4,30] ; 18$ - construção civil $[\mathrm{PBL}=3,798]$; 19 - serviços prestados às famílias $[\mathrm{PBL}=2,615]$; e 2 - resto da agropecuária $[\mathrm{PBL}=1,185]$. Portanto, enquanto no Centro-Sul o setor de material de transporte foi chave naquela região em relação à demanda total na economia brasileira, no Norte-Nordeste este setor mostrou-se pouco importante. Já o resto da agropecuária foi um setor chave como demandante de insumos apenas na economia do Norte-Nordeste.

Especificamente em relação à agroindústria canavieira, verificou-se que, de maneira diferente do resultado obtido com o índice de Rasmussen-Hirschman, o índice puro não identificou os setores de fabricação de açúcar (14) e de álcool (9) como setores chaves em relação à demanda de insumos da economia brasileira. O setor 1 - cana-de-

açúcar também não foi identificado como setor chave para a oferta de produto na economia brasileira em nenhuma das duas regiões analisadas.

Os resultados dos índices de ligação da economia permitiram concluir que os setores da agroindústria de cana-de-açúcar (que inclui a produção de cana-de-açúcar, de açúcar e de álcool) tiveram um nível de importância maior na economia da região NorteNordeste, em relação à economia do Centro-Sul.

\subsubsection{Multiplicadores de produção tipo I e tipo II}

Os índices de ligação, cujos valores foram apresentados e discutidos no item anterior, fornecem uma indicação da relevância dos setores em cada região, como 
demandantes e ofertantes de insumos na economia brasileira. Os efeitos totais na produção e emprego da economia, resultantes dos impactos estimados na primeira parte do trabalho, foram calculados a partir do multiplicador de Leontief. Neste item foram estimados os multiplicadores do tipo I (MS1) e do tipo II (MS2), nas duas regiões da matriz inter-regional analisada.

Na Tabela 44 do Anexo B, estão descritos os resultados do cálculo dos multiplicadores tipo I e tipo II, na matriz inter-regional do Brasil. Os multiplicadores de produção indicam o impacto na produção de toda a economia brasileira, causado por uma variação na demanda final de cada setor e região. A principal diferença entre os multiplicadores tipo I e tipo II é que, neste segundo, o consumo das famílias é incorporado como mais um setor da economia, e não mais como um dos vetores que compõem a demanda final. Dessa maneira, o impacto total calculado pelo multiplicador tipo II é sempre maior do que o do tipo I.

A Figura 28 ilustra os resultados obtidos dos multiplicadores tipo I e tipo II. A diferença (medida verticalmente na Figura 28) entre o valor do MS2 e do MS1 no setor da região analisada ilustra o efeito renda do impacto causado pelo aumento na demanda final daquele setor e daquela região. Assim, essa figura permite identificar, de maneira apenas visual, para facilitar a interpretação dos resultados, os setores onde o efeito renda se apresentou mais importante como estimulador da economia brasileira, em cada uma das regiões analisadas. Os maiores impactos diretos, indiretos e pelo efeito renda, foram verificados na produção da economia brasileira, em relação ao aumento de demanda final nos setores 13 - têxtil, vestuário e calçados [MS2 = 3,986] e 14 -fabricação de açúcar [MS2 = 3,845], da região Norte-Nordeste. 


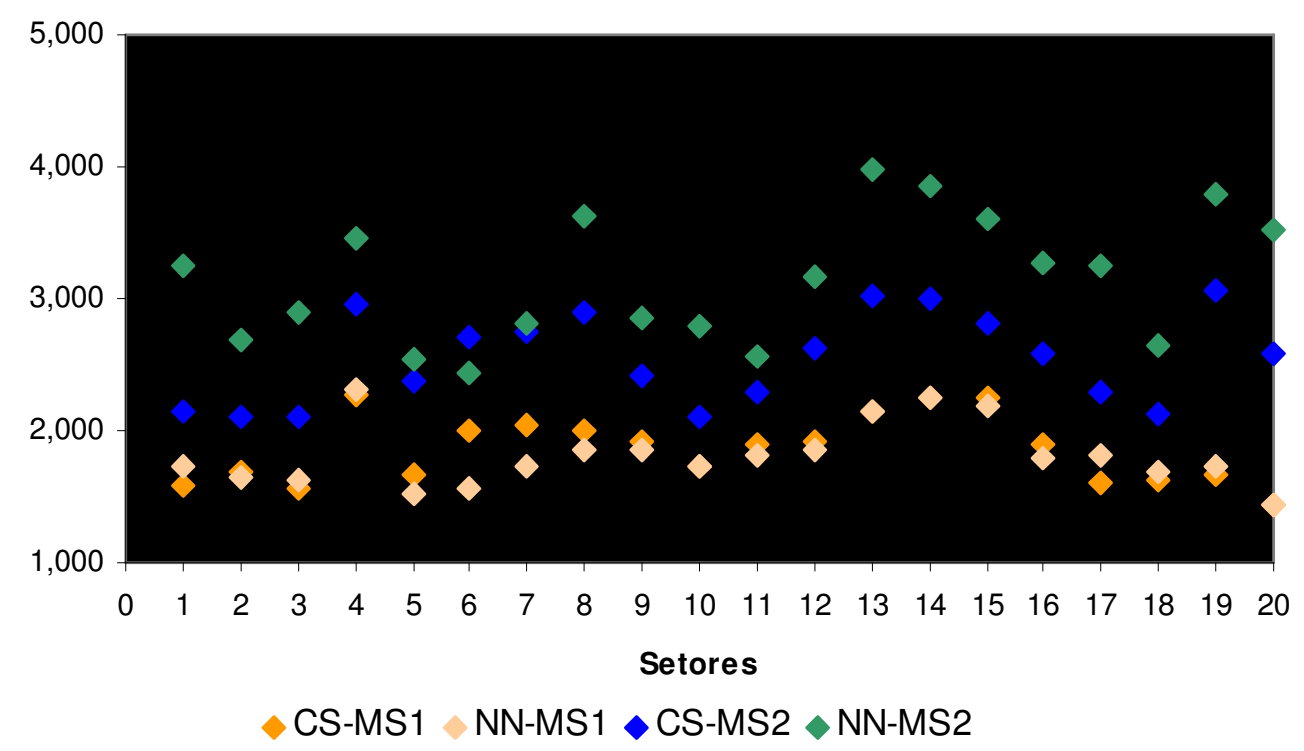

Figura 28 - Multiplicadores de produção tipo I (MS1) e tipo II (MS2), sobre a economia brasileira, em relação ao aumento de demanda final nos setores do CentroSul (CS) e do Norte-Nordeste (NN).

Fonte: resultados de pesquisa.

Nota: setor 1 - Cana-de-açúcar; setor 2 - Resto agropecuária; setor 3 - Extrativa; setor 4 - Metalurgia; setor 5 - Máquinas e tratores; setor 6 - Material elétrico e eletrônico; setor 7 - Material de transporte; setor 8 - Madeira, mobiliário, celulose, papel e gráfica; setor 9 - Álcool; setor 10 - Outros elementos químicos não petroquímicos; setor 11 - Refino de petróleo; setor 12 - Produtos do refino do petróleo; setor 13 - Têxtil, vestuário e calçados; setor 14 - Fabricação de açúcar; setor 15 - Outros produtos alimentares; setor 16 - Indústrias diversas; setor 17 Serviços industriais de utilidade pública; setor 18 - Construção civil; setor 19 Serviços prestados às famílias; setor 20 - Outros serviços.

Avaliando-se os resultados do multiplicador de produção do tipo I, verifica-se que em ambas as regiões, os mesmos setores responderam pelos quatro maiores multiplicadores da economia. Os maiores multiplicadores, em ordem decrescente, foram encontrados nos setores: 4 - metalurgia [MS1-CS = 2,270; $\mathrm{MS1-NN}=2,319] ; 14$ - 
fabricação de açúcar [MS1-CS = 2,257; MS1-NN = 2,255]; 15 - outros produtos alimentares [MS1-CS = 2,24; MS1-NN = 2,189]; e 13 - têxtil, vestuário e calçados [MS1-CS = 2,145; MS1-NN = 2,141]. O valor do multiplicador de produção tipo I do setor 8 - madeira, mobiliário, celulose, papel e gráfica foi o quinto maior na região Norte-Nordeste, com valor de 1,862 e o sexto no Centro-Sul, com valor de 2,009. Para o Centro-Sul, o quinto maior valor do multiplicador tipo I foi o setor 7 - material de transporte [MS1-CS = 2,031], ao passo que no Norte-Nordeste este setor foi colocado em décimo terceiro [MS1-NN = 1,722]. A maior importância do setor de material de transporte no Centro-Sul, em relação à economia do Norte-Nordeste, foi identificada também pelos índices de ligação para trás calculados anteriormente.

Na região Centro-Sul, os setores que apresentaram os maiores multiplicadores de produção tipo II, em ordem decrescente de importância, foram: 19 - serviços prestados às famílias; 13 - têxtil, vestuário e calçados; 14 - fabricação de açúcar; 4 metalurgia; e 8 - madeira, mobiliário, celulose, papel e gráfica. Estes setores causam um aumento de produção na economia brasileira, de cerca de três vezes, quando se aumenta a demanda final dos mesmos (MS2 variou de 3,06 a 2,89 nestes setores). No NorteNordeste, os setores que apresentaram os maiores valores em relação a este mesmo multiplicador foram: 13 - têxtil, vestuário e calçados [MS2 = 3,986]; 14 - fabricação de açúcar [MS2 = 3,845]; 19 - serviços prestados às famílias [MS2 = 3,787]; 8 - madeira, mobiliário, celulose, papel e gráfica $[\mathrm{MS} 2=3,615]$; e 5 - outros produtos alimentares [MS2 = 3,607]. Como pode ser observado nos valores entre colchetes, espera-se um impacto na economia brasileira acima de 3,5 vezes do choque inicial dado em quaisquer desses setores.

Considerando os setores da agroindústria canavieira, identificou-se o setor de fabricação de açúcar como tendo um alto valor de multiplicador de produção, tipo I e tipo II, nas duas regiões. Os valores dos multiplicadores para os setores: 1 - cana-deaçúcar; 9 - álcool e 14 - fabricação de açúcar foram semelhantes, nas duas regiões, em relação ao multiplicador tipo I. Já com os multiplicadores tipo II, estes setores apresentaram, na região Norte-Nordeste, valores maiores do que naqueles setores do 
Centro-Sul. Em geral, verificou-se maior valor do multiplicador tipo II no NorteNordeste do que no Centro-Sul, nos setores analisados. Este resultado pode ser explicado porque, tendo a região Norte-Nordeste um nível de renda menor do que no Centro-Sul, o Norte-Nordeste é mais sensível ao efeito renda.

Em função das relações entre os setores descritas na matriz de insumo-produto, um choque de demanda em um setor tem o impacto de aumentar os insumos utilizados por este, mas não o efeito de reduzir a produção em outro setor que compete pelos mesmos insumos. Uma vez que este trabalho enfocou o aumento da demanda final no setor de fabricação de açúcar (14), e o setor de álcool (9) é concorrente em relação à demanda por cana-de-açúcar, a comparação dos impactos sobre a economia brasileira decorrentes do aumento da demanda nestes dois setores torna-se importante, dado que pode haver substituição entre estes produtos.

Corroborando com o resultado apresentado pelo índice de ligação de Rasmussen-Hirschman, verificou-se com os multiplicadores de produção, uma maior importância do setor de fabricação de açúcar (14) em relação ao de álcool (9). Os multiplicadores de produção calcularam o impacto na economia brasileira em função do aumento na demanda final de álcool sendo cerca de $80 \%$ do impacto estimado pelo aumento de demanda de açúcar, nas duas regiões. Portanto, apesar dos resultados descritos em relação aos impactos na produção e no emprego apresentarem efeitos positivos em todos os setores da economia brasileira, uma possível substituição na produção de açúcar em detrimento ao álcool ainda teria mais benefícios para a economia brasileira.

Segundo Moraes (2002), em função das peculiaridades existentes na cadeia produtiva da agroindústria canavieira, havia dificuldades deste setor equilibrar a oferta e a demanda de açúcar e álcool pelas forças de mercado. Esse foi o principal motivo da escassez de oferta de álcool em vários períodos, em detrimento da produção de açúcar (Moraes, 2002). Entretanto, mais recentemente, várias ações têm sido implementadas visando a regularidade da oferta de álcool combustível. Pinazza \& Alimandro (2003) descrevem algumas dessas ações: a criação dos motores flexíveis, que podem utilizar 
tanto gasolina quanto álcool combustível; a tributação diferenciada em relação ao veículo a álcool, já reconhecido no IPI, e que deve ser estendido ao ICMS e ao IPVA; a Medida Provisória $n^{0} 75$, de 24/10/2002, do governo federal, garantindo o incentivo ao uso de combustíveis de origem renovável para alguns tipos de automóveis, em todo território nacional; projeto de Lei $\mathrm{n}^{\mathrm{o}} 7.189 / 2002$, que trata da subvenção de $\mathrm{R} \$ 1$ mil para os compradores de veículos a álcool ${ }^{33}$; aprovação do Programa de Financiamento para Estocagem do Álcool pelo Conselho Monetário Nacional em 2002; e consignação de parte da produção do álcool via contrato com empresas exportadoras (trading). Além disto, segundo Agroanalysis (2003), o setor sucroalcooleiro assumiu compromisso junto ao atual governo para garantir o abastecimento de álcool. Assumindo que estas ações sejam efetivas, o aumento da demanda pelas exportações de açúcar poderia, realmente, não ter efeito negativo na produção de álcool.

Os resultados dos multiplicadores de produção da economia permitiram concluir, de maneira complementar aos dos índices de ligação, que os setores da agroindústria de cana-de-açúcar da região Norte-Nordeste impactam a economia brasileira em uma proporção maior do que a agroindústria canavieira da região Centro-Sul. No próximo item foi identificada a sensibilidade das duas regiões para um mesmo choque na demanda final do setor de fabricação de açúcar, em cada uma das regiões.

Utilizando os resultados dos multiplicadores obtidos na Tabela 44 no Anexo B, foram estimados: (i) a sensibilidade das exportações de açúcar em cada região e (ii) os impactos sobre o nível total da produção e do emprego, decorrentes de variações nas exportações brasileiras de açúcar estimadas na primeira etapa dos resultados.

\footnotetext{
${ }^{33}$ Segundo estes autores, a subvenção não será financiada apenas pelo Tesouro Nacional, mas também por recursos provenientes da compensação financeira pela redução de gases do efeito estufa, segundo termos do Protocolo de Kyoto, pelo governo alemão.
} 


\subsubsection{Análise de sensibilidade das exportações de açúcar nas regiões Centro-Sul e Norte-Nordeste do Brasil}

Neste item foram calculados os impactos na produção e no número de empregos da economia brasileira resultantes de dois choques, da mesma magnitude, no setor de indústria de açúcar, sendo cada choque dado no setor 14 - fabricação de açúcar de uma região da matriz inter-regional. O choque foi relativo a um aumento de demanda final de açúcar no valor de $\mathrm{R} \$ 1$ milhão. Desta maneira, procurou-se verificar qual região é mais sensível a um aumento de demanda final para o setor analisado neste trabalho.

Na Tabela 45 do Anexo B têm-se os resultados do impacto sobre a produção da economia brasileira, decorrentes de um aumento na demanda final de açúcar de $\mathrm{R} \$ 1$ milhão em cada uma das regiões separadamente. Os resultados descritos nesta tabela são sintetizados na Figura 29. Foram estimados os aumentos da produção sem e com a inclusão do consumo das famílias, ou seja, a partir dos multiplicadores tipo I e tipo II. O aumento da produção calculado a partir do multiplicador tipo I representa o aumento direto e indireto provocado em toda a economia brasileira pelo aumento da demanda final em um setor. O impacto calculado a partir do multiplicador tipo II indica o aumento direto, indireto e o induzido pelo aumento de renda provocado na economia, quando incluída a demanda final das famílias na matriz de setores da economia.

Os resultados visualizados na Figura 29 mostram que o impacto na demanda final de açúcar da região Norte-Nordeste afeta a produção, direta e indireta, da própria região em $R$ \$ 1,847 milhão, enquanto no Centro-Sul este impacto é maior na própria região ( $\mathrm{R}$ \$ 2,162 milhões). Considerando também o impacto do efeito renda na análise, os impactos do aumento na demanda final de uma região, na própria região considerada, tornam-se semelhantes. Assim, observou-se o aumento de R $\$ 2,803$ milhões no CentroSul, quando foi dado um choque na demanda de açúcar de $\mathrm{R} \$ 1$ milhão no Centro-Sul. No Norte-Nordeste, o choque na demanda de açúcar de R \$ 1 milhão gerou o aumento de $\mathrm{R} \$ 2,754$ milhões no valor total da produção desta região. 


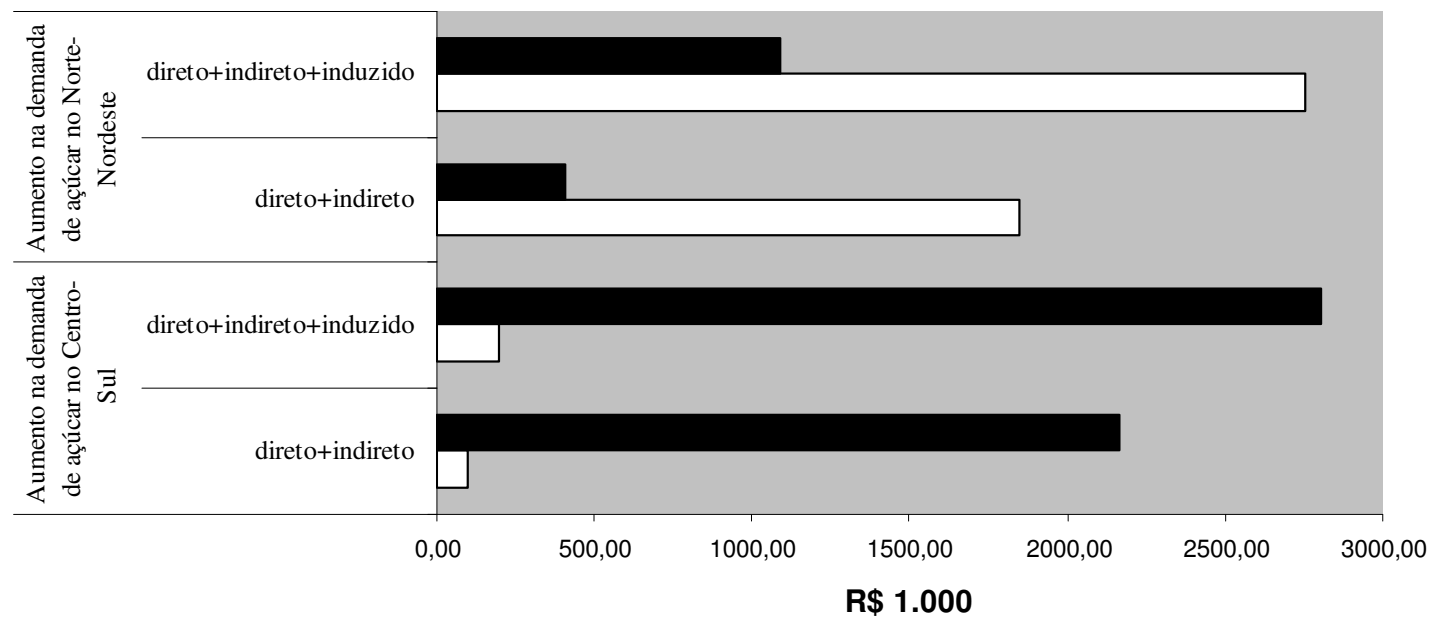

$\square$ Aumento na produção do Norte-Nordeste $\square$ Aumento na produção do Centro-Sul

Figura 29 - Impactos na produção anual da economia das regiões Centro-Sul e NorteNordeste do Brasil, em relação ao aumento de demanda final de açúcar de $\mathrm{R} \$ 1$ milhão nas regiões Centro-Sul e Norte-Nordeste.

Fonte: resultados de pesquisa.

Nota: o efeito induzido corresponde ao aumento da produção em função do aumento do efeito renda das famílias.

É interessante observar que o choque na demanda final de açúcar na região Norte-Nordeste causou um impacto na produção do Centro-Sul (cujo valor foi de $\mathrm{R} \$$ 1,091 milhão, para o total dos impactos diretos, indiretos e induzidos pelo efeito renda) maior do que o impacto provocado no Norte-Nordeste (cujo valor foi de R 0,197 milhão, considerando os impactos diretos, indiretos e induzidos pelo efeito renda). Portanto, o impacto total no valor da produção da economia brasileira apresenta-se maior quando o choque de demanda final de açúcar ocorre na região Norte-Nordeste.

Os resultados destes mesmos choques (aumento de demanda final de açúcar no Centro-Sul e no Norte-Nordeste) frente ao nível de emprego gerado na economia são ainda mais favoráveis quando o choque ocorre para a região Norte-Nordeste. O impacto no número de empregos em cada setor analisado, e em cada região, são descritos na 
Tabela 46 do Anexo B. Na Figura 30 têm-se os resultados totais dos setores para cada região.

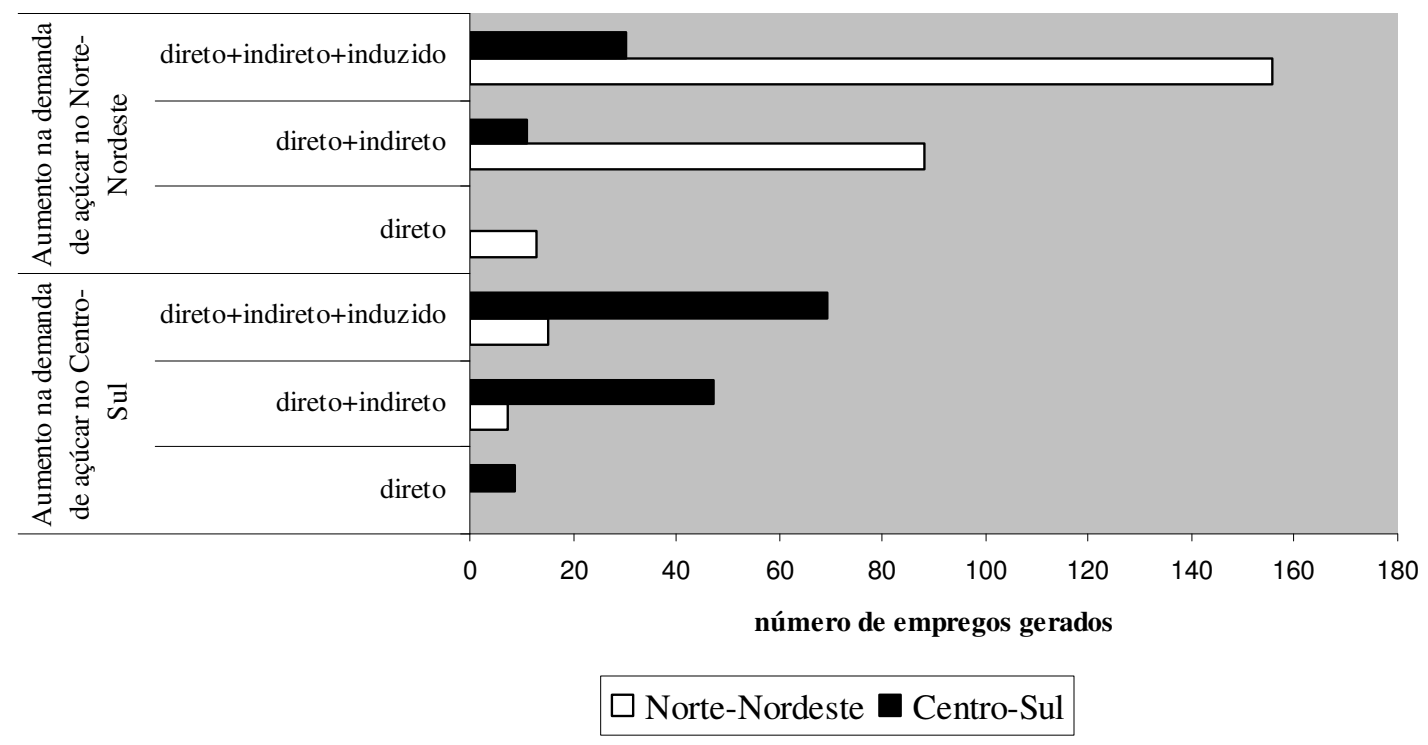

Figura 30 - Impactos no número de empregos/ano da economia das regiões Centro-Sul e Norte-Nordeste do Brasil, em relação ao aumento de demanda final de açúcar de R \$ 1 milhão nas regiões Centro-Sul e Norte-Nordeste.

Fonte: resultados de pesquisa.

Nota: o efeito induzido corresponde ao aumento da produção em função do aumento do efeito renda das famílias.

Observa-se na Figura 30 que o impacto na demanda final de açúcar da região Norte-Nordeste afeta o número de empregos gerados, direta + indiretamente, e, direta + indiretamente + induzido pelo efeito renda, em uma proporção maior na própria região (88 e 156 empregos/ano, respectivamente, na região Norte-Nordeste), do que o impacto no Centro-Sul (47 e 69 empregos/ano, respectivamente).

O efeito do choque de demanda de açúcar em uma região sobre o nível de emprego na outra região foi também maior considerando o choque na demanda final do Norte-Nordeste. Assim, verifica-se que o aumento da demanda final de R \$ 1 milhão no 
setor fabricação de açúcar do Norte-Nordeste aumenta o número de empregos no Centro-Sul em 11 empregos/ano (efeitos direto e indireto) e 30 empregos/ano (efeitos direto, indireto e induzido). O impacto deste aumento da demanda final no setor de fabricação de açúcar na região Centro-Sul, por sua vez, aumenta em apenas 7 empregos/ano (efeitos direto e indireto) e 15 empregos/ano (efeitos direto, indireto e induzido) no Norte-Nordeste.

Portanto, conclui-se que houve um maior poder propagador dos choques de aumento na demanda final de açúcar na economia do Norte-Nordeste em relação à economia do Centro-Sul. Entretanto deve-se ressaltar que, apesar deste resultado, como a produção de açúcar tem um menor custo de produção na região Centro-Sul, as exportações tendem a responder mais a choques nesta região. Este fato foi observado pelos resultados encontrados na primeira etapa deste trabalho. Desta maneira, a seguir foram calculados os impactos do aumento estimado nas exportações de açúcar das duas regiões sobre o nível da produção e emprego na economia brasileira.

\subsubsection{Impactos das alterações estimadas nas exportações brasileiras de açúcar, sobre a economia das regiões exportadoras do Brasil}

Neste item foram calculados os efeitos de alterações nas exportações brasileiras, sobre a produção total e o emprego no Brasil. Os choques iniciais que provocaram o aumento das exportações brasileiras de açúcar foram provenientes da eliminação das políticas protecionistas nos EUA e na UE. Na UE observaram-se os efeitos de dois choques: (i) a eliminação de políticas protecionistas em relação à importação de açúcar bruto, e (ii) as políticas de subsídio cruzado que favorecem as exportações de açúcar refinado. Os resultados foram obtidos para cada um desses choques.

Uma vez que os multiplicadores utilizados são os mesmos para estimação de todos os choques, as magnitudes dos resultados dependeram do aumento das exportações brasileiras de açúcar estimado anteriormente, para cada caso de eliminação 
de política protecionista. De outra maneira, as inferências feitas em relação à sensibilidade das exportações das duas regiões exportadoras analisadas no item anterior devem ser consideradas para interpretação dos resultados descritos neste item.

Na Tabela 39, têm-se, resumidamente, os três choques estimados na primeira fase deste trabalho, e que foram utilizados para analisar os impactos sobre a economia brasileira.

Tabela 39. Choques estimados sobre as exportações brasileiras de açúcar, pela eliminação das políticas protecionistas nos Estados Unidos e na União Européia.

\begin{tabular}{llcc}
\hline & Descrição do choque & \multicolumn{2}{c}{ Aumento das exportações (US\$ mil) } \\
\cline { 3 - 4 } Choque 1 & $\begin{array}{l}\text { Eliminação do protecionismo sobre o } \\
\text { mercado de açúcar dos EUA }\end{array}$ & $7.640,00$ & $7.865,00$ \\
Choque 2 & $\begin{array}{l}\text { Eliminação do protecionismo no mercado } \\
\text { de açúcar bruto na União Européia }\end{array}$ & $6.898,56$ & $6.654,48$ \\
Choque 3 & $\begin{array}{l}\text { Eliminação do subsídio cruzado sobre a } \\
\text { exportação de açúcar refinado na UE }\end{array}$ & $41.891,00$ & $8.320,00$ \\
Choque 4 & Soma dos choques 1, 2 e 3 & $56.429,56$ & $22.839,48$ \\
\hline
\end{tabular}

Fonte: resultados de pesquisa.

Nota: para converter os valores dados em US\$, foi utilizado o índice da taxa de câmbio efetiva real, média mensal, para o ano de 1999. Esta taxa foi de 1,666.

É de se esperar que os impactos originados dos choques 1 e 2 sejam semelhantes, pois causam um valor exportado semelhante nas duas regiões. Já com o choque 3, espera-se que seus impactos sejam superiores aos causados pelos choques 1 e 2 juntos, na região Centro-Sul, uma vez que o volume exportado pelo choque 3 nesta região foi maior que os outros dois. Os impactos foram calculados com base no aumento do valor e não do volume das exportações, uma vez que as matrizes são apresentadas em 
reais (moeda nacional). Entretanto, como foram estimados os valores das exportações em dólares, e a matriz utilizada é representativa do ano de 1999, os valores descritos acima foram convertidos em moeda nacional pelo índice da taxa de câmbio efetiva real para 1999.

Na Tabela 47 (Anexo B) estão descritos os resultados dos impactos na produção da economia brasileira, decorrentes de um aumento de demanda pelas exportações das regiões Centro-Sul e Norte-Nordeste, separadamente, considerando-se cada choque descrito na Tabela 39. Como esperado, os impactos estimados pela política de subsídios cruzados às exportações de açúcar refinado na UE foram superiores aos estimados pelas políticas que restringem as importações de açúcar bruto provenientes do Brasil, nos EUA e na UE. A Figura 31 ilustra este efeito.

Observa-se, na Tabela 47 (Anexo B) e na Figura 31, que o impacto na produção foi maior na região Centro-Sul. Entretanto, considerando a variação da produção em relação ao que já existia naquelas economias, a região Norte-Nordeste teve um impacto 0,0083\% maior do o aumento percentual da produção do Centro-Sul.

Os setores que apresentaram os maiores impactos na produção foram: o próprio setor que sofreu o choque de demanda (setor 14 - fabricação de açúcar) e o setor 1 cana-de-açúcar. Este impacto aumentou a produção do setor 1 em 0,32\% no NorteNordeste, e em $0,086 \%$ no Centro-Sul; e aumentou a produção do setor 14 em 1,02\% no Norte-Nordeste, e em 0,2\% no Centro-Sul. Portanto, levando em conta o nível de produção de cada região separadamente, o Norte-Nordeste sofreu um impacto maior do que a região Centro-Sul. O setor 20 - outros serviços, teve um impacto superior ao verificado para o setor de cana-de-açúcar, nas duas regiões, mas como descrito anteriormente, este setor apresentou um nível de agregação muito grande quando comparados aos demais, sendo este fator responsável pelo maior impacto calculado.

De maneira geral, todos os setores apresentaram um aumento significativo quando inserido o efeito renda na análise. Entretanto, os setores que mais se beneficiaram com o efeito da renda provocado pelo aumento da demanda pelas 
exportações de açúcar, nas duas regiões, foram: 20 - outros serviços; 2 - resto da agropecuária; 15 - outros produtos alimentares; 19 - serviços prestados às famílias.

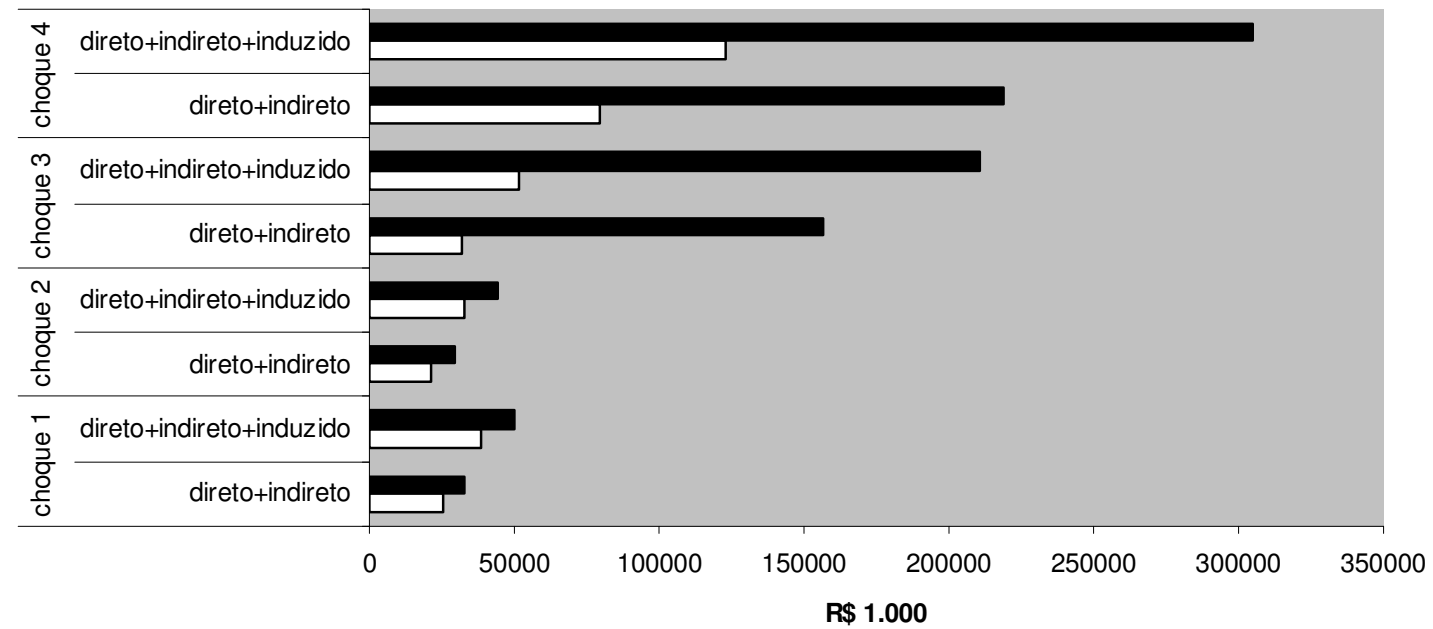

$\square$ Norte-Nordeste $\square$ Centro-Sul

Figura 31 - Impactos na produção da economia das regiões Centro-Sul e Norte-Nordeste do Brasil, em relação ao aumento de demanda final de açúcar estimado anteriormente.

Fonte: resultados de pesquisa.

Nota: choque 1 - eliminação do protecionismo sobre o mercado de açúcar bruto dos EUA; choque 2 - eliminação do protecionismo no mercado de açúcar bruto na UE; choque 3 - eliminação do subsídio cruzado sobre a exportação de açúcar refinado na UE; choque 4 - representa a soma dos três choques descritos anteriormente. O efeito induzido corresponde ao aumento da produção em função do aumento do efeito renda das famílias.

Como pode ser visualizado na Tabela 47 (Anexo B), o álcool (setor 9), apesar de ser produzido de maneira alternativa ao açúcar, também foi impactado de maneira positiva. Como discutido anteriormente, seria de se esperar que um aumento na demanda final por açúcar reduzisse, ou pelo menos, não estimulasse, a oferta de álcool 
combustível, anidro e hidratado. Entretanto, em função do estímulo dado em toda economia brasileira com o açúcar exportado, e como o álcool apresenta-se como insumo em vários setores, sua produção foi, conseqüentemente, incentivada.

Analisando o impacto no emprego da economia, na Tabela 48 (Anexo B) estão descritos os resultados calculados pelo aumento de demanda das exportações nas regiões Centro-Sul e Norte-Nordeste. No setor de fabricação de açúcar (14), o aumento direto e indireto provocado em toda a economia brasileira pelo aumento da demanda final de açúcar, a partir do multiplicador tipo I; e o aumento direto, indireto e o induzido pelo aumento de renda provocado na economia, a partir do multiplicador tipo II. Da mesma maneira que foi verificado em relação ao impacto sobre a produção, os impactos no emprego estimados pela política de subsídios cruzados às exportações de açúcar refinado na UE foram superiores aos estimados pelas políticas que restringem as importações de açúcar bruto provenientes do Brasil, nos EUA e na UE. A Figura 32 demonstra a magnitude de cada um dos choques de demanda estimados para o açúcar, nas economias das duas regiões exportadoras: Centro-Sul e Norte-Nordeste.

Os resultados da geração de empregos visualizados na Figura 32 podem surpreender inicialmente, uma vez que, em relação à produção, a região Centro-Sul do Brasil apresentou resultados superiores aos encontrados para a região Norte-Nordeste. Os resultados descritos na Tabela 48 (Anexo B) e visualizados na Figura 32 apresentaram, de maneira diferente ao observado no aumento da produção, impactos na geração de empregos muito superiores na região Norte-Nordeste, para os choques 1 e 2 . No choque 3, com uma diferença em relação ao emprego gerado no Centro-Sul bem inferior do que quando relacionados em termos de produção. $\mathrm{O}$ choque 4 , que descreve o efeito total quando os três choques anteriores são incididos na economia, também mostra este resultado. 


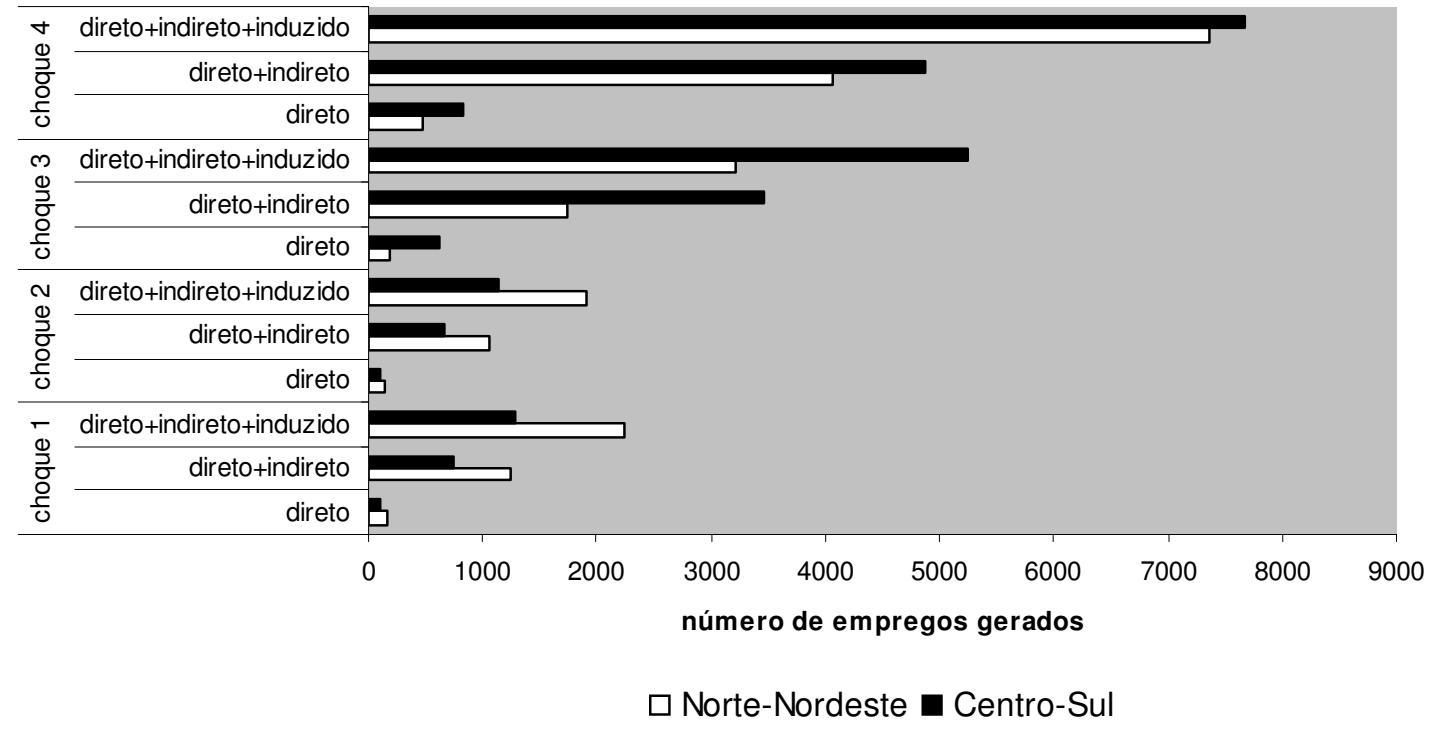

Figura 32 - Impactos no número de empregos da economia das regiões Centro-Sul e Norte-Nordeste do Brasil, em relação ao aumento de demanda final de açúcar estimado anteriormente.

Fonte: resultados de pesquisa.

Nota: choque 1 - eliminação do protecionismo sobre o mercado de açúcar bruto dos EUA; choque 2 - eliminação do protecionismo no mercado de açúcar bruto na UE; choque 3 - eliminação do subsídio cruzado sobre a exportação de açúcar refinado na UE; choque 4 - representa a soma dos três choques descritos anteriormente. $\mathrm{O}$ efeito induzido corresponde ao aumento da produção em função do aumento do efeito renda das famílias.

A explicação para este efeito é que a economia do Norte-Nordeste é mais intensiva em trabalho do que a economia do Centro-Sul. A maior sensibilidade das exportações da região Norte-Nordeste em relação à geração de emprego foi identificada no item anterior. Portanto, um impacto semelhante na produção das duas regiões, supondo que a tecnologia não se altere, emprega mais no Norte-Nordeste do que no Centro-Sul. Os setores que tiveram maior impacto em relação ao emprego são os mesmos descritos anteriormente para o impacto na produção. 
Nas Tabelas 40 e 41 são apresentados os impactos totais das alterações na produção e no emprego da economia das duas regiões, considerando que os três choques estimados afetam simultaneamente a economia brasileira (choque 4 nas Figuras 31 e 32).

Tabela 40. Impactos na produção e no emprego da região Norte-Nordeste em razão de aumento nas exportações brasileiras de açúcar estimadas pela eliminação das políticas protecionistas nos Estados Unidos e na União Européia.

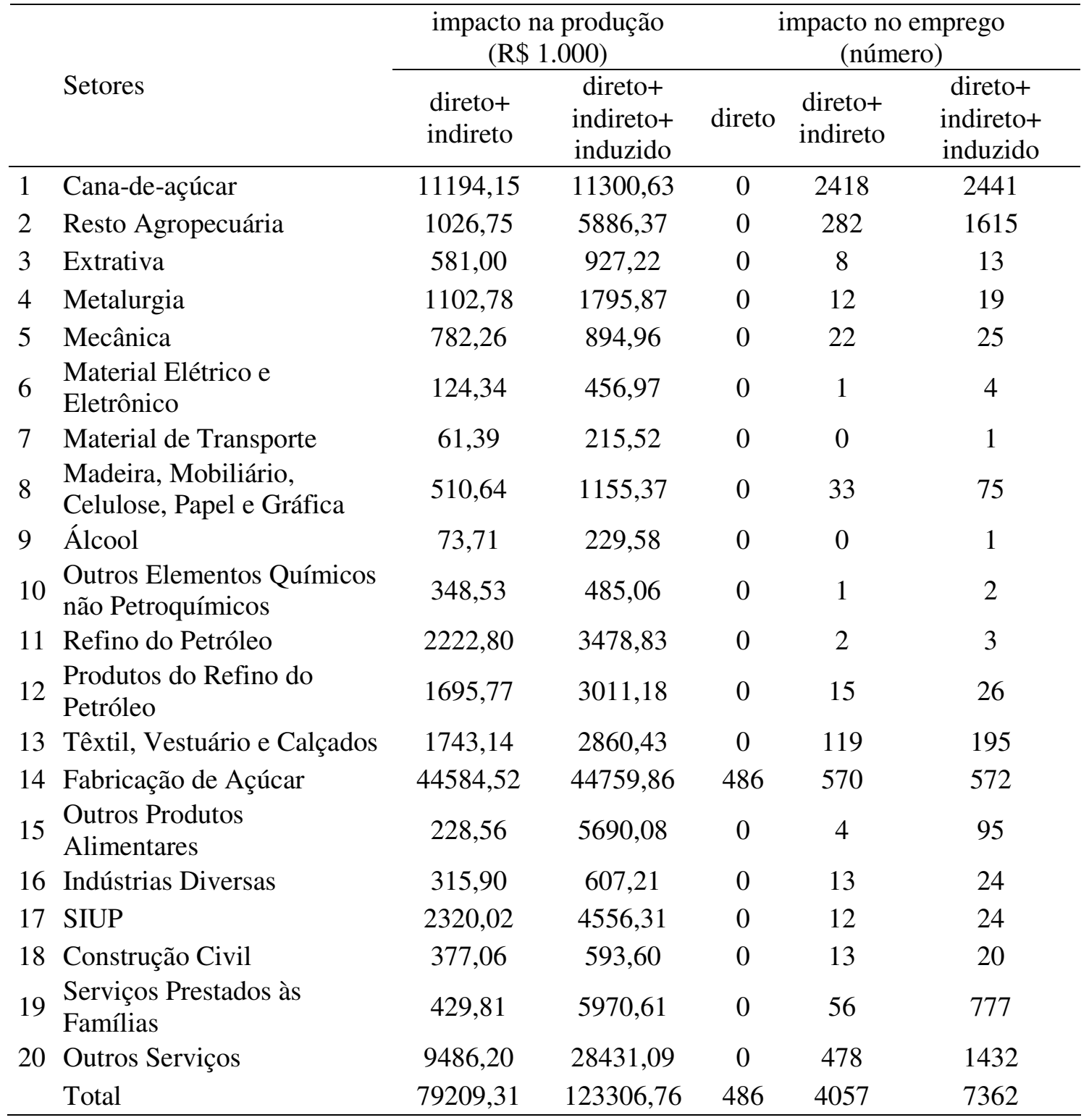

Fonte: resultados de pesquisa. 
Tabela 41. Impactos na produção e no emprego da região Centro-Sul em razão de aumento nas exportações brasileiras de açúcar estimadas pela eliminação das políticas protecionistas nos Estados Unidos e na União Européia.

\begin{tabular}{|c|c|c|c|c|c|c|}
\hline & \multirow[b]{2}{*}{ Setores } & \multicolumn{2}{|c|}{$\begin{array}{l}\text { impacto na produção } \\
(\mathrm{R} \$ 1.000)\end{array}$} & \multicolumn{3}{|c|}{$\begin{array}{l}\text { impacto no emprego } \\
\text { (número) }\end{array}$} \\
\hline & & $\begin{array}{l}\text { direto+ } \\
\text { indireto }\end{array}$ & $\begin{array}{c}\text { direto+ } \\
\text { indireto+ } \\
\text { induzido }\end{array}$ & direto & $\begin{array}{l}\text { direto+ } \\
\text { indireto }\end{array}$ & $\begin{array}{c}\text { direto+ } \\
\text { indireto+ } \\
\text { induzido }\end{array}$ \\
\hline 1 & Cana-de-açúcar & 28858,87 & 29255,12 & 0 & 1939 & 1966 \\
\hline 2 & Resto Agropecuária & 2615,03 & 10357,60 & 0 & 190 & 752 \\
\hline 3 & Extrativa & 1794,93 & 2853,42 & 0 & 16 & 25 \\
\hline 4 & Metalurgia & 4296,10 & 6591,34 & 0 & 44 & 68 \\
\hline 5 & Mecânica & 6536,58 & 7422,86 & 0 & 79 & 90 \\
\hline 6 & $\begin{array}{l}\text { Material Elétrico e } \\
\text { Eletrônico }\end{array}$ & 599,40 & 1990,68 & 0 & 5 & 15 \\
\hline 7 & Material de Transporte & 540,93 & 3494,35 & 0 & 4 & 23 \\
\hline 8 & $\begin{array}{l}\text { Madeira, Mobiliário, } \\
\text { Celulose, Papel e Gráfica }\end{array}$ & 3310,63 & 6230,56 & 0 & 75 & 141 \\
\hline 9 & Álcool & 458,57 & 1174,57 & 0 & 2 & 4 \\
\hline 10 & $\begin{array}{l}\text { Outros Elementos Químicos } \\
\text { não Petroquímicos }\end{array}$ & 1488,47 & 1990,76 & 0 & 5 & 7 \\
\hline 11 & Refino do Petróleo & 8195,91 & 13059,34 & 0 & 5 & 7 \\
\hline 12 & $\begin{array}{l}\text { Produtos do Refino do } \\
\text { Petróleo }\end{array}$ & 3530,03 & 8040,77 & 0 & 31 & 71 \\
\hline 13 & Têxtil, Vestuário e Calçados & 5965,90 & 9129,79 & 0 & 298 & 457 \\
\hline 14 & Fabricação de Açúcar & 111606,18 & 112070,28 & 827 & 981 & 986 \\
\hline 15 & $\begin{array}{l}\text { Outros Produtos } \\
\text { Alimentares }\end{array}$ & 799,39 & 9999,61 & 0 & 8 & 98 \\
\hline 16 & Indústrias Diversas & 1960,25 & 3778,96 & 0 & 33 & 64 \\
\hline 17 & SIUP & 6423,18 & 9939,37 & 0 & 24 & 38 \\
\hline 18 & Construção Civil & 1060,82 & 1468,46 & 0 & 27 & 38 \\
\hline 19 & $\begin{array}{l}\text { Serviços Prestados às } \\
\text { Famílias }\end{array}$ & 1117,67 & 7592,13 & 0 & 103 & 701 \\
\hline \multirow[t]{2}{*}{20} & Outros Serviços & 27635,11 & 58645,14 & 0 & 997 & 2116 \\
\hline & Total & 218793,95 & 305085,10 & 827 & 4866 & 7665 \\
\hline
\end{tabular}

Fonte: resultados de pesquisa.

Na última linha das Tabelas 40 e 41 foi calculado o efeito total na produção e no emprego da economia, para o caso de se eliminar todas as políticas protecionistas descritas conjuntamente. 
Comparando os resultados das Tabelas 40 e 41, tem-se que o efeito multiplicador da produção sobre a economia da região Centro-Sul (R \$ 305 milhões/ano) foi maior do que o aumento da produção calculada para a região Norte-Nordeste ( $\mathrm{R} \$$ 125 milhões/ano). O aumento do número de empregos gerados nas duas regiões, entretanto, foram bastante próximos: 7.362 empregos/ano no Norte-Nordeste, e 7.665 empregos/ano no Centro-Sul.

Dessa maneira, responde-se a principal questão inserida neste trabalho: qual o impacto na produção e no emprego da economia brasileira quando eliminadas as medidas protecionistas que os Estados Unidos e a União Européia praticam, e que afetam as exportações brasileiras de açúcar?

Somando os efeitos totais da eliminação das políticas protecionistas estudadas para as duas regiões exportadoras do Brasil, tem-se que o nível de produção total da economia brasileira aumentaria em $\mathrm{R} \$ 428$ milhões em um ano. Da mesma maneira, o número de empregos gerados na economia brasileira, somando os resultados calculados do aumento das exportações nas duas regiões, aumentaria em 15.027 empregos diretos, indiretos e induzidos pelo aumento de renda, em um ano.

Entretanto, como descrito anteriormente, houveram algumas limitações em relação aos resultados obtidos na primeira parte do trabalho, em que se destacam: no período em foram calculadas as elasticidades, não houve redução no nível das medidas protecionistas consideradas; e o efeito da eliminação dos subsídios na UE foi estimado para um número limitado de países importadores do açúcar europeu. Assim, considerando um choque de maior magnitude, acredita-se que os resultados poderiam ser maiores do que os estimados neste trabalho. 


\section{CONCLUSÕES}

A análise conduzida neste trabalho, para entender o funcionamento do mercado internacional de açúcar permitiu constatar que, a despeito da manutenção de medidas fortemente protecionistas por alguns dos principais players desse mercado, as exportações brasileiras apresentaram uma rápida expansão, o que se deve, particularmente, à competitividade desenvolvida pelo país ao longo dos últimos anos dos anos 90 e princípio desse novo século. Verificou-se, no entanto, que persistem restrições à exploração plena do potencial exportador do país, dentre as quais assumem importância particular, as medidas protecionistas mantidas por países desenvolvidos como a União Européia e os Estados Unidos. Torna-se patente, portanto, a necessidade de investigar a natureza dos efeitos que as referidas medidas protecionistas mantidas por esses países podem ter sobre as exportações brasileiras, de forma a subsidiar a definição de estratégias de negociação de política comercial para o açúcar no âmbito mundial.

Os resultados obtidos sugerem um efeito mais significativo sobre as exportações, e consequientemente, sobre a produção e o emprego na economia brasileira, face a uma redução dos subsídios à exportação de açúcar refinado pela União Européia, do que mediante uma redução do equivalente tarifário sobre as exportações brasileiras de açúcar bruto, tanto para os Estados Unidos, como para países não exportadores de açúcar refinado da União Européia. Esta foi a principal e mais importante conclusão obtida neste trabalho. Isso confirma a importância de se avaliar com maior cuidado e profundidade os efeitos destas políticas que estimulam as exportações, ainda que indiretamente, nos diversos mercados agrícolas. Destaca-se ainda que as políticas de subsídios têm sido interpretadas, de uma maneira geral, como políticas sociais, e não comerciais. No entanto, como se demonstrou neste trabalho, essas medidas têm impactos 
mais expressivos sobre o comércio mundial, desfavoráveis a países em desenvolvimento, do que as caracterizadas como barreiras comerciais (como as quotas tarifárias, por exemplo).

É preciso ter em mente que mudanças maiores no protecionismo destes países em relação às importações de açúcar poderiam alterar os valores das elasticidades-preço estimadas neste trabalho. Dado que o Brasil possui o menor custo de produção de açúcar do mundo, e que as elasticidades-preço das demandas para os Estados Unidos foram estimadas considerando o equivalente tarifário vigente sobre as exportações brasileiras, acredita-se que os valores das elasticidades-preço de oferta do Brasil, das demandas dos Estados Unidos e da União Européia pelas exportações brasileiras, sejam maiores do que os valores estimados neste trabalho em um mercado mundial menos protecionista.

Uma limitação deste trabalho refere-se aos países selecionados para estimar o efeito de eliminação dos subsídios cruzados sobre as exportações de açúcar refinado da União Européia. Acredita-se que esse efeito sobre as exportações brasileiras seria ainda maior do que o estimado, uma vez que foi restrito o número de países importadores que sofreriam os impactos da eliminação destes subsídios. Muitos autores demonstraram, ainda, que a eliminação desta política poderia aumentar o preço internacional do produto, o que também não foi considerado, mesmo porque essa proposição ainda causa polêmica entre os pesquisadores do assunto. Desta maneira, estima-se que a importância dos subsídios cruzados para as exportações de açúcar pela União Européia poderia ser ainda maior para a economia brasileira.

Considera-se importante destacar, ainda, que por se tratar de um estudo que procurou analisar os impactos do comércio internacional, não foram estimados os possíveis efeitos que as mudanças analisadas ocasionariam no mercado doméstico. Entretanto, é plausível considerar que, o aumento estimado no preço das exportações brasileiras pode elevar também o preço doméstico, o que poderia ocasionar, por sua vez, uma possível retração no consumo doméstico, o que poderia ocasionar, por sua vez, uma possível retração no consumo doméstico (assumindo que a elasticidade-preço da demanda é negativa). Acredita-se, entretanto, que esse efeito negativo para a economia 
brasileira poderia ser contrabalançado pelo aumento da renda doméstica, impulsionada pelo aumento das divisas do país, o que não prejudica a qualidade dos resultados obtidos. Esse efeito, analisado pela inclusão da demanda das famílias na matriz de insumo-produto inter-regional da economia brasileira, foi bastante significativo quando foi realizado o choque de demanda sobre as exportações brasileiras de açúcar, principalmente nos estados da região Norte-Nordeste do país.

Outra conclusão deste trabalho refere-se à importância da análise regionalizada dos impactos na economia brasileira. Sendo um país de dimensão continental, e possuindo diferenças significativas nas tecnologias e comportamento entre regiões produtoras e exportadoras de um determinado produto, a análise regional dos impactos causados por um choque de demanda na economia brasileira mostrou-se importante. Verificou-se neste estudo, de um lado, impacto maior na região Norte-Nordeste do Brasil do que na região Centro-Sul, quando incorporado o efeito renda das famílias na análise, e considerando o número de empregos gerados. Na região Centro-Sul, por outro lado, o impacto do valor exportado quando eliminados os subsídios cruzados às exportações de açúcar da União Européia foi maior do que o verificado no NorteNordeste.

Com esse conhecimento, o governo brasileiro poderá escolher entre alternativas de políticas de desenvolvimento regional. Neste sentido, de um lado pode-se incentivar a região Centro-Sul, por ser mais competitiva e gerar, com isto, maiores ganhos para o país. Neste caso, planos alternativos para o desenvolvimento da região Norte-Nordeste devem ser elaborados, contemplando áreas potencialmente competitivas. De outro lado, o governo pode adotar como plano para o desenvolvimento do Norte-Nordeste o maior incentivo à produção e exportação de açúcar. Esta política visaria a redução da concentração regional deste mercado no Centro-Sul.

Em relação ao desenvolvimento do país como um todo, a análise da importância do mercado internacional do açúcar para a economia brasileira mostrou que este é um produto em que o Brasil é competitivo e, portanto, deve ser explorado. A regulamentação que este mercado sofria pelo governo limitava a expansão da produção e 
exportação. Com o processo de desregulamentação, observou-se um crescimento considerável do Brasil no mercado internacional de açúcar. Entretanto, outras limitações para a expansão deste mercado ainda existem: as medidas protecionistas impostas por países desenvolvidos para o açúcar. A análise deste fato mostra ao governo brasileiro que ainda há possibilidade de expansão do Brasil no mercado internacional de açúcar, aumentando assim as divisas do país, a produção agrícola e a geração de empregos.

De outra maneira, a produção de açúcar está diretamente relacionada à produção de álcool combustível, sendo produtos substitutos para o empresário do setor sucroalcooleiro. Esta dicotomia na produção do álcool/açúcar pode interferir na expansão do Brasil no mercado internacional do açúcar.

Os resultados sugerem que a redução das medidas protecionistas nos EUA e UE incentivariam a produção brasileira de açúcar, em detrimento ao álcool. Conforme os resultados descritos pela análise da matriz de insumo-produto inter-regional, a produção do açúcar traria maiores benefícios econômicos ao país em relação à produção de álcool, de forma que este seria um efeito positivo, com potencial de melhorar os resultados obtidos. É importante que se atente, no entanto, que o Brasil é um dos poucos países que detém tecnologia para redirecionar a utilização da cana para produzir açúcar ou álcool, de forma relativamente simples. Mediante a perspectiva de incremento do consumo de álcool por outros países, e da consolidação de um mercado internacional de álcool, é possível que seja necessário reavaliar tal proposição.

Atualmente vem aumentando a expectativa em relação à criação do mercado internacional do álcool, no qual o Brasil ocuparia uma posição de destaque. As exigências do Protocolo de Kyoto em relação à redução na emissão de poluentes, principalmente nos países desenvolvidos, foi o principal motivador desta tendência. $\mathrm{O}$ impacto que a criação deste mercado poderia ocasionar, não para a economia brasileira, mas para o mercado internacional do açúcar, é uma questão interessante a ser analisada. Especialistas do mercado de açúcar descrevem que o desenvolvimento do mercado de álcool nos países desenvolvidos poderia reduzir a produção interna de açúcar destes países, favorecendo o álcool combustível. Desta maneira, aumentaria a demanda por 
importação de açúcar ou seriam reduzidos os excedentes exportáveis na UE. As barreiras protecionistas sobre esse mercado poderiam, conseqüentemente, ser reduzidas. A mensuração destes efeitos é uma sugestão que fica para futuros trabalhos nesta área.

Finalmente, tem-se que o Brasil possui uma fronteira agrícola com potencial de expansão muito grande para a produção agropecuária. A cana-de-açúcar no Brasil, especialmente na região Centro-Sul (onde se tem ampla fronteira agrícola a ser explorada), é uma das mais competitivas do mundo, sendo o açúcar e o álcool produzidos com os menores custos mundiais. Desta maneira, com o potencial de crescimento do mercado internacional de ambos os produtos, o incentivo maior a um deles poderia prejudicar ao outro apenas no curto-prazo, uma vez que há potencial para expansão de cana-de-açúcar no Brasil. 
ANEXOS 


\section{ANEXO A - Derivação algébrico da Teoria da Demanda por Produtos Distinguidos por Local de Produção (Armington, 1969).}

As pressuposições adotadas no modelo descrito por Armington (1969) sugerem uma função utilidade por importações fracamente separável, e com elasticidade de substituição constante.

Assim, a função utilidade de um país com respeito a suas importações é dada por:

$$
U=U\left(M_{11}, M_{12}, \ldots, M_{1 m}, M_{21}, M_{22}, \ldots, M_{2 m}, \ldots, M_{n 1}, M_{n 2}, \ldots, M_{n m}\right)
$$

onde $M$ é a quantidade importada, $n$ é o número de produtos importados e $m$ o número de locais de origem das importações.

A teoria do consumidor deve ser mostrada a partir da função utilidade, que neste caso, representa a função utilidade das importações de um dado país. Assim, como descrito por Armington (1969), a maximização da função utilidade sujeita a uma restrição orçamentária gera uma função de demanda Marshalliana para cada produto importado por um país qualquer. A minimização dos custos da importação desse produto, sujeita a restrição do volume total importado, gera uma função de demanda Hicksiana para cada país de onde esse produto é importado.

A demanda por qualquer produto $M_{i}$ pode ser obtida maximizando a função utilidade, sujeita a uma restrição orçamentária $D=\sum_{i} P_{i} M_{i}$. Dessa forma, assumindo a primeira condição, ou seja, a independência entre os produtos, para o produto $i$ obtem-se a demanda Marshalliana por qualquer produto como:

$$
M_{i}=M_{i}\left(D, P_{1}, P_{2}, \ldots, P_{m}\right)
$$

Considerando agora a elasticidade de substituição constante, a forma da função de demanda é uma função CES (Constant Elasticity of Substitution):

$$
M_{i}=\phi_{i}\left(M_{i 1}, M_{i 2}, M_{i 3}, \ldots, M_{i m}\right)
$$




$$
M_{i}=\left(b_{i 1} M_{i 1}^{-\rho_{i}}+b_{i 2} M_{i 2}^{-\rho_{i}}+b_{i 2} M_{i 2}^{-\rho_{i}}+\ldots+b_{i m} M_{i m}^{-\rho_{i}}\right)^{-\frac{1}{\rho_{i}}}
$$

Considerando-se que $P_{i k}$ é o preço no $k$-ésimo mercado, o dispêndio associado às importações do produto $i$ pode ser dado pela restrição orçamentária a seguir:

$$
D_{i}=\sum_{k=1}^{m} P_{i k} M_{i k}=P_{i} M_{i}
$$

A demanda por qualquer produto $M_{i k}$ pode ser obtida, minimizando-se a restrição orçamentária do volume $M_{i}$ determinado, sujeito ao volume demandado, resultando numa função de demanda Hicksiana. Os passos da minimização até a função de demanda Hicksiana são descritos a seguir:

$$
\begin{gathered}
L=\sum_{k=1}^{m} P_{i k} M_{i k}+\lambda\left[M_{i}-\phi_{i}\right] \\
\frac{\partial L}{\partial M_{i j}}=P_{i j}-\lambda \frac{\partial \phi_{i}}{\partial M_{i j}}=0 \\
\frac{\partial L}{\partial M_{i z}}=P_{i z}-\lambda \frac{\partial \phi_{i}}{\partial M_{i z}}=0
\end{gathered}
$$

e assim sucessivamente, para todo $M_{i k}$, em que $j$ e $z$ são mercados ofertantes $(j$ e $z \in k=$ $1, \ldots, m)$. A taxa marginal de substituição, para todo $k \neq j$ pode, portanto, ser dada por:

$$
\lambda=\frac{P_{i j}}{P_{i z}}=\frac{\frac{\partial \phi_{i}}{\partial M_{i j}}}{\frac{\partial \phi_{i}}{\partial M_{i z}}}
$$

Calculando $\frac{\partial \phi_{i}}{\partial M_{i j}}$ e $\frac{\partial \phi_{i}}{\partial M_{i z}}$ a partir de (82), tem-se:

$$
\frac{\partial \phi_{i}}{\partial M_{i z}}=\frac{-1}{\rho_{i}}\left[\sum_{k} b_{i k} M_{i k}^{-\rho_{i}}\right]^{\frac{-1-\rho_{i}}{\rho_{i}}} b_{i z}\left(-\rho_{i}\right) M_{i z}^{-\rho_{i}-1}
$$


Assim, substituindo (85) em (84), obtém-se:

$$
\begin{aligned}
& \frac{P_{i j}}{P_{i z}}=\frac{b_{i j} M_{i j}^{-\rho_{i}-1}}{b_{i z} M_{i z}^{-\rho_{i}-1}} \\
& \frac{P_{i j}}{P_{i z}}=\frac{b_{i j}}{b_{i z}}\left(\frac{M_{i z}}{M_{i j}}\right)^{\rho_{i}+1} \\
& M_{i z}=\left(\frac{P_{i j}}{P_{i z}} \frac{b_{i z}}{b_{i j}}\right)^{\frac{1}{\rho_{i}+1}} M_{i j}
\end{aligned}
$$

Na forma de taxa marginal de substituição:

$$
\frac{M_{i j}}{M_{i z}}=\left(\frac{b_{i z}}{b_{i j}}\right)^{\frac{-1}{\rho_{i}+1}}\left(\frac{P_{i j}}{P_{i z}}\right)^{\frac{-1}{\rho_{i}+1}}
$$

onde $\frac{1}{1+\rho_{i}}=\sigma_{i}$, é a taxa marginal de substituição para o produto $i$, entre todos os pares de países ofertantes.

Para todos os mercados, ou seja, para todo $k=1, \ldots, j, z, \ldots, m$, obtém-se a nova demanda Hicksiana. Portanto, substituindo (86) em (82):

$$
\begin{aligned}
& M_{i}=\left[\sum_{k} b_{i k}\left[M_{i j}\left(\frac{P_{i j}}{P_{i k}} \frac{b_{i k}}{b_{i j}}\right)^{\sigma_{i}}\right]^{\frac{\sigma_{i}-1}{\sigma_{i}}}\right]^{\frac{\sigma_{i}}{\sigma_{i}-1}} \\
& M_{i}=b_{i j}{ }^{-\sigma_{i}} M_{i j}\left[\sum_{k} b_{i k}^{\sigma_{i}}\left(\frac{P_{i j}}{P_{i k}}\right)^{\sigma_{i}-1}\right]^{\frac{\sigma_{i}}{\sigma_{i}-1}} \\
& M_{i j}=b_{i j}^{{ }^{\sigma_{i}}} M_{i}\left[\sum_{k} b_{i k}^{\sigma_{i}}\left(\frac{P_{i j}}{P_{i k}}\right)^{\sigma_{i}-1}\right]^{\frac{\sigma_{i}}{1-\sigma_{i}}}
\end{aligned}
$$


Partindo da eq. (85) e substituindo $\rho_{i}$ por $\rho_{i}=\frac{1-\sigma_{i}}{\sigma_{i}}$, tem-se:

$\frac{\partial \phi_{i}}{\partial M_{i k}}=M_{i}^{1 / \sigma_{i}} b_{i k} M_{i k}^{-1 / \sigma_{i}}$

Entretanto, como $P_{i}=\frac{\sum_{k} P_{i k} M_{i k}}{M_{i}}$, colocando $M_{i}$ em evidência tem-se:

$M_{i}=\frac{\sum_{k} P_{i k} M_{i k}}{P_{i}}$

Por outro lado, como $\phi_{i}$ é linearmente homogêneo, pelo Teorema de Euler ${ }^{34}$ tem-se que:

$$
M_{i}=\sum_{k} \frac{\partial \phi_{i}}{\partial M_{i k}} M_{i k}
$$

Igualando (92) e (91), e pré-multiplicando ambos os lados por $P_{i}$, tem-se: $P_{i} \sum_{k} \frac{\partial \phi_{i}}{\partial M_{i k}}=P_{i} \sum_{k} \frac{P_{i k}}{P_{i}}$ e disso tem-se que: $P_{i} \frac{\partial \phi_{i}}{\partial M_{i j}}=P_{i} \frac{P_{i j}}{P_{i}}$. Isolando $P_{i}$ :

$$
P_{i}=\frac{P_{i j}}{\frac{\partial \phi_{i}}{\partial M_{i j}}}
$$

para qualquer $j$.

Assim, substituindo (90) em (93):

$$
P_{i}=\frac{P_{i j}}{M_{i}^{1 / \sigma_{i}} b_{i j} M_{i j}^{-1 / \sigma_{i}}} \text {, e substituindo } M_{i} \text { pela eq. (88): }
$$

\footnotetext{
${ }^{34}$ Para ver prova do Teorema de Euler, ver Silberberg (1990, p.98)
} 


$$
\begin{aligned}
& P_{i}=P_{i j} b_{i j}{ }^{-1} M_{i j}^{1 / \sigma_{i}}\left[b_{i j}{ }^{-\sigma_{i}} M_{i j}\left[\sum_{k} b_{i k}{ }^{\sigma_{i}}\left(\frac{P_{i j}}{P_{i k}}\right)^{\sigma_{i}-1}\right]^{\frac{\sigma_{i}}{\sigma_{i}-1}}\right]^{\frac{-1}{\sigma_{i}}} \\
& P_{i}=P_{i j} b_{i j}{ }^{-1} b_{i j} M_{i j}^{1 / \sigma_{i}} M_{i j}^{-1 / \sigma_{i}}\left[\sum_{k} b_{i k}{ }^{\sigma_{i}}\left(\frac{P_{i j}}{P_{i k}}\right)^{\sigma_{i}-1}\right]^{\frac{1}{1-\sigma_{i}}} \\
& \frac{P_{i j}}{P_{i}}=\left[\sum_{k} b_{i k}{ }^{\sigma_{i}}\left(\frac{P_{i j}}{P_{i k}}\right)^{\sigma_{i}-1}\right]^{\frac{-1}{1-\sigma_{i}}} \text {, ou seja, } \\
& \left(\frac{P_{i j}}{P_{i}}\right)^{-\sigma_{i}}=\left[\sum_{k} b_{i k} \sigma_{i}\left(\frac{P_{i j}}{P_{i k}}\right)^{\sigma_{i}-1}\right]^{\frac{\sigma_{i}}{1-\sigma_{i}}}
\end{aligned}
$$

Finalmente, substituindo (94) em (89), tem-se a equação de demanda compensada de $M_{i j}$ simplificadamente escrita como:

$$
M_{i j}=b_{i j}{ }^{\sigma_{i}} M_{i}\left(\frac{P_{i j}}{P_{i}}\right)^{-\sigma_{i}}
$$

A eq. (95) pode ainda ser escrita de várias maneiras, por exemplo, prémultiplicando ambos os lados por $P_{i j}$ e multiplicando o lado direito da igualdade por $\frac{P_{i}}{P_{i}}$ :

$$
P_{i j} M_{i j}=b_{i j}{ }^{\sigma_{i}}\left(P_{i} M_{i}\right)\left(\frac{P_{i j}}{P_{i}}\right)^{1-\sigma_{i}}
$$

que descreve a demanda monetária de $M_{i j}$ para o tamanho do correspondente mercado mensurado em termos de valor. Pode-se, alternativamente, dividir ambos os lados da eq. (95) por $M_{i}$, obtendo-se: 


$$
\frac{M_{i j}}{M_{i}}=b_{i j}{ }^{\sigma_{i}}\left(\frac{P_{i j}}{P_{i}}\right)^{-\sigma_{i}}
$$

e multiplicando a eq. (97) por $\left(\frac{P_{i j}}{P_{i}}\right)$ :

$$
\frac{P_{i j} M_{i j}}{P_{i} M_{i}}=b_{i j} \sigma_{i}\left(\frac{P_{i j}}{P_{i}}\right)^{1-\sigma_{i}}
$$

o qual expressa o market-share como variável dependente. Assim, o valor do marketshare será constante se $\sigma_{i}=1$ (caso especial em que $\phi_{i}$ é uma função Cobb-Douglas com parâmetros $b_{i j}$ ). Se $\sigma_{i}>1$, uma queda (ou aumento) relativo em $P_{i j}$ causa uma aumento (ou redução) no market-share de $M_{i j}$. O inverso é verdadeiro se $\sigma_{i}<1$.

Para estimar $\sigma_{i}$ aplica-se logaritmo em qualquer das eq. (95) a (98) acima e estima-se por procedimento econométrico adequado.

Para analisar efeitos de mudanças nas variáveis envolvidas no modelo proposto por Armington (1969), realizou-se os seguintes passos: primeiramente, diferenciando as eq. (81) e (95) em relação a todas as suas variáveis e dividindo por $M_{i}$ e $M_{i j}$, respectivamente, tem-se as eq. (99) e (100) a seguir:

$$
\begin{aligned}
& \frac{d M_{i}}{M_{i}}=\varepsilon_{i} \frac{d D}{D}-\omega_{i} \frac{d P_{i}}{P_{i}}+\sum_{L} \omega_{i / L} \frac{d P_{L}}{P_{L}} \\
& \frac{d M_{i j}}{M_{i j}}=\frac{d M_{i}}{M_{i}}-\sigma_{i} \frac{d P_{i j}}{P_{i j}}+\sigma_{i} \frac{d P_{i}}{P_{i}}
\end{aligned}
$$

em que $\quad \varepsilon_{i}=\frac{\partial M_{i}}{\partial D} \frac{D}{M_{i}}, \quad \omega_{i}=\frac{\partial M_{i}}{\partial P_{i}} \frac{P_{i}}{M_{i}} \quad$ e $\quad \omega_{i / L}=\frac{\partial M_{i}}{\partial P_{L}} \frac{P_{L}}{M_{i}}, \quad$ que correspondem, respectivamente, às elasticidades: renda, preço direta e preço cruzado da demanda, em que $L=1, \ldots, i, \ldots, n$.

Substituindo (99) em (100) tem-se: 


$$
\frac{d M_{i j}}{M_{i j}}=\varepsilon_{i} \frac{d D}{D}-\omega_{i} \frac{d P_{i}}{P_{i}}+\sum_{L} \omega_{i / L} \frac{d P_{L}}{P_{L}}-\sigma_{i}\left(\frac{d P_{i j}}{P_{i j}}-\frac{d P_{i}}{P_{i}}\right)
$$

Mas, pelo Teorema de Euler:

$$
M_{i}=\sum_{k} \frac{\partial \phi_{i}}{\partial M_{i k}} M_{i k}=\sum_{k} \frac{P_{i k} M_{i k}}{P_{i}} . \quad \text { Então, } \quad P_{i}=\sum_{k} \frac{M_{i k}}{M_{i}} P_{i k} . \quad \text { Fazendo } \quad \text { a }
$$

diferenciação de $P_{i}$ em relação a todas as suas variáveis tem-se:

$$
d P_{i}=\sum_{k}\left(\frac{M_{i k}}{M_{i}}\right) d P_{i k}+\sum_{k} P_{i k} d\left(\frac{M_{i k}}{M_{i}}\right)
$$

dividindo todos os membros por $P_{i}$, multiplicando o primeiro membro do lado direito por $\frac{P_{i k}}{P_{i k}}$ e o segundo membro por $\frac{\frac{M_{i k}}{M_{i}}}{\frac{M_{i k}}{M_{i}}}$ tem-se que:

$$
\frac{d P_{i}}{P_{i}}=\sum_{k}\left(\frac{P_{i k} M_{i k}}{P_{i} M_{i}}\right) \frac{d P_{i k}}{P_{i k}}+\sum_{k} \frac{P_{i k} M_{i k}}{P_{i} M_{i}} \frac{d\left(\frac{M_{i k}}{M_{i}}\right)}{\frac{M_{i k}}{M_{i}}}
$$

Pelo fato da elasticidade de substituição ser constante, supõe-se que a média da

$$
\begin{aligned}
& \text { mudança percentual no market-share }\left(\frac{d\left(\frac{M_{i k}}{M_{i}}\right)}{\frac{M_{i k}}{M_{i}}}\right) \text { seja zero. Portanto, } \\
& \qquad \frac{d P_{i}}{P_{i}}=\sum_{k} S_{i k} \frac{d P_{i k}}{P_{i k}}
\end{aligned}
$$

em que $S_{i k}$ é o market-share de $M_{i k}$ em termos de valor. Ou seja, $S_{i k}=\frac{P_{i k} M_{i k}}{P_{i} M_{i}}$ 
Voltando a eq. (101) e substituindo $\frac{d P_{i}}{P_{i}}$ pela eq. (102):

$$
\frac{d M_{i j}}{M_{i j}}=\varepsilon_{i} \frac{d D}{D}+\sum_{L} \omega_{i / L} \frac{d P_{L}}{P_{L}}-\omega_{i}\left(\sum_{k} S_{i k} \frac{d P_{i k}}{P_{i k}}\right)-\sigma_{i}\left(\frac{d P_{i j}}{P_{i j}}-\sum_{k} S_{i k} \frac{d P_{i k}}{P_{i k}}\right)
$$

Assim, para um dado país $j$, suas elasticidades-preço direta e cruzada são:

$$
\begin{aligned}
& \frac{d M_{i j}}{M_{i j}}=\varepsilon_{i} \frac{d D}{D}+\sum_{L} \omega_{i / L} \frac{d P_{L}}{P_{L}}-\omega_{i}\left(S_{i j} \frac{d P_{i j}}{P_{i j}} \sum_{k \neq j} S_{i k} \frac{d P_{i k}}{P_{i k}}\right)-\sigma_{i}\left(\frac{d P_{i j}}{P_{i j}}-S_{i j} \frac{d P_{i j}}{P_{i j}} \sum_{k \neq j} S_{i k} \frac{d P_{i k}}{P_{i k}}\right) \\
& \frac{d M_{i j}}{M_{i j}}=\varepsilon_{i} \frac{d D}{D}+\sum_{L} \omega_{i / L} \frac{d P_{L}}{P_{L}}-\omega_{i} S_{i j} \frac{d P_{i j}}{P_{i j}}-\left(1-S_{i j}\right) \sigma_{i} \frac{d P_{i j}}{P_{i j}}-\sum_{k \neq j} S_{i k} \omega_{i} \frac{d P_{i k}}{P_{i k}}+\sum_{k \neq j} S_{i k} \sigma_{i} \frac{d P_{i k}}{P_{i k}} \\
& \frac{d M_{i j}}{M_{i j}}=\varepsilon_{i} \frac{d D}{D}+\sum_{L} \omega_{i / L} \frac{d P_{L}}{P_{L}}-\left[\left(1-S_{i j}\right) \sigma_{i}+\omega_{i} S_{i j}\right] \frac{d P_{i j}}{P_{i j}}+\sum_{k \neq j}\left[S_{i k} \sigma_{i}-S_{i k} \omega_{i}\right] \frac{d P_{i k}}{P_{i k}}
\end{aligned}
$$

em que:

$-\left\lfloor\left(1-S_{i j}\right) \sigma_{i}+\omega_{i} S_{i j}\right\rfloor$ é a elasticidade-preço direta da demanda de $M_{i j}$, e $\sum_{k \neq j}\left[S_{i k} \sigma_{i}-S_{i k} \omega_{i}\right]$ é a elasticidade-preço cruzada da demanda de $M_{i j}$. 


\section{ANEXO B - Resultados em relação a matriz insumo-produto inter-regional do Centro-Sul e Norte-Nordeste do Brasil.}

Tabela 42. Índices de ligações de Rasmussen-Hirschman, para frente (FL) e para trás (BL), das matrizes inter-regionais do Centro-Sul e do Norte-Nordeste, e seus respectivos ordenamentos em relação ao impacto na economia brasileira, considerando apenas os setores da região analisada.

\begin{tabular}{|c|c|c|c|c|c|c|c|c|c|}
\hline \multirow{2}{*}{\multicolumn{2}{|c|}{ Setores }} & \multicolumn{4}{|c|}{ Centro-Sul } & \multicolumn{4}{|c|}{ Norte-Nordeste } \\
\hline & & FL & ordem & $\mathrm{BL}$ & ordem & FL & ordem & $\mathrm{BL}$ & ordem \\
\hline & Cana-de-açúcar & 0,927 & 6 & 0,839 & 19 & 1,007 & 6 & 0,930 & 13 \\
\hline 2 & Resto Agropecuária & 1,195 & 5 & 0,918 & 13 & 1,251 & 4 & 0,940 & 12 \\
\hline 3 & Extrativa & 0,886 & 11 & 0,846 & 18 & 0,841 & 11 & 0,902 & 15 \\
\hline 4 & Metalurgia & 1,567 & 2 & 1,244 & 1 & 1,377 & 3 & 1,283 & 1 \\
\hline 5 & Mecânica & 0,828 & 13 & 0,886 & 16 & 0,728 & 17 & 0,876 & 17 \\
\hline 6 & Material Elétrico e Eletrônico & 0,675 & 17 & 1,042 & 7 & 0,718 & 19 & 0,849 & 19 \\
\hline 7 & Material de Transporte & 0,715 & 14 & 1,070 & 6 & 0,720 & 18 & 0,856 & 18 \\
\hline 8 & Madeira, Mobiliário, Celulose, Papel e Gráfica & 0,923 & 8 & 1,083 & 5 & 0,848 & 10 & 1,041 & 6 \\
\hline 9 & Álcool & 0,598 & 20 & 1,022 & 9 & 0,672 & 20 & 1,039 & 7 \\
\hline 10 & Outros Elementos Químicos não Petroquímicos & 0,706 & 16 & 0,934 & 12 & 0,758 & 15 & 0,942 & 11 \\
\hline 11 & Refino do Petróleo & 1,343 & 3 & 1,013 & 10 & 1,140 & 5 & 1,005 & 9 \\
\hline 12 & Produtos do Refino do Petróleo & 0,924 & 7 & 1,010 & 11 & 0,918 & 8 & 0,966 & 10 \\
\hline 13 & Têxtil, Vestuário e Calçados & 0,903 & 9 & 1,162 & 4 & 0,968 & 7 & 1,180 & 4 \\
\hline 14 & Fabricação de Açúcar & 0,709 & 15 & 1,206 & 3 & 0,811 & 13 & 1,211 & 3 \\
\hline 15 & Outros Produtos Alimentares & 0,846 & 12 & 1,215 & 2 & 0,894 & 9 & 1,256 & 2 \\
\hline 16 & Indústrias Diversas & 0,896 & 10 & 1,027 & 8 & 0,839 & 12 & 1,023 & 8 \\
\hline 17 & SIUP & 1,222 & 4 & 0,880 & 17 & 1,396 & 2 & 1,063 & 5 \\
\hline 18 & Construção Civil & 0,642 & 19 & 0,894 & 15 & 0,741 & 16 & 0,879 & 16 \\
\hline 19 & Serviços Prestados às Famílias & 0,662 & 18 & 0,915 & 14 & 0,766 & 14 & 0,920 & 14 \\
\hline 20 & Outros Serviços & 2,831 & 1 & 0,796 & 20 & 2,608 & 1 & 0,839 & 20 \\
\hline
\end{tabular}

Fonte: resultados de pesquisa. 
Tabela 43. Índices puros normalizados, para frente (PFL), para trás (PBL) e total (PTL), nas matrizes inter-regionais do CentroSul e Norte-Nordeste, e seus respectivos ordenamentos em relação ao impacto na economia brasileira, considerando apenas os setores da região analisada.

\begin{tabular}{|c|c|c|c|c|c|c|c|c|c|c|c|c|c|}
\hline & \multirow[b]{2}{*}{ Setores } & \multicolumn{6}{|c|}{ Centro-Sul } & \multicolumn{6}{|c|}{ Norte-Nordeste } \\
\hline & & PFL & ordem & PBL & ordem & PTL & ordem & PFL & ordem & PBL & ordem & PTL & ordem \\
\hline 1 & Cana-de-açúcar & 0,210 & 19 & 0,001 & 20 & 0,106 & 20 & 0,189 & 14 & 0,029 & 19 & 0,109 & 19 \\
\hline 2 & Resto Agropecuária & 2,544 & 2 & 0,830 & 7 & 1,687 & 3 & 3,461 & 2 & 1,185 & 5 & 2,323 & 3 \\
\hline 3 & Extrativa & 0,607 & 11 & 0,086 & 17 & 0,346 & 16 & 0,443 & 11 & 0,091 & 17 & 0,267 & 13 \\
\hline 4 & Metalurgia & 1,847 & 4 & 0,384 & 12 & 1,115 & 7 & 1,476 & 5 & 0,292 & 10 & 0,884 & 7 \\
\hline 5 & Mecânica & 0,477 & 12 & 0,489 & 11 & 0,483 & 13 & 0,146 & 17 & 0,087 & 18 & 0,116 & 18 \\
\hline 6 & Material Elétrico e Eletrônico & 0,229 & 18 & 0,646 & 8 & 0,437 & 15 & 0,144 & 18 & 0,306 & 9 & 0,225 & 14 \\
\hline 7 & Material de Transporte & 0,308 & 14 & 1,109 & 5 & 0,709 & 11 & 0,124 & 19 & 0,166 & 14 & 0,145 & 16 \\
\hline 8 & $\begin{array}{l}\text { Madeira, Mobiliário, Celulose, Papel } \\
\text { e Gráfica }\end{array}$ & 1,002 & 7 & 0,544 & 10 & 0,773 & 9 & 0,563 & 10 & 0,258 & 11 & 0,410 & 11 \\
\hline 9 & Álcool & 0,287 & 15 & 0,055 & 18 & 0,171 & 17 & 0,166 & 16 & 0,093 & 16 & 0,130 & 17 \\
\hline 10 & $\begin{array}{l}\text { Outros Elementos Químicos não } \\
\text { Petroquímicos }\end{array}$ & 0,252 & 17 & 0,049 & 19 & 0,150 & 18 & 0,171 & 15 & 0,012 & 20 & 0,092 & 20 \\
\hline 11 & Refino do Petróleo & 2,453 & 3 & 0,147 & 16 & 1,299 & 6 & 1,700 & 3 & 0,479 & 8 & 1,089 & 6 \\
\hline 12 & Produtos do Refino do Petróleo & 0,924 & 8 & 0,839 & 6 & 0,882 & 8 & 0,782 & 9 & 0,524 & 7 & 0,653 & 9 \\
\hline 13 & Têxtil, Vestuário e Calçados & 0,266 & 16 & 0,615 & 9 & 0,441 & 14 & 0,256 & 13 & 0,536 & 6 & 0,396 & 12 \\
\hline 14 & Fabricação de Açúcar & 0,101 & 20 & 0,195 & 14 & 0,148 & 19 & 0,097 & 20 & 0,195 & 13 & 0,146 & 15 \\
\hline 15 & Outros Produtos Alimentares & 0,704 & 9 & 3,883 & 2 & 2,294 & 2 & 0,959 & 7 & 4,668 & 1 & 2,813 & 2 \\
\hline 16 & Indústrias Diversas & 1,154 & 6 & 0,301 & 13 & 0,728 & 10 & 0,871 & 8 & 0,128 & 15 & 0,500 & 10 \\
\hline 17 & SIUP & 1,159 & 5 & 0,168 & 15 & 0,663 & 12 & 1,501 & 4 & 0,235 & 12 & 0,868 & 8 \\
\hline 18 & Construção Civil & 0,332 & 13 & 2,869 & 3 & 1,601 & 4 & 0,420 & 12 & 3,798 & 3 & 2,109 & 4 \\
\hline 19 & Serviços Prestados às Famílias & 0,670 & 10 & 1,979 & 4 & 1,325 & 5 & 1,085 & 6 & 2,615 & 4 & 1,850 & 5 \\
\hline 20 & Outros Serviços & 4,474 & 1 & 4,812 & 1 & 4,643 & 1 & 5,447 & 1 & 4,303 & 2 & 4,875 & 1 \\
\hline
\end{tabular}

Fonte: resultados de pesquisa. 
Tabela 44. Multiplicadores de Leontief tipos I (MS1) e II (MS2) nas matrizes inter-regionais do Centro-Sul e Norte-Nordeste, e seus respectivos ordenamentos.

\begin{tabular}{|c|c|c|c|c|c|c|c|c|c|}
\hline \multirow{2}{*}{\multicolumn{2}{|c|}{ Setores }} & \multicolumn{4}{|c|}{ Centro-Sul } & \multicolumn{4}{|c|}{ Norte-Nordeste } \\
\hline & & MS1 & ordem & MS2 & ordem & MS1 & ordem & MS2 & ordem \\
\hline 1 & Cana-de-açúcar & 1,591 & 18 & 2,148 & 16 & 1,722 & 14 & 3,257 & 9 \\
\hline 2 & Resto Agropecuária & 1,677 & 13 & 2,113 & 19 & 1,648 & 16 & 2,689 & 16 \\
\hline 3 & Extrativa & 1,558 & 19 & 2,099 & 20 & 1,619 & 17 & 2,891 & 12 \\
\hline 4 & Metalurgia & 2,270 & 1 & 2,964 & 4 & 2,319 & 1 & 3,455 & 7 \\
\hline 5 & Mecânica & 1,672 & 15 & 2,381 & 13 & 1,518 & 19 & 2,542 & 19 \\
\hline 6 & Material Elétrico e Eletrônico & 1,999 & 7 & 2,708 & 8 & 1,556 & 18 & 2,434 & 20 \\
\hline 7 & Material de Transporte & 2,031 & 5 & 2,745 & 7 & 1,722 & 13 & 2,805 & 14 \\
\hline 8 & Madeira, Mobiliário, Celulose, Papel e Gráfica & 2,009 & 6 & 2,891 & 5 & 1,862 & 5 & 3,615 & 4 \\
\hline 9 & Álcool & 1,921 & 8 & 2,422 & 12 & 1,854 & 6 & 2,850 & 13 \\
\hline 10 & Outros Elementos Químicos não Petroquímicos & 1,721 & 12 & 2,114 & 18 & 1,723 & 12 & 2,800 & 15 \\
\hline 11 & Refino do Petróleo & 1,900 & 11 & 2,297 & 14 & 1,823 & 8 & 2,560 & 18 \\
\hline 12 & Produtos do Refino do Petróleo & 1,915 & 9 & 2,624 & 9 & 1,854 & 7 & 3,170 & 11 \\
\hline 13 & Têxtil, Vestuário e Calçados & 2,145 & 4 & 3,017 & 2 & 2,141 & 4 & 3,986 & 1 \\
\hline 14 & Fabricação de Açúcar & 2,257 & 2 & 3,000 & 3 & 2,255 & 2 & 3,845 & 2 \\
\hline 15 & Outros Produtos Alimentares & 2,240 & 3 & 2,815 & 6 & 2,189 & 3 & 3,607 & 5 \\
\hline 16 & Indústrias Diversas & 1,902 & 10 & 2,590 & 11 & 1,790 & 10 & 3,262 & 8 \\
\hline 17 & SIUP & 1,597 & 17 & 2,281 & 15 & 1,818 & 9 & 3,250 & 10 \\
\hline 18 & Construção Civil & 1,632 & 16 & 2,123 & 17 & 1,694 & 15 & 2,640 & 17 \\
\hline 19 & Serviços Prestados às Famílias & 1,675 & 14 & 3,060 & 1 & 1,738 & 11 & 3,787 & 3 \\
\hline 20 & Outros Serviços & 1,446 & 20 & 2,591 & 10 & 1,446 & 20 & 3,517 & 6 \\
\hline
\end{tabular}

Fonte: resultados de pesquisa. 
Tabela 45. Variações nos níveis de produção dos setores da economia brasileira, resultantes de aumento na demanda final de açúcar de R\$ 1 milhão nas regiões Centro-Sul e Norte-Nordeste.

\begin{tabular}{|c|c|c|c|c|c|c|}
\hline & & \multirow[b]{2}{*}{ Setores } & \multicolumn{2}{|c|}{ Aumento na demanda de açúcar no Centro-Sul } & \multicolumn{2}{|c|}{$\begin{array}{l}\text { Aumento na demanda de açúcar no Norte- } \\
\text { Nordeste }\end{array}$} \\
\hline & & & direto+indireto & direto+indireto+induzido & direto+indireto & direto+indireto+induzido \\
\hline 1 & & Cana-de-açúcar & 18,80 & 19,16 & 247,73 & 249,64 \\
\hline 2 & & Resto Agropecuária & 4,96 & 18,29 & 14,72 & 109,50 \\
\hline 3 & & Extrativa & 3,87 & 5,54 & 5,70 & 10,68 \\
\hline 4 & & Metalurgia & 6,12 & 8,80 & 13,86 & 25,46 \\
\hline 5 & & Mecânica & 2,73 & 3,05 & 13,81 & 15,98 \\
\hline 6 & & Material Elétrico e Eletrônico & 0,65 & 1,71 & 1,67 & 7,79 \\
\hline 7 & & $\begin{array}{l}\text { Material de Transporte } \\
\text { Madeira, Mobiliário, Celulose, Papel e }\end{array}$ & 0,36 & 0,90 & 0,72 & 3,43 \\
\hline 8 & $\underset{\overrightarrow{0}}{0}$ & Gráfica & 2,10 & 4,44 & 8,22 & 19,40 \\
\hline 9 & $z_{j}^{0}$ & $\begin{array}{l}\text { Álcool } \\
\text { Outros Elementos Químicos não }\end{array}$ & 0,14 & 0,52 & 1,60 & 4,75 \\
\hline 10 & 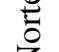 & Petroquímicos & 1,77 & 2,30 & 4,80 & 7,07 \\
\hline 11 & 2 & Refino do Petróleo & 11,89 & 15,69 & 29,04 & 52,66 \\
\hline 12 & $\frac{. \pi}{80}$ & Produtos do Refino do Petróleo & 9,44 & 13,29 & 21,25 & 46,29 \\
\hline 13 & & Têxtil, Vestuário e Calçados & 7,11 & 10,00 & 28,23 & 50,48 \\
\hline 14 & & Fabricação de Açúcar & 0,90 & 1,47 & 1169,44 & 1172,63 \\
\hline 15 & & Outros Produtos Alimentares & 1,01 & 13,41 & 3,52 & 116,40 \\
\hline 16 & & Indústrias Diversas & 1,23 & 2,05 & 5,27 & 10,88 \\
\hline 17 & & SIUP & 3,45 & 8,26 & 52,44 & 99,33 \\
\hline 18 & & Construção Civil & 0,48 & 1,00 & 8,72 & 13,12 \\
\hline 19 & & Serviços Prestados às Famílias & 0,84 & 11,91 & 9,21 & 127,47 \\
\hline 20 & & Outros Serviços & 17,23 & 54,88 & 206,73 & 611,55 \\
\hline
\end{tabular}


Tabela 45. Variações nos níveis de produção dos setores da economia brasileira, resultantes de aumento na demanda final de açúcar de R\$ 1 milhão nas regiões Centro-Sul e Norte-Nordeste.

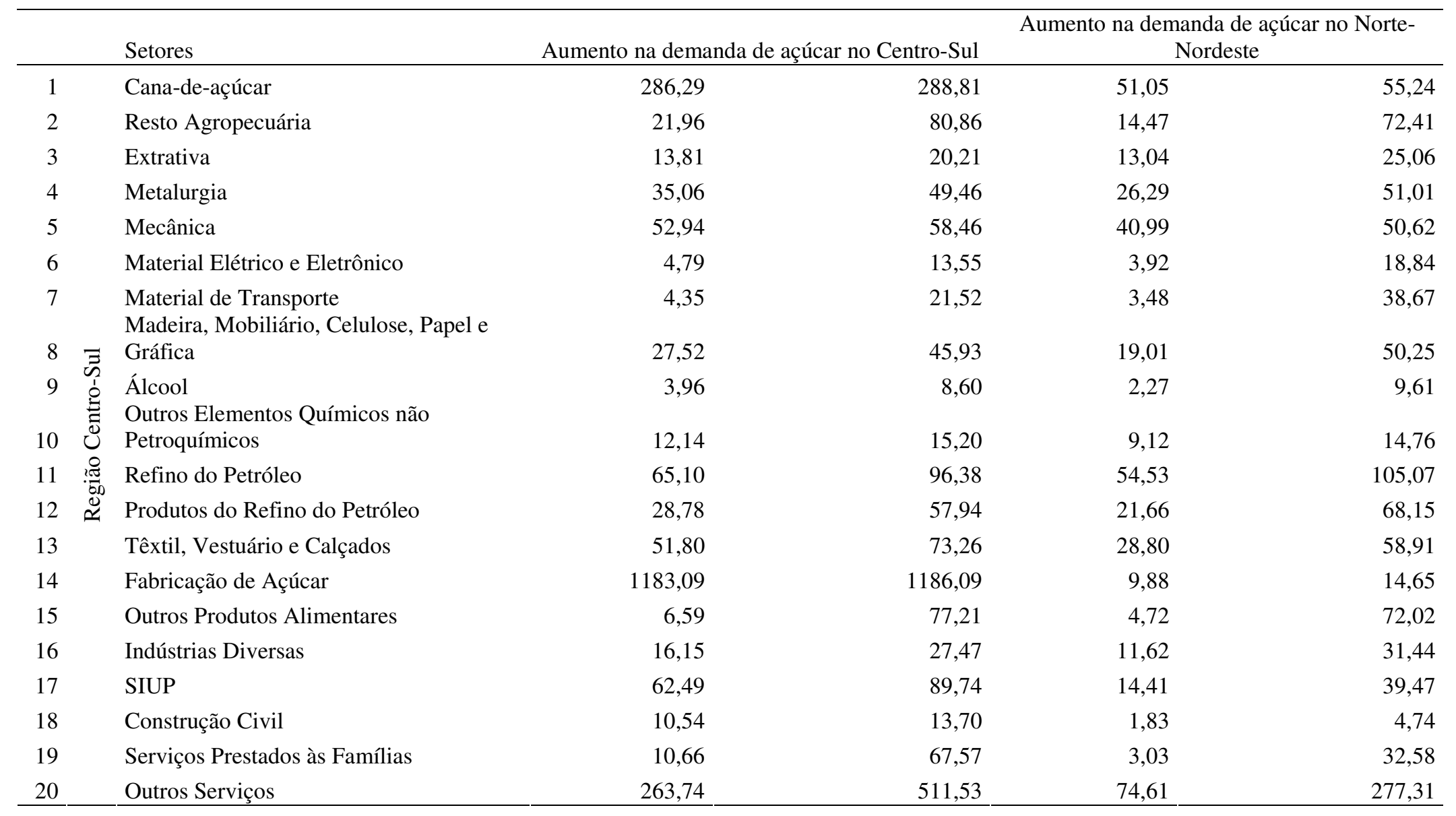

Fonte: resultados de pesquisa. 
Tabela 46. Variações no número de empregos gerados nos setores da economia brasileira, resultantes de aumento na demanda final de açúcar de R\$ 1 milhão nas regiões Centro-Sul e Norte-Nordeste.

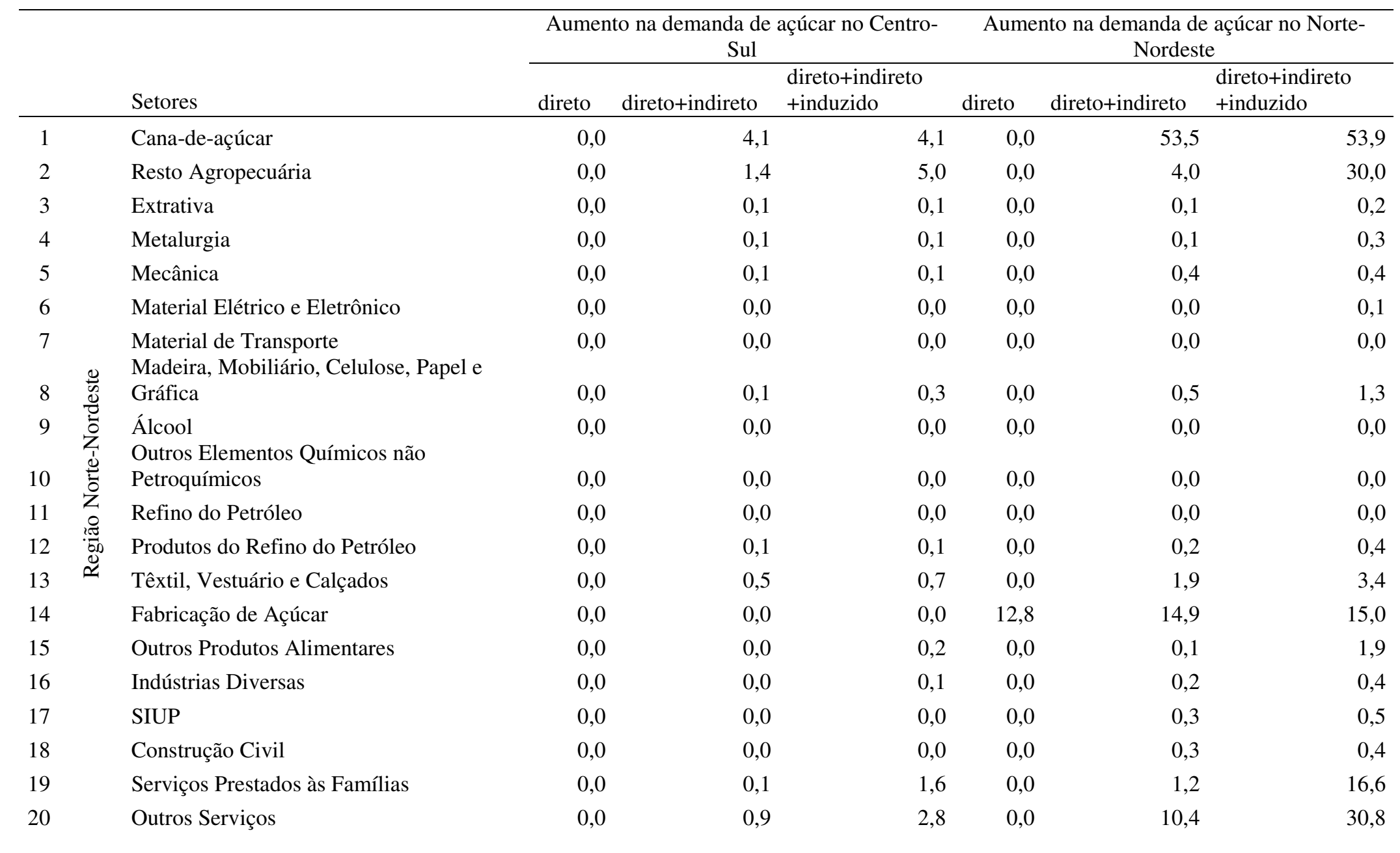


Tabela 46. Variações no número de empregos gerados nos setores da economia brasileira, resultantes de aumento na demanda final de açúcar de R\$ 1 milhão nas regiões Centro-Sul e Norte-Nordeste.

\begin{tabular}{|c|c|c|c|c|c|c|c|c|}
\hline & & \multirow[b]{2}{*}{ Setores } & \multicolumn{3}{|c|}{$\begin{array}{c}\text { Aumento na demanda de açúcar no Centro- } \\
\text { Sul }\end{array}$} & \multicolumn{3}{|c|}{$\begin{array}{l}\text { Aumento na demanda de açúcar no Norte- } \\
\text { Nordeste }\end{array}$} \\
\hline & & & direto & direto+indireto & $\begin{array}{l}\text { direto+indireto } \\
\text { +induzido }\end{array}$ & direto & direto+indireto & $\begin{array}{l}\text { direto+indireto } \\
\text { +induzido }\end{array}$ \\
\hline 1 & \multirow{20}{*}{ 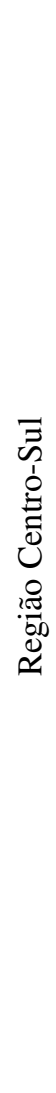 } & Cana-de-açúcar & 0,0 & 19,2 & 19,4 & 0,0 & 3,4 & 3,7 \\
\hline 2 & & Resto Agropecuária & 0,0 & 1,6 & 5,9 & 0,0 & 1,1 & 5,3 \\
\hline 3 & & Extrativa & 0,0 & 0,1 & 0,2 & 0,0 & 0,1 & 0,2 \\
\hline 4 & & Metalurgia & 0,0 & 0,4 & 0,5 & 0,0 & 0,3 & 0,5 \\
\hline 5 & & Mecânica & 0,0 & 0,6 & 0,7 & 0,0 & 0,5 & 0,6 \\
\hline 6 & & Material Elétrico e Eletrônico & 0,0 & 0,0 & 0,1 & 0,0 & 0,0 & 0,1 \\
\hline 7 & & $\begin{array}{l}\text { Material de Transporte } \\
\text { Madeira, Mobiliário, Celulose, Papel e }\end{array}$ & 0,0 & 0,0 & 0,1 & 0,0 & 0,0 & 0,3 \\
\hline 8 & & Gráfica & 0,0 & 0,6 & 1,0 & 0,0 & 0,4 & 1,1 \\
\hline 9 & & $\begin{array}{l}\text { Álcool } \\
\text { Outros Elementos Químicos não }\end{array}$ & 0,0 & 0,0 & 0,0 & 0,0 & 0,0 & 0,0 \\
\hline 10 & & Petroquímicos & 0,0 & 0,0 & 0,0 & 0,0 & 0,0 & 0,0 \\
\hline 11 & & Refino do Petróleo & 0,0 & 0,0 & 0,1 & 0,0 & 0,0 & 0,1 \\
\hline 12 & & Produtos do Refino do Petróleo & 0,0 & 0,3 & 0,5 & 0,0 & 0,2 & 0,6 \\
\hline 13 & & Têxtil, Vestuário e Calçados & 0,0 & 2,6 & 3,7 & 0,0 & 1,4 & 2,9 \\
\hline 14 & & Fabricação de Açúcar & 8,8 & 10,4 & 10,4 & 0,0 & 0,1 & 0,1 \\
\hline 15 & & Outros Produtos Alimentares & 0,0 & 0,1 & 0,8 & 0,0 & 0,0 & 0,7 \\
\hline 16 & & Indústrias Diversas & 0,0 & 0,3 & 0,5 & 0,0 & 0,2 & 0,5 \\
\hline 17 & & SIUP & 0,0 & 0,2 & 0,3 & 0,0 & 0,1 & 0,1 \\
\hline 18 & & Construção Civil & 0,0 & 0,3 & 0,4 & 0,0 & 0,0 & 0,1 \\
\hline 19 & & Serviços Prestados às Famílias & 0,0 & 1,0 & 6,2 & 0,0 & 0,3 & 3,0 \\
\hline 20 & & Outros Serviços & 0,0 & 9,5 & 18,5 & 0,0 & 2,7 & 10,0 \\
\hline
\end{tabular}

Fonte: resultados de pesquisa. 
Tabela 47. Variações nos níveis de produção dos setores da economia brasileira, resultantes de alterações nas exportações de açúcar do Centro-Sul e do Norte-Nordeste do Brasil, em R \$ 1.000, estimadas em função dos choques nas políticas protecionistas para o açúcar nos Estados Unidos e na União Européia.

\begin{tabular}{|c|c|c|c|c|c|c|c|c|}
\hline & & \multirow[b]{2}{*}{ Setores } & \multicolumn{2}{|c|}{ choque 1} & \multicolumn{2}{|c|}{ choque 2} & \multicolumn{2}{|c|}{ choque 3} \\
\hline & & & direto+indireto & $\begin{array}{l}\text { direto+indireto } \\
\quad+\text { induzido }\end{array}$ & direto+indireto & $\begin{array}{l}\text { direto+indireto } \\
\quad+\text { induzido }\end{array}$ & direto+indireto & $\begin{array}{l}\text { direto+indireto } \\
\quad+\text { induzido }\end{array}$ \\
\hline 1 & \multirow{18}{*}{ 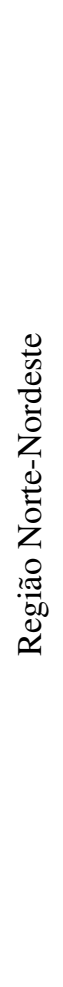 } & Cana-de-açúcar & 3485,53 & 3515,10 & 2962,67 & 2987,95 & 4745,96 & 4797,58 \\
\hline 2 & & Resto Agropecuária & 256,10 & 1667,72 & 220,28 & 1424,28 & 550,38 & 2794,38 \\
\hline 3 & & Extrativa & 124,00 & 210,45 & 107,72 & 182,07 & 349,28 & 534,70 \\
\hline 4 & & Metalurgia & 259,48 & 445,58 & 223,97 & 383,37 & 619,33 & 966,92 \\
\hline 5 & & Mecânica & 215,69 & 248,23 & 184,47 & 212,24 & 382,09 & 434,48 \\
\hline 6 & & Material Elétrico e Eletrônico & 30,08 & 123,83 & 25,92 & 106,00 & 68,33 & 227,14 \\
\hline 7 & & Material de Transporte & 14,07 & 56,49 & 12,17 & 48,45 & 35,15 & 110,58 \\
\hline 8 & & $\begin{array}{l}\text { Madeira, Mobiliário, Celulose, } \\
\text { Papel e Gráfica }\end{array}$ & 134,53 & 310,69 & 115,35 & 266,08 & 260,76 & 578,60 \\
\hline 9 & & Álcool & 22,67 & 68,85 & 19,28 & 58,63 & 31,76 & 102,09 \\
\hline 10 & & $\begin{array}{l}\text { Outros Elementos Químicos não } \\
\text { Petroquímicos }\end{array}$ & 85,33 & 121,88 & 73,47 & 104,79 & 189,74 & 258,39 \\
\hline 11 & & Refino do Petróleo & 531,87 & 889,74 & 458,62 & 764,15 & 1232,31 & 1824,94 \\
\hline 12 & & Produtos do Refino do Petróleo & 398,54 & 775,75 & 344,03 & 665,97 & 953,20 & 1569,46 \\
\hline 13 & & Têxtil, Vestuário e Calçados & 460,51 & 788,65 & 394,78 & 674,50 & 887,84 & 1397,29 \\
\hline 14 & & Fabricação de Açúcar & 15335,50 & 15384,62 & 12975,83 & 13017,80 & 16273,19 & 16357,43 \\
\hline 15 & & Outros Produtos Alimentares & 58,92 & 1695,97 & 50,58 & 1444,65 & 119,05 & 2549,46 \\
\hline 16 & & Indústrias Diversas & 84,67 & 168,73 & 72,53 & 144,25 & 158,69 & 294,23 \\
\hline 17 & & SIUP & 731,12 & 1406,76 & 621,09 & 1196,22 & 967,81 & 1953,33 \\
\hline 18 & & Construção Civil & 120,35 & 184,69 & 102,18 & 156,99 & 154,53 & 251,91 \\
\hline
\end{tabular}


Tabela 47. Variações nos níveis de produção dos setores da economia brasileira, resultantes de alterações nas exportações de açúcar do Centro-Sul e do Norte-Nordeste do Brasil, em R \$ 1.000, estimadas em função dos choques nas políticas protecionistas para o açúcar nos Estados Unidos e na União Européia.

\begin{tabular}{|c|c|c|c|c|c|c|c|c|}
\hline & & \multirow[b]{2}{*}{ Setores } & \multicolumn{2}{|c|}{ choque 1} & \multicolumn{2}{|c|}{ choque 2} & \multicolumn{2}{|c|}{ choque 3} \\
\hline & & & direto+indireto & $\begin{array}{l}\text { direto+indireto } \\
\quad \text { +induzido }\end{array}$ & direto+indireto & $\begin{array}{l}\text { direto+indireto } \\
\quad+\text { induzido }\end{array}$ & direto+indireto & $\begin{array}{l}\text { direto+indireto } \\
\quad+\text { induzido }\end{array}$ \\
\hline 19 & & Serviços Prestados às Famílias & 131,43 & 1821,98 & 111,81 & 1550,18 & 186,57 & 2598,46 \\
\hline 20 & & Outros Serviços & 2928,21 & 8712,28 & 2489,99 & 7411,08 & 4068,00 & 12307,74 \\
\hline 1 & & Cana-de-açúcar & 4313,15 & 4400,15 & 3856,53 & 3931,96 & 20689,19 & 20923,01 \\
\hline 2 & & Resto Agropecuária & 469,13 & 1978,14 & 412,82 & 1732,21 & 1733,08 & 6647,25 \\
\hline 3 & & Extrativa & 346,74 & 585,59 & 303,37 & 510,09 & 1144,82 & 1757,75 \\
\hline 4 & & Metalurgia & 790,67 & 1298,00 & 694,35 & 1134,02 & 2811,07 & 4159,32 \\
\hline 5 & & Mecânica & 1210,93 & 1407,52 & 1062,87 & 1233,20 & 4262,78 & 4782,13 \\
\hline 6 & & Material Elétrico e Eletrônico & 112,35 & 419,33 & 98,52 & 364,60 & 388,54 & 1206,74 \\
\hline 7 & $\bar{B}$ & Material de Transporte & 100,91 & 780,58 & 88,52 & 676,01 & 351,50 & 2037,76 \\
\hline 8 & $\stackrel{1}{0}$ & $\begin{array}{l}\text { Madeira, Mobiliário, Celulose, } \\
\text { Papel e Gráfica }\end{array}$ & 599,36 & 1243,12 & 527,03 & 1085,04 & 2184,25 & 3902,39 \\
\hline 9 & $\underset{0}{\circlearrowright}$ & Álcool & 80,17 & 235,42 & 70,69 & 205,41 & 307,71 & 733,74 \\
\hline 10 & $\begin{array}{l}\frac{i \pi}{60} \\
\stackrel{0}{\simeq}\end{array}$ & $\begin{array}{l}\text { Outros Elementos Químicos } \\
\text { não Petroquímicos }\end{array}$ & 274,05 & 386,93 & 240,66 & 338,38 & 973,76 & 1265,46 \\
\hline 11 & & Refino do Petróleo & 1543,26 & 2603,62 & 1352,86 & 2272,65 & 5299,79 & 8183,06 \\
\hline 12 & & Produtos do Refino do Petróleo & 650,16 & 1630,54 & 570,93 & 1421,52 & 2308,94 & 4988,70 \\
\hline 13 & & Têxtil, Vestuário e Calçados & 1036,74 & 1704,56 & 914,67 & 1495,23 & 4014,50 & 5929,99 \\
\hline 14 & & Fabricação de Açúcar & 15188,93 & 15289,70 & 13707,52 & 13794,96 & 82709,74 & 82985,62 \\
\hline 15 & & Outros Produtos Alimentares & 145,78 & 1926,57 & 128,11 & 1685,93 & 525,50 & 6387,11 \\
\hline 16 & & Indústrias Diversas & 357,83 & 761,66 & 314,44 & 664,31 & 1287,99 & 2352,99 \\
\hline
\end{tabular}


Tabela 47. Variações nos níveis de produção dos setores da economia brasileira, resultantes de alterações nas exportações de açúcar do Centro-Sul e do Norte-Nordeste do Brasil, em R \$ 1.000, estimadas em função dos choques nas políticas protecionistas para o açúcar nos Estados Unidos e na União Européia.

\begin{tabular}{|c|c|c|c|c|c|c|c|}
\hline & \multirow[b]{2}{*}{ Setores } & \multicolumn{2}{|c|}{ choque 1} & \multicolumn{2}{|c|}{ choque 2} & \multicolumn{2}{|c|}{ choque 3} \\
\hline & & direto+indireto & $\begin{array}{l}\text { direto+indireto } \\
\text { +induzido }\end{array}$ & direto+indireto & $\begin{array}{l}\text { direto+indireto } \\
\quad+\text { induzido }\end{array}$ & direto+indireto & $\begin{array}{l}\text { direto+indireto } \\
\quad+\text { induzido }\end{array}$ \\
\hline 17 & SIUP & 984,21 & 1659,59 & 877,96 & 1469,12 & 4561,00 & 6810,66 \\
\hline 18 & Construção Civil & 158,20 & 236,48 & 141,48 & 210,00 & 761,15 & 1021,99 \\
\hline 19 & Serviços Prestados às Famílias & 175,41 & 1286,95 & 156,13 & 1137,78 & 786,12 & 5167,41 \\
\hline
\end{tabular}

Fonte: resultados de pesquisa.

Nota: choque 1 - Eliminação do protecionismo sobre o mercado de açúcar dos EUA; choque 2 - Eliminação do protecionismo no mercado de açúcar bruto na UE; choque 3 - Eliminação do subsídio cruzado sobre a exportação de açúcar refinado na UE. O efeito induzido corresponde ao aumento da produção em função do aumento do efeito renda das famílias. 
Tabela 48. Variações no número de empregos dos setores da economia brasileira, resultantes de alterações nas exportações de açúcar do Centro-Sul e do Norte-Nordeste do Brasil, estimadas em função dos choques nas políticas protecionistas para o açúcar nos Estados Unidos e na União Européia.

\begin{tabular}{|c|c|c|c|c|c|c|c|c|c|c|c|}
\hline & & \multirow[b]{2}{*}{ Setores } & \multicolumn{3}{|c|}{ choque 1} & \multicolumn{3}{|c|}{ choque 2} & \multicolumn{3}{|c|}{ choque 3} \\
\hline & & & direto & $\begin{array}{l}\text { direto+ } \\
\text { indireto }\end{array}$ & $\begin{array}{l}\text { direto+indireto } \\
\quad+\text { induzido }\end{array}$ & direto & $\begin{array}{l}\text { direto+ } \\
\text { indireto }\end{array}$ & $\begin{array}{l}\text { direto+indireto } \\
\quad+\text { induzido }\end{array}$ & direto & $\begin{array}{l}\text { direto+ } \\
\text { indireto }\end{array}$ & $\begin{array}{l}\text { direto+indireto } \\
\quad+\text { induzido }\end{array}$ \\
\hline 1 & \multirow{20}{*}{ 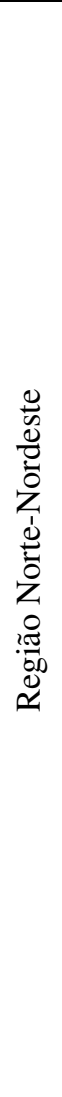 } & Cana-de-açúcar & 0 & 753 & 759 & 0 & 640 & 645 & 0 & 1025 & 1036 \\
\hline 2 & & Resto Agropecuária & 0 & 70 & 457 & 0 & 60 & 391 & 0 & 151 & 767 \\
\hline 3 & & Extrativa & 0 & 2 & 3 & 0 & 2 & 3 & 0 & 5 & 8 \\
\hline 4 & & Metalurgia & 0 & 3 & 5 & 0 & 2 & 4 & 0 & 7 & 10 \\
\hline 5 & & Mecânica & 0 & 6 & 7 & 0 & 5 & 6 & 0 & 11 & 12 \\
\hline 6 & & Material Elétrico e Eletrônico & 0 & 0 & 1 & 0 & 0 & 1 & 0 & 1 & 2 \\
\hline 7 & & Material de Transporte & 0 & 0 & 0 & 0 & 0 & 0 & 0 & 0 & 0 \\
\hline 8 & & $\begin{array}{l}\text { Madeira, Mobiliário, Celulose, Papel } \\
\text { e Gráfica }\end{array}$ & 0 & 9 & 20 & 0 & 7 & 17 & 0 & 17 & 37 \\
\hline 9 & & Álcool & 0 & 0 & 0 & 0 & 0 & 0 & 0 & 0 & 0 \\
\hline 10 & & $\begin{array}{l}\text { Outros Elementos Químicos não } \\
\text { Petroquímicos }\end{array}$ & 0 & 0 & 0 & 0 & 0 & 0 & 0 & 1 & 1 \\
\hline 11 & & Refino do Petróleo & 0 & 0 & 1 & 0 & 0 & 1 & 0 & 1 & 1 \\
\hline 12 & & Produtos do Refino do Petróleo & 0 & 3 & 7 & 0 & 3 & 6 & 0 & 8 & 14 \\
\hline 13 & & Têxtil, Vestuário e Calçados & 0 & 31 & 54 & 0 & 27 & 46 & 0 & 60 & 95 \\
\hline 14 & & Fabricação de Açúcar & 167 & 196 & 197 & 142 & 166 & 166 & 177 & 208 & 209 \\
\hline 15 & & Outros Produtos Alimentares & 0 & 1 & 28 & 0 & 1 & 24 & 0 & 2 & 42 \\
\hline 16 & & Indústrias Diversas & 0 & 3 & 7 & 0 & 3 & 6 & 0 & 6 & 12 \\
\hline 17 & & SIUP & 0 & 4 & 7 & 0 & 3 & 6 & 0 & 5 & 10 \\
\hline 18 & & Construção Civil & 0 & 4 & 6 & 0 & 3 & 5 & 0 & 5 & 9 \\
\hline 19 & & Serviços Prestados às Famílias & 0 & 17 & 237 & 0 & 15 & 202 & 0 & 24 & 338 \\
\hline 20 & & Outros Serviços & 0 & 148 & 439 & 0 & 125 & 373 & 0 & 205 & 620 \\
\hline
\end{tabular}


Tabela 48. Variações no número de empregos dos setores da economia brasileira, resultantes de alterações nas exportações de açúcar do Centro-Sul e do Norte-Nordeste do Brasil, estimadas em função dos choques nas políticas protecionistas para o açúcar nos Estados Unidos e na União Européia.

\begin{tabular}{|c|c|c|c|c|c|c|c|c|c|c|c|}
\hline & & \multirow[b]{2}{*}{ Setores } & \multicolumn{3}{|c|}{ choque 1} & \multicolumn{3}{|c|}{ choque 2} & \multicolumn{3}{|c|}{ choque 3} \\
\hline & & & direto & $\begin{array}{l}\text { direto+ } \\
\text { indireto }\end{array}$ & $\begin{array}{l}\text { direto+indireto } \\
\quad+\text { induzido }\end{array}$ & direto & $\begin{array}{l}\text { direto+ } \\
\text { indireto }\end{array}$ & $\begin{array}{l}\text { direto+indireto } \\
\quad+\text { induzido }\end{array}$ & direto & $\begin{array}{l}\text { direto+ } \\
\text { indireto }\end{array}$ & $\begin{array}{l}\text { direto+indireto } \\
\quad+\text { induzido }\end{array}$ \\
\hline 1 & \multirow{18}{*}{ 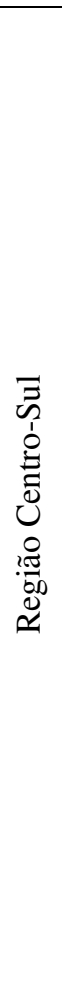 } & Cana-de-açúcar & 0 & 290 & 296 & 0 & 259 & 264 & 0 & 1390 & 1406 \\
\hline 2 & & Resto Agropecuária & 0 & 34 & 144 & 0 & 30 & 126 & 0 & 126 & 482 \\
\hline 3 & & Extrativa & 0 & 3 & 5 & 0 & 3 & 4 & 0 & 10 & 15 \\
\hline 4 & & Metalurgia & 0 & 8 & 13 & 0 & 7 & 12 & 0 & 29 & 43 \\
\hline 5 & & Mecânica & 0 & 15 & 17 & 0 & 13 & 15 & 0 & 52 & 58 \\
\hline 6 & & Material Elétrico e Eletrônico & 0 & 1 & 3 & 0 & 1 & 3 & 0 & 3 & 9 \\
\hline 7 & & Material de Transporte & 0 & 1 & 5 & 0 & 1 & 5 & 0 & 2 & 14 \\
\hline 8 & & $\begin{array}{l}\text { Madeira, Mobiliário, Celulose, Papel } \\
\text { e Gráfica }\end{array}$ & 0 & 14 & 28 & 0 & 12 & 25 & 0 & 50 & 88 \\
\hline 9 & & Álcool & 0 & 0 & 1 & 0 & 0 & 1 & 0 & 1 & 2 \\
\hline 10 & & $\begin{array}{l}\text { Outros Elementos Químicos não } \\
\text { Petroquímicos }\end{array}$ & 0 & 1 & 1 & 0 & 1 & 1 & 0 & 3 & 4 \\
\hline 11 & & Refino do Petróleo & 0 & 1 & 1 & 0 & 1 & 1 & 0 & 3 & 5 \\
\hline 12 & & Produtos do Refino do Petróleo & 0 & 6 & 14 & 0 & 5 & 13 & 0 & 20 & 44 \\
\hline 13 & & Têxtil, Vestuário e Calçados & 0 & 52 & 85 & 0 & 46 & 75 & 0 & 201 & 297 \\
\hline 14 & & Fabricação de Açúcar & 112 & 134 & 134 & 101 & 121 & 121 & 614 & 727 & 730 \\
\hline 15 & & Outros Produtos Alimentares & 0 & 1 & 19 & 0 & 1 & 16 & 0 & 5 & 63 \\
\hline 16 & & Indústrias Diversas & 0 & 6 & 13 & 0 & 5 & 11 & 0 & 22 & 40 \\
\hline 17 & & SIUP & 0 & 4 & 6 & 0 & 3 & 6 & 0 & 17 & 26 \\
\hline 18 & & Construção Civil & 0 & 4 & 6 & 0 & 4 & 5 & 0 & 20 & 26 \\
\hline
\end{tabular}


Tabela 48. Variações no número de empregos dos setores da economia brasileira, resultantes de alterações nas exportações de açúcar do Centro-Sul e do Norte-Nordeste do Brasil, estimadas em função dos choques nas políticas protecionistas para o açúcar nos Estados Unidos e na União Européia.

\begin{tabular}{|c|c|c|c|c|c|c|c|c|c|c|}
\hline & \multirow[b]{2}{*}{ Setores } & \multicolumn{3}{|c|}{ choque 1} & \multicolumn{3}{|c|}{ choque 2} & \multicolumn{3}{|c|}{ choque 3} \\
\hline & & direto & $\begin{array}{l}\text { direto+ } \\
\text { indireto }\end{array}$ & $\begin{array}{l}\text { direto+indireto } \\
\quad+\text { induzido }\end{array}$ & direto & $\begin{array}{l}\text { direto+ } \\
\text { indireto }\end{array}$ & $\begin{array}{l}\text { direto+indireto } \\
\quad \text { +induzido }\end{array}$ & direto & $\begin{array}{l}\text { direto+ } \\
\text { indireto }\end{array}$ & $\begin{array}{l}\text { direto+indireto } \\
\quad+\text { induzido } \\
\end{array}$ \\
\hline 19 & Serviços Prestados às Famílias & 0 & 16 & 119 & 0 & 14 & 105 & 0 & 73 & 477 \\
\hline 20 & Outros Serviços & 0 & 156 & 366 & 0 & 139 & 323 & 0 & 702 & 1427 \\
\hline
\end{tabular}

Fonte: resultados de pesquisa.

Nota: choque 1 - Eliminação do protecionismo sobre o mercado de açúcar dos EUA; choque 2 - Eliminação do protecionismo no mercado de açúcar bruto na UE; choque 3 - Eliminação do subsídio cruzado sobre a exportação de açúcar refinado na UE. O efeito induzido corresponde ao aumento da produção em função do aumento do efeito renda das famílias. 


\section{REFERÊNCIAS BIBLIOGRÁFICAS}

ALVES, L.R.A. Transmissão de preços entre produtos do setor sucroalcooleiro do Estado de São Paulo. Piracicaba, 2002. 107p. Dissertação (M.S.) - Escola Superior de Agricultura "Luiz de Queiroz", Universidade de São Paulo.

ARMINGTON, P.S. A theory of demand for products distinguished by place of production. International Monetary Fund Staff Papers, v.16, n.1, p.159-178, 1969.

BABULA, R.A. An Armington model of U.S. cotton export. The Journal of Agricultural Economics Research, v.39, n.4, p.12-22, 1987.

BACCHI, M.R.P.; ALVES, L.R.A.; SILVEIRA, A.M. Exportações brasileiras de açúcar: um modelo de auto-regressão vetorial (compact disc). In: CONGRESSO BRASILEIRO DE ECONOMIA E SOCIOLOGIA RURAL, 40., Passo Fundo, 2002. Anais. Brasília: SOBER, 2002.

BARROS, G.S.C.; BACCHI, M.R.P.; BURNQUIST, H.L. Estimação de equações de oferta de exportação de produtos agropecuários para o Brasil (1992/2000). Rio de Janeiro: IPEA, 2002. 51p. (Texto para Discussão, 865)

BEGHIN, J.C.; EL OSTA, B.; CHERLOW, J.R.; MOHANTY, S. The cost of the U.S. sugar program revisited. International Sugar Journal, v.105, n.1255, p.293-303, July 2003.

BOLLING, C.; SUAREZ, N.R. The brazilian sugar industry: recent developments. Sugar and Sweetener Situation \& Outlook, SSS-232, p.14-18, Sep. 2001. http://www.ers.usda.gov/publications/so/view.asp?f=specialty/sss-bb/ (05 May 2003)

BORRELL, B.; PEARCE, D. Sugar: the taste test of trade liberalisation. Canberra: Centre for International Economics - CIE, Sep. 1999. (Reports) http://www.thecie.com.au/publicat.htm (02 May 2003)

BOYD, R.; DOROODIAN, K.; POWER, A. The impact of removing the sugar quota on the U.S. economy: a general equilibrium analysis. Journal of Policy Modeling, v.18, n.2, p.185-201, Apr. 1996. 
BRAGA, H.C.; MARKWALD, R.C. Funções de oferta e de demanda das exportações de manufaturados no Brasil: estimação de um modelo simultâneo. Pesquisa e Planejamento Econômico, v.13, n.3, p.707-744, dez. 1983.

BRASIL. Ministério de Agricultura, Pecuária e Abastecimento. Brasil comércio exterior: exportação. Rio de Janeiro: CACEX, 1980-1988.

BRASIL. Ministério de Agricultura, Pecuária e Abastecimento. Exportações brasileiras de açúcar. http://www.agricultura.gov.br/pls/portal/docs/PAGE/MAPA/ ESTATISTICAS/COMERCIO_EXTERIOR_BRASILEIRO/PRINCIPAIS_PROD UTOS/ACUCAR_2002_01_PTB.PDF (12 abr. 2003a)

BRASIL. Ministério do Desenvolvimento, Indústria e Comércio Exterior. Alice Web. http://aliceweb.desenvolvimento.gov.br/alice.asp (12 out. 2002 - 13 set. 2003b)

BRASIL. Ministério do Desenvolvimento, Indústria e Comércio Exterior. Barreiras protecionistas. http://www.mdic.gov.br/progacoes/govern/ExemplosBarreiras.htm (13 abr. 2003c)

BRAZ, A. Tudo se extrai da cana, inclusive lucro. Futuros Agronegócios, v.1, n.9, p.512 , set. 2003.

BREDAHL, M.E.; MEYERS, W.H.; COLLINS K.J. The elasticity of foreign demand for U.S. agricultural products: the importance of the price transmission elasticity. American Journal Agricultural Economics, v.61, n.1, p.58-63, Feb. 1979.

BURNQUIST, H.L.; BACCHI, M.R.P. Análise de barreiras protecionistas no mercado de açúcar. In: MORAES, M.A.F.D.; SHIKIDA, P.F.A. (Org.). Agroindústria canavieira no Brasil: evolução, desenvolvimento e desafios. São Paulo: Atlas, 2002. cap.6, p.139-156.

BURNQUIST, H.L.; BACCHI, M.R.P.; MARJOTTA-MAISTRO, M.C. Análise da comercialização dos produtos do setor sucroalcooleiro brasileiro: evolução, contexto institucional e desempenho. In: MORAES, M.A.F.D.; SHIKIDA, P.F.A. (Org.). Agroindústria canavieira no Brasil: evolução, desenvolvimento e desafios. São Paulo: Atlas, 2002. cap.8, p.182-198.

BURNQUIST, H.L.; MIRANDA, S.M.G. Desempenho recente das exportações brasileiras de açúcar: uma abordagem de "market-share" constante. Revista de Economia e Sociologia Rural, v.37, n.3, p.69-90, jul./set. 1999.

CARUSO, R.C. Análise de oferta e demanda de açúcar no Estado de São Paulo. Piracicaba, 2002. 79p. Dissertação (M.S.) - Escola Superior de Agricultura "Luiz de Queiroz”, Universidade de São Paulo. 
CARVALHO, E.P. Palestras e apresentações: Brasil: quo vadis? São Paulo, nov. 2002. http://www.unica.com.br/pages/palestras.asp (12 abr. 2003)

CARVALHO, F.C. Mercado de exportação de açúcar do Brasil: modelos de equilíbrio e desequilíbrio e avaliação da política de estabilização. Viçosa, 1986. 136p. Tese (Doutorado) - Universidade Federal de Viçosa.

CARVALHO, J.C.C. Pesos diferentes. Agroanalysis, v.20, n.3, p.41-45, mar. 2000.

CARVALHO, L.C.C. Hora da virada: em nome da economia e do meio ambiente, a gasolina deixa espaço para o álcool combustível. Agroanalysis, v.21, n.9, p.28-35, set. 2001.

CENTRAL INTELLIGENCE AGENCY - CIA. The world factbook. http://www.cia.gov/cia/publications/factbook/index.html (20 Oct. 2002)

CENTRE FOR INTERNATIONAL ECONOMICS - CIE. CIE publications and reports: targets for OECD sugar market liberalization. http://www.thecie.com.au/publicat.htm (02 May 2003)

CENTRO DE ESTUDOS AVANÇADOS EM ECONOMIA APLICADA - CEPEA. Indicadores de preço: açúcar. http://www.cepea.esalq.usp.br/ (05 jun. 2003)

COLSERA, L.L. Algodão: as implicações dos subsídios americanos para a produção brasileira. Revista de Política Agrícola, v.11, n.3, p.47-59, jul./ago./set. 2002.

CONJUNTURA: câmbio e balança comercial. Comércio Exterior em Perspectiva, v.10, n.8, p.9-14, maio 2001.

COOPER, J.C.; GIRAUD-HÉRAUD, E.; RÉQUILLART, V. Economic impacts of isoglucose deregulation on the European sweetener market. European Review of Agricultural Economics, v.22, n.4, p.425-445, Nov./Dec. 1995.

COSTA, C.C.; BURNQUIST, H.L. Análise do desempenho das regiões exportadoras de açúcar e dos tipos de açúcar exportados, no Brasil, após a desregulamentação do setor sucroalcooleiro (compact disc). In: CONGRESSO BRASILEIRO DE ECONOMIA E SOCIOLOGIA RURAL, 41., Juiz de Fora, 2003. Anais. Brasília: SOBER, 2003.

COSTA, C.C. Formação de preços de açúcar e álcool combustível anidro e hidratado no Estado de São Paulo. Piracicaba, 2000. 104p. Dissertação (M.S.) - Escola Superior de Agricultura “Luiz de Queiroz", Universidade de São Paulo. 
DEPARTAMENTO INTERSINDICAL DE ESTATÍSTICA E ESTUDOS SÓCIOECONÔMICO - DIEESE. Pesquisa nacional da cesta básica: Recife. http://www.dieese.org.br/rel/rac/cesta.html (06 jun. 2003)

DICKEY, D.A.; FULLER, W.A. Likelihood ratio statistics for auto-regressive time series with a unit root. Econometrica, v.49, n.4, p.1057-72, July 1981.

DUFFY, P.A.; WOHLGENANT, M.K.; RICHARDSON, J.W. The elasticity of export demand for U.S. Cotton. American Journal Agricultural Economics, v.72, n.2, p.468-474, May 1990.

ELBEHRI, A.; HERTEL, T.; INGCO, M.; PEARSON, K.R. Partial liberalization of the world sugar market: a general equilibrium analysis of tariff-rate quota regimes. Melbourne, 2000. http://www.monash.edu.au/policy/conf/10Hertel.pdf (03 abr. 2003)

ENDERS, W. Applied econometric time series. New York: John Wiley \& Sons, 1995. 433p.

EUROPEAN COMMISSION. Internal and external trade of the EU: statistical office of the European Communities (compact disc). Luxembourg: COMEXT, s2/1998.

EUROPEAN COMMISSION. Internal and external trade of the EU: statistical office of the European Communities (compact disc). Luxembourg: COMEXT, n.3/2000.

FAO. FAOSTAT agriculture: population. http://apps.fao.org/page/collections (10 Oct. 2002)

FAO. FAOSTAT agriculture: agricultural production: crops processed. http://apps.fao.org/page/collections (20 Mar. 2003a)

FAO. FAOSTAT agriculture: agriculture \& food trade: crops \& livestock primary \& processed. http://apps.fao.org/page/collections (10 Oct. 2002 - 20 Sep. 2003b)

FERREIRA, A.H.B. Funções de exportação do Brasil: estimativas para os principais mercados. Nova Economia, v.8, n.1, p.65-86, jul. 1998.

FONTES, R.M.O.; GRENNES, T.; JOHNSON, P. Diferenciação de produtos e ajustamento defasados numa análise das exportações de grãos dos Estados Unidos. Revista de Econometria, v.9, n.2, p.211-229, nov. 1989.

FRANDSEN, S.E.; JENSEN, G.G.; WALTER-JORGENSEN, W.Y.A. Modelling the EU sugar policy: a study of policy reform scenarios. /Presented to 77. EAAE Seminar; 325. NJF Seminar, Helsinki, Aug. 2001/ http://www.ptt.fi/eaae-njf/ (23 Aug. 2003) 
GARDNER, B.L. The economics of agricultural policies. New York: Macmillan Publishing Company, 1987. 387p.

GUILHOTO, J.J.M.; SONIS, M.; HEWINGS, G.J.D. Linkages and multipliers in a multiregional famework: integration of alternative approaches. Urbana: University of Illinois, Regional Economics Applications Laboratory, 1996. 20p. (Discussion Paper, 96-T-8)

GUJARATI, D.N. Basic econometrics. 3.ed. New York: McGraw-Hill, 1995. 838p.

HALEY, S.L. U.S. and world sugar and HFCS production costs, 1994/95-1998/99. Sugar and Sweetener Situation \& Outlook, SSS-232, p.10-13, Sep. 2001. http://www.ers.usda.gov/publications/so/view.asp?f=specialty/sss-bb/ $\quad(10$ May 2003)

HIRSCHMAN, A.O. The strategy of economic development. New Haven: Yale University Press, 1958. 217p.

INSTITUTO BRASILEIRO DE GEOGRAFIA E ESTATÍSTICA - IBGE. Produção física industrial por classes de indústrias e tipo de índice: índice acumulado de 12 meses: região geográfica: http://www.sidra.ibge.gov.br/bda/tabela/listabl.asp?c=27\&z=t\&o=8 (15 ago. 2003)

INSTITUTO DE PESQUISA ECONÔMICA APLICADA - IPEA. Ipeadata: tema: câmbio. http://www.ipeadata.gov.br/ (13 jun. 2003a)

INSTITUTO DE PESQUISA ECONÔMICA APLICADA - IPEA. Ipeadata: tema: contas nacionais. http://www.ipeadata.gov.br/ (13 jun. 2003b)

INSTITUTO DE PESQUISA ECONÔMICA APLICADA - IPEA. Ipeadata: tema: economia internacional. http://www.ipeadata.gov.br/ (14 jun. 2003c)

INTERNATIONAL MONETARY FUND - IMF. International financial statistics (compact disc). Washington, Sep. 2000.

JOHANSEN, S.; JUSELIUS, K. Maximum likelihood estimation and inference on cointegration: with aplications to the demand for money. Oxford Bulletin of Economics and Statistics, v.52, n.2, p.169-219, 1990.

JOHANSEN, S. Statistical analysis of cointegration vectors. Journal of Economic Dynamics and Control, v.12, n.2-3, p.231-254, 1988.

JOHANSEN, S. Likelihood: based inference in cointegrated vector auto-regressive models. New York: Oxford University Press, 1996. 267p. 
JOHNSON, P.R.; GRENNES, T.; THURSBY, M. Trade models with differentiated products. American Journal Agricultural Economics, v.61, n.1, p.122-127, Fev. 1979.

LARSON, D.F.; BORRELL, B. Sugar policy and reform. Washington, Apr. 2001. http://econ.worldbank.org/files/1724_wps2602.pdf (10 June 2003)

LÜTKEPOHL, H. Introduction to multiple time series. 2.ed. Berlin: Springer-Verlag, 1993. 545p.

MANKIW, N.G. Introdução à economia: princípios de micro e macroeconomia. 2.ed. Rio de Janeiro: Campus, 2001. 831p.

MARQUES, M. A política de sustentação de preços na comunidade econômica européia. Revista de Política Agrícola, v.2, n.3, p.18-22, 1993.

MILLER, R.E.; BLAIR, P.D. Input-output analysis: foundations and extensions. Englewood Cliffs: Prentice-Hall, 1985. 464p.

MORAES, M.A.F.D. Desregulamentação da agroindústria canavieira: novas formas de atuação do estado e desafios do setor privado. In: MORAES, M.A.F.D.; SHIKIDA, P.F.A. (Org.). Agroindústria canavieira no Brasil: evolução, desenvolvimento e desafios. São Paulo: Atlas, 2002. cap.1, p.21-42.

NAJBERG, S.; IKEDA, M. Modelo de geração de emprego: metodologia e resultados. Rio de Janeiro: IPEA, 1999. 61p. (Textos para Discussão, 72)

OLIVEIRA, A.D.; SILVA, O.M.; REZENDE, J.L.P. Importação de celulose: demandas diferenciadas por local de origem. Nova Economia, v.6, n.1, p.165-193, jul. 1996.

ORDEN, D. Impacts of FTAA integration on sugar markets. Washington, Oct. 2002. http://www.iadb.org/INT/Trade/1_english/4_SpecialInfo/Conference/2002/i_Oct20 2-AgricLiberal/OrdenPPT.pdf (26 Nov. 2003)

OSTERWALD-LENUM, M. A note with quantiles of the asymptotic distribution of the maximum likelihood cointegration rank test statistics. Oxford Bulletin of Economics and Statistics, v.53, n.3, p.461-472, 1992.

PENSON, J.B.; BABULA, R.A. Japanese monetary policies and U.S. agricultural exports. The Journal of Agricultural Economics Research, v.40, n.1, p.11-18, 1988.

PINAZZA, L.A.; ALIMANDRO, R. Alimento bom e doce. Agroanalysis, v.23, n.2, p.10-31, abr. 2003. 
RAMOS, P. O mercado mundial de açúcar no período 1930-1960. Revista de Política Agrícola, v.10, n.4, p.26-33, out./dez. 2001.

RASMUSSEN, P.N. Studies in intersectoral relations. Amsterdam: NorthHolland, 1956. 210p.

REIS, J.N.P.; CRESPO, J.E.Q. Um modelo econométrico para as exportações de açúcar do Brasil. Agricultura em São Paulo, v.45, n.1, p.17-32, 1998.

ROCHA, L.E. Dinâmica das exportações brasileiras de soja em grão (compact disc). In: CONGRESSO BRASILEIRO DE ECONOMIA E SOCIOLOGIA RURAL, 40., Passo Fundo, 2002. Anais. Brasília: SOBER, 2002.

SARRIS, A.H. European community enlargement and world trade in fruits and vegetables. American Journal Agricultural Economics, v.65, n.2, p.235-246, May 1983.

SAS INSTITUTE. SAS/ETS user'guide, version 6. Cary, 1993. 1022p.

SAWYER, W.C.; SPRINKLE, R.L. The demand for imports and exports in the world economy. Ashgate: Aldershot, 1999. 198p.

SHEALES, T.; GORDON, S.; HAFI, A.; TOYNE, C. Sugar: international policies affecting market expansion. Canberra, 1999. (ABARE Research Report, 99.14) http://www.dfat.gov.au/trade/negotiations/ministerial/sugar_9914.pdf (10 Oct. 2002)

SILBERBERG, E. The structure of economics: a mathematical analysis. 2.ed. New York: McGraw-Hill, 1990. 686p.

SILVA, O.M. Elasticidade de substituição para o suco de laranja no mercado internacional. Revista de Economia e Sociologia Rural, v.30, n.2, p.135-147, abr./jun. 1992.

STALDER, S.H.G.M. Análise da participação do Brasil no mercado internacional de açúcar. Piracicaba, 1997. Dissertação (Mestrado) - Escola Superior de Agricultura "Luiz de Queiroz", Universidade de São Paulo.

TANNER, C. Trade liberalization and Uruguay round. Australian Journal of Agricultural Economics, v.40, n.1, p.1-35, Apr. 1996.

THE ASIA PACIFIC ECONOMIC COOPERATION - APEC. Member economies. http://www.apec.org/apec/member_economies.html (30 May 2003) 
THORSTENSEN, V. Organização mundial do comércio: as regras do comércio internacional e a nova rodada de negociações multilaterais. São Paulo: Aduaneiras, 1999. 520p.

UNIÃO DA AGROINDÚSTRIA CANAVIEIRA DE SÃO PAULO - UNICA. Agroindústria da cana-de-açúcar: políticas de produção. http://www.unica.com.br/pages/agroindustria_politicas.asp (11 abr. 2003a)

UNIÃO DA AGROINDÚSTRIA CANAVIEIRA DE SÃO PAULO - UNICA. Sociedade: $\quad$ mercado de trabalho. http://www.unica.com.br/pages/sociedade_mercado2.asp (11 abr. 2003b)

UNIÃO DA AGROINDÚSTRIA CANAVIEIRA DE SÃO PAULO - UNICA. Sociedade: $\quad$ mercado de trabalho. http://www.unica.com.br/pages/sociedade_mercado1.asp (11 abr. 2003c)

UNIÃO DA AGROINDÚSTRIA CANAVIEIRA DE SÃO PAULO - UNICA. Agroindústria da cana-de-açúcar: alta competitividade canavieira. http://www.unica.com.br/pages/agroindustria_alta.asp (11 abr. 2003d)

UNIÃO DA AGROINDÚSTRIA CANAVIEIRA DE SÃO PAULO - UNICA. Estatísticas: produção de açúcar. http://www.unica.com.br/pages/estatisticas.asp (11 abr. 2003e)

UNITED NATIONS. Statistics division. Statistical databases. http://millenniumindicators.un.org/unsd/comtrade/dqBasicQuery.aspx $\quad(13 \quad$ Sep. 2003)

UNITED STATES DEPARTMENT OF AGRICULTURE - USDA. World production, supply, and distribution centrifugal sugar. http://www.fas.usda.gov/htp/sugar/2003/November\%202003\%20PSD.pdf (20 Aug. 2002a)

UNITED STATES DEPARTMENT OF AGRICULTURE - USDA. The U.S sugar program. http://www.fas.usda.gov/info/factsheets/sugar.html (20 Aug. 2002b)

UNITED STATES DEPARTMENT OF AGRICULTURE - USDA. Sugar and $\begin{array}{lllll}\text { Sweetener Situation } & \text { \& } & \text { Outlook }\end{array}$ http://usda.mannlib.cornell.edu/reports/erssor/specialty/sss-bb/2001/sss232.pdf (02 May 2003)

VEIGA FILHO, A. O dilema da "escolha de Sofia" nas exportações de açúcar pelo Brasil. Informações Econômicas, v.30, n.9, p.53-59, set. 2000. 
ZINI, A.A. Funções de exportação e importação para o Brasil. Pesquisa e Planejamento Econômico, v.18, n.3, p.615-662, dez. 1988. 
APÊNDICES 
APÊNDICE 1 - Exportações de açúcar bruto e de açúcar refinado, ofertadas pelas regiões Centro-Sul e Norte-Nordeste do Brasil no período de 1994 a 2002.

As exportações brasileiras de açúcar são distintas quando se relacionam os tipos de açúcar exportados e as regiões exportadoras. Este tópico procurou descrever, de maneira mais detalhada, as diferenças existentes em relação a estas exportações.

A Figura 33 ilustra o comportamento do volume e do preço das exportações de açúcar bruto na região Centro-Sul, após processo de desregulamentação das exportações brasileiras de açúcar. Assim, diante das mudanças na forma como o Estado conduz as políticas de comercialização, o mercado de açúcar ainda passa por um período de transição e de adaptação às forças de mercado. Esta transição pode ser visualizada na Figura 33, caracterizada pelos crescentes volumes exportados, em função da alta competitividade da produção de açúcar da região Centro-Sul.

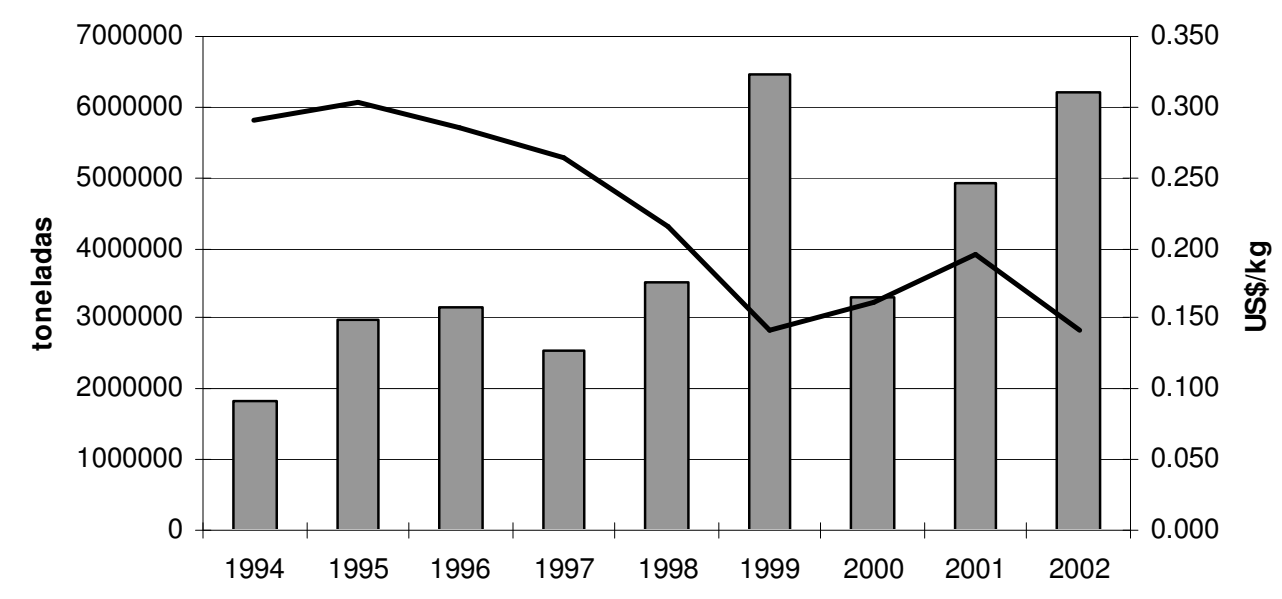

volume exportado (toneladas) — preço de exportação (US\$ $/ \mathrm{kg})$

Figura 33 - Volume total, em tonelada, e preço médio, em US\$/kg, da exportação de açúcar bruto na Região Centro-Sul; período: 1994 a 2002.

Fonte: Brasil (2003b) 
É relevante destacar que o aumento das exportações de açúcar bruto da região Centro-Sul ocorreu mesmo com a redução nos seus preços de exportação, comprovando as condições competitivas do país. Essa redução no preço de exportação, por sua vez, pode ter sido influenciada pelo próprio aumento na oferta do produto dessa região, uma vez que o market-share do Brasil no mercado mundial foi de $31 \%$ em 2001, sendo a maior parte das exportações provenientes da região Centro-Sul. Na Figura 34 observa-se que o preço do açúcar bruto comercializado na Bolsa de Nova Iorque (contrato no. 11) apresentou, claramente, uma tendência de queda após 1994 (tendência apresentada na linha pontilhada), período no qual o Brasil começou a expandir suas exportações de açúcar bruto. Isto pode ser uma evidência de que o aumento das exportações de açúcar da região Centro-Sul, a partir de 1994, levou à baixa do preço mundial de açúcar bruto.

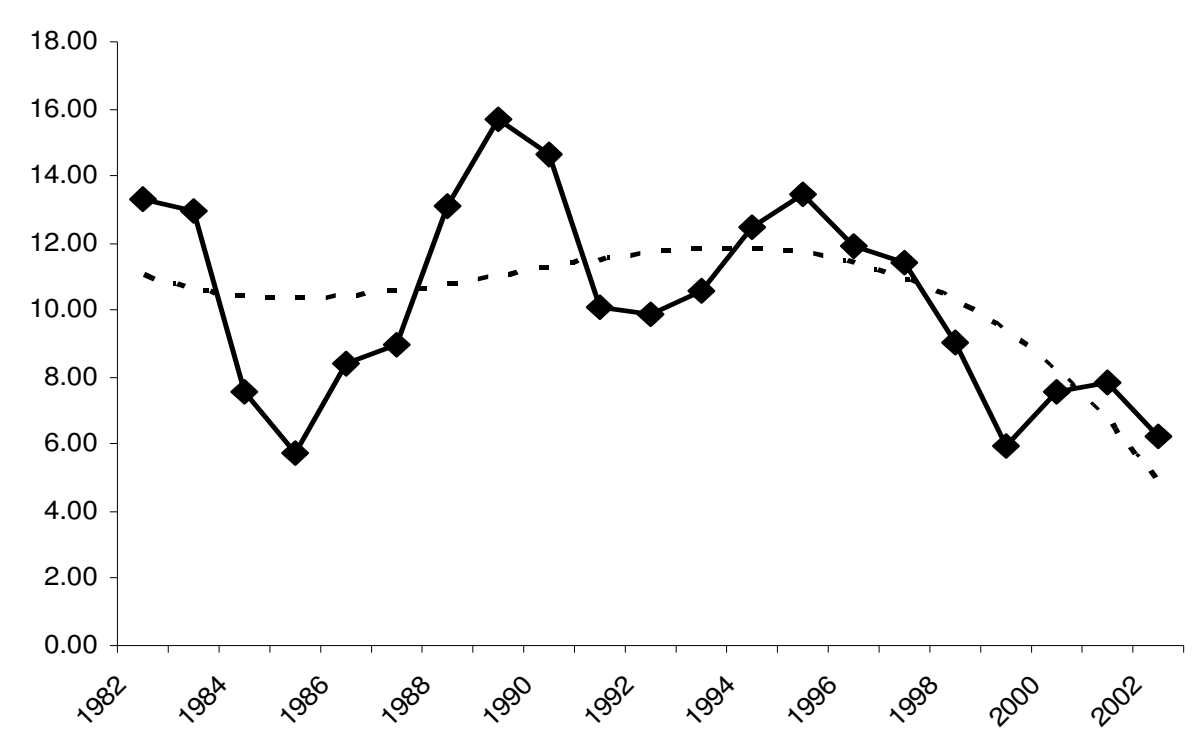

Figura 34 - Preço mundial de açúcar bruto comercializado na Bolsa de Nova Iorque (Cents/lb peso) - contrato $\mathrm{n}^{\circ}$ 11; período: 1982 a 2002.

Fonte: USDA (2001)

Os 13 maiores importadores de açúcar bruto da região Centro-Sul, no período de 1996 a 2002, foram Rússia, Emirados Árabes Unidos, Egito, Irã, Canadá, Marrocos, Romênia, Arábia Saudita, Malásia, Indonésia, Nigéria, Argélia e Bulgária. Esses países 
contribuíram com mais de $83 \%$ das exportações totais de açúcar bruto da região CentroSul no período considerado.

As exportações da região Norte-Nordeste (Figura 35), por sua vez, não apresentaram o mesmo comportamento das exportações da região Centro-Sul. Com a desregulamentação do setor sucroalcooleiro no Brasil, a produção da região NorteNordeste deixou de receber grande parte dos subsídios que compensavam a menor competitividade desta região em relação à produção do Centro-Sul. Para compensar esta perda, as quotas de importação do açúcar brasileiro estabelecidas pelos Estados Unidos e adquiridas a preços consideravelmente superiores que os do mercado mundial, foram alocadas para a região.

Na Figura 35 verifica-se que as exportações de açúcar bruto da região NorteNordeste mantiveram um volume constante, embora os preços de exportação apresentassem um comportamento semelhante ao observado para os preços de exportação da região Centro-Sul (Figura 33).

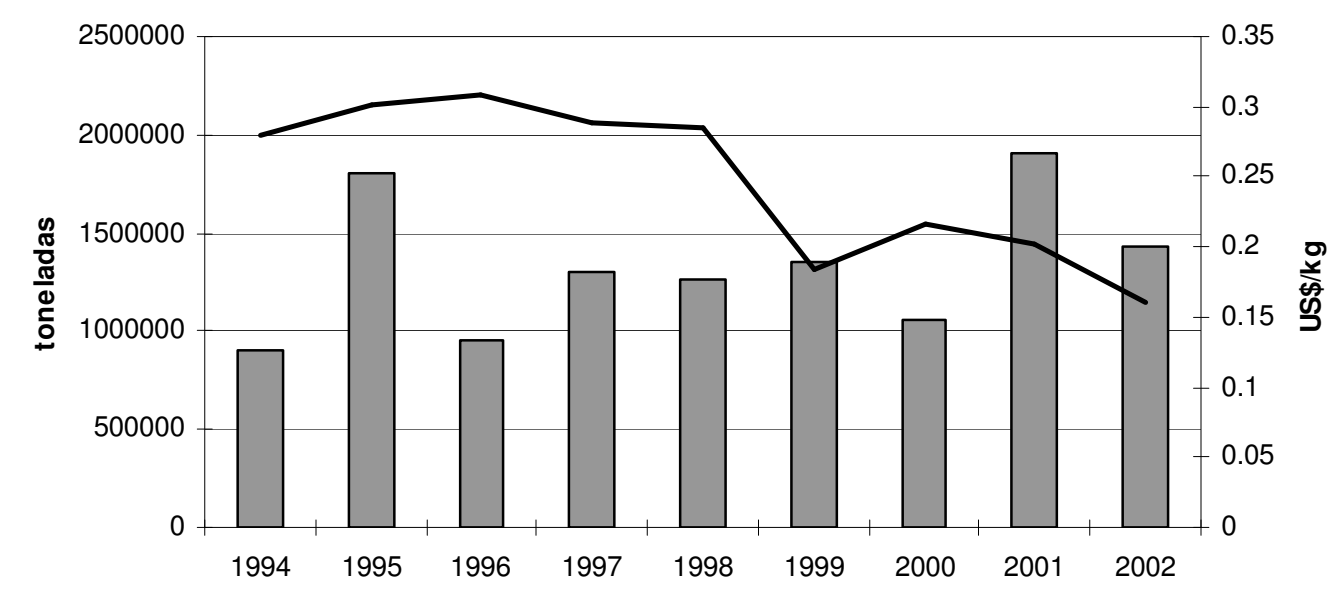

Volume exportado (toneladas) — Preço de exportação (US\$/kg)

Figura 35 - Volume, em tonelada, e preço médio, em US $\$ / \mathrm{kg}$, de exportação de açúcar bruto na região Norte-Nordeste; período: 1994 a 2002.

Fonte: Brasil (2003b) 
Os países que importaram acima de 100 mil toneladas de açúcar bruto da região Norte-Nordeste, no período de 1996 a 2002, foram Rússia, Estados Unidos, Bulgária, Irã, Canadá, Romênia, Marrocos, Argélia e Portugal. Entretanto, a maioria dos países importou de maneira esporádica. Por exemplo, considerando as importações de 1996 a 2002, Irã importou apenas em 1997, 2000, 2001 e 2002, Canadá, em 1996, 1997, 2001 e 2002; Marrocos importou de 1996 a 1999; e Romênia em 1996, 1998, 2000 e 2001.

Observa-se ainda, nas Figuras 33 e 35, uma diferença expressiva quanto às quantidades exportadas pelas duas regiões produtoras de açúcar do país. A região Centro-Sul exportou volume superior a 3 milhões de toneladas desde 1998, atingindo patamar superior a 6 milhões de toneladas de açúcar exportado nos anos de 1999, 2001 e 2002, enquanto a região Norte-Nordeste exportou volumes menores do que 2 milhões de toneladas durante todo o período.

Em relação às exportações de açúcar refinado, as Figuras 36 e 37 mostram a evolução do volume exportado e do preço de exportação, respectivamente, nas regiões Centro-Sul e Norte-Nordeste.

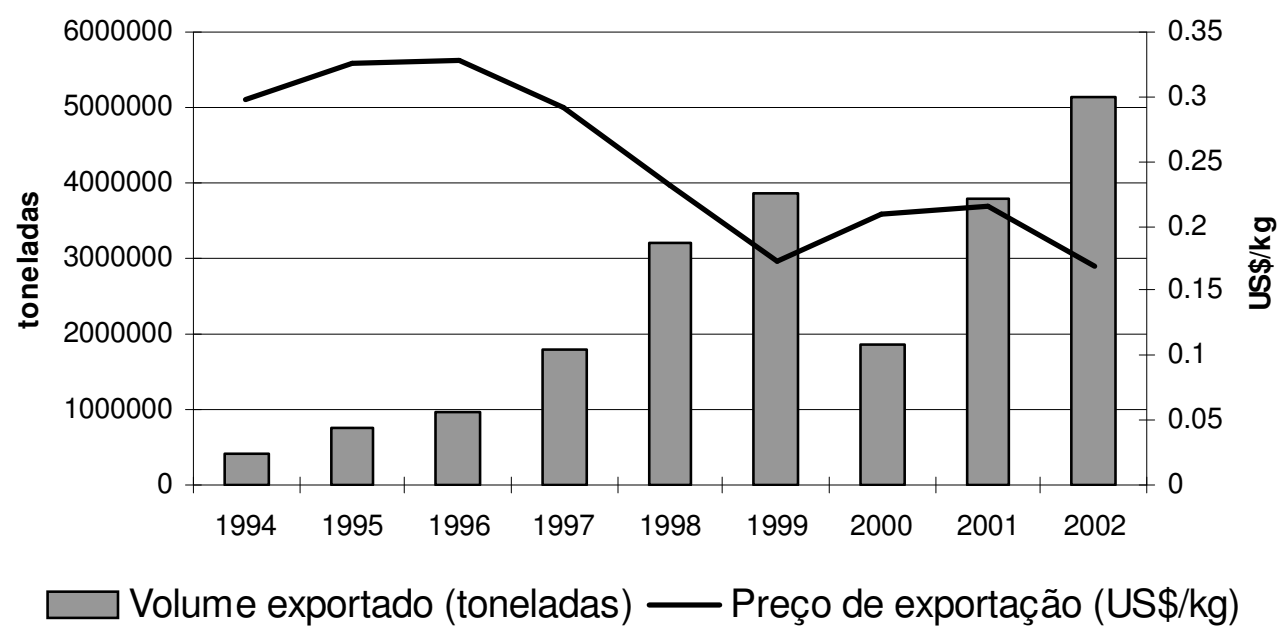

Figura 36 - Volume, em tonelada, e preço médio, em US\$/kg, de exportação de açúcar refinado na região Centro-Sul; período de 1994 a 2002.

Fonte: Brasil (2003b) 


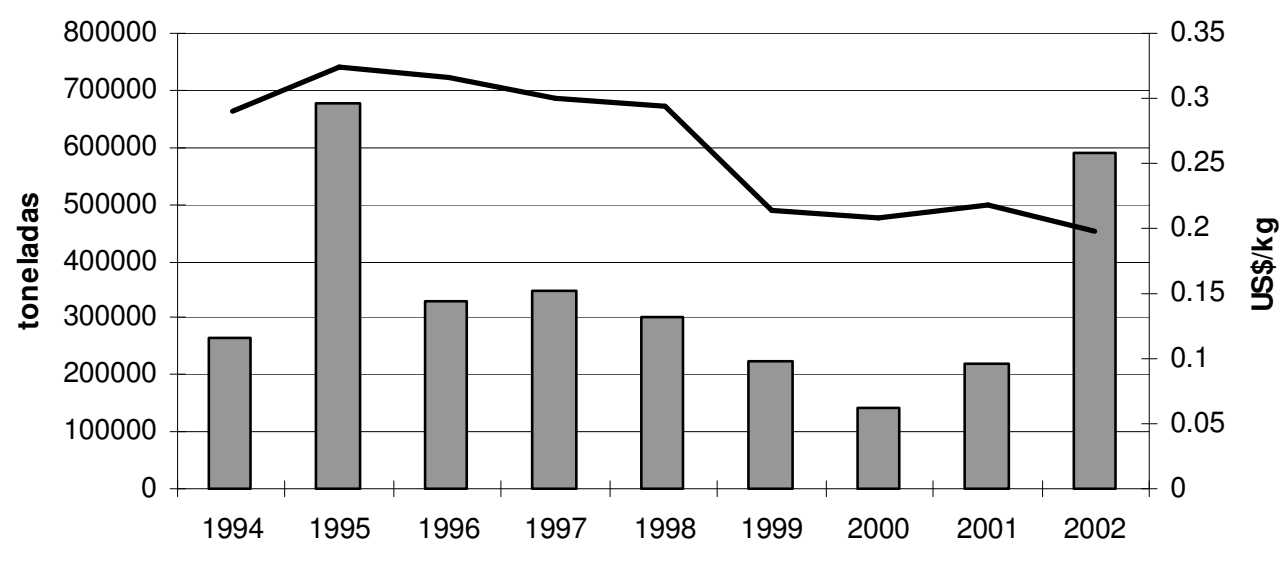

$\square$ Volume exportado (toneladas) — Preço de exportação (US $\$ / \mathrm{kg}$ )

Figura 37 - Volume, em tonelada, e preço médio, em US $\$ / \mathrm{kg}$, de exportação de açúcar refinado na região Norte-Nordeste; período: 1994 a 2002.

Fonte: Brasil (2003b)

Da maneira semelhante ao verificado para as exportações de açúcar bruto, as exportações de açúcar refinado da região Centro-Sul apresentaram um padrão ascendente na segunda metade da década de 1990, comprovando, também nesse mercado, a competitividade da região após a desregulamentação dessas exportações. As exportações do produto chegaram a se ter um volume de açúcar refinado exportado próximo ao volume exportado de açúcar bruto. $\mathrm{O}$ mercado de exportação de açúcar refinado é ainda bastante recente no Brasil, mas cresceu rapidamente, passando de uma participação de 5,2\% do mercado mundial em 1994 para 22,5\% em 2001.

Na região Norte-Nordeste, as exportações de açúcar refinado continuam sendo pouco significativas em termos relativos. Comparando as exportações realizadas pelas duas regiões (Figuras 36 e 37), verifica-se que o volume exportado pela região CentroSul é de até 5 milhões de toneladas, enquanto a exportação deste tipo de açúcar pela região Norte-Nordeste não chega a 700 mil toneladas.

No período de 1996 a 2002, 107 países importaram açúcar refinado da região Centro-Sul e apenas 43 países importaram, esporadicamente, da região Norte-Nordeste. 
Apesar de se posicionar como o segundo maior exportador de açúcar refinado nos últimos anos, o Brasil exportou menos do que a metade das exportações verificadas para a União Européia (Tabelas 12 e 13). Entretanto, os preços mundiais de açúcar refinado, segundo o contrato $n^{0 .} 5$ da Bolsa de Londres, também tiveram redução após o período de aumento das exportações brasileiras deste tipo de açúcar. Na Figura 38 observa-se este movimento (tendência apresentada na linha pontilhada).

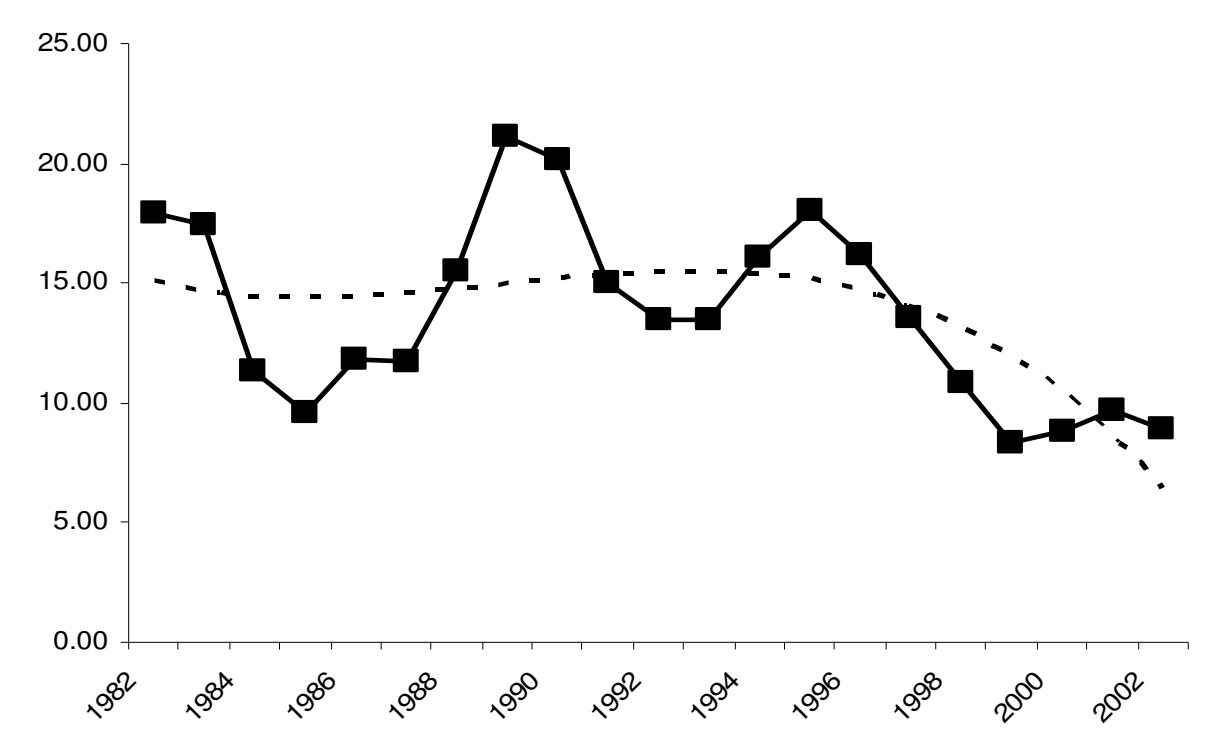

Figura 38 - Preço de açúcar bruto comercializado na Bolsa de Londres - LIFFE Contrato ${ }^{\text {o. }} 5$ (Cents/lb peso); período: 1982 a 2002.

Fonte: USDA (2001)

Outro fator que influenciou os volumes de açúcar bruto e refinado exportados pelo Brasil foi a variação da taxa de câmbio no período. A taxa de câmbio pode ser visualizada na Figura 39, onde se observa uma forte desvalorização cambial em 1999, oscilando em 2000 e 2001. A estiagem na região Centro-Sul, que provocou a quebra da safra 2000/01, foi outro fator responsável pela redução do volume exportado por esta região em 2000 (Conjuntura..., 2001). 


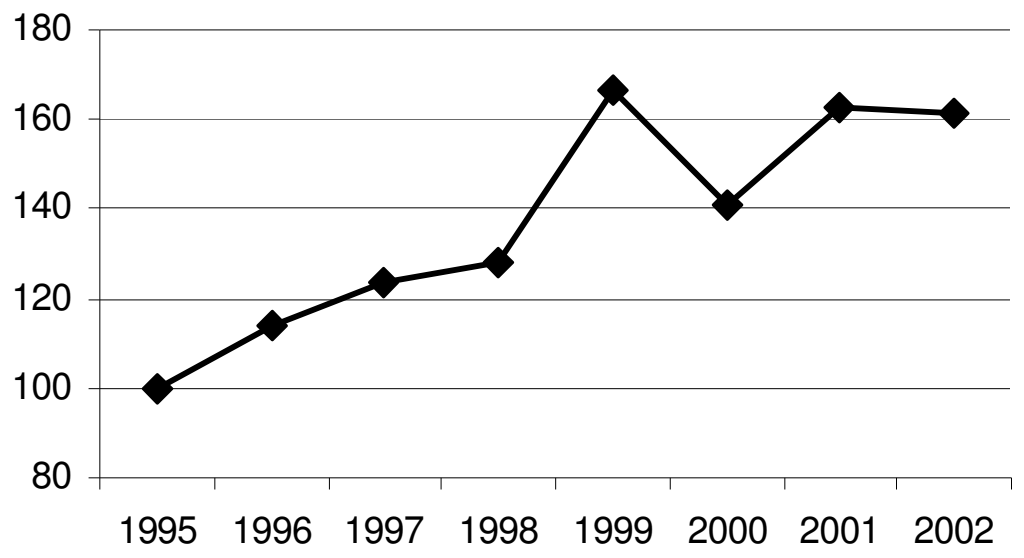

Figura 39 - Índice da taxa de câmbio efetiva real (IPA-OG - exportações, média 1995 = 100); período: 1995 a 2002.

Fonte: IPEA (2003a) 


\section{APÊNDICE 2 - Dados utilizados para estimar a equação de oferta das exportações de açúcar bruto das regiões Centro-Sul e Norte-Nordeste.}

Tabela 49. Volumes (em Toneladas) e Preço (em US\$/kg) de exportação de açúcar bruto da região Centro-sul, para os países considerados na estimação da equação de oferta, de 1996 a 2002.

\begin{tabular}{llrrrrrrr}
\hline & & 1996 & 1997 & 1998 & 1999 & 2000 & 2001 & 2002 \\
\hline BULGARIA & Volume & 39000 & 67000 & 29400 & 146824 & 53404 & 59249 & 125248 \\
& Preço & 0,2559 & 0,2516 & 0,1821 & 0,1261 & 0,1502 & 0,21 & 0,1341 \\
ROMENIA & Volume & 180324 & 7000 & 92000 & 167157 & 253946 & 303964 & 202780 \\
& Preço & 0,252 & 0,2638 & 0,1979 & 0,1448 & 0,1609 & 0,2005 & 0,1385 \\
UCRANIA & Volume & 65883 & 25000 & 84800 & 39500 & 35412 & 29500 & $25000^{2}$ \\
& Preço & 0,2562 & 0,264 & 0,2208 & 0,1165 & 0,1593 & 0,2057 & $0,1422^{2}$ \\
EGITO & Volume & 278720 & 322857 & 345897 & 441088 & $363967^{1}$ & 286845 & 414737 \\
& Preço & 0,28287 & 0,26206 & 0,19819 & 0,12962 & $0,15776^{1}$ & 0,1859 & 0,14204 \\
EMIRADOS & Volume & 172930 & 455406 & 429257 & 423507 & 398412 & 161449 & 265892 \\
ARABES & Preço & 0,268 & 0,25027 & 0,21097 & 0,14415 & 0,16446 & 0,18861 & 0,14373 \\
IRAN & Volume & 42900 & 101367 & 167000 & 276563 & 287732 & 315313 & 452206 \\
& Preço & 0,28829 & 0,26227 & 0,1931 & 0,13241 & 0,16029 & 0,1936 & 0,14353 \\
ARGÉLIA & Volume & 261950 & 4500 & $36714^{1}$ & 68928 & 32296 & 49400 & 113000 \\
& Preço & 0,31266 & 0,2875 & $0,21728^{1}$ & 0,14706 & 0,15354 & 0,19348 & 0,14491 \\
COSTA DO & Volume & 28500 & 7000 & 17748 & 6000 & $3509^{1}$ & 1017 & 7630 \\
MARFIM & Preço & 0,27543 & 0,30857 & 0,24451 & 0,192 & 0,22796 & 0,26392 & 0,1289 \\
MARROCOS & Volume & 148818 & 238581 & 298871 & 194847 & 240083 & 267340 & 200533 \\
& Preço & 0,27245 & 0,25667 & 0,19532 & 0,13702 & 0,16997 & 0,1979 & 0,15777 \\
NIGÉRIA & Volume & 100329 & 48500 & $42875^{1}$ & 37250 & 105000 & 107100 & 214843 \\
& Preço & 0,31151 & 0,27872 & $0,22212^{1}$ & 0,16553 & 0,1469 & 0,19901 & 0,16528 \\
CANADÁ & Volume & 56085 & 65489 & 115050 & 416023 & 173062 & 271937 & 503659 \\
& Preço & 0,26877 & 0,26067 & 0,20926 & 0,13683 & 0,1625 & 0,19603 & 0,14153 \\
RÚSSIA & Volume & 285426 & 512726 & 907235 & 3008987 & 992931 & 2006650 & 2618213 \\
& Preço & 0,27453 & 0,25994 & 0,20913 & 0,1428 & 0,15906 & 0,19319 & 0,13899 \\
\hline Fon & & & & & & & &
\end{tabular}

Fonte: Brasil (2003b)

${ }^{1}$ Calculado como a média aritmética simples entre os períodos anterior e posterior; ${ }^{2} \mathrm{o}$ volume foi calculado como o valor mínimo da série e o preço utilizado foi o preço médio das exportações de açúcar bruto da região Centro-Sul no período de 1996 a 2001. 
Tabela 50. Variáveis utilizadas para estimar a equação de oferta da exportação de açúcar bruto da região Centro-Sul.

\begin{tabular}{|c|c|c|c|c|c|c|c|}
\hline & & $\begin{array}{l}\text { Volume } \\
\text { (ton.) }\end{array}$ & $\begin{array}{c}\text { Preço de } \\
\text { exportação } \\
\text { (US\$ } / \mathrm{kg} \text { ) }\end{array}$ & $\begin{array}{l}\text { Taxa de } \\
\text { Câmbio } \\
\text { (índice) }\end{array}$ & $\begin{array}{c}\text { Preço } \\
\text { doméstico } \\
(\mathrm{R} \$ / \mathrm{kg})\end{array}$ & $\begin{array}{l}\text { PIB - proxy da } \\
\text { renda }\end{array}$ & $\begin{array}{c}\text { Preço de exportação } \\
\text { de refinado } \\
\text { (US } \$ \mathrm{~kg} \text { ) }\end{array}$ \\
\hline \multirow{7}{*}{ Africa $^{1}$} & 1996 & 539597 & 0,2994 & 113,863 & 0,6492 & 1180063093 & 0,3277 \\
\hline & 1997 & 298581 & 0,2619 & 123,492 & 0,5744 & 1218667546 & 0,2907 \\
\hline & 1998 & 396208 & 0,2025 & 128,096 & 0,4813 & 1220275166 & 0,2317 \\
\hline & 1999 & 307025 & 0,1438 & 166,609 & 0,4015 & 1229860109 & 0,1734 \\
\hline & 2000 & 380888 & 0,1628 & 141,172 & 0,6054 & 1283490222 & 0,2088 \\
\hline & 2001 & 424857 & 0,1978 & 162,537 & 0,6204 & 1301655062 & 0,2152 \\
\hline & 2002 & 536005 & 0,1577 & 161,173 & 0,5944 & 1321490497 & 0,1684 \\
\hline \multirow{7}{*}{ Canadá } & 1996 & 56085 & 0,2688 & 113,863 & 0,6492 & 1180063093 & 0,3277 \\
\hline & 1997 & 65489 & 0,2607 & 123,492 & 0,5744 & 1218667546 & 0,2907 \\
\hline & 1998 & 115050 & 0,2093 & 128,096 & 0,4813 & 1220275166 & 0,2317 \\
\hline & 1999 & 416023 & 0,1368 & 166,609 & 0,4015 & 1229860109 & 0,1734 \\
\hline & 2000 & 173062 & 0,1625 & 141,172 & 0,6054 & 1283490222 & 0,2088 \\
\hline & 2001 & 271937 & 0,196 & 162,537 & 0,6204 & 1301655062 & 0,2152 \\
\hline & 2002 & 503659 & 0,1415 & 161,173 & 0,5944 & 1321490497 & 0,1684 \\
\hline \multirow{7}{*}{ Europa $^{2}$} & 1996 & 285207 & 0,2535 & 113,863 & 0,6492 & 1180063093 & 0,3277 \\
\hline & 1997 & 99000 & 0,2556 & 123,492 & 0,5744 & 1218667546 & 0,2907 \\
\hline & 1998 & 206200 & 0,2051 & 128,096 & 0,4813 & 1220275166 & 0,2317 \\
\hline & 1999 & 353481 & 0,1339 & 166,609 & 0,4015 & 1229860109 & 0,1734 \\
\hline & 2000 & 342762 & 0,1591 & 141,172 & 0,6054 & 1283490222 & 0,2088 \\
\hline & 2001 & 392713 & 0,2023 & 162,537 & 0,6204 & 1301655062 & 0,2152 \\
\hline & 2002 & 353028 & 0,1372 & 161,173 & 0,5944 & 1321490497 & 0,1684 \\
\hline \multirow{7}{*}{$\begin{array}{l}\text { Países Árabes } \\
\text { e Egito }^{3}\end{array}$} & 1996 & 494549 & 0,2781 & 113,863 & 0,6492 & 1180063093 & 0,3277 \\
\hline & 1997 & 879630 & 0,256 & 123,492 & 0,5744 & 1218667546 & 0,2907 \\
\hline & 1998 & 942154 & 0,2031 & 128,096 & 0,4813 & 1220275166 & 0,2317 \\
\hline & 1999 & 1141158 & 0,1357 & 166,609 & 0,4015 & 1229860109 & 0,1734 \\
\hline & 2000 & 1050110 & 0,161 & 141,172 & 0,6054 & 1283490222 & 0,2088 \\
\hline & 2001 & 763607 & 0,1897 & 162,537 & 0,6204 & 1301655062 & 0,2152 \\
\hline & 2002 & 1132834 & 0,143 & 161,173 & 0,5944 & 1321490497 & 0,1684 \\
\hline \multirow{7}{*}{ Rússia } & 1996 & 285426 & 0,2745 & 113,863 & 0,6492 & 1180063093 & 0,3277 \\
\hline & 1997 & 512726 & 0,2599 & 123,492 & 0,5744 & 1218667546 & 0,2907 \\
\hline & 1998 & 907235 & 0,2091 & 128,096 & 0,4813 & 1220275166 & 0,2317 \\
\hline & 1999 & 3008987 & 0,1428 & 166,609 & 0,4015 & 1229860109 & 0,1734 \\
\hline & 2000 & 992931 & 0,1591 & 141,172 & 0,6054 & 1283490222 & 0,2088 \\
\hline & 2001 & 2006650 & 0,1932 & 162,537 & 0,6204 & 1301655062 & 0,2152 \\
\hline & 2002 & 2618213 & 0,139 & 161,173 & 0,5944 & 1321490497 & 0,1684 \\
\hline
\end{tabular}

Fonte: Brasil (2003b); CEPEA (2003); IPEA (2003a)

${ }^{1}$ Calculado como a média aritmética simples do volume e valor exportado para Argélia, Costa do Marfim, Marrocos e Nigéria; ${ }^{2}$ calculado como a média aritmética simples do volume e valor exportado para Bulgária, Romênia e Ucrânia; ${ }^{3}$ calculado como a média aritmética simples do volume e valor exportado para Emirados Árabes Unidos, Irã e Egito. 
Tabela 51. Variáveis utilizadas para estimar a equação de oferta da exportação de açúcar bruto da região Norte-Nordeste.

\begin{tabular}{lcccccc}
\hline & & $\begin{array}{c}\text { Volume } \\
\text { (ton.) }\end{array}$ & $\begin{array}{c}\text { Preço de } \\
\text { exportação } \\
\text { (US\$/kg) }\end{array}$ & $\begin{array}{c}\text { Taxa de } \\
\text { Câmbio } \\
\text { (índice) }\end{array}$ & $\begin{array}{c}\text { Preço } \\
\text { doméstico } \\
\text { (R\$/kg) }\end{array}$ & $\begin{array}{c}\text { Índice da produção de } \\
\text { alimentos do Norte- } \\
\text { Nordeste - proxy da } \\
\text { renda }\end{array}$ \\
\hline & 1996 & 15000 & 0,2413 & 113,863 & 0,8816 & 101,17 \\
BULGARIA & 1997 & 53000 & 0,2487 & 123,492 & 0,638 & 103,87 \\
& 1998 & 65000 & 0,2253 & 128,096 & 0,6857 & 85,53 \\
& 1999 & 36000 & 0,161 & 166,609 & 0,4347 & 98,48 \\
& 2000 & 18868 & 0,1875 & 141,172 & 0,6507 & 109,84 \\
& 2001 & 67016 & 0,1878 & 162,537 & 0,7081 & 104,86 \\
& 2002 & 47931 & 0,1452 & 161,173 & 0,7079 & 97,59 \\
& 1996 & 17714 & 0,2454 & 113,863 & 0,8816 & 101,17 \\
& 1997 & 28286 & 0,2579 & 123,492 & 0,638 & 103,87 \\
& 1998 & 3000 & 0,2314 & 128,096 & 0,6857 & 85,53 \\
EGITO & 1999 & 3000 & 0,1388 & 166,609 & 0,4347 & 98,48 \\
RUSSIA & 2000 & 3500 & 0,1615 & 141,172 & 0,6507 & 109,84 \\
& 2001 & 4000 & 0,1786 & 162,537 & 0,7081 & 104,86 \\
& 2002 & 25000 & 0,1288 & 161,173 & 0,7079 & 97,59 \\
& 1996 & 187700 & 0,2458 & 113,863 & 0,8816 & 101,17 \\
& 1997 & 558281 & 0,2517 & 123,492 & 0,638 & 103,87 \\
& 1998 & 737071 & 0,2422 & 128,096 & 0,6857 & 85,53 \\
& 1999 & 1078820 & 0,1541 & 166,609 & 0,4347 & 98,48 \\
& 2000 & 711497 & 0,1848 & 141,172 & 0,6507 & 109,84 \\
& 2001 & 1431510 & 0,192 & 162,537 & 0,7081 & 104,86 \\
& 2002 & 894000 & 0,1459 & 161,173 & 0,7079 & 97,59 \\
& 1996 & $4,33 \mathrm{E}+08$ & 0,255976 & 113,863 & 0,8816 & 101,17 \\
& 1997 & $4,24 \mathrm{E}+08$ & 0,266003 & 123,492 & 0,638 & 103,87 \\
& 1998 & $1,76 \mathrm{E}+08$ & 0,282583 & 128,096 & 0,6857 & 85,53 \\
& 1999 & $1,33 \mathrm{E}+08$ & 0,232138 & 166,609 & 0,4347 & 98,48 \\
& 2000 & $1,29 \mathrm{E}+08$ & 0,183045 & 141,172 & 0,6507 & 109,84 \\
& 2001 & $2,96 \mathrm{E}+08$ & 0,197693 & 162,537 & 0,7081 & 104,86 \\
& 2002 & $3,85 \mathrm{E}+08$ & 0,145785 & 161,173 & 0,7079 & 97,59 \\
\hline
\end{tabular}

Fonte: Brasil (2003b); CEPEA (2003); DIEESE (2003); IBGE (2003a); IPEA (2003a); IPEA (2003b)

${ }^{1}$ Calculado como a média aritmética simples entre os períodos anterior e posterior do volume e valor exportado. 
APÊNDICE 3 - Dados utilizados para estimar as equações de demanda dos EUA pelas exportações de açúcar bruto das regiões Centro-Sul e NorteNordeste do Brasil.

Tabela 52. Variáveis utilizadas para estimar a equação de demanda da importação de açúcar bruto dos EUA.

\begin{tabular}{lcccccccc}
\hline & $\begin{array}{c}\text { Importação } \\
\text { (toneladas) }\end{array}$ & $\begin{array}{c}\text { Preço de } \\
\text { importação } \\
\text { (US\$/kg) }\end{array}$ & $\begin{array}{c}\text { Índice } \\
\text { PIB }\end{array}$ & $\begin{array}{c}\text { Índice } \\
\text { TC }\end{array}$ & $M_{i j}$ & $M_{i j} / M_{i}$ & $P_{i j}$ & $P_{i j} / P_{i}$ \\
\hline 1982 & 2545040 & 0,439 & 65,21 & 168 & 286143 & 0,112 & 0,146 & 0,436 \\
1983 & 2682674 & 0,486 & 68,03 & 169,2 & 286806 & 0,107 & 0,312 & 0,759 \\
1984 & 3080146 & 0,479 & 72,98 & 177,7 & 299426 & 0,097 & 0,375 & 0,879 \\
1985 & 2525839 & 0,448 & 75,79 & 183,8 & 311425 & 0,123 & 0,308 & 0,792 \\
1986 & 1940657 & 0,462 & 78,37 & 150 & 140365 & 0,072 & 0,38 & 1.051 \\
1987 & 1329231 & 0,481 & 81,04 & 130,9 & 116155 & 0,087 & 0,327 & 0,941 \\
1988 & 1212487 & 0,488 & 84,42 & 122,9 & 102372 & 0,084 & 0,433 & 1.126 \\
1989 & 1682764 & 0,503 & 87,38 & 124,5 & 15750 & 0,009 & 0,441 & 1.100 \\
1990 & 1785250 & 0,513 & 88,92 & 115,8 & 395566 & 0,222 & 0,402 & 0,763 \\
1991 & 1804961 & 0,476 & 88,5 & 111,6 & 223698 & 0,124 & 0,397 & 0,914 \\
1992 & 1837022 & 0,47 & 91,2 & 109 & 142199 & 0,077 & 0,409 & 1.019 \\
1993 & 1689195 & 0,477 & 93,62 & 111,1 & 191071 & 0,113 & 0,407 & 1.022 \\
1994 & 1486087 & 0,486 & 97,4 & 108,5 & 82145 & 0,055 & 0,395 & 0,961 \\
1995 & 1602478 & 0,506 & 100 & 100 & 234627 & 0,146 & 0,432 & 0,929 \\
1996 & 2720607 & 0,494 & 103,57 & 103,6 & 363173 & 0,133 & 0,399 & 0,996 \\
1997 & 2877873 & 0,484 & 108,16 & 109,5 & 241309 & 0,084 & 0,426 & 1.186 \\
1998 & 1959872 & 0,486 & 112,79 & 116,6 & 275184 & 0,14 & 0,42 & 1.084 \\
1999 & 1613625 & 0,466 & 117,43 & 114,8 & 107692 & 0,067 & 0,424 & 1.146 \\
2000 & 1336187 & 0,421 & 121,84 & 123,5 & 195639 & 0,146 & 0,356 & 0,932 \\
2001 & 1272746 & 0,465 & 122,15 & 135,1 & 152387 & 0,12 & 0,32 & 0,777 \\
\hline
\end{tabular}

Fonte: Brasil (1988); Brasil (2003b); FAO (2003b); IPEA (2003c)

Nota: $\ln (M i j / M i)=$ Logaritmo da participação das importações originadas do país $j$ nas importações totais do país $i ; \ln (P i j / P i)=$ Logaritmo da relação entre o preço de importação do país $j$ no preço geral da importação do país $i$. 


\section{APÊNDICE 4 - Dados utilizados para estimar as equações de demanda por importação de açúcar bruto e de oferta de}

exportação de açúcar refinado da União Européia.

Tabela 53. Variáveis utilizadas para estimar a equação de demanda da importação extra-bloco de açúcar bruto da União Européia, países do primeiro grupo.

\begin{tabular}{|c|c|c|c|c|c|c|c|c|c|c|}
\hline País & ano & $\begin{array}{l}\text { Volume } \\
\text { importado } \\
\text { (ton.) }-M_{i}\end{array}$ & $\begin{array}{l}\text { Preço comércio } \\
\text { intra-bloco } \\
\text { (US } \$ / \mathrm{kg} \text { ) }\end{array}$ & $\begin{array}{l}\text { Índice taxa } \\
\text { câmbio } \\
\text { efetiva real }\end{array}$ & $\begin{array}{c}\text { Valor } \\
\text { importação total } \\
\text { (bilhões US\$) }\end{array}$ & $\begin{array}{c}\text { Volume } \\
\text { importado de } \\
\text { Mauricius - } M_{i j}\end{array}$ & $M_{i j} / M_{i}$ & $\begin{array}{l}\text { Preço de } \\
\text { importação de ir } \\
\text { Mauricius - } P_{i j}\end{array}$ & $\begin{array}{c}\text { Preço de } \\
\text { Importação extra- } \\
\text { bloco }-P_{j}\end{array}$ & $P_{i j} / P_{j}$ \\
\hline Portugal & 1989 & 335632 & 0,5051 & 82,16 & 19,07 & 18018 & 0,054 & 0,48 & 0,341 & 1.407 \\
\hline Portugal & 1990 & 280411 & 32.758 & 87,17 & 25,26 & 31952 & 0,114 & 0,359 & 0,256 & 1.400 \\
\hline Portugal & 1991 & 173026 & 14.410 & 93,46 & 26,42 & 17953 & 0,104 & 0,513 & 0,218 & 2.350 \\
\hline Portugal & 1992 & 240073 & 0,4743 & 101,31 & 30,31 & 17971 & 0,075 & 0,483 & 0,194 & 2.487 \\
\hline Portugal & 1993 & 246509 & 12.697 & 98,37 & 24,27 & 5837 & 0,024 & 0,524 & 0,233 & 2.243 \\
\hline Portugal & 1994 & 289441 & 0,8541 & 97,16 & 27,3 & 18001 & 0,062 & 0,546 & 0,258 & 2.118 \\
\hline Portugal & 1995 & 310925 & 11.140 & 100 & 33,31 & 18119 & 0,058 & 0,531 & 0,322 & 1.652 \\
\hline Portugal & 1996 & 306732 & 14.066 & 100,94 & 35,18 & 63082 & 0,206 & 0,496 & 0,426 & 1.164 \\
\hline Portugal & 1997 & 295313 & 18.170 & 99,11 & 35,06 & 48801 & 0,165 & 0,489 & 0,446 & 1.097 \\
\hline Portugal & 1998 & 290659 & 13.250 & 99,33 & 37,05 & 88099 & 0,303 & 0,484 & 0,454 & 1.066 \\
\hline Portugal & 1999 & 299913 & 14.091 & 98,87 & 38,46 & 42289 & 0,141 & 0,479 & 0,478 & 1.002 \\
\hline Itália & 1989 & 1220 & 0,9903 & 125,63 & 153,01 & 493 & 0,404 & 0,613 & 0,567 & 1.080 \\
\hline Itália & 1990 & 1817 & 0,8806 & 131,54 & 181,97 & 1214 & 0,668 & 0,629 & 0,564 & 1.115 \\
\hline Itália & 1991 & 1271 & 0,9637 & 132,49 & 182,68 & 1003 & 0,789 & 0,623 & 0,659 & 0,946 \\
\hline Itália & 1992 & 8657 & 0,941 & 130,63 & 188,52 & 1599 & 0,185 & 0,624 & 0,298 & 2.089 \\
\hline Itália & 1993 & 9313 & 0,9545 & 110,48 & 147,34 & 1779 & 0,191 & 0,709 & 0,373 & 1.899 \\
\hline Itália & 1994 & 15945 & 0,9595 & 107,24 & 169,17 & 2021 & 0,127 & 0,756 & 0,323 & 2.337 \\
\hline Itália & 1995 & 3238 & 0,886 & 100 & 206,04 & 1963 & 0,606 & 0,768 & 0,696 & 1.102 \\
\hline Itália & 1996 & 11125 & 0,8801 & 111,65 & 208,09 & 2221 & 0,2 & 0,753 & 0,409 & 1.842 \\
\hline Itália & 1997 & 36479 & 0,9134 & 112,28 & 210,27 & 2768 & 0,076 & 0,729 & 0,303 & 2.403 \\
\hline Itália & 1998 & 30112 & 0,9287 & 113,15 & 218,45 & 2772 & 0,092 & 0,758 & 0,332 & 2.279 \\
\hline Itália & 1999 & 3796 & 0,9516 & 110,87 & 216,62 & 2391 & 0,63 & 0,742 & 0,802 & 0,926 \\
\hline
\end{tabular}


Tabela 53. Variáveis utilizadas para estimar a equação de demanda da importação extra-bloco de açúcar bruto da União Européia, países do primeiro grupo.

\begin{tabular}{|c|c|c|c|c|c|c|c|c|c|c|}
\hline País & ano & $\begin{array}{l}\text { Volume } \\
\text { importado } \\
\text { (ton.) }-M_{i} \\
\end{array}$ & $\begin{array}{c}\text { Preço comércio } \\
\text { intra-bloco } \\
(\mathrm{US} \$ / \mathrm{kg})\end{array}$ & $\begin{array}{l}\text { Índice taxa } \\
\text { câmbio } \\
\text { efetiva real }\end{array}$ & $\begin{array}{c}\text { Valor importação } \\
\text { total (bilhões } \\
\text { US\$) }\end{array}$ & $\begin{array}{c}\text { Volume } \\
\text { importado de } \\
\text { Mauricius - } M_{i j}\end{array}$ & $M_{i j} / M_{i}$ & $\begin{array}{c}\text { Preço de } \\
\text { importação de i } \\
\text { Mauricius - } P_{i j}\end{array}$ & $\begin{array}{c}\text { Preço de } \\
\text { mportação extra- } \\
\text { bloco }-P_{j}\end{array}$ & $P_{i j} / P_{j}$ \\
\hline Grécia & 1989 & 14 & 0,912 & 93,04 & 16,15 & 2 & 0,143 & 1.000 & 0,727 & 1.376 \\
\hline Grécia & 1990 & 1 & 0,99 & 94,8 & 19,78 & $0,50^{3}$ & 0,5 & $0,850^{2}$ & 2.772 & 0,307 \\
\hline Grécia & 1991 & 22 & 0,906 & 92,67 & 21,58 & 20 & 0,909 & 0,7 & 0,82 & 0,854 \\
\hline Grécia & 1992 & 21 & 0,876 & 92,02 & 23,22 & 21 & 1.000 & 0,67 & 0,612 & 1,09 \\
\hline Grécia & 1993 & 181 & 0,835 & 91,85 & 22,01 & $31,5^{2}$ & 0,174 & $0,607^{2}$ & 0,431 & 1.407 \\
\hline Grécia & 1994 & 44 & 0,983 & 93,88 & 18,74 & 42 & 0,955 & 0,55 & 0,595 & 0,92 \\
\hline Grécia & 1995 & 190 & 1.172 & 100 & 22,93 & 190 & 1.000 & 0,61 & 0,562 & 1.077 \\
\hline Grécia & 1996 & 234 & 0,815 & 103,62 & 24,14 & 190 & 0,812 & 0,75 & 0,622 & 1.201 \\
\hline Grécia & 1997 & 147 & 0,788 & 107,27 & 23,64 & 147 & 1.000 & 0,83 & 0,844 & 0,983 \\
\hline Grécia & 1998 & 170 & 1.017 & 103,53 & 23,25 & 169 & 0,994 & 0,81 & 0,82 & 0,989 \\
\hline Grécia & 1999 & 105 & 1,02 & $104,81^{1}$ & $23,68^{1}$ & 105 & 1.000 & 0,8 & 0,852 & 0,939 \\
\hline
\end{tabular}

Fonte: European Commission (1998, 2000); IMF (2000)

Nota: $\ln \left(M_{i j} / M_{i}\right)=$ Logaritmo da participação das importações originadas do país $j$ nas importações totais do país $i$; $\ln \left(P_{i j} / P_{i}\right)=$ Logaritmo da relação entre o preço de importação do país $j$ no preço geral da importação do país $i$. ${ }^{1}$ Calculado como a média aritmética simples dos três últimos anos; ${ }^{2}$ Calculado como a média aritmética simples entre os períodos anterior e posterior do volume e valor exportado; ${ }^{3}$ Calculado como sendo a metade do volume importado naquele ano. 
Tabela 54. Variáveis utilizadas para estimar a equação de demanda da importação extra-bloco de açúcar bruto e oferta de exportação extra-bloco de açúcar refinado da União Européia, países do segundo grupo.

\begin{tabular}{|c|c|c|c|c|c|c|c|c|c|c|c|}
\hline País & ano & $\begin{array}{l}\text { Volume } \\
\text { importado } \\
\text { (ton) }-M_{i}\end{array}$ & $\begin{array}{c}\text { Preço de } \\
\text { importação } \\
\text { extra-bloco } \\
\text { (US } \$ / \mathrm{kg})-P_{j}\end{array}$ & $\begin{array}{l}\text { Índice taxa } \\
\text { câmbio } \\
\text { efetiva real }\end{array}$ & $\begin{array}{c}\text { Valor } \\
\text { importação } \\
\text { total (bilhões } \\
\text { US\$) }\end{array}$ & $\begin{array}{c}\text { Volume } \\
\text { importado de } \\
\text { Mauricius } \\
\text { (ton) }-M_{i j}\end{array}$ & $M_{i j} / M_{i}$ & $\begin{array}{c}\text { Preço de } \\
\text { importação de } \\
\text { Mauricius } \\
\text { (US\$ } / \mathrm{kg})-P_{i j}\end{array}$ & $P_{i j} / P_{j}$ & $\begin{array}{l}\text { Volume } \\
\text { exportado açúcar } \\
\text { refinado (ton) }\end{array}$ & $\begin{array}{l}\text { Preço comércio } \\
\text { intra-bloco } \\
\text { açúcar refinado } \\
\text { (US } \$ / \mathrm{kg})\end{array}$ \\
\hline Alemanha & 1989 & 864 & 0,869 & 88,1 & 269,7 & 227 & 0,263 & 0,652 & 0,75 & 1063001 & 0,633 \\
\hline Alemanha & 1990 & 2054 & 0,677 & 90,78 & 346,15 & 1194 & 0,581 & 0,621 & 0,916 & 1135797 & 0,654 \\
\hline Alemanha & 1991 & 3765 & 0,65 & 87,24 & 389,91 & 2733 & 0,726 & 0,637 & 0,98 & 1208997 & 0,644 \\
\hline Alemanha & 1992 & 2439 & 0,652 & 91,53 & 402,44 & 1935 & 0,793 & 0,653 & 1.000 & 1104150 & 0,648 \\
\hline Alemanha & 1993 & 4448 & 0,697 & 95,41 & 346,03 & 3553 & 0,799 & 0,681 & 0,976 & 1433370 & 0,656 \\
\hline Alemanha & 1994 & 3400 & 0,732 & 95,72 & 385,35 & 2195 & 0,646 & 0,691 & 0,944 & 1142512 & 0,611 \\
\hline Alemanha & 1995 & 4068 & 0,684 & 100 & 464,27 & 2450 & 0,602 & 0,72 & 1.053 & 1124502 & 0,604 \\
\hline Alemanha & 1996 & 4948 & 0,701 & 96,77 & 458,78 & 3266 & 0,66 & 0,719 & 1.025 & 756245 & 0,586 \\
\hline Alemanha & 1997 & 5017 & 0,775 & 92,05 & 445,62 & 3866 & 0,771 & 0,706 & 0,91 & 808503 & 0,596 \\
\hline Alemanha & 1998 & 6067 & 0,793 & 92,54 & 471,42 & 4284 & 0,706 & 0,713 & 0,899 & 948245 & 0,643 \\
\hline Alemanha & 1999 & 6086 & 0,782 & 89,52 & 472,16 & 4175 & 0,686 & 0,692 & 0,886 & 896475 & 0,663 \\
\hline Franca & 1989 & 335175 & 0,496 & 94,79 & 192,95 & 9968 & 0,03 & 0,621 & 1.252 & 941957 & 0,711 \\
\hline Franca & 1990 & 327660 & 0,476 & 98,15 & 234,45 & 9264 & 0,028 & 0,633 & 1.329 & 1577320 & 0,66 \\
\hline Franca & 1991 & 341338 & 0,469 & 95,15 & 231,78 & 5594 & 0,016 & 0,636 & 1.356 & 1523372 & 0,688 \\
\hline Franca & 1992 & 326977 & 0,495 & 96,59 & 239,64 & 4777 & 0,015 & 0,651 & 1.316 & 1605692 & 0,68 \\
\hline Franca & 1993 & 308172 & 0,53 & 97,66 & 203,2 & 17117 & 0,056 & 0,56 & 1.058 & 1950664 & 0,658 \\
\hline Franca & 1994 & 292840 & 0,532 & 97,42 & 234,57 & 4383 & 0,015 & 0,682 & 1.284 & 1291515 & 0,667 \\
\hline Franca & 1995 & 315108 & 0,496 & 100 & 281,44 & 3834 & 0,012 & 0,691 & 1.394 & 1325317 & 0,655 \\
\hline Franca & 1996 & 340604 & 0,507 & 99,87 & 235,1 & 17600 & 0,052 & 0,511 & 1.007 & 1614709 & 0,674 \\
\hline Franca & 1997 & 106815 & 0,541 & 95,61 & 271,91 & 2804 & 0,026 & 0,691 & 1.278 & 1496934 & 0,715 \\
\hline Franca & 1998 & 115050 & 0,525 & 95,98 & 290,24 & 2346 & 0,02 & 0,698 & 1.331 & 1700125 & 0,722 \\
\hline Franca & 1999 & 166957 & 0,5 & 93,17 & 289,93 & 6341 & 0,038 & 0,697 & 1.393 & 1440354 & 0,768 \\
\hline ReinoUnido & 1989 & 1247419 & 0,467 & 113,25 & 199,19 & 483092 & 0,387 & 0,463 & 0,993 & 277734 & 0,639 \\
\hline ReinoUnido & 1990 & 1184790 & 0,424 & 117,1 & 224,41 & 456387 & 0,385 & 0,469 & 1.105 & 287734 & 0,665 \\
\hline ReinoUnido & 1991 & 476316 & 1.198 & 119,84 & 209,81 & 477342 & 1.002 & 0,503 & 0,42 & 173284 & 0,673 \\
\hline ReinoUnido & 1992 & 1293583 & 0,449 & 115,6 & 221,5 & 496556 & 0,384 & 0,492 & 1.095 & 232516 & 0,602 \\
\hline
\end{tabular}


Tabela 54. Variáveis utilizadas para estimar a equação de demanda da importação extra-bloco de açúcar bruto e oferta de exportação extra-bloco de açúcar refinado da União Européia, países do segundo grupo.

\begin{tabular}{|c|c|c|c|c|c|c|c|c|c|c|c|}
\hline País & ano & $\begin{array}{l}\text { Volume } \\
\text { importado } \\
\text { (ton) }-M_{i}\end{array}$ & $\begin{array}{c}\text { Preço de } \\
\text { importação } \\
\text { extra-bloco } \\
(\mathrm{US} \$ / \mathrm{kg})-P_{j}\end{array}$ & $\begin{array}{c}\text { Índice taxa } \\
\text { câmbio } \\
\text { efetiva real }\end{array}$ & $\begin{array}{c}\text { Valor } \\
\text { importação } \\
\text { total (bilhões } \\
\text { US\$) }\end{array}$ & $\begin{array}{c}\text { Volume } \\
\text { importado de } \\
\text { Mauricius } \\
\text { (ton) }-M_{i j} \\
\end{array}$ & $M_{i j} / M_{i}$ & $\begin{array}{c}\text { Preço de } \\
\text { importação de } \\
\text { Mauricius } \\
\text { (US } \$ / \mathrm{kg})-P_{i j}\end{array}$ & $P_{i j} / P_{j}$ & $\begin{array}{c}\text { Volume } \\
\text { exportado } \\
\text { açúcar refinado } \\
\text { (ton) }\end{array}$ & $\begin{array}{l}\text { Preço comércio } \\
\text { intra-bloco } \\
\text { açúcar refinado } \\
\text { (US\$/kg) }\end{array}$ \\
\hline ReinoUnido & 1993 & 1194111 & 0,507 & 103,53 & 206,1 & 443360 & 0,371 & 0,536 & 1.058 & 382594 & 0,713 \\
\hline ReinoUnido & 1994 & 1227651 & 0,513 & 103,74 & 226,16 & 452733 & 0,369 & 0,536 & 1.045 & 472966 & 0,712 \\
\hline ReinoUnido & 1995 & 1201401 & 0,494 & 100 & 265,3 & 472817 & 0,394 & 0,536 & 1.085 & 399885 & 0,708 \\
\hline ReinoUnido & 1996 & 1228804 & 0,505 & 102,35 & 287,43 & 459916 & 0,374 & 0,551 & 1.091 & 289649 & 0,751 \\
\hline ReinoUnido & 1997 & 1228836 & 0,566 & 120,49 & 306,59 & 456768 & 0,372 & 0,56 & 0,99 & 509348 & 0,68 \\
\hline ReinoUnido & 1998 & 1261555 & 0,547 & 128,05 & 314,03 & 493876 & 0,391 & 0,543 & 0,992 & 687366 & 0,7 \\
\hline ReinoUnido & 1999 & 1242770 & 0,561 & 127,62 & 317,97 & 440875 & 0,355 & 0,536 & 0,955 & 534062 & 0,751 \\
\hline BelgicaLux & 1989 & 3089 & 0,61 & 90,92 & 83,35 & 1802 & 0,583 & 0,594 & 0,975 & 104944 & 0,42 \\
\hline BelgicaLux & 1990 & 6283 & 0,537 & 94,75 & 91,92 & 4447 & 0,708 & 0,574 & 1.070 & 545407 & 0,533 \\
\hline BelgicaLux & 1991 & 3395 & 0,595 & 94,07 & 101,02 & 2037 & 0,6 & 0,615 & 1.034 & 833834 & 0,738 \\
\hline BelgicaLux & 1992 & 5616 & 0,578 & 94,99 & 111,08 & 3900 & 0,694 & 0,628 & 1.088 & 919192 & 0,664 \\
\hline BelgicaLux & 1993 & 4482 & 0,638 & 95 & 122,09 & 3749 & 0,836 & 0,672 & 1.053 & 572086 & 0,731 \\
\hline BelgicaLux & 1994 & 4471 & 0,675 & 96,53 & 138,46 & 3110 & 0,696 & 0,699 & 1.035 & 1418847 & 0,756 \\
\hline BelgicaLux & 1995 & 5251 & 0,662 & 100 & 169,43 & 3299 & 0,628 & 0,733 & 1.106 & 1417215 & 0,816 \\
\hline BelgicaLux & 1996 & 5252 & 0,663 & 98,14 & 173,27 & 3564 & 0,679 & 0,717 & 1.081 & 696642 & 0,759 \\
\hline BelgicaLux & 1997 & 6350 & 0,707 & 93,58 & 166,64 & 3607 & 0,568 & 0,703 & 0,994 & 982554 & 0,755 \\
\hline BelgicaLux & 1998 & 7531 & 0,817 & 93,36 & 169,65 & 4162 & 0,553 & 0,712 & 0,872 & 1380150 & 0,817 \\
\hline BelgicaLux & 1999 & 7403 & 0,749 & 91,76 & 174,87 & 5144 & 0,695 & 0,714 & 0,953 & 854039 & 0,849 \\
\hline Espanha & 1989 & 554 & 0,209 & 108,1 & 70,95 & 20 & 0,036 & 0,7 & 3.344 & 80034 & 0,191 \\
\hline Espanha & 1990 & 285 & 0,622 & 114,75 & 87,55 & 23 & 0,081 & 0,609 & 0,978 & 80829 & 0,347 \\
\hline Espanha & 1991 & 447 & 0,639 & 116,15 & 92,97 & $96^{1}$ & 0,215 & $0,618^{1}$ & 0,967 & 76194 & 0,515 \\
\hline Espanha & 1992 & 954 & 0,611 & 115,67 & 99,75 & 169 & 0,177 & 0,627 & 1.027 & 83145 & 0,554 \\
\hline Espanha & 1993 & 160 & 0,655 & 103,09 & 79,67 & 20 & 0,125 & 0,65 & 0,993 & 70518 & 1.807 \\
\hline Espanha & 1994 & 1488 & 0,798 & 98,31 & 92,19 & 742 & 0,499 & 0,953 & 1.194 & 171590 & 0,802 \\
\hline Espanha & 1995 & 2723 & 0,706 & 100 & 113,32 & 1746 & 0,641 & 0,79 & 1.120 & 188599 & 0,733 \\
\hline
\end{tabular}


Tabela 54. Variáveis utilizadas para estimar a equação de demanda da importação extra-bloco de açúcar bruto e oferta de exportação extra-bloco de açúcar refinado da União Européia, países do segundo grupo.

\begin{tabular}{|c|c|c|c|c|c|c|c|c|c|c|c|}
\hline País & ano & $\begin{array}{l}\text { Volume } \\
\text { importado } \\
\text { (ton) }-M_{i}\end{array}$ & $\begin{array}{c}\text { Preço de } \\
\text { importação } \\
\text { extra-bloco } \\
(\mathrm{US} \$ / \mathrm{kg})-P_{j}\end{array}$ & $\begin{array}{l}\text { Índice taxa } \\
\text { câmbio } \\
\text { efetiva real }\end{array}$ & $\begin{array}{c}\text { Valor } \\
\text { importação } \\
\text { total (bilhões } \\
\text { US\$) }\end{array}$ & $\begin{array}{c}\text { Volume } \\
\text { importado de } \\
\text { Mauricius } \\
\text { (ton) }-M_{i j} \\
\end{array}$ & $M_{i j} / M_{i}$ & $\begin{array}{c}\text { Preço de } \\
\text { importação de } \\
\text { Mauricius } \\
(\mathrm{US} \$ / \mathrm{kg})-P_{i j}\end{array}$ & $P_{i j} / P_{j}$ & $\begin{array}{l}\text { Volume } \\
\text { exportado açúcar } \\
\text { refinado (ton) }\end{array}$ & $\begin{array}{l}\text { Preço comércio } \\
\text { intra-bloco } \\
\text { açúcar refinado } \\
\text { (US } \$ / \mathrm{kg})\end{array}$ \\
\hline Espanha & 1996 & 2091 & 0,742 & 102,2 & 121,78 & 716 & 0,342 & 0,846 & 1.141 & 183298 & 1.048 \\
\hline Espanha & 1997 & 2468 & 0,813 & 97,42 & 122,71 & 1365 & 0,553 & 0,808 & 0,993 & 259019 & 0,983 \\
\hline Espanha & 1998 & 3103 & 0,825 & 97,41 & 133,15 & 926 & 0,298 & 0,857 & 1.040 & 217209 & 0,896 \\
\hline Espanha & 1999 & 2538 & 0,861 & 96,66 & 144,44 & 84 & 0,033 & 0,845 & 0,981 & 187027 & 1.165 \\
\hline Holanda & 1989 & 3683 & 0,654 & 91,79 & 104,25 & 2961 & 0,804 & 0,652 & 0,998 & 1893500 & 0,867 \\
\hline Holanda & 1990 & 3982 & 0,583 & 93,68 & 126,48 & 3020 & 0,758 & 0,646 & 1.108 & 1062308 & 0,763 \\
\hline Holanda & 1991 & 4249 & 0,616 & 92,11 & 127,21 & 3616 & 0,851 & 0,651 & 1.056 & 381203 & 0,844 \\
\hline Holanda & 1992 & 4668 & 0,621 & 93,73 & 134,65 & 4484 & 0,961 & 0,678 & 1.091 & 369575 & 0,755 \\
\hline Holanda & 1993 & 4289 & 0,675 & 95,31 & 124,74 & 4018 & 0,937 & 0,707 & 1.047 & 407284 & 0,825 \\
\hline Holanda & 1994 & 4021 & 0,705 & 95,96 & 141,32 & 3070 & 0,763 & 0,72 & 1.022 & 440906 & 0,839 \\
\hline Holanda & 1995 & 3393 & 0,677 & 100 & 176,87 & 2865 & 0,844 & 0,731 & 1.080 & 324500 & 0,911 \\
\hline Holanda & 1996 & 6969 & 0,684 & 98,19 & 180,64 & 4337 & 0,622 & 0,718 & 1.050 & 198597 & 0,83 \\
\hline Holanda & 1997 & 5573 & 0,706 & 93,6 & 178,13 & 2987 & 0,536 & 0,727 & 1.030 & 266699 & 0,946 \\
\hline Holanda & 1998 & 3639 & 0,802 & 94,44 & 187,75 & 964 & 0,265 & 0,707 & 0,882 & 243373 & 0,884 \\
\hline Holanda & 1999 & 5434 & 0,809 & 93,68 & 187,53 & 1277 & 0,235 & 0,709 & 0,876 & 80695 & 0,852 \\
\hline
\end{tabular}

Fonte: European Commission (1998, 2000); IMF (2000)

Nota: $\ln \left(M_{i j} / M_{i}\right)=$ Logaritmo da participação das importações originadas do país $j$ nas importações totais do país $i$; $\ln \left(P_{i j} / P_{i}\right)=$ Logaritmo da relação entre o preço de importação do país $j$ no preço geral da importação do país $i$. ${ }^{1}$ Calculado como a média aritmética simples entre os períodos anterior e posterior do volume e valor exportado. 


\section{APÊNDICE 5 - Dados utilizados para estimar as equações de demanda pelas exportações de açúcar refinado originados}

\section{da União Européia.}

Tabela 55. Variáveis utilizadas para estimar a equação de demanda pela importação de açúcar refinado originado da União

Européia.

\begin{tabular}{|c|c|c|c|c|c|c|c|c|c|}
\hline País importador & ano & $\begin{array}{c}\text { Volume } \\
\text { importado (ton) } \\
-M_{i}\end{array}$ & $\begin{array}{c}\text { Preço de } \\
\text { importação } \\
(\mathrm{US} \$ / \mathrm{kg})-P_{i} \\
\end{array}$ & $\begin{array}{l}\text { Índice da taxa } \\
\text { de câmbio } \\
\text { real }^{1}\end{array}$ & $\begin{array}{c}\text { Valor importação } \\
\text { total (bilhões } \\
\text { US\$) }\end{array}$ & $\begin{array}{c}\text { Volume } \\
\text { importado da } \\
\text { UE (ton) }-M_{i j}\end{array}$ & $M_{i j} / M_{i}$ & $\begin{array}{c}\text { Preço importado } \\
\text { da UE (US\$/kg) - } \\
P_{i j}\end{array}$ & $P_{i j} / P_{i}$ \\
\hline Argélia & 1989 & 286052 & 0,441 & 219,94 & 9,47 & 370471 & 1,2951 & 0,285 & 0,647 \\
\hline Argélia & 1990 & 292061 & 0,497 & 186,15 & 9,78 & 483389 & 1,6551 & 0,298 & 0,600 \\
\hline Argélia & 1991 & 378636 & 0,404 & 110,94 & 7,77 & 721008 & 1,9042 & 0,288 & 0,713 \\
\hline Argélia & 1992 & $335349^{2}$ & 0,445 & 113,25 & 8,55 & 315220 & 0,9400 & 0,257 & 0,578 \\
\hline Argélia & 1993 & $443817^{4}$ & 0,464 & 137,69 & 7,77 & 568724 & 1,2814 & 0,268 & 0,577 \\
\hline Argélia & 1994 & 415089 & 0,464 & 120,41 & 9,37 & 573167 & 1,3808 & 0,291 & 0,629 \\
\hline Argélia & 1995 & 472545 & 0,464 & 100 & 10,25 & 339839 & 0,7192 & 0,264 & 0,570 \\
\hline Argélia & 1996 & 404489 & 0,457 & 103,95 & 8,84 & 232152 & 0,5739 & 0,293 & 0,641 \\
\hline Argélia & 1997 & 514353 & 0,371 & 114,16 & 12,29 & 278494 & 0,5414 & 0,286 & 0,771 \\
\hline Argélia & 1998 & 708334 & 0,354 & 119,67 & 12,11 & 689776 & 0,9738 & 0,245 & 0,691 \\
\hline Argélia & 1999 & 774799 & 0,268 & 110,17 & 12,59 & 613677 & 0,7920 & 0,203 & 0,757 \\
\hline Arábia Saudita & 1989 & 355120 & 0,398 & 119,3 & 21,15 & 245281 & 0,6907 & 0,319 & 0,803 \\
\hline Arábia Saudita & 1990 & 441243 & 0,461 & 109,82 & 24,07 & 225959 & 0,5121 & 0,268 & 0,582 \\
\hline Arábia Saudita & 1991 & 433461 & 0,380 & 110,36 & 29,08 & 271696 & 0,6268 & 0,243 & 0,640 \\
\hline Arábia Saudita & 1992 & 479000 & 0,328 & 104,25 & 33,27 & 172355 & 0,3598 & 0,239 & 0,730 \\
\hline Arábia Saudita & 1993 & 450000 & 0,293 & 107,66 & 28,2 & 120866 & 0,2686 & 0,233 & 0,795 \\
\hline Arábia Saudita & 1994 & 520000 & 0,342 & 103,27 & 23,34 & 294127 & 0,5656 & 0,275 & 0,803 \\
\hline Arábia Saudita & 1995 & 474538 & 0,435 & 100,00 & 28,09 & 167624 & 0,3532 & 0,266 & 0,610 \\
\hline Arábia Saudita & 1996 & 672481 & 0,428 & 102,45 & 27,77 & 195298 & 0,2904 & 0,255 & 0,596 \\
\hline Arábia Saudita & 1997 & 385289 & 0,398 & 107,50 & 28,74 & 86486 & 0,2245 & 0,336 & 0,844 \\
\hline Arábia Saudita & 1998 & 243792 & 0,319 & 111,32 & 30,01 & 73797 & 0,3027 & 0,260 & 0,814 \\
\hline Arábia Saudita & 1999 & 300000 & 0,220 & 106,42 & 28,03 & 26311 & 0,0877 & 0,236 & 1,072 \\
\hline
\end{tabular}


Tabela 55. Variáveis utilizadas para estimar a equação de demanda pela importação de açúcar refinado originado da União Européia.

\begin{tabular}{|c|c|c|c|c|c|c|c|c|c|}
\hline País importador & ano & $\begin{array}{c}\text { Volume } \\
\text { importado (ton) } \\
-M_{i}\end{array}$ & $\begin{array}{c}\text { Preço de } \\
\text { importação } \\
(\mathrm{US} \$ / \mathrm{kg})-P_{i} \\
\end{array}$ & $\begin{array}{c}\text { Índice da taxa } \\
\text { de câmbio } \\
\text { real }^{1}\end{array}$ & $\begin{array}{c}\text { Valor importação } \\
\text { total (bilhões } \\
\text { US\$) }\end{array}$ & $\begin{array}{c}\text { Volume } \\
\text { importado da } \\
\text { UE (ton) }-M_{i j}\end{array}$ & $M_{i j} / M_{i}$ & $\begin{array}{c}\text { Preço importado } \\
\text { da UE (US } \$ / \mathrm{kg} \text { ) - } \\
P_{i j}\end{array}$ & $P_{i j} / P_{i}$ \\
\hline Costa do Marfim & 1989 & 12176 & 0,441 & 139,56 & 2,11 & 14031 & 1,1523 & 0,314 & 0,712 \\
\hline Costa do Marfim & 1990 & 2700 & 0,583 & 141,29 & 2,1 & 2300 & 0,8519 & 0,279 & 0,479 \\
\hline Costa do Marfim & 1991 & 19885 & 0,345 & 136,3 & 2,1 & 17701 & 0,8902 & 0,227 & 0,656 \\
\hline Costa do Marfim & 1992 & 11587 & 0,368 & 142,38 & 2,35 & 17202 & 1,4846 & 0,290 & 0,790 \\
\hline Costa do Marfim & 1993 & 23559 & 0,400 & 140,35 & 2,12 & 2522 & 0,1071 & 0,254 & 0,635 \\
\hline Costa do Marfim & 1994 & 15848 & 0,407 & 86,51 & 1,92 & 4035 & 0,2546 & 0,390 & 0,957 \\
\hline Costa do Marfim & 1995 & 41692 & 0,526 & 100 & 2,93 & 10526 & 0,2525 & 0,316 & 0,600 \\
\hline Costa do Marfim & 1996 & $17959^{6}$ & $0,297^{6}$ & 100,49 & 2,9 & 3957 & 0,2203 & 0,252 & 0,849 \\
\hline Costa do Marfim & 1997 & $28575^{6}$ & $0,298^{6}$ & 98,92 & 2,78 & 22568 & 0,7898 & 0,269 & 0,905 \\
\hline Costa do Marfim & 1998 & $51890^{6}$ & $0,274^{6}$ & 105,53 & 3,28 & 33333 & 0,6424 & 0,262 & 0,956 \\
\hline Costa do Marfim & 1999 & $77715^{6}$ & $0,202^{6}$ & 103,49 & 3,25 & 48686 & 0,6265 & 0,214 & 1,057 \\
\hline Egito & 1989 & 377133 & 0,381 & 155,93 & 18,77 & 304928 & 0,8085 & 0,277 & 0,727 \\
\hline Egito & 1990 & 530111 & 0,410 & 92,61 & 16,78 & 152837 & 0,2883 & 0,282 & 0,688 \\
\hline Egito & 1991 & 485000 & 0,342 & 66,27 & 8,05 & 189605 & 0,3909 & 0,248 & 0,725 \\
\hline Egito & 1992 & 337616 & 0,343 & 78,26 & 8,32 & 94746 & 0,2806 & 0,203 & 0,593 \\
\hline Egito & 1993 & 202411 & 0,300 & 86,95 & 8,21 & 33890 & 0,1674 & 0,203 & 0,677 \\
\hline Egito & 1994 & 53690 & 0,309 & 87,97 & 10,22 & 35596 & 0,6630 & 0,246 & 0,797 \\
\hline Egito & 1995 & 170051 & 0,418 & 100,00 & 11,76 & 95569 & 0,5620 & 0,324 & 0,774 \\
\hline Egito & 1996 & 120878 & 0,396 & 110,93 & 13,04 & 48947 & 0,4049 & 0,250 & 0,632 \\
\hline Egito & 1997 & 256182 & 0,358 & 123,68 & 13,21 & 110121 & 0,4299 & 0,274 & 0,766 \\
\hline Egito & 1998 & 691000 & 0,302 & 123,44 & 16,17 & 205336 & 0,2972 & 0,255 & 0,842 \\
\hline Egito & 1999 & 700000 & 0,300 & 129,97 & 16,02 & 130801 & 0,1869 & 0,200 & 0,666 \\
\hline Emirados Árabes & 1989 & 190361 & 0,403 & $106,78^{7}$ & 10,01 & 165856 & 0,8713 & 0,305 & 0,758 \\
\hline Emirados Árabes & 1990 & 254000 & 0,496 & $102,42^{7}$ & 11,2 & 251116 & 0,9886 & 0,296 & 0,598 \\
\hline Emirados Árabes & 1991 & 235320 & 0,372 & $103,52^{7}$ & 13,75 & 262518 & 1,1156 & 0,233 & 0,626 \\
\hline Emirados Árabes & 1992 & 311889 & 0,337 & $102,15^{7}$ & 17,41 & 254670 & 0,8165 & 0,215 & 0,638 \\
\hline
\end{tabular}


Tabela 55. Variáveis utilizadas para estimar a equação de demanda pela importação de açúcar refinado originado da União Européia.

\begin{tabular}{|c|c|c|c|c|c|c|c|c|c|}
\hline País importador & ano & $\begin{array}{c}\text { Volume } \\
\text { importado (ton) } \\
-M_{i}\end{array}$ & $\begin{array}{c}\text { Preço de } \\
\text { importação } \\
\text { (US\$ } / \mathrm{kg})-P_{i}\end{array}$ & $\begin{array}{c}\text { Índice da taxa } \\
\text { de câmbio } \\
\text { real }^{1}\end{array}$ & $\begin{array}{c}\text { Valor importação } \\
\text { total (bilhões } \\
\text { US\$) }\end{array}$ & $\begin{array}{c}\text { Volume } \\
\text { importado da } \\
\text { UE (ton) }-M_{i j}\end{array}$ & $M_{i j} / M_{i}$ & $\begin{array}{c}\text { Preço importado } \\
\text { da UE (US\$/kg) - } \\
P_{i j}\end{array}$ & $P_{i j} / P_{i}$ \\
\hline Emirados Árabes & 1993 & 248445 & 0,342 & $107,18^{7}$ & 19,52 & 219811 & 0,8847 & 0,212 & 0,620 \\
\hline Emirados Árabes & 1994 & 308548 & 0,377 & $105,33^{7}$ & 21,02 & 333635 & 1,0813 & 0,264 & 0,700 \\
\hline Emirados Árabes & 1995 & 249464 & 0,423 & $100^{7}$ & 20,98 & 195331 & 0,7830 & 0,261 & 0,616 \\
\hline Emirados Árabes & 1996 & 213500 & 0,389 & $103,89^{7}$ & 22,64 & 135398 & 0,6342 & 0,252 & 0,648 \\
\hline Emirados Árabes & 1997 & 235000 & 0,309 & $112,32^{7}$ & 29,95 & 190393 & 0,8102 & 0,277 & 0,897 \\
\hline Emirados Árabes & 1998 & 165000 & 0,258 & $121,15^{7}$ & 24,73 & 138509 & 0,8394 & 0,249 & 0,966 \\
\hline Emirados Árabes & 1999 & 286000 & 0,182 & $119,01^{7}$ & $24,73^{5}$ & 262605 & 0,9182 & 0,204 & 1,121 \\
\hline Gambia & 1989 & 44500 & 0,283 & 109,70 & 0,16 & 41236 & 0,9267 & 0,307 & 1,085 \\
\hline Gambia & 1990 & 32000 & 0,436 & 104,75 & 0,19 & 37776 & 1,1805 & 0,285 & 0,652 \\
\hline Gambia & 1991 & 44682 & 0,406 & 100,21 & 0,2 & 67296 & 1,5061 & 0,210 & 0,517 \\
\hline Gambia & 1992 & 51250 & 0,371 & 102,45 & 0,22 & 51413 & 1,0032 & 0,237 & 0,640 \\
\hline Gambia & 1993 & 65320 & 0,367 & 110,94 & 0,26 & 58836 & 0,9007 & 0,281 & 0,764 \\
\hline Gambia & 1994 & 31000 & 0,387 & 103,11 & 0,21 & 27879 & 0,8993 & 0,293 & 0,758 \\
\hline Gambia & 1995 & 41848 & 0,387 & 100,00 & 0,18 & 22244 & 0,5315 & 0,273 & 0,704 \\
\hline Gambia & 1996 & 30874 & 0,389 & 99,06 & 0,26 & 5808 & 0,1881 & 0,264 & 0,678 \\
\hline Gambia & 1997 & 51651 & 0,387 & 103,56 & 0,17 & 14039 & 0,2718 & 0,274 & 0,707 \\
\hline Gambia & 1998 & 54678 & 0,390 & 101,98 & 0,24 & 13377 & 0,2447 & 0,305 & 0,781 \\
\hline Gambia & 1999 & 83831 & 0,198 & 99,60 & 0,19 & 5307 & 0,0633 & 0,233 & 1,176 \\
\hline Gana & 1989 & 67000 & 0,319 & 136,75 & 1,28 & 43283 & 0,6460 & 0,324 & 1,014 \\
\hline Gana & 1990 & 79000 & 0,494 & 136,14 & $1,17^{3}$ & 56935 & 0,7207 & 0,301 & 0,610 \\
\hline Gana & 1991 & 86000 & 0,453 & 139,21 & 1,06 & 54690 & 0,6359 & 0,265 & 0,583 \\
\hline Gana & 1992 & 120000 & 0,400 & 123 & 2,17 & 59258 & 0,4938 & 0,238 & 0,594 \\
\hline Gana & 1993 & 119000 & 0,330 & 108,03 & 3,94 & 49470 & 0,4157 & 0,228 & 0,693 \\
\hline Gana & 1994 & 79000 & 0,472 & 86,86 & 2,11 & 57285 & 0,7251 & 0,265 & 0,560 \\
\hline Gana & 1995 & 120000 & 0,467 & 100 & 1,91 & 37694 & 0,3141 & 0,261 & 0,559 \\
\hline Gana & 1996 & $24214^{6}$ & $0,394^{6}$ & 109,02 & 2,11 & 22863 & 0,9442 & 0,288 & 0,732 \\
\hline
\end{tabular}


Tabela 55. Variáveis utilizadas para estimar a equação de demanda pela importação de açúcar refinado originado da União Européia.

\begin{tabular}{|c|c|c|c|c|c|c|c|c|c|}
\hline País importador & ano & $\begin{array}{c}\text { Volume } \\
\text { importado (ton) } \\
-M_{i}\end{array}$ & $\begin{array}{c}\text { Preço de } \\
\text { importação } \\
(\mathrm{US} \$ / \mathrm{kg})-P_{i}\end{array}$ & $\begin{array}{l}\text { Índice da taxa } \\
\text { de câmbio } \\
\text { real }^{1}\end{array}$ & $\begin{array}{c}\text { Valor importação } \\
\text { total (bilhões } \\
\text { US\$) }\end{array}$ & $\begin{array}{c}\text { Volume } \\
\text { importado da } \\
\text { UE (ton) }-M_{i j}\end{array}$ & $M_{i j} / M_{i}$ & $\begin{array}{c}\text { Preço importado } \\
\text { da UE (US\$/kg) - } \\
P_{i j}\end{array}$ & $P_{i j} / P_{i}$ \\
\hline Gana & 1997 & $109220^{6}$ & $0,321^{6}$ & 115,62 & 2,33 & 10322 & 0,0945 & 0,361 & 1,126 \\
\hline Gana & 1998 & $245408^{6}$ & $0,265^{6}$ & 125,08 & 2,56 & 16216 & 0,0661 & 0,293 & 1,107 \\
\hline Gana & 1999 & $146358^{6}$ & $0,186^{6}$ & 125,68 & 3,5 & 20268 & 0,1385 & 0,243 & 1,311 \\
\hline India & 1989 & 134321 & 0,434 & 130,29 & 20,55 & 11244 & 0,0837 & 0,358 & 0,826 \\
\hline India & 1990 & 12000 & 0,434 & 123,66 & 23,58 & 385 & 0,0321 & 0,391 & 0,902 \\
\hline India & 1991 & $73161^{2}$ & $0,434^{2}$ & 97,97 & 20,45 & 2357 & 0,0322 & 0,221 & 0,510 \\
\hline India & 1992 & $834889^{4}$ & $0,411^{4}$ & 112,32 & 23,58 & 648 & 0,0008 & 0,279 & 0,679 \\
\hline India & 1993 & 284 & 0,412 & 99,87 & 22,79 & 591 & 2,0810 & 0,263 & 0,638 \\
\hline India & 1994 & 1669494 & 0,411 & 103,55 & 26,84 & 159343 & 0,0954 & 0,273 & 0,664 \\
\hline India & 1995 & 150632 & 0,444 & 100,00 & 34,71 & 611 & 0,0041 & 0,287 & 0,646 \\
\hline India & 1996 & 1123 & 0,428 & 110,29 & 37,94 & 861 & 0,7667 & 0,281 & 0,656 \\
\hline India & 1997 & 128414 & 0,364 & 115,23 & 41,43 & 41107 & 0,3201 & 0,278 & 0,766 \\
\hline India & 1998 & 547229 & 0,294 & 115,61 & 42,98 & 59477 & 0,1087 & 0,260 & 0,886 \\
\hline India & 1999 & 699205 & 0,219 & 121,25 & 44,89 & 44596 & 0,0638 & 0,191 & 0,875 \\
\hline Indonesia & 1989 & 310086 & 0,347 & 87,94 & 16,36 & 3038 & 0,0098 & 0,306 & 0,882 \\
\hline Indonesia & 1990 & 258958 & 0,428 & 82,77 & 21,84 & 3809 & 0,0147 & 0,286 & 0,668 \\
\hline Indonesia & 1991 & 235304 & 0,357 & 85,96 & 25,87 & 15075 & 0,0641 & 0,219 & 0,612 \\
\hline Indonesia & 1992 & 294237 & 0,336 & 92,90 & 27,28 & 19806 & 0,0673 & 0,196 & 0,584 \\
\hline Indonesia & 1993 & 146102 & 0,304 & 99,69 & 28,33 & 28571 & 0,1956 & 0,218 & 0,718 \\
\hline Indonesia & 1994 & 15259 & 0,386 & 97,62 & 31,98 & 15599 & 1,0223 & 0,258 & 0,668 \\
\hline Indonesia & 1995 & 220720 & 0,453 & 100,00 & 40,63 & 37971 & 0,1720 & 0,272 & 0,602 \\
\hline Indonesia & 1996 & 414484 & 0,423 & 108,10 & 42,93 & 25406 & 0,0613 & 0,262 & 0,619 \\
\hline Indonesia & 1997 & 599152 & 0,325 & 63,02 & 41,69 & 58285 & 0,0973 & 0,291 & 0,894 \\
\hline Indonesia & 1998 & 856991 & 0,367 & 55,16 & 27,34 & 40143 & 0,0468 & 0,215 & 0,586 \\
\hline Indonésia & 1999 & 1573105 & 0,249 & 77,25 & 24 & 113132 & 0,0719 & 0,226 & 0,910 \\
\hline Irã & 1990 & 810000 & 0,498 & 166,38 & 20,32 & 378727 & 0,4676 & 0,275 & 0,552 \\
\hline
\end{tabular}


Tabela 55. Variáveis utilizadas para estimar a equação de demanda pela importação de açúcar refinado originado da União Européia.

\begin{tabular}{|c|c|c|c|c|c|c|c|c|c|}
\hline País importador & ano & $\begin{array}{c}\text { Volume } \\
\text { importado (ton) } \\
-M_{i}\end{array}$ & $\begin{array}{c}\text { Preço de } \\
\text { importação } \\
\text { (US\$ } / \mathrm{kg})-P_{i}\end{array}$ & $\begin{array}{c}\text { Índice da taxa } \\
\text { de câmbio } \\
\text { real }^{1}\end{array}$ & $\begin{array}{c}\text { Valor importação } \\
\text { total (bilhões } \\
\text { US\$) }\end{array}$ & $\begin{array}{c}\text { Volume } \\
\text { importado da } \\
\text { UE (ton) }-M_{i j}\end{array}$ & $M_{i j} / M_{i}$ & $\begin{array}{c}\text { Preço importado } \\
\text { da UE (US } \$ / \mathrm{kg} \text { ) - } \\
P_{i j}\end{array}$ & $P_{i j} / P_{i}$ \\
\hline Irã & 1989 & 477840 & 0,461 & 245,52 & 14,79 & 236112 & 0,4941 & 0,257 & 0,557 \\
\hline Irã & 1991 & 880376 & 0,421 & 150,11 & 27,93 & 415317 & 0,4717 & 0,260 & 0,617 \\
\hline Irã & 1992 & 715656 & 0,381 & 152 & 25,86 & 182186 & 0,2546 & 0,246 & 0,646 \\
\hline Irã & 1993 & 415806 & 0,380 & 111,2 & 21,43 & 83033 & 0,1997 & 0,227 & 0,597 \\
\hline Irã & 1994 & 560671 & 0,442 & 74,38 & 13,77 & 233950 & 0,4173 & 0,277 & 0,628 \\
\hline Irã & 1995 & 972000 & 0,492 & 100 & 13,88 & 627825 & 0,6459 & 0,274 & 0,558 \\
\hline Irã & 1996 & 644000 & 0,483 & 135,35 & 16,27 & 351201 & 0,5453 & 0,260 & 0,539 \\
\hline Irã & 1997 & 803000 & 0,400 & 170,84 & 14,17 & 609042 & 0,7585 & 0,290 & 0,724 \\
\hline Irã & 1998 & 214895 & 0,419 & 206,04 & 24,26 & 210114 & 0,9777 & 0,269 & 0,642 \\
\hline Irã & 1999 & 499075 & 0,196 & 250,08 & $25,21^{5}$ & 101335 & 0,2030 & 0,194 & 0,988 \\
\hline Israel & 1989 & 327000 & 0,385 & 102,45 & 14,35 & 218010 & 0,6667 & 0,284 & 0,737 \\
\hline Israel & 1990 & 305400 & 0,425 & 100,07 & 16,79 & 212842 & 0,6969 & 0,275 & 0,648 \\
\hline Israel & 1991 & 340442 & 0,326 & 101,93 & 18,66 & 201099 & 0,5907 & 0,215 & 0,660 \\
\hline Israel & 1992 & 366302 & 0,299 & 99,35 & 15,54 & 262607 & 0,7169 & 0,211 & 0,705 \\
\hline Israel & 1993 & 420377 & 0,278 & 98,14 & 22,62 & 327104 & 0,7781 & 0,217 & 0,781 \\
\hline Israel & 1994 & 366000 & 0,347 & 99,2 & 25,24 & 315935 & 0,8632 & 0,273 & 0,786 \\
\hline Israel & 1995 & 340000 & 0,478 & 100 & 29,58 & 321596 & 0,9459 & 0,306 & 0,640 \\
\hline Israel & 1996 & 408476 & 0,399 & 105,87 & 31,62 & 345264 & 0,8452 & 0,322 & 0,808 \\
\hline Israel & 1997 & 429000 & 0,363 & 113,27 & 30,78 & 428944 & 0,9999 & 0,357 & 0,981 \\
\hline Israel & 1998 & 434000 & 0,330 & 109,93 & 29,34 & 383262 & 0,8831 & 0,340 & 1,030 \\
\hline Israel & 1999 & 438546 & 0,275 & 105,71 & 33,16 & 413579 & 0,9431 & 0,219 & 0,795 \\
\hline Jordânia & 1989 & 86929 & 0,243 & 86,35 & 2,13 & 224323 & 2,5805 & 0,272 & 1,116 \\
\hline Jordânia & 1990 & 187416 & 0,434 & 89,77 & 2,6 & 292352 & 1,5599 & 0,297 & 0,685 \\
\hline Jordânia & 1991 & 174327 & 0,387 & 95,08 & 2,51 & 46012 & 0,2639 & 0,220 & 0,568 \\
\hline Jordânia & 1992 & 135422 & 0,313 & 100,97 & 3,25 & 59187 & 0,4371 & 0,179 & 0,571 \\
\hline Jordânia & 1993 & 156660 & 0,305 & 102,16 & 3,54 & 14225 & 0,0908 & 0,228 & 0,748 \\
\hline
\end{tabular}


Tabela 55. Variáveis utilizadas para estimar a equação de demanda pela importação de açúcar refinado originado da União

Européia.

\begin{tabular}{|c|c|c|c|c|c|c|c|c|c|}
\hline País importador & ano & $\begin{array}{c}\text { Volume } \\
\text { importado (ton) } \\
-M_{i}\end{array}$ & $\begin{array}{c}\text { Preço de } \\
\text { importação } \\
\text { (US\$ } / \mathrm{kg})-P_{i} \\
\end{array}$ & $\begin{array}{c}\text { Índice da taxa } \\
\text { de câmbio } \\
\text { real }^{1}\end{array}$ & $\begin{array}{c}\text { Valor importação } \\
\text { total (bilhões } \\
\text { US\$) }\end{array}$ & $\begin{array}{c}\text { Volume } \\
\text { importado da } \\
\text { UE (ton) }-M_{i j}\end{array}$ & $M_{i j} / M_{i}$ & $\begin{array}{c}\text { Preço importado } \\
\text { da UE (US\$/kg) - } \\
P_{i j}\end{array}$ & $P_{i j} / P_{i}$ \\
\hline Jordânia & 1994 & 212050 & 0,379 & 100,57 & 3,38 & 171762 & 0,8100 & 0,281 & 0,742 \\
\hline Jordânia & 1995 & 94581 & 0,448 & 100,00 & 3,7 & 96307 & 1,0182 & 0,256 & 0,571 \\
\hline Jordânia & 1996 & 100808 & 0,417 & 109,63 & 4,29 & 23309 & 0,2312 & 0,245 & 0,587 \\
\hline Jordânia & 1997 & 159727 & 0,363 & 120,03 & 4,1 & 49439 & 0,3095 & 0,276 & 0,761 \\
\hline Jordânia & 1998 & 164506 & 0,308 & 120,33 & 3,83 & 88959 & 0,5408 & 0,242 & 0,788 \\
\hline Jordânia & 1999 & 174309 & 0,248 & 124,79 & 3,72 & 82304 & 0,4722 & 0,199 & 0,800 \\
\hline Nigéria & 1989 & 279429 & 0,231 & 88,61 & 4,19 & 199687 & 0,7146 & 0,294 & 1,269 \\
\hline Nigéria & 1990 & 285023 & 0,360 & 82,25 & 5,63 & 237631 & 0,8337 & 0,282 & 0,784 \\
\hline Nigéria & 1991 & 449780 & 0,239 & 69,96 & 8,99 & 141569 & 0,3148 & 0,257 & 1,075 \\
\hline Nigéria & 1992 & 477133 & 0,276 & 58,03 & 8,28 & 139707 & 0,2928 & 0,213 & 0,771 \\
\hline Nigéria & 1993 & 529708 & 0,303 & 63,57 & 5,54 & 50165 & 0,0947 & 0,272 & 0,898 \\
\hline Nigéria & 1994 & 406000 & 0,350 & 118,02 & 7,44 & 27792 & 0,0685 & 0,303 & 0,868 \\
\hline Nigéria & 1995 & 719355 & 0,310 & 100 & 7,91 & 9304 & 0,0129 & 0,421 & 1,357 \\
\hline Nigéria & 1996 & 468000 & 0,395 & 123,7 & 6,93 & 13636 & 0,0291 & 0,446 & 1,128 \\
\hline Nigéria & 1997 & 635768 & 0,310 & 141,97 & 10,33 & 68611 & 0,1079 & 0,323 & 1,042 \\
\hline Nigéria & 1998 & 896000 & 0,253 & 155,69 & 10 & 70682 & 0,0789 & 0,292 & 1,152 \\
\hline Nigéria & 1999 & 771782 & 0,179 & 78,92 & $10^{5}$ & 30536 & 0,0396 & 0,355 & 1,981 \\
\hline Serra Leoa & 1989 & 10000 & 0,380 & 126,17 & 0,18 & 9383 & 0,9383 & 0,378 & 0,995 \\
\hline Serra Leoa & 1990 & 12000 & 0,500 & 94,05 & 0,15 & 12270 & 1,0225 & 0,303 & 0,606 \\
\hline Serra Leoa & 1991 & 13000 & 0,377 & 95,26 & 0,16 & 12553 & 0,9656 & 0,244 & 0,647 \\
\hline Serra Leoa & 1992 & 17000 & 0,341 & 86,84 & 0,15 & 16733 & 0,9843 & 0,204 & 0,597 \\
\hline Serra Leoa & 1993 & 16600 & 0,319 & 96,73 & 0,15 & 13934 & 0,8394 & 0,223 & 0,698 \\
\hline Serra Leoa & 1994 & 7000 & 0,557 & 110,65 & 0,15 & 6699 & 0,9570 & 0,420 & 0,753 \\
\hline Serra Leoa & 1995 & 13300 & 0,496 & 100,00 & 0,13 & 13416 & 1,0087 & 0,298 & 0,600 \\
\hline Serra Leoa & 1996 & 8000 & 0,475 & 101,03 & 0,21 & 8204 & 1,0255 & 0,295 & 0,620 \\
\hline Serra Leoa & 1997 & 6000 & 0,400 & 115,97 & 0,09 & 5808 & 0,9680 & 0,314 & 0,784 \\
\hline
\end{tabular}


Tabela 55. Variáveis utilizadas para estimar a equação de demanda pela importação de açúcar refinado originado da União Européia.

\begin{tabular}{|c|c|c|c|c|c|c|c|c|c|}
\hline País importador & ano & $\begin{array}{c}\text { Volume } \\
\text { importado (ton) } \\
-M_{i}\end{array}$ & $\begin{array}{c}\text { Preço de } \\
\text { importação } \\
\text { (US\$ } / \mathrm{kg})-P_{i}\end{array}$ & $\begin{array}{c}\text { Índice da taxa } \\
\text { de câmbio } \\
\text { real }^{1}\end{array}$ & $\begin{array}{c}\text { Valor importação } \\
\text { total (bilhões } \\
\text { US\$) }\end{array}$ & $\begin{array}{c}\text { Volume } \\
\text { importado da } \\
\text { UE (ton) }-M_{i j}\end{array}$ & $M_{i j} / M_{i}$ & $\begin{array}{c}\text { Preço importado } \\
\text { da UE (US\$/kg) - } \\
P_{i j}\end{array}$ & $P_{i j} / P_{i}$ \\
\hline Serra Leoa & 1998 & 16000 & 0,306 & 99,56 & 0,09 & 15999 & 0,9999 & 0,240 & 0,784 \\
\hline Serra Leoa & 1999 & 8700 & 0,299 & 117,13 & 0,08 & 5745 & 0,6603 & 0,217 & 0,727 \\
\hline Siria & 1989 & 206566 & 0,366 & 55,55 & 2,1 & 198536 & 0,9611 & 0,296 & 0,808 \\
\hline Siria & 1990 & 254661 & 0,416 & 61,25 & 2,4 & 160080 & 0,6286 & 0,291 & 0,698 \\
\hline Siria & 1991 & 275902 & 0,341 & 66,40 & 2,77 & 189772 & 0,6878 & 0,246 & 0,723 \\
\hline Siria & 1992 & 228844 & 0,328 & 76,71 & 3,49 & 219309 & 0,9583 & 0,225 & 0,685 \\
\hline Siria & 1993 & 270978 & 0,309 & 86,91 & 4,14 & 173567 & 0,6405 & 0,304 & 0,985 \\
\hline Siria & 1994 & 345336 & 0,337 & 94,31 & 5,47 & 264003 & 0,7645 & 0,307 & 0,910 \\
\hline Siria & 1995 & 248315 & 0,364 & 100,00 & 4,71 & 359275 & 1,4469 & 0,255 & 0,701 \\
\hline Siria & 1996 & 381247 & 0,372 & 111,94 & 5,38 & 295907 & 0,7762 & 0,282 & 0,759 \\
\hline Siria & 1997 & 362033 & 0,363 & 122,04 & 4,03 & 342645 & 0,9464 & 0,309 & 0,853 \\
\hline Siria & 1998 & 455094 & 0,318 & 116,32 & 3,89 & 582567 & 1,2801 & 0,247 & 0,777 \\
\hline Siria & 1999 & 558505 & 0,272 & 116,17 & 3,83 & 383584 & 0,6868 & 0,205 & 0,755 \\
\hline Sri Lanka & 1989 & 218980 & 0,355 & 77,15 & 2,22 & 16188 & 0,0739 & 0,249 & 0,700 \\
\hline Sri Lanka & 1990 & 47060 & 0,414 & 86,07 & 2,69 & 1903 & 0,0404 & 0,301 & 0,728 \\
\hline Sri Lanka & 1991 & 6258 & 0,371 & 90,75 & 3,06 & 990 & 0,1582 & 0,253 & 0,682 \\
\hline Sri Lanka & 1992 & 13630 & 0,304 & 97,34 & 3,5 & 1031 & 0,0756 & 0,200 & 0,658 \\
\hline Sri Lanka & 1993 & $9944^{2}$ & $0,325^{2}$ & 101,06 & 4 & 1440 & 0,1448 & 0,245 & 0,754 \\
\hline Sri Lanka & 1994 & $123707^{4}$ & $0,300^{4}$ & 102,26 & 4,77 & 16304 & 0,1318 & 0,230 & 0,766 \\
\hline Sri Lanka & 1995 & $139938^{4}$ & $0,287^{4}$ & 100,00 & 5,31 & 10628 & 0,0759 & 0,242 & 0,841 \\
\hline Sri Lanka & 1996 & $107475^{6}$ & $0,317^{6}$ & 114,23 & 5,44 & 984 & 0,0092 & 0,277 & 0,874 \\
\hline Sri Lanka & 1997 & $172401^{6}$ & $0,269^{6}$ & 123,43 & 5,85 & 7221 & 0,0419 & 0,284 & 1,054 \\
\hline Sri Lanka & 1998 & $334317^{6}$ & $0,232^{6}$ & 116,95 & 5,89 & 59551 & 0,1781 & 0,231 & 0,995 \\
\hline Sri Lanka & 1999 & $424051^{6}$ & $0,167^{6}$ & 118,06 & 5,89 & 50260 & 0,1185 & 0,198 & 1,184 \\
\hline Tunísia & 1989 & 110534 & 0,300 & 99,11 & 4,39 & 45579 & 0,4124 & 0,299 & 0,997 \\
\hline Tunísia & 1990 & 157728 & 0,408 & 96,39 & 5,51 & 90114 & 0,5713 & 0,293 & 0,719 \\
\hline
\end{tabular}


Tabela 55. Variáveis utilizadas para estimar a equação de demanda pela importação de açúcar refinado originado da União Européia.

\begin{tabular}{|c|c|c|c|c|c|c|c|c|c|}
\hline País importador & ano & $\begin{array}{c}\text { Volume } \\
\text { importado (ton) } \\
-M_{i}\end{array}$ & $\begin{array}{c}\text { Preço de } \\
\text { importação } \\
(\mathrm{US} \$ / \mathrm{kg})-P_{i}\end{array}$ & $\begin{array}{l}\text { Índice da taxa } \\
\text { de câmbio } \\
\text { real }^{1}\end{array}$ & $\begin{array}{c}\text { Valor importação } \\
\text { total (bilhões } \\
\text { US\$) }\end{array}$ & $\begin{array}{c}\text { Volume } \\
\text { importado da } \\
\text { UE (ton) }-M_{i j}\end{array}$ & $M_{i j} / M_{i}$ & $\begin{array}{c}\text { Preço importado } \\
\text { da UE (US\$/kg) - } \\
P_{i j}\end{array}$ & $P_{i j} / P_{i}$ \\
\hline Tunísia & 1991 & 102225 & 0,319 & 98,79 & 5,19 & 98724 & 0,9658 & 0,225 & 0,705 \\
\hline Tunísia & 1992 & 153099 & 0,300 & 100,86 & 6,43 & 69269 & 0,4524 & 0,277 & 0,923 \\
\hline Tunísia & 1993 & 153996 & 0,293 & 97,08 & 6,21 & 47151 & 0,3062 & 0,395 & 1,348 \\
\hline Tunísia & 1994 & 192803 & 0,329 & 97,82 & 6,58 & 138022 & 0,7159 & 0,246 & 0,747 \\
\hline Tunísia & 1995 & 125900 & 0,399 & 100,00 & 7,9 & 147468 & 1,1713 & 0,394 & 0,986 \\
\hline Tunísia & 1996 & 165213 & 0,386 & 100,64 & 7,7 & 112679 & 0,6820 & 0,392 & 1,016 \\
\hline Tunísia & 1997 & 154910 & 0,359 & 100,54 & 7,91 & 157483 & 1,0166 & 0,288 & 0,803 \\
\hline Tunísia & 1998 & 182512 & 0,329 & 100,45 & 8,34 & 214614 & 1,1759 & 0,248 & 0,753 \\
\hline Tunísia & 1999 & 167028 & 0,261 & 100,96 & 8,47 & 115529 & 0,6917 & 0,194 & 0,743 \\
\hline Turquia & 1989 & $476^{5}$ & $0,313^{5}$ & 100,03 & 15,79 & 2 & 0,0042 & 0,509 & 1,625 \\
\hline Turquia & 1990 & 647310 & 0,458 & 116,99 & 22,3 & 538199 & 0,8314 & 0,304 & 0,663 \\
\hline Turquia & 1991 & 11800 & 0,396 & 111,29 & 21,05 & 78734 & 6,6724 & 0,231 & 0,583 \\
\hline Turquia & 1992 & 11462 & 0,346 & 116,86 & 22,87 & 10816 & 0,9436 & 0,221 & 0,638 \\
\hline Turquia & 1993 & 17037 & 0,330 & 114,95 & 29,43 & 14583 & 0,8560 & 0,246 & 0,744 \\
\hline Turquia & 1994 & 11594 & 0,540 & 83,38 & 23,27 & 22272 & 1,9210 & 0,325 & 0,602 \\
\hline Turquia & 1995 & 402160 & 0,470 & 100,00 & 35,71 & 437769 & 1,0885 & 0,266 & 0,567 \\
\hline Turquia & 1996 & $435653^{6}$ & $0,373^{6}$ & 103,19 & 43,63 & 375304 & 0,8615 & 0,272 & 0,729 \\
\hline Turquia & 1997 & $141797^{6}$ & $0,325^{6}$ & 107,06 & 48,56 & 83073 & 0,5859 & 0,279 & 0,859 \\
\hline Turquia & 1998 & $54750^{6}$ & $0,273^{6}$ & 123,86 & 45,92 & 30470 & 0,5565 & 0,201 & 0,737 \\
\hline Turquia & 1999 & $6214^{6}$ & $0,257^{6}$ & 121,68 & 40,69 & 6901 & 1,1105 & 0,249 & 0,969 \\
\hline Iêmen & 1989 & 238063 & 0,284 & $95,35^{4}$ & $2,16^{4}$ & 144835 & 0,6084 & 0,279 & 0,981 \\
\hline Iêmen & 1990 & 226551 & 0,403 & 81,04 & $2,31^{4}$ & 113089 & 0,4992 & 0,259 & 0,641 \\
\hline Iêmen & 1991 & 214995 & 0,367 & 109,67 & 2,02 & 45082 & 0,2097 & 0,240 & 0,654 \\
\hline Iêmen & 1992 & 333073 & 0,383 & 147,63 & 2,59 & 639 & 0,0019 & 0,218 & 0,570 \\
\hline Iêmen & 1993 & 302821 & 0,408 & 198,12 & 2,82 & 28571 & 0,0943 & 0,113 & 0,278 \\
\hline Iêmen & 1994 & 169244 & 0,530 & 271,81 & 2,09 & 141792 & 0,8378 & 0,343 & 0,647 \\
\hline
\end{tabular}


Tabela 55. Variáveis utilizadas para estimar a equação de demanda pela importação de açúcar refinado originado da União Européia.

\begin{tabular}{|c|c|c|c|c|c|c|c|c|c|}
\hline País importador & ano & $\begin{array}{c}\text { Volume } \\
\text { importado (ton) } \\
-M_{i}\end{array}$ & $\begin{array}{c}\text { Preço de } \\
\text { importação } \\
(\mathrm{US} \$ / \mathrm{kg})-P_{i}\end{array}$ & $\begin{array}{c}\text { Índice da taxa } \\
\text { de câmbio } \\
\text { real }^{1}\end{array}$ & $\begin{array}{c}\text { Valor importação } \\
\text { total (bilhões } \\
\text { US\$) }\end{array}$ & $\begin{array}{c}\text { Volume } \\
\text { importado da } \\
\text { UE (ton) }-M_{i j}\end{array}$ & $M_{i j} / M_{i}$ & $\begin{array}{c}\text { Preço importado } \\
\text { da UE (US } \$ / \mathrm{kg} \text { ) - } \\
P_{i j}\end{array}$ & $P_{i j} / P_{i}$ \\
\hline Iêmen & 1995 & 174645 & 0,515 & 100,00 & 1,58 & 33466 & 0,1916 & 0,266 & 0,517 \\
\hline Iêmen & 1997 & 374356 & 0,329 & 57,99 & 2,01 & 19861 & 0,0531 & 0,275 & 0,836 \\
\hline Iêmen & 1998 & 299814 & 0,288 & 55,234 & 2,17 & 77514 & 0,2585 & 0,256 & 0,889 \\
\hline Iêmen & 1999 & 404035 & 0,207 & $56,61^{2}$ & $2,09^{2}$ & 13002 & 0,0322 & 0,173 & 0,836 \\
\hline
\end{tabular}

Fonte: European Commission (1998, 2000); FAO (2003b); IMF (2000); United Nations (2003)

Nota: $\ln \left(M_{i j} / M_{i}\right)=$ Logaritmo da participação das importações originadas do país $j$ nas importações totais do país $i$; $\ln \left(P_{i j} / P_{i}\right)=$ Logaritmo da relação entre o preço de importação do país $j$ no preço geral da importação do país $i .{ }^{1} \mathrm{O}$ índice da taxa de câmbio foi utilizado, conforme disponibilidade das informações no IMF. Assim foram utilizados o índice da taxa de câmbio efetiva real para os países que dispunham destes valores, e para Egito, Jordânia, Turquia, Romênia e Síria, as taxas de câmbio (moeda doméstica/US\$) foram transformadas em índice e deflacionadas pelo índice de preço ao consumidor do país, dados também do IMF. ${ }^{2}$ Valores de renda estimados com a participação nas importações mundiais estimadas do período anterior. ${ }^{3}$ Calculado como a média aritmética simples entre os períodos anterior e posterior do volume e valor importado. ${ }^{4}$ Calculado como a média aritmética simples do volume e do valor importado dos dois anos posteriores. ${ }^{5 /}$ valor igual ao do período anterior. ${ }^{6}$ Os valores de volume e valor importados foram extraídos de Millenium, ao contrário dos demais, extraídos da FAO. ${ }^{7}$ Valor da taxa de câmbio efetiva nominal. 


\section{APÊNDICE 6 - Matriz insumo-produto inter-regional do Brasil.}

Tabela 56. Matriz insumo-produto inter-regional do Brasil, ano de 1999, valores correntes em R\$ 1.000,00.

\begin{tabular}{|c|c|c|c|c|c|c|c|c|c|c|c|c|}
\hline & & \multirow{3}{*}{ Setores } & \multicolumn{10}{|c|}{ Região Norte-Nordeste } \\
\hline & & & \multirow{2}{*}{$\begin{array}{r}\begin{array}{c}\text { Cana-de- } \\
\text { açúcar }\end{array} \\
1 \\
\end{array}$} & \multirow{2}{*}{\begin{tabular}{r}
\multicolumn{1}{c}{ Resto } \\
Agropecuária \\
2 \\
\end{tabular}} & \multirow{2}{*}{$\begin{array}{r}\text { Extrativa } \\
3 \\
\end{array}$} & \multirow{2}{*}{$\begin{array}{r}\text { Metalurgia } \\
\\
4 \\
\end{array}$} & \multirow{2}{*}{$\begin{array}{r}\text { Mecânica } \\
\\
5 \\
\end{array}$} & \multirow{2}{*}{$\begin{array}{r}\begin{array}{c}\text { Material } \\
\text { Elétrico e } \\
\text { Eletrônico }\end{array} \\
6 \\
\end{array}$} & \multirow{2}{*}{$\begin{array}{r}\begin{array}{c}\text { Material de } \\
\text { Transporte }\end{array} \\
7 \\
\end{array}$} & \multirow{2}{*}{$\begin{array}{c}\text { Madeira, } \\
\text { Mobiliário, } \\
\begin{array}{c}\text { Celulose, Papel e } \\
\text { Gráfica }\end{array} \\
\\
\end{array}$} & \multirow{2}{*}{$\begin{array}{r}\text { Álcool } \\
\\
9 \\
\end{array}$} & \multirow{2}{*}{$\begin{array}{c}\text { Outros Elementos } \\
\text { Químicos não } \\
\text { Petroquímicos } \\
10\end{array}$} \\
\hline & & & & & & & & & & & & \\
\hline \multirow{20}{*}{ 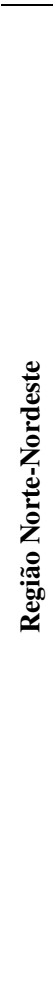 } & 1 & Cana-de-açúcar & 22353 & 19659 & 1 & 1 & 0 & 0 & 0 & 2 & 216737 & 8 \\
\hline & 2 & Resto Agropecuária & 27917 & 3474214 & 2280 & 106141 & 20 & 130 & 48 & 147523 & 8 & 5096 \\
\hline & 3 & Extrativa & 1517 & 39314 & 98285 & 95223 & 23 & 2294 & 55 & 2844 & 82 & 8562 \\
\hline & 4 & Metalurgia & 967 & 22612 & 70496 & 4205337 & 101384 & 151760 & 95629 & 25517 & 319 & 16226 \\
\hline & 5 & Mecânica & 791 & 10943 & 24606 & 63613 & 21574 & 12507 & 11217 & 10576 & 4400 & 6475 \\
\hline & 6 & $\begin{array}{l}\text { Material Elétrico e } \\
\text { Eletrônico }\end{array}$ & 58 & 944 & 2770 & 13358 & 11879 & 198186 & 10543 & 1967 & 473 & 896 \\
\hline & 7 & Material de Transporte & 15 & 806 & 1293 & 12043 & 6468 & 1686 & 180385 & 1470 & 101 & 258 \\
\hline & 8 & $\begin{array}{l}\text { Madeira, Mobiliário, } \\
\text { Celulose, Papel e Gráfica }\end{array}$ & 230 & 12660 & 11057 & 23003 & 4937 & 20851 & 10639 & 644471 & 605 & 915 \\
\hline & 9 & Álcool & 135 & 1460 & 131 & 549 & 38 & 100 & 67 & 380 & 4610 & 303 \\
\hline & 10 & $\begin{array}{l}\text { Outros Elementos Químicos } \\
\text { não Petroquímicos }\end{array}$ & 1053 & 12044 & 1311 & 80726 & 542 & 1103 & 399 & 22089 & 12437 & 48579 \\
\hline & 11 & Refino do Petróleo & 32345 & 409970 & 48758 & 107089 & 5031 & -967 & -2129 & 42934 & 4502 & 57713 \\
\hline & 12 & $\begin{array}{l}\text { Produtos do Refino do } \\
\text { Petróleo }\end{array}$ & 45992 & 621058 & 19550 & 55012 & 8885 & 28129 & 11611 & 67809 & 1030 & 6155 \\
\hline & 13 & Têxtil, Vestuário e Calçados & 22 & 29676 & 2022 & 4645 & 1448 & 1312 & 2235 & 9123 & 472 & 819 \\
\hline & 14 & Fabricação de Açúcar & 255 & 1481 & 340 & 2547 & 40 & 138 & 49 & 373 & 39334 & 257 \\
\hline & 15 & Outros Produtos Alimentares & 2321 & 697343 & 936 & 2108 & 234 & 338 & 277 & 4648 & 294 & 9913 \\
\hline & 16 & Indústrias Diversas & 418 & 5610 & 21695 & 54501 & 9664 & 19767 & 9361 & 14659 & 469 & 7434 \\
\hline & 17 & SIUP & 3376 & 117762 & 161461 & 384750 & 14362 & 22199 & 23806 & 104528 & 30016 & 66860 \\
\hline & 18 & Construção Civil & 36 & 789 & 29422 & 17205 & 2337 & 4244 & 3418 & 8428 & 1680 & 3581 \\
\hline & 19 & $\begin{array}{l}\text { Serviços Prestados às } \\
\text { Famílias }\end{array}$ & 96 & 19961 & 16316 & 15794 & 2791 & 5075 & 2550 & 9159 & 870 & 1867 \\
\hline & 20 & Outros Serviços & 133906 & 2019646 & 720380 & 966683 & 90777 & 320530 & 194912 & 626814 & 46859 & 92231 \\
\hline
\end{tabular}


Tabela 56. Matriz insumo-produto inter-regional do Brasil, ano de 1999, valores correntes em R $1.000,00$.

\begin{tabular}{|c|c|c|c|c|c|c|c|c|c|c|c|c|}
\hline & & \multirow{3}{*}{ Setores } & \multicolumn{10}{|c|}{ Região Norte-Nordeste } \\
\hline & & & \multirow[t]{2}{*}{$\begin{array}{r}\begin{array}{c}\text { Cana-de- } \\
\text { açúcar }\end{array} \\
1 \\
\end{array}$} & \multirow[t]{2}{*}{$\begin{array}{c}\text { Resto } \\
\text { Agropecuária } \\
2 \\
\end{array}$} & \multirow[t]{2}{*}{$\begin{array}{r}\text { Extrativa } \\
\\
3 \\
\end{array}$} & \multirow[t]{2}{*}{$\begin{array}{r}\text { Metalurgia } \\
\\
4 \\
\end{array}$} & \multirow[t]{2}{*}{$\begin{array}{r}\text { Mecânica } \\
\\
5 \\
\end{array}$} & \multirow[t]{2}{*}{$\begin{array}{l}\text { Material } \\
\text { Elétrico e } \\
\text { Eletrônico } \\
6 \\
\end{array}$} & \multirow[t]{2}{*}{$\begin{array}{r}\text { Material de } \\
\text { Transporte } \\
\\
7 \\
\end{array}$} & \multirow[t]{2}{*}{$\begin{array}{l}\text { Madeira, } \\
\text { Mobiliário, } \\
\text { Celulose, } \\
\text { Papel e } \\
\text { Gráfica } \\
8 \\
\end{array}$} & \multirow[t]{2}{*}{$\begin{array}{r}\text { Álcool } \\
\\
9 \\
\end{array}$} & \multirow[t]{2}{*}{$\begin{array}{l}\text { Outros Elementos } \\
\text { Químicos não } \\
\text { Petroquímicos } \\
10 \\
\end{array}$} \\
\hline & & & & & & & & & & & & \\
\hline \multirow{20}{*}{ 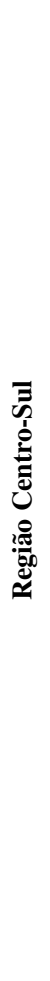 } & 21 & Cana-de-açúcar & 1101 & 24280 & 1 & 1 & 0 & 0 & 0 & 1 & 39289 & 10 \\
\hline & 22 & Resto Agropecuária & 16059 & 245692 & 787 & 62637 & 8 & 32 & 17 & 129018 & 7 & 5043 \\
\hline & 23 & Extrativa & 1796 & 30841 & 13397 & 208790 & 3 & 2586 & 13 & 1758 & 15 & 24079 \\
\hline & 24 & Metalurgia & 914 & 19394 & 88666 & 302440 & 50622 & 176565 & 282336 & 34629 & 561 & 6571 \\
\hline & 25 & Mecânica & 1835 & 35295 & 108894 & 166322 & 2694 & 63024 & 54288 & 26053 & 10729 & 27526 \\
\hline & 26 & $\begin{array}{l}\text { Material Elétrico e } \\
\text { Eletrônico }\end{array}$ & 78 & 1666 & 5162 & 17894 & 6949 & 19395 & 3484 & 1388 & 809 & 2149 \\
\hline & 27 & Material de Transporte & 52 & 2303 & 3456 & 8633 & 3935 & 3422 & 27103 & 1237 & 289 & 791 \\
\hline & 28 & $\begin{array}{l}\text { Madeira, Mobiliário, } \\
\text { Celulose, Papel e Gráfica }\end{array}$ & 400 & 19695 & 30480 & 63207 & 2444 & 27004 & 10395 & 60897 & 1216 & 3345 \\
\hline & 29 & Álcool & 145 & 1797 & 195 & 434 & 19 & 149 & 134 & 563 & 319 & 195 \\
\hline & 30 & $\begin{array}{l}\text { Outros Elementos Químicos } \\
\text { não Petroquímicos }\end{array}$ & 780 & 8497 & 2348 & 40687 & 417 & 4195 & 1559 & 11068 & 10568 & 3658 \\
\hline & 31 & Refino do Petróleo & 41794 & 486801 & 81335 & 55934 & 3070 & 22071 & 18403 & 43380 & 7852 & 19472 \\
\hline & 32 & $\begin{array}{l}\text { Produtos do Refino do } \\
\text { Petróleo }\end{array}$ & 26551 & 381897 & 17458 & 36727 & 1474 & 51259 & 18346 & 44793 & 1209 & 5198 \\
\hline & 33 & Têxtil, Vestuário e Calçados & 3 & 25658 & 2650 & 2861 & 441 & 1264 & 4501 & 14722 & 109 & 444 \\
\hline & 34 & Fabricação de Açúcar & 10 & 641 & 10 & 56 & 1 & 3 & 2 & 10 & 8487 & 9 \\
\hline & 35 & Outros Produtos Alimentares & 1579 & 333518 & 945 & 1435 & 117 & 310 & 281 & 1763 & 158 & 12621 \\
\hline & 36 & Indústrias Diversas & 308 & 12283 & 36500 & 122469 & 3381 & 27821 & 20973 & 18787 & 897 & 13803 \\
\hline & 37 & SIUP & 275 & 11123 & 12998 & 49258 & 1840 & 1775 & 2559 & 5628 & 2197 & 7651 \\
\hline & 38 & Construção Civil & 2 & 51 & 2433 & 1206 & 89 & 235 & 275 & 208 & 71 & 387 \\
\hline & 39 & $\begin{array}{l}\text { Serviços Prestados às } \\
\text { Famílias }\end{array}$ & 6 & 1687 & 1405 & 1109 & 42 & 338 & 259 & 509 & 38 & 203 \\
\hline & 40 & Outros Serviços & 35281 & 481911 & 94261 & 124973 & 4898 & 38351 & 28587 & 56838 & 3020 & 13925 \\
\hline
\end{tabular}


Tabela 56. Matriz insumo-produto inter-regional do Brasil, ano de 1999, valores correntes em R 1.000,00.

\begin{tabular}{|c|c|c|c|c|c|c|c|c|c|c|}
\hline \multirow{3}{*}{ Setores } & \multicolumn{10}{|c|}{ Região Norte-Nordeste } \\
\hline & \multirow{2}{*}{$\begin{array}{r}\begin{array}{c}\text { Cana-de- } \\
\text { açúcar }\end{array} \\
1 \\
\end{array}$} & \multirow{2}{*}{$\begin{array}{c}\text { Resto } \\
\text { Agropecuária } \\
2\end{array}$} & \multirow{2}{*}{$\begin{array}{r}\text { Extrativa } \\
\\
3\end{array}$} & \multirow{2}{*}{$\begin{array}{r}\text { Metalurgia } \\
\\
4\end{array}$} & \multirow{2}{*}{$\begin{array}{r}\text { Mecânica } \\
\\
5\end{array}$} & \multirow{2}{*}{$\begin{array}{r}\begin{array}{c}\text { Material } \\
\text { Elétrico e } \\
\text { Eletrônico }\end{array} \\
6\end{array}$} & \multirow{2}{*}{$\begin{array}{r}\begin{array}{c}\text { Material de } \\
\text { Transporte }\end{array} \\
7\end{array}$} & \multirow{2}{*}{$\begin{array}{c}\text { Madeira, } \\
\text { Mobiliário, } \\
\text { Celulose, Papel e } \\
\text { Gráfica } \\
8\end{array}$} & \multirow{2}{*}{$\begin{array}{r}\text { Álcool } \\
\\
\\
9\end{array}$} & \multirow{2}{*}{$\begin{array}{c}\text { Outros } \\
\text { Elementos } \\
\text { Químicos não } \\
\text { Petroquímicos } \\
10 \\
\end{array}$} \\
\hline & & & & & & & & & & \\
\hline Produção Nacional & 402774 & 9642980 & 1736490 & 7477403 & 364877 & 1229182 & 1028588 & 2198565 & 453141 & 481230 \\
\hline Importado & 29471 & 691003 & 179798 & 817778 & 78584 & 1058247 & 724568 & 218038 & 12395 & 83402 \\
\hline Imposta Importação & 821 & 17983 & 4305 & 25321 & 2578 & 32128 & 16678 & 6228 & 505 & 2829 \\
\hline ICM Nacional & 14483 & 364408 & 78528 & 257135 & 24434 & 121143 & 94538 & 133919 & 15287 & 21329 \\
\hline ICM Impotação & 219 & 6200 & 0 & 0 & 0 & 0 & 0 & 0 & 0 & 0 \\
\hline IPI Nacional & 863 & 19609 & 19087 & 57318 & 5796 & 28709 & 17539 & 24262 & 1942 & 2472 \\
\hline IPI Importação & 282 & 8013 & 847 & 189 & 40 & 206 & 429 & 144 & 3 & 25 \\
\hline $\begin{array}{l}\text { Outros Impostos Indiretos } \\
\text { Líquidos Nacionais }\end{array}$ & 371 & 8732 & 11725 & 9560 & 282 & 2220 & 991 & 1596 & 570 & 828 \\
\hline $\begin{array}{l}\text { Outros Impostos Indiretos } \\
\text { Líquidos Importação }\end{array}$ & 122 & 2836 & 403 & 5363 & 246 & 2998 & 2366 & 593 & 81 & 501 \\
\hline CONSUMO INTERMEDIÁRIO & 449406 & 10761763 & 2031183 & 8650068 & 476836 & 2474833 & 1885698 & 2583346 & 483924 & 592615 \\
\hline REMUNERAÇÕES & 175772 & 3056250 & 444393 & 458544 & 224416 & 371155 & 419737 & 794618 & 58552 & 146616 \\
\hline SALÁRIOS & 148398 & 2580284 & 229795 & 339234 & 164771 & 276164 & 310337 & 606579 & 43156 & 108336 \\
\hline CONTRIBUIÇÕES SOCIAIS & 27374 & 475965 & 214598 & 119310 & 59646 & 94991 & 109401 & 188039 & 15396 & 38280 \\
\hline PREVIDÊNCIA OFICIAL/ GTS & 27292 & 474534 & 76161 & 104585 & 58159 & 86505 & 104402 & 182266 & 14373 & 36304 \\
\hline PREVIDÊNCIA PRIVADA & 82 & 1431 & 138437 & 14725 & 1487 & 8486 & 4998 & 5773 & 1022 & 1975 \\
\hline $\begin{array}{l}\text { CONTRIBUIÇÕES SOCIAIS } \\
\text { FICTÍCIAS }\end{array}$ & 0 & 0 & 0 & 0 & 0 & 0 & 0 & 0 & 0 & 0 \\
\hline $\begin{array}{l}\text { EXCEDENTE OPERACIONAL } \\
\text { BRUTO (EOB) }\end{array}$ & 308531 & 11827566 & 1981728 & 1954124 & 577883 & 943602 & 294433 & 811884 & 342087 & 364580 \\
\hline $\begin{array}{l}\text { RENDIMENTO DE } \\
\text { AUTÔNOMOS }\end{array}$ & 1713 & 61010 & 23387 & 34139 & 0 & 0 & 0 & 107465 & 0 & 0 \\
\hline EOB EXCLUSIVE & & & & & & & & & & \\
\hline $\begin{array}{l}\text { RENDIMENTOS DE } \\
\text { AUTÔNOMOS }\end{array}$ & 306818 & 11766556 & 1958341 & 1919985 & 577883 & 943602 & 294433 & 704419 & 342087 & 364580 \\
\hline $\begin{array}{l}\text { VALOR ADICIONADO CUSTO } \\
\text { FATORES }\end{array}$ & 484303 & 14883816 & 2426121 & 2412667 & 802299 & 1314757 & 714170 & 1606503 & 400639 & 511196 \\
\hline $\begin{array}{l}\text { OUTROS IMPOSTOS SOBRE A } \\
\text { PRODUÇÃO }\end{array}$ & 22 & 597 & 218423 & 537150 & 66174 & 190301 & 132031 & 191513 & 43757 & 54603 \\
\hline $\begin{array}{l}\text { OUTROS SUBSIDIOS À } \\
\text { PRODUÇÃO }\end{array}$ & -7470 & -205179 & 0 & -14 & -6408 & -5186 & -38174 & 0 & 0 & 0 \\
\hline
\end{tabular}


Tabela 56. Matriz insumo-produto inter-regional do Brasil, ano de 1999, valores correntes em R 1.000,00.

\begin{tabular}{|c|c|c|c|c|c|c|c|c|c|c|}
\hline \multirow{3}{*}{ Setores } & \multicolumn{10}{|c|}{ Região Norte-Nordeste } \\
\hline & $\begin{array}{l}\text { Cana-de- } \\
\text { açúcar }\end{array}$ & $\begin{array}{c}\text { Resto } \\
\text { Agropecuária }\end{array}$ & Extrativa & Metalurgia & Mecânica & $\begin{array}{l}\text { Material } \\
\text { Elétrico e } \\
\text { Eletrônico }\end{array}$ & $\begin{array}{l}\text { Material de } \\
\text { Transporte }\end{array}$ & $\begin{array}{c}\text { Madeira, } \\
\text { Mobiliário, } \\
\text { Celulose, Papel e } \\
\text { Gráfica } \\
\end{array}$ & Álcool & $\begin{array}{c}\text { Outros } \\
\text { Elementos } \\
\text { Químicos não } \\
\text { Petroquímicos } \\
\end{array}$ \\
\hline & 1 & 2 & 3 & 4 & 5 & 6 & 7 & 8 & 9 & 10 \\
\hline $\begin{array}{l}\text { VALOR ADICIONADO PREÇO } \\
\text { BÁSICO }\end{array}$ & 476855 & 14679234 & 2644544 & 2949803 & 862064 & 1499872 & 808027 & 1798015 & 444396 & 565799 \\
\hline VALOR DA PRODUÇÃO & 926261 & 25440996 & 4675726 & 11599870 & 1338900 & 3974706 & 2693725 & 4381361 & 928320 & 1158414 \\
\hline Pessoal Ocupado & 200050 & 6979072 & 67518 & 121832 & 37496 & 30816 & 9700 & 283366 & 3116 & 4008 \\
\hline Norte-Nordeste & 273804 & 7517951 & 1233109 & 6210329 & 282434 & 789382 & 555071 & 1745317 & 365298 & 334149 \\
\hline Centro-Sul & 128970 & 2125029 & 503381 & 1267074 & 82443 & 439800 & 473517 & 453249 & 87843 & 147080 \\
\hline
\end{tabular}


Tabela 56. Matriz insumo-produto inter-regional do Brasil, ano de 1999, valores correntes em R 1.000,00.

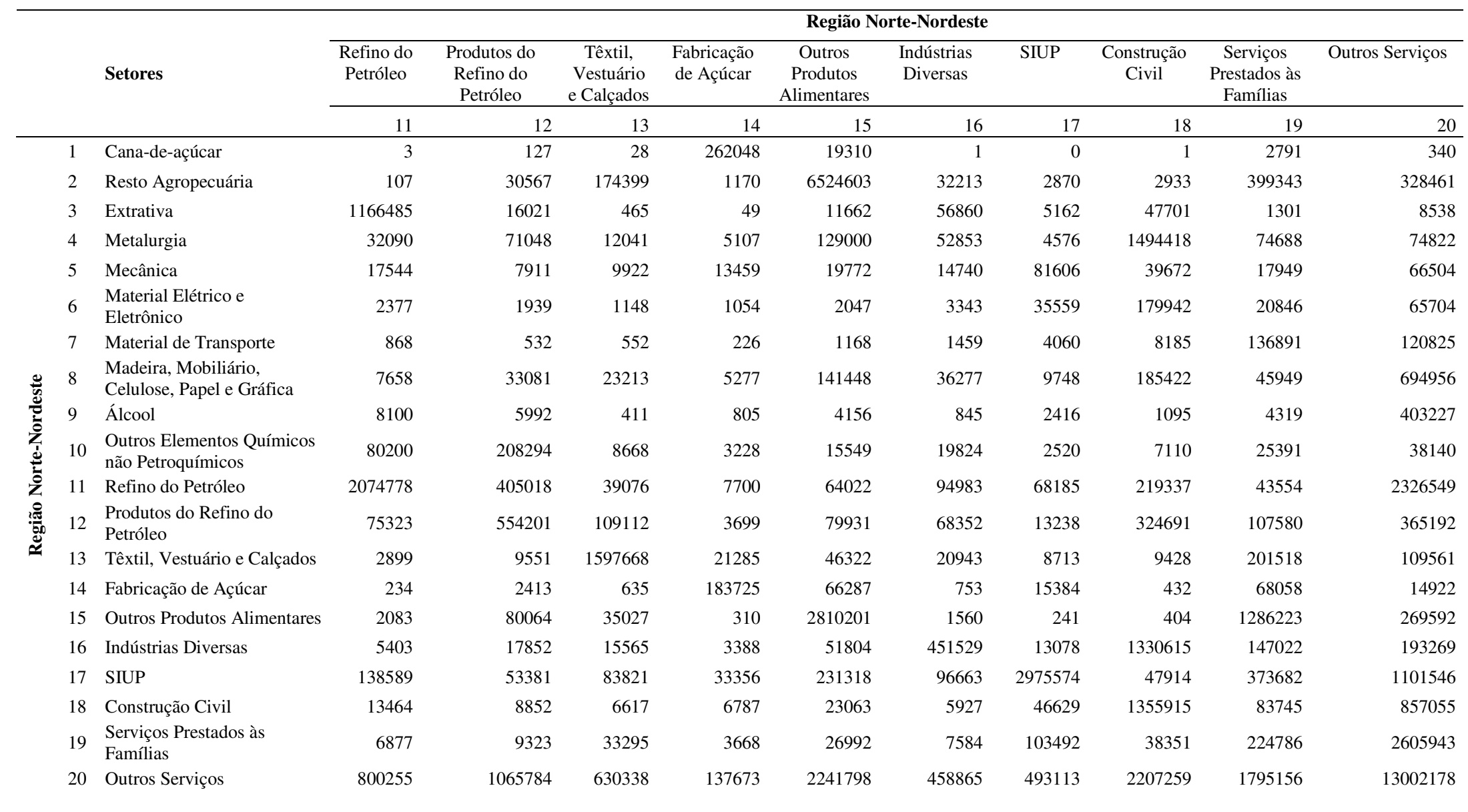


Tabela 56. Matriz insumo-produto inter-regional do Brasil, ano de 1999, valores correntes em R 1.000,00.

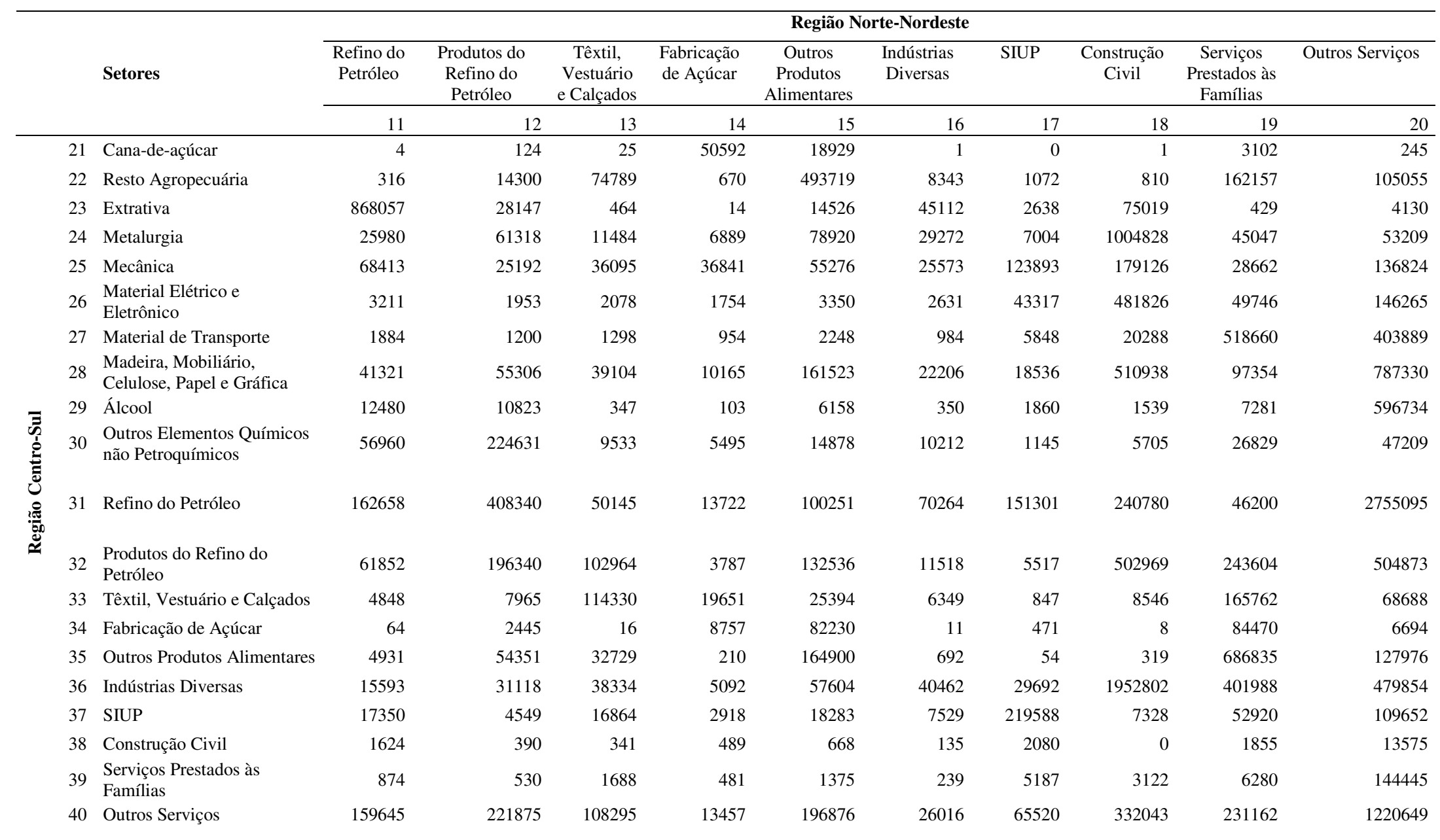


Tabela 56. Matriz insumo-produto inter-regional do Brasil, ano de 1999, valores correntes em R 1.000,00.

\begin{tabular}{|c|c|c|c|c|c|c|c|c|c|c|}
\hline \multirow{3}{*}{ Setores } & \multicolumn{10}{|c|}{ Região Norte-Nordeste } \\
\hline & $\begin{array}{c}\text { Refino do } \\
\text { Petróleo }\end{array}$ & $\begin{array}{c}\text { Produtos do } \\
\text { Refino do } \\
\text { Petróleo } \\
\end{array}$ & $\begin{array}{c}\text { Têxtil, } \\
\text { Vestuário } \\
\text { e Calçados }\end{array}$ & $\begin{array}{l}\text { Fabricação } \\
\text { de Açúcar }\end{array}$ & $\begin{array}{c}\text { Outros } \\
\text { Produtos } \\
\text { Alimentares } \\
\end{array}$ & $\begin{array}{l}\text { Indústrias } \\
\text { Diversas }\end{array}$ & SIUP & $\begin{array}{l}\text { Construção } \\
\text { Civil }\end{array}$ & $\begin{array}{l}\text { Serviços } \\
\text { Prestados às } \\
\text { Famílias } \\
\end{array}$ & Outros Serviços \\
\hline & 11 & 12 & 13 & 14 & 15 & 16 & 17 & 18 & 19 & 20 \\
\hline Produção Nacional & 5943404 & 3932848 & 3422922 & 876056 & 14140097 & 1733471 & 4571737 & 12828823 & 7921135 & 30359714 \\
\hline Importado & 1427534 & 1097767 & 373828 & 37564 & 459385 & 228613 & 336575 & 971913 & 958649 & 2563088 \\
\hline Imposta Importação & 44598 & 31931 & 18805 & 1979 & 10129 & 6754 & 7207 & 55856 & 34828 & 49809 \\
\hline ICM Nacional & 131351 & 124332 & 187710 & 39546 & 519084 & 144624 & 466562 & 1035540 & 753625 & 1269445 \\
\hline ICM Impotação & 0 & 0 & 0 & 0 & 0 & 0 & 1894 & 31081 & 27390 & 50752 \\
\hline IPI Nacional & 18162 & 25948 & 17811 & 4220 & 70069 & 22165 & 15400 & 221799 & 137806 & 255484 \\
\hline IPI Importação & 84 & 153 & 70 & 55 & 363 & 303 & 3118 & 38807 & 18140 & 42015 \\
\hline $\begin{array}{l}\text { Outros Impostos Indiretos } \\
\text { Líquidos Nacionais }\end{array}$ & 6308 & 3400 & 2686 & 522 & 9489 & 1876 & 6187 & 7195 & 6006 & 60508 \\
\hline $\begin{array}{l}\text { Outros Impostos Indiretos } \\
\text { Líquidos Importação }\end{array}$ & 8767 & 6614 & 1117 & 137 & 3075 & 826 & 166 & 3764 & 3455 & 5934 \\
\hline $\begin{array}{l}\text { CONSUMO } \\
\text { INTERMEDIÁRIO }\end{array}$ & 7580208 & 5222994 & 4024949 & 960079 & 15211691 & 2138631 & 5408846 & 15194778 & 9861034 & 34656748 \\
\hline REMUNERAÇÕES & 191210 & 920981 & 992448 & 126993 & 1857706 & 613261 & 2241289 & 2896976 & 6290896 & 48842108 \\
\hline SALÁRIOS & 88477 & 675011 & 752617 & 98190 & 1423392 & 453882 & 1579303 & 2294150 & 4790348 & 33861847 \\
\hline $\begin{array}{l}\text { CONTRIBUIÇÕES } \\
\text { SOCIAIS }\end{array}$ & 102732 & 245970 & 239831 & 28803 & 434314 & 159379 & 661986 & 602826 & 1500549 & 5988254 \\
\hline $\begin{array}{l}\text { PREVIDÊNCIA OFICIAL/ } \\
\text { GTS }\end{array}$ & 29556 & 225041 & 234250 & 28803 & 409953 & 149674 & 488833 & 586877 & 1462215 & 5688981 \\
\hline PREVIDÊNCIA PRIVADA & 73176 & 20929 & 5581 & 0 & 24362 & 9705 & 173153 & 15949 & 38334 & 299273 \\
\hline $\begin{array}{l}\text { CONTRIBUIÇÕES } \\
\text { SOCIAIS FICTÍCIAS } \\
\text { EXCEDENTE }\end{array}$ & 0 & 0 & 0 & 0 & 0 & 0 & 0 & 0 & 0 & 8992007 \\
\hline $\begin{array}{l}\text { OPERACIONAL BRUTO } \\
\text { (EOB) }\end{array}$ & 3859050 & 1453690 & 437136 & 122833 & 2963532 & 846842 & 1690640 & 14990184 & 3317354 & 27193741 \\
\hline $\begin{array}{l}\text { RENDIMENTO DE } \\
\text { AUTÔNOMOS } \\
\text { EOB EXCLUSIVE }\end{array}$ & 0 & 0 & 158216 & 0 & 46494 & 13707 & 0 & 1048891 & 2659724 & 4650923 \\
\hline RENDIMENTOS DE & 3859050 & 1453690 & 278919 & 122833 & 2917038 & 833135 & 1690640 & 13941293 & 657630 & 22542818 \\
\hline $\begin{array}{l}\text { VALOR ADICIONADO } \\
\text { CUSTO FATORES }\end{array}$ & 4050260 & 2374671 & 1429583 & 249826 & 4821238 & 1460103 & 3931929 & 17887160 & 9608251 & 76035849 \\
\hline $\begin{array}{l}\text { OUTROS IMPOSTOS } \\
\text { SOBRE A PRODUÇÃO }\end{array}$ & 564581 & 384207 & 251064 & 60670 & 949853 & 177118 & 486657 & 1164874 & 432609 & 2623605 \\
\hline
\end{tabular}


Tabela 56. Matriz insumo-produto inter-regional do Brasil, ano de 1999, valores correntes em R\$1.000,00.

\begin{tabular}{|c|c|c|c|c|c|c|c|c|c|c|}
\hline \multirow{3}{*}{ Setores } & \multicolumn{10}{|c|}{ Região Norte-Nordeste } \\
\hline & $\begin{array}{c}\text { Refino do } \\
\text { Petróleo }\end{array}$ & $\begin{array}{c}\text { Produtos do } \\
\text { Refino do } \\
\text { Petróleo } \\
\end{array}$ & $\begin{array}{c}\text { Têxtil, } \\
\text { Vestuário } \\
\text { e Calçados }\end{array}$ & $\begin{array}{l}\text { Fabricação } \\
\text { de Açúcar }\end{array}$ & $\begin{array}{c}\text { Outros } \\
\text { Produtos } \\
\text { Alimentares } \\
\end{array}$ & $\begin{array}{l}\text { Indústrias } \\
\text { Diversas }\end{array}$ & SIUP & $\begin{array}{l}\text { Construção } \\
\text { Civil }\end{array}$ & $\begin{array}{c}\text { Serviços } \\
\text { Prestados às } \\
\text { Famílias } \\
\end{array}$ & Outros Serviços \\
\hline & 11 & 12 & 13 & 14 & 15 & 16 & 17 & 18 & 19 & 20 \\
\hline $\begin{array}{l}\text { OUTROS SUBSÍDIOS À } \\
\text { PRODUÇÃOO }\end{array}$ & 0 & 0 & 0 & 0 & 0 & 0 & -13998 & -77005 & -21 & -279929 \\
\hline $\begin{array}{l}\text { VALOR ADICIONADO } \\
\text { PREÇO BÁSICO }\end{array}$ & 4614841 & 2758878 & 1680648 & 310496 & 5771090 & 1637221 & 4404587 & 18975029 & 10040839 & 78379525 \\
\hline VALOR DA PRODUÇÃO & 12195049 & 7981872 & 5705597 & 1270575 & 20982781 & 3775852 & 9813432 & 34169807 & 19901873 & 113036273 \\
\hline Pessoal Ocupado & 9413 & 69159 & 388266 & 16235 & 348859 & 150592 & 51343 & 1159935 & 2589992 & 5694803 \\
\hline Norte-Nordeste & 4435337 & 2581950 & 2782000 & 694014 & 12510452 & 1425573 & 3886164 & 7500826 & 5060792 & 22647324 \\
\hline Centro-Sul & 1508066 & 1350898 & 640922 & 182042 & 1629645 & 307898 & 685573 & 5327998 & 2860342 & 7712390 \\
\hline
\end{tabular}


Tabela 56. Matriz insumo-produto inter-regional do Brasil, ano de 1999, valores correntes em R\$1.000,00

\begin{tabular}{|c|c|c|c|c|c|c|c|c|c|c|c|c|}
\hline & & \multirow{3}{*}{ Setores } & \multicolumn{10}{|c|}{ Região Centro-Sul } \\
\hline & & & \multirow{2}{*}{$\begin{array}{r}\begin{array}{c}\text { Cana-de- } \\
\text { açúcar }\end{array} \\
21 \\
\end{array}$} & \multirow{2}{*}{$\begin{array}{c}\begin{array}{c}\text { Resto } \\
\text { Agropecuária }\end{array} \\
22 \\
\end{array}$} & \multirow{2}{*}{$\begin{array}{r}\text { Extrativa } \\
\\
23 \\
\end{array}$} & \multirow{2}{*}{$\begin{array}{r}\text { Metalurgia } \\
\\
24 \\
\end{array}$} & \multirow{2}{*}{$\begin{array}{r}\text { Mecânica } \\
25 \\
\end{array}$} & \multirow{2}{*}{$\begin{array}{l}\text { Material } \\
\text { Elétrico e } \\
\text { Eletrônico } \\
26 \\
\end{array}$} & \multirow{2}{*}{$\begin{array}{r}\begin{array}{c}\text { Material } \\
\text { de } \\
\text { Transporte }\end{array} \\
27 \\
\end{array}$} & \multirow{2}{*}{$\begin{array}{c}\text { Madeira, } \\
\begin{array}{c}\text { Mobiliário, } \\
\text { Celulose, Papel } \\
\text { e Gráfica }\end{array} \\
28 \\
\end{array}$} & \multirow{2}{*}{$\begin{array}{r}\text { Álcool } \\
\\
29 \\
\end{array}$} & \multirow{2}{*}{$\begin{array}{c}\text { Outros } \\
\text { Elementos } \\
\text { Químicos não } \\
\text { Petroquímicos } \\
30 \\
\end{array}$} \\
\hline & & & & & & & & & & & & \\
\hline \multirow{20}{*}{ 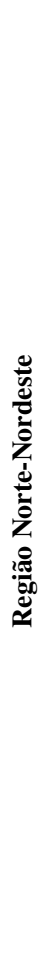 } & 1 & Cana-de-açúcar & 34 & 7825 & 0 & 0 & 1 & 1 & 1 & 3 & 82071 & 5 \\
\hline & 2 & Resto Agropecuária & 30493 & 81083 & 2219 & 119152 & 78 & 263 & 133 & 280297 & 18 & 9277 \\
\hline & 3 & Extrativa & 2066 & 20260 & 16984 & 140393 & 33 & 8110 & 109 & 7309 & 40 & 15044 \\
\hline & 4 & Metalurgia & 1215 & 6857 & 69089 & 20716 & 769307 & 710963 & 1093083 & 47665 & 990 & 7647 \\
\hline & 5 & Mecânica & 101 & 3570 & 22996 & 21705 & 7612 & 28425 & 35457 & 5030 & 4387 & 5073 \\
\hline & 6 & $\begin{array}{l}\text { Material Elétrico e } \\
\text { Eletrônico }\end{array}$ & 23 & 562 & 3512 & 7394 & 12024 & 19433 & 11853 & 1091 & 781 & 1081 \\
\hline & 7 & Material de Transporte & 19 & 556 & 1619 & 1788 & 11241 & 9610 & 192270 & 1096 & 351 & 243 \\
\hline & 8 & $\begin{array}{l}\text { Madeira, Mobiliário, } \\
\text { Celulose, Papel e Gráfica }\end{array}$ & 615 & 3779 & 10597 & 25253 & 30138 & 104927 & 77595 & 192777 & 1803 & 1166 \\
\hline & 9 & Álcool & 40 & 353 & 81 & 144 & 51 & 86 & 175 & 239 & 285 & 153 \\
\hline & 10 & $\begin{array}{l}\text { Outros Elementos Químicos } \\
\text { não Petroquímicos }\end{array}$ & 745 & 3856 & 1997 & 21594 & 4447 & 10752 & 5371 & 52432 & 38268 & 3394 \\
\hline & 11 & Refino do Petróleo & 54240 & 192819 & 93584 & 50158 & 54807 & 79205 & 89949 & 102025 & 29556 & 41147 \\
\hline & 12 & $\begin{array}{l}\text { Produtos do Refino do } \\
\text { Petróleo }\end{array}$ & 81977 & 289718 & 24765 & 28648 & 34715 & 158323 & 110747 & 132668 & 5223 & 5903 \\
\hline & 13 & Têxtil, Vestuário e Calçados & 4 & 12431 & 2433 & 1314 & 5827 & 3015 & 19016 & 14630 & 393 & 397 \\
\hline & 14 & Fabricação de Açúcar & 40 & 294 & 3 & 37 & 10 & 6 & 18 & 22 & 55688 & 8 \\
\hline & 15 & Outros Produtos Alimentares & 1908 & 72845 & 1096 & 1389 & 1220 & 931 & 1182 & 7574 & 530 & 12410 \\
\hline & 16 & Indústrias Diversas & 335 & 2627 & 16492 & 30874 & 20513 & 62495 & 54273 & 26107 & 2182 & 5952 \\
\hline & 17 & SIUP & 984 & 6186 & 14598 & 32576 & 28642 & 18485 & 27285 & 56768 & 22705 & 8221 \\
\hline & 18 & Construção Civil & 7 & 37 & 2140 & 3808 & 3049 & 2273 & 3193 & 3452 & 818 & 949 \\
\hline & 19 & $\begin{array}{l}\text { Serviços Prestados às } \\
\text { Famílias }\end{array}$ & 20 & 1530 & 1319 & 3106 & 3669 & 2750 & 3375 & 3449 & 434 & 367 \\
\hline & 20 & Outros Serviços & 46485 & 277147 & 56699 & 87006 & 102652 & 167403 & 219540 & 231052 & 18873 & 13107 \\
\hline
\end{tabular}


Tabela 56. Matriz insumo-produto inter-regional do Brasil, ano de 1999, valores correntes em R 1.000,00.

\begin{tabular}{|c|c|c|c|c|c|c|c|c|c|c|c|c|}
\hline & & \multirow{3}{*}{ Setores } & \multicolumn{10}{|c|}{ Região Centro-Sul } \\
\hline & & & \multirow{2}{*}{$\begin{array}{r}\begin{array}{c}\text { Cana-de- } \\
\text { açúcar }\end{array} \\
21 \\
\end{array}$} & \multirow{2}{*}{$\begin{array}{r}\begin{array}{c}\text { Resto } \\
\text { Agropecuária }\end{array} \\
22 \\
\end{array}$} & \multirow{2}{*}{$\begin{array}{r}\text { Extrativa } \\
\\
23 \\
\end{array}$} & \multirow{2}{*}{$\begin{array}{r}\text { Metalurgia } \\
24 \\
\end{array}$} & \multirow{2}{*}{$\begin{array}{r}\text { Mecânica } \\
25 \\
\end{array}$} & \multirow{2}{*}{$\begin{array}{l}\text { Material } \\
\text { Elétrico e } \\
\text { Eletrônico } \\
26 \\
\end{array}$} & \multirow{2}{*}{$\begin{array}{r}\begin{array}{c}\text { Material } \\
\text { de } \\
\text { Transporte }\end{array} \\
27 \\
\end{array}$} & \multirow{2}{*}{$\begin{array}{c}\text { Madeira, } \\
\text { Mobiliário, } \\
\text { Celulose, Papel } \\
\text { e Gráfica } \\
28 \\
\end{array}$} & \multirow{2}{*}{$\begin{array}{r}\text { Álcool } \\
\\
29 \\
\end{array}$} & \multirow{2}{*}{$\begin{array}{c}\text { Outros } \\
\text { Elementos } \\
\text { Químicos não } \\
\text { Petroquímicos } \\
30 \\
\end{array}$} \\
\hline & & & & & & & & & & & & \\
\hline \multirow{20}{*}{ 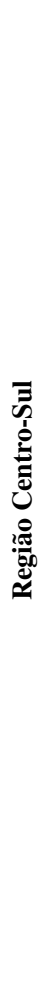 } & 21 & Cana-de-açúcar & 94205 & 161416 & 6 & 9 & 3 & 2 & 4 & 28 & 2337051 & 108 \\
\hline & 22 & Resto Agropecuária & 146296 & 14314390 & 8636 & 721519 & 692 & 686 & 705 & 2310389 & 183 & 54372 \\
\hline & 23 & Extrativa & 12243 & 246517 & 512801 & 1431235 & 479 & 42159 & 1214 & 46733 & 634 & 205387 \\
\hline & 24 & Metalurgia & 6356 & 152865 & 438974 & 22176581 & 3423340 & 2623183 & 4755023 & 536927 & 7947 & 131931 \\
\hline & 25 & Mecânica & 10790 & 186083 & 458664 & 1427159 & 686094 & 740140 & 1104599 & 460071 & 144276 & 221111 \\
\hline & 26 & $\begin{array}{l}\text { Material Elétrico e } \\
\text { Eletrônico }\end{array}$ & 544 & 8689 & 22978 & 159101 & 463800 & 2160741 & 184281 & 26259 & 11415 & 16602 \\
\hline & 27 & Material de Transporte & 479 & 15832 & 19096 & 204930 & 251450 & 50663 & 5802363 & 34746 & 6768 & 12522 \\
\hline & 28 & $\begin{array}{l}\text { Madeira, Mobiliário, } \\
\text { Celulose, Papel e Gráfica }\end{array}$ & 2527 & 155265 & 118333 & 427263 & 180670 & 414639 & 312865 & 8380918 & 16549 & 26063 \\
\hline & 29 & Álcool & 911 & 16618 & 1657 & 5324 & 1110 & 1078 & 4488 & 9589 & 45945 & 5069 \\
\hline & 30 & $\begin{array}{l}\text { Outros Elementos Químicos } \\
\text { não Petroquímicos }\end{array}$ & 8860 & 66068 & 14660 & 595281 & 24824 & 50561 & 30695 & 366947 & 178038 & 324365 \\
\hline & 31 & Refino do Petróleo & 249773 & 3270736 & 442312 & 775233 & 193300 & 187237 & 275475 & 877407 & 84914 & 438204 \\
\hline & 32 & $\begin{array}{l}\text { Produtos do Refino do } \\
\text { Petróleo }\end{array}$ & 191771 & 3314574 & 110571 & 415180 & 223511 & 661803 & 571942 & 966140 & 16282 & 67479 \\
\hline & 33 & Têxtil, Vestuário e Calçados & 50 & 197743 & 16193 & 24563 & 41006 & 20707 & 126810 & 207995 & 2667 & 4778 \\
\hline & 34 & Fabricação de Açúcar & 365 & 5784 & 567 & 3074 & 494 & 256 & 916 & 1710 & 392679 & 605 \\
\hline & 35 & Outros Produtos Alimentares & 13650 & 3845075 & 6838 & 16703 & 8647 & 6048 & 14574 & 65365 & 3469 & 129705 \\
\hline & 36 & Indústrias Diversas & 2012 & 78006 & 221302 & 844961 & 338195 & 422987 & 1126884 & 378927 & 12196 & 114958 \\
\hline & 37 & SIUP & 13934 & 487507 & 572739 & 2138246 & 404657 & 217201 & 384853 & 1133427 & 286956 & 459490 \\
\hline & 38 & Construção Civil & 144 & 3172 & 90388 & 88400 & 63065 & 43035 & 65869 & 92173 & 15749 & 24062 \\
\hline & 39 & $\begin{array}{l}\text { Serviços Prestados às } \\
\text { Famílias }\end{array}$ & 382 & 79987 & 57492 & 79818 & 70690 & 50549 & 60753 & 95235 & 8018 & 12418 \\
\hline & 40 & Outros Serviços & 641852 & 9663419 & 2688343 & 5322109 & 2483064 & 3356291 & 5141956 & 6633442 & 452099 & 652887 \\
\hline
\end{tabular}


Tabela 56. Matriz insumo-produto inter-regional do Brasil, ano de 1999, valores correntes em R 1.000,00.

\begin{tabular}{|c|c|c|c|c|c|c|c|c|c|c|}
\hline \multirow{3}{*}{ Setores } & \multicolumn{10}{|c|}{ Região Centro-Sul } \\
\hline & $\begin{array}{l}\text { Cana-de- } \\
\text { açúcar }\end{array}$ & $\begin{array}{c}\text { Resto } \\
\text { Agropecuária }\end{array}$ & Extrativa & Metalurgia & Mecânica & $\begin{array}{l}\text { Material } \\
\text { Elétrico e } \\
\text { Eletrônico }\end{array}$ & $\begin{array}{l}\text { Material } \\
\text { de } \\
\text { Transporte }\end{array}$ & $\begin{array}{c}\text { Madeira, } \\
\text { Mobiliário, } \\
\text { Celulose, Papel e } \\
\text { Gráfica } \\
\end{array}$ & Álcool & $\begin{array}{l}\text { Outros Elementos } \\
\text { Químicos não } \\
\text { Petroquímicos }\end{array}$ \\
\hline & 21 & 22 & 23 & 24 & 25 & 26 & 27 & 28 & 29 & 30 \\
\hline Produção Nacional & 1618495 & 37254080 & 6144771 & 37453746 & 9949129 & 12437425 & 21910893 & 23790117 & 4289229 & 3033658 \\
\hline Importado & 148806 & 3227328 & 776823 & 3963936 & 1205456 & 2081951 & 4787250 & 1894306 & 162985 & 618117 \\
\hline Imposta Importação & 6763 & 148701 & 48498 & 249373 & 111548 & 267644 & 366788 & 142634 & 11382 & 44720 \\
\hline ICM Nacional & 54321 & 1147833 & 258154 & 1155379 & 598366 & 773317 & 1605282 & 1342080 & 135465 & 123502 \\
\hline ICM Impotação & 2940 & 63243 & 0 & 0 & 0 & 0 & 0 & 0 & 0 & 0 \\
\hline IPI Nacional & 4953 & 108222 & 127010 & 543295 & 289172 & 448135 & 679190 & 507476 & 29054 & 26930 \\
\hline IPI Importação & 3730 & 80180 & 7188 & 2806 & 1131 & 1338 & 2908 & 2199 & 121 & 471 \\
\hline $\begin{array}{l}\text { Outros Impostos Indiretos } \\
\text { Líquidos Nacionais }\end{array}$ & 6997 & 153215 & 155424 & 183362 & 38937 & 93488 & 117255 & 92105 & 30616 & 22766 \\
\hline $\begin{array}{l}\text { Outros Impostos Indiretos } \\
\text { Líquidos Importação }\end{array}$ & 1072 & 23399 & 4057 & 66751 & 8977 & 20043 & 44964 & 12208 & 2014 & 7880 \\
\hline $\begin{array}{l}\text { CONSUMO } \\
\text { INTERMEDIÁRIO }\end{array}$ & 1848078 & 42206200 & 7521924 & 43618646 & 12202716 & 16123341 & 29514530 & 27783125 & 4660866 & 3878044 \\
\hline REMUNERAÇÕES & 459957 & 6421605 & 1797319 & 5308011 & 5023173 & 2325307 & 4374126 & 6176720 & 401994 & 287443 \\
\hline SALÁRIOS & 388325 & 5421535 & 1063071 & 3995940 & 3682626 & 1727932 & 3221493 & 4699925 & 296293 & 212395 \\
\hline CONTRIBUIÇÕES SOCIAIS & 71631 & 1000069 & 734248 & 1312071 & 1340546 & 597375 & 1152632 & 1476795 & 105701 & 75048 \\
\hline $\begin{array}{l}\text { PREVIDÊNCIA OFICIAL/ } \\
\text { GTS }\end{array}$ & 71416 & 997062 & 319600 & 1203632 & 1307134 & 541252 & 1083886 & 1424106 & 98683 & 71176 \\
\hline PREVIDÊNCIA PRIVADA & 215 & 3008 & 414648 & 108439 & 33412 & 56123 & 68746 & 52689 & 7018 & 3873 \\
\hline $\begin{array}{l}\text { CONTRIBUIÇÕES SOCIAIS } \\
\text { FICTÍCIAS } \\
\text { EXCEDENTE }\end{array}$ & 0 & 0 & 0 & 0 & 0 & 0 & 0 & 0 & 0 & 0 \\
\hline $\begin{array}{l}\text { OPERACIONAL BRUTO } \\
\text { (EOB) }\end{array}$ & 2271702 & 46906043 & 7994118 & 7547668 & 9922560 & 3757910 & 4978977 & 5921011 & 2381763 & 2732788 \\
\hline $\begin{array}{l}\text { RENDIMENTO DE } \\
\text { AUTOONOMOS }\end{array}$ & 12614 & 253895 & 89274 & 372890 & 0 & 0 & 0 & 682763 & 0 & 0 \\
\hline $\begin{array}{l}\text { EOB EXCLUSIVE } \\
\text { RENDIMENTOS DE } \\
\text { AUTÔNOMOS }\end{array}$ & 2259087 & 46652149 & 7904844 & 7174778 & 9922560 & 3757910 & 4978977 & 5238249 & 2381763 & 2732788 \\
\hline $\begin{array}{l}\text { VALOR ADICIONADO } \\
\text { CUSTO FATORES }\end{array}$ & 2731658 & 53327648 & 9791437 & 12855680 & 14945733 & 6083217 & 9353103 & 12097731 & 2783757 & 3020231 \\
\hline $\begin{array}{l}\text { OUTROS IMPOSTOS SOBRE } \\
\text { A PRODUÇÃO }\end{array}$ & 107 & 2223 & 844979 & 2705293 & 1404479 & 1115602 & 1954440 & 1851750 & 368269 & 341242 \\
\hline
\end{tabular}


Tabela 56. Matriz insumo-produto inter-regional do Brasil, ano de 1999, valores correntes em R \$ 1.000,00.

\begin{tabular}{|c|c|c|c|c|c|c|c|c|c|c|}
\hline \multirow{3}{*}{ Setores } & \multicolumn{10}{|c|}{ Região Centro-Sul } \\
\hline & $\begin{array}{l}\text { Cana-de- } \\
\text { açúcar }\end{array}$ & $\begin{array}{c}\text { Resto } \\
\text { Agropecuária }\end{array}$ & Extrativa & Metalurgia & Mecânica & $\begin{array}{c}\text { Material } \\
\text { Elétrico e } \\
\text { Eletrônico }\end{array}$ & $\begin{array}{l}\text { Material } \\
\text { de } \\
\text { Transporte }\end{array}$ & $\begin{array}{c}\text { Madeira, } \\
\text { Mobiliário, } \\
\text { Celulose, Papel e } \\
\text { Gráfica } \\
\end{array}$ & Álcool & $\begin{array}{l}\text { Outros Elementos } \\
\text { Químicos não } \\
\text { Petroquímicos }\end{array}$ \\
\hline & 21 & 22 & 23 & 24 & 25 & 26 & 27 & 28 & 29 & 30 \\
\hline $\begin{array}{l}\text { OUTROS SUBSÍDIOS À } \\
\text { PRODUÇÃO }\end{array}$ & -36640 & -764324 & 0 & -210 & -136014 & -46946 & -295462 & 0 & 0 & 0 \\
\hline $\begin{array}{l}\text { VALOR ADICIONADO } \\
\text { PREÇO BÁSICO }\end{array}$ & 2695124 & 52565547 & 10636416 & 15560763 & 16214199 & 7151873 & 11012081 & 13949481 & 3152026 & 3361473 \\
\hline VALOR DA PRODUÇÃO & 4543203 & 94771747 & 18158341 & 59179410 & 28416915 & 23275213 & 40526611 & 41732607 & 7812892 & 7239517 \\
\hline Pessoal Ocupado & 305306 & 6878972 & 159082 & 606568 & 343404 & 177684 & 270100 & 946334 & 25751 & 23725 \\
\hline Norte-Nordeste & 221351 & 984334 & 342224 & 597058 & 1090038 & 1387457 & 1944624 & 1165688 & 265394 & 131544 \\
\hline Centro-Sul & 1397144 & 36269746 & 5802547 & 36856688 & 8859091 & 11049967 & 19966269 & 22624429 & 4023835 & 2902114 \\
\hline
\end{tabular}


Tabela 56. Matriz insumo-produto inter-regional do Brasil, ano de 1999, valores correntes em R 1.000,00.

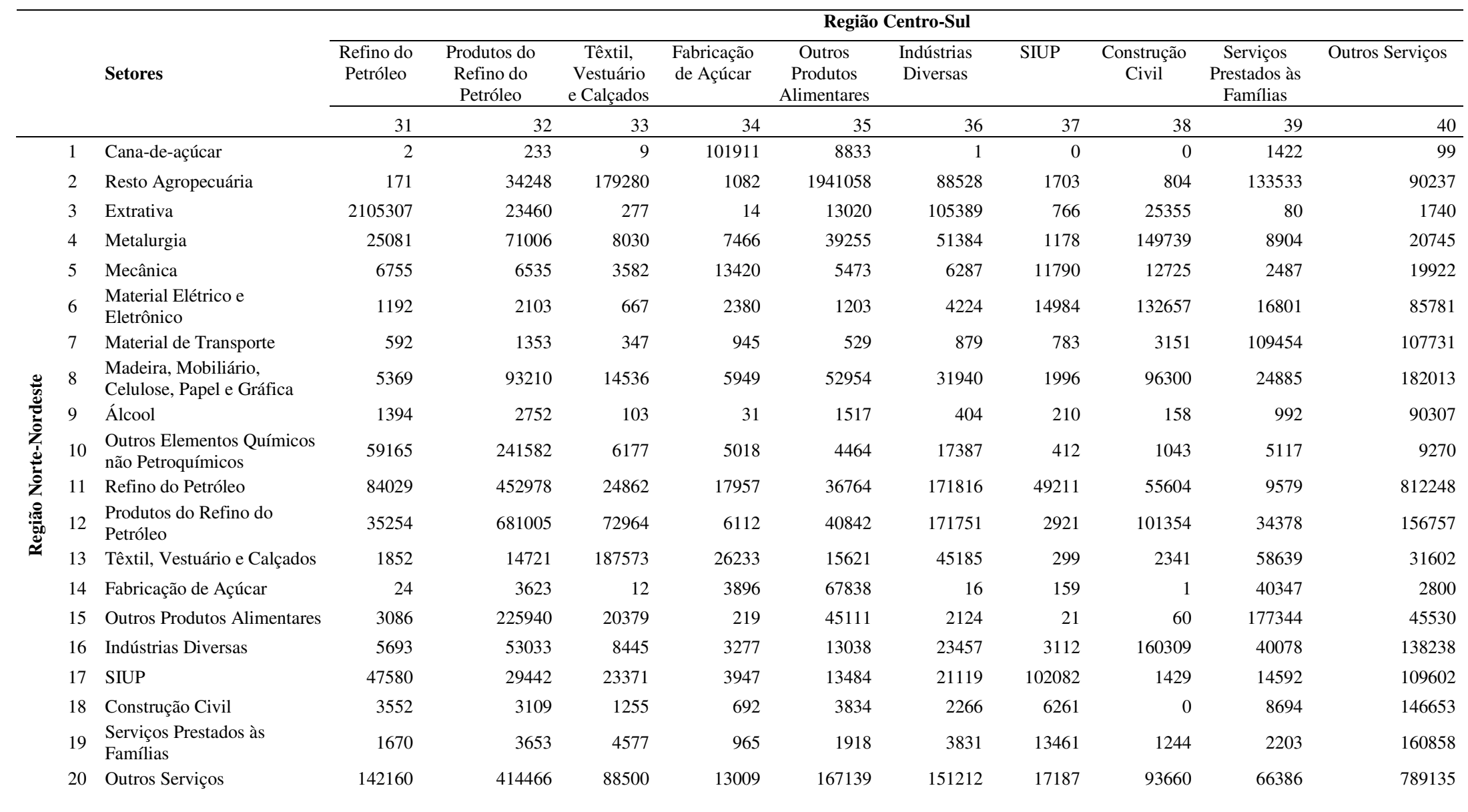


Tabela 56. Matriz insumo-produto inter-regional do Brasil, ano de 1999, valores correntes em R 1.000,00.

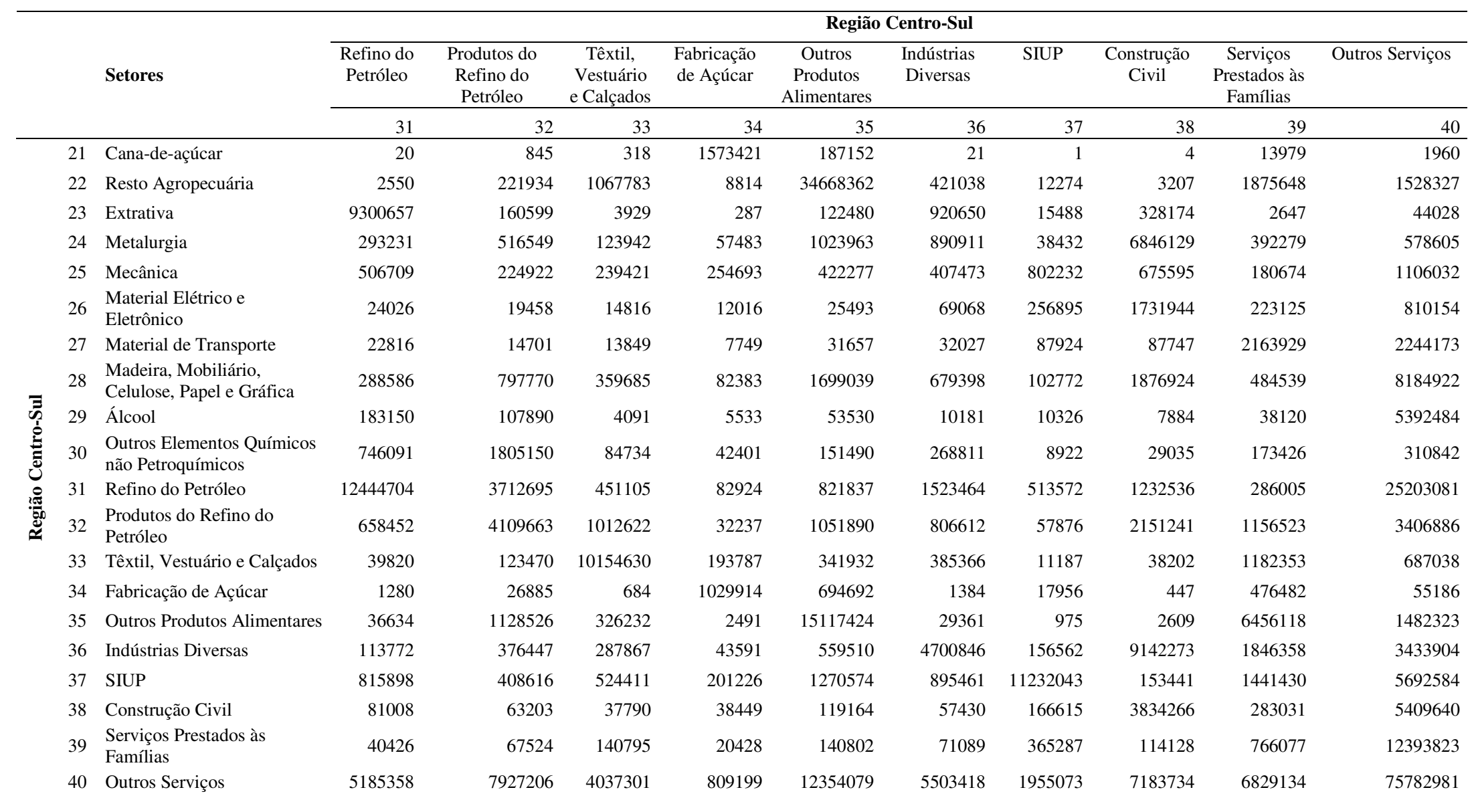


Tabela 56. Matriz insumo-produto inter-regional do Brasil, ano de 1999, valores correntes em R 1.000,00.

\begin{tabular}{|c|c|c|c|c|c|c|c|c|c|c|}
\hline \multirow{3}{*}{ Setores } & \multicolumn{10}{|c|}{ Região Centro-Sul } \\
\hline & $\begin{array}{l}\text { Refino do } \\
\text { Petróleo }\end{array}$ & $\begin{array}{l}\text { Produtos do } \\
\text { Refino do } \\
\text { Petróleo } \\
\end{array}$ & $\begin{array}{c}\text { Têxtil, } \\
\text { Vestuário } \\
\text { e Calçados } \\
\end{array}$ & $\begin{array}{l}\text { Fabricação } \\
\text { de Açúcar }\end{array}$ & $\begin{array}{c}\text { Outros } \\
\text { Produtos } \\
\text { Alimentares } \\
\end{array}$ & $\begin{array}{l}\text { Indústrias } \\
\text { Diversas }\end{array}$ & SIUP & $\begin{array}{l}\text { Construção } \\
\text { Civil }\end{array}$ & $\begin{array}{l}\text { Serviços } \\
\text { Prestados às } \\
\text { Famílias } \\
\end{array}$ & $\begin{array}{l}\text { Outros } \\
\text { Serviços }\end{array}$ \\
\hline & 31 & 32 & 33 & 34 & 35 & 36 & 37 & 38 & 39 & 40 \\
\hline Produção Nacional & 33315112 & 24172504 & 19530953 & 4713546 & 73331242 & 18573211 & 16040947 & 36277453 & 27027791 & 156750240 \\
\hline Importado & 6849007 & 3771040 & 2432415 & 279242 & 3302438 & 2157780 & 1047681 & 3237461 & 3113399 & 14869469 \\
\hline Imposta Importação & 491860 & 326045 & 241597 & 25161 & 128856 & 162567 & 54111 & 360283 & 250507 & 528277 \\
\hline ICM Nacional & 670547 & 828934 & 993851 & 199442 & 2697148 & 1298137 & 1527922 & 2636089 & 2235052 & 5829249 \\
\hline ICM Impotação & 0 & 0 & 0 & 0 & 0 & 0 & 13353 & 257765 & 220808 & 710689 \\
\hline IPI Nacional & 165298 & 338898 & 140986 & 35669 & 606799 & 423494 & 97656 & 988794 & 901142 & 2105989 \\
\hline IPI Importação & 940 & 1467 & 1277 & 1273 & 5371 & 5524 & 20075 & 310853 & 183110 & 584042 \\
\hline $\begin{array}{l}\text { Outros Impostos Indiretos } \\
\text { Líquidos Nacionais }\end{array}$ & 153203 & 73324 & 59869 & 14554 & 231619 & 91531 & 117040 & 103933 & 122975 & 1846108 \\
\hline $\begin{array}{l}\text { Outros Impostos Indiretos } \\
\text { Líquidos Importação }\end{array}$ & 92787 & 49381 & 14243 & 1905 & 42420 & 17252 & 1130 & 24370 & 24445 & 62820 \\
\hline CONSUMO INTERMEDIÁRIO & 41738752 & 29561593 & 23415190 & 5270793 & 80345893 & 22729497 & 18919914 & 44197000 & 34079230 & 183286883 \\
\hline REMUNERAÇÕES & 1407050 & 5342616 & 3398281 & 568700 & 5763091 & 3894736 & 7730760 & 6894379 & 25357018 & 203865951 \\
\hline SALÁRIOS & 651075 & 3930978 & 2609407 & 439712 & 4389592 & 2887409 & 5447407 & 5459740 & 19308684 & 141957507 \\
\hline CONTRIBUIÇÕES SOCIAIS & 755976 & 1411638 & 788874 & 128988 & 1373499 & 1007327 & 2283353 & 1434639 & 6048333 & 24307737 \\
\hline PREVIDÊNCIA OFICIAL/ GTS & 217496 & 1305156 & 776689 & 128988 & 1295286 & 948563 & 1686106 & 1396682 & 5893820 & 22447362 \\
\hline PREVIDÊNCIA PRIVADA & 538480 & 106482 & 12185 & 0 & 78212 & 58764 & 597247 & 37957 & 154513 & 1860375 \\
\hline $\begin{array}{l}\text { CONTRIBUIÇÕES SOCIAIS } \\
\text { FICTÍCIAS }\end{array}$ & 0 & 0 & 0 & 0 & 0 & 0 & 0 & 0 & 0 & 37600707 \\
\hline $\begin{array}{l}\text { EXCEDENTE OPERACIONAL } \\
\text { BRUTO (EOB) }\end{array}$ & 16970572 & 9052141 & 4498936 & 512840 & 14631449 & 7566733 & 14657947 & 51845396 & 13516679 & 178457682 \\
\hline $\begin{array}{l}\text { RENDIMENTO DE } \\
\text { AUTÔNOMOS }\end{array}$ & 0 & 0 & 1461663 & 0 & 184092 & 144659 & 0 & 3627719 & 10422876 & 23937374 \\
\hline $\begin{array}{l}\text { EOB EXCLUSIVE } \\
\text { RENDIMENTOS DE } \\
\text { AUTÔNOMOS }\end{array}$ & 16970572 & 9052141 & 3037274 & 512840 & 14447357 & 7422074 & 14657947 & 48217677 & 3093803 & 154520308 \\
\hline $\begin{array}{l}\text { VALOR ADICIONADO CUSTO } \\
\text { FATORES }\end{array}$ & 18377622 & 14394757 & 7897218 & 1081540 & 20394540 & 11461469 & 22388707 & 58739775 & 38873696 & 382323633 \\
\hline $\begin{array}{l}\text { OUTROS IMPOSTOS SOBRE A } \\
\text { PRODUÇÃO }\end{array}$ & 2918248 & 2225699 & 1380515 & 318533 & 4784527 & 1679749 & 2152415 & 3624587 & 1509432 & 14903768 \\
\hline
\end{tabular}


Tabela 56. Matriz insumo-produto inter-regional do Brasil, ano de 1999, valores correntes em R\$1.000,00.

\begin{tabular}{|c|c|c|c|c|c|c|c|c|c|c|}
\hline \multirow{3}{*}{ Setores } & \multicolumn{10}{|c|}{ Região Centro-Sul } \\
\hline & $\begin{array}{l}\text { Refino do } \\
\text { Petróleo }\end{array}$ & $\begin{array}{c}\text { Produtos do } \\
\text { Refino do } \\
\text { Petróleo } \\
\end{array}$ & $\begin{array}{c}\text { Têxtil, } \\
\text { Vestuário } \\
\text { e Calçados }\end{array}$ & $\begin{array}{l}\text { Fabricação } \\
\text { de Açúcar }\end{array}$ & $\begin{array}{c}\text { Outros } \\
\text { Produtos } \\
\text { Alimentares }\end{array}$ & $\begin{array}{l}\text { Indústrias } \\
\text { Diversas }\end{array}$ & SIUP & $\begin{array}{l}\text { Construção } \\
\text { Civil }\end{array}$ & $\begin{array}{c}\text { Serviços } \\
\text { Prestados às } \\
\text { Famílias } \\
\end{array}$ & Outros Serviços \\
\hline & 31 & 32 & 33 & 34 & 35 & 36 & 37 & 38 & 39 & 40 \\
\hline $\begin{array}{l}\text { OUTROS SUBSÍDIOS À } \\
\text { PRODUÇÃOO }\end{array}$ & 0 & 0 & 0 & 0 & 0 & 0 & -57562 & -239607 & -63 & -1258351 \\
\hline $\begin{array}{l}\text { VALOR ADICIONADO } \\
\text { PREÇO BÁSICO }\end{array}$ & 21295870 & 16620456 & 9277732 & 1400073 & 25179068 & 13141218 & 24483561 & 62124755 & 40383065 & 395969050 \\
\hline VALOR DA PRODUÇÃO & 63034622 & 46182049 & 32692922 & 6670866 & 105524961 & 35870715 & 43403476 & 106321755 & 74462295 & 579255933 \\
\hline Pessoal Ocupado & 35487 & 408441 & 1635234 & 58665 & 1032641 & 604008 & 164157 & 2748865 & 6876008 & 20902897 \\
\hline Norte-Nordeste & 2529926 & 2358452 & 644948 & 214521 & 2473894 & 899200 & 228536 & 837933 & 755915 & 3001267 \\
\hline Centro-Sul & 30785185 & 21814052 & 18886005 & 4499026 & 70857348 & 17674011 & 15812410 & 35439520 & 26271876 & 153748973 \\
\hline
\end{tabular}


Tabela 56. Matriz insumo-produto inter-regional do Brasil, ano de 1999, valores correntes em R 1.000,00.

\begin{tabular}{|c|c|c|c|c|c|c|c|c|c|c|c|c|}
\hline & & & $\begin{array}{c}\text { Dummy } \\
\text { Financeira }\end{array}$ & $\begin{array}{c}\text { Dummy } \\
\text { Financeira }\end{array}$ & $\begin{array}{c}\text { Consumo } \\
\text { Intermediário } \\
\text { Total }\end{array}$ & $\begin{array}{l}\text { Formação de } \\
\text { Capital }\end{array}$ & Exportação & $\begin{array}{l}\text { Variação de } \\
\text { Estoque }\end{array}$ & $\begin{array}{l}\text { Consumo da } \\
\text { Administração } \\
\text { Pública }\end{array}$ & $\begin{array}{c}\text { Consumo } \\
\text { das Famílias }\end{array}$ & $\begin{array}{l}\text { Formação de } \\
\text { Capital }\end{array}$ & Exportação \\
\hline & & Setores & $\begin{array}{c}\text { Norte- } \\
\text { Nordeste }\end{array}$ & $\begin{array}{l}\text { Centro- } \\
\text { Sul }\end{array}$ & & $\begin{array}{c}\text { Norte- } \\
\text { Nordeste }\end{array}$ & $\begin{array}{c}\text { Norte- } \\
\text { Nordeste }\end{array}$ & $\begin{array}{c}\text { Norte- } \\
\text { Nordeste }\end{array}$ & Norte-Nordeste & $\begin{array}{c}\text { Norte- } \\
\text { Nordeste }\end{array}$ & Centro-Sul & Centro-Sul \\
\hline \multirow{20}{*}{ 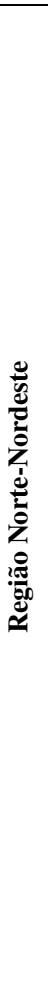 } & 1 & Cana-de-açúcar & 0 & 0 & 745862 & 0 & 12800 & 142781 & 0 & 17640 & 0 & 0 \\
\hline & 2 & Resto Agropecuária & 0 & 0 & 14253698 & 607549 & 416292 & 1116416 & 0 & 6487057 & 134392 & 0 \\
\hline & 3 & Extrativa & 0 & 0 & 4048198 & 1071 & 1471300 & -877943 & 0 & 30681 & 280 & 0 \\
\hline & 4 & Metalurgia & 0 & 0 & 9751210 & 54759 & 2144659 & -868251 & 0 & 439262 & 13905 & 0 \\
\hline & 5 & Mecânica & 0 & 0 & 679114 & 509381 & 21741 & -146702 & 0 & 130247 & 133671 & 0 \\
\hline & 6 & $\begin{array}{l}\text { Material Elétrico e } \\
\text { Eletrônico }\end{array}$ & 0 & 0 & 874782 & 381698 & 326527 & 792807 & 0 & 812932 & 278916 & 0 \\
\hline & 7 & Material de Transporte & 0 & 0 & 923851 & 72764 & 124126 & 1290750 & 0 & 151709 & 37479 & 0 \\
\hline & 8 & $\begin{array}{l}\text { Madeira, Mobiliário, } \\
\text { Celulose, Papel e Gráfica }\end{array}$ & 0 & 0 & 2870197 & 78569 & 856417 & -1336043 & 0 & 766934 & 261759 & 0 \\
\hline & 9 & Álcool & 0 & 0 & 538616 & 146 & 47108 & 13329 & 0 & 253182 & 11 & 0 \\
\hline & 10 & $\begin{array}{l}\text { Outros Elementos Químicos } \\
\text { não Petroquímicos }\end{array}$ & 0 & 0 & 1081696 & 171 & 135048 & -107647 & 0 & 43019 & 25 & 0 \\
\hline & 11 & Refino do Petróleo & 0 & 0 & 8550985 & -6515 & 209389 & 2420940 & 0 & 857275 & 624 & 0 \\
\hline & 12 & $\begin{array}{l}\text { Produtos do Refino do } \\
\text { Petróleo }\end{array}$ & 0 & 0 & 4742576 & 3503 & 196615 & -144650 & 0 & 2600149 & 1476 & 0 \\
\hline & 13 & Têxtil, Vestuário e Calçados & 0 & 0 & 2523188 & 2342 & 526598 & -179349 & 0 & 2217985 & 519 & 0 \\
\hline & 14 & Fabricação de Açúcar & 0 & 0 & 572500 & 234 & 431513 & -144980 & 0 & 250295 & 16 & 0 \\
\hline & 15 & Outros Produtos Alimentares & 0 & 0 & 5825012 & 5586 & 1172384 & -2915476 & 0 & 14113615 & 884 & 0 \\
\hline & 16 & Indústrias Diversas & 0 & 0 & 3043636 & 34272 & 137486 & 128630 & 0 & 365002 & 6766 & 0 \\
\hline & 17 & SIUP & 0 & 0 & 6648062 & 1573 & 2075 & -740004 & 0 & 3715291 & 36 & 0 \\
\hline & 18 & Construção Civil & 0 & 0 & 2675235 & 29410875 & 7552 & -633303 & 0 & 4774 & 2704279 & 0 \\
\hline & 19 & $\begin{array}{l}\text { Serviços Prestados às } \\
\text { Famílias }\end{array}$ & 0 & 0 & 3349189 & 2684 & 366107 & -3314237 & 0 & 17657985 & 496 & 0 \\
\hline & 20 & Outros Serviços & 3533245 & 0 & 34741221 & 1261134 & 2506162 & -19684284 & 40281002 & 51662689 & 83962 & 0 \\
\hline
\end{tabular}


Tabela 56. Matriz insumo-produto inter-regional do Brasil, ano de 1999, valores correntes em R 1.000,00.

\begin{tabular}{|c|c|c|c|c|c|c|c|c|c|c|c|c|}
\hline & & & $\begin{array}{c}\text { Dummy } \\
\text { Financeira }\end{array}$ & $\begin{array}{c}\text { Dummy } \\
\text { Financeira }\end{array}$ & $\begin{array}{c}\text { Consumo } \\
\text { Intermediário } \\
\text { Total }\end{array}$ & $\begin{array}{l}\text { Formação } \\
\text { de Capital }\end{array}$ & Exportação & $\begin{array}{l}\text { Variação de } \\
\text { Estoque }\end{array}$ & $\begin{array}{c}\text { Consumo da } \\
\text { Administração } \\
\text { Pública } \\
\end{array}$ & $\begin{array}{c}\text { Consumo } \\
\text { das Famílias }\end{array}$ & $\begin{array}{l}\text { Formação de } \\
\text { Capital }\end{array}$ & Exportação \\
\hline & & Setores & $\begin{array}{c}\text { Norte- } \\
\text { Nordeste }\end{array}$ & $\overline{\text { Centro-Sul }}$ & & $\begin{array}{c}\text { Norte- } \\
\text { Nordeste }\end{array}$ & $\begin{array}{c}\text { Norte- } \\
\text { Nordeste }\end{array}$ & $\begin{array}{c}\text { Norte- } \\
\text { Nordeste }\end{array}$ & Norte-Nordeste & $\begin{array}{c}\text { Norte- } \\
\text { Nordeste }\end{array}$ & Centro-Sul & Centro-Sul \\
\hline \multirow{20}{*}{ 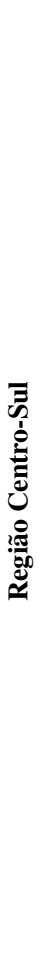 } & 21 & Cana-de-açúcar & 0 & 0 & 4508258 & 0 & 0 & 0 & 0 & 10323 & 1 & 986902 \\
\hline & 22 & Resto Agropecuária & 0 & 0 & 58688336 & 62785 & 0 & 0 & 0 & 1127577 & 2168137 & 3859538 \\
\hline & 23 & Extrativa & 0 & 0 & 14720157 & 1090 & 0 & 0 & 0 & 11320 & 3302 & 2837824 \\
\hline & 24 & Metalurgia & 0 & 0 & 47301299 & 70224 & 0 & 0 & 0 & 245084 & 671127 & 7279912 \\
\hline & 25 & Mecânica & 0 & 0 & 11471569 & 1303181 & 0 & 0 & 0 & 97382 & 11338399 & 2993046 \\
\hline & 26 & $\begin{array}{l}\text { Material Elétrico e } \\
\text { Eletrônico }\end{array}$ & 0 & 0 & 7036509 & 497020 & 0 & 0 & 0 & 1401641 & 4767262 & 3590322 \\
\hline & 27 & Material de Transporte & 0 & 0 & 12113897 & 723766 & 0 & 0 & 0 & 3160071 & 4677147 & 10150571 \\
\hline & 28 & $\begin{array}{l}\text { Madeira, Mobiliário, } \\
\text { Celulose, Papel e Gráfica }\end{array}$ & 0 & 0 & 26553973 & 145327 & 0 & 0 & 0 & 1614989 & 1105225 & 4649997 \\
\hline & 29 & Álcool & 0 & 0 & 6546601 & 10 & 0 & 0 & 0 & 332041 & 1061 & 279057 \\
\hline & 30 & $\begin{array}{l}\text { Outros Elementos Químicos } \\
\text { não Petroquímicos }\end{array}$ & 0 & 0 & 5767578 & 10 & 0 & 0 & 0 & 15634 & 1025 & 1221252 \\
\hline & 31 & Refino do Petróleo & 0 & 0 & 57845381 & 3150 & 0 & 0 & 0 & 603045 & -14514 & 1529958 \\
\hline & 32 & $\begin{array}{l}\text { Produtos do Refino do } \\
\text { Petróleo }\end{array}$ & 0 & 0 & 23334131 & 1622 & 0 & 0 & 0 & 3214307 & 23676 & 1659740 \\
\hline & 33 & Têxtil, Vestuário e Calçados & 0 & 0 & 14275330 & 1626 & 0 & 0 & 0 & 1922375 & 18211 & 3945238 \\
\hline & 34 & Fabricação de Açúcar & 0 & 0 & 2905756 & 8 & 0 & 0 & 0 & 231373 & 1001 & 1219096 \\
\hline & 35 & Outros Produtos Alimentares & 0 & 0 & 30118489 & 395 & 0 & 0 & 0 & 3532451 & 26424 & 13773335 \\
\hline & 36 & Indústrias Diversas & 0 & 0 & 27511320 & 69408 & 0 & 0 & 0 & 735433 & 684607 & 3124469 \\
\hline & 37 & SIUP & 0 & 0 & 29286978 & 82 & 0 & 0 & 0 & 302425 & 3132 & 12403 \\
\hline & 38 & Construção Civil & 0 & 0 & 10602768 & 189536 & 0 & 0 & 0 & 124 & 94858869 & 21995 \\
\hline & 39 & $\begin{array}{l}\text { Serviços Prestados às } \\
\text { Famílias }\end{array}$ & 0 & 0 & 14805537 & 215 & 0 & 0 & 0 & 83879 & 7789 & 2414418 \\
\hline & 40 & Outros Serviços & 0 & 37684259 & 205744788 & 94221 & 0 & 0 & 0 & 5543132 & 4899650 & 17206853 \\
\hline
\end{tabular}


Tabela 56. Matriz insumo-produto inter-regional do Brasil, ano de 1999, valores correntes em R 1.000,00.

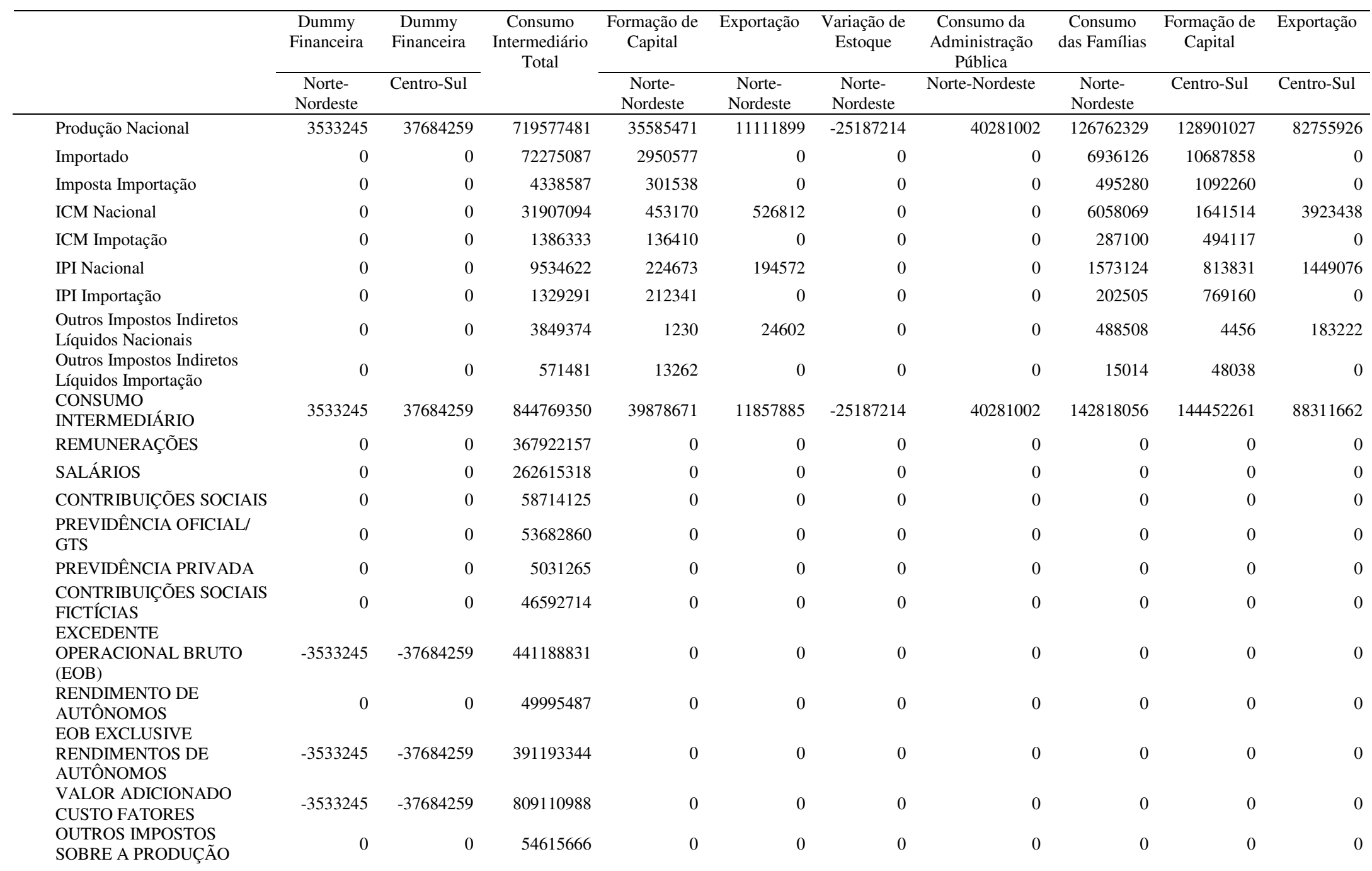


Tabela 56. Matriz insumo-produto inter-regional do Brasil, ano de 1999, valores correntes em R \$ 1.000,00.

\begin{tabular}{|c|c|c|c|c|c|c|c|c|c|c|}
\hline & $\begin{array}{c}\text { Dummy } \\
\text { Financeira }\end{array}$ & $\begin{array}{c}\text { Dummy } \\
\text { Financeira }\end{array}$ & $\begin{array}{c}\text { Consumo } \\
\text { Intermediário } \\
\text { Total }\end{array}$ & $\begin{array}{l}\text { Formação de } \\
\text { Capital }\end{array}$ & Exportação & $\begin{array}{l}\text { Variação de } \\
\text { Estoque }\end{array}$ & $\begin{array}{c}\text { Consumo da } \\
\text { Administração } \\
\text { Pública }\end{array}$ & $\begin{array}{l}\text { Consumo das } \\
\text { Famílias }\end{array}$ & $\begin{array}{l}\text { Formação de } \\
\text { Capital }\end{array}$ & Exportação \\
\hline & $\begin{array}{c}\text { Norte- } \\
\text { Nordeste }\end{array}$ & Centro-Sul & & $\begin{array}{c}\text { Norte- } \\
\text { Nordeste }\end{array}$ & $\begin{array}{c}\text { Norte- } \\
\text { Nordeste }\end{array}$ & $\begin{array}{c}\text { Norte- } \\
\text { Nordeste }\end{array}$ & Norte-Nordeste & $\begin{array}{c}\text { Norte- } \\
\text { Nordeste }\end{array}$ & Centro-Sul & Centro-Sul \\
\hline $\begin{array}{l}\text { OUTROS SUBSÍDIOS À } \\
\text { PRODUÇÃO }\end{array}$ & 0 & 0 & -3468563 & 0 & 0 & 0 & 0 & 0 & 0 & 0 \\
\hline $\begin{array}{l}\text { VALOR ADICIONADO } \\
\text { PREÇO BÁSICO }\end{array}$ & -3533245 & -37684259 & 860258091 & 0 & 0 & 0 & 0 & 0 & 0 & 0 \\
\hline VALOR DA PRODUÇÃO & 0 & 0 & 1705027441 & 0 & 0 & 0 & 0 & 0 & 0 & 0 \\
\hline Pessoal Ocupado & 0 & 0 & 62418900 & 0 & 0 & 0 & 0 & 0 & 0 & 0 \\
\hline Norte-Nordeste & 3533245 & 0 & 108438826 & 32421794 & 11111899 & -25187214 & 40281002 & 102577723 & 3659496 & 0 \\
\hline Centro-Sul & 0 & 37684259 & 611138655 & 3163677 & 0 & 0 & 0 & 24184606 & 125241531 & 82755926 \\
\hline
\end{tabular}


Tabela 56. Matriz insumo-produto inter-regional do Brasil, ano de 1999, valores correntes em R \$ 1.000,00.

\begin{tabular}{|c|c|c|c|c|c|c|c|c|c|c|c|}
\hline & & & $\begin{array}{l}\text { Variação } \\
\text { de Estoque }\end{array}$ & $\begin{array}{c}\text { Consumo da } \\
\text { Administração } \\
\text { Pública }\end{array}$ & $\begin{array}{c}\text { Consumo } \\
\text { das Famílias }\end{array}$ & $\begin{array}{l}\text { Demanda } \\
\text { Final }\end{array}$ & $\begin{array}{l}\text { Produção } \\
\text { Total }\end{array}$ & $\begin{array}{l}\text { Consumo } \\
\text { Intermediário }\end{array}$ & $\begin{array}{c}\text { Consumo } \\
\text { Intermediário }\end{array}$ & Demanda Final & Demanda Final \\
\hline & & Setores & Centro-Sul & Centro-Sul & Centro-Sul & & & Norte-Nordeste & Centro-Sul & Norte-Nordeste & Centro-Sul \\
\hline \multirow{20}{*}{ 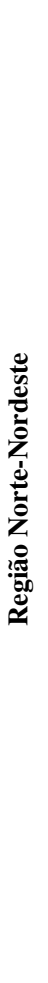 } & 1 & Cana-de-açúcar & 0 & 0 & 7176 & 180399 & 926261 & 543411 & 202451 & 173222 & 7176 \\
\hline & 2 & Resto Agropecuária & 0 & 0 & 2425592 & 11187299 & 25440996 & 11260042 & 2993656 & 8627314 & 2559985 \\
\hline & 3 & Extrativa & 0 & 0 & 2139 & 627528 & 4675726 & 1562443 & 2485755 & 625109 & 2419 \\
\hline & 4 & Metalurgia & 0 & 0 & 64325 & 1848661 & 11599870 & 6640891 & 3110319 & 1770430 & 78231 \\
\hline & 5 & Mecânica & 0 & 0 & 11449 & 659786 & 1338900 & 455782 & 223332 & 514666 & 145120 \\
\hline & 6 & $\begin{array}{l}\text { Material Elétrico e } \\
\text { Eletrônico }\end{array}$ & 0 & 0 & 507044 & 3099924 & 3974706 & 555034 & 319748 & 2313964 & 785960 \\
\hline & 7 & Material de Transporte & 0 & 0 & 93046 & 1769874 & 2693725 & 479293 & 444558 & 1639349 & 130525 \\
\hline & 8 & $\begin{array}{l}\text { Madeira, Mobiliário, } \\
\text { Celulose, Papel e Gráfica }\end{array}$ & 0 & 0 & 883528 & 1511164 & 4381361 & 1912395 & 957802 & 365877 & 1145287 \\
\hline & 9 & Álcool & 0 & 0 & 75930 & 389705 & 928320 & 439141 & 99475 & 313764 & 75940 \\
\hline & 10 & $\begin{array}{l}\text { Outros Elementos Químicos } \\
\text { não Petroquímicos }\end{array}$ & 0 & 0 & 6102 & 76718 & 1158414 & 589208 & 492489 & 70590 & 6128 \\
\hline & 11 & Refino do Petróleo & 0 & 0 & 162352 & 3644064 & 12195049 & 6048447 & 2502538 & 3481089 & 162976 \\
\hline & 12 & $\begin{array}{l}\text { Produtos do Refino do } \\
\text { Petróleo }\end{array}$ & 0 & 0 & 582202 & 3239296 & 7981872 & 2566551 & 2176026 & 2655618 & 583678 \\
\hline & 13 & Têxtil, Vestuário e Calçados & 0 & 0 & 614314 & 3182409 & 5705597 & 2079661 & 443527 & 2567576 & 614833 \\
\hline & 14 & Fabricação de Açúcar & 0 & 0 & 160998 & 698076 & 1270575 & 397658 & 174842 & 537062 & 161014 \\
\hline & 15 & Outros Produtos Alimentares & 0 & 0 & 2780776 & 15157770 & 20982781 & 5204116 & 620896 & 12376109 & 2781660 \\
\hline & 16 & Indústrias Diversas & 0 & 0 & 60061 & 732216 & 3775852 & 2373105 & 670532 & 665389 & 66826 \\
\hline & 17 & SIUP & 0 & 0 & 186400 & 3165371 & 9813432 & 6064962 & 583099 & 2978935 & 186435 \\
\hline & 18 & Construção Civil & 0 & 0 & 396 & 31494572 & 34169807 & 2479193 & 196042 & 28789897 & 2704675 \\
\hline & 19 & $\begin{array}{l}\text { Serviços Prestados às } \\
\text { Famílias }\end{array}$ & 0 & 0 & 1839647 & 16552683 & 19901873 & 3134789 & 214400 & 14712540 & 1840143 \\
\hline & 20 & Outros Serviços & 0 & 0 & 2184386 & 78295051 & 113036273 & 28045156 & 3162820 & 76026703 & 2268349 \\
\hline
\end{tabular}


Tabela 56. Matriz insumo-produto inter-regional do Brasil, ano de 1999, valores correntes em R 1.000,00.

\begin{tabular}{|c|c|c|c|c|c|c|c|c|c|c|c|}
\hline & & & $\begin{array}{c}\text { Variação } \\
\text { de Estoque }\end{array}$ & $\begin{array}{c}\text { Consumo da } \\
\text { Administração } \\
\text { Pública } \\
\end{array}$ & $\begin{array}{c}\text { Consumo } \\
\text { das Famílias }\end{array}$ & $\begin{array}{l}\text { Demanda } \\
\text { Final }\end{array}$ & $\begin{array}{l}\text { Produção } \\
\text { Total }\end{array}$ & $\begin{array}{c}\text { Consumo } \\
\text { Intermediário }\end{array}$ & $\begin{array}{c}\text { Consumo } \\
\text { Intermediário }\end{array}$ & $\begin{array}{l}\text { Demanda } \\
\text { Final }\end{array}$ & $\begin{array}{l}\text { Demanda } \\
\text { Final }\end{array}$ \\
\hline & & Setores & Centro-Sul & Centro-Sul & Centro-Sul & & & $\begin{array}{c}\text { Norte- } \\
\text { Nordeste }\end{array}$ & Centro-Sul & $\begin{array}{c}\text { Norte- } \\
\text { Nordeste }\end{array}$ & Centro-Sul \\
\hline \multirow{17}{*}{ 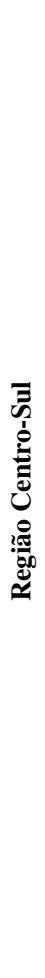 } & 22 & Resto Agropecuária & 6151610 & 0 & 22713764 & 36083411 & 94771747 & 1320532 & 57367804 & 1190362 & 34893049 \\
\hline & 23 & Extrativa & 524007 & 0 & 60640 & 3438183 & 18158341 & 1321816 & 13398341 & 12410 & 3425773 \\
\hline & 24 & Metalurgia & 1528928 & 0 & 2082836 & 11878110 & 59179410 & 2286648 & 45014652 & 315307 & 11562803 \\
\hline & 26 & $\begin{array}{l}\text { Material Elétrico e } \\
\text { Eletrônico }\end{array}$ & -566149 & 0 & 6548608 & 16238704 & 23275213 & 795105 & 6241404 & 1898661 & 14340043 \\
\hline & 27 & Material de Transporte & -913829 & 0 & 10614988 & 28412714 & 40526611 & 1008475 & 11105421 & 3883837 & 24528877 \\
\hline & 28 & $\begin{array}{l}\text { Madeira, Mobiliário, } \\
\text { Celulose, Papel e Gráfica }\end{array}$ & 663214 & 0 & 6999882 & 15178634 & 41732607 & 1962866 & 24591107 & 1760315 & 13418318 \\
\hline & 29 & Álcool & -1145210 & 0 & 1799332 & 1266292 & 7812892 & 641624 & 5904977 & 332051 & 934240 \\
\hline & 30 & $\begin{array}{l}\text { Outros Elementos Químicos } \\
\text { não Petroquímicos }\end{array}$ & 56053 & 0 & 177966 & 1471939 & 7239517 & 486377 & 5281202 & 15644 & 1456295 \\
\hline & 31 & Refino do Petróleo & -1914695 & 0 & 4982298 & 5189241 & 63034622 & 4778867 & 53066513 & 606195 & 4583046 \\
\hline & 33 & Têxtil, Vestuário e Calçados & 70394 & 0 & 12459749 & 18417593 & 32692922 & 475034 & 13800296 & 1924002 & 16493591 \\
\hline & 34 & Fabricação de Açúcar & 1023905 & 0 & 1289727 & 3765110 & 6670866 & 194396 & 2711359 & 231381 & 3533729 \\
\hline & 35 & Outros Produtos Alimentares & 5525883 & 0 & 52547983 & 75406472 & 105524961 & 1425723 & 28692766 & 3532846 & 71873626 \\
\hline & 36 & Indústrias Diversas & -26915 & 0 & 3772393 & 8359395 & 35870715 & 3309761 & 24201559 & 804841 & 7554554 \\
\hline & 37 & SIUP & 1132742 & 0 & 12665714 & 14116497 & 43403476 & 552284 & 28734694 & 302507 & 13813990 \\
\hline & 38 & Construção Civil & 638251 & 0 & 10212 & 95718987 & 106321755 & 26115 & 10576653 & 189659 & 95529328 \\
\hline & 39 & $\begin{array}{l}\text { Serviços Prestados às } \\
\text { Famílias }\end{array}$ & 3416160 & 0 & 53734297 & 59656759 & 74462295 & 169816 & 14635720 & 84094 & 59572665 \\
\hline & 40 & Outros Serviços & 20102134 & 145577481 & 180087674 & 373511146 & 579255933 & 3457584 & 164602945 & 5637354 & 367873792 \\
\hline
\end{tabular}


Tabela 56. Matriz insumo-produto inter-regional do Brasil, ano de 1999, valores correntes em R 1.000,00.

\begin{tabular}{|c|c|c|c|c|c|c|c|c|c|}
\hline & $\begin{array}{l}\text { Variação de } \\
\text { Estoque }\end{array}$ & $\begin{array}{c}\text { Consumo da } \\
\text { Administração } \\
\text { Pública } \\
\end{array}$ & $\begin{array}{c}\text { Consumo } \\
\text { das Famílias }\end{array}$ & $\begin{array}{l}\text { Demanda } \\
\text { Final }\end{array}$ & $\begin{array}{l}\text { Produção } \\
\text { Total }\end{array}$ & $\begin{array}{l}\text { Consumo } \\
\text { Intermediário }\end{array}$ & $\begin{array}{c}\text { Consumo } \\
\text { Intermediário }\end{array}$ & Demanda Final & $\begin{array}{l}\text { Demanda } \\
\text { Final }\end{array}$ \\
\hline & Centro-Sul & Centro-Sul & Centro-Sul & & & Norte-Nordeste & Centro-Sul & Norte-Nordeste & Centro-Sul \\
\hline Produção Nacional & 35640202 & 145577481 & 404021836 & 985449960 & 1705027441 & 110745436 & 567614541 & 188553487 & 796896473 \\
\hline Importado & 0 & 0 & 22107092 & 42681654 & 114956741 & 12348199 & 59926888 & 9886704 & 32794950 \\
\hline Imposta Importação & 0 & 0 & 1578576 & 3467653 & 7806240 & 371271 & 3967315 & 796818 & 2670835 \\
\hline ICM Nacional & 0 & 0 & 19308512 & 31911514 & 63818609 & 5797023 & 26110071 & 7038051 & 24873464 \\
\hline ICM Impotação & 0 & 0 & 915057 & 1832684 & 3219017 & 117536 & 1268797 & 423510 & 1409174 \\
\hline IPI Nacional & 0 & 0 & 5013923 & 9269199 & 18803821 & 966459 & 8568162 & 1992369 & 7276830 \\
\hline IPI Importação & 0 & 0 & 645430 & 1829436 & 3158726 & 113287 & 1216004 & 414845 & 1414590 \\
\hline $\begin{array}{l}\text { Outros Impostos Indiretos } \\
\text { Líquidos Nacionais }\end{array}$ & 0 & 0 & 1556993 & 2259011 & 6108385 & 141053 & 3708321 & 514340 & 1744671 \\
\hline $\begin{array}{l}\text { Outros Impostos Indiretos } \\
\text { Líquidos Importação }\end{array}$ & 0 & 0 & 47855 & 124169 & 695650 & 49364 & 522117 & 28276 & 95892 \\
\hline $\begin{array}{l}\text { CONSUMO } \\
\text { INTERMEDIÁRIO }\end{array}$ & 35640202 & 145577481 & 455195274 & 1078825280 & 1923594630 & 130649629 & 672902218 & 209648400 & 869176880 \\
\hline REMUNERAÇÕES & 0 & 0 & 0 & 0 & 367922157 & 71123921 & 296798236 & 0 & 0 \\
\hline SALÁRIOS & 0 & 0 & 0 & 0 & 262615318 & 50824270 & 211791048 & 0 & 0 \\
\hline $\begin{array}{l}\text { CONTRIBUIÇÕES } \\
\text { SOCIAIS }\end{array}$ & 0 & 0 & 0 & 0 & 58714125 & 11307644 & 47406481 & 0 & 0 \\
\hline $\begin{array}{l}\text { PREVIDÊNCIA OFICIAL/ } \\
\text { GTS }\end{array}$ & 0 & 0 & 0 & 0 & 53682860 & 10468764 & 43214096 & 0 & 0 \\
\hline PREVIDÊNCIA PRIVADA & 0 & 0 & 0 & 0 & 5031265 & 838880 & 4192385 & 0 & 0 \\
\hline $\begin{array}{l}\text { CONTRIBUIÇÕES } \\
\text { SOCIAIS FICTÍCIAS } \\
\text { EXCEDENTE }\end{array}$ & 0 & 0 & 0 & 0 & 46592714 & 8992007 & 37600707 & 0 & 0 \\
\hline $\begin{array}{l}\text { OPERACIONAL BRUTO } \\
\text { (EOB) }\end{array}$ & 0 & 0 & 0 & 0 & 441188831 & 76281419 & 406124916 & 0 & 0 \\
\hline $\begin{array}{l}\text { RENDIMENTO DE } \\
\text { AUTÔNOMOS }\end{array}$ & 0 & 0 & 0 & 0 & 49995487 & 8805669 & 41189818 & 0 & 0 \\
\hline $\begin{array}{l}\text { EOB EXCLUSIVE } \\
\text { RENDIMENTOS DE } \\
\text { AUTÔNOMOS }\end{array}$ & 0 & 0 & 0 & 0 & 391193344 & 67475749 & 364935098 & 0 & 0 \\
\hline $\begin{array}{l}\text { VALOR ADICIONADO } \\
\text { CUSTO FATORES }\end{array}$ & 0 & 0 & 0 & 0 & 809110988 & 147405339 & 702923152 & 0 & 0 \\
\hline $\begin{array}{l}\text { OUTROS IMPOSTOS } \\
\text { SOBRE A PRODUÇÃO }\end{array}$ & 0 & 0 & 0 & 0 & 54615666 & 8529807 & 46085859 & 0 & 0 \\
\hline
\end{tabular}


Tabela 56. Matriz insumo-produto inter-regional do Brasil, ano de 1999, valores correntes em R\$1.000,00 35 .

\begin{tabular}{|c|c|c|c|c|c|c|c|c|c|}
\hline & $\begin{array}{l}\text { Variação de } \\
\text { Estoque }\end{array}$ & $\begin{array}{c}\text { Consumo da } \\
\text { Administração } \\
\text { Pública } \\
\end{array}$ & $\begin{array}{c}\text { Consumo } \\
\text { das Famílias }\end{array}$ & $\begin{array}{l}\text { Demanda } \\
\text { Final }\end{array}$ & $\begin{array}{l}\text { Produção } \\
\text { Total }\end{array}$ & $\begin{array}{l}\text { Consumo } \\
\text { Intermediário }\end{array}$ & $\begin{array}{c}\text { Consumo } \\
\text { Intermediário }\end{array}$ & Demanda Final & $\begin{array}{l}\text { Demanda } \\
\text { Final }\end{array}$ \\
\hline & Centro-Sul & Centro-Sul & Centro-Sul & & & Norte-Nordeste & Centro-Sul & Norte-Nordeste & Centro-Sul \\
\hline $\begin{array}{l}\text { OUTROS SUBSÍDIOS À } \\
\text { PRODUÇÃO }\end{array}$ & 0 & 0 & 0 & 0 & -3468563 & -633384 & -2835179 & 0 & 0 \\
\hline $\begin{array}{l}\text { VALOR ADICIONADO } \\
\text { PREÇO BÁSICO }\end{array}$ & 0 & 0 & 0 & 0 & 860258091 & 155301762 & 746173833 & 0 & 0 \\
\hline VALOR DA PRODUÇÃO & 0 & 0 & 0 & 0 & 1705027441 & 285951390 & 1419076051 & 0 & 0 \\
\hline Pessoal Ocupado & 0 & 0 & 0 & 0 & 62418900 & 18215571 & 44203328 & 0 & 0 \\
\hline Norte-Nordeste & 0 & 0 & 12647864 & 177512564 & 285951390 & 82831276 & 22074305 & 161205204 & 16307360 \\
\hline Centro-Sul & 35640202 & 145577481 & 391373972 & 807937395 & 1419076051 & 27914160 & 545540237 & 27348283 & 780589113 \\
\hline
\end{tabular}

\footnotetext{
${ }^{35}$ GUILHOTO, J.J.M. (USP. FEA. Departamento de Economia, São Paulo). Comunicação pessoal, 2003.
} 